\title{
The common European asylum system
}

Citation for published version (APA):

Yabasun, D. (2019). The common European asylum system: Vulnerable asylum applicants. [Doctoral Thesis, Maastricht University]. Wolf Legal Publishing. https://doi.org/10.26481/dis.20191003dy

Document status and date:

Published: 01/01/2019

DOI:

10.26481/dis.20191003dy

Document Version:

Publisher's PDF, also known as Version of record

\section{Please check the document version of this publication:}

- A submitted manuscript is the version of the article upon submission and before peer-review. There can be important differences between the submitted version and the official published version of record.

People interested in the research are advised to contact the author for the final version of the publication, or visit the DOI to the publisher's website.

- The final author version and the galley proof are versions of the publication after peer review.

- The final published version features the final layout of the paper including the volume, issue and page numbers.

Link to publication

\footnotetext{
General rights rights.

- You may freely distribute the URL identifying the publication in the public portal. please follow below link for the End User Agreement:

www.umlib.nl/taverne-license

Take down policy

If you believe that this document breaches copyright please contact us at:

repository@maastrichtuniversity.nl

providing details and we will investigate your claim.
}

Copyright and moral rights for the publications made accessible in the public portal are retained by the authors and/or other copyright owners and it is a condition of accessing publications that users recognise and abide by the legal requirements associated with these

- Users may download and print one copy of any publication from the public portal for the purpose of private study or research.

- You may not further distribute the material or use it for any profit-making activity or commercial gain

If the publication is distributed under the terms of Article $25 \mathrm{fa}$ of the Dutch Copyright Act, indicated by the "Taverne" license above, 


\section{The Common European Asylum System}

Vulnerable Asylum Applicants

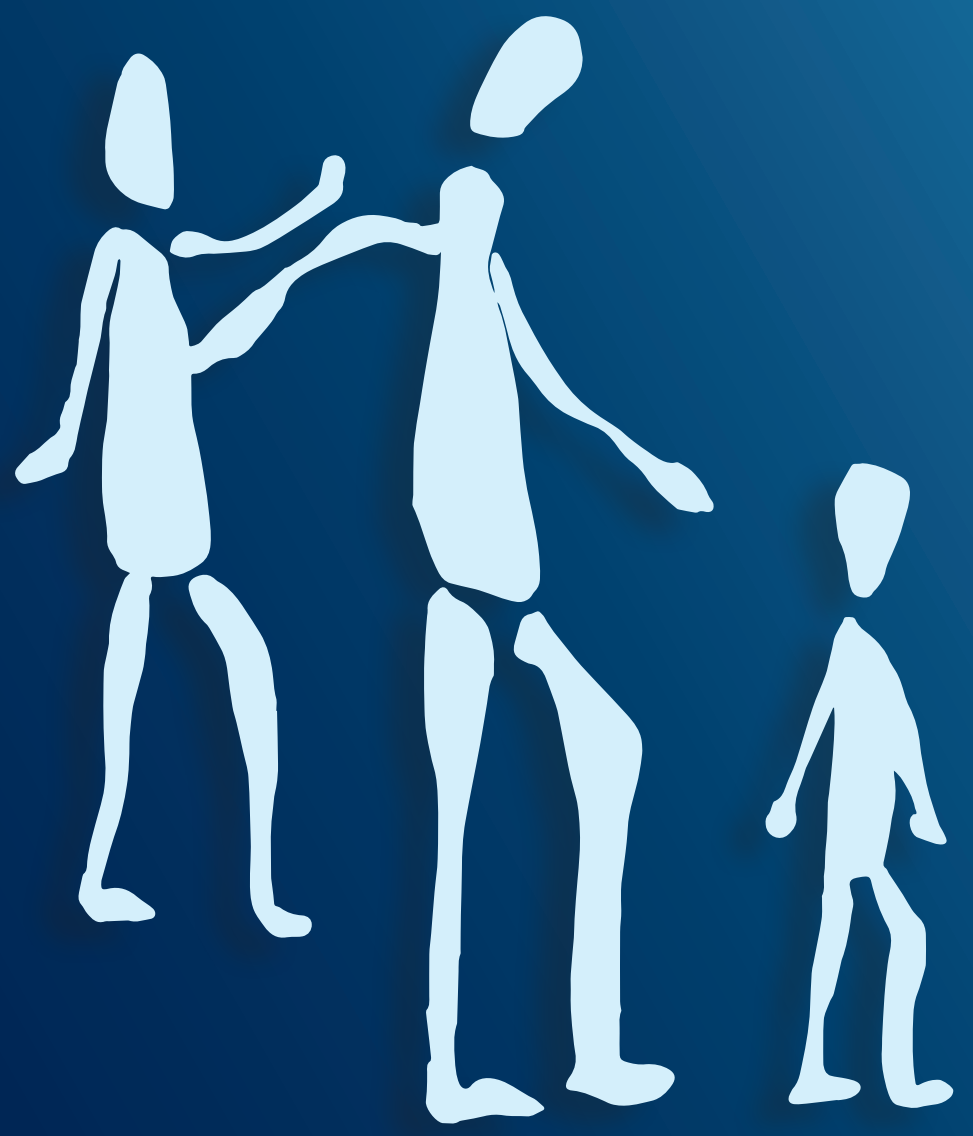

Dersim Yabasun 


\section{The Common European Asylum System: Vulnerable Asylum Applicants}

\section{Dersim Yabasun}


The Common European Asylum System:

Vulnerable Asylum Applicants

Dersim Yabasun

ISBN: 9789462405363

ฟolf Legal Publishers

Postbus 31051

6503 CB Nijmegen

wlp@hetnet.nl 


\title{
(1) Maastricht University
}

\section{The Common European Asylum System: Vulnerable Asylum Applicants}

\author{
Dissertation \\ To obtain the Degree of Doctor at Maastricht University, \\ On the authority of the Rector Magnificus, \\ Prof. dr. Rianne M. Letschert \\ In accordance with the decision of the Board of Deans, \\ To be defended in public \\ on Thursday, 3 October 2019 at 10:00 hours \\ by \\ Dersim Yabasun
}




\section{Supervisors:}

Prof. dr. H.E.G.S. Schneider

Prof. dr. M.P. Vink

\section{Assessment Committee:}

Prof. dr. A.P.M. Coomans (Chair, Maastricht University)

Prof. dr. S. Carrera Nuñez (European University Institute, Florence, CEPS Brussels)

Dr. C.H. Slingenberg (Vrije Universiteit Amsterdam)

Prof. dr. A.P. van der Mei (Maastricht University)

Dr. E.C.H.J. van der Linden (Maastricht University) 


\section{Acknowledgements}

The support of my supervisors, colleagues, friends and family was key in the realization of this dissertation.

First and foremost, I would like to express my deepest gratitude to Hildegard Schneider who gave me the opportunity to teach at Maastricht University and to work on my dissertation. I am grateful for her academic guidance and encouragement throughout the years. I am also genuinely grateful to Maarten Vink for his supervision, advice and constant support. Your detailed comments have significantly improved my chapters.

I am truly thankful to the members of the Assessment Committee for reading my dissertation and for their valuable comments: Fons Coomans, Sergio Carrera, Lieneke Slingenberg, Anne Pieter van der Mei and Eveline van der Linden.

I also want to thank René de Groot for the pleasant cooperation during the course European Migration Law \& Citizenship. Furthermore, I want to thank Diana Schabregs for her advice on financial and personal matters.

Unquestionably, I am indebted to Suzanne Jongste for her friendship, trust and support throughout the years. Suzanne, I want to thank you for always finding the time to talk to me and for listening to my concerns. I would also like to thank Alexander Hoogenboom and Stelios Charitakis for the many lively discussions we had over lunch/coffee breaks.

On a more personal note, I am very thankful to my cousin Hanna Sezgin for creating a great book cover design. I would like to thank my friends who have always been a major source of support: Ruud Wassen, Caglar Sarac, Mathias Holvoet and Dennis Yokum.

This dissertation could never have been achieved without the encouragement of my mother Mürside Sezgin and my wife Patricia Aguilera Loman. To my mother, you have always believed in me and supported me no matter what. Words cannot express how much I am indebted to you. Seni cok seviyorum! My wife Patricia and my daughter Sophia are the most important persons in my life. Patricia, I am deeply indebted to you for your support during the past years. You and Sophia are my source of inspiration. Te amo!

Finally, I would like to mention my father Seref Yabasun, who passed away in 2002 at a tragically young age. My father came to the Netherlands in the $1980^{s}$ as a refugee from Turkey. He was the reason why I became interested in asylum and migration law. Hence, I dedicate this book to him. 



\section{Table of contents}

Acknowledgements $\quad$ v

1 - Introduction 1

1.1. Setting the scene 1

1.2. The purpose and research questions of the study 4

1.3. Methodology 9

1.3.1. Research method 9

$\begin{array}{ll}\text { 1.3.2. Sources } & 10\end{array}$

1.3.3. Methods of interpretation 12

$\begin{array}{ll}\text { 1.4. Definitions and concepts } & 14\end{array}$

1.4.1. Asylum applicant 14

1.4.2. Recast CEAS instruments $\quad 15$

$\begin{array}{ll}\text { 1.4.3. The notion of vulnerability } & 15\end{array}$

1.5. Contribution to existing literature 20

1.6. Limitations of the study 21

2 - The notion of vulnerability under international human $\begin{array}{ll}\text { rights law } & 23\end{array}$

2.1. Introduction 23

2.2. The 1951 Refugee Convention 24

2.2.1. Text and context 24

$\begin{array}{ll}\text { 2.2.2. Non-refoulement } & 27\end{array}$

2.2.3. Interpretation 28

2.3. The International Covenant on Civil and Political Rights 30

2.3.1. Text and context 30

2.3.2. Interpretation 31

2.4. The International Covenant on Economic, Social and

Cultural Rights $\quad 32$

2.4.1. Text and context 32

2.4.2. Interpretation 33

2.5. The Convention on the Elimination of All Forms of Discrimination against Women 36

2.5.1. Text and context 36

2.5.2. Interpretation 36

2.5.3. Women in the asylum process 38

2.6. The Convention on the Rights of Persons with Disabilities 40

2.6.1. Text and context 40

2.6.2. Interpretation 41

2.6.3. Disabled persons in the asylum process 42

2.7. The European Convention on Human Rights 43

2.7.1. Introduction 43

2.7.2. The notion of vulnerability in the case law of the ECtHR 46 
2.7.3. Vulnerable groups: asylum applicants 48

2.7.4. Legal implications of belonging to a vulnerable group 52

2.8. Analysis 53

2.9. Concluding remarks 55

3 - Victims of torture and unaccompanied minors 57

3.1. Introduction $\quad 57$

3.2. Convention against Torture $\quad 57$

3.2.1. Text and context $\quad 57$

3.2.2. Interpretation 58

3.2.3. Victims of torture in the asylum process 62

3.2.4. European human rights standards 63

3.3. Analysis 65

3.4. Convention on the Rights of the Child 66

3.4.1. Text and context 66

$\begin{array}{ll}\text { 3.4.2. Interpretation } & 67\end{array}$

3.4.3. Unaccompanied minors in the asylum process 72

3.4.4. European human rights standards 73

$\begin{array}{ll}\text { 3.5. Analysis } & 79\end{array}$

3.6. Concluding remarks 80

4- The development of asylum co-operation in the European Union $\quad 83$

4.1. Introduction 83

4.2. The beginning of asylum co-operation in the EU 83

4.3. The 1st phase of the Common European Asylum System 90

4.4. The 2nd phase of the Common European Asylum System 103

4.5. The 3rd phase of the Common European Asylum System 115

4.6. Legislative and policy responses (2016-2018) 123

$\begin{array}{ll}\text { 4.7. Analysis } & 135\end{array}$

$\begin{array}{ll}\text { 4.8. Concluding remarks } & 137\end{array}$

5 - The Common European Asylum System 139

5.1. Introduction 139

5.2. The recast Qualification Directive 2011/95/EU 139

5.3. Commission proposal Qualification Regulation 147

5.4. The recast Reception Conditions Directive 2013/33/EU 149

5.5. Commission proposal to recast the Reception Conditions Directive 153

5.6. The recast Asylum Procedures Directive 2013/32/EU 154

5.7. Commission proposal Asylum Procedures Regulation 164

5.8. The recast Dublin III Regulation (EU) No 604/2013 169

5.9. Commission proposal Dublin IV Regulation 176

5.10. The recast Eurodac Regulation (EU) No 603/2013 179 
5.11. Commission proposal Eurodac Regulation 182

5.12. Analysis 183

$\begin{array}{ll}\text { 5.13. Concluding remarks } & 188\end{array}$

6- Vulnerable asylum applicants in the Common European Asylum System $\quad 191$

$\begin{array}{ll}\text { 6.1. Introduction } & 191\end{array}$

6.2. The Reception Conditions Directive 2003/9/EC and vulnerability 192

6.3. Vulnerable asylum applicants in the Common European Asylum System: What are the relevant instruments and legal standards? 196

6.4. Reception Conditions Directive 2013/33/EU (recast): Vulnerable asylum applicants with special reception needs 196

6.5. Commission proposal and applicants in need of special reception guarantees 206

6.6. Asylum Procedures Directive 2013/32/EU (recast): Applicants in need of special procedural guarantees 208

6.7. Commission proposal and applicants in need of special procedural

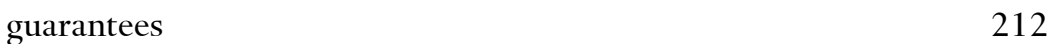

6.8. Qualification Directive 2011/95/EU (recast) 213

6.9. Commission proposal and vulnerable beneficiaries of international $\begin{array}{ll}\text { protection } & 214\end{array}$

6.10. Dublin III Regulation 604/2013 (recast) 215

6.11. Commission proposal and vulnerable asylum applicants in the Dublin procedure

6.12. Eurodac Regulation 603/2013 (recast) 219

6.13. Commission proposal and vulnerable applicants 219

6.14. Analysis 220

6.15. Legal standards with regard to victims of torture in the Common European Asylum System 222

6.16. Commission proposals and the implications for victims of torture 225

6.17. Legal standards with regard to unaccompanied minors in the Common European Asylum System

6.18. Commission proposals and the implications for unaccompanied minors $\quad 232$

6.19. Analysis 238

6.19.1. Victims of torture 238

6.19.2. Unaccompanied minors 240

6.20. Concluding remarks 243

7 - Vulnerable asylum applicants in EU Member States 245

$\begin{array}{ll}\text { 7.1. Introduction } & 245\end{array}$

7.2. The scale of vulnerability in the context of asylum 245

7.3. Legal challenges, shortcomings and promising approaches with 
regard to vulnerable asylum applicants in EU Member States

7.4. Legal challenges, shortcomings and promising approaches with regard to victims of torture and unaccompanied minors in EU Member States

7.5. Analysis

7.6. Concluding remarks 269

8- Vulnerable asylum applicants in the Netherlands 271

8.1. Introduction 271

8.2. The Dutch legal framework 272

8.3. The Dutch asylum procedure 276

8.4. Grounds for protection 280

8.5. Family reunification 282

8.6. The reception system 283

8.7. The Dublin procedure 285

8.8. Legislative and policy responses during the refugee crisis 286

8.9. The notion of vulnerability in the Dutch asylum law and policy 288

8.10. Implementation of the recast Reception Conditions Directive 2013/33/EU and the recast Asylum Procedures Directive 2013/32/EU 290

8.11. The notion of vulnerability in the Dutch asylum process 293

8.12. Victims of torture 310

8.13. Unaccompanied minors 316

8.14. Analysis 331

8.15. Concluding remarks 333

9- Conclusions 335

9.1. The purpose of the study 335

9.2. Examination of the CEAS standards with regard to vulnerable asylum appplicants in relation to international human rights law $\quad 335$

9.3. Assessment of common standards for a fair and efficient asylum procedure with regard to vulnerable asylum applicants 338

9.4. Evaluation of the implementation of CEAS standards with regard to vulnerable asylum applicants at the national level 340

9.5. Recommendations 342

Samenvatting $\quad 345$

Summary $\quad 349$

Valorisation addendum 353

Bibliography and Annexes $\quad 355$

About the author 403 


\section{1 - Introduction}

\subsection{Setting the scene}

2019 is an important milestone for the European asylum policy. Twenty years ago, the European Council decided in the Tampere Conclusions to create a Common European Asylum System (CEAS). One of the main Tampere policy objectives was to establish a system that includes common standards for a fair and efficient asylum procedure in the European Union (EU). ${ }^{1}$ Since its inception in 1999, the CEAS has undergone two legislative phases. The first legislative acts were concluded in 2005, which consisted of minimum standards on asylum. The second phase of the CEAS was concluded in 2013 and recasted the existing minimum standards (recast CEAS). ${ }^{2}$

In 2015, when the number of asylum applications in the EU doubled compared to previous years, it appeared that the recast legislative acts of the CEAS were unable to address the migration challenges. ${ }^{3}$ This sense of crisis has caused a political turmoil across Member States. In 2016, a number of legislative proposals and ad-hoc measures have been submitted by the European Commission (Commission) in response to the migration challenges, including new proposals to reform the existing recast CEAS legislative acts. The proposals of the Commission that are currently under negotiations mark the thirdphase of the CEAS. The unprecedented number of asylum applicants has caused serious challenges for Member States to meet their obligations in providing adequate reception conditions and to ensure procedural arrangements. This situation has most likely affected a growing number of 'vulnerable asylum applicants' arriving in the EU territory.4 The question that logically follows is who are these so-called 'vulnerable asylum applicants'? Although it is generally

1 Council of the European Union, Presidency Conclusions, Tampere European Council, 15-16 October 1999, 16 October 1999, para. 14.

2 Hailbronner, K. and Thym, D., Legal Framework for EU Asylum Policy in Kay Hailbronner and Daniel Thym (eds.), EU Immigration and Asylum Law, Commentary, $2^{\text {nd }}$ edition (C.H. BECK/Hart/Nomos, 2016), pp. 1024-1025.

3 See Wagner, M., Dimitriadi, A., O'Donell, R., Perumadan, J., Schlotzhauer, J. H., Simic, I., \& Yabasun, D. (2016), The implementation of the Common European asylum system. Brussels: European Parliament, pp. 84-87. See also AIDA (2016): Wrong counts and closing doors - The reception of refugees and asylum seekers in Europe, pp. 34-43.

4 See ECRE, The concept of vulnerability in European asylum procedures, 2017, p. 13; European Commission, Communication from the Commission to the European Parliament and the Council, The protection of children in migration, $\{\operatorname{SWD}(2017) 129$ final $\}$, Brussels, 12.4.2017, COM(2017 211 final; and CIR Rifugati, Time for Needs - Listening, Healing, Protecting, A Joint Action for an Appropriate Assessment of Special Needs of Victims of Torture and Violence, 2017, p. 15. 
accepted that asylum applicants may find themselves in a vulnerable situation, there are, however, asylum applicants who are presumed to be particularly vulnerable because they have special needs based on their individual characteristics or conditions. Under the CEAS, identified vulnerable asylum applicants may benefit from special guarantees in terms of reception and or procedural arrangements in order to fully participate in the asylum process. Examples of applicants who are presumed to be particularly vulnerable include: unaccompanied minors; ${ }^{5}$ torture victims; persons with disabilities; elderly people; pregnant women; and victims of human trafficking. ${ }^{6}$ Under the arrivals to the EU in recent years, there has been an increase of unaccompanied minors and torture survivors. ${ }^{7}$ Both groups of applicants are generally recognized to be particularly vulnerable in the context of asylum. Their vulnerability also has been recognized in the case law of the European Court of Human Rights (ECtHR) ${ }^{8}$ and the Court of Justice of the European Union (CJEU). ${ }^{9}$ The legal instruments of the CEAS explicitly offer these two vulnerable groups special guarantees in the asylum process. The Commission has even claimed that the current applicable Asylum Procedures Directive provides for better protection to victims of torture and unaccompanied minors in comparison to the former Asylum Procedures Directive. ${ }^{10}$

Although, the CEAS never adopted a clear definition of the notion of vulnerability, legal standards with regard to vulnerable asylum applicants were already included in the 2001 proposal for a Directive on minimum standards for the reception of asylum applicants in Member States. According to the Commission, 'when asylum applicants belong to groups with special needs, or when they are in detention, reception conditions should be designed to meet their

5 At least 15 Member States consider unaccompanied minors to be vulnerable. See chapter 7 for more details.

6 Article 21 of the recast Reception Conditions Directive.

7 See ECRE, The concept of vulnerability in European asylum procedures, 2017, p. 13; and CIR Rifugati, Time for Needs - Listening, Healing, Protecting, A Joint Action for an Appropriate Assessment of Special Needs of Victims of Torture and Violence, 2017, p. 15.

8 See Rahimiv Greece, Application no. 8687/08, European Court of Human Rights, 5 April 2011 and Aksoy v Turkey, Application no. 21897/93, European Court of Human Rights, 18 December 1996; Bati and Others v Turkey, Application nos. 33097/96 and 57834/00, European Court of Human Rights, 3 June 2004.

9 See inter alia Case C-648/11, The Queen, on the application of MA, BT, DA v Secretary of State for the Home Department, 6 June 2013, Court of Justice of the European Union, ECLI:EU:C:2013:367 and Case C-353/16, MP v Secretary of State for the Home Department, 24 April 2018, Court of Justice of the European Union, ECLI:EU: C:2018:276.

10 European Commission, Fact sheet, Towards a Comprehensive Migration Policy: 20 Years of EU Action, Brussels 4 March 2015 http://europa.eu/rapid/press-release_ MEMO-15-4544_en.htm 
specific needs'. ${ }^{11}$ Subsequently, with the adoption of the 2003 Reception Conditions Directive, the EU had adopted minimum standards that would take into account the specific situation of vulnerable asylum applicants.

The implementation at the national level of CEAS standards with regard to vulnerable asylum applicants appeared, however, to be a problem. The Commission implementation report submitted that there were serious shortcomings in the transposition and implementation of the standards laid down in the CEAS with regard to vulnerable asylum applicants. The Commission stressed that 'identification of vulnerable asylum seekers is a core element without which the provisions of the Directive aimed at special treatment of these persons will lose any meaning'. ${ }^{12}$ Also the United Nations High Commissioner for Refugees (UNHCR) submitted that the identification of vulnerable asylum applicants should take place as soon as possible. ${ }^{13}$ Otherwise they may not fully benefit from the rights and special guarantees enshrined in the CEAS instruments.

Following the overall evaluation of the first-generation instruments of the CEAS, the 2008 Policy Plan on Asylum published by the Commission stipulated that a comprehensive CEAS should take into account the special needs of vulnerable persons and that amendments should be proposed to 'guarantee that the special needs of vulnerable persons, such as children, women, victims of torture or person with medical needs, are identified immediately and that adequate care is available for them.' The objective was to establish improved legal standards with regard to vulnerable asylum applicants. Not only Commission evaluation reports, but also studies have revealed the insufficient protection of such asylum applicants and the poor implementation by Member States. ${ }^{14}$ In 2008 and in 2009, several legislative proposals were submitted by the Commission to recast the legal instruments on asylum. In line with the Policy Plan on Asylum, the objectives of these recast proposals were to reach higher common legal standards and greater equality in protection across the Union as well as better legal safeguards vulnerable asylum applicants. The set of legal instruments representing the second-phase of the CEAS was agreed in 2013 and in-

11 European Commission, Explanatory Memorandum, Proposal for a Council Directive laying down minimum standards on the reception of applicants for asylum in Member States, Brussels, 3.4.2001, COM(2001) 181 final, 2001/0091 (CNS), p. 4.

12 European Commission, Report from the Commission to the Council and to the European Parliament on the application of Directive 2003/9/EC of 27 January 2003 laying down minimum standards for the reception of asylum seekers, Brussels, 26.11.2007, $\operatorname{COM}(2007) 745$ final, paras. 3.5.1.-3.5.2.

13 UNHCR, Procedural Standards for Refugee Status Determination Under UNHCR's Mandate, 20 November 2003, para.3.4.1.

14 Odysseus Academic Network, Comparative overview of the implementation of the Directive 2003/9 of 27 January 2003 laying down minimum standards for the reception of asylum seekers in the EU member States, 2007. 
cluded strengthened special guarantees for vulnerable asylum applicants. These developments show that the vulnerability of asylum applicants in the asylum process has become more prominent in recent years within the EU.

It is important to note that the notion of vulnerability is also an important theme within the international human rights law context. Specific UN human rights treaties provide protection to groups who are classified as vulnerable such as the Convention on the Rights of the Child (CRC) ${ }^{15}$; the Convention against Torture and other Cruel, Inhuman or Degrading Treatment or Punishment (CAT) ${ }^{16}$; the Convention on the Elimination of All Forms of Discrimination against Women (CEDAW) ${ }^{17}$; and the Convention on the Rights of Persons with Disabilities (CRPD). ${ }^{18}$ Recognizing that certain groups are particularly vulnerable and requiring State parties to adopt specific measures to improve their situation has been addressed by various UN treaty monitoring bodies. ${ }^{19}$

Another noticeable development concerns the case law of the ECtHR with regard to vulnerable groups. The ECtHR has held in the landmark case M.S.S. v Belgium and Greece that asylum applicants are a vulnerable group. It attached 'considerable importance to the applicant's status as an asylum-seeker and, as such, a member of a particularly underprivileged and vulnerable population in need of special protection', and pointed out 'the existence of a broad consensus at the international and European level concerning this need for special protection, as evidenced by the Geneva Convention, the remit and activities of UNHCR and the standards set out in the European Reception Directive.'20

\subsection{The purpose and research questions of the study}

In view of the developments above, the purpose of this study is twofold. The first purpose of this study is to analyse the CEAS and to assess whether the

15 UN General Assembly, Convention on the Rights of the Child, 20 November 1989, United Nations, Treaty Series, vol. 1577, p. 3.

16 UN General Assembly, Convention Against Torture and Other Cruel, Inhuman or Degrading Treatment or Punishment, 10 December 1984, United Nations, Treaty Series, vol. 1465 , p. 85.

17 UN General Assembly, Convention on the Elimination of All Forms of Discrimination Against Women, 18 December 1979, United Nations, Treaty Series, vol. 1249, p. 13.

18 UN General Assembly, Convention on the Rights of Persons with Disabilities: resolution / adopted by the General Assembly, 24 January 2007, A/RES/61/106.

19 Chapman, A., and Carbonetti, B., Human Rights Protections for Vulnerable and Disadvantaged Groups: The Contributions of the UN Committee on Economic, Social and Cultural Rights, Human Rights Quarterly, Vol. 33, No. 3, 2011, pp. 683-685.

20 M.S.S. v Belgium and Greece, Application no. 30696/09, European Court of Human Rights, 21 January 2011, para. 251. 
Tampere policy objective of establishing common standards for a fair and efficient asylum procedure has been realized with regard to vulnerable asylum applicants. The second purpose of this study is to examine whether the legal standards that stem from the recast CEAS legislative acts with regard to vulnerable asylum applicants are in accordance with international human rights law, and whether these legal standards have been adequately implemented at the national level. The main research questions for this study are as follows:

1 To what extent are the legal standards that stem from the recast CEAS legislative acts with regard to vulnerable asylum applicants, in particular with regard to victims of torture and unaccompanied minors, in accordance with international human rights law?

2. Does the recast CEAS provide common standards for a fair and efficient asylum procedure with regard to vulnerable asylum applicants?

3. To what extent are the legal standards that are laid down in the recast CEAS legislative acts with regard to vulnerable asylum applicants, in particular with regard to victims of torture and unaccompanied minors, adequately implemented at the national level?

The objectives require a detailed examination of relevant international human rights law instruments and an assessment of the legislative acts of the CEAS, including its specific provisions with regard to vulnerable asylum applicants. In addition, the objectives require an examination of national implementing measures, case law and practice at the national level.

On the categories of vulnerable asylum applicants covered by this study, I have decided to focus in particular on victims of torture and unaccompanied minors. The discussion of international and European human rights standards with regard to other categories of vulnerable asylum applicants, such as female asylum applicants, disabled asylum applicants will be limited. The focus on victims of torture and unaccompanied minors in this study is based on a number of reasons. Both categories of applicants are generally considered to be the most vulnerable groups in the context of asylum. Considering their vulnerability, the CEAS explicitly provides enhanced legal standards aimed at their special protection. In addition, both selected categories are most likely to require special guarantees in terms of reception and procedural arrangements. Both selected vulnerable groups were the subject matter of lengthy debates during the trilogues of the recast CEAS instruments. Moreover, as mentioned above, in recent years there has been an increase in arrivals to the EU of applicants who are torture survivors and unaccompanied minors, which makes it more relevant to examine. ${ }^{21}$

21 See ECRE, The concept of vulnerability in European asylum procedures, 2017, p. 13; and 
The selected country to assess the implementation of relevant legal standards with regard to vulnerable asylum applicants is the Netherlands. The selection of the Netherlands as a case study is based on several grounds. First, it is often considered that the Netherlands has a relatively advanced asylum system. It is therefore relevant to investigate how the Netherlands has integrated the EU's concept of vulnerability in the context of asylum and to what extent it has effectively implemented the legal standards enshrined in the CEAS for the protection of vulnerable applicants in the national asylum procedure, rather than exploring the domestic asylum system of a Member State that is considered to be dysfunctional. The assumption is that well-functioning asylum systems such as the Netherlands are adequately responding to the special needs of vulnerable asylum applicants and that they can benefit from the special guarantees in order to effectively participate in the asylum procedure. The question is whether this is actually the case. Lastly, the reason to select the Netherlands is also influenced by practical considerations such as language skills and access to legislation.

The main research questions can be divided into several sub-questions. The first part of this study will begin by reflecting on the notion of vulnerability under international human rights law. Certain groups, such as children and women, have been recognized as vulnerable under international human rights law. The examination of international human rights law is not only conducted at the UN level but also at the Council of Europe (CoE) level. As mentioned above, the ECtHR has also developed a certain approach to vulnerability. In chapter 2, the following sub-questions are addressed:

1.1. What is the approach to vulnerability under international human rights law?

1.2. Why are certain groups presumed to be vulnerable under international human rights law?

1.3. What are the legal implications to be considered vulnerable under international human rights law?

After having discussed the notion of vulnerability under international human rights law, this study will examine the obligations stemming from international human rights law with regard to victims of torture and unaccompanied minors. The aim is to examine the Member States' obligations with regard to these two vulnerable groups and compare them with the relevant legal standards laid down in the recast legislative acts of the CEAS. The sub-question examined in chapter 3 is formulated as follows:

1.4. Which obligations stem from international human rights law with regard to victims of torture and unaccompanied minors?

CIR Rifugati, Time for Needs - Listening, Healing, Protecting, A Joint Action for an Appropriate Assessment of Special Needs of Victims of Torture and Violence, 2017, p. 15. 
The second part of this study will focus on the CEAS. In chapter 4, I examine the development of EU co-operation on asylum and provide a critical evaluation of the EU asylum policy. The following sub-question is addressed in chapter 4:

\subsection{What has the EU done so far in the field of asylum?}

Subsequently, I will evaluate in chapter 5 the key shortcomings and challenges in each legislative act of the CEAS. I also provide an appraisal of the Commission proposals that are issued to reform the CEAS. In chapter 5, the subquestion is:

2.2. What are the key shortcomings and challenges of the recast CEAS legislative acts?

Subsequently, chapter 6 focuses on the notion of vulnerability in the CEAS. The purpose of this chapter is to examine how the EU has conceptualized the notion of vulnerability in the CEAS. I will examine in more detail the legal standards that stem from the CEAS with regard to vulnerable asylum applicants. This chapter seeks to identify which vulnerable asylum applicants and under what conditions can they benefit from special guarantees in the asylum process, and what special guarantees are owed to vulnerable asylum applicants. The following sub-questions are addressed:

2.3. How has the EU conceptualized the notion of vulnerability in the context of asylum?

2.4. Which legal standards stem from the CEAS recast legislative acts with regard to vulnerable asylum applicants?

In the second part of chapter 6, I will examine the legal standards that stem from the CEAS recast legislative acts with regard to victims of torture and unaccompanied minors, and compare them with the obligations laid down in international human rights law. It is important to note that the following formulated sub-question is related to the first main research question of this study:

1.5. Which legal standards stem from the CEAS recast legislative acts with regard to victims of torture and unaccompanied minors and how are these legal standards compared to the obligations adopted under international human rights law?

The third part of this study will evaluate the implementation at the national level of relevant legal standards stemming from the recast legislative acts of the CEAS with regard to vulnerable asylum applicants. I will also examine the implementation of CEAS standards with regard to victims of torture and unaccompanied minors. In chapter 7 , I will provide a general examination of the na- 
tional practices with regard to vulnerable asylum applicants in the context of asylum in various EU Member States. In order to know the scale of the issue surrounding vulnerable asylum applicants, I examine how many vulnerable asylum applicants arrive in the EU. I also assess how the notion of vulnerability is defined by Member States and whether Member States have implemented a procedure to identify vulnerable asylum applicants in the asylum process. After this general examination, which is mainly based on secondary sources, such as reports from relevant international organisations and NGOs, I will contextualize the subject matter in chapter 8 . The sub-question that is posed in chapter 7 is formulated as follows:

3.1. To what extent have Member States implemented the legal standards that stem from the recast legislative acts of the CEAS at the national level with regard to vulnerable asylum applicants, and also with regard to victims of torture and unaccompanied minors?

Finally, in chapter 8, I carry out a case study on the Netherlands. I provide a detailed analysis of the national implementing measures, case law and practice of the Netherlands with regard to vulnerable asylum applicants in the asylum procedure. Special attention is paid to victims of torture and unaccompanied minors, I will analyse the Dutch legal framework on asylum and examine whether the Netherlands complies with the standards enshrined in the recast CEAS legislative acts with regard to vulnerable asylum applicants. Furthermore, I examine the gaps and challenges at the national level in ensuring special reception and procedural arrangements. The in-depth analysis of the domestic law and practice of a single Member State can provide a clearer picture of the implementation of EU legal standards and can reveal whether vulnerable asylum applicants can benefit from special measures enshrined in the recast CEAS legislative acts. Ultimately, this analysis examines whether vulnerable asylum applicants can fully participate in the asylum process. Chapter 8 is an important evaluative chapter that addresses the following sub-qestions:

3.2. How has the Netherlands implemented the EU's approach to vulnerability in the national asylum process?

3.3. To what extent does the Netherlands comply with the legal standards that stem from the recast legislative acts of the CEAS with regard to vulnerable asylum applicants, and also with regard to victims of torture and unaccompanied minors?

Finally, in chapter 9, I will summarize the most important research findings and answer the main research questions of this study. The last part of this chapter will provide recommendations for the future. 


\subsection{Methodology}

Methodology means the approach that is used to carry out the research. More specifically, how the relevant information has been found, how it has been organized, and how the results have been interpreted.22 The approach should follow from the research questions. In human rights research, there is no preference for a particular method of conducting research. The method employed, however, should be clearly explained and justified.23 The different methods employed in this study will be explained in this section.

\subsubsection{Research method}

The primary research method used in this study is a doctrinal legal approach. This approach is descriptive, evaluative and critical. ${ }^{24}$ For the purposes of this study, this approach involves a systematic legal analysis of the most relevant international law sources as well as relevant EU primary and secondary law, case law and legal academic literature in order to explain what the law entails as regards Member States' obligations concerning vulnerable asylum applicants in the asylum procedure. As such, this study is partly descriptive (lex lata). However, at various parts throughout the study I will put forward my own critical views on the approach of the EU towards vulnerable asylum applicants and the development of the EU asylum policy in general.

Additionally, this study includes an evaluative aspect. I assess in detail how the Netherlands has applied the law and to what extent they comply with their legal obligations surrounding vulnerable asylum applicants. The underlying reasons for applying a country study approach was not only aimed at providing a detailed research on the effective implementation of international and European legal standards on asylum and to identify the gaps, but also to better understand the challenges that vulnerable asylum applicants face at the domestic level. Following my research findings, I provide recommendations as to how the law should be and suggest legislative improvements surrounding vulnerable asylum applicants in order for them to effectively participate in the asylum procedure. This part of the study is normative (lex ferenda).

The next section explains what sources I have used for the legal research and I address the question of how these sources have been interpreted (section 1.3.3.).

22 Coomans, F., Grunfeld, F., and Kamminga, M., Methods of Human Rights Research, 2009, Intersentia, p. 14.

23 Coomans, F., Grunfeld, F., and Kamminga, M., Methods of Human Rights Research, 2009, Intersentia, p. 15.

24 Tiller, E.H. and Cross, F.B., What is Legal Doctrine? Northwestern University Law Review, 517, 2006, p. 518. 


\subsubsection{Sources}

The focus of analysis in this study lies on the recast legislative acts of the CEAS and to what extent vulnerable asylum applicants, and in particular on victims of torture and unaccompanied minors, are safeguarded at the national level. A relatively large part of this study is limited to sources of EU secondary law that are relevant to vulnerable asylum applicants. The used sources for this study are the recast Reception Conditions Directive, the recast Asylum Procedures Directive, the recast Qualification Directive, the recast Dublin Regulation and the recast Eurodac Regulation. Furthermore, I have made use of secondary sources, such as relevant case law of the Court of Justice of the European Union (CJEU), legal and policy documents issued by the Commission, including scholarly legal writings on asylum and policy reports by international organisations and NGOs working in the field of asylum.

The sources at the domestic level are limited to the domestic asylum legislation relevant to the protection of vulnerable asylum applicants. For the purposes of this study, the Dutch legislation on aliens will be described and analysed, which consists of the Aliens Act 2000 (VreemdelingenWet 2000), the Aliens Decree 2000 (Vreemdelingenbesluit 2000), the Aliens Regulation 2000 (Voorschrift Vreemdelingen 2000). Next to these general binding regulations, this study considers also the policy rules on aliens that are laid down in the Aliens Circular 2000 (Vreemdelingencirculaire 2000).

It follows from Article 78(1) of the Treaty on the Functioning of the EU (TFEU) that the European policy on asylum must be in accordance with the Refugee Convention and other relevant treaties. The CJEU has also clarified that the CEAS instruments must be interpreted in the light of its general scheme and purpose, and in a manner consistent with the Geneva Convention and the other relevant treaties', and also 'interpreted in a manner consistent with the rights recognised by the Charter.'25 Hence, the Refugee Convention and other relevant treaties form a direct standard of review. This concerns also the review of national implementation measures in the light of relevant treaties. ${ }^{26}$ Accordingly, part of the analysis in this study examines the instruments of international human rights law. The instruments of international human rights law include international refugee law (Refugee Convention and the 1967 Refugee Protocol) and other relevant human rights instruments at the UN and CoE level. To interpret international human rights law, it is important to un-

25 Case C-199/12 to C-201/12, X, Y, and Z v Minister voor Immigratie en Asiel, 7 November 2013, Court of Justice of the European Union, ECLI:EU:C:2013:720, para. 40.

26 Battjes, H., European Asylum Law and International Law, Martinus Nijhoff Publishers, 2006, pp. 98-105. 
derstand the sources of international law. ${ }^{27}$ Article 38(1) of the Statute of the International Court of Justice establishes the following sources of international law: conventions, 'international custom' and 'general principles of law recognized by civilized nations'. For the purposes of this study, 'international custom and the 'general principles of law recognized by civilized nations' are of limited relevance. According to Article 38(1)(d) of the Statute of the International Court of Justice, judicial decisions and legal doctrine serve as 'subsidiary means for the determination of rules of law'. This means that judicial decisions and legal doctrine are not sources of international law. Instead, they act as method of interpretation. 28

This study has used the Refugee Convention ${ }^{29}$ and other relevant instruments of international human rights law as sources of international law, such as the 1966 International Covenant on Civil and Political Rights (ICCPR), ${ }^{30}$ the International Covenant on Economic, Social and Cultural Rights (ICESCR), 31 the Convention on the Elimination of All forms of Racial Discrimination (ICERD), 32 the 1979 Convention on the Elimination of All Forms of Discrimination against Women (CEDAW) including its Optional Protocol ${ }^{33}$ and the UN Convention on the Rights of Persons with Disabilities (CRPD). In addition, an important source used in this study concerns the European Convention on Human Rights (ECHR). ${ }^{34}$ This study will address in more detail two specialized UN instruments that are relevant for the protection of victims of torture and unaccompanied minors, namely the 1984 UN Convention against Torture and other Cruel, Inhuman or Degrading Treatment or Punishment (CAT) and the Convention on the Rights of the Child (CRC).

27 Scheinin, M., The art and science of interpretation in human rights law in Andreassen, B.A., Sano, H. and McInerney-Lankford, S. (eds.), Research methods in human rights: a handbook, Edward Elgar, 2017, p. 21.

28 Battjes, H., European Asylum Law and International Law, Martinus Nijhoff Publishers, 2006, p. 14.

29 UN General Assembly, Convention Relating to the Status of Refugees, 28 July 1951, United Nations, Treaty Series, vol. 189, p. 137 (Entry into force: 22 April 1954).

30 International Covenant on Civil and Political Rights, G.A. res. 2200A (XXI), 21 U.N. GAOR Supp. (No. 16) at 52, U.N. Doc. A/6316 (1966), 999 U.N.T.S. 171, entered into force Mar. 23, 1976.

31 UN General Assembly, International Covenant on Economic, Social and Cultural Rights, 16 December 1966, United Nations, Treaty Series, vol. 993, p. 3.

32 UN General Assembly, International Convention on the Elimination of All Forms of Racial Discrimination, 21 December 1965, United Nations, Treaty Series, vol. 660, p. 195.

33 UN General Assembly, Optional Protocol to the Convention on the Elimination of All Forms of Discrimination Against Women, 6 October 1999, United Nations, Treaty Series, vol. 2131, p. 83.

34 Council of Europe, European Convention for the Protection of Human Rights and Fundamental Freedoms, as amended by Protocols Nos. 11 and 14, 4 November 1950, ETS 5. 


\subsubsection{Methods of interpretation}

This section will explain the methods of interpretation applied in this study. As explained earlier, the primary research method used in this study is a traditional doctrinal legal approach and thus the method of interpretation employed is a textual and legal analysis of European, international and national legal sources, including an analysis of the case law of the CJEU and the ECtHR.

As regards the interpretation of obligations of State parties under international refugee law and international human rights law, I have used the rules on interpretation of international treaties that are enshrined in Articles 31 and 32 of the Vienna Convention on the Law Treaties (VCLT). ${ }^{35}$ Article 31 of the VCLT stipulates the general of treaty interpretation:

'1. A treaty shall be interpreted in good faith in accordance with the ordinary meaning to be given to the terms of the treaty in their context and in the light of its object and purpose.

2. The context for the purpose of the interpretation of a treaty shall comprise, in addition to the text, including its preamble and annexes:

(a) any agreement relating to the treaty which was made between all the parties in connection with the conclusion of the treaty;

(b) any instrument which was made by one or more parties in connection with the conclusion of the treaty and accepted by the other parties as an instrument related to the treaty.

3. There shall be taken into account, together with the context:

(a) any subsequent agreement between the parties regarding the interpretation of the treaty or the application of its provisions;

(b) any subsequent practice in the application of the treaty which establishes the agreement of the parties regarding its interpretation;

(c) any relevant rules of international law applicable in the relations between the parties.

4. A special meaning shall be given to a term if it is established that the parties so intended.'

In accordance with pacta sunt servanda, the first element of treaty interpretation is that a treaty should be interpreted in good faith. The general rule of treaty interpretation includes literal (text), systematic (context) and teleological (object and purpose) interpretation methods. ${ }^{36}$ It is also important to mention that

35 Scheinin, M., The art and science of interpretation in human rights law in Andreassen, B.A., Sano, H. and McInerney-Lankford, S. (eds.), Research methods in human rights: a handbook, Edward Elgar, 2017, p. 21.

36 Scheinin, M., The art and science of interpretation in human rights law in Andreassen, B.A., Sano, H. and McInerney-Lankford, S. (eds.), Research methods in human rights: a handbook, Edward Elgar, 2017, p. 23. 
there is no hierarchy between the different methods of interpretation. ${ }^{37}$ It is further important to note that in addition to the text of the treaty, the preamble and annexes, the context of a treaty comprises also 'any agreement relating to the treaty which was made between all the parties in connection with the conclusion of the treaty' and 'any instrument which was made by one or more parties in connection with the conclusion of the treaty and accepted by the other parties as an instrument related to the treaty'.

Subsequently, in interpreting a treaty one has to take into account, together with the context, any subsequent agreement among the State parties concerning the interpretation of the treaty and subsequent practice in the application of the treaty. Furthermore, Article 31(3)(c) of the VCLT specifies the general principle of treaty interpretation, which is the 'systemic integration' within the international legal system. This implies that treaties should be 'applied and interpreted against the background of the general principles of international law.'38

Article 32 of the VCLT entails the 'supplementary means of interpretation'. This means that recourse may be had to supplementary means, such as preparatory work (travaux preparatoires), in order to confirm an interpretation resulting from the application of Article 31 of the VCLT, and when the interpretation of Article 31 of the VCLT 'leaves the meaning ambiguous or obscure' or which is 'manifestly absurd or unreasonable.'

As addressed above, in addition to the general and supplementary means of interpretation, judicial decisions, such as of the ECtHR and legal doctrine are significant subsidiary means for the determination of rules of law. Important for the interpretation of treaties are the views of international UN treaty monitoring bodies. This study will scrutinize the General Comments and General Recommendations, which are considered authorative interpretations of the substantive provisions of the international human rights treaties. In addition, this study takes also into account the views of the UN treaty monitoring bodies on individual complaints (Communications). I will not consider the Concluding Observations of the UN treaty monitoring bodies because they discuss the implementing measures in a particular country and 'their jurisprudential impact is marginal and exceptional'. ${ }^{39}$ References to Concluding Observations will only be made in chapter 8 with regard to the national implementing measures of the Netherlands.

37 Battjes, H., European Asylum Law and International Law, Martinus Nijhoff Publishers, 2006, p. 16.

38 McLachlan, C., The Principle of Systemic Integration and Article 31(3)(c) of the Vienna Convention, International \& Comparative Law Quarterly, Vol. 54, Issue 2, 2005, p. 280.

39 Mechlem, K., Treaty Bodies and the Interpretation of Human Rights, Vanderbilt Journal of Transnational Law, Vol. 42, 2009, p. 923. 
The Refugee Convention does not have a monitoring body. Instead, the interpretation of the Refugee Convention lies with the State parties. Any dispute between the State parties on the interpretation of the Refugee Convention is referred to the International Court of Justice. There are two other significant sources for the interpretation of the Refugee Convention. First, the UNHCR has the duty to supervise the application of the Refugee Convention and therefore the opinions of the UNHCR and the UNHCR Handbook on Procedures and Criteria for Determining Refugee Status (Handbook) are important subsidiary means of interpretation. ${ }^{40}$ Their authority depends on the quality of reasoning. Second, the Conclusions of the Executive Committee of the programme of the High Commissioner (ExCom), which consists of the State parties, are an important source for the interpretation of the Refugee Convention. The Conclusions of the ExCom could be considered as 'subsequent agreement between the parties' in the context of Article 31(3)(a) of the VCLT. 41

As regards the method of interpretation of EU asylum legislation, I have followed the approach of the CJEU. This means interpretation of EU asylum legislation is based on the wording, context and purpose. ${ }^{42}$ In addition, relevant for the interpretation of EU asylum legislation are the Commission proposals and their Explanatory Memorandums, including the implementation reports.

\subsection{Definitions and concepts}

\subsubsection{Asylum applicant}

Where reference is made to an 'asylum applicant' in this study, it should be taken to refer to an applicant for international protection (refugee protection or subsidiary protection within the meaning of the recast Qualification Directive). Both asylum applicant and applicant for international protection are used interchangeably in this study, unless otherwise stated.

\subsubsection{Recast CEAS instruments}

Where reference is made to the recast CEAS instruments, it refers to the second-generation or second-phase CEAS instruments, which are currently still

40 Kälin, W., Supervising the 1951 Convention Relating to the Status of Refugees: Article 35 and beyond in Refugee Protection in International Law, Erika Feller, Volker Türk and Frances Nicholson (eds.), UNHCR's Global Consultations on International Protection, 2003, p. 619.

41 Battjes, H., European Asylum Law and International Law, Martinus Nijhoff Publishers, 2006, pp. 19-20.

42 Battjes, H., European Asylum Law and International Law, Martinus Nijhoff Publishers, 2006, pp. $42-46$. 
the applicable EU legislation on asylum.

\subsubsection{The notion of vulnerability}

How should vulnerability be understood in the context of asylum? A general notion of vulnerability is lacking in the CEAS. In this section, I develop a working definition of the notion of vulnerability that is meaningful for the purpose of asylum law. In the literature efforts have been made to adequately identify vulnerable persons in the migration context and how to respond to their specific needs. ${ }^{43}$ The point of departure is that there is no single and undisputed definition of vulnerability. The term vulnerable originates from the Latin expressions 'vulnerare' ('to wound') and 'vulnus' ('wound'). The official definition of 'vulnerable' in the Oxford English Dictionary is 'exposed to the possibility of being attacked or harmed, either physically or emotionally'; '(a person) in need of special care, support, or protection because of age, disability, or risk of abuse or neglect.' These definitions suggest an individual that is weak or is in need of particular attention due to individual circumstances. The interpretation of vulnerability may differ depending on the context. For example, from an economics perspective, the notion of vulnerability can be interpreted in relation to risk or insecurity. In the medical sector, vulnerability may concern the ability of a patient to recover from physical or mental harm. Professionals working in the environmental science sector interpret vulnerability in terms of harm and resilience and lawyers may refer to weakness or fragility. ${ }^{44}$

To develop a working definition on the notion of vulnerability that is also meaningful in the asylum context, I have examined other disciplines. Vulnerability has been the subject of much debate in sociology, bioethics and healthcare. For example, Schroeder and Genefas suggest that a definition of vulnerability should entail two aspects: first, the exposure to the possibility of harm: and second, the capacity or the means to protect oneself from that harm. They define vulnerability as follows: 'to be vulnerable means to face a significant probability of incurring an identifiable harm while substantially lacking ability and/or means to protect oneself. 45

Often cited by scholars is the vulnerability approach by Fineman. ${ }^{46}$ Accord-

43 See inter alia Flegar, V., Who is deemed vulnerable in the governance of migration? Asiel \& Migrantenrecht, 2018, Nr. 8, pp. 374-383.

44 Truscan, 'Considerations of vulnerability: from principles to action in the case law of the European Court of Human Rights', Retfcerd: Nordic Journal of Law and Justice, no. 3/142, 2013, pp. 64-65.

45 Schroeder, D., and Gefenas, E., Vulnerability: Too Vague and Too Broad? Cambridge Quarterly of Healthcare Ethics, 2009, pp. 115-117.

46 Fineman, M.A., The Vulnerable Subject: Anchoring Equality in the Human Condition, Yale Journal of Law \& Feminism, Vol. 20, (1), 2008. 
ing to Fineman all human beings are vulnerable. She opposes the groupapproach to vulnerability or the idea that certain individuals and groups are vulnerable. ${ }^{47}$ There is no such thing as invulnerability. Fineman points out that 'the vulnerable subject is the embodiment of the realization that vulnerability is a universal and constant aspect of the human condition.' 48 Vulnerable is not only universal but also constant because human beings are constantly susceptible to harm, injury or illness. Fineman submits the view that vulnerability must at the same time be considered 'as particular, varied and unique on the individual level.' ${ }^{49}$ This is because human beings are 'positioned differently within a web of economic and institutional relationships, our vulnerabilities range in magnitude and potential at the individual level. ${ }^{50}$ The vulnerability approach of Fineman argues for a State that is more responsive to and responsible for the vulnerable individual. ${ }^{51}$ The notion of universal vulnerability as an element of the human condition may explain that we all are vulnerable or become vulnerable at some time in our lives and that we are all somehow dependent on others. This approach is, however, in my opinion not useful to respond to the specific kinds and sources of vulnerability in the context of asylum.

The second approach of vulnerability that appears in the academic literature emphasizes that vulnerability depends on a person's capacity and the resources available to protect them from harm. ${ }^{52}$ Thus, although all individuals are vulnerable to harm, some individuals compared to others have a limited capacity to protect their own interests, which makes them particularly vulnerable. Contrary to the universal approach which interprets vulnerability as an inherent aspect of the human condition and equal susceptibility to suffering, the understanding of vulnerability in the second approach, which is dependent on the context, places the emphasis on the different inequalities in resources that make

47 Fineman, M.A., Beyond Identities: The Limits of an Anti-discrimination Approach to Equality, Boston University Law Review, Vol. 92, No. 6, 2012, p. 1750.

48 Fineman, M.A., Equality, Autonomy, and the Vulnerable Subject in Law and Politics in Vulnerability: Reflections on a New Ethical Foundation for Law and Politics, Martha Albertson Fineman and Anna Grear (eds.), Ashgate, 2013, p. 17.

49 Fineman, M.A., Equality, Autonomy, and the Vulnerable Subject in Law and Politics in Vulnerability: Reflections on a New Ethical Foundation for Law and Politics, Martha Albertson Fineman and Anna Grear (eds.), Ashgate, 2013, p. 21.

50 Fineman, M.A., The Vulnerable Subject: Anchoring Equality in the Human Condition, Yale Journal of Law \& Feminism, Vol. 20, (1), 2008, p. 10.

51 Fineman, M.A., The Vulnerable Subject: Anchoring Equality in the Human Condition, Yale Journal of Law \& Feminism, Vol. 20, (1), 2008, p. 13.

52 Mackenzie, C., Rogers, W. and Dodds, S., Introduction: what is Vulnerability, and Why Does It Matter for Moral Theory? In Vulnerability: New Essays in Ethics and Feminist Philosophy (Mackenzie, C.,Rogers, W. and Dodds, S. eds.), Oxford University Press, 2014, p. 4. 
some vulnerable individuals more susceptible to harm. ${ }^{53}$

Rogers et al. cite Goodin as follows: "the principle of protecting the vulnerable is first and foremost an argument for aiding those in dire need". Hence, vulnerability is linked to human needs, which should be met in order to flourish. As not all needs are equally morally demanding. According to Rogers et al. Goodin suggests that 'vital needs' that are so fundamental that a person without it will be seriously harmed or not flourish, should be prioritised. The interpretation of which needs are vital to a person is dependent on the human condition and the context-specific circumstances of the person's personal, social and political situation. The conceptual approach of vulnerability that appears from Goodin entails three elements: vulnerability means 1) to be susceptible to serious harms; 2) with regard to the vital needs that should be met; and 3) harms that impair the person's capacity to live the best possible life. The reality is that human beings have needs, which shows that vulnerability is inherent to the human condition. Persons are, however, particularly vulnerable when they have actual needs, which they may not be able to meet themselves without support. ${ }^{54}$

Vulnerability stems from different sources and identifying these sources may help to find an adequate response to vulnerability. Rogers et al. distinguish different sources and types of vulnerability. The first type is referred as inherent' vulnerability and indicates to sources of vulnerability that are innate to the human condition. Vulnerability stems from the fact that human beings have needs and our dependence on others. The degree of a person's inherent vulnerability depends on a variety of factors, such as age, health, gender and disability. Additionally, the degree of vulnerability is also dependent on the capacity of the person. The second type of vulnerability is referred as 'situational' vulnerability, which stands for vulnerability that is context-specific. Situational vulnerability stems from the personal, social, political, economic or environmental situation of a person. The last type of vulnerability is referred as 'pathogenic' vulnerability. A range of sources are linked to pathogenic vulnerability, which may be

53 Mackenzie, C., Vulnerability, Needs and Moral Obligation in Vulnerability, Autonomy and Applied Ethics (editor Christine Straehle), Routledge, 2017; Mackenzie, C.,Rogers, W. and Dodds, S., Introduction: what is Vulnerability, and Why Does It Matter for Moral Theory? In Vulnerability: New Essays in Ethics and Feminist Philosophy (Mackenzie, C.,Rogers, W. and Dodds, S. eds.), Oxford University Press, 2014, pp. 3-6. See also Waddington, L., Vulnerable and confused: the protection of "vulnerable" consumers under EU law, European Law Review, 2013, 38(6), pp. 757-782. See also Van der Aa, S., Variable Vulnerabilities? Comparing the Rights of Adult Vulnerable Suspects and Vulnerable Victims under EU Law, New Journal of European Criminal Law, Vol. 7, Issue 1, 2016.

54 Gooding as cited by Rogers, W., MacKenzie, C. and Dodds, S., Why bioethics needs a concept of vulnerability, International Journal of Feminist Approaches to Bioethics, Vol. 5, No. 2, 2012, pp. 21-22. 
caused by abuse in social relationships or by socio-political situations, such as political oppression. 55

The following elements stem from the literature:

- There is no common understanding of the notion of vulnerability.

- All human beings are vulnerable.

- To be vulnerable means often to be at increased risk of harm.

- Certain persons are more susceptible to harm than others.

- Vulnerability can be temporary or permanent.

- Vulnerability presupposes weakness, defencelessness or dependence on others.

- Vulnerability assumes that an individual is unable to protect oneself from harm.

- Vulnerability is linked to human needs.

- Vulnerability may be caused by inherent factors, which means sources of vulnerability that are inherent to the human conditions, such as age, disability or illness.

- Vulnerability may be caused or exacerbated by situational factors, which refers to vulnerability that is context-specific.

The previous sections show that vulnerability is a contentious and multidimensional concept, which has diverse meanings in different contexts. Based on these considerations, I employ the following working definition of vulnerability in the context of the asylum:

To be vulnerable should be understood as being susceptible to an increased risk of harms and having actual needs, which the person in question is unable to meet him-or herself without special measures in order to fully participate in the asylum process.

Subsequently, the next question is how can we adequately identify particularly vulnerable persons and respond to their needs? There has been a practice in policy work to label certain groups as vulnerable. This has been also the case in the recast CEAS. The principal provision on the notion of vulnerability in the recast CEAS is Article 21 of the recast Reception Conditions Directive, which stipulates:

'Member States shall take into account the specific situation of vulnerable persons such as minors, unaccompanied minors, disabled people, elderly people, pregnant women, single parents with minor children, victims of human trafficking, persons with serious illnesses, persons with mental disorders and persons who have been subjected to torture, rape or other serious forms of psychological, physical or sex-

55 Rogers, W., MacKenzie, C. and Dodds, S., Why bioethics needs a concept of vulnerability, International Journal of Feminist Approaches to Bioethics, Vol. 5, No. 2, 2012, pp. 24-25. 
ual violence, such as victims of female genital mutilation, in the national law implementing this Directive.'

A criticism that is raised with the labelling of groups as vulnerable is that the notion of vulnerability may become too broad. Bossuyt asks 'what will further developments in identifying "particularly vulnerable groups" accomplish? If women, children, the elderly, aliens, people with disabilities or suffering from illnesses, people living in poverty, and people belonging to racial, ethnic, religious, or sexual minorities are all classified as "particularly vulnerable" persons, the overwhelming majority of any country's population will then be recognized as "particularly vulnerable." If they all deserve particular attention from the Government and special efforts must be undertaken to meet their specific needs, one may wonder whether the small minority of persons not belonging to any of those groups do not also become vulnerable since they are not entitled to any special effort.' 56 I agree with the critical note of Bossuyt when he argues that an expansion of the notion of vulnerability that labels everyone as 'particularly vulnerable' renders the whole notion of vulnerability meaningless. However, the problem is not that various groups are labelled as particularly vulnerable, but when groups are labelled as particularly vulnerable without justification. Luna submits that the pitfall of labelling groups as vulnerable based on the presence of certain characteristics ignores the fact that a person or a group may have multiple types and degrees of vulnerabilities, which is not captured by just labelling them as vulnerable. ${ }^{57}$ Luna suggests an approach that considers why a particular situation renders a person vulnerable, rather than labelling that someone is vulnerable. ${ }^{58}$

As I pointed out above, there is some consensus in the CEAS about categories of asylum applicants who may qualify as vulnerable. Article 21 of the recast Reception Conditions Directive includes a non-exhaustive list of potential vulnerable groups, such as unaccompanied minors, disabled people, elderly people, pregnant women and persons who have been subjected to torture. The CEAS only includes groups and does not consider the situations that render people vulnerable in the asylum process. To develop a nuanced approach, it is equally important to recognize sources of vulnerability that is context-

56 Bossuyt, M., Categorical rights and vulnerable groups: moving away from the universal human being, The George Washington International Law Review, 48:4, 2016, p. 742.

57 Luna, F., Identifying and evaluating layers of vulnerability - a way forward, Developing World Bioethics, 2018, p. 2.

58 Luna, F, Elucidating the Concept of Vulnerability: Layers not Labels, International Journal of Feminist Approaches to Bioethics, Vol. 2, No.1, 2009, p. 129. See also Rogers, W., MacKenzie, C. and Dodds, S., Why bioethics needs a concept of vulnerability, International Journal of Feminist Approaches to Bioethics, Vol. 5, No. 2, 2012, p. 15. 
specific. ${ }^{59}$ For example, LGBTI asylum applicants are vulnerable to discrimination, harassment and violence during their stay at the reception centre. The source of their vulnerability is caused or exacerbated by the situation.

I argue that while the labelling approach used in the CEAS may stigmatize and stereotype groups, rejecting the labelling approach may risk leaving certain groups unprotected. Labelling groups may ensure that national authorities are more vigilant on asylum applicants that belong to a vulnerable group with specific needs. Hence, in my view, a nuanced approach to vulnerability in the asylum process includes sources of vulnerability that are linked to certain groups, but also takes into account context-specific sources of vulnerability.

\subsection{Contribution to existing literature}

There have been several analyses and scholarly comments on the notion of vulnerability in the context of asylum. ${ }^{60}$ Nevertheless, in the view of this author, this is the first study that analyses the development of EU asylum policy, the recast CEAS legislative acts and the notion of vulnerability in such a comprehensive and systematic manner.

Moreover, there has been some scholarly analysis on the implementation of legal standards that stem from the recast CEAS with regard to vulnerable asylum applicants at the national level, ${ }^{61}$ but these contributions are limited in scope. This study analyses in a comprehensive and extensive manner the legal

59 Rogers, W., MacKenzie, C. and Dodds, S., Why bioethics needs a concept of vulnerability, International Journal of Feminist Approaches to Bioethics, Vol. 5, No. 2, 2012, p. 24.

60 Jakuleviciene, L., Vulnerable Persons as a New Sub-Group of Asylum Seekers? De Bruycker, P., Chetail, V. and Maiani, F. (eds.), Reforming the Common European Asylum System: The New European Refugee Law, Brill Nijhoff, 2016; Pétin, J., La vulnérabilité en droit Européen de l'asile, RDLF 2017; Pétin, J., Vulnérabilité et droit Européen de l'asile: quelques précisions nécessaires, 18 April 2015; and Stoyanova, V., Victims of Trafficking, A Legal Analysis of the Guarantees for 'Vulnerable Persons' under the Second Phase of the EU Asylum Legislation, Seeking Asylum in the European Union, Selected Protection Issues Raised by the Second Phase of the Common European Asylum System (Bauloz, C., Ineli-Ciger, M., Singer, S. and Stoyanova, V. eds.), Brill Nijhoff, 2015; ECRE, The concept of vulnerability in European asylum procedures, 2017; and De Bauche, L., Vulnerability in European law on asylum: A conceptualization under construction, Study on reception conditions for asylum seekers, Bruylant, 2012; including the study by Bruycker, P. and De Bauche, L., Odysseus Academic Network, Study on the conformity checking of the transposition by Member States of 10 EC Directives in the sector of asylum and immigration done for DG JLS of the European Commission, Directive 2003/09 on Reception Conditions, Synthesis Report, 2007.

61 Reneman, M., Identification of asylum seekers with special reception needs and procedural needs in the Dutch asylum procedure, VU Migration Law Serieus, No. 16, 2018; Flegar, V. and Veys, M., De Europese verplichting voor procedurele waarborgen in de Nederlandse asielprocedure en de implementatie vanuit kwetsbaarheidsperspectief, Journaal Vreemdelingenrecht, Nr. 2/11, 2017. 
standards for the protection of vulnerable asylum applicants both from an international and European perspective and carries out an in-depth country study on the Dutch asylum law and policy with regard to vulnerable asylum applicants, with a particular focus on victims of torture and unaccompanied minors, which has to my knowledge not yet been undertaken. It is important to note that this research does not address developments occurred after March 2019.

\subsection{Limitations of the study}

This study has certain limitations that need to be addressed. In particular, this study makes no express contribution to the academic debate on the notion of vulnerability from a philosophical standpoint developed in the literature62 nor does it extensively dwell on the issue of vulnerable groups in the case law of the ECtHR, mainly because other scholars already have covered those issues. ${ }^{63} \mathrm{In}$ stead, this study will focus on the legal standards that stem from the recast CEAS legislative acts with regard to vulnerable asylum applicants.

An important part of this study focuses on vulnerable asylum applicants at the national level. Chapter 7 examines from a bird's eye view the implementation of CEAS standards with regard to vulnerable asylum applicants in the Member States. The examination in chapter 7 is based on secondary sources and therefore limited. In chapter 8 , however, I provide a detailed and robust analysis on the national implementing measures, case law and practice with re-

62 Luna, F., Identifying and evaluating layers of vulnerability - a way forward, Developing World Bioethics, 2018; Mackenzie, C., Vulnerability, Needs and Moral Obligation in Vulnerability, Autonomy and Applied Ethics (editor Christine Straehle), Routledge, 2017; Fineman, M.A., The Vulnerable Subject: Anchoring Equality in the Human Condition, Yale Journal of Law \& Feminism, Vol. 20, (1), 2008. See for further discussions on the concept of vulnerabilty: Fineman, M.A., and Grear, A., (eds.), Vulnerability: reflections on a new ethical foundation for law and politics, 2013; Turner, B.S., Vulnerability and Human Rights, 2006;

63 Peter Fritzsche, K., in Menschenrechte besonders verletzlicher Gruppen, Menschenrechte Eine Einführung mit Dokumenten, 2016, pp. 127-149; Carlier, J., Des droits de l'homme vulnérable à la vulnérabilité des droits de l'homme, la fragilité des équilibres. Revue interdisciplinaire d'études juridiques, 2017, volume 79(2), 175-204; Peroni, L. and Timmer, A., Vulnerable groups: The promise of an emerging concept in European Human Rights Convention law, International Journal of Constitutional Law, 2013; Brandl, U. and Czech, P., General and Specific Vulnerability of Protection-Seekers in the EU: Is there an Adequate Response to their Needs? Protecting Vulnerable Groups, The European Human Rights Framework, (Ippolito, F., and Iglesias Sanchez, S. eds.), 2015; Truscan, 'Considerations of vulnerability: from principles to action in the case law of the European Court of Human Rights', Retfeerd: Nordic Journal of Law and Justice, no. 3/142, 2013; Al Tamimi, Y. (2016). The Protection of Vulnerable Groups and Individuals by the European Court of Human Rights, Journal européen des droits de l'homme / European Journal of Human Rights, 2016(5). 
gard to vulnerable asylum applicants within the Dutch asylum context. Moreover, the case study in chapter 8 could serve as a template to examine the law and practice surrounding vulnerable asylum applicants in all Member States. Lastly, this study does not address vulnerable asylum applicants whose asylum applications have been rejected in the final instance at the national level. 


\section{2 - The notion of vulnerability under international human rights law}

\subsection{Introduction}

International human rights law has recognized certain groups as vulnerable in need of special protection. The purpose of this chapter is therefore to examine the notion of vulnerability employed in international human rights law and to examine why certain groups are presumed to be vulnerable.

This chapter will discuss the Refugee Convention with regard to the notion of vulnerability. In interpreting the notion of vulnerability within the Refugee Convention, I take into account the opinions of the UNHCR, including the Conclusions of ExCom with regard to groups considered to be vulnerable, such as minors, ${ }^{64}$ disabled persons, ${ }^{65}$ women ${ }^{66}$ and elderly people. ${ }^{67}$

After the discussion on the Refugee Convention, this chapter continues with an examination of the notion of vulnerability under relevant international human rights treaties. To this end, I will discuss the following treaties: the International Covenant on Civil and Political Rights (ICCPR) ${ }^{68}$; the International Covenant on Economic, Social and Cultural Rights (ICESCR) ${ }^{69}$; the Convention on the Elimination of All Forms of Discrimination against Women (CEDAW) ${ }^{70}$; and the Convention on the Rights of Persons with Disabilities (CRPD). ${ }^{71}$ In interpreting the human rights treaties, I rely on the interpretation of treaty monitoring bodies issued in General Comments and General Recommendations, including individual complaints. I will not examine the concluding observations or conclusions of the treaty monitoring bodies as they are

64 UNHCR, Policy on Refugee Children, 6 August 1993, EC/SCP/82; UNHCR, Conclusion on Children at Risk No. 107 (LVIII) - 2007, 5 October 2007, No. 107 (LVIII) - 2007.

65 UNHCR, Conclusion on refugees with disabilities and other persons with disabilities protected and assisted by UNHCR No. 110 (LXI) - 2010, 12 October 2010, No. 110 (LXI) - 2010.

66 UNHCR, Policy on Refugee Women, 20 August 1990; UNHCR, Conclusion on Women and Girls at Risk No. 105 (LVII) - 2006, 6 October 2006, No. 105 (LVII) - 2006.

67 UNHCR, Conclusion on International Protection No. 85 (XLIX) - 1998, 9 October 1998, No. 85 (XLIX) - 1998; UNHCR, UNHCR's Policy on Older Refugees, 19 April 2000, EC/50/SC/CRP.13, Annex II.

68 UN General Assembly, International Covenant on Civil and Political Rights, 16 December 1966, United Nations, Treaty Series, vol. 999, p. 171.

69 UN General Assembly, International Covenant on Economic, Social and Cultural Rights, 16 December 1966, United Nations, Treaty Series, vol. 993, p. 3.

70 UN General Assembly, Convention on the Elimination of All Forms of Discrimination Against Women, 18 December 1979, United Nations, Treaty Series, vol. 1249, p. 13.

71 UN General Assembly, Convention on the Rights of Persons with Disabilities: resolution / adopted by the General Assembly, 24 January 2007, A/RES/61/106. 
more country specific. Furthermore, I rely on the decisions issued by international courts as well as legal doctrine.

As I have pointed out in chapter 1, the examination of international human rights law is not only carried out at the UN level but also conducted at the $\mathrm{CoE}$ level. Consequently, in the second part of this chapter, I will discuss the ECHR and the notion of vulnerability in the case law of the ECtHR, in particular with regard to asylum applicants. The examination of Member States' obligations with regard to victims of torture and unaccompanied minors will be examined in chapter 3.

\subsection{The 1951 Refugee Convention}

\subsubsection{Text and context}

The point of departure for this study on asylum is the Refugee Convention. Drafted in the aftermath of the Second World War, the Refugee Convention, regardless of whether an asylum applicant is considered to be vulnerable, is the cornerstone of the international refugee protection regime.

The Refugee Convention is grounded in Article 14(1) of the UDHR, which sets out that 'everyone has the right to seek and to enjoy in other countries asylum from persecution'. The wording in the original text of the UDHR entailed that 'everyone has the right to seek and be granted, in other countries, asylum from persecution. A number of States opposed the obligation to grant asylum to persons seeking asylum. Hence, the drafters replaced the words 'and be granted' by 'and to enjoy'. The question of asylum can be traced back to ancient writers such as Grotius. Although Grotius was not of the opinion that everybody had a right to asylum, he stated that 'a permanent residence ought not to be denied to foreigners who, expelled from their homes, are seeking refuge, provided that they submit themselves to the established government and observe any regulations which are necessary to avoid strife'.$^{72}$ Contemporary experts such as Goodwin-Gill and McAdam point out that 'while individuals may not be able to claim a 'right to asylum', States have a duty under international law not to obstruct the individual's right to seek asylum. ${ }^{73}$ Currently, Article 12(3) of the African Charter on Human and Peoples' Rights and Article 18 of the EU Charter of Fundamental Rights are the only instruments stipulating 'the right to asylum'.

The Refugee Convention was adopted by the UN General Assembly on 10 December 1950 and entered into force on 22 April 1954. The 1967 New York

72 Grahl-Madsen, A., The Status of Refugees in International Law, Volume II, Asylum, Entry and Sojourn, A. W. Slijthoff-Leiden, 1972, p. 13.

73 Goodwin-Gill, G., and McAdam, J., The Refugee in International Law, Oxford University Press, 2007, pp. 358-362. 
Protocol attached to the Refugee Convention removed the geographical and temporal limits. Hence, the Refugee Convention provided universal coverage. ${ }^{74}$ Currently, 142 States are Parties to the Refugee Convention and the 1967 New York Protocol, including all EU Member States. ${ }^{75}$ Four States Parties still maintain a geographical limitation to the Refugee Convention. ${ }^{76}$

The object and purpose of the Refugee Convention can be traced, in addition to the text, to its preamble. According to the Preamble the aim of the Refugee Convention is to protect the fundamental human rights of refugees. ${ }^{77}$

The Refugee Convention lays down details for the refugee status and the assessment of who is a refugee. The Convention rights should be applied without discrimination as to race, religion, country of origin or sex, age and disability. The Refugee Convention does not provide a definition of who should be deemed vulnerable. The only implicit reference to a vulnerable group made in the Refugee Convention is the recommendation to take the necessary measures for the protection of refugee families, in particular to guarantee family unity and the protection of (unaccompanied) minors. ${ }^{78}$

Furthermore, the Refugee Convention does not explicitly stipulate which procedures Contracting States have to adopt for determining refugee status. States are given leeway to implement procedures that they assume are suitable. ${ }^{79}$ The key provision of the Refugee Convention is Article 1A(2) of the Refugee Convention, which specifies the definition of a refugee:

'For the purposes of the present Convention, the term "refugee" shall apply to any person who (...) owing to a well- founded fear of being persecuted for reasons of race, religion, nationality, membership of a particular social group or political opinion, is out- side the country of his nationality and is unable or, owing to such fear, is unwilling to avail himself of the protection of that country; or who, not having a nationality and being outside the country of his former habitual residence as a result of such events, is unable or, owing to such fear, is unwilling to return to it.'

74 Introductory note UNHCR, Refugee Convention, p. 2.

75 State Parties to the 1951 Convention relating to the Status of Refugees and 1967 Protocol: http://www.unhcr.org/3b73b0d63.html (last visited December 2016).

76 Turkey, Congo, Monaco and Madagascar.

77 Battjes, H., European Asylum Law and International Law, Martinus Nijhoff Publishers, 2006, p. 460.

78 The Refugee Convention, Final Act of the Conference recommendation B (principle of unity of the family).

79 UNHCR Handbook and Guidelines on Procedures and Criteria for Determining Refugee Status under the 1951 Convention and the 1967 Protocol Relating to the Status of Refugees, December 2011, HCR/1P/4/ENG/REV. 3, para. 189. 
Article $1 \mathrm{~A}(2)$ of the Refugee Convention provides a general definition of the refugee. The following four elements are important: ${ }^{80}$

- The person is outside the country of nationality;

- Unable or, owing to such fear, is unwilling to avail himself or herself of the protection of that country;

- Owing to a well-founded fear of being persecuted; and

- For reasons of race, religion, nationality, political opinion or membership of a particular social group.

The term 'persecution' is considered the central element for the definition of refugee status. Although, the Refugee Convention does not provide a definition of 'persecution', the term includes severe human rights violations. In addition, the persecution that is feared must be related to reasons of 'race, religion, nationality, political opinion or membership of a particular social group'.

In addition, the Refugee Convention provides rules when the refugee status ceases. For example, when the person has acquired a new nationality and receives protection of the country of his new nationality. ${ }^{81}$ The Refugee Convention also includes exclusion clauses. For instance, the refugee status does not apply to Palestinian refugees who receive protection from UN agencies. ${ }^{82} \mathrm{Sec}-$ ondly, the Refugee Convention does also not apply to persons who are 'recognized by the competent authorities of the country in which they have taken residence as having the rights and obligations which are attached to the possession of the nationality of that country' ${ }^{83}$ Finally, persons for whom there are serious reasons for considering that they committed a crime against peace, a war crime, or a crime against humanity, or a serious non-political crime before admission to that country of refuge or have been guilty of acts contrary to the purposes and principles of the United Nations are excluded from refugee protection. ${ }^{84}$

Which rights are granted to a refugee in accordance with the Refugee Convention? Next to basic rights, the Refugee Convention ensures several civil and socio-economic rights to refugees. ${ }^{85}$ However, these rights are not accorded to

80 See for a more detailed analysis Goodwin-Gill, G., The International Law of Refugee Protection, E. Fiddian-Qasmiyeh, G. Loescher, K. Long, and N. Sigona (eds.), The Oxford Handbook of Refugee and Forced Migration Studies, Oxford, OUP, 2014, pp. 36-47; Zimmerman, A. and Mahler, C., Article 1A, para. 2, The 1951 Convention Relating to the Status of the Refugees and its 1967 Protocol - A Commentary, Oxford, OUP, 2011, pp. 280-479.

81 Article 1C(2) of the Refugee Convention.

82 Article 1D of the Refugee Convention.

83 Article 1E of the Refugee Convention.

84 Article $1 \mathrm{~F}$ of the Refugee Convention.

85 Articles 2-34 of the Refugee Convention. Hathaway, J., The Rights of Refugees under International Law, Cambridge University Press, 2005, p. 94. 
all persons who fulfil the refugee definition. According to Hathaway, refugees acquire more rights as their relationship with the country of asylum increases. The Refugee Convention differentiates between five types of refugees with different attached rights: first, refugees, regardless of their legal status; secondly, refugees who are 'physically present' in the territory of the State; thirdly, refugees who are 'lawfully present' in a State; fourthly, refugees who are 'lawfully staying' in a State; and lastly, refugees who are 'durably resident' in the country of asylum. ${ }^{86}$ The fundamental right applicable to any refugee is the prohibition of refoulement.

\subsubsection{Non-refoulement}

The Refugee Convention does not include 'a right to asylum', however, States should prevent individuals from being exposed to persecution, torture or inhumane treatment when they are returning an individual to a third country, including denying the entry of persons fleeing from persecution at the border. ${ }^{87}$ The prohibition of refoulement was first enshrined in Article 3(2) of the Convention relating to the International Status of Refugees of 28 October 1933.88 The principle of non-refoulement is currently laid down in Article 33(1) of the Refugee Convention:

'No Contracting State shall expel or return ("refouler") a refugee in any manner whatsoever to the frontiers of territories where his life or freedom would be threatened on account of his race, religion, nationality, membership of a particular social group or political opinion.'

The prohibition of refoulement represents the most important principle under the Refugee Convention. This fundamental principle applies to all persons in the context of refugee and human rights law. States have the obligation not to remove a refugee to a territory where his life or freedom is threatened. However, a refugee who constitutes a threat to the society or who has been convicted of a serious crime may also no longer claim protection against refoulement. ${ }^{89}$ In addition to the negative obligation to abstain from removing a person

86 Hathaway, J., Refugees and Asylum, 2012, pp. 191-192. See for a more detailed analysis Hathaway, J., The Rights of Refugees under International Law, Cambridge University Press, 2005, p. $514 \mathrm{ff}$.

87 Kritzman-Amir, T. and Spijkerboer, T., On the Morality and Legality of Border: Border Policies and Asylum Seekers, Harvard Human Rights Journal, Volume. 26, Issue 1, 2013, pp. 5-15.

88 Grahl-Madsen, A., The Status of Refugees in International Law, Volume II, Asylum, Entry and Sojourn, A. W. Slijthoff - Leiden, 1972, p. 93.

89 Article 33(2) of the Refugee Convention. See also Zimmerman, A., The 1951 Convention Relating to the Status of Refugees and its 1967 Protocol - A Commentary, Oxford University Press, 2011, p. 1413. 
to a country where he faces the risk of being subjected to serious harm, the prohibition on refoulement may also have a positive obligation for the State. This implies that States may also be obliged to take measures in order to ensure that individuals seeking protection are not removed to a territory where they have a risk of being subjected to human rights violations..$^{90}$ Next to the Refugee Convention, the prohibition of refoulement has also been enshrined in various international human rights instruments such as Article 3 of the CAT and Article 7 of the ICCPR and as well in non-binding declarations. ${ }^{91}$

\subsubsection{Interpretation}

Relevant soft law, such as the ExCom Conclusions submit that children, in particular unaccompanied children, are particularly vulnerable because of their dependency to their parents, they are physically less capable to cope with diseases, malnutrition or to deal with deprivation of basis needs. ${ }^{92}$ Other groups that are addressed as having specific needs and are at greater risk of abuse, exploitation, discrimination, sexual and gender-based violence and also may be deprived from services are refugees with disabilities ${ }^{93}$ and refugee women. Although the latter group is not expressly addressed as particularly vulnerable, the ExCom Conclusion does state that women and girls in the refugee context are facing particular challenges related to, inter alia, their gender and socio-economic position that may hinder them more than men to exercise their rights. Hence, specific support is required for refugee women in order for them to enjoy protection. ${ }^{94}$

90 Wouters, K., International Legal Standards for the Protection from Refoulement, Intersentia, 2009, p. 29.

91 Regional instruments establishing the prohibition of refoulement are inter alia the 1969 OAU Convention Governing the Specific Aspects of Refugee Problems in Africa (Article II(3)); the 1969 American Convention on Human Rights (Article 22(8)); the 1981 African Charter of Human and Peoples' Rights (Article 12(3)); the 1889 Montevideo Treaty on International Penal Law (Article 16 and 20). The Declarations reflecting the nonrefoulement principle are embodied in inter alia the 1967 Declaration on Territorial Asylum; the 1984 Cartagena Declaration; the Declaration on the Protection of All Persons from Enforced Disappearance; the 2005 Council of Europe Convention on Action against Trafficking in Human Beings. See for a more detailed analysis Goodwin-Gill, G., and McAdam, J., The Refugee in International Law, Oxford University Press, 2007, pp. 208-215.

92 ExCom Conclusion, Policy on Refugee Children, 6 August 1993, EC/SCP/82, paras. 9-15. See also ExCom Conclusion, Children at Risk No. 107 (LVIII) - 2007, 5 October 2007, No. 107 (LVIII) - 2007.

93 ExCom Conclusion, Refugees with disabilities and other persons with disabilities protected and assisted by UNHCR No. 110 (LXI) - 2010, 12 October 2010, No. 110 (LXI) - 2010.

94 ExCom Conclusion, Women and Girls at Risk No. 105 (LVII) - 2006, 6 October 2006, No. 105 (LVII) - 2006. 
According to the UNHCR Handbook, applicants for refugee status are in a 'particularly vulnerable situation' because of the situation in which they find themselves, namely they are in a foreign country and due to language barriers they may have troubles understanding the procedural aspects of submitting an asylum application..$^{95}$ Their vulnerability stems not from inherent factors but instead vulnerability is linked to the situation. In addition, the Handbook recognizes that applicants may have specific needs that need to be identified during the asylum process. The distinction between the notions of vulnerability and special needs is not always clearly used by the UNHCR. For example, the Procedural Standards for Refugee Status Determination of the UNHCR indicates a list of applicants who may be vulnerable or applicants who have special needs. In addition, two recommendations are put forward by the UNHCR. First, applicants with vulnerabilities or special needs should be given priority during the reception and registration procedure. Second, those who work with vulnerable applicants or applicants with special needs should be trained in counselling. Counselling should include identifying the needs of the applicant and to further assist the applicant during the refugee status procedure. ${ }^{96} \mathrm{Al}$ though I agree with their recommendations, the UNHCR does not, however, make clear what they mean with the notion's vulnerability or special needs, which, in my view, create conceptual uncertainty. The UNHCR Procedural Standards considers the following groups to be either vulnerable or having special needs:

Table 2.1. UNHCR: categories of applicants 'who may be vulnerable or have special needs'97

\begin{tabular}{|l|}
\hline$>$ Persons Manifestly in Need of Protection Intervention \\
\hline$>$ Victims of Torture and Persons Suffering from Trauma \\
\hline$>$ Women with Special Needs \\
\hline$>$ Certain Child Applicants (under 18 years) and Unaccompanied \& \\
Separated Children \\
\hline$>$ Elderly Asylum Seekers \\
\hline$>$ Disabled Asylum Seekers \\
\hline$>$ Asylum Seekers who Require Medical Assistance \\
\hline
\end{tabular}

95 UNHCR, Handbook and Guidelines on Procedures and Criteria for Determining Refugee Status under the 1951 Convention and the 1967 Protocol Relating to the Status of Refugees, December 2011, HCR/1P/4/ENG/REV. 3, para. 190.

96 UNHCR, Procedural Standards for Refugee Status Determination under UNHCR's Mandate, 20 November 2003, para. 3.4.1.

97 UNHCR, Procedural Standards for Refugee Status Determination under UNHCR's Mandate, 20 November 2003, para. 3.4.1. 
In resettlement, the notion of vulnerability is important aspect of the resettlement policy. The UNHCR Resettlement Handbook states that the following groups may require resettlement intervention based on their vulnerabilities:

1) Women and girls are particularly vulnerable because conflicts increase violence against women and girls. Sexual and gender-based violence are one of the harms experienced by refugee women and they may be more vulnerable than other refugees;

2) Children are particularly vulnerable because they are more susceptible to malnutrition and diseases. The lack of resources that is experienced by refugees a greater impact on the physical and psychological condition of refugee children;

3) Older refugees are particularly vulnerable in the refugee context because they are susceptible to physical, sexual and psychological abuse;

4) Persons with disabilities are particularly vulnerable because they may face discrimination, exploitation and violence, and they may face obstacles in accessing protection facilities. Children with disabilities are at greater risk of experiencing abuse, exploitation and a range of other harms;

5) LGBTI refugees are particularly vulnerable because they are experience various types of harms and discrimination;

6) Refugees from minority and indigenous groups are considered particularly vulnerable because their position as a minority in society may place them at risk of marginalization, discrimination and abuse..$^{98}$

\subsection{The International Covenant on Civil and Political Rights}

\subsubsection{Text and context}

The ICCPR was adopted in 1966 and entered into force in 1976. The Covenant has two Optional Protocols, ${ }^{99}$ which include an individual complaint mechanism respectively abolishing the death penalty. According to Article 2(1) State parties are required to guarantee to all individuals within their territory and jurisdiction the rights enshrined in the ICCPR without any distinction of 'race, colour, sex, language, religion, political or other opinion, national or social origin, property, birth or other status.'

The Covenant provides a range of civil and political rights. For example, Article 7 contains the prohibition of torture and aims to protect the dignity, physi-

98 UNHCR, Resettlement Handbook, 2011, pp. 182-201.

99 UN General Assembly, Optional Protocol to the International Covenant on Civil and Political Rights, 19 December 1966, United Nations, Treaty Series, vol. 999, p. 171 and UN General Assembly, Second Optional Protocol to the International Covenant on Civil and Political Rights, Aiming at the Abolition of the Death Penalty, 15 December 1989, A/RES/44/128. 
cal and mental integrity of every individual. ${ }^{100}$ Another noteworthy provision is Article 9 on the right to liberty and security of person. The provision requires that no person shall be deprived of his liberty 'except on such grounds and in accordance with such procedures as are established by law.' In addition, persons who are arrested or detained shall have the right to be informed of the reasons of their arrest, be promptly brought before a judge and to access court proceedings. Where persons are unlawfully arrested or detained, they shall have a right to compensation. Article 13 protects aliens lawfully residing in the territory of a State Party from being expelled without a decision reached in accordance with law. Other significant fundamental rights include, inter alia, the equality before the courts for all persons, the freedom of thought, conscience and religion and the freedom of association with others.

The ICCPR expressly mentions two groups that need enhanced protection. First, Article 3 requires that State parties take all necessary steps to ensure equality between men and women in the enjoyment of the Covenant rights. 101 The ICCPR has included women in order to protect them from sex-based discrimination that impedes their enjoyment of civil and political rights. 102 In addition, in Article 6(5) the prohibition of the death penalty against pregnant women is laid down and Article 23(2) enshrines the right of women of marriageable age to marry.

Another group that is explicitly protected in the ICCPR concerns children. Article 24 explicitly requires that children are protected against discrimination as to 'race, colour, sex, language, religion, national or social origin, property or birth.' State parties are mandated to implement special protective measures to ensure that children enjoy the rights provided in the Covenant. This protection is required by their status as minors. ${ }^{103}$

\subsubsection{Interpretation}

There are a few examples where the Human Rights Committee mentions the term vulnerable in its General Comments. First, in its General Comment on the interpretation of Article 7 of the ICCPR (prohibition of torture) the Human

100 UN Human Rights Committee (HRC), CCPR General Comment No. 20: Article 7 (Prohibition of Torture, or Other Cruel, Inhuman or Degrading Treatment or Punishment), 10 March 1992, para. 2.

101 UN Human Rights Committee (HRC), CCPR General Comment No. 28: Article 3 (The Equality of Rights Between Men and Women), 29 March 2000, CCPR/C/21/Rev.1/ Add.10, para.3.

102 Nifosi-Sutton, I., The Protection of Vulnerable Groups under International Human Rights Law, Routledge, 2017, p. 29.

103 UN Human Rights Committee (HRC), CCPR General Comment No. 17: Article 24 (Rights of the Child), 7 April 1989, paras.1-5. 
Rights Committee expresses that State parties should provide detailed information to guarantee the special protection of particularly vulnerable persons. 104 Second, in the General Comment on the deprivation of liberty, the Human Rights Committee addressed the situation of vulnerable persons in detention and pointed out that State parties have 'a positive obligation towards persons who are particularly vulnerable because of their status as persons deprived of liberty'. ${ }^{105}$ This means, in my view, that persons in detention should be considered as particularly vulnerable. Third, the Human Rights Committee considers women who find themselves in an armed conflict as particularly vulnerable. 106 The General Comment does, however, not explain why women are particularly vulnerable under these circumstances. Only that State parties should take measures to protect women from rape and other forms of gender-based violence. I interpret this as follows: women are particularly vulnerable to multiple forms of gender-based harm during an armed conflict. Fourth, the Committee takes the view that State parties should not only guarantee an effective protection of the Covenant rights but also guarantee that persons have effective remedies to vindicate those rights. These remedies should take the vulnerability of certain persons into account, especially that of children. ${ }^{107}$ In brief, although the Human Rights Committee in its General Comments does provide some examples as to who may be deemed vulnerable in the context of the ICCPR, however, it remains, unclear why certain groups are presumed to be particularly vulnerable.

\subsection{The International Covenant on Economic, Social and Cultural Rights}

\subsubsection{Text and context}

The ICESCR together with the ICCPR and the UDHR represent the International Bill of Human Rights. The ICESCR was adopted in 1966 and entered into force in 1976.

104 UN Human Rights Committee (HRC), CCPR General Comment No. 20: Article 7 (Prohibition of Torture, or Other Cruel, Inhuman or Degrading Treatment or Punishment), 10 March 1992, para. 11.

105 UN Human Rights Committee (HRC), CCPR General Comment No. 21: Article 10 (Humane Treatment of Persons Deprived of Their Liberty), 10 April 1992, para. 3.

106 UN Human Rights Committee (HRC), CCPR General Comment No. 28: Article 3 (The Equality of Rights Between Men and Women), 29 March 2000, CCPR/C/21/Rev.1/ Add.10, para. 8 .

107 UN Human Rights Committee (HRC), General Comment no. 31 [80], The nature of the general legal obligation imposed on States Parties to the Covenant, 26 May 2004, CCPR/C/21/Rev.1/Add.13, para. 15. 
Article 2(1) requires State parties 'to use all the means at their disposal to give effect to the rights recognized in the Covenant'. ${ }^{108}$ In addition, Article 2(2) specifies that State parties are obliged to ensure that the Covenant rights will be implemented without discrimination based on race, colour, sex, language, religion, political or other opinion, national or social origin, property, birth or other status. The Covenant provides in Article 6-15 several economic, social and cultural rights, such as the right to work; the right to form trade unions; the right to an adequate standard of living for everyone, including adequate food, clothing and housing; the enjoyment of the highest attainable standard of physical and mental health; and the right to education. Furthermore, the Committee has pointed out that the ICESCR may also have an effect outside the territorial scope of State parties. 109

Two groups are expressly protected under the Covenant, namely women and children. As regards women, in particular, Article 7(a)(i) provides that State parties should ensure that women are "guaranteed conditions of work not inferior to those enjoyed by men, with equal pay for equal work'. Children are explicitly mentioned in Article 10(3), which stipulates specific requirements that State parties should undertake, such as special protective measures 'on behalf of children and young persons without any discrimination for reasons of parentage or other conditions' and that 'children and young persons should be protected from economic and social exploitation.'

\subsubsection{Interpretation}

The Committee on Economic, Social and Cultural Rights has adopted two views under the Optional Protocol to the ICESCR that are relevant to the notion of vulnerability. The first relevant view issued concerned a divorced older woman with serious health problems living in poverty. She claimed that the State had violated her right to social security under Article 9 of the ICESCR because her application for retirement was denied. The Committee takes the view that the older woman is particularly vulnerable to discrimination compared to other the general population because of her social-economic position, her health issues and the multiple forms of discrimination she experienced. ${ }^{110}$ The

108 UN Committee on Economic, Social and Cultural Rights (CESCR), General Comment No. 9: The domestic application of the Covenant, 3 December 1998, E/C.12/1998/24, para. 2.

109 Coomans, F., The Extraterritorial Scope of the International Covenant on Economic, Social and Cultural Rights in the Work of the United Nations Committee on Economic, Social and Cultural Rights, Human Rights Law Review, Volume, 11, Issue 1, 1 March 2011, pp. 1-35.

110 UN Committee on Economic, Social and Cultural Rights, Views adopted by the Committee under the Optional Protocol to the Covenant concerning, Marcia Cecilia Trujillo 
approach of the Committee in this case is welcome since it shows that the notion of vulnerability is layered and the Committee explains the factors that make the older woman particularly vulnerable to discrimination than other women or men in comparable circumstances.

The other case concerned a family with two minor children who were forcibly evicted from their house without having alternative accommodation. The persons concerned claimed that the State violated their rights under Article 11(1) of the ICESCR. The Committee issued the view that under such circumstances State parties should be more vigilant concerning evictions that 'involve women, children, older persons, persons with disabilities or other vulnerable individuals or groups who are subjected to systemic discrimination.' The Committee concluded that State party had violated Article 11(1) of the ICESCR and recommended 'to ensure that evicted persons have alternative housing, especially in cases involving families, older persons, children and/or other persons in vulnerable situations'.111 By contrast, the Committee in this particular case has drafted a list of groups deemed to be particularly vulnerable when they are confronted with forced eviction, however, without considering the sources of vulnerability.

In its General Comments, the Committee touches upon the notion of vulnerability of individuals and groups or disadvantaged and later marginalized groups various times. For example, the Committee has considered, inter alia, persons with disabilities as a vulnerable group. ${ }^{112}$ Especially in the context of forced eviction, the following groups are considered vulnerable: 'women, children, youth, older persons, indigenous people, ethnic and other minorities, and other vulnerable individuals and groups'. With regard to the right of adequate housing, the Committee considers women are particularly vulnerable because they suffer from multiple forms of discrimination that occur in relation to property rights. ${ }^{113}$ Children are considered particularly vulnerable to forced labour and other forms of exploitation where there is a shortage of educational opportunities for them. ${ }^{114}$

Calero v Ecuador, Communication No. 10/2015, 26 March 2018.

111 UN Committee on Economic, Social and Cultural Rights, Views adopted by the Committee under the Optional Protocol to the International Covenant on Economic, Social and Cultural Rights with regard to Mohamed Ben Djazia and Naouel Belliliv Spain, Communication No. 5/2015, 20 June 2017.

112 UN Committee on Economic, Social and Cultural Rights (CESCR), General Comment No. 5: Persons with Disabilities, 9 December 1994, E/1995/22.

113 UN Committee on Economic, Social and Cultural Rights (CESCR), General Comment No. 7: The right to adequate housing (Art.11.1): forced evictions, 20 May 1997, E/ 1998/22, para. 10.

114 UN Committee on Economic, Social and Cultural Rights (CESCR), General Comment No. 11: Plans of Action for Primary Education (Art. 14 of the Covenant), 10 May 1999, 
As regards accessibility of food, the Committee identifies, inter alia, the following groups as vulnerable: 'infants and young children, elderly people, the physically disabled, the terminally ill and persons with persistent medical problems, including the mentally ill.' ${ }^{115}$ In several other General Comments, the Committee refers to 'the most vulnerable' without defining who these most vulnerable groups are. ${ }^{116}$ Other groups that are, inter alia, deemed vulnerable are: 'ethnic minorities and indigenous populations, women, children, adolescents, older persons, persons with disabilities and persons with HIV/aids'. ${ }^{117}$ In relation to the right to social security, refugees, stateless persons and asylum applicants, and 'other disadvantaged and marginalized individuals and groups' are deemed vulnerable. ${ }^{118}$

What are the legal implications owed to particularly vulnerable groups? $\mathrm{Ni}$ fosi-Sutton submits that State parties to the Covenant are obliged to provide a level of protection that reduces the vulnerability and to guarantee that vulnerable groups have access to the Covenant without any form of discrimination. ${ }^{119}$ The Committee in its General Comments applies a very broad understanding of vulnerable groups in relation to the topic being addressed. Certain individuals and groups are addressed in the General Comments without explaining why they are vulnerable and vulnerable to what. At times the Committee refers to 'the most vulnerable' groups without indicating which groups qualify as the most vulnerable or refers to disadvantaged/marginalized groups. To bring more clarity, it would be advisable to explain the differences in terminological terms. This approach suggests that the Committee has not developed a nuanced definition of vulnerability, which is not helpful for State parties to determine an

E/1992/23, para. 4.

115 UN Committee on Economic, Social and Cultural Rights (CESCR), General Comment No. 12: The Right to Adequate Food (Art. 11 of the Covenant), 12 May 1999, para. 13.

116 UN Committee on Economic, Social and Cultural Rights (CESCR), General Comment No. 13: The Right to Education (Art. 13 of the Covenant), 8 December 1999, E/C.12/1999/10, para. 6; UN Committee on Economic, Social and Cultural Rights (CESCR), General Comment No. 14: The Right to the Highest Attainable Standard of Health (Art. 12 of the Covenant), 11 August 2000, E/C.12/2000/4, para. 12; UN Committee on Economic, Social and Cultural Rights (CESCR), General Comment No. 15 : The Right to Water (Arts. 11 and 12 of the Covenant), 20 January 2003, E/C.12/ 2002/11, para. 60 .

117 UN Committee on Economic, Social and Cultural Rights (CESCR), General Comment No. 14: The Right to the Highest Attainable Standard of Health (Art. 12 of the Covenant), 11 August 2000, E/C.12/2000/4, para. 12.

118 UN Committee on Economic, Social and Cultural Rights (CESCR), General Comment No. 19: The right to social security (Art. 9 of the Covenant), 4 February 2008, E/C.12/GC/19, para. 38.

119 Nifosi-Sutton, I., The Protection of Vulnerable Groups under International Human Rights Law, Routledge, 2017, pp. 147-150. 
adequate response to reduce the vulnerability of persons and protect the 'most vulnerable’.

\subsection{The Convention on the Elimination of All Forms of Discrimina- tion against Women}

\subsubsection{Text and context}

The CEDAW including its Optional Protocol establishes the international rights of women and the fundamental principle of non-discrimination against women. The Convention was adopted in 1979 and entered into force in 1981. The CEDAW is a specific UN human rights treaty that has been adopted to enhance the situation of women for the purposes of ensuring them to enjoy the fundamental human rights on an equal basis with men.

The general obligations for State parties are enshrined in Articles 1-5. Article 2 of the CEDAW and have been referred to as the very core of the CEDAW and as being essential to the full implementation by State parties. Article 2 requires State parties to condemn discrimination against women in all its forms and to take all appropriate legislative measures to ensure the implementation of this principle. The CEDAW supports the realization of equality between women and men and the full enjoyment of human rights for women in all public and private spheres, irrespective of their nationality, citizenship or legal status. 120

Articles 6-16 include the specific obligations for State parties in order to effectuate the equality between men and women in terms of human rights. The Convention includes, inter alia, the following obligations for State parties: to suppress all forms of women and sexual exploitation of women; eliminate discrimination against women in the political and public life; the right to acquire, change or retain their nationality; eliminate discrimination against women in the field of education, employment, healthcare, economic and social life and equality with men before the law.

\subsubsection{Interpretation}

The Committee on the Elimination of Discrimination against Women has used in various General Recommendation the notions of vulnerable, vulnerability and vulnerable groups in relation to the rights enshrined in the CEDAW. For example, in General Recommendation No. 18, disabled women are mentioned as vulnerable, however, no explanation is provided as to why they should be

120 Freeman, M., Chinkin, C. and Rudolf, B., The UN Convention on the Elimination of All Forms of Discrimination against Women, A Commentary, Oxford University Press, 2012, pp. 2-18. 
deemed vulnerable. The only indication that is provided is that disabled women suffer from 'a double discrimination linked to their living conditions'. ${ }^{121}$ In the General Recommendation on violence against women, the Committee refers to prostitutes who are especially vulnerable because 'their status, which may be unlawful, tends to marginalize them.'

Nifosi-Sutton notes that the notion of vulnerability in the General Recommendations is used in two ways: firstly, to describe the susceptibility of women to violence, abuse and exploitation; and secondly, vulnerability has legal implications. This means that State parties are required to adopt specific measures to improve the situation of women. ${ }^{122}$ For example, on the right of girls and women to education, vulnerable or disadvantaged groups entail the following groups: ethnic minority and indigenous groups, refugees, asylum applicants, Stateless persons, undocumented persons, internally displaced persons and migrants, persons with disabilities and LBTI persons. The Committee recommends State parties to take measures to guarantee the right of vulnerable groups to education. ${ }^{123}$ In General Recommendation No. 27, the Committee submits that older women are considered particularly vulnerable because they are susceptible to exploitation and abuse. In addition, State parties should ensure that older women are included in rural and urban development planning and State parties should 'appropriate gender- and age-sensitive laws and policies to ensure the protection of older women with refugee status or who are stateless, as well as those who are internally displaced or are migrant workers.' 124

In another General Recommendation, women with mental disabilities are considered particularly vulnerable because they are susceptible to gender discrimination, violence, poverty or other forms of deprivation. State parties should therefore take measures to ensure that health services take into account the needs of women with mental disabilities. ${ }^{125}$ In General Recommendation No. 28, the Committee considers specific groups as particularly vulnerable to discrimination 'through civil and penal laws, regulations and customary law and

121 UN Committee on the Elimination of Discrimination Against Women (CEDAW), General Recommendation, No. 18 on disabled women, 1991.

122 Nifosi-Sutton, I., The Protection of Vulnerable Groups under International Human Rights Law, Routledge, 2017, pp. 94-95.

123 UN Committee on the Elimination of Discrimination Against Women (CEDAW), General Recommendation No. 36, (2017) on the right of girls and women to education 27 November 2017, CEDAW/C/GC/36, paras. 40-46.

124 UN Committee on the Elimination of Discrimination Against Women (CEDAW), General Recommendation No. 27 on older women and protection of their human rights, 16 December 2010, CEDAW/C/GC/27, para. 27 and paras. 49-50.

125 UN Committee on the Elimination of Discrimination Against Women (CEDAW), CEDAW General Recommendation No. 24: Article 12 of the Convention (Women and Health), 1999, A/54/38/Rev.1, chap. I, para. 25. 
practices'. The following vulnerable groups are listed: 'groups of women, including women deprived of their liberty, refugees, asylum- seeking and migrant women, stateless women, lesbian women, disabled women, women victims of trafficking, widows and elderly women, are particularly vulnerable to discrimination through civil and penal laws, regulations and customary law and practices.' 126

With regard to asylum, the CEDAW rights have played an important role in combatting gender-related persecution during refugee status determination procedures $^{127}$ The Committee on the Elimination of Discrimination against Women has urged State parties to implement recognized gender-related human rights violations as a basis to grant asylum in the domestic asylum procedures. ${ }^{128}$ The Committee has also called for the removal of legislation or practices that discriminate against women and that in particular asylum seeking women and refugees are vulnerable to discrimination by domestic laws and practices. 129

Furthermore, the Committee has also recommended State parties to address the specific risks and special needs of refugee women. State parties should enable refugee women and girls who are subjected to gender-related persecution to have direct access to medical and legal assistance and to be hosted in a safe setting. ${ }^{130}$

\subsubsection{Women in the asylum process}

It is important to note that female asylum applicants may, like all other women, invoke the rights and fundamental freedoms enshrined in the CEDAW.131 The

126 UN Committee on the Elimination of Discrimination Against Women (CEDAW), General Recommendation No. 28 on the Core Obligations of States Parties under Article 2 of the Convention on the Elimination of All Forms of Discrimination against Women, 16 December 2010, CEDAW/C/GC/2, para. 31.

127 Edwards, A., UNHCR Displacement, Statelessness and Questions of Gender Equality under the Convention on the Elimination of All Forms of Discrimination against Women, August 2009, PPLAS/2009/02, p. 5.

128 Edwards, A., UNHCR Displacement, Statelessness and Questions of Gender Equality under the Convention on the Elimination of All Forms of Discrimination against Women, August 2009, PPLAS/2009/02, p. 18.

129 CEDAW, General recommendation No. 28 on the core obligations of States parties under article 2 of the Convention on the Elimination of All Forms of Discrimination against Women, 16 December 2010, CEDAW/C/GC/28, para. 31.

130 Committee on the Elimination of Discrimination against Women, General Recommendation No. 30 on women in conflict prevention, conflict and post-conflict situations, CEDAW/C/GC/30, 18 October 2013, p. 15/24.

131 Zhen Zhen Zheng $v$ The Netherlands, CEDAW/C/42/D/15/2007, UN Committee on the Elimination of Discrimination Against Women (CEDAW), Communication No. 15/2007, 17 February 2009; N.S.F. v United Kingdom of Great Britain and Northern Ireland, 
rights provided by the CEDAW are applicable to female asylum applicants during all phases of the asylum procedure. ${ }^{132}$

The ExCom Conclusions have repeatedly recognized that refugee women are vulnerable, which makes them subject to physical and sexual violence and discrimination. ${ }^{133}$

To ensure that gender-related asylum claims are taken into consideration by national authorities, the UNHCR has provided procedural guidelines. It is very important, for asylum applicants claiming to be victims of gender-related persecution and who feel ashamed of what happened to them, to create a safe environment in which they feel secure that their claim is examined confidentially. The UNHCR has recommended that:

'female asylum applicants must be interviewed individually and they should be able to submit their own claim to asylum; they should have the choice to be interviewed and interpreted by the same sex; the interviewer should ask questions that can disclose relevant gender-related issues in an asylum procedure; and women who were victims of sexual violence or have experienced other types of trauma might need multiple interviews in order to create a safe environment for the claimant to express their experiences and to collect all the relevant information to establish refugee status. ${ }^{134}$

From the perspective of the UNHCR, the detention of single women and unaccompanied girls should be carefully assessed, as this group is highly vulnerable

CEDAW/C/38/D/10/2005, UN Committee on the Elimination of Discrimination Against Women (CEDAW), Communication No. 10/2005, 12 June 2007; M.P.M. v Canada, CEDAW/C/51/D/25/2010 (CEDAW), Communication No. 25/2010, 24 February 2012; and Guadalupe Herrera Rivera v Canada, CEDAW/C/50/D/26/2010, Communication No. 26/2010, 18 October 2011, (all cases declared inadmissible).

132 Committee on the Elimination of Discrimination against Women, General recommendation No. 30 on women in conflict prevention, conflict and post-conflict situations, CEDAW/C/GC/30, 18 October 2013, pp. 14/24-15/24.

133 ExCom Conclusions, Refugee Women and International Protection, No. 39 (XXXVI) 1985, 18 October 1985, paras. (c) and (d). See also ExCom Conclusions, Refugee Women, No. 60 (XL) - 1989, 13 October 1989; ExCom Conclusions, Refugee Women and International Protection, No. 64 (XLI) - 1990, 5 October 1990; ExCom Conclusions, Refugee Protection and Sexual Violence, No. 73 (XLIV) - 1993, 8 October 1993; ExCom Conclusions, General Conclusion on International Protection, No. 77 (XLVI) - 1995, 20 October 1995, para. (g); and ExCom Conclusions, Women and Girls at Risk, No. 105 (LVII) 2006, 6 October 2006. See also UNHCR, Thematic Compilation of Executive Committee Conclusions, August 2009, 4th edition, pp. 251-252.

134 See for other procedural issues UNHCR, Guidelines on International Protection No. 1: Gender-Related Persecution Within the Context of Article 1A(2) of the 1951 Convention and/or its 1967 Protocol Relating to the Status of Refugees, 7 May 2002, HCR/GIP/02/01, pp. 8-10 and also UNHCR, Sexual and Gender-Based Violence against Refugees, Returnees and Internally Displaced Persons, Guidelines for Prevention and Response, May 2003. 
when they remain in detention. The UNHCR advocates that pregnant women in their final phase of pregnancy and nursing mothers should as far as possible be kept out of detention. If national authorities do detain female asylum applicants, they should be separated from male detainees, except if it is close family members. ${ }^{135}$ Moreover, the UNHCR recommends that female asylum applicants should have access to legal and other services in order to accommodate their special needs. ${ }^{136}$

\subsection{The Convention on the Rights of Persons with Disabilities}

\subsubsection{Text and context}

The CRPD was adopted in 2006 and entered into force in 2008. The aim of the CRPD is to improve and provide specific protection to disabled persons that have been historically excluded in the social domain and discriminated against. The CRPD represents persons with disabilities as rights-holders. ${ }^{137}$ The Convention includes civil and political rights and also socio-economic rights. The definition of persons with disabilities is stipulated in Article 1 of the CRPD, which reads:

'Persons with disabilities include those who have long-term physical, mental, intellectual or sensory impairments which in interaction with various barriers may hinder their full and effective participation in society on an equal basis with others.'

It follows from this definition that disability is a multi-faceted concept. It follows from Article 5(3) that States are required to provide reasonable accommodation in order to promote equality and eliminate discrimination. The definition of 'reasonable accommodation' is according to Article 2 of the CRPD:

'necessary and appropriate modification and adjustments not imposing a disproportionate or undue burden, where needed in a particular case, to ensure to persons with disabilities the enjoyment or exercise on an equal basis with others of all human rights and fundamental freedoms'.

The responsibility to provide reasonable accommodation in the CRPD concerns different actors such as the State, employers, education and health service providers, goods and services providers and private actors. This range of actors should reasonably facilitate the access and participation of persons with dis-

135 UNHCR, Revised Guidelines on Applicable Criteria and Standards relating to the Detention of Asylum-Seekers, 26 February 1999, Guideline 8.

136 UNHCR, Revised Guidelines on Applicable Criteria and Standards relating to the Detention of Asylum-Seekers, 26 February 1999, Guideline 8.

137 For a more detailed analysis see Broderick, A., The Long and Winding Road to Equality and Inclusion for Persons with Disabilities, Intersentia, 2015. 
abilities by amending their policies, practices and buildings. More concretely, reasonable accommodation implies that these actors take positive action to accommodate the special needs of disabled persons. It is to ensure that persons with disabilities have equal access to labour, education, health and an adequate standard of living. ${ }^{138}$

Another key principle of the CRPD is enshrined in Article 9, which indicates that accessibility covers not only the physical environment but also information and communication in order to have equal access to the facilities and services provided to the public. The Committee on the Rights of Persons with Disabilities considered that problems with accessibility to persons with disabilities in detention buildings might give rise to inhuman and degrading treatment. 139

Other specific obligations for State parties include, inter alia, all necessary measures to guarantee the protection and safety of persons with disabilities in humanitarian situations; equal recognition for disabled persons before the law; to ensure that detained disabled persons are treated in compliance with the Convention and provided with reasonable accommodation; persons with disabilities should not be subjected to torture or inhuman or degrading treatment; to protect persons with disabilities from all forms of exploitation, violence and abuse; the right to education and the enjoyment of the highest attainable standard of health without discrimination on the basis of disability; and the right to an adequate standard of living.

\subsubsection{Interpretation}

The CRPD expressly recognizes women and children with disabilities facing multiple discrimination. Although, both groups could be considered as particularly vulnerable because both groups may be susceptible to increased risk of harms in different situations, the General Comments show that the Committee on the Rights of Persons with Disabilities does not expressly use the notion of vulnerability or vulnerable groups. The reason is that the CRPD does not perceive persons with disabilities as vulnerable. Labelling them as vulnerable may lead to stereotyping persons with disabilities.

138 Lord, J., and Brown, R., The Role of Reasonable Accommodation in Securing Substantive Equality for Persons with Disabilities: The UN Convention on the Rights of Persons with Disabilities, Social Science Research Network (SSRN), 2010, p. 5.

139 Office of the High Commissioner for Human Rights, Observations on the Standard Minimum Rules for the Treatment of Prisoners prepared by Committee on the Rights of Persons with Disabilities, 20 November 2013, paras. 3-5. See further General Comment No. 2 (2014), Article 9 Accessibility, Committee on the Rights of Persons with Disabilities Eleventh session 31 March-11 April 2014, CRPD/C/GC/2, 22 May 2014. 


\subsubsection{Disabled persons in the asylum process}

Both the Refugee Convention and the CRPD are relevant to disabled persons in the context of asylum. The UNHCR's ExCom has recognized the adoption of the CRPD through its Conclusion. ${ }^{140}$ Although, the ExCom Conclusion does not explicitly state that the CRPD applies to disabled persons in the asylum process, there is no valid argument to assume that the CRPD only applies to nationals. Both the Refugee Convention and the CRPD are based on the principle of universality and non-discrimination. ${ }^{141}$

Furthermore, the UNHCR has advocated that State parties should make 'reasonable accommodation' or, in the case of the detention of persons with disabilities, to adjust the domestic policy on detention in order to meet the needs and requirements. The general rule should be that asylum applicants with physical, mental, intellectual and sensory disabilities should not be detained. These particular types of vulnerable asylum applicants should be registered and identified as soon as possible in order to prevent detention in an arbitrary manner, and they should be provided with the necessary assistance and accommodation should be adjusted to their specific needs. ${ }^{142}$

As regards applicants suffering from mental disabilities, the UNHCR Handbook prescribes lowering the burden of proof for applicants with mental disabilities. Whenever possible, the decision-maker should acquire expert medical evidence and a medical report with information on the nature and severity of the mental illness and as well as whether the applicant is able to participate during the asylum procedure. The assessment of the refugee status of applicants with mental disabilities should be taken with more attention than normally and there should be more research of background, history and other relevant information. ${ }^{143}$ The UNHCR advocates that applicants with mental disabilities should be examined in order to assess whether they are capable of understanding and submitting the necessary evidence to assess their claim for refugee status and other procedural aspects of the asylum review. In addition,

140 UNHCR Executive Committee (ExCom), Conclusion on refugees with disabilities and other persons with disabilities protected and assisted by UNHCR, Conclusion No 110 (LXI), 12 October 2010.

141 Crock, M., Ernst, C., and McCallum, R., Where Disability and Displacement Intersect: Asylum Seekers and Refugees with Disabilities, International Journal of Refugee Law, Vol. 24, No. 4, 2012, pp. 738-741. See also Conte, C., What about Refugees with Disabilities? The Interplay between EU Asylum Law and the UN Convention on the Rights of Persons with Disabilities, European Journal of Migration and Law, Volume 18, Issue 3, 2016.

142 UNHCR, Guidelines on the Applicable Criteria and Standards relating to the Detention of Asylum-Seekers and Alternatives to Detention, 2012, paras. 9.4-9.5.

143 Handbook on Procedures and Criteria for Determining Refugee Status under the 1951 Convention and the 1967 Protocol relating to the Status of Refugees, HCR/IP/4/Eng/REV.1 Reedited, Geneva, January 1992, UNHCR 1979, paras. 206-212. 
they should acquire counselling as soon as possible during the asylum procedure in order to identify any health or psychological assistance they may need. ${ }^{144}$

The notion of vulnerability is not only used by the UN treaty monitoring bodies but also more frequently by the ECtHR. The next section will first briefly discuss relevant judgments of the ECtHR in relation to particularly vulnerable groups and subsequently assess the ECtHR's approach of vulnerability with regard to asylum applicants.

\subsection{The European Convention on Human Rights}

\subsubsection{Introduction}

The ECHR was adopted in 1950 and entered into force in 1953. All EU Member States are party to the Council of Europe and signatories to the ECHR.145 The ECtHR observes the ECHR. The ECtHR may receive claims both from State parties as from individuals of alleged breach of rights enshrined in the ECHR. Although the ECHR does not enshrine the right to asylum, the ECtHR held in Salah Sheekh that 'the right to political asylum is not contained in either the Convention or its Protocols. However, in exercising their right to expel such aliens, Contracting States must have regard to Article 3 of the Convention which enshrines one of the fundamental values of democratic societies'. ${ }^{146}$ The bulk of case law that has emerged at the ECtHR with respect to the protection of asylum applicants is mostly related to the non-refoulement principle in Article 3 of the ECHR, which reads: 'No one shall be subjected to torture or to inhuman or degrading treatment or punishment.' The protection provided by Article 3 of the ECHR is broader than the protection offered by Article 33(1) of the Refugee Convention since it protects anyone and not just refugees. The CJEU has confirmed in Schmidberger that the prohibition of refoulement in Article 3 ECHR is absolute. ${ }^{147}$ This means that other national interests cannot provide a basis to limit or derogate from this right not to be tortured or ill-treated, including in expulsion and extradition cases. ${ }^{148}$ For example, the expulsion of an asy-

144 UNHCR, Procedural Standards for Refugee Status Determination under UNHCR's Mandate, 20 November 2003, para. 3.4.7.

145 Council of Europe, European Convention for the Protection of Human Rights and Fundamental Freedoms, as amended by Protocols Nos. 11 and 14, 4 November 1950, ETS 5.

146 Salah Sheekh v The Netherlands, Application no. 1948/04, European Court of Human Rights, 11 January 2007, para. 135.

147 Case C-112/00 Eugen Schmidberger, Internationale Transporte und Planzüge and Austria, 12 June 2003, Court of Justice of the European Union, ECLI:EU:C:2003:333, para. 80

148 Battjes, H., In Search of a Fair Balance: The Absolute Character of the Prohibition of Refoulement under Article 3 ECHR Reassessed, Leiden Journal of International Law, 22, p. 584. 
lum applicant to his country of origin where he faces a real risk to human rights violations may breach the prohibition of refoulement as stipulated in Article 3 of the ECHR. The ECtHR in Vilvarajah held:

'Expulsion by a Contracting State of an asylum applicant may give rise to an issue under Article 3, and hence engage the responsibility of that State under the Convention, where substantial grounds have been shown for believing that the person concerned faced a real risk of being subjected to torture or to inhuman or degrading treatment or punishment in the country to which he was returned'. 149

The ECtHR has determined in Bader and Kanbor 150 that the prohibition of refoulement may exist under Article 2 of the ECHR and Articles 1 Protocol No. 6 and Protocol No. 13 of the ECHR and in exceptional cases in Article 6 of the ECHR. ${ }^{151}$

For ill-treatment to fall within the scope of Article 3 of the ECHR, a minimum level of severity must be attained. The assessment of this minimum standard depends on the circumstances of the case. ${ }^{152}$ The committed acts may derive from State actors or non-State actors. However, 'it must be shown that the risk is real and that the authorities of the receiving State are not able to obviate the risk by providing appropriate protection.'153 To invoke the protection provided by Article 3 of the ECHR, an applicant has to demonstrate substantial grounds for believing that he faces a real risk of being subjected to such treatment contrary to Article 3.154 In examining of whether there are substantial grounds for believing that the applicant faces such a real risk, the ECtHR in Mamatkulov and Askarov stated that 'the establishment of such responsibility inevitably involves an assessment of conditions in the requesting country against the standards of Article 3 of the Convention.' ${ }^{155}$ In Chalal, the ECtHR determined that the assessment of the existence of a real risk must be 'a rigor-

149 Vilvarajah and Others $v$ the United Kingdom, Application no. 13163/87, 13164/87, 13165/87, 13447/87, 13448/87, European Court of Human Rights, 30 October 1991.

150 Bader and Kanbor $v$ Sweden, Application no. 13284/04, European Court of Human Rights, 8 November 2005, para. 42.

151 Boeles, P., den Heijer, M., Lodder, G., and Wouters, K., European Migration Law, Intersentia, 2009, p. 297.

152 Hilalv the United Kingdom, Application no. 45276/99, European Court of Human Rights, 6 March 2001, para. 60.

153 H.L.R. v France, Application no. 24573/94, European Court of Human Rights, 29 April 1997, para. 40.

154 N.v Finland, Application no. 38885/02, European Court of Human Rights, 26 July 2005.

155 Mamatkulov and Askarov v Turkey, Application no. 46827/99 and 46951/99, European Court of Human Rights, 4 February 2005, para. 67. 
ous one'. ${ }^{156}$ According to the ECtHR, the focus of the risk assessment should be on the foreseeable consequences of the removal. This removal must be assessed in the light of the general situation of the country of destination and the personal circumstances of the applicant. 157 The principle of non-refoulement is also enshrined in Article 4 and Article 19(2) of the Charter, which has the same meaning and scope as Article 3 of the ECHR. ${ }^{158}$

The ECtHR has addressed the prohibition of (in)direct refoulement in M.S.S. respectively in Hirsi Jamaa. In M.S.S., the ECtHR determined that Belgium had infringed the prohibition of direct refoulement because the Belgian authorities by transferring the applicant to Greece knowingly exposed the applicant to conditions of detention and living conditions that amounted to degrading treatment as enshrined in Article 3 of the ECHR. ${ }^{159}$ Hirsi Jamaa is a rich judgment with great implications on the protection of asylum applicants intercepted at sea. ${ }^{160}$ In Hirsi Jamaa, the ECtHR dealt amongst others with the possibility of indirect refoulement of irregular migrants intercepted at sea. ${ }^{161}$ The ECtHR decided that by sending the applicants to Libya, Italy had violated Article 3 of the ECHR because it exposed the applicants to the risk of arbitrary repatriation. In addition, the ECtHR added that Contracting States should:

'ensure that the placement in a detention facility of those intercepted - always excluding minors and vulnerable categories - regardless of their status, is authorized by the judicial authorities and occurs only where necessary and on grounds prescribed by law, that there is no other suitable alternative and that such placement conforms to the minimum standards and principles'. ${ }^{162}$

156 Chahal $v$ the United Kingdom, Application no. 22414/93, European Court of Human Rights, 15 November 1996, para. 96.

157 N.A. $v$ the United Kingdom, Application no. 25904/07, European Court of Human Rights, 17 July 2008, para. 113; Vilvarajah and Others $v$ the United Kingdom, Application no. 13163/87, 13164/87, 13165/87, 13447/87, 13448/87, European Court of Human Rights, 30 October 1991, para. 108. See Boeles, P., den Heijer, M., Lodder, G., and Wouters, K., European Migration Law, Intersentia, 2009, pp. 298-299.

158 See Explanations relating to the Charter of Fundamental Rights, (2007/C 303/02).

159 M.S.S. v Belgium and Greece, Application no. 30696/09, European Court of Human Rights, 21 January 2011, para. 367. See also direct and indirect refoulement KrtizmanAmir, T., and Spijkerboer, T., On the Morality and Legality of Borders: Border Policies and Asylum Seekers, Harvard Human Rights Journal, Volume 26, Issue 1, 2013, pp. 15-25.

160 See for a detailed analysis Den Heijer, M., Reflections on Refoulement and Collective Expulsion in the Hirsi Case, International Journal of Refugee Law, Volume 25, No. 2, 2013.

161 Hirsi Jamaa and Others v Italy, Application no. 27765/09, European Court of Human Rights, 23 February 2012.

162 Resolution 1821 (2011) of the Parliamentary Assembly of the Council of Europe, para. 9.8 . 
Additional provisions that are relevant in the context of asylum are Article 8 of the ECHR on the right to respect for private and family life and Article 13 of the ECHR on the right to an effective remedy.

\subsubsection{The notion of vulnerability in the case law of the ECtHR}

In recent years, the literature has identified an emerging vulnerability approach in the case law of the ECtHR. ${ }^{163}$ The notion of 'particularly vulnerable groups' was first developed in cases related to the Roma minority. ${ }^{164}$ The ECtHR has also considered persons with mental disabilities, ${ }^{165}$ people living with HIV166 to be particularly vulnerable groups. In establishing these groups as particularly vulnerable, discrimination, stigmatization and marginalization in the past of these groups seem to play a role. The ECtHR has gradually expanded its list of particularly vulnerable groups to include also asylum applicants. ${ }^{167}$

Another relevant indicator for the ECtHR to consider a person vulnerable is related to applicants who are in detention. The ECtHR held that they are in a vulnerable position. ${ }^{168}$ In addition, the vulnerability of the detained person has to be taken into account in the assessment of detention conditions. For example, In Keenan, the ECtHR has held that in the assessment of the standards of Article 3 of the ECHR, where it concerns persons with mental illnesses and

163 See for a detailed analysis Peroni, L. and Timmer, A., Vulnerable groups: The promise of an emerging concept in European Human Rights Convention law, International Journal of Constitutional Law, 2013.

164 Chapman v the United Kingdom, Application no. 27238/95, European Court of Human Rights, 18 January 2001. See also D.H. and others v The Czech Republic, Application no. 57325/00, European Court of Human Rights, 13 November 2007. Peroni, L. and Timmer, A., Vulnerable groups: The promise of an emerging concept in European Human Rights Convention law, International Journal of Constitutional Law, 2013, p. 1063.

165 Alajos Kiss v Hungary, Application no. 38832/06, European Court of Human Rights, 20 May 2010.

166 Kiyutin v Russia, Application no. 2700/10, European Court of Human Rights, 10 March 2011.

167 M.S.S. v Belgium and Greece, Application no. 30696/09, European Court of Human Rights, 21 January 2011. Peroni, L. and Timmer, A., Vulnerable groups: The promise of an emerging concept in European Human Rights Convention law, International Journal of Constitutional Law, 2013, p. 1064.

168 Shamayev and Others v Georgia and Russia, Application no. 3637802 European Court of Human Rights, 12 October.2005, para. 375. See also Al Tamimi, Y., The Protection of Vulnerable Groups and Individuals by the European Court of Human Rights. Journal européen des droits de l'homme / European Journal of Human Rights, 2016(5), p. 570. See also Timmer, A., A Quiet Revolution: Vulnerability in the European Court of Human Rights, Fineman, M.A., Equality, Autonomy, and the Vulnerable Subject in Law and Politics, Fineman, M.A., and Grear, A., (eds.), Vulnerability: reflections on a new ethical foundation for law and politics, 2013, p. 154. 
persons with disabilities, account should be taken of vulnerability and inability. ${ }^{169}$ In Slawomir, the ECtHR determined that detained persons who suffer from mental disorders are more vulnerable than the average detainee, ${ }^{170}$ and in M.S., the ECtHR held that persons who are mentally ill are considered to be in a position of particular vulnerability. ${ }^{171}$ Hence, State parties are under the obligation to ensure the human dignity of detained persons with mental illnesses and to provide them the necessary treatment.

In several other judgments, the ECtHR has considered certain applicants to be 'particularly vulnerable'. In Sufi and Elmi, the ECtHR held that the forced return of two Somali nationals from the UK to Somalia would amount to a violation of Article 3 of the ECHR. The Court found that 'the conditions in these camps are sufficiently dire to reach the Article 3 threshold.' In respect to the first applicant, the Court held that he would be 'particularly vulnerable on account of his psychiatric illness.'172 Furthermore, for example with regard to elderly people, the ECtHR in Heinisch has recognized the particular vulnerability of elderly people in living in nursing homes. ${ }^{173}$ In Mudric, the ECtHR considered a single woman aged 72 attacked by her former husband as particularly vulnerable. ${ }^{174}$ In Farbtuhs, the applicant who was sent to detention when he was 84 years old and suffering from chronic diseases, complained that his detention amounted to a violation of Article 3 of the ECHR due to his age and infirmity and that the prison conditions did not meet his specific needs. The ECtHR held that the national authorities 'had to be particularly careful to ensure that the conditions of detention were consistent with the specific needs arising out of the prisoner's infirmity'. In the light of his age, infirmity and his physical condition, the continued detention of the applicant constituted therefore a violation of Article 3 of the ECHR. ${ }^{175}$

169 Keenan $v$ the United Kingdom, Application no. 27229/95, European Court of Human Rights, 3 April 2001, para. 111.

170 Slawomir Musial v Poland, Application no. 28300/06, European Court of Human Rights, 5 June 2009, para. 96.

171 M.S. $v$ the United Kingdom, Application no. 24527/08, European Court of Human Rights, 3 August 2012, paras. 39-44 and Dybekuv Albania, Application no. 41153/06, European Court of Human Rights, 18 December 2007, para. 41.

172 Sufi and Elmi $v$ The United Kingdom, Applications nos. 8319/07 and 11449/07, European Court of Human Rights, 28 June 2011, para. 303.

173 Heinisch v Germany, Application no. 28274/08, European Court of Human Rights, 21 July 2011, para. 71.

174 Mudric v The Republic of Moldova, Application no. 74839/10, European Court of Human Rights, 16 July 2013, para. 51.

175 Farbtuhs v Latvia, Application no. 4672/02, European Court of Human Rights, 6 June 2005. 
The ECtHR has also deemed women who are victims of domestic violence as 'particularly vulnerable'. In Opuz, the ECtHR took the view that women subjected to domestic violence may fall within the category of vulnerable individuals because of the violence suffered in the past, the threats received and because of their social background (the vulnerable situation of women in South-East Turkey). ${ }^{176}$ The ECtHR has held in Hajduová and in B. that victims of domestic violence are particularly vulnerable and that active State protection is needed as enshrined in international instruments. ${ }^{177}$ The ECtHR has also recognized women who are in an advanced stage of pregnancy as particularly vulnerable. ${ }^{178}$ Hence, it seems that the ECtHR considers elderly people and women as particularly vulnerable individuals, however, it does not consider them as a vulnerable group per se.

\subsubsection{Vulnerable groups: asylum applicants}

The notion of vulnerability in relation to asylum applicants was first dealt with in the M.S.S. judgment and in which the ECtHR widened its scope with regard to the determination of particularly vulnerable groups. The ECtHR attached 'considerable importance to the applicant's status as an asylum-seeker and, as such, a member of a particularly under-privileged and vulnerable population group in need of special protection'.179

The applicant in M.S.S. was a person who fled Afghanistan and entered into the EU through Greece. Upon entry, the Greek authorities took his fingerprints and subsequently he was detained for a week. In Greece, he did not apply for asylum and after being released, the applicant continued further to Belgium where he claimed asylum with the Belgian Aliens office in 2009. Following a 'hit' in the Eurodac database and on the basis of the Dublin Regulation, the Belgium authorities decided to return him to Greece. When the applicant arrived back in Greece, he was put in detention under appalling conditions. After a couple of days, he was released and was notified to report to the police station in two days where he would be informed about the further procedure of his asylum application. The applicant then decided not to report to the police headquarters in Attica but to leave Greece. However, he was arrested again and de-

176 Opuz v Turkey, Application no. 33401/02, European Court of Human Rights, 9 June 2009, paras. 159-160.

177 Hajduová v Slovakia, Application no. 2660/03, European Court of Human Rights, 30 November 2010, para. 46. B. v The Republic of Moldova, Application no. 61382/09, European Court of Human Rights, 16 July 2013, para. 70.

178 Nechiporuk and Yonkalo v Ukraine, Application no. 42310/04, European Court of Human Rights, 21 April 2011, para. 156.

179 M.S.S. v Belgium and Greece, Application no. 30696/09, European Court of Human Rights, 21 January 2011, para. 251. 
tained in the same dreadful conditions. During this period, the applicant, like many other Afghan asylum applicants, slept in a park in the centre of Athens and had no means of subsistence or access to sanitary facilities. He had spent days trying to get food. The applicant submitted that situation of vulnerability in which he found himself due to the circumstances and as well as the material and psychological deprivation resulted in treatment contrary to Article 3 of the ECHR. ${ }^{180}$

The applicant made a complaint to the ECtHR claiming that both Greece and Belgium had ill-treated him. The applicant alleged that Greece violated Article 3 of the ECHR because of the extreme poverty in which he had to live, and it was in breach of Article 13 of the ECHR because he had not been given an effective remedy by the Greek authorities with regard to Articles 2 and 3 of the ECHR. Belgium was alleged of breaching Articles 2 and 3 of the ECHR and Article 13 of the ECHR for exposing him to conditions of detention and living conditions in Greece and the lack of an effective remedy to challenge his expulsion order. As regards the alleged violations of Article 3 of the ECHR in relation to the detention and living conditions, the ECtHR held:

'in the present case the Court must take into account that the applicant, being an asylum seeker, was particularly vulnerable because of everything he had been through during his migration and the traumatic experiences he was likely to have endured previously'. ${ }^{181}$

According to the ECtHR, Greece violated Article 3 of the ECHR because not only were the detention conditions unacceptable but they had an effect on a person's dignity, and also 'the applicant's distress was accentuated by the vulnerability inherent in his situation as an asylum seeker.' 182

As to the alleged violation of Article 3 of the ECHR by Greece due to the applicant's living conditions in the receiving State, the ECtHR held that the applicant's living conditions, being homeless with no means of subsistence, were of serious concern. The applicant allegedly spent months living in the streets in extreme poverty with no means to take care of the most basic needs such as food, hygiene and a place to live. Moreover, the fear of being attacked and robbed together with no real chance of improving his situation made his situation vulnerable and insecure. Consequently, the ECtHR ruled:

180 M.S.S. v Belgium and Greece, Application no. 30696/09, European Court of Human Rights, 21 January 2011, para. 238.

181 M.S.S. v Belgium and Greece, Application no. 30696/09, European Court of Human Rights, 21 January 2011, para. 232.

182 M.S.S. v Belgium and Greece, Application no. 30696/09, European Court of Human Rights, 21 January 2011, para. 233. 
'that the Greek authorities have not had due regard to the 'applicant's vulnerability as an asylum seeker and thus must be held responsible for their inaction, for the situation in which he has found himself for several months, living in the street, with no resources or access to sanitary facilities, and without any means of providing for his essential needs. ${ }^{.183}$

And further concluded:

'that such living conditions, combined with the prolonged uncertainty in which he has remained and the total lack of any prospects of his situation improving, have attained the level of severity required to fall within the scope of Article 3 of the Convention.' ${ }^{184}$

In essence, the ECtHR held that asylum applicants who are on the territory of a State, but who have no access to reception facilities or placed in administrative detention, should be safeguarded by the State against extreme material poverty. ${ }^{185}$ However, this does not mean that, on the basis of Article 3 of the ECHR, the State has to provide accommodation to everyone on its territory or that it has an obligation to provide refugees with financial assistance so that they can support themselves in a certain standard of living. ${ }^{186}$ Accordingly, the ECtHR found that Greece had violated Article 3 of the ECHR. Belgium in turn had violated the prohibition of direct refoulement because the Belgian authorities by transferring the applicant to Greece knowingly exposed the applicant to conditions of detention and living conditions that amounted to degrading treatment as enshrined in Article 3 of the ECHR. 187

In M.S.S. the applicant was considered particularly vulnerable because of 'everything he had been through during his migration and the traumatic experiences he was likely to have endured previously.' Hence, the migration journey and past traumatic experiences play a role in rendering asylum applicants vulnerable. Moreover, the ECtHR justifies the vulnerability of asylum applicants by referring to international and European instruments, indicating that the Refugee Convention and the standards adopted in the Reception Conditions Directive demonstrate the need for the special protection of applicants of in-

183 M.S.S. v Belgium and Greece, Application no. 30696/09, European Court of Human Rights, 21 January 2011, para. 263.

184 M.S.S. v Belgium and Greece, Application no. 30696/09, European Court of Human Rights, 21 January 2011, paras. 251-263.

185 See Ktistakis, Y., Protecting Migrants under the European Convention on Human Rights and The European Social Charter, Council of Europe, A handbook for legal practitioners, 2013, p. 47.

186 M.S.S. v Belgium and Greece, Application no. 30696/09, European Court of Human Rights, 21 January 2011, para. 249.

187 M.S.S. v Belgium and Greece, Application no. 30696/09, European Court of Human Rights, 21 January 2011, para. 367. 
ternational protection. ${ }^{188}$

Judge Sajó in his (partly) dissenting opinion criticized the broadening of the concept of 'particularly vulnerable groups' to include also asylum applicants. He agreed with the majority of the judges that many asylum applicants are vulnerable persons, however, 'they cannot be unconditionally considered as a particularly vulnerable group'. The notion of a 'particularly vulnerable group' has according to him 'a specific meaning in the jurisprudence of the Court' and asylum applicants are not a group who are historically subject to prejudice resulting in their social exclusion, such as Roma people or persons with mental disabilities. Asylum applicants are not a homogenous group. ${ }^{189}$ Judge Sajó has been widely criticized in the literature for focussing too narrowly on the notion of vulnerability. 190 I agree with him that asylum applicants are not a homogenous group. However, Judge Sajó fails to recognize that there are many other sources of vulnerability that can render a group vulnerable, which requires an adequate response. A history of discrimination, prejudice and social exclusion are a few factors that may render someone vulnerable. Vulnerability may also arise from dependency to others. The source of vulnerability shared by all asylum applicants, regardless of individual circumstances, is in my opinion, their dependency on the host State. I posit the view that the ECtHR's classification that all asylum applicants are inherently vulnerable because 'the applicant, being an asylum seeker, was particularly vulnerable 'because of everything he had been through during his migration and the traumatic experiences he was likely to have endured previously,' is not persuasive. This reasoning assumes that all asylum applicants automatically arrive by boat or that all asylum applicants have been through past traumatic experiences during or previous to their migration.

The interpretation of vulnerability in the context of asylum has been further discussed in the ECtHR's Grand Chamber case of Khlaifia. This case concerned three Tunisian nationals who crossed the Mediterranean Sea and were intercepted by the Italian coastguard. Subsequently, they were transferred to an 'Early Reception and Aid Centre' on the island of Lampedusa. From there they were transferred to Palermo and later on confined on ships in the harbour with

188 M.S.S. v Belgium and Greece, Application no. 30696/09, European Court of Human Rights, 21 January 2011, para. 251. See further case note Battjes, H., Journaal Vreemdelingenrecht, JV 2011/68.

189 Partly concurring and partly dissenting opinion of judge Sajó in M.S.S. v Belgium and Greece, Application no. 30696/09, European Court of Human Rights, 21 January 2011.

190 See inter alia I. Truscan, 'Considerations of vulnerability: from principles to action in the case law of the European Court of Human Rights', Retfrerd: Nordic Journal of Law and Justice, no. 3/142, 2013; Peroni, L. and Timmer, A., Vulnerable groups: The promise of an emerging concept in European Human Rights Convention law, International Journal of Constitutional Law, 2013, p. 1069. 
hundreds of other people. The applicants claimed that the Italian authorities have breached, inter alia, their rights under Article 5 and Article 3 of the ECHR. The assessment of whether the detention conditions on Lampedusa constituted a breach of Article 3, the Grand Chamber reversed the Chamber who considered earlier that hat 'the applicants, who had just undergone a dangerous journey on the high seas, were in a situation of vulnerability.' Instead, the Grand Chamber submitted that:

'the applicants were weakened physically and psychologically because they had just made a dangerous crossing of the Mediterranean. Nevertheless, the applicants, who were not asylum-seekers, did not have the specific vulnerability inherent in that status, and did not claim to have endured traumatic experiences in their country of origin.'

The Grand Chamber found that the vulnerability of the applicants despite their dangerous journey at sea was not realized because the applicants were also not asylum applicants and they did not claim to have suffered from 'traumatic experiences in their country of origin'. In addition, the Grand Chamber has held that they did not belong to one of the other vulnerable groups such as elderly people or minors. They were young men between 23 and 28 . Neither were the applicants suffering from a medical condition. ${ }^{191}$

\subsubsection{Legal implications of belonging to a vulnerable group}

As vulnerability has become a part of the legal assessment of the ECtHR, a more pertinent question arises, namely what are the legal implications of belonging to a group considered to be vulnerable. Belonging to a vulnerable group has important implications. The first implication is that vulnerability reinforces the positive obligations of State parties in cases where they dealt with vulnerable groups. In other words, States should provide enhanced protection that is more responsive and takes into account their particular needs.192 In Mubilanzila, which concerned the detention of a five years old unaccompanied minor, the ECtHR held that concerning individuals who are considered highly vulnerable, the State has a duty to take adequate measures to provide care and protection for them as part of its positive obligations under Article 3 of the Convention'. ${ }^{193}$

191 Khlaifia and Others v Italy, Application no. 16483/12, European Court of Human Rights, Grand Chamber, 15 December 2016, para. 194.

192 Peroni, L. and Timmer, A., Vulnerable groups: The promise of an emerging concept in European Human Rights Convention law, International Journal of Constitutional Law, 2013, p. 1076.

193 Mubilanzila Mayeka and Kaniki Mitunga v Belgium, Application no. 13178/03, European Court of Human Rights, 12 October 2006, para. 55. 
The second implication is that the vulnerability of an applicant is relevant for the ECtHR's assessment of whether the severity of a conduct reached the minimum level of severity required amounting to inhuman or degrading treatment within the meaning of Article 3 of the ECHR. ${ }^{194}$ M.S.S. has shown that where authorities had not taken into account the vulnerability of the applicant in the context of detention or living conditions in the receiving State, the threshold to reach violation of Article 3 of the ECHR is low. Peroni and Timmer submit that when it concerns (unaccompanied) minors that are placed in detention, the level required to reach a violation of Article 3 of the ECHR is even lower. ${ }^{195}$ In addition, the notion of vulnerability has in discrimination cases narrowed the margin of appreciation accorded to the State concerned, ${ }^{196}$ such as in cases dealing with persons with mental disabilities ${ }^{197}$ or persons with HIV. 198

\subsection{Analysis}

The foregoing sections show that the Refugee Convention does not contain a definition of vulnerability or indicates which refugees are presumed to be vulnerable. Due to the lack of an explicit notion of vulnerability in the Refugee Convention, it could be argued that its interpretation is left to the State parties. I identified that the ExCom Conclusions on children and women adopt a nuanced approach to vulnerability because they explain why women and children are presumed to be particularly vulnerable in the refugee context. In addition, the ExCom Conclusions on children and women also include individual as well

194 See Mustaniemi-Laakso, M, Heikkila, M, Del Gaudio, E., Konstantis, S., Nagore Casas, M., Morondo, D., G.Hegde, V. and Finlay, G., The protection of vulnerable individuals in the context of EU policies on border checks, asylum and immigration, FRAME, 31 May 2016, pp. 25-26.

195 Peroni, L. and Timmer, A., Vulnerable groups: The promise of an emerging concept in European Human Rights Convention law, International Journal of Constitutional Law, 2013, pp. 1079-1080. See also Brandl, U. and Czech, P., General and Specific Vulnerability of Protection-Seekers in the EU: Is there an Adequate Response to their Needs? Protecting Vulnerable Groups, The European Human Rights Framework, Ippolito, F., and Iglesias Sanchez, S. (eds.), 2015, pp. 253-258.

196 Peroni, L. and Timmer, A., Vulnerable groups: The promise of an emerging concept in European Human Rights Convention law, International Journal of Constitutional Law, 2013, pp. 180-182. See also Al Tamimi, Y., The Protection of Vulnerable Groups and Individuals by the European Court of Human Rights. Journal européen des droits de l'homme | European Journal of Human Rights, 2016(5), pp. 581-582.

197 Alajos Kiss v Hungary, Application no. 38832/06, European Court of Human Rights, 20 May 2010.

198 Kiyutin v Russia, Application no. 2700/10, European Court of Human Rights, 10 March 2011. 
as wider environmental factors that may put children or women at heightened risk of violating their rights. Such an approach is nuanced as they address both inherent sources of vulnerability as well as recognizes situational sources of vulnerability. The UNHCR Guidelines and Procedural Standards distinguish between vulnerable asylum applicants and asylum applicants with special needs without defining the notion or the sources of vulnerability or illustrate how the notion of special needs relates to vulnerability. Hence, I have argued that this approach is not helpful and not effective for its implementation in practice.

The reviewed General Comments and General Recommendations of the UN human rights treaty monitoring bodies show that certain groups are labelled as particularly vulnerable, marginalized or disadvantaged to highlight that they are at greater risk of harms, and recommends State parties to take appropriate measures to enhance their protection. This approach may potentially lead to an increased enjoyment of the substantive rights at issue for vulnerable groups. However, the vulnerability approach as used by the treaty monitoring bodies in the General Comments and General Recommendations is, in my opinion, both too narrow and too broad. In some instances, a specific list of vulnerable groups is provided without specifying that the list is non-exhaustive. The risk is that groups who may be particularly vulnerable are excluded from special protection. As mentioned above, at times a broad understanding of vulnerability is applied, resulting in the fact that nearly everyone has been deemed vulnerable. In addition, there are references to 'the most vulnerable groups' without specifying which groups qualify as the most vulnerable.

The ECtHR's vulnerability approach of labelling groups as particularly vulnerable may serve as a basis for an increased scrutiny in cases involving groups that require special attention and protection. However, the drawback is that classifying groups as vulnerable may further stigmatize them. Essentially, presuming that a whole group is weak and not capable of protecting their own interests and needs. It has been submitted that in M.S.S., the ECtHR held that asylum applicants are particularly vulnerable because of 'everything he had been through during his migration and the traumatic experiences he was likely to have endured previously.' Hence, the migration journey and past traumatic experiences are two important aspects that render asylum applicants as vulnerable. However, in Khlaifia, the ECtHR's Grand Chamber held that irregular migrants despite their dangerous migration journey are not considered to be particularly vulnerable because they were not asylum applicants and they did not claim to have suffered from 'traumatic experiences in their country of origin'. Hence, they 'did not have the specific vulnerability inherent in that status'. Moreover, the Grand Chamber held that the applicants did not belong to one of the other vulnerable groups such as elderly people or minors. 
In my view, the ECtHR's analysis of vulnerability in this particular case is reduced to the question of who is vulnerable rather than what renders someone vulnerable. The Khlaifia case shows that the ECtHR's approach to vulnerability is rigid and not persuasive.

\subsection{Concluding remarks}

The purpose of this chapter has been to examine the notion of vulnerability employed in the international human rights law and to examine why certain groups are expressly deemed vulnerable, and the legal implications of being considered vulnerable.

I have argued that vulnerability is an important notion in international human rights law. Both the ExCom Conclusions and the reviewed UN treaty monitoring bodies have interpreted various issues related to the human rights situation of groups that are considered vulnerable and both have recognized certain groups as particularly vulnerable. This chapter has shown that the vulnerability approach in the reviewed General Comments and General Recommendations seem rather too narrow or too broad. A clear definition of the notion of vulnerability or certain criteria of why someone is vulnerable is not provided. Hence, it is not always evident why certain groups are presumed to be vulnerable. It has been further submitted that the legal implication to be considered vulnerable in the view of the UN monitoring bodies has led to recommendations to State parties to take appropriate measures for the removal of legislation or practices that affect the enjoyment of their human rights.

Following my analysis on the approach to vulnerability employed in the UN human rights instruments, the second part of this chapter sought to identify the vulnerability approach in the case law of the ECtHR. The notion of vulnerability is neither defined in the case law of the ECtHR nor is it completely evident how the Court determines vulnerability. Rather it determines on a case-by-case basis whether an applicant is part of a group that is confronted with a situation of vulnerability. In the M.S.S. case, asylum applicants as a group were recognized as vulnerable. I also submitted that despite this positive development, the ECtHR applies a rigid approach to vulnerability. Furthermore, the notion of vulnerability in the case law of the ECtHR has important implications for the positive obligations of State parties. It has been submitted that State parties are required to provide enhanced protection that is more responsive and takes into account the particular needs of applicants who belong to a vulnerable group. In addition, vulnerability has important implications for the assessment of whether the severity of a conduct reached the minimum level of severity required to amount to inhuman or degrading treatment within the meaning of Article 3 of the ECHR. 
For the reasons I have explained in chapter 1, this study will focus on two vulnerable groups, namely victims of torture and unaccompanied minors. The next chapter will examine the international human rights instruments with regard to these vulnerable groups. 


\section{3 - Victims of torture and unaccompanied minors}

\subsection{Introduction}

The aim of this chapter is to find out which obligations stem from international human rights law with regard to victims of torture and unaccompanied minors. The identified obligations will be compared with the relevant legal standards enshrined in the recast legislative acts of the CEAS with regard to victims of torture and unaccompanied minors. 199

This chapter will discuss the relevant provisions of the Convention against Torture (CAT) and subsequently the Convention on the Rights of the Child (CRC). In addition to the examination of these international treaties, attention will be focused on the case law of the ECtHR. As I have explained in the introduction chapter, I will focus on victims of torture and unaccompanied minors in preference to other vulnerable groups because the CEAS explicitly provides them enhanced legal standards aimed at their special protection. In addition, both selected vulnerable groups are most likely to require special guarantees in terms of reception and procedural arrangements in the asylum process.

I will first discuss the CAT and its relevant provisions. Subsequently, I will discuss the relevant provisions of the CRC with a specific focus on unaccompanied minors. In interpreting these treaties, I rely on the interpretation of treaty monitoring bodies, individual complaints and international court decisions, such as the ECtHR.

\subsection{Convention against Torture}

\subsubsection{Text and context}

The primary treaty for the protection of victims of torture is the CAT, which was adopted in 1984 and entered into force in 1987. The act of torture is defined in Article 1. Torture constitutes not only an intentionally inflicted act on a person that causes severe pain, but also physical or mental suffering and carried out by a person acting in an official capacity.

Article 2 obliges State parties to implement 'effective legislative, administrative, judicial or other measures' that prevents the commission of acts of torture in their jurisdiction. Article 3 enshrines the non-refoulement principle, which requires that State parties should not send a person to another State where he or she may be in danger of being subjected to torture.

Another relevant provision for asylum applicants who are torture victims is laid down in Article 14, which requires State parties to safeguard the right to

199 This comparison will be carried out in chapter 6 . 
redress and rehabilitation for torture victims. Article 14(1) of the CAT reads:

'Each State Party shall ensure in its legal system that the victim of an act of torture obtains redress and has an enforceable right to fair and adequate compensation including the means for as full rehabilitation as possible. In the event of the death of the victim as a result of an act of torture, his dependents shall be entitled to compensation.'

\subsubsection{Interpretation}

It is important to note that the prohibition of torture is absolute and is never in any circumstances whatsoever justified. 200

The Committee against Torture takes the view that State parties are required to protect 'certain minority or marginalized individuals or populations' who are at risk of torture. All persons should be able to benefit from the rights enshrined in the Convention, irrespective of 'race, colour, ethnicity, age, religious belief or affiliation, political or other opinion, national or social origin, gender, sexual orientation, transgender identity, mental or other disability, health status, economic or indigenous status, reason for which the person is detained, including persons accused of political offences or terrorist acts, asylumseekers, refugees or others under international protection, or any other status or adverse distinction. ${ }^{201}$ Hence, the CAT is applicable to all persons, including asylum applicants and refugees.

The Committee further notes that the obligation of non-refoulment applies exists whenever there are "substantial grounds" for believing that the person concerned would be in danger of being subjected to torture in a State to which the person is facing deportation'. Moreover, a person who is at risk of being tortured if deported to another State should stay in the territory as long as the risk exists. In addition, the detention of persons that are at risk of being subjected to torture should be exceptional and if detention is applied, they should be regularly monitored. State parties should refrain from adopting measures that would somehow force asylum applicants who require protection_against_refoulement to return to their country of origin. ${ }^{202}$ The vulnerability of the victim is one of the factors that need to be taken into account by State parties in assess-

${ }^{200}$ UN Committee Against Torture (CAT), General Comment No. 2: Implementation of Article 2 by States Parties, 24 January 2008, CAT/C/GC/2, para. 5.

201 UN Committee Against Torture (CAT), General Comment No. 2: Implementation of Article 2 by States Parties, 24 January 2008, CAT/C/GC/2, para. 21.

202 UN Committee Against Torture (CAT), General Comment No. 4 (2017) on the implementation of article 3 of the Convention in the context of article 22, 9 February 2018, paras. 11-14. 
ing the impact of the physical or mental abusive act has on the person concerned. 203

An important consideration in the procedure of examining whether a person is facing a risk of being tortured in the State of deportation is that State parties should provide the persons in question with guarantees, especially when the person is in vulnerable situation. The Committee considers, inter alia, asylum applicants, unaccompanied minors, women who have experienced violence or disabled persons as persons who are in a vulnerable situation. The Committee further takes the view that victims of torture and other vulnerable persons often suffer from PTSD. Hence, victims of torture are expressly considered vulnerable persons. Furthermore, State parties should not apply a standard credibility assessment to assess their claim of being subjected to torture if deported.204 This consideration had been decided in Hayden, where the Committee against Torture has held 'that complete accuracy is seldom to be expected from victims of torture, especially when the victim suffers from post-traumatic stress syndrome; it also notes that the principle of strict accuracy does not necessarily apply when the inconsistencies are of a material nature. 205 Hence, victims of torture who suffer from PTSD should be treated less strictly where there are inconsistencies in the applicant's claim or it lacks details during the credibility assessment. Furthermore, the Committee takes the view that the burden of proof lies with the complainant to present detailed arguments demonstrating that the risk of being subjected to torture is 'foreseeable, personal, actual and real.' However, when the complainant finds himself in a situation in which he is unable to give details of his case, the burden of proof is shifted. The State party has then the responsibility to investigate the allegations and verify the information. ${ }^{206}$ Moreover, the Committee considers that State parties should make an individual assessment of the personal and actual risk to which the complainant

203 UN Committee Against Torture (CAT), General Comment No. 4 (2017) on the implementation of article 3 of the Convention in the context of article 22, 9 February 2018, para. 17.

204 UN Committee Against Torture (CAT), General Comment No. 4 (2017) on the implementation of article 3 of the Convention in the context of article 22, 9 February 2018, paras. $40-42$.

205 CAT Communication No. 101/1997, CAT/C/21/D/101/1997, Halil Hayden v Sweden, 16 December 1998, para. 6.7; CAT Communication No. 43/1996, CAT/C/17/D/43/1996, Kaveh Yaragh Tala v Sweden, 15 November 1996, para. 10.3. CAT Communication No. 416/2010, CAT/C/49/D/416/2010, Ke Chun Rongv Australia, Committee Against Torture Forty-ninth session 29 October - 23 November 2012, para. 7.5

206 CAT Communication 258/2016, CAT/C/65/D/758/2016, Adam Harun v Switzerland, 6 December 2018, para. 9.5. 
would be exposed in the State of deportation, especially in light of their particular vulnerability as torture victims and asylum applicants. ${ }^{207}$

As regards the interpretation Article 14, the Committee considers that State parties are obliged to guarantee access to prompt and effective redress mechanisms for persons belonging to vulnerable groups. Moreover, State parties should pay special attention to gender in ensuring that persons, in particular 'members of groups made vulnerable, including lesbian, gay, bisexual and transgender (LGBT) people' should have access to redress and rehabilitation which corresponds to their special needs. ${ }^{208}$ The right to redress entails restitution, compensation, rehabilitation, satisfaction and guarantees of nonrepetition. ${ }^{209}$ The legal obligations under Article 14(1) of the CAT require, first, in terms of procedural terms, that State parties have to establish effective and accessible mechanisms at the domestic level to provide redress for victims of torture and, second, in substantive terms, to guarantee victims of torture 'an enforceable right to fair and adequate compensation including the means for as full rehabilitation as possible'. ${ }^{210}$ Hence, State parties have the obligation to guarantee the means for 'as full rehabilitation as possible', which implies that the rehabilitation must be holistic and 'include medical and psychological care as well as legal and social services'.211 Rehabilitation involves:212

'The restoration of function or the acquisition of new skills required as a result of the changed circumstances of a victim in the aftermath of torture or illtreatment. It seeks to enable the maximum possible self-sufficiency and function for the individual concerned, and may involve adjustments to the person's physical and social environment. Rehabilitation for victims should aim to restore, as far as possible, their independence, physical, mental, social and vocational ability; and full inclusion and participation in society'.

To fulfil these legal obligations, State parties should thus adopt:

207 CAT Communication 258/2016, CAT/C/65/D/758/2016, Adam Harun v Switzerland, 6 December 2018, para. 9.9.

208 UN Committee Against Torture (CAT), General comment no. 3, 2012 : Convention against Torture and Other Cruel, Inhuman or Degrading Treatment or Punishment : implementation of article 14 by States parties, 13 December 2012, para. 39.

209 CAT, General Comment No. 3 of the Committee against Torture Implementation of article 14 by States parties, 19 November 2012, para. 2 .

210 CAT, General Comment No. 3 of the Committee against Torture Implementation of article 14 by States parties, 19 November 2012, para. 5 .

211 CAT, General Comment No. 3 of the Committee against Torture Implementation of article 14 by States parties, 19 November 2012, para. 11.

212 CAT, General Comment No. 3 of the Committee against Torture Implementation of article 14 by States parties, 19 November 2012, para.11 
'A long-term and integrated approach and ensure that specialised services for the victim of torture or ill-treatment are available, appropriate and promptly accessible. These should include: a procedure for the assessment and evaluation of an individual's therapeutic and other needs, based on, among others, the Istanbul Protocol; and may include a wide range of inter-disciplinary measures, such as medical, physical and psychological rehabilitative services; re-integrative and social services; community and family-oriented assistance and services; vocational training, education etc.'213

These rehabilitative services can be provided by the State or through the 'funding of private medical, legal and other facilities, including those administered by non-governmental organizations (NGOs)'. ${ }^{214}$ With regard to the access to rehabilitative services, the Committee took the view in A.N. that a transfer of an asylum applicant under the Dublin Regulation would violate Article 14 of the CAT where State parties have not ascertained before transferring whether appropriate rehabilitative services are effectively available in the receiving State and accessible to the applicant to guarantee the right to rehabilitation as a torture victim. ${ }^{215}$

Medical reports have played an important role to support the claim of the applicant of being subjected to torture in the past. In establishing whether the applicant has been tortured, all pertinent information may be introduced by both parties relevant to the issue. Pertinent information could include whether medical, psychological or other independent evidence to support the claim that the applicant has been tortured or subject to ill-treatment in the past. ${ }^{216}$ In Singh, the Committee decided that the complainant has corroborated medical reports indicating that he was tortured in the past by the Indian police. ${ }^{217}$ Likewise, in Combey Brice Magloire Gbadjavi, the complainant had submitted medical certificates and reports in support of his asylum request. The Committee concluded that the medical evidence presented by the complainant should have taken more seriously by the State authorities by investigating the alleged risks more thoroughly. 218

213 CAT, General Comment No. 3 of the Committee against Torture Implementation of article 14 by States parties, 19 November 2012, para. 13.

214 CAT, General Comment No. 3 of the Committee against Torture Implementation of article 14 by States parties, 19 November 2012, para. 15.

215 A.N. v. Switzerland, communication no. 742/2016, UN Committee Against Torture (CAT), 3 August 2018, para. 8.8.

216 UN Committee Against Torture (CAT), General Comment No. 4 (2017) on the implementation of article 3 of the Convention in the context of article 22, 9 February 2018, para. 49(b) and (c).

217 Nirmal Singh v Canada, CAT/C/46/D/319/2007, UN Committee Against Torture (CAT), 8 July 2011.

218 CAT Communication No. 396/2009, Combey Brice Magloire Gbadjavi v Switzerland, De- 
Lastly, it is important to note that 'Manual on the Effective Investigation and Documentation of Torture and Other Cruel, Inhuman or Degrading Treatment or Punishment' (Istanbul Protocol) ${ }^{219}$ provides guidelines for States and professionals on the investigation and documentation of allegations of torture and other ill-treatment. Although the Istanbul Protocol has not been designed for asylum procedures, it does indicate that it can be applied during asylum procedures. $^{220}$ The Istanbul Protocol is useful in the asylum process because it provides guidelines on how to interview asylum applicants who have been victims of torture. It provides also guidelines with regard to the medical examination, the medical report and the levels of causality between the physical traces and the applicant's statements on torture or ill-treatment in the country of origin. ${ }^{221}$ It is also important to note that Committee has submitted that one of the measures that should be taken by State parties against possible violations of the principle of non-refoulement is to refer the applicant alleging to have been subjected to torture in the past to an independent medical examination free of charge, in accordance with the Istanbul Protocol.222

\subsubsection{Victims of torture in the asylum process}

As regards reception arrangements, the ExCom Conclusion recommend State parties to take into account the specific needs of torture victims and applicants who have suffered other forms of violence. ${ }^{223}$

The UNHCR Guidelines provide, inter alia, that victims of torture and persons suffering from trauma require a safe environment to submit their claim. ${ }^{224}$

cision adopted by the Committee against Torture at its forty-seventh session, 7 May-1 June 2012, para. 7.8. See also Zwaan, K., Medisch steunbewijs in de asielprocedure: de processie van Echternach?, Asiel \& Migrantenrecht, Nr. 10, 2013, p. 530.

219 United Nations Istanbul Protocol, Manual on the Effective Investigation and Documentation of Torture and Other Cruel, Inhuman or Degrading Treatment or Punishment, 1999.

220 United Nations Istanbul Protocol, Manual on the Effective Investigation and Documentation of Torture and Other Cruel, Inhuman or Degrading Treatment or Punishment, 1999, para. 121.

221 Zwaan, K., Medisch steunbewijs in de asielprocedure: de processie van Echternach? Asiel \& Migrantenrecht, Nr. 10, 2013, p. 528. See also Bloemen, E., and Kollen, M., Bewijs geleverd - Medisch steunbewijs en medische beperkingen in asiel, Journaal Vreemdelingenrecht, Nr. 3/27, 2015.

222 UN Committee Against Torture (CAT), General Comment No. 4 (2017) on the implementation of article 3 of the Convention in the context of article 22, 9 February 2018, para. $18(\mathrm{~d})$.

223 UNHCR, Executive Committee Conclusion No. 93 - 2002: Conclusion on reception of asylum-seekers in the context of individual asylum systems, 2002

224 UNHCR, Sexual and Gender-Based Violence against Refugees, Returnees and Internally Displaced Persons, 2003, p. 120. 
They should also be referred to specialized counselling and services. ${ }^{225}$ In addition, the detention of victims of torture is a serious concern. According to the UNHCR, victims of serious physical, psychological or sexual violence, need special consideration and should, as a rule, not be detained because detention may aggravate their symptoms such as depression, anxiety and lead to other physical and psychological issues. Furthermore, State parties need to make a serious assessment whether it is necessary to detain this particular group of vulnerable asylum applicants. The mental and physical health of detainees should be assessed by qualified medical examiners. They should be given adequate treatment and medical reports should be issued periodically concerning their state of mind during detention. ${ }^{226}$

\subsubsection{European human rights standards}

The prohibition of torture and inhuman or degrading treatment in Article 3 of the ECHR is one of the most significant provisions in particular to migration cases at the European human rights level. In assessing torture cases, the ECtHR has provided particular weight to the vulnerable position of torture victims. ${ }^{227}$ In Aksoy, the ECtHR delivered that the injuries were the result of torture and there has been a violation of Article 3 of the ECHR. Moreover, the ECtHR pointed out that 'given the fundamental importance of the prohibition of torture and the especially vulnerable position of torture victims,' Article 13 of the ECHR obliges State parties to conduct a thorough and effective investigation on torture allegations. 228

The ECtHR has also attached great importance to medical evidence that demonstrates the physical or mental trauma and past torture allegations of the applicant. In R.C., an Iranian asylum applicant issued a medical certificate as proof of having been tortured. Despite the fact that the certificate was not written by a medical expert in examining torture injuries, the ECtHR regarded that there were strong indications for believing that the injuries and scars on the applicant may have been caused by torture or ill-treatment. The Swedish authorities should have acted upon these indications by obtaining an expert opinion to

225 UNHCR, Procedural Standards for Refugee Status Determination under UNHCR's Mandate, 20 November 2003, para.3.4.3.

226 UNHCR, Guidelines on the Applicable Criteria and Standards relating to the Detention of Asylum-Seekers and Alternatives to Detention, 2012, Guideline 9.1.

227 Gisayev v Russia, Application no. 14811/04, European Court of Human Rights, 20 June 2011, para. 116. Aydin v Turkey, Application no. 23178/94, European Court of Human Rights, 25 September 1997, para. 103.

228 Aksoy v Turkey, Application no. 21987/93, European Court of Human Rights, 18 December 1996, para. 98. See also Bati and Others v Turkey, Application nos. 33097/96 and 57834/00, European Court of Human Rights, 3 June 2004, para. 133. 
assess the probable cause of the injuries. The ECtHR stipulated:

'while the burden of proof, in principle, rests on the applicant, the Court disagrees with the Government's view that it was incumbent upon him to produce such expert opinion. In cases such as the present one, the State has a duty to ascertain all relevant facts, particularly in circumstances where there is a strong indication that an applicant's injuries may have been caused by torture.'229

The ECtHR has given further clarification on the duty of examination on the side of the authorities in circumstances where the applicant presents medical evidence of having been tortured or ill-treated. In R.J. the applicant claimed that he was tortured in Sri Lanka by the authorities because of his ethnicity as a Tamil and political activities for the Liberation Tigers of Tamil Eelam (LTTE). During his asylum procedure, the applicant had submitted a medical report with evidence of injuries caused by torture during his detention in Sri Lanka. Despite this strong indication of having being tortured, the French authorities were not convinced that the applicant upon return would risk being subjected to a treatment contrary to Article 3 ECHR. According to the French asylum authorities, the claim of the applicant was inconsistent and not accurate. The ECtHR concluded that the French authorities could not just reject the asylum claim due to reasons of inaccuracy and that the French authorities had to further investigate where it appeared from medical reports that the applicant had been subjected to torture. Hence, for this negligence, the ECtHR held that France had violated Article 3 of the ECHR. ${ }^{230}$

In $I$, where there was strong medical evidence that the applicant was subjected to torture, the ECtHR held, however, that it could be expected from the applicant to indicate that there are 'substantial and concrete grounds for believing that upon return to the home country he or she would be exposed to a risk of such treatment again'.231 Furthermore, in evaluating medical reports, the ECtHR has referred to the standards laid down in the Istanbul Protocol. 232

At the political level, the Committee of Ministers of the Council of Europe has addressed on the subject of torture of victims and detention in Recommendation $\operatorname{Rec}(2003) 5$. State parties are encouraged to identify victims of torture

229 R.C. $v$ Sweden, Application no. 41827/07, European Court of Human Rights, 9 March 2010, para. 53.

230 R.J. v France, Application No. 10466/11, European Court of Human Rights, 19 September 2013. See also Zwaan, K., Medisch steunbewijs in de asielprocedure: de processie van Echternach? Asiel \& Migrantenrecht, Nr. 10, 2013, p. 529.

${ }^{231}$ I v Sweden, Application No. 61204/09, European Court of Human Rights, 5 September 2013, para. 62.

232 Desdev Turkey, Application no. 23909/03, European Court of Human Rights, 1 February 2011, para. 109. 
and persons who have been subjected to trauma before they are placed in detention in order to provide, if needed, for adequate medical treatment and psychological assistance as well to create the conditions they may need. ${ }^{233}$

\subsection{Analysis}

The previous sections show that the General Comments consider torture victims as vulnerable persons or to be in a particularly vulnerable situation, such as asylum applicants. However, the Committee has not expressly commented upon the underlying reasons that make this group vulnerable.

Based on the General Comments and Communications, I identified three aspects that are relevant with regard to torture victims in the asylum process. First, medical reports play an important role in the assessment of the applicant's claim of being subjected to torture. The Committee further takes the view that victims of torture often suffer from PTSD, which gives rise to numerous symptoms. Such symptoms may have an impact on the capacity of the person in question to provide all relevant details. State parties should be more lenient when it concerns the credibility assessment of asylum applicants claiming to be victims of torture. Second, the measure to detain torture victims should be regularly reviewed. Further, State parties should refrain from adopting measures that would allow the detention of asylum applicants in deplorable conditions. Third, asylum applicants who are torture victims should have prompt and effective access to rehabilitative services, which includes medical and psychological care as well as legal and social support.

Relatively few recommendations have been issued by the UNHCR dealing with torture victims in the asylum process. One important recommendation addressed by the ExCom refers to the reception conditions and to take into account the specific needs of torture victims. The Conclusion does not address the question of procedural arrangements with regard to victims of torture or make references to the CAT. Apart from referring to specialized counselling, the UNHCR has made several suggestions to State parties with regard to the detention of torture victims. First, victims of torture should, as a principle, not be detained. Second, a thorough assessment should be carried out whether it is necessary to detain victims of torture. Third, victims of torture in detention should be regularly monitored by qualified medical examiners.

Standing case law of the ECtHR has made it clear that victims of torture are vulnerable and that it attaches considerable weight to medical reports explaining the physical or mental trauma and past torture allegations of the applicant. Hence, effective documentation of torture allegations is highly important in the

233 Council of Europe Committee of Ministers, Recommendation Rec(2003)5 on measures of detention of asylum seekers, 2003, paras. 12-13. 
asylum process as it may support the credibility of the asylum claim of the applicant.

\subsection{Convention on the Rights of the Child}

\subsubsection{Text and context}

The most specific international human rights treaty aiming to protect the rights of children is the CRC. The Convention was adopted in 1989 and entered into force in 1990. The CRC is grounded on four general principles:234

1) The non-discrimination principle in Article 2;235

2) The best interests of the child; ${ }^{236}$

3) The right to life, survival and development; 237 and

4) Respect for the views of the child.238

The first two principles, namely the non-discrimination principle and the best interests of the child are key principles in the protection of the rights of unaccompanied minors. 239 The principle of the best interests of the child is enshrined in Article 3 of the CRC, which stipulates:

'In all actions concerning children, whether undertaken by public or private social welfare institutions, courts of law, administrative authorities or legislative bodies, the best interests of the child shall be a primary consideration'.

The principle of best interests of the child in the asylum context has two obligations. First, all actions relating to children seeking asylum must be subject to a best interests scrutiny. Second, all legislation and policies that include children should be assessed throughout the asylum procedure on the basis of the best interests of the child. 240

In addition to this important principle, the CRC includes other substantive provisions that are relevant for the protection of children in the asylum context. In family reunification procedures, State parties should ensure that a child is not separated from his parents, except when such separation is in the best interest

234 Detrick, S., A Commentary on the United Nations Convention on the Rights of the Child, Martinus Nijhoff Publishers, 1999, p. 86.

235 Article 2 of the CRC.

236 Article 3 of the CRC.

237 Article 6 of the CRC.

238 Article 12 of the CRC.

239 Crescenzi, A., Unaccompanied Minors in International Law, Unaccompanied Minors in International, European and National Law, (Ralf Rosskopf ed.), Berliner WissenschaftsVerlag, 2016, p. 33.

240 Smyth, C., The common European asylum system and the rights of the child: an exploration of meaning and compliance, 2013, Doctoral Thesis, Leiden University, p. 38. 
of the child. ${ }^{241}$ Other protective measures for children included in the CRC such as Article 19(1) provide that State Parties to take all appropriate measures in terms of legislative, administrative, social and educational to protect the child from violence (physically or mentally). Article 22(1) indicates that asylum seeking children must receive appropriate protection in the enjoyment of the rights enshrined in the Convention.

Furthermore, Article 24(1) compels State parties to ensure that children enjoy the highest attainable standard of health. Article 27(1) ensures to every child a standard of living adequate for the child's physical, mental, spiritual, moral and social development. Articles 32 and 34 aim to protect children from economic sexual exploitation. Article 37 requires, inter alia, that children should not be subjected to torture or other cruel, inhuman or degrading treatment or 'be deprived of his or her liberty unlawfully or arbitrarily'.

\subsubsection{Interpretation}

The CRC, which has been almost universally ratified, has explicitly recognized the vulnerability of asylum seeking children.242 State parties are obliged to protect the rights of all children in their territory and subject to its jurisdiction, whether they are asylum seeking children, refugees or any form of immigration status or nationality.243 The principle of non-discrimination in Article 2 means that any discrimination with regard to the status of a child as being unaccompanied, a refugee, an asylum applicant or a migrant is prohibited. The prohibition of discrimination applies to all actions involving unaccompanied minors. 244

The best interests of the child must be a primary consideration in all (private or public) actions concerning children. The Committee on the Rights of the Child has stated that 'the principle must be respected during all stages of the displacement cycle'. ${ }^{245}$ More specifically, the Committee has held that:

'ensuring that the best interests of the child are a primary consideration in all

241 Article 9 of the CRC.

242 UN Committee on the Rights of the Child (CRC), CRC General Comment No 14. (2013): on the right of the child to have his or her best interests taken as a primary consideration (art. 3, para. 1), 29 May 2013, CRC /C/GC/14, para. 75.

243 UN Committee on the Rights of the Child (CRC), General comment No. 6 (2005): Treatment of Unaccompanied and Separated Children Outside their Country of Origin, 1 September 2005, CRC/GC/2005/6, para. 12.

244 UN Committee on the Rights of the Child (CRC), CRC General Comment No. 6 (2005): Treatment of Unaccompanied and Separated Children Outside their Country of Origin, 1 September 2005, CRC/GC/2005/6, para. 18.

245 UN Committee on the Rights of the Child (CRC), CRC General Comment No. 6 (2005): Treatment of Unaccompanied and Separated Children Outside their Country of Origin, 1 September 2005, CRC/GC/2005/6, para. 19. 
actions concerning children (Article 3(1)), and that all the provisions of the Convention are respected in legislation and policy development and delivery at all levels of government demands a continuous process of child impact assessment (predicting the impact of any proposed law, policy or budgetary allocation which affects children and the enjoyment of their rights) and child impact evaluation (evaluating the actual impact of implementation). This process needs to be built into government at all levels and as early as possible in the development of policy. 246

The child's best interests include three elements: firstly, a substantive right; secondly, a fundamental, interpretative legal principle; and thirdly, a rule of procedure. ${ }^{247}$ In assessing and determining the child's best interests, it is important to take into account the child's situation of vulnerability. Situations of vulnerability may include disability, belonging to a minority group, being a refugee or asylum seeker, victims of abuse or living in a street situation. The objective of determining the best interests of children in a vulnerable situation is to ensure the full enjoyment of all Convention rights and with regard to other human rights norms such as those enshrined in the Refugee Convention. ${ }^{248}$

Paragraphs 2 and 3 of Article 3 require that State parties take measures to guarantee the protection of a child that is necessary for his or her well-being and that institutions which provide services and facilities responsible for the protection of children need to be in conformity with the standards established by competent authorities. According to Article 4 State parties are required to take all 'appropriate legislative, administrative, and other measures for the implementation of the rights recognized in the present Convention'. ${ }^{249}$

The Committee has held that assessment of the best interests of the child with regard to unaccompanied minors should include:250

${ }^{246}$ UN Committee on the Rights of the Child (CRC), CRC General Comment No. 5, 'General measures of implementation of the Convention on the Rights of the Child', U.N. Doc CRC/C/GC/2003/5 (2003), para. 45.

247 UN Committee on the Rights of the Child (CRC), General comment No. 14 (2013) on the right of the child to have his or her best interests taken as a primary consideration (art. 3, para. 1), 29 May 2013, CRC/C/GC/14, para. 6.

248 UN Committee on the Rights of the Child (CRC), General comment No. 14 (2013) on the right of the child to have his or her best interests taken as a primary consideration (art. 3, para. 1), 29 May 2013, CRC /C/GC/14, paras. 75-76.

249 UN Committee on the Rights of the Child (CRC), General comment no. 5 (2003): General measures of implementation of the Convention on the Rights of the Child, 27 November 2003, CRC/GC/2003/5, paras. 1-6.

250 UN Committee on the Rights of the Child, General Comment No. 6 (2005) - Treatment of unaccompanied and separated children outside their country of origin, 1 September 2005, para. 20. 
'A clear and comprehensive assessment of the child's identity, including her or his nationality, upbringing, ethnic, cultural and linguistic background, particular vulnerabilities and protection needs.'

The following table shows the definition of an 'unaccompanied minor' employed by the Committee and the UNHCR:

\section{Table 3.1. Definition of an unaccompanied minor}

\begin{tabular}{|l|l|}
\hline $\begin{array}{l}\text { The Committee of } \\
\text { the Rights of the } \\
\text { Child }\end{array}$ & $\begin{array}{l}\text { Children, as defined in article 1 of the Convention, who } \\
\text { have been separated from both parents and other relatives } \\
\text { and are not being cared for by an adult who, by law or cus- } \\
\text { tom, is responsible for doing } \mathrm{so}^{251}\end{array}$ \\
\hline The UNHCR & $\begin{array}{l}\text { An unaccompanied child is a person who is under the age } \\
\text { of eighteen, unless, under the law applicable to the child, } \\
\text { majority is attained earlier and who is separated from both } \\
\text { parents and is not being cared for by an adult who by law } \\
\text { or custom has responsibility to do } \mathrm{so}^{252}\end{array}$ \\
\hline
\end{tabular}

In the context of asylum, there are several procedural standards to be followed by State parties. Article 22(1) of the CRC requires State parties taking 'appropriate measures' to guarantee that a minor seeking asylum whether unaccompanied or accompanied, or who has been granted refugee status in accordance with international refugee law and national law and procedures, obtains adequate protection. The Committee interprets appropriate measures as follows: State parties should establish an asylum system that functions smoothly and which addresses in particular the rights of unaccompanied minors in compliance with the CRC and other human rights and refugee standards. ${ }^{253}$ Appropriate measures also involve taking into account the individual vulnerabilities of unaccompanied minors. ${ }^{254}$ Furthermore, State parties should appoint a guardian, an adult or a legal representative as soon as possible. Unaccompanied minors should have in all cases free legal qualified representation in asylum procedure. ${ }^{255}$ Applications submitted by unaccompanied minors should be given

251 UN Committee on the Rights of the Child (CRC), CRC General Comment No. 6 (2005): Treatment of Unaccompanied and Separated Children Outside their Country of Origin, 1 September 2005, CRC/GC/2005/6, para. 7.

252 UNHCR Guidelines on Policies and Procedures in Dealing with Unaccompanied Children Seeking Asylum, February 1997.

253 UN Committee on the Rights of the Child (CRC), CRC General Comment No. 6 (2005): Treatment of Unaccompanied and Separated Children Outside their Country of Origin, 1 September 2005, CRC/GC/2005/6, para. 64.

254 UN Committee on the Rights of the Child (CRC), CRC General Comment No. 6 (2005): Treatment of Unaccompanied and Separated Children Outside their Country of Origin, 1 September 2005, CRC/GC/2005/6, para. 68.

255 UN Committee on the Rights of the Child (CRC), CRC General Comment No. 6 
priority and competent authorities with expertise in refugee law should assess their application. In addition, unaccompanied minors should be given the benefit of the doubt about the credibility of their asylum story and have access to an appeal against the asylum decision. ${ }^{256}$ When State authorities assess asylum claims of unaccompanied minors and separated children, they should take into account the personal, family and cultural background.257 State authorities should also focus on child-specific forms and manifestations of persecution as well as gender-based violence when assessing the asylum application. ${ }^{258}$ An important aspect is the involvement of trained personnel of the competent determining authority in refugee law. Lastly, unaccompanied minors with an international protection status should enjoy not only the rights entailed in the Refugee Convention but have equal access to rights to which other children who reside in that country are entitled.259

As regards family unity, the general objective of national authorities should be to achieve a durable solution for unaccompanied minors by examining the possibilities of family reunification. In achieving this goal, State parties should promptly start by tracing the parents of unaccompanied minors, unless where separation is in the best interests of the child. Moreover, if there is a 'reasonable risk' that when the return of the child to the country of origin for the purposes of family reunification would result in human rights violation of the child, this would, obviously, not be in the best interests of the child.260

To determine whether the child has specific needs, identification of information of particular vulnerabilities such as health, physical, psychological, material and other protection needs, including registration of domestic violence, trafficking or trauma is highly important. An assessment should be made of not only the age and physical condition, but also the psychological maturity of the

(2005): Treatment of Unaccompanied and Separated Children Outside their Country of Origin, 1 September 2005, CRC/GC/2005/6, para. 69.

256 UN Committee on the Rights of the Child (CRC), CRC General Comment No. 6 (2005): Treatment of Unaccompanied and Separated Children Outside their Country of Origin, 1 September 2005, CRC/GC/2005/6, paras. 70-71.

257 UN Committee on the Rights of the Child (CRC), CRC General Comment No. 6 (2005): Treatment of Unaccompanied and Separated Children Outside their Country of Origin, 1 September 2005, CRC/GC/2005/6, para. 72.

258 UN Committee on the Rights of the Child (CRC), CRC General Comment No. 6 (2005): Treatment of Unaccompanied and Separated Children Outside their Country of Origin, 1 September 2005, CRC/GC/2005/6, para. 74.

259 UN Committee on the Rights of the Child (CRC), CRC General Comment No. 6 (2005): Treatment of Unaccompanied and Separated Children Outside their Country of Origin, 1 September 2005, CRC/GC/2005/6, paras, 75-76.

260 UN Committee on the Rights of the Child (CRC), CRC General Comment No. 6 (2005): Treatment of Unaccompanied and Separated Children Outside their Country of Origin, 1 September 2005, CRC/GC/2005/6, paras. 79-83. 
unaccompanied minor. The examination must be performed in a scientific, child and gender-sensitive and fair manner. ${ }^{261}$ Moreover, in the context of providing the highest attainable standard of health for children and facilities for the treatment of illness and rehabilitation of health, ${ }^{262}$ State parties should examine and address vulnerabilities of such children. ${ }^{263}$

Play and recreational opportunities are important for the well-being of a child. The Committee has interpreted Article 31 with regard to asylum seeking and refugee children in the form of three obligations: 1) State parties should refrain from interfering in the enjoyment of rights enshrined in Article 31 of the CRC; or 2) to prevent third parties from interfering; and 3) to implement the necessary measures and actions to ensure the enjoyment of the rights in Article 31.264

Which legal standards apply to the detention of minors? Article 37 contains the rule that 'no child shall be deprived of his or her liberty unlawfully or arbitrarily.' Article 37(b) determines that the detention of a child should be (i) in conformity with the law; (ii) be used only as a measure of last resort; and (iii) for the shortest appropriate period of time. Article 37(c) provides the conditions of detention. An important requirement is, inter alia, that where detention is applied, the needs of the minor should be taken into account and minors should not be separated from adults unless it is determined that it's in the child's best interests. Article 37(d) establishes the procedural guarantees in detention such as the prompt access to legal and other assistance for detained children.265 According to the Committee, this legal obligation requires that the child should be assigned a legal representative as well as a guardian or adviser to safeguard the best interests of the child. ${ }^{266}$ The current international opinio juris is that detention of minors may only be conducted if an individual assessment has been performed and only in exceptional circumstances, which is in conformity with the

${ }^{261}$ UN Committee on the Rights of the Child (CRC), CRC General Comment No. 6 (2005): Treatment of Unaccompanied and Separated Children Outside their Country of Origin, 1 September 2005, CRC/GC/2005/6, para. 31.

262 In compliance with Articles 23, 24 and 39 of the CRC.

263 UN Committee on the Rights of the Child (CRC), CRC General Comment No. 6 (2005): Treatment of Unaccompanied and Separated Children Outside their Country of Origin, 1 September 2005, CRC/GC/2005/6, paras. 46-48.

264 UN Committee on the Rights of the Child (CRC), CRC General Comment No. 17 (2013) on the right of the child to rest, leisure, play, recreational activities, cultural life and the arts (art.31), 17 April 2013, para. 54.

265 See for a more detailed analysis in this regard Smyth, C., Is the Right of the Child to Liberty Safeguarded in the Common European Asylum System? European Journal of Migration and Law, Volume 15, Issue 2, 2013.

266, UN Committee on the Rights of the Child, General Comment No. 6, (2005): Treatment of Unaccompanied and Separated Children Outside their Country of Origin, 1 September 2005, CRC/GC/2005/6, para. 36. 
principle of last resort. Hence, the automatic detention of minors is not allowed.267 If a minor is detained, the minor should be treated in accordance with the needs and rights of his age. Further requirements provide that the minor should be separated from adult detainees unless it goes against the best interests of the child. The minor should be kept united with his family in the case where the family is also detained and the unaccompanied minor should at all times be permitted to communicate with his relatives. ${ }^{268}$

According to the Committee, when detention is exceptionally justified, it should be in conformity with the law and only be applied as a measure of last resort and for the shortest appropriate period of time. Moreover, the principle of the best interests of the child should govern detention conditions. In addition, children have the right to education and recreation during their detention period. They should also have the right to free access to legal assistance. 269

\subsubsection{Unaccompanied minors in the asylum process}

The ExCom Conclusions take the view that children in the context of asylum are more vulnerable than adults because of their 'age, social status and physical and mental development.' They are vulnerable to physical and psychological abuse and exploitation. Individual and situational factors may place children at increased risk. With respect to unaccompanied minors, prioritized processing, family tracing and reunification should be facilitated, including accommodation designed for unaccompanied minors. ${ }^{270}$

The UNHCR Handbook advises that a legal representative should be appointed in order to assist the unaccompanied minor throughout the asylum procedure. Other important elements to be taken into account during the examination of asylum claims of children are the age, the level of education, the ability to understand the procedural aspects, the capacity to remember key events of past persecution, the ability to communicate in an intelligent manner. Furthermore, a minor asylum applicant may present a vague or inconsistent narrative or he may be unaware of the proceedings that might be relevant to the claim of persecution. Therefore, it is essential that the degree of his mental development and maturity should be taken into account when assessing the refu-

267 Smyth, C., Is the Right of the Child to Liberty Safeguarded in the Common European Asylum System? European Journal of Migration and Law, Volume 15, Issue 2, 2013, p. 119.

268 Smyth, C., Is the Right of the Child to Liberty Safeguarded in the Common European Asylum System? European Journal of Migration and Law, Volume 15, Issue 2, 2013, p. 124.

269 UN Committee on the Rights of the Child (CRC), CRC General Comment No. 6 (2005): Treatment of Unaccompanied and Separated Children Outside their Country of Origin, 1 September 2005, CRC/GC/2005/6, paras. 61-63.

270 UNHCR, Conclusion on Children at Risk No. 107 (LVIII) - 2007, 5 October 2007, No. 107 (LVIII) -2007. 
gee status. ${ }^{271}$ The mental maturity of a minor should be determined against his personal, family and cultural background. 272

The UNHCR Guidelines interpret the 'best interests' as the child's wellbeing. What precisely the well-being of the child entails depends on different individual circumstances, which are 'age, the level of maturity of the child, the presence or absence of parents, the child's environment and experiences'. ${ }^{273}$

As regards the detention of asylum applicants, the UNHCR Guidelines provide that, inter alia, minors (or unaccompanied children) under the age of 18 should not be detained. Minors should be placed with family members who are already in the country or alternatives to detention should be made possible for this extremely vulnerable group. When State parties cannot provide for alternatives to detention, then the detention of minors should be in conformity with Article 37(b) of the CRC, which provides that the detention of asylum seeking children should be used 'only as a measure of last resort' and for the 'shortest appropriate period of time.'

In addition, in case minors are detained at airports, they should not be kept in prison-like conditions. State parties should strive to release them and locate them in other suitable accommodation or if this is not possible, children and their families should be placed in special living quarters. Furthermore, the right to education should be guaranteed at all times during detention and children should benefit from child friendly recreation that is good for their well-being and mental development. As to procedural guarantees, children should benefit from the same minimum legal provisions as adults and unaccompanied minors should be designated a legal adviser. ${ }^{274}$

\subsubsection{European human rights standards}

It is important to note that the ECtHR has on several occasions recognized in its case law the principle of the best interests of the child. In Neulinger, the ECtHR underlined that 'there is currently a broad consensus - including in international law - in support of the idea that in all decisions concerning children, their best interests must be paramount'. ${ }^{275}$

271 Handbook on Procedures and Criteria for Determining Refugee Status under the 1951 Convention and the 1967 Protocol relating to the Status of Refugees, HCR/IP/4/Eng/REV.1 Reedited, Geneva, January 1992, UNHCR 1979, para. 214.

272 Handbook on Procedures and Criteria for Determining Refugee Status under the 1951 Convention and the 1967 Protocol relating to the Status of Refugees, HCR/IP/4/Eng/REV.1 Reedited, Geneva, January 1992, UNHCR 1979, para. 216.

273 UNHCR, Guidelines on Determining the Best Interests of the Child, May 2008, p. 14.

274 UNHCR, Revised Guidelines on Applicable Criteria and Standards relating to the Detention of Asylum-Seekers, 26 February 1999, Guideline 6, pp. 7-8.

275 Neulinger and Shuruk $v$ Switzerland, Application no. 41615/07, European Court of Hu- 
The ECtHR has recognized in its case law the extreme vulnerability of minors, whether accompanied or unaccompanied. In Mubilanzila, the ECtHR had to examine whether the detention of a five years old unaccompanied minor constituted a violation of Article 3 of the ECHR. The unaccompanied minor was kept in a detention centre with adults for two months. Moreover, the Belgian authorities provided no guardian to assist the applicant throughout the procedure. The other applicant in this case, was the mother of the unaccompanied minor who had already arrived in Canada in 2000, where she received her refugee status. The mother asked her brother who lived in the Netherlands to pick her up in the country of origin and to take care of her daughter until she was able to reunite with her. The ECtHR held that that the unaccompanied minor 'was in an extremely vulnerable situation (...) She therefore indisputably came within the class of highly vulnerable members of society to whom the Belgian State owed a duty to take adequate measures to provide care and protection as part of its positive obligations under Article 3 of the Convention.'276 Additionally, the applicant's complained that Belgium violated Article 8 of the ECHR. The applicant submitted that the detention of the unaccompanied daughter interfered with the right to respect their private life and family life as enshrined under Article 8 of the ECHR. The Belgian authorities were, or should have been, aware of the refugee status of the mother in Canada, which was also confirmed by UNHCR. The ECtHR observed that the detention of the unaccompanied minor delayed family reunification. Considering the fact that the unaccompanied minor was under the responsibility of the Belgian State, the authorities have a duty to facilitate the family reunification. Accordingly, there has been disproportionate interference with the applicants' right to respect for their family life, resulting in a violation of Article 8 of the ECHR. ${ }^{277}$

In a similar case Muskhadzhiyeva, the applicant, a Russian national of Chechen origin arrived in Belgium through Poland with her four children and requested asylum. ${ }^{278}$ The Belgian authorities denied their application on the basis of the Dublin Regulation which provided that Poland was responsible for examining their asylum claim. The single mother and her four children were kept in a closed transit centre near Brussels airport pending their removal. During their detention period, the international organization "Doctors without borders" carried out an examination on the mental and physical state of the appli-

man Rights, 6 July 2010, para. 135.

276 Mubilanzila Mayeka and Kaniki Mitunga v Belgium, Application no. 13178/03, European Court of Human Rights, 12 October 2006, para. 55.

277 Mubilanzila Mayeka and Kaniki Mitunga v Belgium, Application no. 13178/03, European Court of Human Rights, 12 October 2006, paras. 83-87.

278 Muskhadzhiyeva and Others v Belgium, Application no. 41442/07, European Court of Human Rights, 19 January 2010. 
cants and it appeared that the four children had serious psychological and psycho traumatic symptoms. The medical examiners advised the authorities to immediately release the applicants. However, the Belgian authorities returned the applicants back to Poland. The mother Aina Muskhadzhiyeva filed a complaint at the ECtHR complaining that Belgium had breached Article 3 of the ECHR because of the detention conditions which lasted for more than a month and the applicant complained that Belgium had violated Article 5(1) and (4) of the ECHR since their detention was unlawful and there was no effective remedy to challenge the detention order. The ECtHR decided that the detention of the four children for over a month violated Article 3 of the ECHR considering the extreme vulnerability of a child. The Belgian State had a duty to effectively protect the children and not place them in a closed detention centre. The ECtHR stated:

'que, combinée avec l'article 3, l'obligation que l'article 1 de la Convention impose aux Hautes Parties contractantes de garantir à toute personne relevant de leur juridiction les droits et libertés consacrés par la Convention leur commande de prendre des mesures propres à empêcher que lesdites personnes ne soient soumises à des tortures ou à des peines ou traitements inhumains ou dégradants. Ces dispositions doivent permettre une protection efficace, notamment des enfants et autres personnes vulnérables et inclure des mesures raisonnables pour empêcher des mauvais traitements dont les autorités avaient ou auraient dû avoir connaissance'. ${ }^{279}$

In respect of the mother, the ECtHR decided that there was no violation of Article 3 ECHR. Although the mother was under constant stress and pressure, she was not separated from her children. This did not lead to a breach of Article 3 ECHR. ${ }^{280}$ As to the alleged violation of Article 5(1) of the ECHR, the ECtHR provided that it was lawful to put the mother in detention in view of her expulsion, however, the ECtHR did find a breach of Article 5(1) of the ECHR with respect to the children. Here again, the ECtHR found that the extremely vulnerable position of the children and their detention in a closed centre with adults, violated Article 5(1) of the ECHR.281

In Rahimi, the ECtHR has determined that the Greek authorities violated Article 3 of the ECHR by subjecting an unaccompanied minor to ill-treatment. The case concerned an Afghan minor who was unaccompanied and entered Greece irregularly to seek asylum. The applicant was held in a detention centre

279 Muskhadzhiyeva and Others v Belgium, Application no. 41442/07, European Court of Human Rights, 19 January 2010, para. 55.

280 Muskhadzhiyeva and Others v Belgium, Application no. 41442/07, European Court of Human Rights, 19 January 2010, para. 66.

281 Muskhadzhiyeva and Others v Belgium, Application no. 41442/07, European Court of Human Rights, 19 January 2010, paras. 72-75. 
pending his expulsion order. The applicant complained that Greece violated Article 3 of the ECHR and 13 of the ECHR and as well as Article 5(4) of the ECHR. The ECtHR concluded that considering the applicant's extremely vulnerable position and the detention conditions the unaccompanied minor was placed in, the Greek authorities had the obligation to provide him with care and attention and as well as to appoint a legal guardian and thus the 'inaction' (en raison de leur passivité) of the Greek authorities amounted to a breach of Article 3 of the ECHR.282

In Kanagaratnam, another example of a single parent with minor children, the ECtHR assessed the detention by the Belgium authorities pending their removal. ${ }^{283}$ Upon their arrival and request for asylum in Belgium, the Sri Lankan applicant and her children were placed in a closed detention centre. The family remained in detention until their removal. After a subsequent asylum application, the applicant and her children were granted this time refugee status. Despite the positive decision on their refugee status, the applicant filled a complaint that Belgium violated Article 3 of the ECHR because the detention lasted almost four months and that Belgium violated Article 5(1)(f) of the ECHR because their detention was not in compliance with the law and thus had been arbitrary.

The ECtHR ruled that the children were already particularly vulnerable upon their arrival in Belgium due to the difficult experiences they had in the country of origin and that their vulnerability had been increased following their detention in Belgium. By placing them in a closed detention centre, the authorities subjected the children to feelings of anxiety and inferiority and thereby obstructed their development. The ECtHR therefore ruled that Belgium had violated Article 3 of the ECHR regarding the detention of the children. The ECtHR did not find, as in the Muskhadzhiyeva case, a violation of Article 3 of the ECHR concerning the detention of the mother. According to the ECtHR, the children were not separated from their mother throughout the procedure and thus the level of treatment in this respect did not fall under the minimum of Article 3 of the ECHR. As to the alleged violation of Article 5(1) of the ECHR, the ECtHR ruled that the placement of the children in a closed centre together with adults in circumstances that adversely affected the vulnerability of the children and the detention of the mother amounted to a violation of Article 5(1) of the ECHR.284

282 Rahimi v Greece, Application no. 8687/08, European Court of Human Rights, 5 April 2011, paras. 86-93.

283 Kanagaratnam and Others v. Belgium, Application no. 15297/09, European Court of Human Rights, 13 December 2011.

284 Press release issued by the Registrar of the Court, ECHR 282 (2011), 13 December 2011. 
The ECtHR, referring to the Nunez case, 285 emphasized that the best interests of the child should be a primary consideration in all actions taken by public authorities concerning children, especially in expulsion issues. The ECtHR starts from the assumption that children are vulnerable due to their status as children and because of their personal history ('Il faut donc partir de la présomption que les enfants étaient vulnérables tant en raison de leur qualité d'enfants que de leur histoire personnelle'). ${ }^{286}$

The question of when the level of severity is attained resulting in treatment contrary to Article 3 of the ECHR was also addressed in Popov. ${ }^{287}$ The detention of two minor applicants was considered to violate Article 3 of the ECHR, however, the detention of the parents was not considered to be such a violation. The applicants and their minor children from Kazakhstan were held in a detention centre pending their removal. The applicants complained about the conditions and the duration of the detention and thus alleged violation of Article 3 of the ECHR. The French authorities argued that the case at issue differs from the Mubilanzila because the applicant in that case was an unaccompanied minor detained separately. In the present case the minor children and their parents were not separated from each other. Secondly, according to the French authorities, the present case differed from the Muskhadzhiyeva case because of the circumstances in that case such as the age, health status and the inadequate accommodation facilities of the minor applicants, which resulted in a violation of Article 3 of the ECHR. Moreover, the authorities in France argued that the detention was lawful and the length of the detention was relatively shorter compared to the Mubilanzila and Muskhadzhiyeva. ${ }^{288}$ However, the ECtHR held that the young age of the children and the length of their detention, including the conditions violated Article 3 of the ECHR. ${ }^{289}$ The ECtHR ruled that the extreme vulnerability of children is far more important than any other measures regarding irregular migrants. State authorities are not exempted from their positive obligation to protect children and to adopt adequate measures. Children, whether alone or accompanied should be granted protection and authorities should be aware that children have specific needs because of 'their age and lack

285 Nunez v Norway, Application no. 5597/09, European Court of Human Rights, 28 June 2011.

286 Kanagaratnam and Others v Belgium, Application no. 15297/09, European Court of Human Rights, 13 December 2011, para. 67.

287 Popov v France, Application no. 39472/07 and 3947/07, European Court of Human Rights, 19 January 2012.

288 Popov v France, Application no. 39472/07 and 3947/07, European Court of Human Rights, 19 January 2012, para. 61.

289 Popov v France, Application no. 39472/07 and 3947/07, European Court of Human Rights, 19 January 2012, para. 76. 
of independence, but also to their asylum-seeker status.' 290 The ECtHR has also found that the detention of an unaccompanied minor in police premises constituted a violation of Article 3 of the ECHR. In line with previous jurisprudence, the ECtHR has held that the State in question did not take into account the vulnerability of the applicant and the fact that he was disabled. ${ }^{291}$

The ECtHR in Tarakhel reiterated its general principles stressing that it is important to bear in mind that the child's extreme vulnerability is the decisive factor and takes precedence over considerations relating to the status of illegal immigrant'. ${ }^{292}$ Children are considered to have specific needs and to be extremely vulnerable and therefore they should be accommodated in adequate reception conditions that take into account the age of the child. If reception condition facilities are not adapted to the specific needs of the child, Article 3 of the ECHR could be violated.293 Moreover, the vulnerability of the applicants was aggravated when it concerns asylum applicants who are also unaccompanied minors. ${ }^{294}$ Hence, in the view of the ECtHR, minors require special protection because of their special needs and extreme vulnerability. National authorities should be aware that children have specific needs that are related to their age and dependency on others, but also because of their status as asylum applicants.

Complementary to the ECHR, the human rights of the child enshrined in the European Social Charter have specific safeguards and guarantees for the protection of children. The European Committee of Social Rights has pointed out in Defence for Children International (DCI ${ }^{295}$ that the European Social Charter provides several specific rights for children. ${ }^{296}$ Moreover, the rights in the

290 Popov v France, Application no. 39472/07 and 3947/07, European Court of Human Rights, 19 January 2012, para. 91.

${ }^{291}$ H.A. v Greece, Application no. 19951/16, European Court of Human Rights, 28 February 2019, para. 166. See also Khan v France, Application no. 12267/16, European Court of Human Rights, 28 February 2019.

292 Tarakhel v Switzerland, Application no. 29217/12, European Court of Human Rights, 4 November 2014, para. 99 citing Mubilanzila Mayeka and Kaniki Mitunga v Belgium, Application no. 13178/03, European Court of Human Rights, 12 January 2007, para. 55.

293 Tarakhel $v$ Switzerland, Application no. 29217/12, European Court of Human Rights, 4 November 2014, para. 119.

294 Abdullahi Elmi and Aweys Abubakar v Malta, Applications nos. 25794/13 and 28151/13, European Court of Human Rights, 22 November 2016, para. 113.

295 Council of Europe, European Committee of Social Rights, Defence for Children International (DCI) $v$ the Netherlands, Complaint No. 47/2008, Decision on the merits, 20 October 2009.

296 See para. 25 in Defence for Children International (DCI) $v$ the Netherlands, Complaint No. 47/2008, Decision on the merits, 20 October 2009: 'Right to shelter in Article 31(2); right to health in Articles 8, 11, 7, 19(2); right to education in Articles 9, 10, 15, 17, 19(11-12); protection of the family and right to family reunion in Articles 16, 27, 19(6); protection against danger and abuse in Articles 7(1) and 17; protection of child labour 
Social Charter should be implemented in a practical and effective manner as well as to the CRC's principle best interests of the child. ${ }^{297}$

At the political level, the Committee of Ministers has adopted a Recommendation with regard to unaccompanied minors in accelerated procedures and in detention. The Committee of Ministers encourages State parties to take into account the vulnerability of unaccompanied minors or victims of torture in the determination of applying accelerated procedures in the context of asylum, and as a principle not to detain unaccompanied minors. ${ }^{298}$ In addition, the Parliamentary Assembly of the Council of Europe (PACE) has adopted in 2016 a Resolution on the harmonization of the protection of unaccompanied minors in Europe. The Parliamentary Assembly identifies that the special protection of unaccompanied minors is not systematically guaranteed in the Member States and therefore encourages its Member States to closely work together in order to improve the protection of unaccompanied minors. ${ }^{299}$

\subsection{Analysis}

The General Comments of the CRC show a nuanced understanding of vulnerability because they include both inherent and situational sources of vulnerability. Vulnerability is not just linked to children because of their age, particular situations that may render or aggravate the vulnerability of children are also discussed. In addition, the General Comments recognize that each individual child has different kinds and degrees of vulnerability. Hence, recognizing that there are layers of vulnerability. 300

The foregoing sections show that the CRC contains a number of obligations for State parties with regard to children and especially on unaccompanied minors in the field of asylum. The notion of vulnerability plays an important role in this area. For example, State parties should guarantee that the best interests of the child are a primary consideration in all actions concerning children. In the

under the age of 15 in Articles 7(1), (3); and specific work conditions between 15 and 18 in Article 7.'

297 Defence for Children International (DCI) v the Netherlands, Complaint No. 47/2008, Decision on the merits, 20 October 2009, paras. 26-29.

298 Council of Europe, Committee of Ministers (2009), Guidelines on human rights protection in the context of accelerated asylum procedures, Guideline III.1 and XI.2.

299 Council of Europe, Parliamentary Assembly, PACE Resolution 2136 (2016), Harmonising the protection of unaccompanied minors in Europe. See also Council of Europe, Parliamentary Assembly, PACE Resolution 1810 (2011), Unaccompanied children in Europe: issues of arrival, stay and return and Council of Europe Committee of Ministers, Recommendation $\operatorname{Rec}(2003) 5$ on measures of detention of asylum seekers.

300 Luna, F, Elucidating the Concept of Vulnerability: Layers not Labels, International Journal of Feminist Approaches to Bioethics, Vol. 2, No.1, 2009. 
assessment and determination of the best interests of the child principle and whether the child has special needs, State parties should take the vulnerability of the child into consideration. In addition, State parties should take appropriate measures to ensure adequate protection to asylum seeking children and refugee children. Furthermore, as regards unaccompanied minors, State parties should appoint a guardian or a legal representative to the unaccompanied minor and free legal representation in the asylum process. It is important to note that the vulnerability of unaccompanied minors should be taken into account. Asylum applications of unaccompanied minors should be prioritized and be given the benefit of the doubt about the credibility of their asylum story. Another important obligation concerns the facilitation of family tracing and reunification of unaccompanied minors. Finally, it is important to note that minors may not automatically be detained. When detention is applied, State parties are required to apply certain procedural guarantees.

The consideration that children are vulnerable and that asylum applications of unaccompanied minors should be prioritized, and also that tracing of family members should facilitated has been confirmed by the ExCom. The UNHCR Handbook refers in line with the CRC that unaccompanied minors have a guardian appointed in the asylum process. It is also important to note that there are inconsistencies in the definition of 'unaccompanied minor' between the UNHCR and the Committee of the Rights of the Child.

At the ECHR level, it has been submitted that the ECtHR has delivered important case law with regard to children and unaccompanied minors in the context of migration. In the understanding of the ECtHR, children are vulnerable or in a vulnerable situation and unaccompanied minors are considered to be extremely vulnerable. Established case law of the ECtHR shows in a number of cases involving the detention of children that Article 3 of the ECHR was violated because the conditions of detention were not adapted to the child's age. It has been submitted that children have specific needs that are related to their age and dependency to others, but also because of their status as asylum applicants. It is also noticeable that the ECtHR in Mubilanzila has held that the applicant, an unaccompanied minor and an irregular migrant, was deemed to be in an extremely vulnerable situation. In contrast, as discussed in chapter 2, although the applicants in Khlaifia were also irregular migrants, albeit adults, they were not considered to be in a vulnerable situation. The Grand Chamber did not accept the vulnerability of the applicants in question. ${ }^{301}$

301 Khlaifia and Others v Italy, Application no. 16483/12, European Court of Human Rights, Grand Chamber, 15 December 2016, para. 194. 


\subsection{Concluding remarks}

This chapter has identified a number of obligations that stem from international human rights law that are of relevance with regard to victims of torture and unaccompanied minors in the asylum process.

As regard victims of torture, an important procedural obligation for State parties concerns, inter alia, the requirement to guarantee the means for 'as full rehabilitation as possible', which implies that the rehabilitation must be holistic and 'include medical and psychological care as well as legal and social services'. These services should be available, appropriate and easily accessible. In terms of reception conditions, the Conclusion of the ExCom provides that the specific needs of torture victims should be taken into account. Another important finding of this chapter is that the ECtHR attaches considerable weight to medical reports explaining the physical or mental trauma and past torture allegations of the applicant. Arguably, effective documentation of torture allegations is an important aspect in the asylum process as it may support the credibility of the applicant.

As regards unaccompanied minors, the findings show, inter alia, that in addition to the best interests of the child, which should be a primary consideration in all actions concerning children, State parties should take appropriate measures to guarantee that a minor seeking asylum whether unaccompanied or accompanied, or who has been granted refugee obtains adequate protection. Furthermore, it is important to note that minors may not automatically be detained. When detention is applied, State parties are required to apply certain procedural guarantees. The analysis of the ECtHR case law has shown that minors require special protection because of their special needs and extreme vulnerability. State parties should take into account that children have specific needs that are related to their age and dependency on others, but also because of their status as asylum applicants. It can be concluded that unaccompanied minors in the view of the ECtHR are considered to be the most vulnerable group.

In chapter 6, I will compare the obligations that have been identified in this chapter with the relevant legal standards enshrined in the recast legislative acts of the CEAS with regard to victims of torture and unaccompanied minors, and examine to what extent these CEAS standards are in accordance with the obligations resulting from international law. The next chapter focuses on the CEAS and examines the EU policy responses in the field of asylum. 


\section{4- The development of asylum co-operation in the Euro- pean Union}

\subsection{Introduction}

The purpose of this chapter is to identify what the EU has done so far in the field of asylum. I examine the context to the establishment of the CEAS. I analyse why and how the CEAS has been established. To this end, I provide an extensive description of asylum co-operation in the EU. In my view, an extensive discussion on the background and development of EU asylum co-operation is necessary in order to better understand the current challenges facing the CEAS. As the protection of vulnerable persons has become more significant within the CEAS, I also examine how the EU has addressed the situation of vulnerable persons.

This chapter is divided in three parts. The first part includes a historical overview of the period before the establishment of the CEAS. The second part discusses the development of the first and second-phase of the CEAS. The third part provides an examination of the adopted policies and legislative measures issued by the EU in the context of the so-called refugee crisis.

\subsection{The beginning of asylum co-operation in the EU}

\subsubsection{Intergovernmental ad-hoc co-operation on asylum (1985-1992)}

European political co-operation in the area of asylum can be traced back to the mid-1980s, which was primarily an intergovernmental ad-hoc co-operation and outside the framework of the European Community. A major event that stimulated the co-operation in asylum issues was the introduction of the Single European Act (SEA) in 1986.302 The SEA introduced the idea of free movement of goods, services, capital and persons. In order to achieve a common market, the internal borders were to be removed. The concept of the abolition of the internal borders in order to enhance economic integration activated the fear of national governments of losing control over the entry of third-country nationals to their territory. Thus, Member States required compensatory measures and better co-ordination in the field of asylum and migration. ${ }^{303}$ Hence, an

302 Single European Act, adopted 28 February 1986, entered into force 1 July 1987, Official Journal L 169, 29 June 1987.

303 Bonjour, S., Explaining Ambition: the Elaboration of the Working Program for the European Asylum Policy, 1996-1999, Migration, Integration and Citizenship, A Challenge for Europe's Future, Volume II, Edited by Hildegard Schneider, Forum Maastricht, 2005, p. 175. 
intergovernmental 'Ad Hoc Immigration Group' was created by the 'Trevi' ministers to deal with issues around visa, immigration, border controls and asylum. ${ }^{304}$ The 'Trevi' group established in 1976 was composed of ministerial meetings, senior representatives of the twelve Member States and working groups discussing counter-terrorism and the co-ordination of policing. ${ }^{305}$

The compensatory measures were defined in the Palma document and prepared by the Co-ordinators group on the Free Movement of Persons. Priority was given to the co-ordination of asylum matters since asylum claims were increasing and carrier sanctions were not substantially effective. Moreover, some Member States observed the migratory movement as a serious issue. ${ }^{306}$ The measures on asylum defined by the Palma document concerned: 'acceptance of identical international commitments with regard to asylum; determining the State responsible for examining the application for asylum; simplified or priority procedures for the examination of clearly unfounded requests; conditions governing the movement of the applicant between Member States and study of the need for a financing system to fund the economic consequences of implementing the common policy. ${ }^{307}$ The measures suggested by the Co-ordinators group on the Free Movement of Persons resulted in the adoption of the Dublin Convention ${ }^{308}$ and the Draft Convention on the Crossing of External Borders.

\subsubsection{Schengen}

Alongside the intergovernmental process of the Ad Hoc Group Immigration, another process influenced the co-operation on asylum and immigration. France, Germany and the Benelux countries agreed to an abolition of internal border controls. The so-called 'Schengen' co-operation resulted in 1985 in the adoption of the first Schengen Agreement on the Gradual abolition of Checks at the Common Borders. ${ }^{309}$ A second Schengen Agreement was adopted in

304 Schneider, H., Migration, Integration and Citizenship, A Challenge for Europe's Future, Volume II, Forum Maastricht, 2005, pp. 22-23.

305 See for further details Bunyan, T., Trevi, Europol and the European State in Statewatching the new Europe, Statewatch Publication, 1993.

306 Boccardi, I., Europe and Refugees, Towards an EU Asylum Policy, Kluwer Law International, 2002, pp. 28-34.

307 See Vink, M., The Europeanization of Domestic Asylum Policy: National Executive Power and Two-Level Games, Paper presented at the ECSA Seventh Biennial International Conference, May 31- June 2, 2001, Madison Winconsin, p. 8.

308 Convention Determining the State Responsible for Examining Applications for Asylum lodged in one of the Member States of the European Communities ("Dublin Convention"), 15 June 1990, Official Journal C 254, 19/08/1997 p. 0001 - 0012.

309 Da Lomba, S., The Right to seek Refugee Status in the European Union, Intersentia, 2004, pp. 23-24. 
1990.310 The Schengen area has expanded throughout the years to include all Member States (including non-EU Member States such as Iceland, Norway, Switzerland and Liechtenstein) except the United Kingdom (UK) and Ireland. Lavenex noted that 'the starting point and central concern of the Schengen and Dublin Conventions are not refugees, but the questions of freedom of movement and territorial borders in the European Union'. ${ }^{311}$ The Schengen Agreements and the Dublin Convention did not aim to harmonize the asylum rules in the Member States and received much criticism by the UNHCR especially regarding the provisions on visa entry requirements and carrier sanctions. ${ }^{312}$

\subsubsection{Treaty of Maastricht (1993)}

The dysfunctional intergovernmental ad-hoc co-operation in the area of asylum and migration in the 1980s resulted in the prioritization of this matter on the political agenda of the Intergovernmental Conference (IGC). ${ }^{313}$ The intergovernmental co-operation on asylum was taken a step further with the entering into force of the Treaty of Maastricht in November 1993.314 The Maastricht Treaty established a new legal structure in the form of Three Pillars. The First Pillar comprised the European Community Treaty, the Second and Third Pillars consisted of Security and Foreign Policy and Justice and Home Affairs.

A key achievement was highlighted in Article K.1 the Treaty on the European Union (TEU), which to referred asylum policy as 'matters of common interest.' In addition, Article K.2 TEU required that all initiatives with respect to matters enshrined in Article K.1 must comply with the ECHR, the Refugee Convention and the protection provided by the Member States to persons who have successfully claimed persecution on political grounds should be taken into account. ${ }^{315}$ Although Title VI codified a new framework for law making, the procedures concerning the enforcement of legal instruments were not pro-

310 Convention Implementing the Schengen Agreement of 14 June 1985 between the Governments of the States of the Benelux Economic Union, the Federal Republic of Germany and the French Republic, on the Gradual Abolition of Checks at their Common Borders ("Schengen Implementation Agreement"), 19 June 1990.

311 Lavenex, S., The Europeanisation of Refugee Policies, between human rights and internal security, Ashgate Publishing Company, 2001, p. 94.

312 UNHCR, Position on Conventions Recently Concluded in Europe (Dublin and Schengen Conventions), 16 August 1991, p. 385.

313 Bonjour, S., Explaining Ambition: the Elaboration of the Working Program for the European Asylum Policy, 1996-1999, Migration, Integration and Citizenship, A Challenge for Europe's Future, Volume II, Edited by Hildegard Schneider, Forum Maastricht, 2005, pp. 171-172.

314 The Treaty on European Union, adopted on 7 February 1992, entered into force 1 November 1993, Official Journal C 191, 29 July 1992.

315 Boccardi, I., Europe and Refugees, Towards an EU Asylum Policy, Kluwer Law International, 2002, pp. 61-64. 
gressing swiftly. On the basis of K.3 TEU the Council had the right to adopt initiatives, joint actions and joint positions which resulted in international conventions that had to be adopted by the national governments and ratified by the national parliaments of Member States. ${ }^{316}$ There was a possibility, by virtue of the passerelle in Article K.9 TEU, to transfer the rules with respect to asylum and immigration to the competence of the Community. However, the passerelle was never invoked. ${ }^{317}$ Generally, the new provisions under the Third Pillar in the Maastricht Treaty gave the EU cooperation on asylum an impulse. Asylum policy entered the EU legal framework as part of the Third Pillar.

\subsubsection{London Resolutions}

In November 1992, the Ministers responsible for Immigration agreed on three instruments that were adopted a month later by the European Council in December 1992. These instruments, although non-binding, closely reflected the further prioritization of co-operating on asylum matters. The 'London Resolutions' comprised of a Resolution on 'manifestly unfounded applications for asylum', the Resolution on 'a harmonized approach to questions regarding host third countries' and the Conclusions on 'countries in which there is generally no serious risk of persecution. ${ }^{318}$

The first Resolution adopted was the manifestly unfounded applications for asylum, which states that applications for asylum should be considered as manifestly unfounded when 'there is clearly no substance to the applicant's claim to fear persecution in his own country' or 'when the claim is based on deliberate deception or is an abuse of asylum procedures'. These applications are handled in accelerated procedures.

The second adopted Resolution concerns the 'safe third countries', which provides that the first country the applicant has entered, or has had contact with, should examine the asylum application. The system extends to all potentially safe third countries. A country is considered 'safe' when the applicant should not fear for his or her life or freedom within the meaning of Article 33 of the Refugee Convention. A second criterion is when the applicant has not been subjected to torture or inhuman or degrading treatment and the final criteria is whether

316 Schneider, H., Migration, Integration and Citizenship, A Challenge for Europe's Future, Volume II, Forum Maastricht, 2005, p. 23.

317 Noll, G., Negotiating Asylum, the EU Acquis, Extraterritorial Protection and the Common Market of Deflection, Martinus Nijhoff Publishers, 2000, pp. 133-134.

318 Resolution on manifestly unfounded applications for asylum, Ad Hoc Immigration Group, SN 4822/1/92 WGI 1282 of 2//12/92; Resolution on a harmonized approach to questions concerning host third countries, SN 4823/92 WGI 1283 of 19/11/92; Conclusion on countries in which there is generally no serious risk of persecution, SN 4821/92 WGI 1281 of $1 / 12 / 92$. 
the applicant has been granted effective protection against refoulement as enshrined in the Refugee Convention. The Conclusions on countries in which there is no serious risk of persecution are attached to the Resolution on manifestly unfounded applications and establish the criteria to consider a country to be 'safe'. 319

\subsubsection{European cooperation on asylum (1995-1999)}

During the post-Maastricht period, two instruments were adopted that are significant in the field of asylum. The first instrument was the 1995 'Resolution on Minimum Guarantees in Asylum Procedures'320 (1995 Resolution). Where individuals may freely move, Member States realized that an adequate procedure was needed to deal with the claims of asylum applicants. The 1995 Resolution was a non-binding instrument, which enshrines certain procedural guarantees to the examination as provided under Article 3 of the Dublin Convention. References are made to the Refugee Convention and emphasizing the commitments Member States have under the ECHR. The 1995 Resolution provided for minimum rights that should be ensured during the entire asylum examination procedure. The principle of non-refoulement should be respected and 'no expulsion measure should be carried out as long as no decision has been taken on the asylum application'. It is noteworthy to mention the derogation clauses with respect to the minimum guarantees. The minimum guarantees are not applicable if a case is 'manifestly unfounded' as defined in the 1992 'London Resolutions'. This would result in a situation where an asylum applicant had limited rights to stay during an appeal. A second derogation was applicable if there was a 'host third country'. In that case an asylum applicant would be restricted to enter the territory of the Member State. ${ }^{321}$

The other attempt to harmonize certain procedures in asylum is the 1996 'Joint Position on the Harmonized Application of the Refugee Definition' (1996 Joint Position). ${ }^{322}$ The definition of who should be recognized as a refugee is defined in Article 1 of the Refugee Convention but it does not elaborate

319 Boccardi, I., Europe and Refugees, Towards an EU Asylum Policy, Kluwer Law International, 2002, pp. 74.-87; Lavenex, S., The Europeanisation of Refugee Policies, between human rights and internal security, Ashgate Publishing Company, 2001, pp. 112-113.

320 Council Resolution of 20 June 1995 on minimum guarantees for asylum procedures, OJ C274, 19 September 1996.

321 Boccardi, I., Europe and Refugees, Towards an EU Asylum Policy, Kluwer Law International, 2002, pp. 101-105; See for a more detailed analysis Boeles, P., and Terlouw, A., Minimum Guarantees for Asylum Procedures, International Journal of Refugee Law, Vol. 9, No. 3, 1997.

322 The Joint Position 96/196/JHA of 4 March 1996 adopted by the Council on the basis of Article K.3 of the Treaty of the European Union on the harmonised application of the definition of the term 'refugee' in Article 1 of the Geneva Convention of 28 July 1951 relating to the Status of Refugee, OJ L63/2., 13 March 1996. 
on how to examine this. Hence, this created divergent applications on the definition of the term refugee in Member States. In order to avoid this, Member States achieved agreement on common guidelines in a Joint Position. A contentious issue in the 1996 Join Position is the definition of agents of persecution. There was much criticism regarding this definition because it restricts the applicability of refugee protection to persons who are persecuted by state authorities. Individuals who have been persecuted by 'third-parties' will only fall within the scope of Article 1 of the Refugee Convention where they can prove it 'is individual in nature and is encouraged or permitted by the authorities'. ${ }^{323}$ Especially France and Germany adhered to a strict application of persecution by the State authorities. ${ }^{324}$ Even though, the Joint Position was not legally binding, it represented the restrictive position several Member State had on this issue. ${ }^{325}$

\subsubsection{Burden-sharing}

Another important development behind the further cooperation in the field of asylum was the rise in asylum applications in a few Member States due to the war in the former Yugoslavia. Germany and Austria received more than 450,000 refugees from the Balkans. In November 1992, the Council adopted a 'Conclusion on people displaced by the conflict in the former Yugoslavia'326 and in 1993 a 'Resolution on certain common guidelines with regard to the admission of particularly vulnerable persons from the former Yugoslavia'.327 The Resolution defined vulnerable groups as: 'detainees as prisoners of war in internment camps who are at risk for 'life or limb'; persons in need of medical assistance; severe sexually assaulted persons with no assistance possible near their home, including those who are 'under direct threat to limb or life' with no protection'. 328

However, concerned by the uneven distribution and the limited impact of these instruments, Germany aimed to find a consensus on this issue in the form of a burden-sharing agreement. Subsequently, an agreement was reached in 1995 with the 'Resolution on burden-sharing with regard to the admission and resi-

323 Lavenex, S., The Europeanisation of Refugee Policies, between human rights and internal security, Ashgate Publishing, 2001, p. 119. See para. 5.2 of the 1996 Joint Position.

324 Boccardi, I., Europe and Refugees, Towards an EU Asylum Policy, Kluwer Law International, 2002, pp. 107-111.

325 Phuong, C., Persecution by Non-state Agents: Comparative Judicial Interpretations of the 1951 Refugee Convention, European Journal of Migration and Law, 4, 2003, p. 531.

326 Conclusion on people displaced by the conflict in the former Yugoslavia (London, 30 November - 1 December 1993).

327 Resolution on certain common guidelines as regards the admission of particularly vulnerable persons from the former Yugoslavia (Copenhagen, 1 June 1993).

328 Joly, D., Haven or Hell?: Asylum policies and refugees in Europe, Oxford, Palgrave Macmillan, 1996, p. 76. 
dence of displaced persons on a temporary basis'. ${ }^{329}$ This Resolution contained common guidelines on the rules of procedure during mass influx of refugees. A year later, a 'Decision on an alert and emergency of displaced persons on a temporary basis' 330 was adopted in order to supplement the Resolution on burdensharing. The Council made efforts to create a warning system for crisis situations to which the procedures of the 1995 Resolution on burden-sharing would apply. During the Kosovo conflict in 1999, both instruments were applied. ${ }^{331}$

In 1995, the Schengen Convention had finally entered into force and the Dublin Convention entered into force in September 1997, seven years after it was signed. It was also during this period that the Commission made use for the first time of its right of initiative in the field of asylum.

In March 1997, the Commission submitted a Joint Action proposal 332 regarding temporary protection of displaced persons on the basis of Article K.3 (2) (b) of the TEU. The Commission aimed to develop a temporary protection regime containing minimum rights for the Union. However, the Council did not endorse the proposal. Especially, Article 5 on burden-sharing, which stated 'on the basis of the report of the Commission referred to in Article 4, the Council shall examine how best to support Member States which have been particularly affected by the mass influx of persons in need of international protection', was not accepted by some Member States. ${ }^{333}$

However, the absence of legal binding measures, the unanimity decisionmaking rule in the Council, the lack of parliamentary control, the limited role for the Commission and the lack of the judicial control of the ECJ characterized the short-comings of the intergovernmental framework during these years. By 1995, the Commission, the European Parliament and the Council have reported critically on how the intergovernmental co-operation on asylum functioned. These shortcomings on asylum and related measures provided for in the Maastricht Treaty required a reshaping of the existing framework. These issues

329 Council Resolution 95/C 262/01 of 25 September 1995 on burden-sharing with regard to the admission and residence of displaced persons on a temporary basis.

330 European Council Decision of 4 March 1996 on an alert and emergency of displaced persons on a temporary basis, OJ L63/10, 13 March 1996.

331 Boccardi, I., Europe and Refugees, Towards an EU Asylum Policy, Kluwer Law International, 2002, pp. 111-114; Lavenex, S., The Europeanisation of Refugee Policies, between human rights and internal security, Ashgate Publishing, 2001, pp. 120-122.

332 European Commission, Proposal to the Council for a Joint Action based on Article K.3(2)(b) of the Treaty on European Union concerning temporary protection of displaced persons (OJ 1997 C106/13).

333 Noll, G., and Vested-Hansen, J., Temporary Protection and Burden-Sharing: Conditionalising Access Suspending Refugee Rights? Implementing Amsterdam, Immigration and Asylum Rights in EC Law, Edited by Guild, E., and Harlow, C., Hart Publishing, 2001, pp. 204-207. 
became therefore important on the political agenda during the IGC in 19961997 and which resulted in the adoption of the Treaty of Amsterdam in 1997. ${ }^{334}$ The rules and concepts agreed in the different Resolutions, Conclusions, Joint Positions, Agreements and Conventions in the field of asylum during the period 1992-1999 have laid the fundamentals for the individual legally binding instruments adopted under the CEAS.

Figure 4.1. Timeline prior to the adoption of the Common European Asylum System (1985-1999)

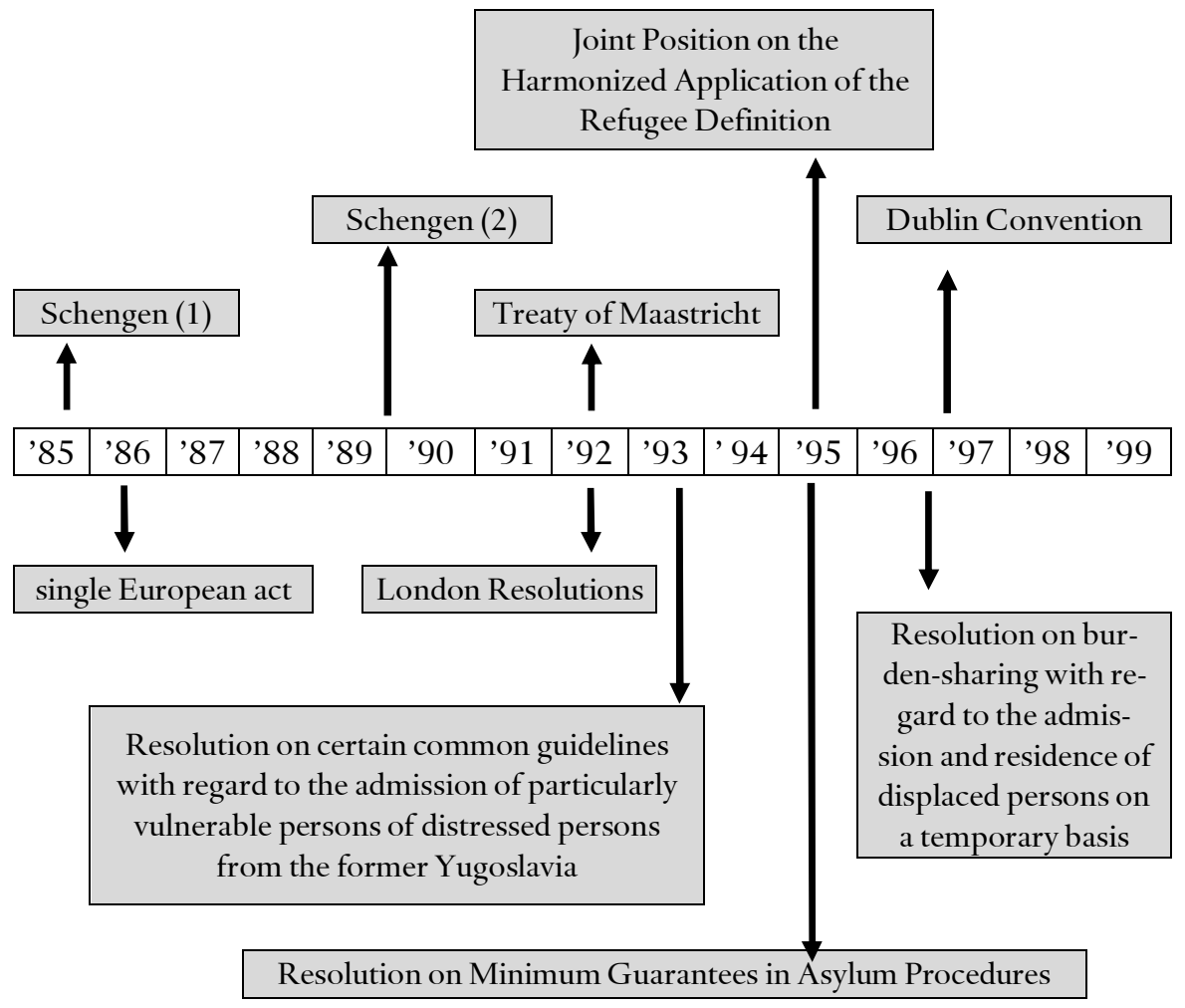

\subsection{The 1 st phase of the Common European Asylum System}

\subsubsection{Amsterdam (1999)}

The entry into force of the Treaty of Amsterdam on 1 May 1999 introduced an 'Area of Freedom, Security and Justice' (AFSJ). ${ }^{335}$ The provisions with regard to

334 Lavenex, S., The Europeanisation of Refugee Policies, between human rights and internal security, Ashgate Publishing, 2001, p. 126.

335 The Treaty of Amsterdam (Amending the Treaty on European Union, The Treaties es- 
asylum matters in the Treaty of Amsterdam were, to a large extent, already developed in the Vienna Action Plan ${ }^{336}$ in 1998 and also with the Tampere Conclusions of the European Council meeting on Justice and Home Affairs in October 1999. ${ }^{337}$ The Vienna Action Plan called for the adoption of certain asylum measures within two $^{338}$ and five years ${ }^{339}$ and measures that should be adopted as soon as possible in accordance with the Treaty of Amsterdam. ${ }^{340}$ The Treaty of Amsterdam introduced (partly) 'communitarisation' by moving asylum and immigration from the intergovernmental Third Pillar to the supranational First Pillar, under a new Part III, Title IV of the Treaty Establishing the European Community (EC Treaty). Title IV was categorized as 'visa, asylum, immigration and other policies related to the free movement of persons.' 341 This meant that the Community was granted the competence to adopt legally binding acts on asylum, which have direct effect in the national legal systems of the Member States. ${ }^{342}$

Article 63(1) of the EC Treaty required the Council to adopt minimum standards in the field of asylum policy during a transitional period of five years from the entry into force of the Treaty of Amsterdam. The transitional period ended on 1 May 2004 (the day that ten new Member States joined the EU). In many ways the "communitarisation" by the Treaty of Amsterdam constitutes a major breakthrough in the EU co-operation to establish a common EU asylum policy.

Boccardi observed that 'up until the Amsterdam Treaty, all asylum initia-

tablishing the European Communities and certain related acts, adopted 2 October 1997, Amsterdam, entered into force 1 May 1999) Official Journal C 340.

336 Action Plan of the Council and the Commission on How Best to Implement the Provisions of the Treaty of Amsterdam on an Area of Freedom, Security and Justice, Text adopted by the Justice and Home Affairs Council of 3 December 1998, OJ C 19/01, 23 January 1999.

337 Bonjour, S., Explaining Ambition: the Elaboration of the Working Program for the European Asylum Policy, 1996-1999, Migration, Integration and Citizenship, A Challenge for Europe's Future, Volume II, Edited by Hildegard Schneider, Forum Maastricht, 2005, p. 167.

338 Para. 36(b)(i): continued examination of the criteria and conditions for improving the implementation of the Dublin Convention and of the possible transformation of the legal basis to the system of Amsterdam; (ii) the implementation of Eurodac; (v) minimum standards on the reception of asylum seekers.

339 Para. 38 (b)(i): adoption of minimum standards with respect to the qualification of nationals of third countries as refugees; (ii) defining minimum standards for subsidiary protection to persons in need of international protection.

340 Para. 37 (a) minimum standards for giving temporary protection to displaced persons from third countries who cannot return to their country of origin.

341 Articles 61-69 TEC.

342 See Gondek, M., The Emerging European Asylum Law: Between Protection and Rejection, Migration, Integration and Citizenship, A Challenge for Europe's Future, Volume II, Edited by Hildegard Schneider, Forum Maastricht, 2005, pp. 191-192. 
tives had been justified as compensatory measures to be put in place before the abolition of internal border controls. However, in the years following the Maastricht Treaty, a number of asylum initiatives were adopted, whose logical connection to the necessities of the Single Market appeared to be rather remote. By leaving open the definition of measures concerning the very essence of refugee status and burden-sharing, Member States appeared to finally imply that asylum issues were to become a policy in their own right' ${ }^{343}$ While, the transfer of asylum issues from the Third Pillar to the First Pillar enabled (limited) judicial control for the CJEU ${ }^{344}$ and a shared initiative (during the transitional period) of the Commission with the Council to propose initiatives in the area of asylum, the decision-making procedure applied in the Council remained unanimous. Unlike now the European Parliament had a limited consultative role. ${ }^{345}$

Another new measure introduced to the new Title IV EC Treaty was 'Protocol No. 24' on asylum for nationals of EU Member States, or also known as the 'Aznar Protocol'. The central assumption is that the common level of protection of fundamental human rights and freedoms throughout the $\mathrm{EU}$ is of such a high level that all of its Member States should be considered as safe countries. Applications for international protection by a national of a Member State should therefore be declared inadmissible, save for a few exceptional situations. ${ }^{346}$ The Treaty of Amsterdam and 'Protocol No. 24' on asylum for nationals of EU Member States modified the Member States approach dealing with their international obligations. ${ }^{347}$

During the negotiations leading to the Treaty of Amsterdam, Denmark, Ireland and the UK were not in favour of endorsing further "communitarisation" of asylum and immigration matters. These Member States agreed because they were provided with an 'opt-out' from the implementation of this Title IV of the Treaty of Amsterdam. Furthermore, the Treaty of Amsterdam integrated the Schengen acquis into the EU legal order in order to ensure the coherence of European policies in the field of Justice and Home Affairs. ${ }^{348}$

343 Boccardi, I., Europe and Refugees, Towards an EU Asylum Policy, Kluwer Law International, 2002, p. 135.

344 Article 68 EC Treaty; only courts of last instance in Member States may request the CJEU for a preliminary ruling.

345 Article 67 EC Treaty.

346 Protocol (No 24) on asylum for nationals of Member States of the European Union, OJ C 115/305, 9 May 2008.

347 Guild, E., and Garlick, M., Refugee Protection, Counter Terrorism, and Exclusion in the European Union, Refugee Survey Quarterly, Vol. 29, No. 4, 2011, pp. 63-64.

348 Bonjour, S., Explaining Ambition: the Elaboration of the Working Program for the European Asylum Policy, 1996-1999, Migration, Integration and Citizenship, A Challenge for Europe's Future, Volume II, Edited by Hildegard Schneider, Forum Maastricht, 2005, p. 176. 


\subsubsection{Tampere (1999)}

In October 1999, the first ambitious multi-annual programme in the field of Justice and Home Affairs was adopted during the Council summit in Tampere (Finland). In the field of asylum, the Tampere Programme called for the development of an integrated EU asylum policy, which is fully committed to the Refugee Convention and other relevant international human rights obligations. ${ }^{349}$ The CEAS should be established 'based on a full and inclusive application of the Geneva Convention, thus ensuring that nobody is sent back to persecution, i.e. maintaining the principle of non-refoulement'. Moreover, the Union and the Member States reaffirmed 'the absolute respect of the right to seek asylum'. 350 The Tampere Programme emphasized not only the harmonization of refugee status but also the subsidiary protection measures complementing the refugee status. A two-stage approach was foreseen regarding the creation of a CEAS. In the short term, the Member States had to harmonize their asylum policies within five years. ${ }^{351}$ Such harmonization would be established by minimum standards in order to reduce differences between Member States. In the long-term, these rules should lead to 'a common asylum procedure and a uniform status for those who are granted asylum valid throughout the Union'. 352

The Commission proposed that Member States should be in a position to assess which person is in need of international protection and to 'respond properly to situations of vulnerability'. ${ }^{353}$ The political compass adopted under the Tampere Programme has influenced the substantive framework of EU asylum law of today. The policy on asylum was given an independent significance with a strong emphasis to international human rights obligations. ${ }^{354}$ When the negotiations began on the adoption of the individual asylum instruments, it was clear that the unanimity rule in the Council was problematic. Thus, Article 67 of the EC Treaty was amended with the Treaty of Nice, ${ }^{355}$ which made it possible to introduce qualified majority voting in the field of asylum, albeit from

349 See European Council, Presidency Conclusions, Tampere 15-16 October 1999, other focal points in the field of asylum and migration were 'Partnerships with countries of origin', 'Fair treatment of third country nationals' and 'Management of migration flows'.

350 European Council, Presidency Conclusions, Tampere 15-16 October 1999, para. 13.

351 European Council, Presidency Conclusions, Tampere 15-16 October 1999, para. 14.

352 European Council, Presidency Conclusions, Tampere 15-16 October 1999, para. 15.

353 Communication from the Commission to the Council and the European Parliament, Towards a common asylum procedure and uniform status, valid throughout the Union, for persons granted asylum, Brussels, 22.11.2000, COM(2000) 755 final, para, 1.2.

354 See Boccardi, I., Europe and Refugees, Towards an EU Asylum Policy, Kluwer Law International, 2002, pp. 173-175.

355 European Union, Treaty of Nice, Amending the Treaty on European Union, the Treaties Establishing the European Communities and Certain Related Acts, 11 December 2000, Official Journal C 80 of 10 March 2001; 2001/C 80/01. 
January 2005 on. ${ }^{356}$

\subsubsection{European Refugee Fund}

The first project undertaken by the EU in pursuit of its ambition to build a CEAS was to set up a European Refugee Fund. One of its objectives was to support Member States with regard to their reception conditions. Secondly, it sought to support Member States in integrating refugees into the society of the country in which they had started a new life and to create an equal burden for the Member States in receiving refugees and displaced persons. The integration process included support in the form of social housing assistance, health care and education of refugees. Thirdly, the European Refugee Fund assisted Member States in organizing action programmes on voluntary return to countries of origin, vocational training and support in resettlement. The European Refugee Fund has operated from 2000 to 2004, with financial resources of 216 million Euros. Subsequently, the European Refugee Fund was extended for the period 2005 to 2010 to support the efforts made by Member States in receiving refugees. ${ }^{357}$ A third Fund Decision was adopted in 2007, which covers the period from 2008 to 2013 as part of the General programme 'Solidarity and Management of Migration Flows'. 358

Currently, the Asylum, Migration and Integration Fund (AMIF) ${ }^{359}$ operate as the financial instrument to promote the efficient management of asylum and migration for the period 2014 to 2020. AMIF has a budget of 3.137 billion Euros, which serves four objectives: first, to establish an efficient and uniform asylum policy in the EU; strengthening legal migration to the EU and the integration of third country nationals; to facilitate Member States' efforts to return irregular migrants; and to support solidarity between Member States, in particular those that are most affected by the large number of arrivals of asylum applicants and migrants. 360

356 Peers, S., Legislative Update: EU Immigration and Asylum Competence and DecisionMaking in the Treaty of Lisbon, European Journal of Migration and Law, 10, 2008, p. 220.

357 Council Decision of 2 December 2004 establishing the European Refugee Fund for the period 2005 to 2010, L 381/52, 28 December 2004.

358 Decision No 573/2007/EC of the European Parliament and of the Council of 23 May 2007 establishing the European Refugee Fund for the period 2008 to 2013 as part of the General programme Solidarity and Management of Migration Flows and repealing Council Decision 2004/904/EC.

359 Regulation (EU) No 516/2014 of the European Parliament and of the Council of 16 April 2014 establishing the Asylum, Migration and Integration Fund, amending Council Decisions 2008/381/EC and repealing Decisions No 573/3007/EC and No $575 / 2007 / E C$ of the European Parliament and of the Council and Council Decision 2007//435/EC.

360 Article 3 of the Asylum, Migration and Integration Fund. 


\subsection{4. 'Spill-over'}

The question remains why the Member States chose to give up competences to 'Brussels' in a highly sensitive policy field such as asylum that is so closely connected to national sovereignty? Bonjour explains that in highly industrial economies, integration in one sector will inevitably lead to problems that can only by resolved by integrating other sectors', also known as the 'functional spillover'. The European asylum policy is a policy that fits in this functional spill-over theory. ${ }^{361}$ Bonjour continues to elaborate that the construction of a common European asylum policy 'cannot be explained only in neo-functionalist terms. The European asylum policy is more than just a by-product of the common market project. It is also used by national governments to accomplish a domestic policy goal, namely to improve their control over asylum flows. ${ }^{362}$

\subsubsection{More restrictive stance towards refugee protection}

Did the terror attacks of 11 September 2001 in the United States have an effect on the development of the EU's asylum legislation? In the short term, the terror attacks may not have had a direct and imminent impact on the EU or national asylum policies. However, in the longer term, the terror attacks have changed the political climate and have further contributed to the prioritization of the internal security of the Member States over asylum. ${ }^{363}$ This trend of a more restrictive stance towards refugee protection did not start post-9/11. A closer look reveals that this trend in fact gradually evolved from the adoption of the Treaty of Maastricht onwards. ${ }^{364}$ In the second half of 1998, the Austrian

361 See Bonjour, S., Explaining Ambition: the Elaboration of the Working Program for the European Asylum Policy, 1996-1999, Migration, Integration and Citizenship, A Challenge for Europe's Future, Volume II, Edited by Hildegard Schneider, Forum Maastricht, 2005, p. 169.

362 See Bonjour, S., Explaining Ambition: the Elaboration of the Working Program for the European Asylum Policy, 1996-1999, Migration, Integration and Citizenship, A Challenge for Europe's Future, Volume II, Edited by Hildegard Schneider, Forum Maastricht, 2005, p. 170; See also Guiraudon, V., The constitution of a European immigration policy domain: a political sociology approach, Journal of European Public Policy, 10:2 April 2003: pp. 263-282.

363 Nicholson, F., Challenges to Forging a Common European Asylum System in EU Immigration and Asylum Law, Text and Commentary, Edited by Steve Peers and Nicola Rogers, Martinus Nijhoff Publishers, 2006, p. 521.

364 See the 'London Resolutions' on 'manifestly unfounded applications for asylum', 'a harmonized approach to questions concerning host third countries' and the Conclusions on 'countries in which there is generally no serious risk of persecution'. See also the 'derogations clauses in the 1995 'Resolution on minimum guarantees for asylum procedures' and the 'definition of agents of persecution' in the 1996' Joint Position on the Harmonized Application of the Refugee Definition'. 
presidency issued a controversial strategy paper in which they proposed to move away from the individual right of protection enshrined in the Refugee Convention. Although, the other Member States did not endorse this proposition, other parts of the paper influenced the EU work program in the field of asylum and immigration in the following years. ${ }^{365}$

The EU swiftly responded in the aftermath of the 9/11 attacks. The Council gathered together on 20 September during an Extraordinary JHA Council meeting. During this meeting the Council decided to strengthen the external borders and invited the Commission to scrutinize 'the relationship between safeguarding internal security and complying with international protection obligations and instruments' ${ }^{366}$ In response to the Council meeting, the Commission argued that asylum applicants should not become victims of the recent events and that there should be no ways for terrorists to access the territory of the EU. The Commission favoured a balanced compromise between security and refugee protection. Hence, agreeing with the UNHCR to carefully apply the exceptions from refugee protection rather than drastically change the refugee protection system. ${ }^{367}$

During the Seville European Council meeting in 2002 the political focus changed from the 'right to seek asylum' and 'based on the full and inclusive application of the Geneva Convention' as stated in the Tampere Programme towards 'combating illegal immigration' and to 'prevent abuse of the system'. Member States highlighted the "joint management of migration flows" and the balance that should be struck between "policy for the integration of lawfully resident immigrants and an asylum policy complying with international conventions, principally the 1951 Geneva Convention, and, on the other, resolute action to combat illegal immigration and trafficking in human beings". ${ }^{668}$ Subsequently, in 2003, the European Council meeting in Thessaloniki prioritized again the combat against irregular immigration. The Council invited the Commission examine the establishment of an operational structure and cooperation to manage the external borders of the EU. ${ }^{369}$ Consequently, Frontex the agency for the management of the external borders was established in 2004,

\footnotetext{
365 Van Selm, J., Immigration and Asylum or Foreign Policy: The EU's Approach to Migrants and Their Countries of Origin, Migration and the Externalities of European Integration, edited by Sandra Lavenex, and Emek Ucarer, Lexington Books, 2003, p. 147.

366 Extraordinary Council meeting, Justice, Home Affairs and Civil Protection, Brussels, 20 September 2001, paras. 24 and 29.

367 European Commission Working Document, The relationship between safeguarding internal security and complying with international protection obligations and instruments, Brussels, 05.12.2001, COM(2001) 743 final, p. 6.

368 Presidency Conclusions, Seville, 21 and 22 June 2002.

369 Thessaloniki European Council 19 and 20 June 2003 Presidency Conclusions.
} 
which signified the fight against irregular migration. ${ }^{370}$

\subsubsection{The Hague (2004)}

Under the auspices of the Dutch Presidency, the second multi-annual programme in the field of freedom, security and justice was adopted on November 2004. The Hague Programme ${ }^{371}$ laid down the basis for the second- phase development of the CEAS. Notwithstanding the objective of establishing a common procedure and a uniform status throughout the Union in accordance with Refugee Convention and other international human rights standards, the Hague Programme emphasized a more security-based approach in comparison with the ambitious Tampere Programme. Whereas the Tampere Programme stressed 'a shared commitment to freedom based on human rights, democratic institutions and the rule of law', the Hague Programme puts much more emphasis on 'the security of the European Union and its Member States'. ${ }^{372}$ Together with the adoption of the Hague Programme, the European Council invited the Commission to come up with an Action Plan in 2005 which provided concrete measures in the Justice and Home Affairs field. In response, the Commission proposed, inter alia, to evaluate the first-phase CEAS instruments and to develop the second-phase of the CEAS. ${ }^{373}$

\subsubsection{EU's external dimension of asylum and migration}

The 1999 Tampere Programme also introduced the political objective to interconnect the EU's internal asylum and migration policy with the external dimension. ${ }^{374}$ The Tampere Council Conclusion stressed the need for a 'comprehensive approach to migration' and the establishment of a 'greater coherence between internal and external policies' of the EU. Concluding partnerships with

370 Council Regulation (EC) 2007/2004 of 26 October 2004 establishing a European Agency for the Management of Operational Cooperation at the External Borders of the Member States of the European Union, OJ L 349, 25.11.2004.

371 The Hague Programme: Strengthening Freedom, Security and Justice in the European Union, OJ C 53/1, 3 March 2005.

372 Carrera, S., The Impact of the Treaty of Lisbon over EU Policies on Migration, Asylum and Borders: The Struggles over the Ownership of the Stockholm Programme, The First Decade of EU Migration and Asylum Law, Edited by Elspeth Guild and Paul Minderhoud, Martinus Nijhoff Publishers, 2012, p. 235.

373 Council and Commission Action Plan implementing the Hague Programme on strengthening freedom, security and justice in the European Union, OJ C198/01, 12 August 2005, para. 2.3.

${ }^{374}$ Haddad, E., The External Dimension of EU Refugee Policy: A New Approach to Asylum? Government and Opposition, An International Journal of Comparative Politics, Volume 43, Issue 2, p. 191. 
third countries is an important aspect to achieve that end. ${ }^{375}$

At the 2001 Laeken Summit the European Council endorsed the concept of integrating 'the policy on migratory flows into the European Union's foreign policy'. ${ }^{376}$ Again, in 2002 at the Seville Summit, the European Council reiterated in its Conclusions that 'management of migration flows in cooperation with the countries of origin and transit is crucial' 377 and that effective return and readmission agreements should become an important tool in the prevention of illegal immigration. ${ }^{378}$

Subsequently, the Council meeting in Thessaloniki called upon the Commission 'to explore all parameters in order to ensure more orderly and managed entry into the EU of persons in need of international protection and to examine ways and means to enhance the protection capacity of regions of origin with a view to presenting to the Council before June 2004, a comprehensive report suggesting measures to be taken, including legal implications' ${ }^{379}$ The Commission Communication issued to further develop the concept of Regional Protection Programmes (RPPs) in close co-operation with the UNHCR in order to ensure access to durable solutions for refugees who reside outside the EU.380 The three durable solutions for such refugees are 'repatriation, local integration or resettlement'. 381

The 2004 Hague Programme and its Action Plan, stressed with regard to the external dimension of asylum and migration the objectives of 'co-operation with third countries in managing migration and asylum, development of EU Regional Protection Programmes, including an EU Resettlement scheme, as well as intensified co-operation with countries of transit to enable these countries to better

375 European Council, Presidency Conclusions, Tampere 15-16 October 1999, para. 11.

376 European Council, Presidency Conclusions, Laeken 14-15 December 2001, para. 40.

377 European Council, Presidency Conclusions, Seville 21-22 June 2002, para. 27.

378 European Council, Presidency Conclusions, Seville 21-22 June 2002, para. 33. See on the historical development of 'readmission agreements' Billet, C., EC Readmission Agreements: A Prime Instrument of the External Dimension of the EU's Fight against Irregular Immigration. An Assessment after Ten Years of Practice, European Journal of Migration and Law, Volume 12, Issue 1, 2010.

379 European Council, Presidency Conclusions, Thessaloniki 19-20 June 2003, para. 26.

380 Communication from the Commission to the Council and the European Parliament on the Managed Entry in the EU of Persons in Need of International Protection and the Enhancement of the Protection Capacity of the Regions of Origin: 'Improving Access to Durable Solutions', Brussels, 4.6.2004, COM(2204 410 final, paras. 48-54. See also Sorel, A., Asylum, Migration and Border controls in the Hague Programme, Freedom, Security and Justice in the European Union, Implementation of the Hague Programme, T.M.C. Asser Press, De Zwaan, J., and Goudappel, F. Editors, 2006, p. 14.

381 Communication from the Commission to the Council and the European Parliament on Regional Protection Programmes, Brussels, 1.9.2005, COM(2005) 388 final. 
manage migration and to provide adequate protection for refugees. 382

\subsubsection{The Global Approach to Migration and Mobility}

The discourse on migration was intensified by the dreadful incidents on the Spanish enclaves of Ceuta and Melilla in North Africa in September 2005 and also on Lampedusa and some Greek Islands. In the light of these events and following an appeal of the informal meeting of the Heads of State and Government at Hampton Court for renewed action on migration flows, the Commission responded in its Communication to establish a comprehensive and balanced approach to migration. According to the Commission, 'migration, if well managed, can be beneficial both to the EU and to the countries of origin. However, with increased migration comes the challenge of combating illegal immigration and human trafficking, including to avert the human tragedy that is a frequent consequence.' 383 The 'renewed' approach became the so-called 'Global Approach to Migration', which was adopted during the European Council meeting in Brussels in December 2005.384 The Global Approach to Migration is now called 'the Global Approach to Migration and Mobility' (GAMM).385

The GAMM focuses on four central themes or pillars:

1) Legal migration and mobility;

2) Irregular migration and trafficking in human beings;

3) International protection and asylum policy; and

4) Maximizing the development impact of migration and mobility.

The human rights aspect is an imperative element relevant in all pillars. Moreover, the GAMM underlines that vulnerable persons such as unaccompanied minors, asylum applicants, stateless persons and victims of trafficking should receive special protection. ${ }^{386}$

382 Council and Commission Action Plan implementing the Hague Programme on strengthening freedom, security and justice in the European Union, (2005/C 198/01), para. 27. See for a more comprehensive analysis Eisele, K., The External Dimension of the EU's Migration Policy, Different Legal Positions of Third-Country Nationals in the EU, A Comparative Perspective, Wolf Legal Publishers, 2013, pp. 66-69.

383 Communication from the Commission to the Council and the European Parliament, Priority actions for responding to the challenges of migration: First follow-up to Hampton Court, Brussels, 30.11.2005, COM(2005) 621 final, p. 3.

384 European Council, Presidency Conclusions, Brussels 15 and 16 December 2005, paras. 8-10.

385 Communication from the Commission to the European Parliament, the Council, the European Economic and Social Committee and the Committee on the Regions, The Global Approach to Migration and Mobility, Brussels, 18.11.2011, COM(2011) 743 final.

386 Communication from the Commission to the European Parliament, the Council, the European Economic and Social Committee and the Committee on the Regions, The Global Ap- 


\subsubsection{Evaluating the CEAS}

The first-phase legislative building blocks of the CEAS, namely the Reception Conditions Directive 2003/9/EC, 387 the Dublin II Regulation 343/2003/EC,388 the Eurodac Regulation No 2725/2000,389 the Qualification Directive 2004/83/EC 390 and the Asylum Procedures Directive 2005/85/EC ${ }^{391}$ were established during the period of 1999-2005. Before continuing further with the harmonization of the CEAS, the Commission needed to evaluate the CEAS instruments. In 2007, the Commission issued a Green Paper on the future of the CEAS. In this document, the main stakeholders were invited to provide input on how to build the second stage of the CEAS. The over-arching ambition of the Commission was to establish an integrated, comprehensive approach to asylum. Another goal pursued was to eliminate the gaps in the EU asylum system and ensuring further harmonization by improving legal standards had become a priority. ${ }^{392}$

One of the main issues addressed by the Commission relates to the special needs of vulnerable applicants. The Commission identified 'serious inadequacies' as to the interpretation and insufficient implementation and as well as the procedural issues of vulnerable asylum applicants in the domestic systems of the Member States. Moreover, the Commission report reveals that the national authorities have limited resources, capacities and expertise. Hence, in order to address the special needs of the most vulnerable asylum applicants, more detailed and elaborated measures were needed, such as issues concerning 'adequate medical and psychological assistance and counseling' for vulnerable persons. Another key aspect is to establish a mechanism to identify the needs of

proach to Migration and Mobility, Brussels, 18.11.2011, COM(2011) 743 final, pp. 3-6.

387 Council Directive 2003/9/EC of 27 January 2003 laying down minimum standards for the reception of asylum seekers, OJ $2003 \mathrm{~L} 31 / 18$.

388 Council Regulation 343/2003/EC of 18 February 2003 establishing the criteria and mechanisms for determining the Member State responsible for examining an application for asylum lodged in one of the Member States by a third-country national, OJ $2003 \mathrm{~L}$ $50 / 1$.

389 Council Regulation No 2725/2000 of 11 December 2000 concerning the establishment of 'Eurodac' for the comparison of fingerprints for the effective application of the Dublin Convention, OJ L 316/1, 15 December 2000.

390 Council Directive 2004/83/EC of 29 April 2004 on minimum standards for the qualification and status of third country nationals and stateless persons as refugees or as persons who otherwise need international protection and the content of the protection granted, OJ 2004, L 304/12.

391 Council Directive 2005/85/EC of 1 December 2005 on minimum standards on procedures in Member States for granting and withdrawing refugee status, OJ 2005, L 326/18.

392 Green Paper on the future of the Common European Asylum System, presented by the European Commission, Brussels, 6.6.2007 COM(2007) 301 final. 
(unaccompanied) minors. Furthermore, there should be measures with regard to gender, and child-specific based asylum claims and interview techniques that take into account the culture, age and gender circumstances of the applicant. ${ }^{393}$

\subsubsection{Policy Plan on Asylum}

As a result of the public consultation with stakeholders, the Commission introduced in 2008 a strategic road-map referred to as a 'Policy Plan on Asylum'. This road-map represented the Commission's actions to complete the secondphase of the CEAS. A future comprehensive CEAS should integrate gender related issues and most importantly ensures that the special needs of vulnerable applicants are immediately identified and adequate treatment is provided. ${ }^{394}$

In addition, the Commission identified three trends and their impact on asylum. The first trend is a historically low percentage of asylum claims in the EU, which signifies that the asylum systems of most Member States are under less pressure than in previous the years. Member States should therefore focus on enhancing the standards of their asylum legislation. Second, there is a disparity in asylum adjudication across Member States. Divergences in assessing the country of origin information and the absence of common practices in the Member States have led to different outcomes. As a result, secondary movements and unequal access to protection in the EU have emerged. Third, more asylum claims are granted subsidiary protection or other forms of protection than refugee status because the Refugee Convention does not cover current conflicts and persecutions. More attention should be given to the subsidiary protection regime and persons granted subsidiary rights should be granted the same rights as recognized refugees since this could impede their integration. ${ }^{395}$ Finally, the principles of solidarity and responsibility-sharing are key elements to address the asylum challenges faced by the Member States on the external borders of the EU.

\subsubsection{Impact Assessment and vulnerability}

The 'Impact Assessment'396 attached to the Policy Plan foresaw four policy op-

393 Green Paper on the future of the Common European Asylum System, presented by the European Commission, Brussels, 6.6.2007 COM(2007) 301 final, para. 2.4.1.

394 Communication from the Commission to the European Parliament, the Council, the European Economic and Social Committee and the Committee of Regions, Policy Plan on Asylum, an integrated approach to protection across the EU, Brussels, 17.6.2008 COM (2008) 360 final, pp. 3-5.

395 Communication from the Commission to the European Parliament, the Council, the European Economic and Social Committee and the Committee of Regions, Policy Plan on Asylum, an integrated approach to protection across the EU, Impact Assessment, Brussels, 17.6.2008 SEC (2008) 2029, p. 3.

396 Communication from the Commission to the European Parliament, the Council, the Eu- 
tions for the future. The different policy options were each assessed in the light of criteria concerning relevance and political and economic feasibility. ${ }^{397}$ Preference was given to further harmonize the EU legislation combined with practical co-operation and exchange of best practices. The Impact Assessment emphasized that certain categories of asylum applicants such as unaccompanied minors, victims of torture or women who are subjected to sexual violence are more vulnerable than others. The lack of gender- and child sensitive- procedures remained an issue. ${ }^{398}$ Hence, better rules are needed with regard to vulnerable asylum applicants in relation to health care, gender and child-sensitive matters. In the area of reception conditions, an improved mechanism should thus be created to identify the special needs of vulnerable asylum applicants. ${ }^{399}$

\subsubsection{Reform proposals}

The EU postponed the deadline for completing the second phase of the CEAS from 2010 to 2012. The Council issued during the French Presidency in 2008 a political document called 'the European Pact on Immigration and Asylum'. The document acknowledged the divergence that exists between national asylum systems and invited the Commission to propose new initiatives to finalize the CEAS by 2012.400 The Commission underlined again that 'shortcomings have been identified and it is clear that the agreed common minimum standards have not created the desired level playing field.'401 As a result, the Commission proposed in 2008 and in 2009 several reforms in the field of asylum. In 2008, proposals

ropean Economic and Social Committee and the Committee of Regions, Policy Plan on Asylum, an integrated approach to protection across the EU, Impact Assessment, Brussels, 17.6.2008 SEC (2008) 2029.

397 Communication from the Commission to the European Parliament, the Council, the European Economic and Social Committee and the Committee of Regions, Policy Plan on Asylum, an integrated approach to protection across the EU, Impact Assessment, Brussels, 17.6.2008 SEC (2008) 2029, pp. 28-85.

398 Communication from the Commission to the European Parliament, the Council, the European Economic and Social Committee and the Committee of Regions, Policy Plan on Asylum, an integrated approach to protection across the EU, Impact Assessment, Brussels, 17.6.2008 SEC (2008) 2029, pp. 14-15.

399 Communication from the Commission to the European Parliament, the Council, the European Economic and Social Committee and the Committee of Regions, Policy Plan on Asylum, an integrated approach to protection across the EU, Impact Assessment, Brussels, 17.6.2008 SEC (2008) 2029, p. 29.

400 Council of the European Union, European Pact on Immigration and Asylum, Brussels, 24 September 2008, 13440/08, ASIM 72, pp. 11-12.

401 Communication from the Commission to the European Parliament, the Council, the European Economic and Social Committee and the Committee of Regions, Policy Plan on Asylum, an integrated approach to protection across the EU, Impact Assessment, Brussels, 17.6.2008 SEC (2008) 2029, p. 4. 
(recast) were made to amend the Directive on Reception Conditions, ${ }^{402}$ the Dublin II Regulation ${ }^{403}$ and the Eurodac Regulation. ${ }^{404}$ In 2009, the Qualification Directive ${ }^{405}$ and the Asylum Procedures Directive ${ }^{406}$ were subjected to recast.

\subsection{The 2nd phase of the Common European Asylum System}

This section discusses another important period in the field of the EU's AFSJ (2008-2013). More specifically, this section discusses the important actions taken in the field of EU asylum law and policy that had an impact on the further development of the CEAS.

\subsubsection{Lisbon (2009)}

The entry into force of the Treaty of Lisbon ${ }^{407}$ on 1 December 2009 and the endorsement of the Stockholm Programme by the European Council in the second half of 2009 constituted a new period for the EU's AFSJ domain. In essence, the Treaty of Lisbon amended the Treaty on the European Union (TEU) and the EC Treaty by changing it to the TFEU. 408 Through this reform the in-

402 Proposal for a Directive of the European Parliament and of the Council laying down minimum standards for the reception of asylum-seekers (Recast), COM(2008) 815 final, 3 December 2008.

403 Proposal for a Regulation of the European Parliament and of the Council establishing the criteria and mechanisms for determining the Member State responsible for examining an application for international protection lodged in one of the Member States by a thirdcountry national or a stateless person (Recast), COM(2008) 820 final, 3 December 2008.

404 Proposal for a Regulation of the European Parliament and of the Council concerning the establishment of 'EURODAC' for the comparison of fingerprints for the effective application of the Regulation (EC) No 343/2003 (Recast), COM(2008) 825 final, 3 December 2008 .

405 Proposal for a Directive of the European Parliament and of the Council on minimum standards for the qualification and status of third country nationals or stateless persons as beneficiaries of international protection and the content of the protection granted (Recast), COM(2009) 551 final, 21 October 2009.

406 Proposal for a Directive of the European Parliament and of the Council on minimum standards on procedures in Member States for granting and withdrawing international protection (Recast), COM(2009) 554 final, 21 October 2009.

407 Treaty of Lisbon amending the Treaty on European Union and the Treaty establishing the European Community, OJ C 306/1, 17 December 2007. See for a more detailed analysis of the development towards the adoption of the Treaty of Lisbon, Berman, P., From Laeken to Lisbon: The Origins and Negotiation of the Lisbon Treaty, EU Law After Lisbon, Edited by Andrea Biondi, Piet Eeckhout, Stefanie Ripley, Oxford University Press, 2012, pp. 3-39.

408 See Cremona, M., The Two (or Three) Treaty Solution: The New Treaty Structure of the EU, EU Law After Lisbon, Edited by Andrea Biondi, Piet Eeckhout, Stefanie Ripley, Oxford University Press, 2012, pp. 40-44. 
stitutional framework and competences in the Justice and Home Affairs domain was substantially changed. ${ }^{409}$ The ordinary legislative procedure (codecision procedure between the European Parliament and the Council) became standardized. Hence, the European Parliament acquired a stronger role in the adoption of measures in the field of asylum. Furthermore, Article 267 of the TFEU amended Article 68 of the TEC, which allowed only national courts of last instance to refer a preliminary ruling. The content of the AFSJ was placed in Title V of Part Three of the TFEU.

The Treaty of Lisbon mentions several objectives regarding the EU's AFSJ policies in the field of asylum, immigration and external border controls. The new Article 3(2) of the TEU stipulates that the fundamental EU freedom of movement should be accompanied with 'appropriate measures' with respect to, inter alia, asylum. ${ }^{410}$ Article 67(2) of the TFEU sets out the general objective for asylum, immigration and external border controls. 411

With regard to asylum, a common policy is envisaged, which is based on solidarity between Member States and fair in relation to third-country nationals. As enshrined in Article 80 of the TFEU, solidarity is considered an important guiding principle in the implementation of the EU's AFSJ area of asylum, migration and borders policies. ${ }^{412}$

\subsubsection{Article 78 of the Treaty on the Functioning of the European Union}

Article 78(1) of the TFEU establishes the new legal basis for developing a common European asylum policy. Article 78(1) reads:

'The Union shall develop a common policy on asylum, subsidiary protection

409 See for a detailed analysis Carrera, S., The Impact of the Treaty of Lisbon over EU Policies on Migration, Asylum and Borders: The Struggles over the Ownership of the Stockholm Programme, The First Decade of EU Migration and Asylum Law (Elspeth Guild and Paul Minderhoud eds.), Martinus Nijhoff Publishers, 2012, pp. 243-248.

410 Article 3(2) of the TEU provides: 'The Union shall offer its citizens an area of freedom, security and justice without internal frontiers, in which the free movement of persons is ensured in conjunction with appropriate measures with respect to external border controls, asylum, immigration and the prevention and combating of crime.'

411 Article 67(2) of the TFEU reads: 'It shall ensure the absence of internal border controls for persons and shall frame a common policy on asylum, immigration and external border control, based on solidarity between Member States, which is fair towards thirdcountry nationals.'

412 Article 80 of the TFEU provides: 'The policies of the Union set out in this Chapter and their implementation shall be governed by the principle of solidarity and fair sharing of responsibility, including its financial implications, between the Member States. Whenever necessary, the Union acts adopted pursuant to this Chapter shall contain appropriate measures to give effect to this principle.' 
and temporary protection with a view to offering appropriate status to any third-country national requiring international protection and ensuring compliance with the principle of non-refoulement. This policy must be in accordance with the Geneva Convention of 28 July 1951 and the Protocol of 31 January 1967 relating to the status of refugees, and other relevant treaties.'

For the first time a clear reference was laid down to develop a 'common' policy on asylum, subsidiary protection and temporary protection consisting of a 'uniform status' of asylum and subsidiary protection and 'common procedures'. More importantly, the Treaty of Lisbon requires that the common policy on asylum must be in in accordance with the Refugee Convention and other human rights treaties. Compared with Article 63 of the EC Treaty, the obligation to comply with international instruments of human rights protection when adopting asylum measures is much more explicitly formulated in Article 78(1) TFEU.

Article 78(2) of the TFEU is the legal basis for the EU to adopt asylum measures for establishing a common EU policy on asylum. According to Article 78(2) of the TFEU, the European Parliament and the Council ('ordinary legislative procedure') should adopt a comprehensive common European asylum policy consisting of:

(a) a uniform status of asylum for nationals of third countries, valid throughout the Union;

(b) a uniform status of subsidiary protection for nationals of third countries who, without obtaining European asylum, are in need of international protection;

(c) a common system of temporary protection for displaced persons in the event of a massive inflow;

(d) common procedures for the granting and withdrawing of uniform asylum or subsidiary protection status;

(e) criteria and mechanisms for determining which Member State is responsible for considering an application for asylum or subsidiary protection;

(f) standards concerning the conditions for the reception of applicants for asylum or subsidiary protection;

(g) partnership and co-operation with third countries for the purpose of managing inflows of people applying for asylum or subsidiary or temporary protection.

Again, a comparison with Article 63 of EC Treaty reveals that the new legislation on asylum enshrined in the Treaty of Lisbon is no longer limited to 'minimum' standards. In other words, Article 63 EC Treaty provided for 'minimum' standards to be adopted in the field of asylum, which meant that the Member States could not adopt rules that go below this 'minimum' level. ${ }^{413}$ The Treaty

413 Member States were allowed to adopt 'more favourable standards' than the 'minimum standards'. 
of Lisbon requires that a CEAS must consist of a 'uniform status' and 'common procedures', which seems to indicate that new legislation on asylum aims at further harmonization by setting 'higher standards' than the 'minimum standards' adopted during the Treaty of Amsterdam. This transformation of 'minimum' to 'common' standards and a 'uniform status' is reflected in the recast Directives on asylum. ${ }^{414}$

The following observations can be made of the remaining sub-paragraphs of Article 78 of the TFEU. First, Article 78(2)(a) and (b) of the TFEU makes a distinction between a 'uniform status of asylum' and a 'uniform status of subsidiary protection.' The latter meaning third country nationals or stateless persons who do not qualify as a refugee in the meaning of the Refugee Convention, nevertheless need international protection. Second, Article 78(2) (c) of the TFEU provides the basis to adopt protective measures for displaced persons in the event of a massive inflow. Article 63(2)(a) of the EC Treaty mentions minimum standards to be adopted for giving temporary protection to displaced persons. The provision as enshrined in the Treaty of Amsterdam also does not mention in the event of a massive inflow'. Third, Article 78(2)(d) of the TFEU on 'common asylum procedures' introduces a distinction between common procedures for the granting and withdrawing of uniform asylum or subsidiary protection status. A closer look at Article 63(1)(d) of the EC Treaty illustrates only the granting or withdrawing of 'refugee status'. Fourth, Article 78(2)(e) of the TFEU which regulates 'the criteria and mechanisms for determining which Member State is responsible for considering an asylum application' has been extended by adding the wording 'or subsidiary protection'. Article 63(1)(a) of the EC Treaty stipulates 'criteria and mechanisms (...) an application for asylum by a national of a third country in one of the Member States.' Fifth, Article 78(2)(f) of the TFEU on the reception conditions also sets a distinction between applicants for asylum or subsidiary protection. Article 63(1)(b) of the EC Treaty on the other hand lays down standards on the reception of only asylum applicants. ${ }^{415}$ Sixth, the last paragraph (g) of Article 78(2) of the TFEU establishes a legal basis to adopt partnerships and to assist third countries aiming to manage persons who want to make an application for international protection. This paragraph is new compared to the Treaty of Amsterdam. This provision remains unclear and raises many questions as to the human rights obligations of the EU and its Member States. ${ }^{416}$ Finally, Article 78(3) of the TFEU established the legal basis for adopt-

414 Velluti, S., Reforming the Common European Asylum System - Legislative Developments and Judicial Activism of the European Courts, Springer, 2014, pp. 29-30.

415 Battjes, European Asylum Law and International Law, Martinus Nijhoff Publishers, 2006, pp. 176-180.

416 Already observed by Guild, E., The Europeanisation of Europe's Asylum Policy, International Journal of Refugee Law, 2006, Vol. 18, Issue 3-4, pp. 646-647. 
ing 'provisional measures' for situations where Member State(s) are confronted by a sudden influx of third country nationals. If such an emergency situation occurs, the Council may, on an initiative of the Commission, adopt the measures, after it has consulted the European Parliament. A significant difference to remember is that the Treaty of Lisbon does not foresee a time limit for the adoption of the new legislation, whereas the Treaty of Amsterdam envisaged a deadline of five years to adopt measures on asylum. ${ }^{417}$

\subsubsection{Impact of the Lisbon Treaty}

What was the impact of the Treaty of Lisbon on the EU asylum policy? Three important aspects can be identified. ${ }^{418}$ First, the Treaty of Lisbon stipulates in Article 78 of the TFEU the adoption of measures on asylum, not limited to 'minimum' standards anymore. Second, the Treaty of Lisbon standardized the ordinary legislative procedure on all related asylum measures (except for Article 78(3) of the TFEU). The strengthened role for the European Parliament as co-legislator in this sensitive field has changed the dynamics in the decisionmaking procedure with the Council. In addition, Article 267 of the TFEU has significantly broadened the role for the CJEU in the AFSJ domain in general. In particular for asylum law, all national courts (not restricted anymore to courts of last instance) may now ask the CJEU for a preliminary ruling with respect to the interpretation of European asylum law. Third, with the entering into force of the Treaty of Lisbon in 2009, the Charter of Fundamental Rights of the European Union (Charter $)^{419}$ became legally binding. The Charter had obtained 'the same legal value as the Treaties'. 420 The Charter enshrines fundamental rights and principles which have significantly strengthened the rights of asylum applicants in the EU. The Charter contains 54 provisions (rights and freedoms), which applies to EU citizens but also to third country nationals. A significant Charter provision that is relevant in the context of asylum is Article 18 on the 'right to asylum'. ${ }^{421}$ The Advocate-General in Puid specified:

417 Kaunert, C., and Leonard, S., The European Union asylum policy after the Treaty of Lisbon and the Stockholm Programme: Towards supranational governance in a common area of protection? Refugee Survey Quarterly, Vol. 31, No. 4, p. 16.

418 Kaunert, C., and Leonard, S., The EU asylum policy: Towards a common area of protection and solidarity? Freedom, Security and Justice after Lisbon and Stockholm (Sarah Wolf, Flora Goudappel and Jaap de Zwaan eds.), T.M.C. Asser Press, 2011, pp. 90-93.

419 Charter of Fundamental Rights of the European Union, (2010/C 83/02). See also Explanations relating to the Charter of Fundamental Rights, (2007/C 303/02).

420 Article 6(1) of the Treaty on European Union (TEU).

421 See also Gil-Bazo, M., The Charter of Fundamental Rights of the European Union and the Right to be Granted Asylum in the Union's Law, Refugee Survey Quarterly, Volume 27, Issue 3, 2008. 
'The principle of non-refoulement forms the essence of the fundamental right to asylum guaranteed in Article 18 of the Charter and Article 78(1) TFEU. These provisions do not create for the asylum seekers a subjective substantive right to be granted asylum, (13) but a right to fair and effective examination of the application for asylum, together with the right not to be transferred to countries or territories in breach of the principle of non-refoulement.' ${ }^{422}$

Other relevant provisions are Article 19 on the 'protection in the event of removal, expulsion or extradition', Article 4 on the 'prohibition of torture and inhuman or degrading treatment or punishment reflects the wording of Article 3 of the ECHR. In particular, the Charter explicitly recognizes in Chapter III 'Equality', the rights of certain vulnerable persons such as children, elderly and persons with disabilities. ${ }^{423}$ For instance, Article 24 on 'the rights of the child'. Other relevant provisions are Article 41 on the 'right to good administration and Article 47 on 'the right to an effective remedy and to a fair trial'. According to Article 51(1) of the Charter the provisions are addressed to all EU institutions, bodies and agencies 'with due regard for the principle of subsidiarity' and to the Member States 'only when they are implementing Union law.' Member States, including the EU institutions and bodies 'shall therefore respect the rights, observe the principles and promote the application thereof in accordance with their respective powers.' Hence, any action taken by the EU and its Member States must be in compliance with the Charter when implementing EU law. ${ }^{424}$ This would mean that in the context of asylum, the Reception Conditions Directive or the Asylum Procedures Directive and the national implementing measures must be in accordance with the Charter. Article 51(1) of the Charter requires the EU institutions and Member States where they implement EU law to respect and to promote the rights in the Charter. The CJEU ruled in N.S. and M.E. that the concept of 'implementing EU law' in the sense of Article 51(1) of the Charter also includes the situation where Member States make use of discretionary powers granted by EU legislation. ${ }^{425}$ The Charter enshrines numerous rights that correspond with the guaranteed rights in the ECHR. Accordingly, the ECHR represents a minimum standard. ${ }^{426}$ Inevitably, the Char-

422 Case C-4/11 Opinion of Advocate General Jääskinen, Bundesrepublik Deutschland $v$ Kaveh Puid, 18 April 2013, ECLI:EU:C:2013:244, para. 49.

423 Articles 24, 25 and 26 of the Charter.

424 ECRE, Chartering a way to protection: the EU Charter of Fundamental Rights - an indispensable instrument in the field of asylum, 2017, p. 3.

425 Joined Cases C-411/10 and C-493/10, N.S. v Secretary of State for the Home Department and M. E. and others v. Refugee Applications Commissioner, Minister for Justice, Equality and Law Reform, 21 December 2011, Court of Justice of the European Union, ECLI:EU:C:2011:865, para. 68.

426 52(3) of the Charter. See De Mol, M., De Directe Werking van de Grondrechten van de Europese Unie, Wolf Legal Publishers, 2014, p. 38. 
ter standards will gradually have a greater impact in asylum procedures.

\subsubsection{Stockholm (2009)}

The Stockholm Programme adopted in December 2009 represented the third multi-annual programme setting the EU's AFSJ new political ambitions (20102014). ${ }^{427}$ The Stockholm Programme re-iterates the objective of the CEAS 'establishing a common area of protection and solidarity based on a common asylum procedure and a uniform status for those granted international protection.' The CEAS should be 'based on high protection standards' and 'it is crucial that individuals, regardless of the Member States in which their application for asylum is lodged, are offered an equivalent level of treatment as regards reception conditions, and the same level as regards procedural arrangements and status determination. The objective should be that similar cases should be treated alike and result in the same outcome'.

Unlike the Hague Programme, the Stockholm Programme paid more attention to the specific needs of vulnerable groups. In particular unaccompanied minors are considered a particularly vulnerable group. Other vulnerable groups that should receive special attention are women who are victims of genderbased violence or female genital mutilation and also the Roma community. 428

The Stockholm Programme further indicated that there are serious differences between the national implementing measures of the Member States in the field of asylum. These divergences undermine the harmonization process and that the further development of a CEAS should be based on a full and inclusive application of the 1951 Geneva Convention relating to the Status of Refugees and other relevant international treaties.' Moreover, the Commission was invited to explore the legal and practical outcomes if the EU should seek accession to the Refugee Convention and its 1967 Protocol. ${ }^{429}$

\subsubsection{European Asylum Support Office}

Already called upon in The Hague Programme of 2004, the European Asylum Support Office ${ }^{430}$ (EASO) established in 2010 , should play an important role in the monitoring of the implementation of the EU asylum instruments and

427 The Stockholm Programme - An open and secure Europe serving and protecting citizens, OJ C 115/1, 4 May 2010.

428 The Stockholm Programme - An open and secure Europe serving and protecting citizens, OJ C 115/1, 4 May 2010, paras. 2.3.2 -2.3.3 and 6.1.7.

429 The Stockholm Programme - An open and secure Europe serving and protecting citizens, OJ C 115/1, 4 May 2010, paras. 6.2 and 6.2.1.

430 Regulation (EU) No 439/2010 of the European Parliament and of the Council of 19 May 2010 establishing a European Asylum Support Office, 2010, OJ L132/11. 
strengthen the practical co-operation between the Member States. ${ }^{431} \mathrm{~A}$ substantial part is devoted to the promotion of effective solidarity with the Member States facing particular pressure on their national asylum systems. The EASO should as a key actor contribute to the co-ordination and development of a mechanism to support capacity building with respect to the national asylum systems.

Training of staff of national services dealing with asylum matters is another key component of EASO. Article 6(4)(b) and (f) of Regulation (EU) No $439 / 2010$ makes a specific reference to training modules with regard to the assessment of asylum cases of minors and vulnerable persons with specific needs, as well as issues on reception conditions with a special focus on vulnerable groups and victims of torture.

\subsubsection{External dimension of asylum}

As to the external dimension of asylum, the Stockholm Programme urged the EU to further develop capacity building in third countries and the RPPs in cooperation with the UNHCR, which should be integrated in the framework of the Global Approach to Migration. Furthermore, Member States should be persuaded into voluntarily participation in the Joint EU Resettlement Programme.

\subsubsection{Stockholm Action Plan}

In April 2010, the Commission presented its Action Plan ${ }^{432}$ with concrete actions for the implementation of the aims and priorities of the Stockholm Programme. The Commission stressed the obligation of the Member States to respect the fundamental right to asylum and the principle of non-refoulement. The core value of the CEAS is solidarity between Member States and with persons seeking international protection. ${ }^{433}$ The Stockholm Action Plan introduces

431 See Compte, F., A New Agency is Born in the European Union: The European Asylum Support Office, European Journal of Migration and Law, Volume 12, Issue 4, 2010, pp. 372405.

432 European Commission, Communication from the Commission to the European Parliament, to the Council, The European Economic and Social Committee and the Committee of the Regions, Delivering an area of freedom, security and justice for Europe's citizens, Action Plan Implementing the Stockholm Programme, Brussels, 20 April 2010, $\operatorname{COM}(2010) 171$ final.

433 European Commission, Communication from the Commission to the European Parliament, to the Council, The European Economic and Social Committee and the Committee of the Regions, Delivering an area of freedom, security and justice for Europe's citizens, Action Plan Implementing the Stockholm Programme, Brussels, 20 April 2010, $\operatorname{COM}(2010) 171$ final, p. 7. 
several communications, ${ }^{434}$ reports, ${ }^{435}$ evaluations ${ }^{436}$ and initiatives ${ }^{437}$ to be issued by the Commission and the EASO in the field of asylum (including the external dimension). ${ }^{438}$

\subsubsection{EU Action Plan on Unaccompanied Minors}

Following the adoption of the Stockholm Programme, the Commission adopted in May 2010 the EU Action Plan on Unaccompanied Minors (20102014). ${ }^{439}$ Both the Commission and the Council ${ }^{440}$ underlined the need for a more coherent approach with respect to the specific situation of unaccompa-

434 European Commission Communication on Eurodac development, namely on the feasibility on its development into a supporting tool for the entire Common European Asylum System (CEAS) (by 2012); Communication on the appropriateness, the possibilities and the difficulties as well as the legal and practical implications of joint processing of asylum applications within the Union (by 2014); Communication on a framework for the transfer of protection of beneficiaries of international protection and mutual recognition of asylum decisions (by 2014); Communication on enhanced intra-EU solidarity (by 2011); Communication on new approaches concerning access to asylum procedures targeting main transit countries (by 2013).

435 Report of the Commission on the legal and practical consequences of the EU's accession to the Geneva Convention and its 1967 Protocol (by 2013); Annual Reports on EU resettlement efforts (ongoing).

436 First evaluation report on the EASO's impact on practical cooperation and on the Common European Asylum System (by 2013); Evaluation and development of procedures for facilitation of the secondment of officials in order to help those Member States facing particular pressures of asylum seekers (by 2011); Mid-term evaluation of the EU Resettlement Programme (by 2012).

437 Further develop a common educational platform for national asylum officials, building on in particular the European Asylum Curriculum (by 2011); Development of a common methodology with a view to reducing disparities of asylum decisions (no time table indicated); Establishing a mechanism to review the Member States' national asylum systems and identify the issues related to capacities which will enable Member States to support each other in building capacity (by 2011); Establish strategic partnership with UNHCR (Office of the United Nations High Commissioner for Refugees) (by 2011); Proposal on how to improve the EU Resettlement Programme (by 2014); Launching and developing new Regional Protection Programmes, including in the horn of Africa (ongoing).

438 European Commission, Communication from the Commission to the European Parliament, to the Council, The European Economic and Social Committee and the Committee of the Regions, Delivering an area of freedom, security and justice for Europe's citizens, Action Plan Implementing the Stockholm Programme, Brussels, 20 April 2010, $\operatorname{COM}(2010) 171$ final, pp. 55-57.

439 European Commission, Communication from the Commission to the European Parliament and the Council, Action Plan on Unaccompanied Minors (2010-2014), Brussels, 6.5.2010, $\mathrm{COM}(2010) 213$ final.

440 Council Conclusions on unaccompanied minors, 1018th Council meeting, Justice and Home Affairs, Luxembourg, 3-4 June 2010. 
nied minors and more intensive co-operation within the EU and countries of origin. Such an approach should be carried out on the basis of the 'best interests of the child' principle as enshrined in the EU Charter and the CRC. ${ }^{441}$ In relation to reception and procedural standards, the Commission clearly emphasizes the need for extra safeguards for unaccompanied minors. They should have access to special reception and procedural guarantees from the moment unaccompanied minors are identified at the external borders or when they arrive at EU territory. 442

\subsubsection{The Asylum Package}

The deadline set by the EU in the Stockholm Programme to establish a CEAS in 2012 was not going to be achieved. The recast Qualification Directive was adopted in December 2011 (replaced the Qualification Directive 2004/83/EC) and a political agreement was concluded on the recast of the Reception Conditions Directive and on the recast Dublin III Regulation. However, the trilogue negotiations between the Commission, the European Parliament and the Council on the recast proposals with respect to the Asylum Procedures Directive and the recast Eurodac Regulation were still ongoing in the first half of 2013.443

It was not until the Irish Presidency, after almost five years of trilogues and debates within the different EU institutions, that the second-phase instruments of the CEAS - the so-called asylum package - was formally adopted on 12 June 2013 by the European Parliament during the plenary session in Strasbourg. A few days later, on 20 June 2013 the Council adopted the long debated recast Eurodac Regulation and the last piece of instrument of the asylum package. The new asylum measures enshrined in the recast Directives and Regulations were officially published on 29 June 2013. Hence, after 14 years the establishment of the CEAS was completed. ${ }^{44}$ Following the adoption of the CEAS in 2013, the priority for the coming years was to guarantee a coherent implementation of the asylum measures in the domestic legislation and practice of the Member States.

441 European Commission, Communication from the Commission to the European Parliament and the Council, Action Plan on Unaccompanied Minors (2010-2014), Brussels, 6.5.2010, $\operatorname{COM}(2010) 213$ final, p. 3.

442 European Commission, Communication from the Commission to the European Parliament and the Council, Action Plan on Unaccompanied Minors (2010-2014), Brussels, 6.5.2010, COM(2010)213 final, pp 8-9. See also Commission staff working document on the implementation of the EU Action Plan on Unaccompanied Minors, Brussels, 28.9.2012, SDW(2012) 281 final. The report provides an overview of actions implemented at the EU and national level.

443 The Council of the European Union, Stockholm Programme mid-term review, 15921/12, Brussels 13 November 2012, p. 2.

444 Press release Council of the European Union, Luxembourg, 20 June 2013 11160/13 (OR. en) Presse 267. 
The first reactions with regard to the revision and completion of the CEAS were mildly positive. According to the UNHCR who closely followed the recast negotiations and as well tried to lobby during the negotiations, the new measures improved the EU asylum system. It is relevant to note that the UNHCR welcomed the additional safeguards that have been agreed with respect to vulnerable applicants, which contains an identification mechanism, improved representation for unaccompanied minors, special reception and procedural guarantees. Other welcome aspects of these new CEAS rules were better safeguards in the asylum decision-making procedure, more guarantees were adopted as to the detention of new asylum applicants and the period to access the labour market was shortened for applicants of international protection. ${ }^{445}$

Figure 4.2. Timeline Common European Asylum System, phase I and II (1999-2015)
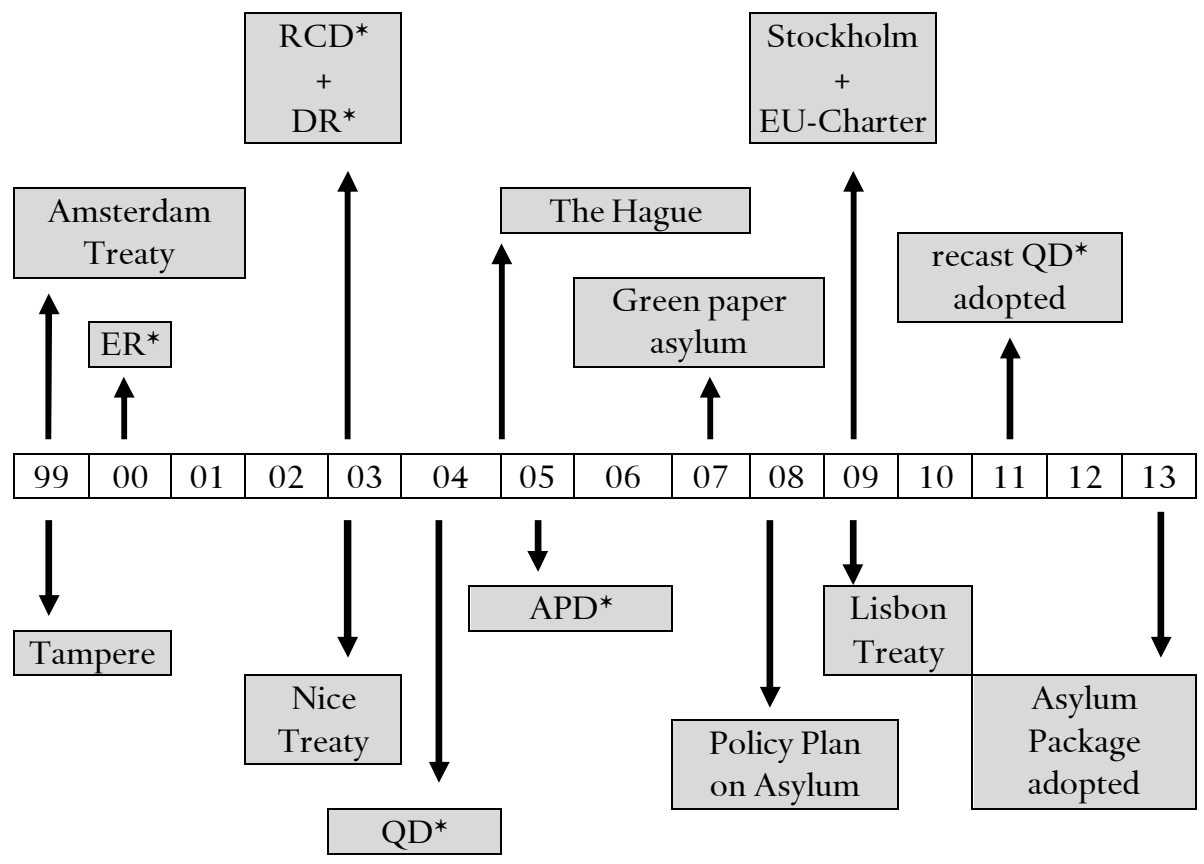

* ER: Eurodac Regulation

* RCD: Reception Conditions Directive

* DR: Dublin Regulation

* QD: Qualification Directive

* APD: Asylum Procedures Directive

445 UNHCR welcome EU moves towards a common asylum system, Briefing notes, 14 June 2013. 


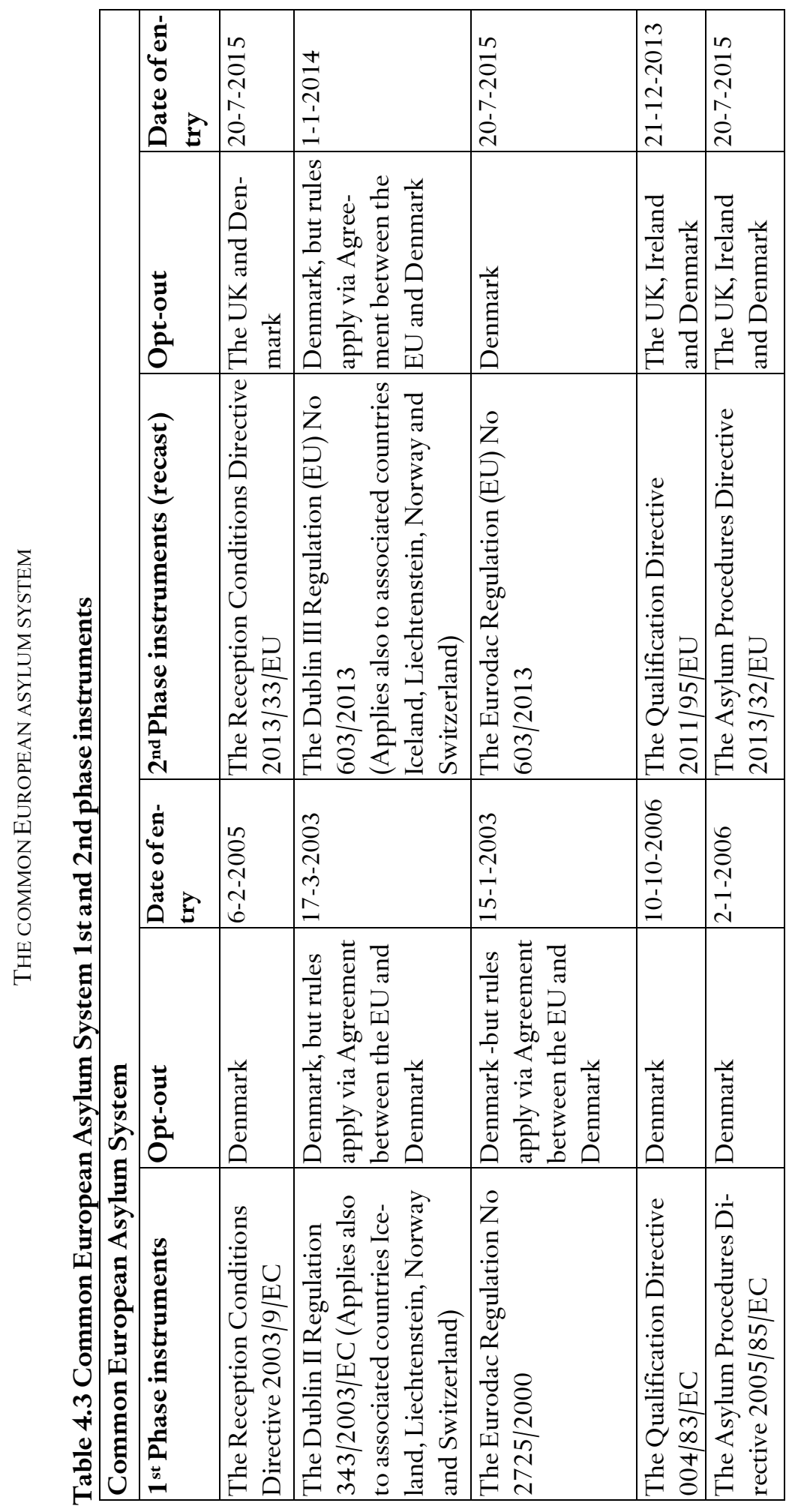




\subsection{The 3rd phase of the Common European Asylum System}

\subsubsection{The European Agenda on Migration (2015)}

In October 2014 a new European Commission led by President Juncker presented its political priorities for the years ahead. In his opening speech, President Juncker underlined the need for a strong asylum and migration policy and addressed, inter alia, that Member States should fully implement the newly agreed measures on asylum and should eliminate the differences in national implementation. In addition, the common asylum and migration policy could fully work if the EU prevents and controls the entry of 'illegal' migrants. One way to achieve this objective is by penalizing human traffickers who exploit persons who are in a vulnerable situation. ${ }^{446}$ The Commissioner for Migration, Home Affairs and Citizenship who is also responsible for EU asylum issues stated in its opening speech that 'the full and effective implementation of the Common European Asylum System is an absolute priority. The Commission will closely monitor implementation by the Member States and support their efforts. ${ }^{447}$ Member States who are bound by the second-phase asylum instruments have to correctly implement the new EU asylum rules into their domestic asylum systems.

Following the tragedies on the Mediterranean, the Commission presented on 13 May 2015 the European Agenda on Migration (Migration Agenda) determining to take immediate action and adopt long-term solutions that should result in a better management of migration in all aspects both internal and external. ${ }^{48}$ The Commission addressed five immediate actions to prevent more migrants dying at sea. These measures include:

- Firstly, to increase the Frontex search and rescue missions at sea. The Commission tripled the budget for the joint-operations Triton and Poseidon.

- Secondly, the Commission aimed to destroy criminal smuggling networks. The Commission considers migrants as vulnerable who are exploited by these criminal networks.

446 Juncker, J.C., Setting Europe in Motion, Main Messages Opening Statement in the European Parliament Plenary Session, Strasbourg, 22 October 2014.

447 European Commission, Opening Statement by Commissioner Dimitris Avramopoulos during the European Parliament plenary debate on Migration, Strasbourg 25 November 2014.

448 European Commission, Communication from the Commission to the European Parliament, the Council, the European Economic and Social Committee and the Committee of the Regions, A European Agenda on Migration, Brussels, 13.5.2015, COM(215) 240 final. 
- Thirdly, in order to alleviate the pressure of reception in Italy and Greece, a relocation scheme for refugees was established.

- Fourthly, the Commission aimed to resettle 20.000 refugees from third countries to the EU Member States and increase the budget with 50 million Euros. Refugees are considered as vulnerable people who cannot be left to the hands of smugglers and traffickers.

Alongside the immediate actions, the Commission presented four pillars of the new Agenda. These pillars represent initiatives to manage migration better:

I. 'Reducing the incentives for irregular migration' refers to three key aspects. First, tackling the roots causes of migration and entering into partnerships with countries of origin and transit is critical. Second, according to the Commission, eliminating criminal smugglers and traffickers is way to reduce irregular migration. Third, a more effective return policy is crucial.

II. 'Border management - saving lives and securing external borders' underlines the importance for the EU of having the duty to save lives at sea and at the same time to protect its external borders.

III. 'Europe's duty to protect: a strong common asylum policy' stresses the objective of a coherent transposition and implementation of the CEAS by Member States. Another priority for the Commission is to revise the Dublin system, which was put into effect in 2016.449 The Commission explicitly attaches great importance to provide particular attention to the needs of vulnerable groups. According to the Commission, children have specific vulnerabilities and therefore following the Action Plan on Unaccompanied Minors (2010-2014) $)^{450}$ an inclusive strategy will be developed.

IV. 'A new policy on legal migration' represents steps to establish a better management of regular migration, such as a reform of the Blue Card Directive, ${ }^{451}$ including a more effective integration policy for the EU. Additionally, the Commission aims to guarantee that countries of origin benefit from migration.

449 Proposal for a Regulation of the European Parliament and of the Council establishing the criteria and mechanisms for determining the Member State responsible for examining an application for international protection lodged in one of the Member States by a thirdcountry national or a stateless person (recast), Brussels, 4.5.2016, COM(2016) 270 final, 2016/0133 (COD).

450 European Commission, Communication from the Commission to the European Parliament and the Council, Action Plan on Unaccompanied Minors (2010-2014), Brussels, 6.5.2010, $\operatorname{COM}(2010) 213$ final.

451 European Commission, Proposal for a Directive of the European Parliament and the Council on the conditions of entry and residence of third-country nationals for the purposes of highly skilled employment, Strasbourg, 7.6.2016, COM(2016) 378 final, 2016/0176 (COD). 
In addition to this Migration Agenda, the Commission priorities for the years ahead are the further development of the CEAS, a new European border management and a new legal migration framework.

\subsubsection{Refugee crisis}

Since 2014 Member States have observed a sharp increase in the number of persons seeking asylum. This resulted into a state of crisis or at least a sense of crisis. ${ }^{452} 2015$ and 2016 have been widely referred to as a 'refugee crisis' or as other scholars have argued that 'the present European crisis is a crisis of refugee policy, not a refugee crisis'. ${ }^{453}$ The number of applicants for asylum doubled from 625.000 in 2014 to nearly 1.3 million in 2015.454 More than 330.000 applicants received protection, which was an increase of $72 \%$ compared to 2014.455 Despite numerous efforts of the EU and the introduction of deterrent measures by Member States in order to contain the refugee crisis, the number of persons seeking asylum in the EU in 2016 remained around 1.2 million. 456 The number of asylum decisions that has resulted in a protection status increased in 2016 to more than 700.000 .457 In 2017, the number of first time asylum applications dropped to 705.705 .

452 Battjes, H., Brouwer, E., Slingenberg, L. and Spijkerboer, T., The Crisis of European Refugee Law: Lessons from Lake Success, Preadviezen Christen Juristen Vereniging , 2016, p. 1.

453 Den Heijer, M, Rijpma, J. and Spijkerboer, T., Coercion, prohibition, and great expectations: The continuing failure of the Common European Asylum System, Common Market Law Review, Issue 3, 2016, p. 641.

454 Eurostat newsrelease, The number of asylum applicants in the EU jumped to more than 625000 in 2014, 53/2015 - 20 March 2015; Eurostat newsrelease, Record number of over 1.2 million first time asylum seekers registered in 2015, 44/2016 - 4 March 2016.

455 Eurostat newsrelease, EU Member States granted protection to more than 330000 asylum seekers in 2015, 75/2016-20 April 2016.

456 Eurostat newsrelease, 1.2 million first time asylum seekers registered in 2016, 46/2017, 16 March 2017.

457 Eurostat newsrelease EU Member States granted protection to more than 700000 asylum seekers in 2016, 70/2017, 26 April 2017. 
Figure 4.4. Asylum applications in the EU-28 Member States (2008$2017)^{458}$

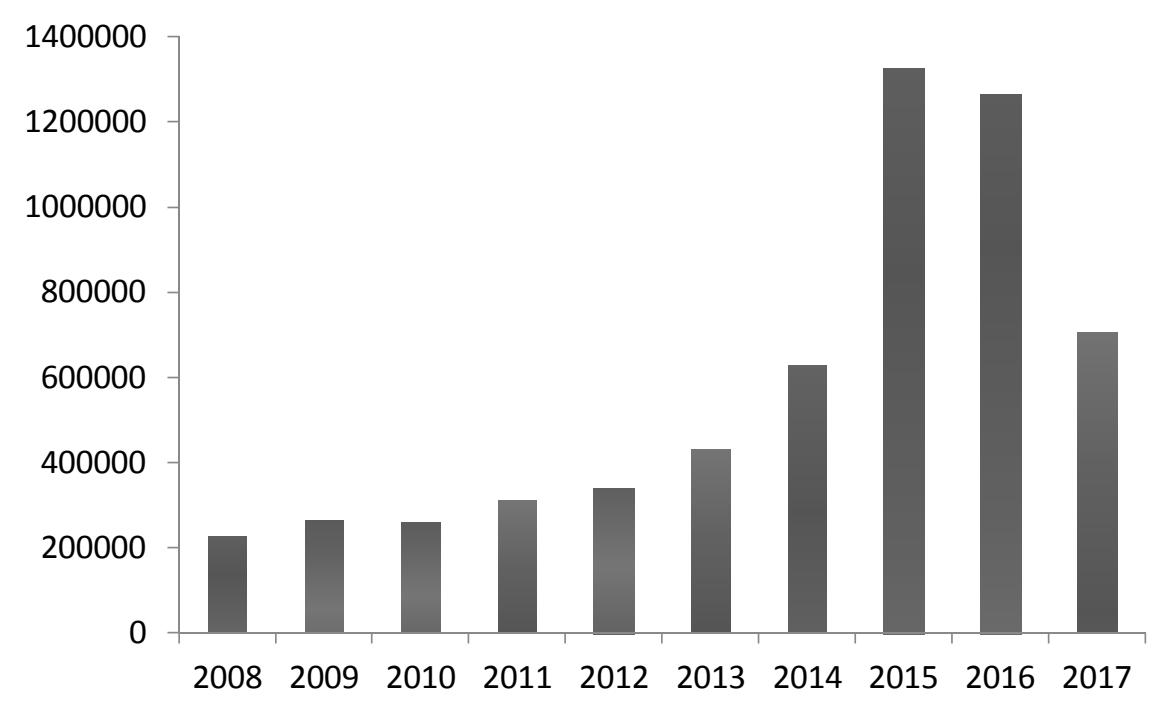

To put things in perspective, the numbers of asylum applicants in the EU significantly increased in recent years from 625.000 to 1.2 million; these numbers, however, represent $0.2 \%$ of the total EU inhabitants. ${ }^{459}$ Whereas $86 \%$ of the world refugee population still resides in developing regions. Turkey provides reception to 2.5 million refugees, followed by Pakistan and Lebanon with 1.6 million respectively 1.1 million refugees. 460

\subsubsection{Addressing the refugee crisis from a European and national per- spective}

Between 2015-2016, the EU has tabled various policy initiatives and legislative proposals in order to address the refugee crisis. At the national level, Member States had to deal with an increasing backlog of pending asylum cases and adopted various measures with the objective of deterring asylum applicants from arriving to their territory.

One instrument that has not been addressed by the EU and Member States in situations of arrivals of large numbers of asylum applicants and to lower the pressure on the asylum procedures in Member States is the Temporary Protec-

458 Eurostat, Asylum and first time asylum applicants by citizenship, age and sex Annual aggregated data, last update 30-03-2018:

http://appsso.eurostat.ec.europa.eu/nui/show.do?dataset=migr_asyappctza\&lang=en

459 Chetail, V., Looking Beyond the Rhetoric of the Refugee Crisis: The Failed Reform of the Common European Asylum System, European Journal of Human Rights, 2016/5, p. 585.

460 UNHCR Global Trends, Forced Displacement 2015, pp. 2-3. 
tion Directive. 461 The EU adopted the Temporary Protection Directive on 20 July 2001 following the Kosovo crisis in 1999. The Temporary Protection Directive addressed situations where large numbers of displaced persons cannot return to their country of origin. It was intended as a solution for a mass influx of displaced persons brought about by the conflict in the former Yugoslavia. According to the Temporary Protection Directive, a mass influx means 'arrival in the Community of a large number of displaced persons, who come from a specific country or geographical area'. ${ }^{462}$ Despite the large arrivals of Syrian refugees in recent years, the Commission is not convinced enough that the current circumstances justify the application of the Temporary Protection Directive. 463 The following section addresses the actions that have been taken at the EU and national level to cope with the refugee crisis.

\subsubsection{Relocation of beneficiaries of international protection}

One of the key features to address the migration challenge and to relief the pressure for several Member States that were confronted with high numbers of asylum applicants, the Council adopted a relocation scheme to redistribute 160.000 refugees from Greece and Italy to other EU Member States.

In order to implement the temporary relocation scheme, several 'hotspots' were established in Italy and Greece. EU Agencies (EASO, Frontex, Europol and Eurojust) have the task to operate on the ground with national authorities to register, identify and fingerprint migrants and processing of asylum applications. One of the key challenges to the hotspot concept is that it lacks a clear legal basis and purpose. ${ }^{464}$ The relocation mechanism consists of two Council Decisions, which are based on Article 78(3) TFEU:

1. Council Decision (EU) 2015/1523 of 14 September 2015465

2. Council Decision (EU) 2015/1601 of 22 September 2015466

461 Council Directive 2001/55/EC of 20 July 2001 on minimum standards for giving temporary protection in the event of a mass influx of displaced persons and on measures promoting a balance on efforts between Member States in receiving such persons and bearing the consequences thereof, OJ 2001 L 212/12.

462 Article 2(d) of the Temporary Protection Directive.

463 EN E-008507/2014 Answer given by Mr. Avramopoulos on behalf of the Commission (28.1.2015), period January- October 2014.

464 Wagner, M., Dimitriadi, A., O'Donell, R., Perumadan, J., Schlotzhauer, J. H., Simic, I., \& Yabasun, D. (2016), The implementation of the Common European asylum system, Brussels: European Parliament, p. 60.

465 Council Decision (EU) 2015/1523 of 14 September 2015 establishing provisional measures in the area of international protection for the benefit of Italy and of Greece.

466 Council Decision (EU) 2015/1601 of 22 September 2015 establishing provisional measures in the area of international protection for the benefit of Italy and Greece. 
The first Council Decision 2015/1523 was adopted on 14 September 2015 and involves the voluntary relocation of 40,000 refugees from Greece and Italy. The second Council Decision 2015/1601 was adopted on 22 September 2015 and includes an additional relocation of 120.000 refugees. In comparison to the first Council Decision, which was a voluntary commitment, the second Council Decision clearly set out a specific number of refugees that need to be relocated. ${ }^{467}$ Member States have two years to meet their targets. Thus, Member States have until September 2017 to comply with the Council Decisions. Moreover, the Council Decisions imply a temporary exemption from the Dublin system.

The relocation scheme only applies to those in clear need of international protection'. According to the Commission, only 'applicants with nationalities who have an average EU recognition rate for international protection that is equal to or above 75\%, are eligible for relocation. Currently, only Syrians and Eritreans fall into this category. The relocation mechanism is based on a distribution key. The following four indicators are included:

1. 'Population size ( $40 \%$ weighting)

2. Total GDP ( $40 \%$ weighting)

3. The average number of asylum applications per one million inhabitants over the previous five years $(10 \%$ weighting with a $30 \%$ cap of the population and GDP effect on the key to avoid disproportionate impact)

4. Unemployment rate $(10 \%$ weighting with a $30 \%$ cap of the population and GDP effect on the key to avoid disproportionate effect). ${ }^{468}$

On 9 October 2015, the first relocation of Eritrean refugees took place from Italy to Sweden. 469 From the very start Slovakia, Poland, Hungary and Czech Republic voted against a mandatory distribution quota. Overall, a systematic fulfilment of the commitments appeared to be very challenging for Member States. Hence, the Commission has urgently called upon Member States to speed up their relocation obligations or otherwise infringement procedures will be started against those Member States not fulfilling their commitments. ${ }^{470}$

467 See Annex I and II attached to the Council Decision (EU) 2015/1601 of 22 September 2015 establishing provisional measures in the area of international protection for the benefit of Italy and Greece.

468 European Commission - Fact Sheet, Refugee Crisis: European Commission takes decisive action - Questions and answers, 9 September 2015.

469 European Commission - Fact Sheet, First measures under the European Agenda on Migration: Questions and Answers, 27 May 2015.

470 European Commission - Press Release, Relocation and Resettlement: Commission calls on all Member States to deliver and meet obligations, 16 May 2017. 


\subsubsection{Relocation of vulnerable applicants}

Importantly, both Council Decisions give priority to relocate vulnerable applicants, in particular unaccompanied minors, within the meaning of Articles 21 and 22 of the recast Reception Conditions Directive over 'ordinary' applicants. Moreover, any special needs of applicants should be of primary concern. ${ }^{471}$ However, due to the limited availability of adequate reception facilities in Member States of relocation, the relocation of applicants with special needs has slowed down the process. The UNHCR encourages Member States to establish adequate reception standards in order to guarantee the participation of vulnerable groups in the relocation procedure. 472

\subsubsection{Permanent crisis relocation mechanism}

In addition to the temporary relocation mechanism, the Commission also proposed a Regulation establishing a permanent crisis relocation mechanism. ${ }^{473}$ The Regulation proposes for a permanent system for relocation to structurally deal with asylum crisis situations in any Member State that is affected by high numbers of arrivals of third-country nationals. The proposal includes a derogation from the Dublin criteria. ${ }^{474}$

What are the conditions to establish a crisis relocation mechanism in a certain Member State? The Commission must assess, based on information provided by EASO and Frontex that due to the increased influx of third-country nationals a Member State is confronted with an asylum crisis and is unable to apply the Dublin Regulation. The second step is to assess the magnitude of the

471 See Recital 33 Council Decision (EU) 2015/1601 of 22 September 2015 establishing provisional measures in the area of international protection for the benefit of Italy and Greece.

472 UNHCR, Building on the Lessons Learned to Make the Relocation Schemes Work More Effectively, UNHCR's Recommendations, January 2016, pp. 6-7.

473 European Commission proposal for a Regulation of the European Parliament and of the Council establishing a crisis relocation mechanism and amending Regulation (EU) No 604/2013 of the European Parliament and of the Council of 26 June 2013 establishing the criteria and mechanisms for determining the Member State responsible for examining an application for international protection lodged in one of the Member States by a third country national or a stateless person, Brussels, 9.9.2015, $\operatorname{COM}(2015) 450$ final, 2015/0208(COD).

474 European Commission proposal for a Regulation of the European Parliament and of the Council establishing a crisis relocation mechanism and amending Regulation (EU) No 604/2013 of the European Parliament and of the Council of 26 June 2013 establishing the criteria and mechanisms for determining the Member State responsible for examining an application for international protection lodged in one of the Member States by a third country national or a stateless person, Brussels, 9.9.2015, COM(2015) 450 final, 2015/0208(COD), p. 6. 
crisis situation based on certain indicators. ${ }^{475}$ Where a crisis situation is established in respect of a Member State, the Commission should subsequently determine both the number of persons to be relocated and the distribution of those persons between Member States by applying the formula for a distribution key, including the period of implementing the crisis mechanism. ${ }^{476}$ Like the relocation scheme, the calculation of the distribution key of this mechanism is based on the size of the population and the total of the GDP (both $40 \%$ weighting), the average number of asylum applications lodged over the period $2010-2014$ (10\% weighting) and the unemployment rate (10\% weighting). ${ }^{477}$

Only applicants who are, prima facie, in need of international protection may be relocated and priority should be given to vulnerable applicants within the meaning of Articles 21 and 22 of the recast Reception Conditions Directive.478 Applicants who are relocated to another Member State are granted specific guarantees such as the right to obtain information regarding their relocation procedure, to which Member State they are relocated and the right to relocate family members to the same Member State. Carrera and Guild have argued

475 European Commission proposal for a Regulation of the European Parliament and of the Council establishing a crisis relocation mechanism and amending Regulation (EU) No 604/2013 of the European Parliament and of the Council of 26 June 2013 establishing the criteria and mechanisms for determining the Member State responsible for examining an application for international protection lodged in one of the Member States by a third country national or a stateless person, Brussels, 9.9.2015, COM(2015) 450 final, 2015/0208(COD), p. 7.

476 European Commission proposal for a Regulation of the European Parliament and of the Council establishing a crisis relocation mechanism and amending Regulation (EU) No 604/2013 of the European Parliament and of the Council of 26 June 2013 establishing the criteria and mechanisms for determining the Member State responsible for examining an application for international protection lodged in one of the Member States by a third country national or a stateless person, Brussels, 9.9.2015, COM(2015) 450 final, 2015/0208(COD), p. 9.

477 European Commission proposal for a Regulation of the European Parliament and of the Council establishing a crisis relocation mechanism and amending Regulation (EU) No 604/2013 of the European Parliament and of the Council of 26 June 2013 establishing the criteria and mechanisms for determining the Member State responsible for examining an application for international protection lodged in one of the Member States by a third country national or a stateless person, Brussels, 9.9.2015, COM(2015) 450 final, 2015/0208(COD), p. 15.

478 European Commission proposal for a Regulation of the European Parliament and of the Council establishing a crisis relocation mechanism and amending Regulation (EU) No 604/2013 of the European Parliament and of the Council of 26 June 2013 establishing the criteria and mechanisms for determining the Member State responsible for examining an application for international protection lodged in one of the Member States by a third country national or a stateless person, Brussels, 9.9.2015, $\operatorname{COM}(2015) 450$ final, 2015/0208(COD), p. 8. 
that one of the crucial weaknesses of the relocation mechanism is that it is still functioning under the Dublin Regulation. They recommend a permanent relocation system that entails an individual assessment of the personal circumstances and vulnerabilities of the asylum applicant. ${ }^{479}$

\subsubsection{Valletta Summit on Migration}

A few months later, at the Valletta Summit of 11-12 November 2015, which was solely focused on migration, the EU and African leaders agreed on two documents: a political declaration and an action plan. The political declaration put forward the adoption of long-term actions in order to tackle the challenges of migration and the launch of sixteen policy initiatives before the end of 2016 . The action plan was grounded on five pillars: 480

1. Addressing the root causes of irregular migration and forced displacement.

2. Enhancing the co-operation on legal migration and mobility between the EU and African nations.

3. Strengthening the international protection of asylum applicants, refugees and migrants. Moreover, promoting global refugee resettlement efforts and expanding the legal pathways for persons in need of international protection.

4. Fighting against irregular migration, smuggling and trafficking.

5. Reinforcing return, re-admission of irregular migrants, including reintegration. Particular attention should be given to unaccompanied minors and to respect the best interest of the child.

In addition to the objectives that are constantly repeated by the EU when it comes to the topic of asylum, at the same time the EU adopted a more controversial strategy to stem the migratory movement of asylum applicants and migrants to the EU. The most obvious is the EU-Turkey Statement.

\subsection{Legislative and policy responses (2016-2018)}

\subsubsection{EU-Turkey Statement}

Following the EU-Turkey Joint Action Plan in October 2015,481 which under-

479 Carrera, S., and Guild, E., CEPS Policy Brief, Can the new refugee relocation system work? Perils in the Dublin logic and flawed reception conditions in the EU, October 2015, pp. 9-12.

480 Valletta summit on migration, 11-12 November 2015 - action plan and political declaration: http://www.consilium.europa.eu/nl/press/press-releases/2015/11/12-valletta-finaldocs/

481 The EU-Turkey Joint Action Plan pointed out three areas of co-operation: first, identifying the reasons that are leading to the migration movement of Syrians; second, supporting Turkey in their efforts to provide protection to the Syrians; third strengthening the co-operation with Turkey to reduce the number of migration flows to the EU. 
scored the co-operation between the EU and Turkey in the field of migration, the Council adopted on 18 March 2016, in the form of a press release, the contentious EU-Turkey Statement (also known as the EU-Turkey deal). ${ }^{482}$ The EU-Turkey consolidated the agreement that was made between the EU and Turkey in the field of migration. This deal was already addressed on 7 March $2016^{483}$ and further elaborated in the Commission Communication on 16 March 2016.484

Basically, the objective of the EU-Turkey deal is to return migrants and asylum applicants arriving irregularly on the Greek islands as from 20 March 2016 back to Turkey. Migrants that arrive on the Greek islands are registered and asylum applications will be processed in compliance with the Asylum Procedures Directive. EU Member States resettle one Syrian refugee from Turkey for every Syrian refugee returned back to Turkey from the Greek islands (the 'one for one' deal). In operational terms, the UNHCR assesses the candidates to be resettled on their vulnerability taking into account the UN Vulnerability Criteria. 485 The EU has allocated in total of 72,000 Syrians for resettlement from Turkey to the EU Member States. ${ }^{486}$ The 'one for one' resettlement scheme operates 'within the framework of the existing commitments'. 487 That means fulfilling the commitments under the current EU resettlement scheme: 18,000 of the 22,504 places remain. An additional 54,000 places are envisaged that were meant for relocations. 488

In return, Turkey and the EU also agreed to accelerate the visa liberation

482 European Council: EU-Turkey statement, 18 March 2016:

http://www.consilium.europa.eu/en/press/press-releases/2016/03/18-eu-turkeystatement/

483 Statement of the EU Heads of State or Government, 07/03/2016.

484 Communication from the Commission to the European Parliament, the European Council and the Council, Next operational steps in EU-Turkey co-operation in the field of migration, Brussels, 16.3.2016, COM(2016) 166 final.

485 European Commission, Communication from the Commission to the European Parliament, to the European Council and the Council, First Report on the progress made in the implementation of the EU-Turkey Statement, Brussels, 20.4.2016, COM(2016) 231 final, para. 3.2. UN Vulnerability Criteria: Women and girls at risk; survivors of violence and or torture; refugees with legal and or physical protection needs; refugees with medical needs or disabilities; children and adolescents at risk.

486 European Commission - Announcement, EU and Turkey agree European response to refugee crisis, 19 March 2016.

487 Communication from the Commission to the European Parliament, the European Council and the Council, Next operational steps in EU-Turkey cooperation in the field of migration, Brussels, 16.3.2016, $\operatorname{COM(2016)~} 166$ final, para. 2.2.

488 European Commission, Communication from the Commission to the European Parliament and the Council, Towards a reform of the Common European Asylum System and enhancing legal avenues to Europe, Brussels, 6.4.2016, COM(2016) 197 final, p. 15. 
roadmap for Turkish citizens and 3 billion euro in aid is allocated for the period 2016-2017 under the Facility for Refugees in Turkey.489 This funding aims to support the food, healthcare, education and shelter of Syrians in Turkey.

The deal had raised since its announcement serious questions with regard to the legality of the deal and the potential violation of the non-refoulement principle. 490

The contentious issue with this deal concerns the return of asylum applicants and refugees from Greece to Turkey. The Commission stated that the legal basis for these returns is laid down in the Asylum Procedures Directive. Asylum applications can be declared inadmissible because Turkey can be considered a 'first country of asylum' under Article 35(b) of the Asylum Procedures Directive or asylum applications can be declared inadmissible because Turkey can be considered a 'safe third country' under Article 38 of the Asylum Procedures Directive. ${ }^{491}$ However, due to the geographical limitation that Turkey maintains to the Refugee Convention, Syrians (and other non-European nationalities) are not able to apply for refugee status and to receive protection in accordance with the Refugee Convention. Hence, the criteria established in Article 38(1)(e), namely 'the possibility exists to request refugee status and, if found to be a refugee, to receive protection in accordance with the Geneva Convention' cannot be fulfilled. Therefore, to declare Turkey a 'safe third country' under Article 38 of the Asylum Procedures Directive is at odds with the Asylum Procedures Directive. In addition, given the reports on the situation of Turkey, it is unlikely that Turkey can provide 'sufficient protection', including benefiting from the principle of non-refoulement, to asylum applicants and refugees. 492

489 Communication from the Commission to the European Parliament and the Council, First Annual Report on the Facility for Refugees in Turkey, Brussels, 2.3.2017, $\operatorname{COM}(2017) 130$ final.

490 See inter alia Provera, M., JRS Europe, Discussion paper, The EU-Turkey deal, 29 April 2016; Collet, E., The Paradox of the EU-Turkey Refugee Deal, Migration Policy Institute, March 2016; Carrera, S. and Guild, E., EU-Turkey plan for handling refugees is fraught with legal and procedural challenges, CEPS, 10 March 2016; UNHCR, Legal considerations on the return of asylum-seekers and refugees from Greece to Turkey as part of the EU-Turkey Cooperation in Tackling the Migration Crisis under the safe third country and first country of asylum concept, 23 March 2016; Peers, S., The final EU/Turkey refugee deal: a legal assessment, EU Law Analysis Blog, 18 March 2016; and Den Heijer, M. and Spijkerboer, T., Is the EU-Turkey refugee and migration deal a treaty?, EU Law Analysis Blog, 7 April 2016; and Wagner, M., Dimitriadi, A., O'Donell, R., Perumadan, J., Schlotzhauer, J. H., Simic, I., \& Yabasun, D. (2016), The implementation of the Common European asylum system, Brussels: European Parliament, pp. 68-69.

491 European Commission - Fact Sheet, EU - Turkey Statement: Questions and Answers, Brussels, 19 March 2016.

492 Collet, E., The Paradox of the EU -Turkey Refugee Deal, Migration Policy Institute, March 
A year after the conclusion of the deal, the outcomes have been ambiguous. While the Commission proudly announced that the trend of irregular crossings from Turkey to Greece has been drastically reduced and that progress has been made on all areas of the EU Turkey deal, ${ }^{493}$ Spijkerboer argued that the declining number of asylum applications in the EU could be traced back to the closure of the Western Balkan route.494 NGOs such as Amnesty International has reported that asylum applicants and migrants on the Greek Islands have no access to legal assistance and consider the situation on the ground as inhumane. Despite the Commission's statement that due account must be given to particularly vulnerable groups, in particular unaccompanied minors, ${ }^{495}$ large numbers of vulnerable persons, such as mothers with babies, small children and persons with disabilities, trauma and serious illnesses were in immediate need of medical assistance. 496 Others scholars have reported that readmitted migrants from Greece to Turkey have limited access to international protection. 497

The issue of legality of the deal has been also discussed before the CJEU. Three asylum applicants (two Pakistani nationals and an Afghan national) argued that they risked persecution if they were to be returned from Greece to Turkey under the EU-Turkey Statement. 498 The applicants argued that the deal is an international agreement, which violates the TFEU rules regarding the concluding of international agreements by the EU. Therefore, the EU- Turkey deal should be annulled. The General Court of the EU declares that 'it was not the

2016; ECRE and the Dutch Council for Refugees report, The DCR/ECRE desk research on application of a safe third country and a first country of asylum concepts to Turkey, May 2016: Amnesty International report, Asylum-seekers and refugees denied effective protection in Turkey, March 2016:; Roman, E., Baird, T., and Radcliffe, T., Why Turkey is Not a "Safe Country”, Statewatch Analysis, February 2016.

493 Report from the Commission to the European Parliament, the European Council and the Council, Fifth Report on the Progress made in the implementation of the EU-Turkey Statement, Brussels, 2.3.2017, COM(2017) 204 final, p. 13. See also Annex to the report from the Commission to the European Parliament, the European Council and the Council, Fifth Report on the Progress made in the implementation of the EU-Turkey Statement, Joint Action Plan on the implementation of the EU-Turkey Statement, Brussels, 2.3.2017, $\operatorname{COM}(2017) 204$ final.

494 Spijkerboer, T., Fact Check: Did the EU -Turkey Deal Bring Down the Number of Migrants and of Border Deaths? Border Criminologies Blog, 28 September 2016.

495 European Commission, Fact Sheet, Implementing the EU-Turkey Agreement - Questions and Answers, Brussels, 4 April 2016.

496 Oxfam International, Vulnerable and abandoned, 9 January 2019. Amnesty International Report, A blueprint for despair - Human rights impact of the EU-Turkey deal, 2017.

497 Ulusoy, O., and Battjes, H., Situation of Readmitted Migrants and Refugees from Greece to Turkey under the EU-Turkey Statement, VU Migration Law Series No 15, 2017.

498 Cases T-192/16, T-193/16 and T-257/16, NF, NG and NMv European Council, 28 February 2017, Court of Justice of the European Union, ECLI:EU:T:2017:128. 
EU but its Member States, as actors under international law, that conducted negotiations with Turkey in that area, including on 18 March 2016'. Disappointingly, the CJEU held that it lacked jurisdiction and dismissed the cases brought by the asylum applicants. 499

\subsubsection{National developments}

In addition to the initiatives at the EU level to reduce the volume of migration flows, several Member States adopted measures during the 'refugee crisis' aimed at deterring asylum applicants. Border controls, security fences, changes in the family reunification rules and amendments to the residence permits of beneficiaries of international protection represent a few aspects of the actions taken at the national level. ${ }^{500}$ Germany and Austria introduced, inter alia, rules extending the waiting period of two years to three years before beneficiaries of subsidiary protection may apply for family reunification. Sweden introduced temporary residence permits for beneficiaries of international protection. Applicants granted refugee status obtain a residence permit valid for three years (previously permanently). Beneficiaries of subsidiary protection obtain a residence permit valid for thirteen months (previously permanently). Similar to Germany and Austria, the rules on family reunification have been tightened in Sweden. ${ }^{501}$

\subsubsection{Structural shortcomings of the CEAS}

Is the current CEAS able to deal with the refugee crisis? Not according to the Commission. ${ }^{502}$ In its Communication, the Commission presented five priorities that addressed the structural shortcomings of the CEAS: ${ }^{503}$

1. The Commission emphasized the significance of a sustainable and fair Dublin system. Two options were presented to reform the dysfunctional system. First, to supplement the current Dublin system with a corrective

499 General Court of the European Union, Press release No. 19/17, Luxembourg, 28 February 2017.

500 Wagner, M., Dimitriadi, A., O'Donell, R., Perumadan, J., Schlotzhauer, J. H., Simic, I., \& Yabasun, D. (2016), The implementation of the Common European asylum system, Brussels: European Parliament, pp. 38-42.

501 Yabasun, D., Hervorming Europees asielbeleid: Commissievoorstel Kwalificatieverordening, Journaal Vreemdelingenrecht, No. 3, (2016), p. 12.

502 See also Wagner, M., Dimitriadi, A., O'Donell, R., Perumadan, J., Schlotzhauer, J. H., Simic, I., \& Yabasun, D. (2016), The implementation of the Common European asylum system. Brussels: European Parliament.

503 European Commission, Communication from the Commission to the European Parliament and the Council, Towards a reform of the Common European Asylum System and enhancing legal avenues to Europe, Brussels, 6.4.2016, COM(2016) 197 final. 
fairness mechanism. Second, to opt for a new fundamental system for allocating asylum applications.

2. The second priority for the Commission was to extend the scope of the Eurodac system, which will facilitate the fight against irregular migration and the return of irregularly arrived migrants.

3. To further harmonize the asylum procedures, the Commission proposed to amend the Asylum Procedures Directive and the Qualification Directive into a Regulation. The aim is to establish a single common asylum procedure with uniform rules on the procedures and rights of beneficiaries of international protection. The Commission did not intend to change the Reception Conditions Directive into a Regulation.

4. Several measures are envisaged to prevent secondary movements of asylum applicants and beneficiaries of international protection. In addition, the Commission aimed to modify the Long-Term Residence Directive with respect to beneficiaries of international protection.

5. The implementation and the functioning of the CEAS illuminate chronic deficits. Therefore, a new EU Asylum Agency replacing EASO should be established with a stronger mandate to operational support Member States on the ground and to improve the implementation of CEAS standards.

In addition, the Communication paid much attention to safe and legal avenues for applicants of international protection to arrive in the EU. The envisaged concept is to develop a more structured resettlement mechanism. Complementary to resettlement, Member States should also consider using other forms of legal avenues such as humanitarian admissions and private sponsorships for refugees. Lastly, the EU aims to further enhance its labour migration policy by proposing to reform the EU Blue Card Directive. ${ }^{504}$ At the same time, strengthening re-admission and returning irregular migrants to countries of origin or third countries is another priority for the EU.505

\subsubsection{Humanitarian visas}

The concept of humanitarian visas (not to be confused with humanitarian admissions) as a legal pathway to the EU is another option that has been discussed in recent years. Currently, there is no EU humanitarian visa scheme. Member States may individually issue humanitarian visa. A study undertaken on behalf

504 Proposal for a Directive of the European Parliament and of the Council on the conditions of entry and residence of third-country nationals for the purposes of highly skilled employment, Strasbourg, 7.6.2016, COM(2016) 378 final, 2016/0176 COD.

505 European Commission, Communication from the Commission to the European Parliament and the Council, Towards a reform of the Common European Asylum System and enhancing legal avenues to Europe, Brussels, 6.4.2016, COM(2016) 197 final, pp. 14-20. 
of the European Parliament showed that 16 Member States have or have had some form of humanitarian visas scheme. 506

The issue of humanitarian visas has been brought up before the CJEU. In the $X$ and $X v$ Etat belge $e^{507}$ case, a Syrian family applied for a humanitarian visa at the Belgian embassy in Beirut. The objective of the application was to obtain visas with limited territorial validity on the basis of Article 25(1)(a) of the Visa Code, in order to enter Belgium and apply for asylum. Advocate-General Mengozzi stated:

'allow me to draw your attention to how much the whole world, in particular here in Europe, was outraged and profoundly moved to see, two years ago, the lifeless body of the young boy Alan, washed up on a beach, after his family had attempted, by means of smugglers and an over-crowded makeshift vessel full of Syrian refugees, to reach, via Turkey, the Greek island of Kos. Of the four family members, only his father survived the capsizing. It is commendable and salutary to be outraged. In the present case, the Court nevertheless has the opportunity to go further, as I invite it to, by enshrining the legal access route to international protection which stems from Article 25(1)(a) of the Visa Code. Make no mistake: it is not because emotion dictates this, but because EU law demands it', 508

Despite the poignant appeal by Advocate-General Mengozzi, the CJEU did not follow the AG's opinion and ruled that humanitarian visas are national matter and falls outside the scope of EU law.509

\subsubsection{Reforming the asylum acquis}

Three years after the adoption of the recast instruments of the CEAS and following the Commission Communication on the reform of the CEAS, new Commission proposals with significant implications for asylum applicants have been presented. The reform proposals also contain several significant provisions focused on the protection of unaccompanied minors and other vulnerable persons. ${ }^{510}$ Strengthening the rights of vulnerable groups is considered a key

506 Jensen, U., Humanitarian visas: option or obligation? European Parliament study, Brussels 2014, pp. 43-49; See also Neville, D. and Rigon, A., European Parliament Briefing, Towards an EU humanitarian visa scheme? 2016.

507 Case C-638/16, PPU, X and X v Etat belge, 7 March 2017, Court of Justice of the European Union, ECLI:EU:C:2017:173.

508 AG Mengozzi in Case C-638/16 PPU, $X$ and $X v$ Etat belge, Opinion delivered on 7 February 2017, ECLI:EU:C:2017:93, para. 175.

509 A similar case is pending before the ECtHR: Nahhas and others v Belgium.

510 European Commission, Press release, Completing the reform of the Common European Asylum System: towards an efficient, fair and humane asylum policy, Brussels, 13 July 2016. 
priority in a reformed CEAS. 511

The reform asylum package includes the following proposals: the Qualification Directive to be replaced by a Regulation; 512 the Asylum Procedures Directive to be replaced by a Regulation; 513 a new recast Reception Conditions Directive; ${ }^{514}$ reform of the Dublin Regulation; 515 and reform of the Eurodac Regulation. ${ }^{516}$ Furthermore, the Commission is proposing a Regulation establishing a Union Resettlement Framework. ${ }^{517}$

The Commission has also submitted a proposal to reform EASO into a new EU Asylum Agency, ${ }^{518}$ which would give the Agency a stronger mandate lead-

511 European Commission, Communication from the Commission to the European Parliament, the Council, the European Economic and Social Committee and the Committee of the Regions, A European Agenda on Migration, Brussels, 13.5.2015, COM(215) 240 final, p. 12.

512 Proposal for a Regulation of the European Parliament and of the Council on standards for the qualification of third-country nationals or stateless persons as beneficiaries of international protection, for a uniform status for refugees or for persons eligible for subsidiary protection and for the content of the protection granted and amending Council Directive 2003/109/EC of 25 November 2003 concerning the status of third-country nationals who are long-term residents, Brussels, 13.7.2016, $\operatorname{COM}(2016) 466$ final 2016/0223 (COD).

513 Proposal for a Regulation of the European Parliament and of the Council establishing a common procedure for international protection in the Union and repealing Directive 2013/32/EU, Brussels, 13.7.2016, COM(2016) 467 final, 2016/0224 (COD).

514 Proposal for a Directive of the European Parliament and of the Council laying down standards for the reception of applicants for international protection (recast), Brussels, 13.7.2016, COM(2016) 465 final, 2016/0222 (COD).

515 Proposal for a Regulation of the European Parliament and of the Council establishing the criteria and mechanisms for determining the Member State responsible for examining an application for international protection lodged in one of the Member States by a thirdcountry national or a stateless person (recast), Brussels, 4.5.2016, COM(2016) 270 final, 2016/0133 (COD).

516 Proposal for a Regulation of the European Parliament and of the Council on the establishment of 'Eurodac' for the comparison of fingerprints for the effective application of [Regulation (EU) No 604/2013 establishing the criteria and mechanisms for determining the Member State responsible for examining an application for international protection lodged in one of the Member States by a third-country national or a stateless person], for identifying an illegally staying third-country national or stateless person and on requests for the comparison with Eurodac data by Member States' law enforcement authorities and Europol for law enforcement purposes (recast), Brussels, 4.5.2016, COM(2016) 272 final, 2016/0132 (COD).

517 Proposal of the European Parliament and of the Council establishing a Union Resettlement Framework and amending Regulation (EU) No 516/2014 of the European Parliament and the Council, Brussels, 13.7.2016, COM(2016) 468 final, 2016/0225 (COD).

518 Proposal for a Regulation of the European Parliament and of the Council on the European Union Agency for Asylum and repealing Regulation (EU) No 439/2010, Brussels, 
ing to enhanced co-operation on asylum. The new Agency should guarantee increased convergence in the assessment of protection in the EU. Since the adoption of the CEAS, divergent national practices, inter alia, in the recognition rates and the type of protection status (refugee status or beneficiary of subsidiary protection status) to asylum applicants originating from the same country of origin remains a challenge. ${ }^{519}$ In addition, the Agency should promote EU law, operational asylum standards, including developing guidelines and best practices regarding the implementation of asylum instruments. As the CEAS suffers from a structural implementation deficit, a stronger monitoring role in all areas of asylum is envisaged for the new Agency. The Commission has proposed to intensify the role of the Agency with regard to its operational and technical assistance to Member States. Furthermore, since October 2016 the EU has established a new European Border and Coast Guard (EBCG) ${ }^{520}$ in the field of European border management. 521 The EBCG builds on the existing structures of Frontex.

\subsubsection{Global Compact on Refugees}

At the international level new commitments have been adopted to respond to the large movements of refugees and migrants around the globe and to address protracted refugee situations. On 17 December 2018, 181 State parties of the UN adopted in favour of the Global Compact on Refugees (GCR). 522 The GCR (non-binding) is the result of the UN Declaration for Refugees and Migrants (Declaration) that was signed in 2016. In addition to the GCR, the other impor-

4.5.2016, $\operatorname{COM}(2016) 271$ final.

519 Wagner, M., Dimitriadi, A., O'Donell, R., Perumadan, J., Schlotzhauer, J. H., Simic, I., \& Yabasun, D. (2016), The implementation of the Common European asylum system, Brussels: European Parliament, pp. 72-73. See also Mouzourakis, M., Taylor, A., Dorber, J., Sbarai, E., and Pollet, K., Common asylum system at a turning point: Refugees caught in Europe's solidarity crisis, Asylum Information Database, Annual Report 2014/2015, pp. 18-23.

520 Regulation of the European Parliament and of the Council of 14 September 2016 on the European Border and Coast Guard and amending Regulation (EU) 2016/399 of the European Parliament and of the Council and repealing Regulation (EC) No 863/2007 of the European Parliament and of the Council, Council Regulation (EC) No 2007/2004 and Council Decision 2005/267/EC, OJ L251/1, 16.9.2016.

521 European Commission - Press release, European Agenda on Migration: Commission reports on progress in making the new European Border and Coast Guard fully operational, Brussels 25 January 2017. See for an analysis Rijpma, J., The Proposal for a European Border and Coast Guard: evolution or revolution in external border management? European Parliament Study, Brussels (2016).

522 Global Compact on Refugees: https://www.unhcr.org/gcr/GCR_English.pdf. See UN Press release, 17 December 2018: https://www.un.org/press/en/2018/ga12107.doc.htm (accessed 10 February 2019). 
tant document that was adopted was the Global Compact on Migration (GCM). ${ }^{523}$

For the purposes of this study, it important to note that there was a particular focus in the Declaration on vulnerable groups of refugees and migrants. The Declaration particularly addressed the special needs of persons, whether they are refugees or migrants, in vulnerable situations in the context of large migratory movements. Other vulnerable groups that were also discussed in the Declaration concerned 'women at risk, children, especially those who are unaccompanied or separated from their families, members of ethnic and religious minorities, victims of violence, older persons, persons with disabilities, persons who are discriminated against on any basis, indigenous peoples, victims of human trafficking, and victims of exploitation and abuse in the context of the smuggling of migrants.' 524

While the GCR enshrines a rights-based approach to refugees and migrants, the European asylum policy and actual practice in Member States shows, however, a different reality. It is also important to note that in comparison to the GCM there are no strong references in the GCR to the notion of vulnerability. Instead the GCR uses the notion 'persons with specific needs' to refer to groups of refugees that are vulnerable. These groups include: 'children, including those who are unaccompanied or separated; women at risk; survivors of torture, trauma, trafficking in persons, sexual and gender-based violence, sexual exploitation and abuse or harmful practices; those with medical needs; persons with disabilities; those who are illiterate; adolescents and youth; and older persons. ${ }^{525}$ The approach of the GCR is simply labelling groups as having specific needs without explaining the reasons for their specific needs. In addition, the text of the GCR seems to consider that the list is exhaustive, which excludes other potential vulnerable groups. Children are explicitly identified as a group with vulnerabilities. ${ }^{526}$

The GCM on the other hand, makes several explicit references to migrants in situation of vulnerability or vulnerabilities. One of the objectives is to 'establish comprehensive policies and develop partnerships that provide migrants in a situation of vulnerability, regardless of their migration status, with necessary support at all stages of migration, through identification and assistance, as well as protection of their human rights'. Groups that are presumed to be in a situation of vulnerability includes: 'women at risk, children, especially those unac-

523 Global Compact on Migration: https://undocs.org/A/CONF.231/3 (accessed 10 February 2019).

524 UN General Assembly, New York Declaration for Refugees and Migrants: resolution / adopted by the General Assembly, 3 October 2016, A/RES/71/1, para. 23.

525 Global Compact on Refugees, para. 1.5.

526 Global Compact on Refugees, para. 2.5. 
companied or separated from their families, members of ethnic and religious minorities, victims of violence, including sexual and gender-based violence, older persons, persons with disabilities, persons who are discriminated against on any basis, indigenous peoples, workers facing exploitation and abuse, domestic workers, victims of trafficking in persons, and migrants subject to exploitation and abuse in the context of smuggling of migrants'. Similar to GCR, the list suggests to be exhaustive, which may result in the exclusion of other potential groups that may find themselves in a vulnerable situation. It is also noticeable that the approach to vulnerability in the GCM does not explain the underlying reasons for presuming these specific groups to be in a vulnerable situation. In my view, the conceptual understanding of vulnerability in the GCR and GCM is unclear and ineffective.

\subsubsection{Commission political roadmap for a sustainable migration policy}

As the number of migrants and asylum applicants reaching the EU has reduced in 2017, the Commission considered it as the moment to move away from a migration management based on ad-hoc decisions and to take this opportunity to present a political roadmap for a sustainable EU migration policy for the long term. ${ }^{527}$ On 7 December 2017, the Commission submitted several recommendations to establish a solid future-proof migration management. ${ }^{528}$ The aim of the Commission is to proceed with their strategy of recent years which is not only to focus on the internal dimension of migration policy but at the same time also strengthen the external dimension of migration policy.

As regards the internal dimension, the Commission urged the Council to unblock the discussions on the Commission's CEAS reform proposals and take the way forward on the reform of the Dublin Regulation. Following the end of the relocation schemes in September 2017, the Commission launched another new resettlement scheme in which they proposed to take up another 50.000 particularly vulnerable refugees from North Africa and the Horn of Africa to be taken by the Member States by October 2019. More recently, the Council proposed a contentious concept of 'regional disembarkation platforms' to be placed outside the EU territory in cooperation with UNHCR and IOM. According to the Council document 'such platforms should provide for rapid processing to distinguish between economic migrants and those in need of international protection, and reduce the incentive to embark on perilous jour-

527 European Commission - Press release, Future-proof migration management: European Commission sets out way forward, Brussels, 7 December 2018.

528 European Commission, Communication from the Commission to the European Parliament, the European Council and the Council, Commission contribution to the EU Leaders' thematic debate on a way forward on the external and the internal dimension of migration policy, Brussels, 7.12.2017, COM(2017) 820 final, p. 2. 
neys' ${ }^{529}$ Carrera and Lannoo rightly remark that disembarkation platforms in third countries would deny people's rights to international protection. It remains also obscure whose law would apply in these disembarkation platforms. 530

As regards the external dimension, despite the human rights and humanitarian challenges the objective is to continue with the implementation of the EUTurkey deal. In addition, while the UN, the OHCHR have expressed their concerns on the systematic detention of migrants in Libya, ${ }^{531}$ the Commission remains to support the co-operation with the Libyan authorities to stem the flows of migration to the EU.532

529 General Secretariat of the Council, Draft conclusions, European Council meeting (28 June 2018), Brussels, 19 June 2018, 8147/18. See also General Secretariat of the Council, Conclusions European Council meeting (28 June 2018)

http://www.consilium.europa.eu/media/35936/28-euco-final-conclusions-en.pdf

530 Carrera, S., and Lannoo, K, We're in this boat together - Time for a Migration Union, CEPS, June 2018, p. 7.

531 UN human rights chief: Suffering of migrants in Libya outrage to conscience of humanity, 14 November 2017. Available at:

http://www.ohchr.org/EN/NewsEvents/Pages/DisplayNews.aspx?NewsID=22393\&La $\mathrm{ngID}=\mathrm{E}$ See also Office of the United Nationals High Commissioner for Human Rights in co-operation with the United Nations Support Mission in Libya, Abuse Behind Bars: Arbitrary and unlawful detention in Libya, April 2018. Available at http://www.ohchr.org/Documents/Countries/LY/AbuseBehindBarsArbitraryUnlawful_ EN.pdf

532 EU Action in Libya on Migration, The Commission's Contribution to the Leaders' Agenda. Available at: https://ec.europa.eu/home-affairs/sites/homeaffairs/files/what-wedo/policies/european-agenda-migration/20171207_eu_action_in_libya_on_migration _en.pdf 
Figure 4.5. Timeline Common European Asylum System, phase III (20142018)

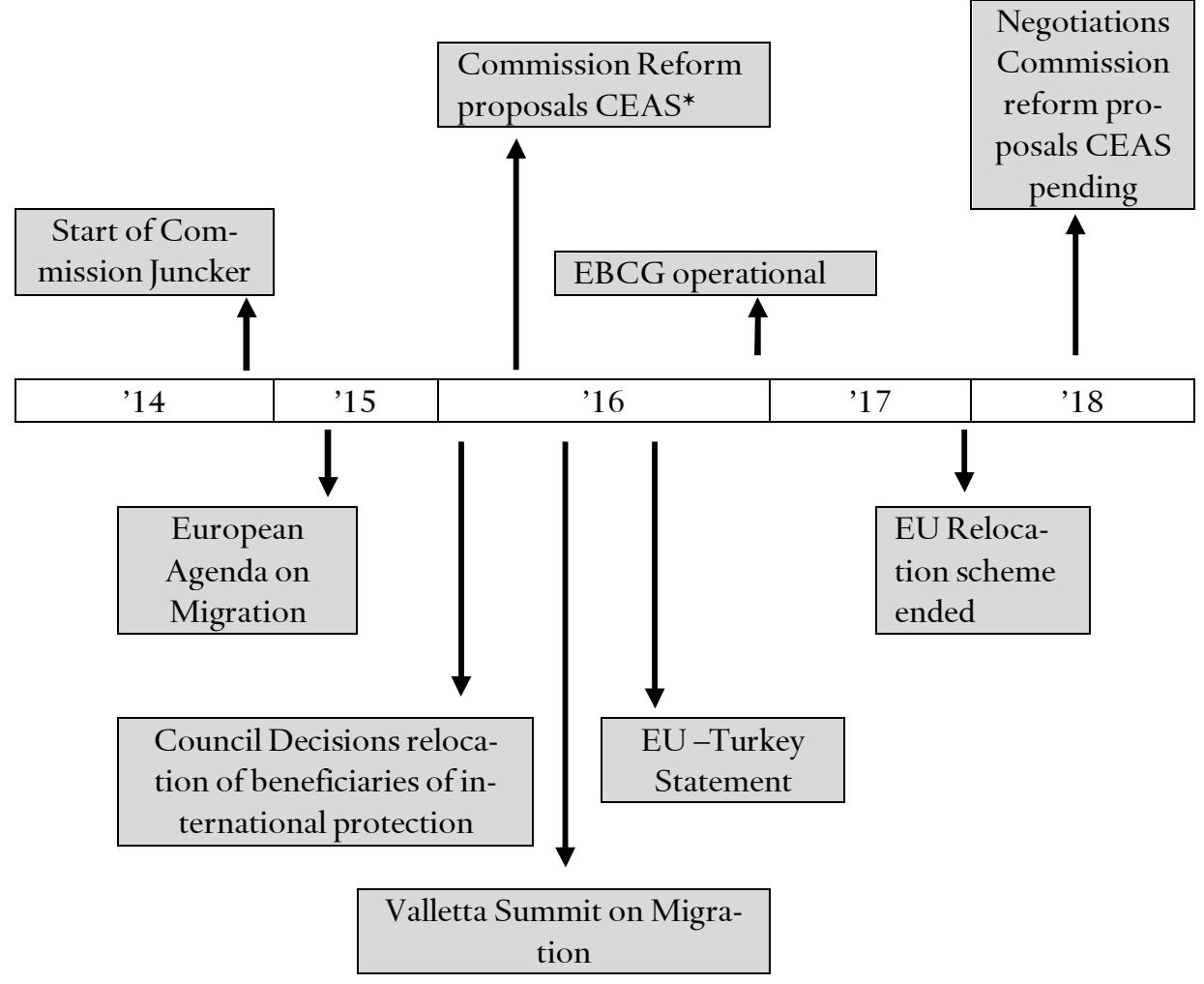

^Commission reform proposals:

- The Qualification Regulation;

- The Asylum Procedures Regulation;

- A new recast Reception Conditions Directive;

- Reform of the Dublin III Regulation and reform of the Eurodac Regulation;

- Establishing a Union Resettlement Framework; and

- Reform EASO into a new EU Asylum Agency.

\subsection{Analysis}

The previous sections show that in the past years the EU has put much work to deal with the 'refugee crisis'. The 2019 Commission progress report shows that the numbers of asylum applicants in the EU in 2018 has fallen to the pre-crisis 
levels. ${ }^{533}$ The question is at what price? In their efforts to deal with the continuing 'refugee crisis', the EU extended its scope to third countries. A controversial deal was concluded with Turkey, which allowed the return of migrants and asylum applicants arriving irregularly on the Greek islands as from 20 March 2016 back to Turkey. One of the contentious issues is whether Turkey can be considered a safe third country. I would argue that Turkey should not be considered a 'safe third country' under Article 38 of the Asylum Procedures Directive because of the geographical limitation that Turkey applies to the Refugee Convention. This means that Syrians (and other non-European nationalities) are not able to apply for refugee status and to receive protection in accordance with the Refugee Convention. The EU seems to be considering new migration partnerships with African states. 534 While the EU is proclaiming that the aim of such co-operation is to prevent persons taking dangerous journeys overseas and to stop the smuggler networks, it is in fact to stem the migration flows to the EU. Hence, in my view, the approach of the EU shows that there is clear tendency to prevent the access of asylum applicants to the territory of the EU, which undermines the fundamental right to seek asylum.

This chapter has also shown the important historical developments that led to the gradual communitarisation of asylum policies in the EU. Since 1999 it has been the aim of the EU to establish a CEAS, which includes common standards on the reception, procedures for determining whether a person qualifies for international protection and the allocation of responsibility among Member States for the examination of asylum claims. The CEAS should be established 'based on a full and inclusive application of the Geneva Convention, thus ensuring that nobody is sent back to persecution, i.e. maintaining the principle of nonrefoulement'. Moreover, the Union and the Member States reaffirmed 'the absolute respect of the right to seek asylum'. ${ }^{535}$ However, this chapter has shown that the CEAS is far from being coherent.

To begin with the first-phase of the CEAS, a number of derogations in the legislative acts and the wide discretion left for the Member States in the interpretation and implementation of legal standards impeded the desired harmonisation between national asylum systems. Compared to the first-phase CEAS

533 European Commission, Progress report on the implementation of the European Agenda on Migration, Brussels, 6.3.2019, COM(2019) 126 final.

534 Report from the Commission to the European Parliament and the Council, Fourth Progress Report on the Partnership Framework with third countries under the European Agenda on Migration, Strasbourg, 13.6.2017, COM (2017) 350 final. See also European Commission, Rencontre à Paris sur la migration: Déclaration conjointe 'Relever le défi de la migration et de l'asile', Déclaration Conjointe relever le défi de la migration et de l'asile, Paris, 28 August 2017.

535 European Council, Presidency Conclusions, Tampere 15-16 October 1999, para. 13. 
legislative acts, the second-phase legislative acts have improved the standards on qualification, reception and procedures. However, this is mainly due to the developing case law of the CJEU and the ECtHR, including the position of the European Parliament as a co-legislator during the negotiations of the asylum package. For the purposes of this study, it is important to note that one of the main amendments of the second-phase CEAS legislation was the introduction of enhanced special guarantees for vulnerable asylum applicants in terms of reception and procedural guarantees. During the evaluation of the first-phase CEAS legislative acts, the Commission identified 'serious inadequacies' as to the interpretation and insufficient implementation and as well as the procedural issues of vulnerable asylum applicants in the domestic systems of the Member States. Hence, more detailed measures were needed to address the situation of vulnerable persons in the asylum process.

The high increase of migratory arrivals in 2015 also showed that the CEAS was not able to provide the desired response to the 'refugee crisis'. In addition, the EU relocation schemes that were adopted to relief the pressure for several Member States that were confronted with high numbers of asylum applicants and which prioritized the relocation of vulnerable persons was a failure. Several Member States have refused from the beginning to take beneficiaries of international protection. Other Member States barely met their commitments. Such responses showed a lack of solidarity and commitment to share responsibility between Member States. The structural shortcomings of the EU asylum policy and the response of the Member States to the 'refugee crisis' shows, in my view, that a future European asylum policy that is fair, efficient and sustainable could be achieved when Member States transfer their national competences on asylum to a centralised EU asylum agency that carries out the registration of asylum applicants, examines who qualifies for international protection and also relocates the refugees among the Member States based on a distribution key. 536

\subsection{Concluding remarks}

This chapter has shown the constant tension that exists between the legitimate interest of states to control the access to the territory and the international obligation to protect the fundamental rights of refugees. This chapter asked the question what has the EU done so far in the field of asylum. I have examined extensively the development of asylum co-operation in the EU. I started with the

536 See also Ballegooij, W. et al., European Parliamentary Research Service, The Cost of Non-Europe in Asylum Policy, 2018, pp. 137-138; Carrera, S., et al., The European Border and Coast Guard, Addressing migration and asylum challenges in the Mediterranean? 2017; and Guild, E., Does the EU Need a European Migration and Protection Agency? International Journal of Refugee Law, vol. 28, Issue 4, 2016. 
inter-governmental co-operation on asylum and moved on to discuss the adoption of legally binding instruments in the EU and beyond. It has been submitted that the CEAS as it stands now is far from being a coherent, uniform and efficient. More importantly, I have submitted that a future EU asylum policy could effectively function when Member States give up their national competences on asylum. It is in my view that the solution to the challenges in the field of asylum is more integration not less. The next chapter examines in more detail the recast CEAS legislative acts and also the Commission reform proposals, which marks the third-phase of the CEAS. 


\section{5 -The Common European Asylum System}

\subsection{Introduction}

Before embarking on an assessment of the CEAS legal standards with regard to vulnerable asylum applicants, a general understanding of the legal instruments of the CEAS is in order. The purpose of this chapter is to assess the key shortcomings and challenges in each individual legal instrument of the CEAS. The CEAS instruments to be examined in this chapter include three Directives, namely the recast Qualification Directive, the recast Asylum Procedures Directive and the recast Reception Conditions Directive. The Directives are complemented by two Regulations, which are the recast Dublin III Regulation and the recast Eurodac Regulation. The Temporary Protection Directive could be considered the fourth Directive that is part of the CEAS. However, as this instrument has never been activated by Member States, this specific instrument will not be included in the general analysis with regard to the CEAS instruments. The Temporary Protection Directive has been discussed in the previous chapter in relation to the refugee crisis.

In addition, the Commission proposed in May 2016 to reform the recast Dublin III Regulation and the recast Eurodac Regulation. In July 2016, the Commission proposed to replace the current recast Qualification Directive and the recast Asylum Procedures Directive with a Regulation, including a recast of the Reception Conditions Directive. I will also examine these proposals and identify the differences with the current legislative acts.

\subsection{The recast Qualification Directive 2011/95/EU}

The recast Qualification Directive 2011/95/EU (recast Qualification Directive) $)^{537}$ is at the core of the CEAS as it establishes the shared standards of who is to be recognized as a refugee or to be granted subsidiary protection, including the content of the international protection. The recast Qualification Directive has replaced former Qualification Directive 2004/83/EC.538

537 Directive 2011/95/EU of the European Parliament and of the Council of 13 December 2011 on standards for the qualification of third-country nationals or stateless persons as beneficiaries of international protection, for a uniform status for refugees or for persons eligible for subsidiary protection, and for the content of the protection granted (recast) OJ L 337/9.

538 Council Directive 2004/83/EC of 29 April 2004 on minimum standards for the qualification and status of third country nationals and stateless persons as refugees or as persons who otherwise need international protection and the content of the protection granted, OJ 2004, L 304/12. 
The adopted recast Qualification Directive was published in the Official Journal of the European Union on 20 December 2011 and was applicable as from 21 December 2013. The majority of Member States have implemented the Directive. The Commission has sent 'reasoned opinions' to Bulgaria and Spain for not having informed them about the transposition of the recast Qualification Directive. 539 The UK, Ireland and Denmark did not take part in the adoption and application of the recast Qualification Directive. The UK and Ireland remain bound by the 2004 Qualification Directive.

\subsubsection{Refugee status}

The definition of a refugee in the recast Qualification Directive is largely based on Article 1A(2) of the Refugee Convention. Article 2(d) of the recast Qualification Directive reads:

'refugee' means a third-country national who, owing to a well-founded fear of being persecuted for reasons of race, religion, nationality, political opinion or membership of a particular social group, is outside the country of nationality and is unable or, owing to such fear, is unwilling to avail himself or herself of the protection of that country, or a stateless person, who, being outside of the country of former habitual residence for the same reasons as mentioned above, is unable or, owing to such fear, unwilling to return to it, and to whom Article 12 does not apply.'

\subsubsection{Assessing the asylum claim}

The assessment of facts and circumstances of the asylum claim takes place in two separate stages. ${ }^{540}$ In general, the first stage concerns the collecting of factual circumstances. The applicant needs to submit as soon as possible all elements in order to substantiate the application. It is up to Member States to cooperate with the applicant and to assess the relevant elements of the application. ${ }^{541}$ The elements to be submitted by the applicant refer, inter alia, to statements and documentation concerning the background, identity, travel route of the applicant and the grounds for submitting an asylum claim. Furthermore, the assessment must take into account, inter alia, 'all relevant facts as they relate to

539 European Commission, Press release, More responsibility in managing the refugee crisis: European Commission adopts 40 infringement decisions to make European Asylum System work, 23 September 2015.

540 Article 4(1) of the recast Qualification Directive. See Case C-473/16, F, 25 January 2018, Court of Justice of the European Union, ECLI:EU:C:2018:36.

541 Case C-277-/11, M.M. v Minister for Justice, Equality and Law Reform, Ireland, Attorney General, 22 November 2012, Court of Justice of the European Union, ECLI:EU:C:2012:744, para. 65. 
the country of origin at the time of taking a decision on the application' and also personal elements, gender and age. 542

The second stage concerns the legal examination of the claim for international protection. The competent authorities of the Member State examine whether international protection can be granted on the grounds of acts of persecution. ${ }^{543}$ There must be a connection between the reasons for persecution ${ }^{544}$ (race, religion, ${ }^{545}$ nationality, political opinion or membership of a particular social group) and the acts of persecution. ${ }^{546}$ It is further important to note that Member States must consider 'gender related aspects, including gender identity, for the purposes of defining membership of a particular social group. ${ }^{547}$

An application for international protection may also be claimed on events that occurred since the applicant left the country of origin. ${ }^{548}$ As part of the assessment of persons applying for international protection, the Directive stipulates next to State persecution two other actors of persecution or serious harm: parties or organisations controlling the State and non-State actors.549 Traditionally, the State has been considered to be the entity that is able to provide protection. The recast Directive recognizes also non-state entities as actors of protection, ${ }^{550}$ which include 'parties or (international) organisations controlling the State or a substantial part of the territory of the State and provided they are willing and able to offer protection. ${ }^{551}$ In Salahadin Abdulla, the CJEU ac-

542 Article 4(3) of the recast Qualification Directive. See also credibility assessment and sexual orientation Joined Cases C-148/13 to C-150/13, A (C-148/13), B (C-149/13), C (C150/13) v Staatssecretaris van Veiligheid en Justitie, 2 December 2014, Court of Justice of the European Union, ECLI:EU:C:2014:2406.

543 Article 9 of the recast Qualification Directive.

544 Article 10 of the recast Qualification Directive.

545 See Case C-56/17, Bahtiyar Fathi v Predsedatel na Darzhavna agentsia za bezhantsite, 4 October 2018, Court of Justice of the European Union, ECLI:EU:C:2018:803; Cases C71/11 and C-99/11 Bundesrepublik Deutschland $v$ Y and Z, 5 September 2012, Court of Justice of the European Union, ECLI:EU:C:2012:518.

546 Article 9(3) of the recast Qualification Directive.

547 Case C-199/12 to C-2012/12, X (C-199/12), Y (C200/12) and Z v Minister voor Immigratie en Asiel (C-201/12), 7 November 2013, Court of Justice of the European Union, ECLI:EU:C:2013:720. See also Jansen, S., Pride or Shame? Assessing LGBTI asylum applications in the Netherlands following the XYZ and ABCjudgments, 2019.

548 Refugees sur place in Article 5 (1)(2) of the recast Qualification Directive.

549 Article 6 of the recast Qualification Directive.

550 Article 7 of the recast Qualification Directive. See comments Dörig, H., Asylum Qualification Directive 2011/95/EU, EU in Kay Hailbronner and Daniel Thym (eds.), EU Immigration and Asylum Law, Commentary, 2nd edition (C.H. BECK/Hart/Nomos, 2016), pp. 1152-1157.

551 See O'Sullivan, M., Acting the Part: Can Non-State Entities Provide Protection Under International Refugee Law? International Journal of Refugee Law, Vol. 24, Issue 1, 2012, pp. 85-110. 
knowledged that protection could be provided by the presence of an international organization in the territory of a third country. 552 In addition, protection against persecution or harm must be 'effective and of a non-temporary nature' and that the protection provided is sufficient when the actors of protection 'take reasonable steps' to prevent the persecution or harm. ${ }^{553}$ Applications for international protection may be rejected where it is established that an applicant has no well-founded fear of being persecuted or is not at real risk of suffering serious harm in a particular part of his country of origin and the applicant has access to protection against persecution or serious harm in that specific part of the country of origin. ${ }^{554}$ The applicant should, however, be able to 'safely and legally travel' to that part of the country and can reasonably be expected to settle there.' 555

\subsubsection{Cessation or exclusion from refugee status}

A third country national may also cease to be a refugee ${ }^{556}$ or excluded from being a refugee. ${ }^{557}$ Palestinian refugees who are receiving protection or assistance from the United Nations Relief and Works Agency for Palestine Refugees in the Near East (UNWRA) fall under the exclusion clause of Article 1D of the Refugee Convention. ${ }^{558}$ It follows from Bolbol559 that only Palestinians who

552 Joined Cases C-175/08, C-176/08, C-178/08 and C-179/08, Aydin Salahadin Abdulla (C175/08), Kamil Hasan (C-176/08), Ahmed Adem, Hamrin Mosa Rashi (C-178/08), Dler Jamal (C-179/08) v Bundesrepublik Deutschland, 2 March 2010, Court of Justice of the European Union, ECLI:EU:C:2010:105, para. 75.

553 Article 7(2) of the recast Qualification Directive. See also Yabasun, D., The revised Asylum Qualification Directive: a first step towards the completion of a common European asylum system by 2012? Journaal Vreemdelingenrecht, No. 1, 2012, p. 11.

554 Article 8 of the recast Qualification Directive. See UNHCR, Guidelines on International Protection No. 4: "Internal Flight or Relocation Alternative" Within the Context of Article 1A(2) of the 1951 Convention and/or 1967 Protocol Relating to the Status of Refugees, 23 July 2003, HCR/GIP/03/04.

555 Salah Sheekh $v$ the Netherlands, Application no. 1948/04, European Court of Human Rights, 25 May 2007.

556 Article 11 of the recast Qualification Directive. On the interpretation of Article $11(1)(\mathrm{e})(\mathrm{f})$ and (2) related to the 'circumstance to cease' see Joined Cases C-175/08, C176/08, C-178/08 and C-179/08, Aydin Salahadin Abdulla (C-175/08), Kamil Hasan (C176/08), Ahmed Adem, Hamrin Mosa Rashi (C-178/08), Dler Jamal (C-179/08) v Bundesrepublik Deutschland, 2 March 2010, Court of Justice of the European Union, ECLI:EU:C:2010:105.

557 Article 12 of the recast Qualification Directive.

558 UNHCR, Revised Note on the Applicability of Article 1D of the 1951 Convention relating to the Status of Refugees to Palestinian Refugees, October 2009. See also Case C-585/16, Serin Alheto $v$ Zamestnik-predsedatel na Darzhavna agentsia za bezhantsite, 25 July 2018, Court of Justice of the European Union, ECLI:EU:C:2018:584. 
had actually availed himself or herself of that protection or assistance of the UNWRA would be excluded from refugee status. ${ }^{560}$ However, the second subparagraph of Article 12(1) of the recast Qualification Directive stipulates 'when such protection or assistance has ceased for any reason, without the position of such persons being definitely settled (...) these persons shall ipso facto be entitled to the benefits of this Directive.' The notion 'for any reason' involves the condition in which the applicant 'who, after actually availing himself of such protection or assistance, ceases to receive it for a reason beyond his control and independent of his volition.' The applicant may qualify as a refugee where the competent national authorities determine that the applicant was forced to leave the area that was under the mandate of the UN agency for the reasons of personal safety and it was impossible for that UN agency to ensure the living conditions for the applicant as assigned by the mission. ${ }^{561}$

Third country nationals are also excluded from refugee status if there are serious grounds to assume that the person has committed 'criminal acts against humanity' or a 'serious non-political crime outside the country of refuge and prior to his admission as a refugee' or the person has been 'guilty of acts contrary to the purposes and principles of the United Nations'. The CJEU has held in $B$ and $D^{562}$ that 'the mere fact that a person is a member of a terrorist organization cannot automatically entail that he or she is excluded from refugee status pursuant to Article 12(2)(b) and (c) of the recast Qualification Directive. Firstly, the competent authority must assess the specific facts on a case-by-case basis and consider whether the applicant was individually responsible for carrying out terrorist acts while he or she was a member of that organization. ${ }^{563}$ Where applicants fulfil the conditions for qualifying as a refugee, Member States are required to grant refugee status. ${ }^{564}$ The recast Directive also allows Member

559 Case C-31/09, Nawras Bolbol v Bevándorlási és Állampolgársági Hivatal, 17 June 2010, Court of Justice of the European Union, ECLI:EU:C:2010:351.

560 UNHCR, Note on UNHCR's Interpretation of Article 1D of the 1951 Convention relating to the Status of Refugees and Article 12(1)(a) of the EU Qualification Directive in the context of Palestinian refugees seeking international protection, May 2013, p. 4.

561 Case C-364/11, Mostafa Abed El Karem El Kott, Chadi Amin A Radi, Hazem Kamel Ismail v Bevándorlási és Állampolgársági Hivatal, 19 December 2012, Court of Justice of the European Union, ECLI:EU:C:2012:826.

562 Joined Cases C $\square 57 / 09$ and C $\square 101 / 09$, Bundesrepublik Deutschland v B (C $\square 57 / 09$ ), D (C $\square$ 101/09), 9 November 2010, Court of Justice of the European Union, ECLI:EU:C:2010:661, para. 99.

563 Yabasun, D., The revised Asylum Qualification Directive: a first step towards the completion of a common European asylum system by 2012? Journaal Vreemdelingenrecht, No. 1, 2012, p. 13.

564 Article 13 of the recast Qualification Directive. 
States to revoke or end or refuse to renew a refugee status. ${ }^{565}$

\subsubsection{Subsidiary protection status}

A significant part of the recast Qualification Directive is dedicated to the status of subsidiary protection. The incorporation of the legal status of beneficiaries of subsidiary protection into the former 2004 Qualification Directive was an important step, since most Member States did not grant legal status to persons who did not qualify for refugee status but were able to remain on human rights grounds. ${ }^{566}$ The importance of including legal protection status for persons falling outside the refugee status but who are in need of some other form of international protection had already emerged during the Austrian Presidency in 1998. ${ }^{567}$ The definition of subsidiary protection is stipulated in Article 2(f) of the recast Qualification Directive:

'person eligible for subsidiary protection' means a third- country national or a stateless person who does not qualify as a refugee but in respect of whom substantial grounds have been shown for believing that the person concerned, if returned to his or her country of origin, or in the case of a stateless person, to his or her country of former habitual residence, would face a real risk of suffering serious harm as defined in Article 15, and to whom Article 17(1) and (2) does not apply, and is unable, or, owing to such risk, unwilling to avail himself or herself of the protection of that country'.

Article 2(f) must be read in conjunction with Article 15 of the recast Qualification Directive in order to understand what is meant by subsidiary protection. Article 15 stipulates what 'serious harm' constitutes, namely (a) 'death penalty or 'execution'; or (b) 'torture' or 'inhuman or degrading treatment or punishment of an applicant in the country of origin'; or (c) 'serious and individual threat to a civilian's life or person by reason of indiscriminate violence in situations of international or internal armed conflict'. Article 15(b) reflects the wording of Article 3 of the ECHR. 568

One of the main contentious provisions in the recast Qualification Directive remains Article 15(c). The CJEU has been referred to give clarity on the rela-

565 Article 14 of the recast Qualification Directive.

566 Storey, H., EU Refugee Qualification Directive: A Brave New World? International Journal of Refugee Law, 2008, p. 6.

567 See McAdam, J., The European Union Qualification Directive: The Creation of a Subsidiary Protection Regime, International Journal of Refugee Law, Volume 17, Issue 3, 2005, p. 463.

568 See analysis on the relation between Article 15(b) and Article 3 of the ECHR, Tiedemann, P., Subsidiary protection and the function of Article 15(c) of the Qualification Directive, Refugee Survey Quarterly, 2012, Vol. 31, No.1, pp. 124-129. 
tion between 'serious and individual threat' and 'indiscriminate violence'569 as well as the meaning of 'international or internal armed conflict' 570 in the context of Article 15(c). ${ }^{571} \mathrm{~A}$ serious shortcoming remains the implementation and practice of Article 15(c) of the recast Qualification Directive, which differ widely between Member States. To give an example, whereas eleven Member States considered parts of Afghanistan a 15(c) situation, two other Member States assessed the whole territory of Afghanistan as a 15(c) situation..$^{572}$

Furthermore, Article 16 and Article 17 provide the cessation and exclusion clauses with regard to subsidiary protection. It is important to note that the scope for exclusion from subsidiary protection status in Article 17(1)(b) is broader than the ground for exclusion from refugee status enshrined in the Refugee Convention. ${ }^{573}$

\subsubsection{Non-refoulement}

An indispensable provision derived from the Refugee Convention and enshrined in the recast Qualification Directive is the principle of non-refoulement in Article 21 of the Directive. Provided that it is not prohibited by international obligations Member States are allowed to refoule a refugee where there are reasonable grounds for considering that the person is a danger to the security or the community of the Member State or the person has been convicted of a serious crime.

\subsubsection{Rights and benefits beneficiaries of international protection}

Once asylum applicants are granted international protection status, they are entitled to certain rights and benefits under the recast Directive. The CJEU has held in Alo and Osso that beneficiaries of subsidiary protection should receive the same rights and benefits as those granted to persons holding refugee status, 'with the exception of derogations which are necessary and objectively justified. 574 Additionally, with regard to vulnerable persons with special needs,

569 Case C-465/07, Meki Elgafaji and Noor Elgafaji v Staatssecretaris van Justitie, 17 February 2009, Court of Justice of the European Union, ECLI:EU:C:2009:94.

570 Case C-285/12, Aboubacar Diakité v Commissaire général aux réfugiés et aux apatrides, 30 January 2014, Court of Justice of the European Union, ECLI:EU:C:2014:39.

571 See Velluti, S., Reforming the Common European Asylum System - Legislative Developments and Judicial Activism of the European Courts, Springer, 2014, p. 10.

572 EASO, The Implementation of Article 15(c) QD in EU Member States, EASO Practical Guided Series, July 2015, p. 8.

573 Case C-369/17, Shajin Ahmedv Bevándorlási és Menekültügyi Hivatal, 13 September 2018, Court of Justice of the European Union, ECLI:EU:C:2018:713, para. 46.

574 Case C-443/14 and C-444/14, Kreis Warendorf v Ibrahim Alo and Amira Osso v Region Hannover, 1 March 2016, Court of Justice of the European Union, ECLI:EU:C:2016:127, 
Member States have to take into account of their specific situation when they implement the benefits of international protection..$^{575}$

Next to the aforementioned prohibition of refoulement in Article 21 and to be informed about their rights and benefits, ${ }^{576}$ Member States have to ensure family unity. ${ }^{577}$ The concept of family unity is limited to families that have formed before arriving in the host State. According to Article 2(j) family members include: spouses; or unmarried partner in a stable relationship recognized by the law of the host State; unmarried minor children whether born in or out of wedlock; and parents of the refugee or subsidiary protection status holder.

With regard to the duration of residence permits, applicants who have been granted refugee status should receive a residence permit that is valid for at least 'three years' whereas beneficiaries of subsidiary protection status should receive a residence permit which is valid for at least 'one year'. ${ }^{578}$ Refugee status holders should acquire travel documents in the form specified in the Schedule to the Geneva Convention, for the purpose of travel outside their territory'. Beneficiaries of subsidiary protection will receive documents for travel if they are unable to obtain a national passport. ${ }^{579}$

The former 2004 Qualification Directive made a differentiation between refugee status holders and beneficiaries of subsidiary protection with regard to access to employment. Persons with the refugee status were directly able to engage in employed activities. Where it concerned beneficiaries of subsidiary protection, Member States could consider 'the situation of the labour market'. ${ }^{580}$ The current Directive determines that Member States should authorize beneficiaries of international protection to participate in employed activities. ${ }^{581}$

An important right for refugee status holders and beneficiaries of subsidiary protection is access to social assistance. ${ }^{582}$ However, by way of derogation to the general rule, Article 29(2) determines that Member States may limit social assistance granted to beneficiaries of subsidiary protection status to 'core benefits'. The question that follows is what are 'core benefits'? According to Recital 45 of the Directive it should be understood as 'covering at least minimum income support, assistance in the case of illness, or pregnancy, and parental assistance, in so far as those benefits are granted to nationals under national law.'

para. 32.

575 Article 20(3) and 20(4) of the recast Qualification Directive.

576 Article 22 of the recast Qualification Directive.

577 Article 23(1) of the recast Qualification Directive.

578 Article 24 of the recast Qualification Directive.

579 Article 25 of the recast Qualification Directive.

580 Article 26(3) of Qualification Directive 2004/83/EC.

581 Article 26(1) of the recast Qualification Directive.

582 See Case C-713/17, Ahmad Shah Ayubi v Bezirkshauptmannschaft Linz-Land, 21 November 2018, Court of Justice of the European Union, ECLI:EU:C:2018:929. 
Hence, the Directive allows Member States to limit social assistance to beneficiaries of subsidiary protection in comparison to refugee status holders.

As regards health care, refugee status holders and beneficiaries of subsidiary protection have equal access. ${ }^{583}$ Beneficiaries of international protection who have special needs such as 'pregnant women, disabled people, persons who have undergone torture, rape or other serious forms of psychological, physical or sexual violence or minors who have been victims of any form of abuse, neglect, exploitation, torture, cruel, inhuman and degrading treatment or who have suffered from armed conflict' have access to 'adequate' healthcare. ${ }^{584}$ Finally, the recast Directive further includes essential rights to unaccompanied minors. ${ }^{585}$ Beneficiaries of international protection have access to appropriate accommodation ${ }^{586}$ and the right to freely move within the territory. ${ }^{587} \mathrm{An}$ important aspect is the issue of integration. Refugee status holders and beneficiaries of subsidiary protection must have access to integration programmes. ${ }^{588} \mathrm{It}$ is important to note that the previous Directive allowed Member States to grant beneficiaries of subsidiary protection access to integration facilities 'where it is considered appropriate'. 589

\subsection{Commission proposal Qualification Regulation}

The proposal of the Commission to reform the Qualification Directive and to replace the current instrument with a Regulation was issued on 13 July 2016. The legal basis of the proposal is Article 78(2)(a)(b) TFEU. The ordinary legislative procedure is applicable.

The proposal is part of a reform package, which aims to structurally reform the CEAS. The proposal if adopted will have significant consequences for beneficiaries of international protection. According to the Commission, the fact that recognition rates and the level in rights granted to one of the protection statuses significantly differ between Member States, demonstrates the necessity of a more harmonized system. Moreover, such differences may motivate applicants to submit an asylum application in Member States where the level of rights and the chances to be granted protection are perceived to be higher than in the

\footnotetext{
583 See on social welfare and health care benefits (Articles 28 and 29 of the Qualification Directive 2004/83/EC) Case C $\square$ 542/13, Mohamed M'Bodj v État belge, 18 December 2014, Court of Justice of the European Union, ECLI:EU:C:2014:2452.

584 Article 30(2) of the recast Qualification Directive.

585 Article 31 of the recast Qualification Directive. For more details on the rights of unaccompanied minors see chapter 6 .

586 Article 32 of the recast Qualification Directive.

587 Article 33 of the recast Qualification Directive.

588 Article 34 of the recast Qualification Directive.

589 Article 33(2) of Qualification Directive 2004/83/EC.
} 
Member State that is responsible for examining the application on the basis of the Dublin Regulation.

There are several changes proposed by the Commission. This section will discuss three key features: 590 First, the Commission introduces a mandatory and regular re-assessment of the protection status granted to refugees and beneficiaries of international protection when there is 'a significant relevant change in the country of origin' and when residence permits of protection holders have to be renewed. The Commission proposes to grant refugee status holders a temporary residence permit of three years, which can be extended with another three years. Subsequently, following the first renewal of the residence permit, which is after the first three years, Member States have to review whether the refugee status holder is still in need of protection.

Whereas subsidiary protection holders receive a temporary residence permit of one year, which can be extended by another two years and an additional two years. For this specific status of protection holders, Member States have to review after the first and the second time of renewal of the residence permit (this is after one year and another review after two years) whether beneficiaries of subsidiary protection are still in need of protection. ${ }^{591}$ These rules not only explicitly reflect the temporary nature of the protection due to the obligatory reviews of the protection status that should be carried out by Member States, but it also represents a further disparity between the two protection statuses in terms of the duration of residence permits.

The second key important element of this proposal concerns the change to the Long-Term Residents Directive 2003/109/EC.592 Currently, the Directive grants third country nationals, including beneficiaries of international protection, who have resided lawfully for five years in the Member State concerned, the status of long-term resident. In order to prevent secondary movements within the EU, the Commission is proposing that the five years period should be recounted for every time the beneficiary of international protection is stay-

590 See Yabasun, D., Hervorming Europees asielbeleid: Commissievoorstel Kwalificatieverordening, Journaal Vreemdelingenrecht, no. 3, 2016.

591 European Commission, Proposal for a Regulation of the European Parliament and of the Council on standards for the qualification of third-country nationals or stateless persons as beneficiaries of international protection, for a uniform status for refugees or for persons eligible for subsidiary protection and for the content of the protection granted and amending Council Directive 2003/109/EC of 25 November 2003 concerning the status of third-country nationals who are long-term residents, Brussels, 13.7.2016, $\operatorname{COM}(2016) 466$ final 2016/0223 (COD), pp. 14-16.

592 Council Directive 2003/109/EC of 25 November 2003 concerning third-country nationals who are long-term residents, OJ L 16/44, 23.1.2004. 
ing in a Member State other than the one that has granted him international protection. 593

The third key element that is interesting in this proposal is that the access to certain social assistance may be made conditional on the effective participation of the beneficiary of international protection in integration measures. ${ }^{594}$ In addition, Member States are allowed to oblige beneficiaries of international protection to participate in integration measures. ${ }^{595}$

\subsection{The recast Reception Conditions Directive 2013/33/EU}

The recast Reception Conditions Directive 2013/33/EU (recast Reception Conditions Directive) $)^{596}$ applies to 'third-country nationals and stateless persons who make an application for international protection on the territory, including at the border, in the territorial waters or in the transit zones of a Member State, as long as they are allowed to remain in the territory as applicants, as well as to family members, if they are covered by such application for international protection according to national law.'597 The recast Reception Conditions Directive has replaced the Reception Conditions Directive 2003/9/EC.

The adopted recast Reception Conditions Directive was published in the Official Journal of the European Union on 26 June 2013. In accordance with the relevant Protocols, Denmark, Ireland and the UK are not taking part in this Directive. The UK is, however, still bound by the 2003 Reception Conditions Directive. The Member States had to fully implement the recast Reception Conditions Directive into their domestic system by 20 July 2015 . With regard to the

593 European Commission, Proposal for a Regulation of the European Parliament and of the Council on standards for the qualification of third-country nationals or stateless persons as beneficiaries of international protection, for a uniform status for refugees or for persons eligible for subsidiary protection and for the content of the protection granted and amending Council Directive 2003/109/EC of 25 November 2003 concerning the status of third-country nationals who are long-term residents, Brussels, 13.7.2016, $\operatorname{COM}(2016) 466$ final 2016/0223 (COD), p. 15.

594 European Commission, Proposal for a Regulation of the European Parliament and of the Council on standards for the qualification of third-country nationals or stateless persons as beneficiaries of international protection, for a uniform status for refugees or for persons eligible for subsidiary protection and for the content of the protection granted and amending Council Directive 2003/109/EC of 25 November 2003 concerning the status of third-country nationals who are long-term residents, Brussels, 13.7.2016, $\operatorname{COM}(2016) 466$ final 2016/0223 (COD), p. 5 and Article 34(1) the proposal.

595 Article 38(2) of the proposal.

596 Directive 2013/33/EU of the European Parliament and of the Council of 26 June 2013 laying down standards for the reception of applicants for international protection (recast), OJ L 180/96.

597 Article 3 of the recast Reception Conditions Directive. 
transposition of the recast Reception Conditions Directive, the Commission has sent nineteen Member States a 'letter of formal notice'. ${ }^{598}$

The recast Reception Conditions Directive provides standards for the reception of asylum applicants in Member States, including the conditions of detention. ${ }^{599}$ The recast Directive also stipulates rules as to how Member States should deal with the identification of vulnerable asylum applicants. 600 The objective of the recast Directive is to further harmonize the domestic legislation of the Member States regarding the conditions of reception for applicants of international protection. The Commission initiated its first recast proposal in 2008. ${ }^{601}$ The 2008 Commission proposal aimed to guarantee higher standards of reception conditions for asylum applicants. An additional objective was to reduce the disparities of reception conditions between Member States, which causes secondary movements of asylum applicants. Due to the difficult negotiations in the Council, mainly under the auspices of the Czech and the Swedish Presidencies, no agreement was reached on the text in the Council. Several Member States feared that the adjustments would lead to high financial implications and administrative burdens for the national authorities. Hence, the Commission submitted in June 2011 a modified proposal. The amended proposal provided further clarification and more simplified reception standards, which would facilitate the implementation in the national asylum systems. ${ }^{602}$

\subsubsection{General reception conditions}

Applicants should be informed within fifteen days about the reception conditions in terms benefits and obligations. Information should be in writing in a language that the applicant understands or 'may reasonably be supposed to understand'. ${ }^{603}$ In addition, within three days applicants should receive documen-

598 European Commission, Press release, More responsibility in managing the refugee crisis: European Commission adopts 40 infringement decisions to make European Asylum System work, 23 September 2015.

599 Article 1 of the recast Reception Conditions Directive. See for a more detailed analysis on the reception of asylum applicants from an international law perspective, Slingenberg, L., The reception of asylum seekers under international law - Between sovereignty and Equality, Hart Publishing, 2014.

600 See chapter 6 on vulnerable asylum applicants.

601 Proposal for a Directive of the European Parliament and of the Council laying down minimum standards for the reception of asylum seekers (recast), Brussels, 3.12.2008, $\operatorname{COM}(2008) 815$ final, 2008/0244 (COD).

602 Amended proposal for a Directive of the European Parliament and of the Council laying down standards for the reception of asylum seekers (recast), Brussels, 1.6.2011, $\operatorname{COM}(2011) 320$ final, 2008/0244 (COD), pp. 2-9.

603 Article 5 of the recast Reception Conditions Directive. 
tation certifying a person's status as an applicant for international protection. ${ }^{604}$

As soon as applicants make an application for international protection, Member States are required to provide for housing, food and clothing. ${ }^{605} \mathrm{Re}-$ ception conditions also apply to asylum applicants to whom the Dublin procedure applies. ${ }^{606}$ The material reception conditions should ensure 'an adequate standard of living', 607 including for the specific situation of vulnerable applicants and for applicants in detention. The CJEU has held in Saciri that 'Member States are required to adjust the reception conditions to the situation of persons having specific needs', ${ }^{608}$ Asylum applicants may be provided with different forms of housing such as premises used at the border or transit zones, accommodation centres, private houses, flats, hotels or other premises that is suitable for the housing of applicants. ${ }^{609}$ Where families are provided with housing, Member States should take appropriate measures to uphold the family unity. 610 Where applicants abandon the reception centre without authorization or fail to comply with the obligations, their material reception conditions may be withdrawn. 611

Applicants of international protection have access to the labour market. The recast Reception Conditions Directive has decreased the waiting period for applicants to have access to the labour market from twelve to nine months, which starts from the moment the application for international protection has been made. ${ }^{612}$ Member States may, however, determine the conditions for the right to work. ${ }^{613}$

\subsubsection{Detention}

Former 2003 Reception Conditions Directive enshrined a contentious clause stipulating that Member States may confine (detain) an applicant to a particular place for reasons of public order. This current controversial provision has been

604 Article 6 of the recast Reception Conditions Directive.

605 Article 17(1) of the recast Reception Conditions Directive.

606 Case C-179/11, Cimade, Groupe d'information et de soutien des immigrés (GISTI) v Ministre de l'Intérieur, de l'Outre-mer, des Collectivités territoriales et de l'Immigration, 27 September 2012, Court of Justice of the European Union, ECLI:EU:C:2012:594.

607 Article 17(2) of the recast Reception Conditions Directive.

608 Case C-79/13, Federaal agentschap voor de opvang van asielzoekers v Selver Saciri and Others, 27 February 2014, Court of Justice of the European Union, ECLI:EU:C:2014:103, para. 41.

609 Article 18 of the recast Reception Conditions Directive.

610 Article 12 of the recast Reception Conditions Directive.

611 Article 20(1)(a) of the recast Reception Conditions Directive.

612 Current situation of Member States in EMN Ad-Hoc Query on Ad-Hoc Query on access of international protection applicants to the labour market, 19 July 2016.

613 Article 15 of the recast Reception Conditions Directive. 
removed from the Directive. ${ }^{614}$ Most Member States detained vulnerable asylum applicants such as minors and unaccompanied minors. The detention of asylum applicants with special needs, such as minors and unaccompanied minors were allowed by some of the Member States. The report raised serious questions with regard to whether the special needs of vulnerable asylum applicants in detention facilities could be met. Although a few Member States have indeed provided for facilities that are necessary to meet the special needs of vulnerable asylum applicants, it does not cover all categories of vulnerable persons with special needs. ${ }^{615}$ The Commission underlined that vulnerable asylum applicants in general should 'only be detained as a last resort, in duly justified cases.' With regard to minors and unaccompanied minors, the best interests of the child must be assessed against their detention. Specifically, with regard to the situation of unaccompanied minors, the Commission emphasized that Article 19(2) 'clearly' prohibits the detention of unaccompanied minors. ${ }^{616}$

The proposed detention grounds and conditions of detention were one of the main points of intense discussions during the recast negotiations between the European co-legislators.617 The current rules only allow detaining asylum applicants on six grounds. ${ }^{618}$ Member States are required to examine whether less coercive alternatives to detention are available. Where Member States do detain an applicant, they have to ensure certain guarantees. ${ }^{619}$ The Directive does not specify the maximum time of detention. Applicants should be detained 'only for as short a period as possible' and they may be detained only for the

614 Former Article 7(3) of the recast Reception Conditions Directive.

615 European Commission, Report from the Commission to the Council and to the European Parliament on the application of Directive 2003/9/EC of 27 January 2003, laying down minimum standards for the reception of asylum seekers, Brussels 26 November 2007, COM(2007) 745 final, para. 3.5., pp. 9-11.

616 European Commission, Report from the Commission to the Council and to the European Parliament on the application of Directive 2003/9/EC of 27 January 2003 laying down minimum standards for the reception of asylum seekers, Brussels, 26.11.2007, $\operatorname{COM}(2007) 745$ final, pp. 9-10.

617 For a more detailed explanation of the negotiations on the recast Reception Conditions Directive see Tsourdi, E., The Impact of the Negotiations on the recast Reception Conditions Directive in The recast Reception Conditions Directive: Central Themes, Problem Issues, and Implementation in Selected Member States, Minderhoud, P, and Zwaan, K. (eds.), Wolf Legal Publishers, 2016.

618 Article 8(3) of the recast Reception Conditions Directive. See Case C-18/16, K. v Staatssecretaris van Veiligheid en Justitie, 14 September 2017, Court of Justice of the European Union, ECLI:EU:C:2017:680; Case C-601/15 PPU, J.N. v Staatssecretaris voor Veiligheid en Justitie, 15 February 2016, Court of Justice of the European Union, ECLI:EU:C:2016:84.

619 Article 9 of the recast Reception Conditions Directive. 
reasons enshrined in the Directive. ${ }^{620}$

Lastly, the recast Directive enshrines important safeguards to different types of vulnerable asylum applicants in detention. ${ }^{621}$ The general rule is that Member States are required to regularly monitor the specific situation and the health of vulnerable applicants and provide them with adequate support. Vulnerable asylum applicants should be of primary concern to Member States. ${ }^{622}$

\subsection{Commission proposal to recast the Reception Conditions Direc- tive}

Unlike the proposals to replace the recast Qualification Directive and the recast Asylum Procedures Directive for a Regulation, the Commission has chosen to recast again the Reception Conditions Directive. The Commission is of the opinion that a full harmonization of the reception conditions is not feasible given the social and economic divergences in the Member States. ${ }^{623}$ The legal basis for the proposal is Article 78(2)(f) TFEU and, as for the other CEAS instruments, subject to the ordinary legislative procedure.

The objectives of the proposal are threefold: first, to further harmonize EU reception standards in several areas; second, to minimize the secondary movements of asylum applicants between Member States; third, to strengthen the integration of asylum applicants. The proposal includes a number of changes to the current instrument on reception conditions. A few of the key provisions will be highlighted. As to the first objective of the Commission 'to further harmonize EU reception standards', the Commission has proposed several measures: the aim is to guarantee each asylum applicant, as long as they are permitted to stay on the territory of the Member State, a dignified standard of living, including health care. The new EU Asylum Agency will also play a role in the monitoring and assessment of the reception conditions in Member States. In addition, Member States should develop contingency plans in order to guarantee adequate reception capacities in times of disproportionate arrivals of asylum applicants.

In order to prevent an applicant leaving the territory where he or she is required to be present and follow the asylum procedure of the Member State concerned, or to prevent the applicant from absconding, a number of coercive measures are proposed. Member States may 'assign an applicant to residence in

\footnotetext{
620 Article 9(1) of the recast Reception Conditions Directive.

621 Article 11 of the recast Reception Conditions Directive.

622 Article 11(1) of the recast Reception Conditions Directive.

623 European Commission, Proposal for a Directive of the European Parliament and of the Council laying down standards for the reception of applicants for international protection (recast), Brussels, 13.7.2016, COM(2016) 465 final, 2016/0222 (COD), p. 6.
} 
a specific place' (accommodation centre, private house, flat, hotel or other suitable forms of housing) where the applicant has not submitted an asylum application in the first Member State of entry; or where the applicant has absconded from the Member State where he is required to be present; or where the applicant has been sent back to the Member State where he is required to be present after having absconded to another Member State. All decisions must however take into account the individual circumstances of the applicant and any specific reception needs the applicant may have. Furthermore, an additional basis for detention has been included in the proposal in the following circumstances: where the applicant has been assigned a specific place of residence but has not respected this duty and where there is a high risk that the applicant may abscond. Regrettably, the detention of applicants with special needs is still allowed under the new proposed Directive.

The final aspect of the proposal focuses on strengthening the access to the labour market. The Commission aims to increase the integration chances of asylum applicants with these new measures. The proposal stipulates reducing the current time-limit period to access the labour market from nine months to six months from the moment the asylum application has been lodged. Moreover, asylum applicants should be guaranteed the same rights as nationals once they have entered the labour market. In addition, asylum applicants should, inter alia, be treated equally as other nationals with regard to social security.

A significant aspect of the proposal is the introduction of new rules with regard to the vulnerable persons and applicants with special reception needs, which will be discussed in more detail in chapter 6 .

\subsection{The recast Asylum Procedures Directive 2013/32/EU}

The recast Asylum Procedures Directive 2013/32/EU624 (recast Asylum Procedures Directive) establishes common standards regulating the procedures for making decisions on international protection in compliance with the recast Qualification Directive.625 The recast Asylum Procedures Directive applies to all international protection applications made within the territory of Member States, including at the border, transit zones and territorial waters, except to requests for diplomatic or territorial asylum. ${ }^{626}$

The recast Asylum Procedures Directive replaced the Asylum Procedures

${ }^{624}$ Directive 2013/32/EU of the European Parliament and of the Council of 26 June 2013 on common procedures for granting and withdrawing international protection (recast) OJ L $180 / 60$.

625 Article 1 of the recast Asylum Procedures Directive.

626 Article 3 of the recast Asylum Procedures Directive. 
Directive 2005/85/EC.627 The 2005 Asylum Procedures Directive has been considered a weak instrument in terms of fair and efficient asylum procedures. According to the Commission, the provisions in the 2005 Asylum Procedures Directive were insufficient and vague which resulted in unfair and inadequate asylum procedures. The 2010 Commission evaluation report on the application of the 2005 Asylum Procedures Directive acknowledged that the many derogation clauses are a serious concern, and this causes the wide divergence of the implementation in Member States. 628

The Commission presented on 21 October 2009 a proposal to recast the Asylum Procedures Directive. ${ }^{629}$ The European Parliament approved the text at first reading. However, the Council could not reach an agreement on the text. Hence, the Commission submitted a modified proposal on 1 June 2011. The Commission aimed to provide more clarification and simplification of the procedural rules in order to make it easier to implement the standards within the domestic asylum systems. ${ }^{630}$ The 2009 Stockholm Programme underlined the importance of establishing common procedural standards in the EU:

'While CEAS should be based on high protection standards, due regard should also be given to fair and effective procedures capable of preventing abuse. It is crucial that individuals, regardless of the Member State in which their application for asylum is lodged, are offered an equivalent level of treatment with regard to reception conditions, and the same level with regard to procedural arrangements and status determination. The objective should be that similar cases should be treated alike and result in the same outcome. ${ }^{631}$

The adopted recast Asylum Procedures Directive was published on 29 June 2013 and was applicable as from 20 July 2015. The UK, Ireland and Denmark

627 Council Directive 2005/85/EC of 1 December 2005 on minimum standards on procedures in Member States for granting and withdrawing refugee status, OJ 2005, L 326/18.

628 European Commission, Report from the Commission to the European Parliament and the Council on the application of Directive 2005/85/EC of 1 December 2005 on minimum standards on procedures in Member States for granting and withdrawing refugee status, Brussels, 8 September 2010, COM(2010) 465 final, p. 15. See also UNHCR, Improving Asylum Procedures: Comparative Analysis and Recommendations for Law and Practice - Key Findings and Recommendations, March 2010.

${ }^{629}$ Proposal for Directive of the European Parliament and of the Council on minimum standards on procedures in Member States for granting and withdrawing international protection (Recast), Brussels, 21.10.2009, COM(2009) 554 final, 2009/0165 (COD).

630 Amended proposal for a Directive of the European Parliament and of the Council on common procedures for granting and withdrawing international protection status (Recast), Brussels 1 June 2011, COM(2011) 319 final, 2009/0165 (COD), pp. 1-9.

631 The Stockholm Programme - An Open and Secure Europe Serving and Protecting the Citizen, OJ C 115/1, 4.5.2010, para. 6.2. 
do not take part in the recast Asylum Procedures Directive. The UK and Ireland remain bound by the Asylum Procedures Directive 2005/85/EC. Denmark is not bound by the recast Asylum Procedures Directive as it is not taking part to the adoption and application of the 2005 Asylum Procedures Directive.

\subsubsection{Basic procedural safeguards}

Member States are required to designate for all asylum procedures 'an appropriate determining authority' that is responsible for examining the applications. ${ }^{632}$ The determining authorities must receive relevant training. ${ }^{633}$

Basic principles and guarantees are laid down in Chapter II. Member States may adopt more favourable provisions as long as they do not conflict with this Directive. ${ }^{634}$ An important procedural guarantee enshrined in the Directive is access to the asylum procedure for asylum applicants. Registration of applications for international protection should take place no later than three working days. Member States are required to make sure that the person who made an application for international protection has the possibility 'to effectively lodge' it as soon as possible. 635 The standard rule is that adults with legal capacity have the right to make an application for international protection. However, Member States may provide that an application may be made on behalf of his dependents. ${ }^{636}$ Member States are under the duty to provide information on the possibilities of making an application for international protection to persons held in detention, border crossing points, transit zones and at external borders. 637

The right to remain in the Member State pending examination of the application for international protection is another important procedural guarantee. ${ }^{638}$ Member States are allowed to make two exceptions to this right. The first possibility is when the applicant has made a subsequent application. The second possibility is when there is an extradition to another Member State, a third country or to international criminal courts.

When Member States examine and decide on applications for international protection, they must take a number of requirements into account. First, Member States may not reject nor exclude an application from examination just because the application has not been made as soon as possible. ${ }^{639}$ Second, the de-

\footnotetext{
632 Article 4(1) of the recast Asylum Procedures Directive.

633 Article 4(3) of the recast Asylum Procedures Directive.

634 Article 5 of the recast Asylum Procedures Directive.

635 Article 6 of the recast Asylum Procedures Directive.

636 Article 7 of the recast Asylum Procedures Directive.

637 Article 8 of the recast Asylum Procedures Directive.

638 Article 9 of the recast Asylum Procedures Directive.

639 Article 10(1) of the recast Asylum Procedures Directive.
} 
termining authorities have to examine whether the applicant first qualifies as a refugee before deciding on the possibility whether the applicant may qualify as a beneficiary of subsidiary protection. ${ }^{640}$ Third, Member States must ensure that, inter alia, applications are examined and decisions are taken 'individually, objectively and impartially'. Decisions on applications should be issued in writing. ${ }^{641}$

Examination procedures at first instance are accompanied with guarantees for the applicants. For instance, applicants must, inter alia, be informed about the procedure and the result of the decision 'in a language which they understand or are reasonably supposed to understand' and to be assisted by an interpreter during an interview. 642 Applicants must co-operate with the competent authorities with the objective of establishing their identity and other relevant aspects referred to in Article 4(2) of the recast Qualification Directive. ${ }^{643}$

\subsubsection{Recording of personal interview}

The recast Asylum Procedures Directive also provides Member States with the opportunity to make recordings of the personal interview (audio or audiovisual). ${ }^{644}$ However, the majority of the Member States do not make use of this option. ${ }^{645}$

\subsubsection{Legal assistance and representation}

Legal representation is crucial for asylum applicants. On the request of the applicant, Member States must provide legal and procedural information in the first instance, which is free of charge. ${ }^{646}$ In appeals procedures, Member States are required, on request of the applicant, to guarantee free legal assistance and representation. ${ }^{647}$ However, Member States are allowed to reject the free legal assistance and representation if a court or tribunal or other competent authority finds that the appeal has 'no tangible prospect of success'. ${ }^{648}$ The recast Directive allows Member States to impose certain conditions upon the duty to ensure free legal and procedural information including legal assistance and

\footnotetext{
640 Article 10(2) of the recast Asylum Procedures Directive.

641 Article 11(1) of the recast Asylum Procedures Directive.

642 Article 12 of the recast Asylum Procedures Directive.

643 Article 13(1) of the recast Asylum Procedures Directive.

${ }^{644}$ Article 17(2) of the recast Asylum Procedures Directive.

645 EMN Ad-hoc query on using video-recordings as the evidence in the asylum procedures, 2014.

646 Article 19 of the recast Asylum Procedures Directive.

647 Article 20(1) of the recast Asylum Procedures Directive.

648 Article 20(3) of the recast Asylum Procedures Directive.
} 
representation. ${ }^{649}$ Applicants of international protection have the right, at their own cost, to seek legal assistance and representation of the applicant during all stages of the procedures. ${ }^{650}$ Lastly, legal advisers who represent applicants should have access to the information in the file of the applicant and to the detention facilities or attend during the interview of the applicant. ${ }^{651}$

\subsubsection{Medical examination}

A pertinent obligation for Member States is to arrange a medical examination where the determining authority deems it relevant. Medical reports can support the applicant's statements about past persecution. ${ }^{652}$

\subsubsection{Applicants in need of special procedural guarantees}

A highly important provision for vulnerable applicants is stipulated in Article 24. Member States are obliged to assess whether an applicant is in need of special procedural guarantees within a reasonable period of time after an application for international protection have been made. 653 The recast Directive provides certain applicants with special procedural guarantees. In other words, adequate support and sufficient time should be provided to these applicants in order to establish the conditions necessary to access the asylum procedure and for presenting the elements to substantiate their asylum claim. ${ }^{654}$

\subsubsection{Unaccompanied minors}

The Commission had identified significant discrepancies between Member States when it addressed procedural guarantees for unaccompanied minors in the former Asylum Procedures Directive. For instance, Member States differed significantly when it concerned the institutional arrangements, the authorities that worked with unaccompanied minors and also the role and the qualifications of the guardian varied. ${ }^{655}$ Therefore, the recast Directive enshrines important procedural safeguards with regard to this particularly vulnerable group. ${ }^{656}$

\footnotetext{
649 Article 21 of the recast Asylum Procedures Directive.

650 Article 22 of the recast Asylum Procedures Directive.

651 Article 23(1),(2), (3) of the recast Asylum Procedures Directive.

652 Article 18 of the recast Asylum Procedures Directive.

653 See chapter 6 for a more detailed analysis on applicants in need of special procedural guarantees.

654 Recital 29 of the recast Asylum Procedures Directive.

655 European Commission, Report from the Commission to the European Parliament and the Council on the application of Directive 2005/85/EC of 1 December 2005 on minimum standards on procedures in Member States for granting and withdrawing refugee status, Brussels, 8.9. 2010, COM(2010) 465 final, para. 5.1.6.

656 Article 25 of the recast Asylum Procedures Directive. Chapter 6 will examine in more de-
} 


\subsubsection{Detention}

With regard to detention under the recast Asylum Procedures Directive, the general principle applies, which stipulates that an applicant may not be held in detention just because the applicant applied for international protection. ${ }^{657}$ Where applicants are detained, there should be a possibility for a speedy judicial review of the lawfulness of the detention. .58

\subsubsection{Withdrawal of the asylum application}

The last part of Chapter II of the Directive lays down the reasons for allowing Member States to discontinue or reject the examination in case the applicant explicitly or implicitly withdraws or abandons the asylum application. ${ }^{659}$ An implicit withdrawal or abandonment of the asylum application is considered when the applicant has failed to respond to requests to provide information essential to the application or if the applicant does not appear for the interview. An application may also be considered withdrawn of abandoned where the applicant has absconded or has left the place of living without notifying the competent authorities within a reasonable time, or not complying with their reporting duties or other obligations to communicate. An applicant may demonstrate that this was due to circumstances beyond his control. ${ }^{660}$ Subject to certain conditions, Member States must allow applicants to request a re-opening of the case against decisions to discontinue the application. ${ }^{661}$

\subsubsection{The position of UNHCR in asylum procedures}

UNHCR has several prerogatives in European asylum procedures. They are allowed to have access to applicants at the border, transit zones and in detention. In addition, they should have access on individual asylum applications and have the opportunity to present their views at any moment of the procedure. 662

\subsubsection{Procedural rules at first instance}

5.6.10.1. Procedure for examining the application for international protection The normal time limit to conclude an examination procedure is established at a maximum of six months. The time limit may be extended with another nine

\footnotetext{
tail the procedural safeguards for unaccompanied minors within the recast CEAS.

657 Article 26(1) of the recast Asylum Procedures Directive.

658 Article 26(2) of the recast Asylum Procedures Directive.

659 Articles 27 and 28 of the recast Asylum Procedures Directive.

660 Article 28(1),(a),(b) of the recast Asylum Procedures Directive.

661 Article 28(2) of the recast Asylum Procedures Directive.

662 Article 29 of the recast Asylum Procedures Directive.
} 
months in certain cases. ${ }^{663}$ First, if the case is complex and requires more time. Second, where a large number of applicants arrive to the Member State and the authorities have trouble in handling the cases within six months. This scenario has been experienced by Member States during the 'refugee crisis'. Third, where the applicant caused the delay because of non-compliance of his obligations. The maximum time limit is set to twenty-one months. 664 A new clause allows Member States to postpone the finalizing of the examination procedure 'where the determining authorities cannot reasonably be expected to decide within the time-limits laid down in paragraph 3 due to an uncertain situation in the country of origin which is expected to be temporary'. The recast Directive is silent about the definition of 'uncertain situation'. 665

\subsubsection{Accelerated or prioritized asylum examinations}

Articles 31(7) and 31(8) of the recast Asylum Procedures Directive allow Member States to 'accelerate' or 'prioritize' asylum examinations. For instance, Member States may 'prioritize' an examination procedure where the application is likely to be well-founded or where the applicant is a vulnerable person within the context of Article 22 of the recast Reception Conditions Directive or where the applicant is in need of special procedural guarantees. In this regard, unaccompanied minors are explicitly mentioned.666 The former Directive specified fifteen reasons justifying the application of a prioritized or accelerated procedure. ${ }^{667}$ The current instrument stipulates ten grounds for allowing an accelerated examination procedure. 668

\subsubsection{3. (Manifestly) unfounded and inadmissible applications}

Member States may also consider an asylum application 'unfounded' if the determining authority has considered that the applicant is not eligible for international protection. ${ }^{669}$ In addition, where the applicant is from a safe country of origin, Member States may consider an application manifestly unfounded. ${ }^{670}$

663 Article 31(3) of the recast Asylum Procedures Directive.

664 Article 31(5) of the recast Asylum Procedures Directive.

665 Article 31(4) of the recast Asylum Procedures Directive.

666 Article 31(7)(b) of the recast Asylum Procedures Directive.

667 See former Articles 23(3) and (4) of Council Directive 2005/85/EC. See also Case C175/11, H.I.D., B.A.v Refugee Applications Commissioner, Refugee Appeals Tribunal, Minister for Justice, Equality and Law Reform, Ireland, Attorney General, 31 January 2013, Court of Justice of the European Union, ECLI:EU:C:2013:45.

668 Article 31(8) of the recast Asylum Procedures Directive.

669 Article 32 of the recast Asylum Procedures Directive.

670 Article 32(2) of the recast Asylum Procedures Directive. See also Case C-404/17, Av Migrationsverket, 25 July 2018, Court of Justice of the European Union, ECLI:EU:C:2018:588. 
The current recast Directive also provides five grounds to consider an application as 'inadmissible'. This means that Member States are not obliged to examine such applications. ${ }^{671}$ One of the reasons to consider an application inadmissible is when another Member State has previously granted international protection. It is important to note that the CJEU has held in Ibrahim that the beneficiary of international protection cannot be returned to the Member State who previously granted international protection status, where the living conditions would expose the beneficiary of international protection to a substantial risk of suffering inhuman or degrading treatment. ${ }^{672}$ Applicants have the right to be heard with regard to the application of the inadmissibility grounds. ${ }^{673}$

\subsubsection{Safe country concepts}

The recast Directive enshrines several contentious safe country concepts: 'first country of asylum';674 'safe country of origin'; 675 'national designation of third countries as safe countries of origin';676 'safe third country';677 and 'the European safe third country' ${ }^{678}$ In the light of the increased migratory flows to the EU, the Commission proposed on 9 September 2015 a Regulation to establish a EU common list of safe countries of origin. ${ }^{679}$ According to this proposal,

671 Article 33(2) of the recast Asylum Procedures Directive.

${ }^{672}$ Joined Cases C-297/17, C-318/17, C-319/17 and C-438/17, Ibrahim and others v Bundesrepublik Deutschland, 19 March 2019, Court of Justice of the European Union, ECLI:EU:C:2019:219.

673 Article 34 of the recast Asylum Procedures Directive.

674 Article 35 of the recast Asylum Procedures Directive.

675 Article 36 of the recast Asylum Procedures Directive.

676 Article 37 of the recast Asylum Procedures Directive. The European Parliament has successfully annulled the adoption of common list of third countries as regards safe countries of origin adopted in former Article 29(1) and (2) of the Asylum Procedures Directive 2005/85/EC in Case C-133-/06, European Parliament $v$ Council of the European Union, 6 May 2008, Court of Justice of the European Union, ECLI:EU:C:2008:257.

677 Article 38 of the recast Asylum Procedures Directive. See for more detailed analysis on 'safe third country' concepts Peers, S., Moreno-Lax, V., Garlick, M., en Guild, E. (red.), EU Immigration and Asylum Law (Text and Commentary), Second Revised Edition, EU Asylum Law, Vol. 3, 2015, pp. 262-277; Moreno-Lax, V., The legality of the 'safe third country' notion reconsidered: an appraisal in light of general international rules on the law of treaties, International Migrants, 2010 Research Session of the Centre for Studies and Research in International Law and International Relations, The Hague Academy of International Law, Goodwin-Gill (ed.), 2014.

678 Article 39 of the recast Asylum Procedures Directive.

679 European Commission, Proposal for a Regulation of the European Parliament and of the Council establishing an EU common list of safe countries of origin for the purposes of Directive 2013/32/EU of the European Parliament and of the Council on common procedures for granting and withdrawing international protection, and amending Directive 2013/32/EU, Brussels, 9.9.2015, COM92015) 452 final. The initial list of third countries 
Member States may accelerate the asylum application of a person that is a national from one of this designated list of safe countries. Currently, there is no EU wide list of safe countries of origin. A few Member States have adopted their own national list. 680

\subsubsection{Subsequent asylum applications}

Where an applicant has made a subsequent application, 681 Member States must examine whether 'new elements or findings have arisen' before a decision is taken on the admissibility of an application for international protection. Member States are allowed to make an exception from the right to remain on the territory in the case of a subsequent application, provided that the return decision may not result in a direct or indirect violation of the non-refoulement principle. 682

\subsubsection{Border procedures}

Member States may decide at the border or transit zones on the admissibility of an application and on the substance of an application in an accelerated procedure in accordance with Article 31(8) of the recast Asylum Procedures Directive. ${ }^{683}$ Reports from various organizations have shown that the examination of asylum applications at the border is problematic. Member States apply various standards as regards the scope, grounds, procedural time limits and guarantees in border procedures, including the use of detention. ${ }^{684}$ EASO revealed that the

includes: Albania, Bosnia and Herzegovina, the former Yugoslav Republic of Macedonia, Kosovo, Montenegro, Serbia and Turkey.

680 Wagner, M., Dimitriadi, A., O'Donell, R., Perumadan, J., Schlotzhauer, J. H., Simic, I., \& Yabasun, D. (2016), The implementation of the Common European asylum system, Brussels: European Parliament, p. 77. See further Peers, S., The second phase of the Common European Asylum System: A brave new world - or lipstick on a pig?, 8 April 2013; Costello, C. and Hancox, E., The Recast Asylum Procedures Directive 2013/32/EU: Caught between the Stereotypes of the Abusive Asylum Seeker and the Vulnerable Refugee, De Bruycker, P., Chetail, V. and Maiani, F. (eds.), Reforming the Common European Asylum System: The New European Refugee Law, Brill Nijhoff, 2016; ECRE, Information Note on Directive 2013/32/EU of the European Parliament and of the Council of 26 June 2013 on common procedures for granting and withdrawing international protection (recast), December 2014.

681 Article 2(q) provides the definition of subsequent application: 'a further application for international protection made after a final decision has been taken on a previous application, including cases where the applicant has explicitly withdrawn his or her application and cases where the determining authority has rejected an application.'

682 Article 41 of the recast Asylum Procedures Directive.

683 Article 43 of the recast Asylum Procedures Directive.

684 See European Commission, Report from the Commission to the European Parliament and the Council on the application of Directive 2005/85/EC of 1 December 2005 on minimum standards on procedures in Member States for granting and withdrawing refugee status, p. 13; European Migration Network, Ad-Hoc Query on detention of asylum 
application of accelerated and border procedures result in higher rejections of the asylum applications compared to the application examined in normal asylum procedures. .85

\subsubsection{The right to an effective remedy}

Finally, the right to an effective remedy is a fundamental right, which is enshrined in Article 47 of the Charter and also in Article 13 of the ECHR. Applicants have the right to an effective remedy against a decision taken with regard to their application for international protection before a court or tribunal. 686 Subsidiary protection status holders have the right to an effective remedy against a decision to consider an application for refugee status unfounded. ${ }^{687}$ Inspired by ECtHR case law, ${ }^{688}$ the present Directive now ensures that an effective remedy provides for 'a full and ex nunc examination of both facts and points of law'. ${ }^{689}$ Member States must also provide for reasonable time limits in order for the applicant to exercise his right to an effective remedy. ${ }^{690}$ What is a reasonable time limit? That depends on the circumstances of the case.691 The

applicants at the border: Requested by NL EMN NCP, 28 November 2014; and ECRE Asylum Information Database, The Legality of Examining Asylum Claims in Detention from the Perspective of Procedural Rights and their Effectiveness, October 2015, pp. 2-3.

685 EASO, Annual Report on the Situation of Asylum in the European Union 2016, p, 99.

686 Article 46 of the recast Asylum Procedures Directive. See Case C-180/17, X. and Yv Staatssecretaris van Veiligheid en Justitie, 26 September 2018, Court of Justice of the European Union, ECLI:EU:C:2018:775; Case C-175/17, X, 26 September 2018, Court of Justice of the European Union, ECLI:EU:C:2018:776; Case C-239/14, Tall, 17 December 2015, Court of Justice of the European Union, ECLI:EU:C:2015:824; Case C-69/10, Brahim Samba Dioufv Ministre du Travail, de l'Emploi et de l'Immigration, 28 July 2011, Court of Justice of the European Union, ECLI:EU:C:2011:524. See also Case C-175/11, H.I.D., B.A. v Refugee Applications Commissioner a.o., 31 January 2013, Court of Justice of the European Union, ECLI: EU: C:2013: 45, para. 81. For a more detailed analysis on the EU right to an effective remedy in asylum procedures see Reneman, M., EU Asylum Procedures and the Right to an Effective Remedy, Hart Publishing, 2016.

687 Article 46(2) of the recast Asylum Procedures Directive. See Case C-662/17, E.G. v Republika Slovenija, 18 October 2018, Court of Justice of the European Union, ECLI:EU:C:2018:847.

688 Salah Sheekh $v$ the Netherlands, Application no. 1948/04, European Court of Human Rights, 11 July 2007, para. 136.

689 Article 46(3) of the recast Asylum Procedures Directive. See Case C-56/17, Bahtiyar Fathi v Predsedatel na Darzhavna agentsia za bezhantsite, 4 October 2018, Court of Justice of the European Union, ECLI:EU:C:2018:803.

690 Article 46(4) of the recast Asylum Procedures Directive.

691 Costello, C. and Hancox, E., The Recast Asylum Procedures Directive 2013/32/EU: Caught between the Stereotypes of the Abusive Asylum Seeker and the Vulnerable Refugee, De Bruycker, P., Chetail, V. and Maiani, F. (eds.), Reforming the Common European Asylum System: The New European Refugee Law, Brill Nijhoff, 2016, p. 435. 
CJEU ruled in Samba Diouf that 'a 15-day time limit for bringing an action does not seem, generally, to be insufficient in practical terms to prepare and bring an effective action and appears reasonable and proportionate in relation to the rights and interests involved'. 692

The recast Directive provides an applicant with the right to stay in the territory of the Member State to await the outcome of the remedy. ${ }^{693}$ However, with certain type of cases, a court or tribunal may have the power to rule whether or not the applicant may remain on the territory of the Member State. The applicant may request interim relief before a court or the court may act ex officio. ${ }^{694}$ It follows from M.S.S. that 'any complaint that expulsion to another country will expose an individual to treatment prohibited by Article 3 of the Convention requires close and rigorous scrutiny'. 695 The specific cases mentioned in the Directive concern manifestly unfounded applications; or just simply unfounded applications; or inadmissible applications; or the decision to reopen the application is rejected; or the application is not going to be examined or not fully examined because the applicant entered the territory from a safe third country. ${ }^{696}$ Where Member States aim to make an exception to the right to an appeal with automatic suspensive effect in border procedures, certain conditions should be observed: the applicant has the necessary interpretation and legal assistance; the applicant has at least one week to prepare the request to remain on the territory pending the outcome of the remedy; and a court or tribunal examines the negative decision concerning fact and law. ${ }^{697}$ Furthermore, it is important to note that Member States should 'allow the applicant to remain in the territory pending the outcome of the procedure to rule whether or not the applicant may remain on the territory'.698

\subsection{Commission proposal Asylum Procedures Regulation}

The recast Asylum Procedures Directive has not been effective enough in order

692 Case C-69/10, Brahim Samba Diouf v Ministre du Travail, de l'Emploi et de l'Immigration, Court of Justice of the European Union, 28 July 2011, EU:C:2011:524, para. 67.

693 Article 46(5) of the recast Asylum Procedures Directive.

694 Article 46(6) of the recast Asylum Procedures Directive.

695 M.S.S. v Belgium and Greece, Application no. 30696/09, European Court of Human Rights, 21 January 2011, para. 387.

696 Article 46(6), (a), (b), (c), (d) of the recast Asylum Procedures Directive.

${ }^{697}$ Article 46(7),(a),(b) of the recast Asylum Procedures Directive. See for a more detailed analysis Reneman, M., EU Asylum Procedures and the Right to an Effective Remedy, Hart Publishing, 2016, pp. 117-145.

698 Article 46(8) of the recast Asylum Procedures Directive. Case C-269/18, Staatssecretaris van Veiligheid en Justitie v C \& J, 5 July 2018, Court of Justice of the European Union, ECLI:EU:C:2018:544. 
to bring more harmonization in the EU with regard to different procedural aspects in the field of asylum. The current instrument still leaves wide discretion to Member States with regard to the implementation of EU norms. The Commission has proposed to replace the Asylum Procedures Directive with a Regulation. The objective is to remove the discretion granted to Member States and to establish a 'truly' common procedure for international protection, which is efficient, fair and balanced. ${ }^{699}$ The legal basis of the Commission proposal is Article 78(2)(d) TFEU and subject to the ordinary legislative procedure.

This proposal aims to establish a fair and efficient procedure at the EU level. The Commission focuses on four important procedural aspects. The first aspect is introducing 'simpler, clearer and shorter procedures'. Second, procedural guarantees ensuring the rights of asylum applicants. Third, the Commission wants stricter rules and the power to sanction asylum applicants who abuse the system, including preventing secondary movements. Fourth, this proposal aims to establish more convergence in the rules regarding safe countries concepts. ${ }^{700}$ The four aspects will be further highlighted in the following paragraphs.

The first objective is to further harmonize asylum procedures and to remove the disparities between Member States concerning time limits in asylum procedures. Therefore, the Commission is proposing to shorten existing time limits. The application for international protection needs to be registered within three working days and the applicant has ten working days to lodge the application from the moment the application is registered. The overall maximum time limit for examining an asylum application is reduced from twenty-one months to fifteen months. Regrettably, the Commission has maintained the option for Member States to postpone concluding the examination procedure "due to an uncertain situation in the country of origin which is expected to be temporary". Postponing a decision on an asylum application may have implications for the applicant's right to family reunification. In addition, new time limits are proposed with regard to the conclusion of an examination of an application in accelerated procedures and in inadmissibility cases. The current recast Directive does not provide for time limits in such special procedures. ${ }^{701}$ An illustrative

699 European Commission, Proposal for a Regulation of the European Parliament and of the Council establishing a common procedure for international protection in the Union and repealing Directive 2013/32/EU, Brussels, 13.7.2016, COM(2016) 467 final, 2016/0224 (COD), p. 3.

700 European Commission, Proposal for a Regulation of the European Parliament and of the Council establishing a common procedure for international protection in the Union and repealing Directive 2013/32/EU, Brussels, 13.7.2016, COM(2016) 467 final, 2016/0224 (COD), pp. 4-5.

701 European Commission, Proposal for a Regulation of the European Parliament and of the Council establishing a common procedure for international protection in the Union and 
example of this is that the Directive currently provides that the time limits to conclude an accelerated examination procedure should be 'reasonable'. Research has shown that Member States have implemented different time limits. Some Member States applied two to three days and others applied two months. ${ }^{702}$ The time limit to conclude an accelerated examination procedure is with this proposal established at two months from the moment of lodging the application and one month for inadmissibility cases.

Second, the Commission proposal discusses the procedural guarantees of asylum applicants. The proposal obliges Member States to provide the applicant with a document, within three working days after the application has been lodged, verifying that the person is an asylum applicant with a right to stay. Applicants should have the right to remain on the territory of a Member State pending the examination of the asylum application. Except in cases where a person makes a subsequent application. The wording is much stronger than the current recast Asylum Procedures Directive, which stipulates that Member States shall 'allow' applicants to remain in the territory. Currently, making audio- and audio-visual recordings of the personal interview is not mandatory. As stated above, the majority of the Member States do not make use of this option. For the future, the Commission wants to oblige Member States to record the personal interview and send the recording, including the transcript of the interview to the applicant and his lawyer before a decision has been taken. Another important issue to asylum applicants during the procedure is free legal assistance. The Commission proposes that applicants should have access to free legal assistance throughout all stages of the procedure. Despite this important safeguard, the proposal allows Member States to exclude the right to free legal assistance in the administrative and in the appeal procedure, inter alia, where the applicant has sufficient resources or the applicant is considered as not having any tangible prospect of success. ${ }^{703}$ Where the authorities carry out a status review in accordance with the Qualification Regulation and consider withdrawing international protection, beneficiaries of international protection must be informed in writing of the reasons for such consideration and provide the beneficiary with the possibility to submit reasons in the form of a written statement and a personal interview to enable the applicant to explain why the interna-

repealing Directive 2013/32/EU, Brussels, 13.7.2016, COM(2016) 467 final, 2016/0224 (COD), pp. 11-12.

702 ECRE Asylum Information Database, The length of asylum procedures in Europe, 2016, pp. 7-8.

703 European Commission, Proposal for a Regulation of the European Parliament and of the Council establishing a common procedure for international protection in the Union and repealing Directive 2013/32/EU, Brussels, 13.7.2016, COM(2016) 467 final, 2016/0224 (COD), pp. 12-14. 
tional protection should not be withdrawn. An additional procedural guarantee provided by the Commission proposal is to grant applicants the services of an interpreter.

Furthermore, applicants have the right to an effective remedy before a court or tribunal against decisions taken by authorities to withdraw international protection and against a decision on their application for international protection. An effective remedy entails a full and ex nunc assessment of facts and points of law. In addition, applicants have the right to an effective remedy against decisions considering the application as inadmissible, unfounded or manifestly unfounded, or the implicit withdrawal of applications and against decisions taken in border procedures. The proposal also lays down short time limits to lodge appeals against these decisions. Lastly, the Commission broadens the guarantees that currently only applied in border procedures to all cases where asylum applicants have to make a separate request for interim protection. ${ }^{704}$

Third, as to the stricter rules, and sanctions against the asylum applicant who abuses the system, it seems that with this proposal, accelerated examination procedures become more prominent than before. Accelerated examination procedures are mandatory where the applicant has, inter alia, made clearly inconsistent, contradictory, false statements, or has misled the authorities with false information or the applicant arrives from a safe country of origin. The number of grounds to accelerate an application has been reduced from ten to eight. In addition, Member States must conclude an accelerated application within a maximum of two months from the lodging of the application. Except in the case where the applicant is making an application with the objective of delaying or frustrating an earlier decision. In this case the authorities have eight working days to conclude the accelerated examination procedure. ${ }^{705}$

Compared to the current recast Asylum Procedures Directive, this new proposal enshrines two new possible grounds to the list of accelerated examination procedures: first, where the applicant does not comply with the Dublin Regulation; and second, where the application is a subsequent application with no tangible prospect of success. ${ }^{706}$ The proposal maintains the possibility for Member States to apply accelerated procedures and border procedures to un-

704 European Commission, Proposal for a Regulation of the European Parliament and of the Council establishing a common procedure for international protection in the Union and repealing Directive 2013/32/EU, Brussels, 13.7.2016, COM(2016) 467 final, 2016/0224 (COD), p. 19.

705 European Commission, Proposal for a Regulation of the European Parliament and of the Council establishing a common procedure for international protection in the Union and repealing Directive 2013/32/EU, Brussels, 13.7.2016, COM(2016) 467 final, 2016/0224 (COD), pp. 15-16.

706 ECRE, Comments on the Commission Proposal for an Asylum Procedures Regulation $\operatorname{COM}(2016)$ 467, November 2016, p. 47. 
accompanied minors. This is undesirable given the extremely vulnerable position of unaccompanied minors in the asylum procedure. ${ }^{707}$ Furthermore, under this proposal Member States must assess the admissibility of an asylum application. The application may be declared inadmissible where a third country is considered to be a first country of asylum or where a third country is considered to be a safe third country or the application is a subsequent application or an application is lodged by a spouse, partner or accompanied minor who had consented to have an application lodged on his or her behalf. The current recast Directive provides Member States with the possibility of considering an application inadmissible and to reject the application in certain cases. Next, clearer rules have been presented with regard to the examination of subsequent applications. In order to initiate a subsequent asylum application, national authorities must determine whether relevant new elements or findings have arisen or presented by the applicant that will notably increase the likelihood of qualifying as a beneficiary of international protection or where it is established that the applicant was unable to present those new elements or findings in an earlier stage of the procedure. The preliminary examination must be assessed through written submissions and a personal interview. Subsequent applications are inadmissible where the grounds for initiating a new procedure are not met or considered as manifestly unfounded with no tangible prospect of success. In addition, Member States may reject the right to remain on the territory in the cases of inadmissible and manifestly unfounded subsequent applications, and no automatic suspension effect may be applied in a case a subsequent application is rejected. ${ }^{708}$

Fourth, in line with earlier Communications, the proposal aims for a more harmonized application of safe country concepts (first country of asylum, safe third country and safe countries of origin). The objective is to achieve a common approach towards the implementation of safe country concepts at the national level. Additionally, the Commission aims to incorporate the earlier proposal of a Regulation establishing a common EU list of safe countries of origin with this proposal. 709

707 See chapter 6 for an analysis with regard to unaccompanied minors in the asylum process.

708 European Commission, Proposal for a Regulation of the European Parliament and of the Council establishing a common procedure for international protection in the Union and repealing Directive 2013/32/EU, Brussels, 13.7.2016, COM(2016) 467 final, 2016/0224 (COD), p. 17.

709 European Commission, Proposal for a Regulation of the European Parliament and of the Council establishing a common procedure for international protection in the Union and repealing Directive 2013/32/EU, Brussels, 13.7.2016, COM(2016) 467 final, 2016/0224 (COD), pp. 17-19. 


\subsection{The recast Dublin III Regulation (EU) No 604/2013}

The recast Dublin III Regulation No 604/2013710 (recast Dublin III Regulation) is probably the most contentious instrument of the CEAS. The Dublin system is considered a cornerstone of the CEAS ${ }^{711}$ and based on the presumption that all Member States equally respect international human rights instruments and equally apply the standards on asylum procedures and reception conditions..$^{712}$ However, judgments in recent years by the ECtHR in M.S.S. and by the CJEU in N.S. concluded that there are flaws in the asylum systems in Greece. In another landmark ruling with regard to Dublin transfers, the ECtHR concluded in Tarakhel that Member States are obliged to obtain prior guarantees that vulnerable asylum applicants at their arrival will be accommodated in adequate reception conditions. ${ }^{713}$

Dublin serves for two main purposes: first, a clear and workable method for determining the Member State responsible for the examination of an asylum application; and second, this method should be based on objective and fair criteria that will determine rapidly the Member State responsible in order to guarantee effective access to the asylum procedure. ${ }^{714}$ Hence, the Dublin instrument provides a set of hierarchical criteria for identifying the responsible Member State for examining an asylum application. ${ }^{715}$

The Commission's proposal to recast the Dublin II Regulation No 343/2003/EC was submitted on 3 December 2008. The objective of the proposal was to enhance the efficiency of the Dublin system and to guarantee better legal protection for persons subjected to Dublin transfers. ${ }^{716}$ The changes aimed at improving the efficiency of the system and to ensure that persons subjected to Dublin procedures have better legal remedies. The recast Dublin III

710 Regulation (EU) No 604/2013 of the European Parliament and of the Council of 26 June 2013, establishing the criteria and mechanisms for determining the Member State responsible for examining an application for international protection lodged in one of the Member States by a third-country national or a stateless person (recast).

711 European Council, The Stockholm Programme - An Open and Secure Europe Serving and Protecting the Citizens, OJ C115/1, 4 May 2010, p. 32.

712 M.S.S. v Belgium and Greece, Application no. 30696/09, European Court of Human Rights, 21 January 2011, para. 78.

713 Tarakhel $v$ Switzerland, Application no. 29217/12, European Court of Human Rights, 4 November 2014, paras. 120-122.

714 Recitals 4 and 5 of the recast Dublin III Regulation.

715 Article 1 of the recast Dublin III Regulation.

716 European Commission, Proposal for a Regulation of the European Parliament and of the Council establishing the criteria and mechanisms for determining the Member State responsible for examining an application for international protection lodged in one of the Member States by a third-country national or a stateless person (Recast), Brussels, 3.12.2008, COM(2008) 820 final, 2008/0243 (COD). 
Regulation has been published in the Official Journal of the European Union on 26 June 2013 and replaced the former Dublin II Regulation ${ }^{717}$ as of 19 July 2013. The recast Dublin III Regulation applies to applications of international protection lodged as from 1 January 2014.

The Dublin system is comprised of the Commission Implementing Regulation (EU) No 118/2014 718 (replaced No 1560/2003719). The new Commission Implementing Regulation lays down detailed rules on the application of the recast Dublin III Regulation and entered into force on 9 February $2014 . .^{720}$ On the basis of agreements between the EU, the new Dublin rules also apply to associated countries such as Norway, Iceland, Switzerland and Liechtenstein.

\subsubsection{Determination of responsibility}

The recast Dublin III Regulation applies to applications made for international protection by a third country national at the border or in the territory of a Member State, including the transit zones. The application for international protection must be examined by a single Member State on the basis of the criteria established by the recast Dublin III Regulation. ${ }^{721}$

Chapter III stipulates the criteria for determining the Member State responsible. These criteria 'shall be applied in the order in which they are set out in this Chapter.' 722 Minors and the family unity are categorized as the most important in the hierarchy of criteria for determining the Member State responsible. ${ }^{723}$ Subsequently, Member States that have issued a residence document or visa

717 Council Regulation (EC) 343/2003 of 18 February 2003 establishing the criteria and mechanisms for determining the Member State responsible for examining an asylum application lodged in one of the Member States by a third-country national, OJ L50/1, 25.2.2003.

718 Commission Implementing Regulation (EU) (EU) No 118/2014 of 30 January 2014 amending Regulation (EC) No 1560/2003 laying down detailed rules for the application of Council Regulation (EC) No 343/2003 establishing the criteria and mechanisms for determining the Member State responsible for examining an asylum application lodged in one of the Member States by a third-country national.

719 Commission Regulation (EC) No 1560/2003 of 2 September 2003 laying down detailed rules for the application of Council Regulation (EC) No 343/2003 establishing the criteria and mechanisms for determining the Member State responsible for examining an asylum application lodged in one of the Member States by a third-country national, OJ L 222/3, 5 September 2003.

720 Joined cases C-47/17 and C-48/17, X \& Xv Staatssecretaris van Veiligheid en Justitie, 13 November 2018, Court of Justice of the European Union, ECLI:EU:C:2018:900.

721 Article 3(1) of the recast Dublin III Regulation. See Case C-56/17, Bahtiyar Fathi v Predsedatel na Darzhavna agentsia za bezhantsite, 4 October 2018, Court of Justice of the European Union, ECLI:EU:C:2018:803.

722 Article 7(1) of the recast Dublin III Regulation.

723 Articles 8-11 of the recast Dublin III Regulation. 
will be responsible for examining the application for international protection. ${ }^{724}$ Finally, where it is established that the applicant irregularly crossed the border of a particular Member State, that Member State will be responsible 725 Where it cannot be established that the applicant irregularly entered a particular Member State, and it is demonstrated that the applicant has been living for at least five months in a Member State before applying for an application for international protection, that Member State will be responsible. ${ }^{726}$

If none of the aforementioned criteria applies, the first Member State in which the asylum application was lodged will become responsible pursuant to Article 3(2). Article 3(2) of the recast Dublin III Regulation has been amended during the recast negotiations. The present provision codified the N.S. judgment. ${ }^{727}$ The CJEU has held in N.S. that 'Member States may not transfer an asylum seeker to the Member State which the criteria set out in Chapter III of the Regulation indicate is responsible, where they cannot be unaware that systemic deficiencies in the asylum procedure and in the conditions for the reception of asylum seekers in that Member State provide substantial grounds for believing that the asylum seeker would face a real risk of being subjected to inhuman or degrading treatment within the meaning of Article 4 of the Charter of Fundamental Rights of the European Union'. ${ }^{728}$ In Puid, the Grand Chamber of the CJEU ruled that the procedure to identify the responsible Member State must not take 'an unreasonable length of time'. In such circumstances, the Member State where the asylum applicant resides must itself continue with the examination of the asylum application. ${ }^{729}$ Furthermore, Member States are allowed under Article 3(3) of the Dublin III Regulation to send an asylum applicant to a safe third country based on the recast Asylum Procedures Directive 2013/32/EU.

724 Article 12 of the recast Dublin III Regulation. See Case C-646/16, Jafari v Bundesamt für Fremdenwesen und Asyl, 26 July 2017, Court of Justice of the European Union, ECLI:EU:C:2017:586.

725 Article 13(1) of the recast Dublin III Regulation. See Case C-490/16, A.S. v Republika Slovenija, 26 July 2017, Court of Justice of the European Union, ECLI:EU:C:2017:585.

726 Article 13(2) of the recast Dublin III Regulation.

727 Joined Cases C-411/10 and C-493/10, N.S. v Secretary of State for the Home Department and M. E. and others v. Refugee Applications Commissioner, Minister for Justice, Equality and Law Reform, 21 December 2011, Court of Justice of the European Union, ECLI:EU:C:2011:865.

728 Joined Cases C-411/10 and C-493/10, N.S. v Secretary of State for the Home Department and M. E. and others v. Refugee Applications Commissioner, Minister for Justice, Equality and Law Reform, 21 December 2011, Court of Justice of the European Union, ECLI:EU:C:2011:865, para. 94.

729 Case C-4/11, Bundesrepublik Deutschland v Kaveh Puid, 14 November 2013, Court of Justice of the European Union, ECLI:EU:C:2013:740, para. 35. 


\subsubsection{Procedural safeguards}

The recast Dublin III Regulation has strengthened the procedural rights of applicants. ${ }^{730}$ Applicants who apply for international protection must be informed about the Dublin system ${ }^{731}$ and they should be interviewed in a language that the applicant 'understands or is reasonably supposed to understand' and is able to speak. ${ }^{732}$ Practice has shown that important information regarding the Dublin procedure differ between Member States. In some Member States information was outdated or not even provided to applicants, whereas in other Member States the information provided was very general, which is not in compliance with the Dublin Regulation. ${ }^{733}$

The recast Dublin III Regulation contains important safeguards with regard to minors, including unaccompanied minors. The best interest of the child must 'a primary consideration' in all Dublin procedures. ${ }^{734}$ Where the applicant is an unaccompanied minor, Member States must implement additional guarantees, such as to assign a representative and to identify the family members, siblings or relatives.

The CJEU has dealt with the position of unaccompanied minors, which are considered a particularly vulnerable group, in the framework of the Dublin system in the M.A. case. ${ }^{735}$ The M.A. case concerned three unaccompanied minors who all applied for asylum in the UK and who had all three lodged an asylum claim before in the Netherlands and Italy. According to the CJEU, Article 6(2) of the Dublin II Regulation focuses on the position of unaccompanied minors and to ensure an effective access to an assessment of the applicant's refugee status. Considering that unaccompanied minors are a special category of vulnerable persons, it is paramount not to delay unnecessarily the asylum procedure for designating a Member State responsible for examining the applications and thus unaccompanied minors should not be transferred to another

730 For a more detailed analysis see Maiani, F., The Dublin III Regulation, De Bruycker, P., Chetail, V. and Maiani, F. (eds.), Reforming the Common European Asylum System: The New European Refugee Law, Brill Nijhoff, 2016.

731 Article 4 of the recast Dublin III Regulation.

732 Article 5(4) of the recast Dublin III Regulation.

733 European Commission, Proposal for a Regulation of the European Parliament and of the Council establishing the criteria and mechanisms for determining the Member State responsible for examining an application for international protection lodged in one of the Member States by a third-country national or a stateless person (recast), Brussels, 4.5.2016, COM(2016) 270 final, 2016/0133 (COD), p. 9.

734 Article 6 of the recast Dublin III Regulation.

735 Case C-648/11, The Queen, on the application of MA, BT, DA v Secretary of State for the Home Department, 6 June 2013, Court of Justice of the European Union, ECLI:EU:C:2013:367. 
Member State. ${ }^{736}$ The CJEU interpreted that 'where an unaccompanied minor with no member of his family legally present in the territory of a Member State has lodged asylum applications in more than one Member State, the Member State in which that minor is present, after having lodged an asylum application there, is to be designated the 'Member State responsible'.

The ruling of the CJEU significantly improves the uncertain situation of unaccompanied minors that was created by the Dublin II Regulation and confirms that unaccompanied minors constitute a category of particularly vulnerable group of asylum applicants. The judgment underlines that the best interests of the child should be a primary consideration at all times when applying the Dublin II Regulation and that Member States may not transfer an unaccompanied minor to another Member State where they have applied for asylum previously. In line with the judgment in the M.A. case, the Commission proposed in June 2014 to amend Article 8(4) of the Dublin III Regulation. ${ }^{737}$

Where a Member State accepts the Dublin-transfer, whether it is a 'take back' or a 'take charge' request, the applicant has to be notified of the decision. ${ }^{738}$ The applicant has the right to an effective remedy, in the form of an appeal or review, against the decision of transfer before a court or tribunal. ${ }^{739}$

\subsubsection{Discretionary clauses and dependent persons}

Former Dublin II Regulation contained two significant clauses, namely the sovereignty clause in Article 3(2) of the Dublin II Regulation and the humanitarian clause in Article 15(1) of the Dublin II Regulation. The sovereignty clause al-

736 Case C-648/11, The Queen, on the application of MA, BT, DA v Secretary of State for the Home Department, 6 June 2013, Court of Justice of the European Union, ECLI:EU:C:2013:367, paras. 54-55.

737 European Commission, Proposal for a Regulation of the European Parliament and of the Council amending Regulation (EU) No 604/2013 as regards determining the Member State responsible for examining the application for international protection of unaccompanied minors with no family member, sibling or relative legally present in a Member State, Brussels, 26.6.2014, COM(2014) 382 final, 2014/0202 (COD), p. 3.

738 Article 26 of the recast Dublin III Regulation. See Case C-647/16, Adil Hassan v Préfet du Pas-de-Calais, 31 May 2018, Court of Justice of the European Union, ECLI:EU: C:2018:368.

739 Article 27 of the recast Dublin III Regulation. Case C-201/16, Majid Shiri v Bundesamt für Fremdenwesen und Asyl, 25 October 2017, Court of Justice of the European Union, ECLI:EU:C:2017:805; Case C-670/16, Tsegezab Mengesteab v Bundesrepublik Deutschland, 26 July 2017, Court of Justice of the European Union, ECLI:EU:C:2017:587; Case C-394/12, Shamso Abdullahi v Bundesasylamt, 10 December 2013, Court of Justice of the European Union, ECLI:EU:C:2013:813; Case C-63/15, Mehrdad Ghezelbash v Staatssecretaris van Veiligheid en Justitie, 7 June 2016, Court of Justice of the European Union, ECLI:EU:C:2016:410; Case C-155/15, George Karim v Migrationsverket, 7 June 2016, Court of Justice of the European Union, ECLI:EU:C:2016:410. 
lows a Member State to examine an asylum request even if another Member State is responsible according to the Dublin criteria. The new sovereignty clause is now enshrined in Article 17(1) of the recast Dublin III Regulation. ${ }^{740}$ The humanitarian clause in former Article 15 of the Dublin II Regulation provided the possibility for a Member State, even though it is not responsible to examine the asylum application, to reunite family members on humanitarian grounds. The humanitarian clause is now laid down in Article 17(2) of the recast Dublin III Regulation. Moreover, the CJEU has ruled that a Member State is also permitted to examine an asylum claim on the basis of Article 3(2) of the Dublin II Regulation in situations where there are no grounds to apply the humanitarian clause of Article 15. ${ }^{741}$ It appears that Member States do not often apply the discretionary clauses. ${ }^{742}$

The recast Dublin III Regulation includes provisions on dependent persons. According to Article 16(1) 'Where, on account of pregnancy, a new-born child, serious illness, severe disability or old age, an applicant is dependent on the assistance of his or her child, sibling or parent legally resident in one of the Member States, or his or her child, sibling or parent legally resident in one of the Member States is dependent on the assistance of the applicant, Member States should normally keep or bring together the applicant with that child, sibling or parent', on condition that 'family ties existed in the country of origin'; the child, sibling or parent or the applicant is able to take care of the dependent person; and the persons concerned consent in writing. The CJEU has ruled in the $K$ judgment that Member States are obliged to bring together persons where the dependency is evidenced. ${ }^{743}$

\subsubsection{Procedural rules Member State responsible}

Chapter V of the recast Dublin III Regulation stipulates several clauses when a responsible Member State should 'take' charge' or 'take back' and in which circumstances the obligations of a responsible Member State cease. ${ }^{744}$ Where a Member State considers that another Member State is responsible for examin-

740 See Case C-661/17, M.A., S.A., A.Z., 23 January 2019, Court of Justice of the European Union, ECLI:EU:C:2019:53.

741 Case C-528/11, Zuheyr Frayeh Halaf v Darzhavna agentsia za bezhantsite pri Ministerskia savet, 30 May 2013, Court of Justice of the European Union, ECLI:EU:C:2013:342.

742 UNHCR, Study on the implementation of the Dublin III Regulation, Left in Limbo, 2017, pp. 115-32.

743 Case C-245/11, Kv Bundesasylamt, 6 November 2012, Court of Justice of the European Union, ECLI:EU:C:2012:685. Garlick, M., The Dublin System, Solidarity and Individual Rights, De Bruycker, P., Chetail, V. and Maiani, F. (eds.), Reforming the Common European Asylum System: The New European Refugee Law, Brill Nijhoff, 2016, p. 182.

744 Articles 18-19 of the recast Dublin III Regulation. 
ing the asylum claim, a request can be made to the other Member State to 'take charge' of the asylum applicant. At the same time, Dublin provides procedural rules on the 'taking back' request of an asylum applicant. ${ }^{745}$ According to the data of the Commission, the number of 'take back' requests was much higher than the number of 'take charge' requests ( $72 \%$ 'take back' requests against $28 \%$ 'take back' requests, 2008-2014). ${ }^{746}$

\subsubsection{Detention}

Unlike the former Dublin II Regulation, the present recast Dublin III Regulation introduces rules with regard to the detention of asylum applicants in Dublin cases. ${ }^{747}$ Member States may secure transfer procedures by detaining an applicant when there is a risk of absconding. Detained applicants appeared to be less informed with regard to the right to appeal. Moreover, detention may have a negative impact on particularly vulnerable applicants. ${ }^{748}$ The Commission underlined that Member States should take the specific situation of vulnerable applicants into account, such as 'families, applicants with medical needs, women and unaccompanied minors' ${ }^{749}$

745 Articles 20-25 of the recast Dublin III Regulation. See also Case C-213/17, Xv Staatssecretaris van Veiligheid en Justitie, 5 July 2018, Court of Justice of the European Union, ECLI:EU:C:2018:538; Case C-360/16, Aziz Hasan v Bundesrepublik Deutschland, 25 January 2018, Court of Justice of the European Union, ECLI:EU:C:2018:35; Case C19/08, Migrationsverket $v$ Edgar Petrosian and Others, 29 January 2009, Court of Justice of the European Union, ECLI:EU:C:2009:41 and Case C-620/10, Migrationsverket v Nurije Kastrati and Others, 3 May 2012, Court of Justice of the European Union, ECLI:EU:C:2012:265.

${ }^{746}$ European Commission, Proposal for a Regulation of the European Parliament and of the Council establishing the criteria and mechanisms for determining the Member State responsible for examining an application for international protection lodged in one of the Member States by a third-country national or a stateless person (recast), Brussels, 4.5.2016, COM(2016) 270 final, 2016/0133 (COD), p. 10.

747 Article 28 of the recast Dublin III Regulation. Case C-60/16, Mohammad Khir Amayry v Migrationsverket, 13 September 2017, Court of Justice of the European Union, ECLI:EU:C:2017:675; Case C-528/15, Chodor, 15 March 2017, Court of Justice of the European Union, ECLI:EU:C:2017:213. See also comments Hruschka, C. and Maiani, F. in Kay Hailbronner and Daniel Thym (eds.), EU Immigration and Asylum Law, Commentary, $2^{\text {nd }}$ edition (C.H. BECK/Hart/Nomos, 2016), p. 1572.

748 Fratzke, S., Not adding up, The fading promise of Europe's Dublin system, Migration Policy Institute, March 2015, p. 19.

749 European Commission, Report from the Commission to the European Parliament and the Council on the evaluation of the Dublin system, $\{\operatorname{SEC}(2007) 742\}$, Brussels, 6.6.2007, $\operatorname{COM(2007)~} 299$ final, pp. 7-8. 


\subsubsection{Time limits and exchange of data before a transfer takes place}

The final part of the Regulation specifies details on modalities and time limits with regard to transfers. ${ }^{750}$ Importantly, the CJEU has held in Jawo that the asylum applicant, given his particular vulnerability, should not be transferred to the Member State, which is responsible for examining the asylum application, where the living conditions would expose the applicant to a substantial risk of suffering inhuman or degrading treatment. ${ }^{751}$

Other important aspects regulated are the costs of transfers, ${ }^{752}$ including the requirements for Member States to exchange important data about vulnerable applicants with special needs before a transfer takes place. ${ }^{753}$ There are cases identified where authorities of the sending Member State failed to notify the receiving Member State of the applicant's illnesses or special needs. ${ }^{754}$

\subsubsection{Early warning mechanism}

A new 'early warning mechanism' has been added to the recast Dublin III Regulation. ${ }^{755}$ The provision enables the Commission, in co-operation with EASO, to present an action plan, or if needed, a crisis management plan for a specific Member State whose asylum system is malfunctioning. To date, this mechanism has not been implemented.

\subsection{Commission proposal Dublin IV Regulation}

As part of the first package to reform of the CEAS, the Commission issued a proposal to reform the Dublin III Regulation. The reform package further includes a proposal for a recast of the Eurodac Regulation and a proposal for establishing an Agency on Asylum. ${ }^{756}$ The legal basis to recast the Dublin III Regulation is Article 78(2)(e) TFEU and subject to the ordinary legislative procedure.

750 Article 29 of the recast Dublin III Regulation.

751 Case C-163/17, Abubacarr Jawo v Bundesrepublik Deutschland, 19 March 2019, Court of Justice of the European Union, ECLI:EU:C:2019:218.

752 Article 30 of the recast Dublin III Regulation.

753 Articles 31 and 32 of the recast Dublin III Regulation.

754 Fratzke, S., Not Adding Up: The fading promise of Europe's Dublin System, Migration Policy Institute, March 2015, p. 17.

755 Article 33 of the recast Dublin III Regulation.

756 European Commission, Proposal for a Regulation of the European Parliament and of the Council establishing the criteria and mechanisms for determining the Member State responsible for examining an application for international protection lodged in one of the Member States by a third-country national or a stateless person (recast), Brussels, 4.5.2016, COM(2016) 270 final, 2016/0133 (COD), p. 2. 
The aims of this proposal are threefold: first, to improve the efficiency of the system; second, to discourage secondary movements; and third, the proposal introduces a new 'corrective allocation mechanism', which should ensure a more equitable sharing of responsibility. ${ }^{757}$ The rationale behind the new Commission proposal on the reform of the Dublin system remains that the Member State where the applicant first irregularly entered is responsible for examining the asylum application. The Commission maintains the current Dublin criteria and supplements the system with a 'corrective allocation mechanism'.

In order to improve the efficiency of the Dublin system, new obligations are introduced for the applicant and Member States. For example, an applicant must apply in the first Member State of irregular entry or where the applicant is legally present in a Member State. Where the applicant does not comply with this obligation, the application shall be examined in an accelerated procedure in line with Article 31(8) of the Asylum Procedures Directive. In addition, Member States must check before every start of the asylum procedure whether the asylum applicant arrived in the territory from a 'first country of asylum' safe third country' and thus whether the asylum application is inadmissible. Furthermore, a few changes have been made to the current Dublin criteria such as to delete the cessation of responsibility after 12 months from irregular entry; the 'early warning and preparedness mechanism' is deleted from the current Dublin Regulation and transferred as a permanent task for the new EU Asylum Agency; and the proposal introduces shorter time limits, and simpler 'take back' procedures, including changes to rules on remedies.

The second main element of this proposal is the introduction of a 'corrective allocation mechanism', which should guarantee a 'fair sharing of responsibility between Member States and swift access for applicants to procedures for granting international protection, in situations when a Member State is confronted with a disproportionate number of applications'. ${ }^{758}$ How does this mechanism operate and how does it differ from the relocation scheme or the permanent crisis relocation mechanism? Basically, an automatic system for the registration, monitoring and application of the allocation should be established. The

757 European Commission, Proposal for a Regulation of the European Parliament and of the Council establishing the criteria and mechanisms for determining the Member State responsible for examining an application for international protection lodged in one of the Member States by a third-country national or a stateless person (recast), Brussels, 4.5.2016, COM(2016) 270 final, 2016/0133 (COD), p. 14.

758 European Commission, Proposal for a Regulation of the European Parliament and of the Council establishing the criteria and mechanisms for determining the Member State responsible for examining an application for international protection lodged in one of the Member States by a third-country national or a stateless person (recast), Brussels, 4.5.2016, COM(2016) 270 final, 2016/0133 (COD), p. 18. 
application of the corrective mechanism is automatically triggered where a Member State is confronted with a high number of migratory arrivals, which is higher than $150 \%$ as determined by the reference key. In contrast with the relocation scheme or the permanent crisis relocation mechanism, the corrective allocation mechanism is triggered automatically. Furthermore, two criteria form the basis for the reference key: the size of the population and the total GDP of a Member State (both 50\% weighting). The proposal for a permanent crisis relocation mechanism was based on the size of the population and the total of the GDP (both $40 \%$ weighting), the average number of asylum applications lodged over the period $2010-2014$ (10\% weighting) and the unemployment rate $(10 \%$ weighting). Moreover, only applicants who are in clear need of international protection could benefit from the permanent crisis relocation mechanism and the relocation schemes. Once this mechanism is applied to a Member State facing a high influx of asylum applicants, all new applications lodged in that Member State will be allocated to another Member State. A Member State may decide to temporarily not take part in the corrective mechanism for twelve months. However, these Member States that do not take part temporarily will be sanctioned with a fine of $250 \mathrm{~K}$ per allocated applicant. The financial sanctioning is another aspect that is not applied in the relocation scheme or the permanent crisis relocation mechanism.

One significant aspect remains the same for all relocation mechanisms: these mechanisms do not take the applicant's preferences into account. During consultation meetings of the Commission with stakeholders on the evaluation of the Dublin Regulation, there were different views on whether the preferences of the asylum applicant should be taken into account. Member States pointed out that applicants of international protection flee for persecution and that they should have their say concerning the Member State of destination. The UNHCR and NGOs have argued that preferences of the applicant should be taken into account for the determination of a Member State responsible in the light of the integration prospects and to minimize secondary movements between Member States. ${ }^{759}$

The Commission's proposal retains the disputed irregularly entry criterion, which will most likely continue to put the frontline Member States under heavy pressure. It remains to be seen in practice how the 'corrective allocation mechanism' will alleviate this burden on border Member States and guarantee a fair sharing of responsibility between Member States.

759 European Commission, Proposal for a Regulation of the European Parliament and of the Council establishing the criteria and mechanisms for determining the Member State responsible for examining an application for international protection lodged in one of the Member States by a third-country national or a stateless person (recast), Brussels, 4.5.2016, COM(2016) 270 final, 2016/0133 (COD), p. 13. 


\subsection{The recast Eurodac Regulation (EU) No 603/2013}

The recast Eurodac Regulation (EU) No 603/2013760 (recast Eurodac Regulation) has replaced No 2725/2000.761 The Eurodac Regulation is part of the Dublin system. The negotiations on the recast of the Eurodac Regulation were extremely difficult. The first proposal of the Commission to recast the Eurodac Regulation was taken in $2008^{762}$ and subsequently subjected to three modifications before it was adopted in 2013. The main modification inserted in the 2008 Eurodac recast proposal is the possibility for law enforcement authorities to have access to the Eurodac database, albeit with strict conditions. ${ }^{763}$ In October 2010, the Commission withdrew their proposal regarding the references with respect to the access for law enforcement purposes. ${ }^{764}$ However, in May

760 Regulation (EU) No 603/2013 of the European Parliament and of the Council of 26 June 2013 on the establishment of 'Eurodac' for the comparison of fingerprints for the effective application of Regulation (EU) No 604/2013 establishing the criteria and mechanisms for determining the Member State responsible for examining an application for international protection lodged in one of the Member States by a third-country national or a stateless person and on requests for the comparison with Eurodac data by Member States' law enforcement authorities and Europol for law enforcement purposes, and amending Regulation (EU) No 1077/2011 establishing a European Agency for the operational management of large-scale IT systems in the area of freedom, security and justice (recast) OJ L 180/1.

761 Council Regulation No 2725/2000 of 11 December 2000 concerning the establishment of 'Eurodac' for the comparison of fingerprints for the effective application of the Dublin Convention, OJ L 316/1, 15 December 2000.

762 European Commission, Proposal for a Regulation of the European Parliament and of the Council concerning the establishment of 'Eurodac' for the comparison of fingerprints for the effective application of Regulation (EC) No [.../...] [establishing the criteria and mechanisms for determining the Member State responsible for examining an application for international protection lodged in one of the Member States by a third-country national or a stateless person] (Recast version), Brussels, 3.12.2008, COM(2008) 825 final, 2008/0242 (COD).

763 Amended proposal for a Regulation of the European Parliament and of the Council concerning the establishment of 'Eurodac' for the comparison of fingerprints for the effective application of Regulation (EC) No [.../...] [establishing the criteria and mechanisms for determining the Member State responsible for examining an application for international protection lodged in one of the Member States by a third-country national or a stateless person] (Recast version), Brussels, 10.9.2009, COM(2009) 342 final, 2008/0242 (COD).

764 Amended proposal for a Regulation of the European Parliament and of the Council on the establishment of 'Eurodac' for the comparison of fingerprints for the effective application of Regulation (EC) No [.......] [establishing the criteria and mechanisms for determining the Member State responsible for examining an application for international protection lodged in one of the Member States by a third-country national or a stateless 
2012, the provisions as to the access for law enforcement purposes have been included again in a new proposal presented by the Commission. ${ }^{765}$

The new Eurodac Regulation was published in the Official Journal of the European Union on 26 June 2013 and is applicable as from 20 July 2015. The UK takes part in the adoption and application of the new Eurodac Regulation. Ireland has opted out of the new Eurodac Regulation and Denmark is not taking part in the adoption of the new Eurodac rules. However, Denmark has agreed via a Council Decision to apply Eurodac Regulation No 2725/2000.766

\subsubsection{Mandatory fingerprinting}

Basically, the Eurodac system is a computerized database of fingerprints of asylum applicants in order to facilitate the Dublin system. The database determines whether an applicant has applied for asylum in one of the Member States. The concept is not new. Eurodac was already launched in 1991 and in 1998 an agreement was reached on the content of the draft. ${ }^{767}$

Member States must take the fingerprints of every asylum applicant of at least 14 years of age. ${ }^{768}$ Secondly, each Member State must take the fingerprints of every alien coming from a third country of at least 14 years of age who is apprehended whilst irregularly crossing by land, sea or air the border of the Member State and who is not returned back. ${ }^{769}$ Thirdly, Member States may

person] (Recast version), Brussels, 11.10.2010, COM(2010 555 final, 2008/0242 (COD).

765 Amended proposal for a Regulation of the European Parliament and of the Council on the establishment of 'Eurodac' for the comparison of fingerprints for the effective application of Regulation (EU) No [.../...] (establishing the criteria and mechanisms for determining the Member State responsible for examining an application for international protection lodged in one of the Member States by a third-country national or a stateless person) and to request comparisons with EURODAC data by Member States' law enforcement authorities and Europol for law enforcement purposes and amending Regulation (EU) No 1077/2011 establishing a European Agency for the operational management of large-scale IT systems in the area of freedom, security and justice (Recast version), Brussels, 30.5.2012, COM(2012 254 final, 2008/0242 (COD).

766 Council Decision of 21 February 2006 on the conclusion of the Agreement between the European Community and the Kingdom of Denmark extending to Denmark the provisions of Council Regulation (EC) No 343/2003 establishing the criteria and mechanisms for determining the Member State responsible for examining an asylum application lodged in one of the Member States by a third-country national and Council Regulation (EC) No 2725/2000 concerning the establishment of 'Eurodac' for the comparison of fingerprints for the effective application of the Dublin Convention, OJ L 66/37, 8.3.2006.

${ }^{767}$ Lavenex, S., The Europeanisation of Refugee Policies, between human rights and internal security, Ashgate Publishing, 2001, p. 117.

768 Article 9 of the recast Eurodac Regulation.

769 Article 14 of the recast Eurodac Regulation. 
compare the fingerprints of an alien found illegally present within its territory in order to check whether he or she has previously applied for asylum in another Member State. ${ }^{770}$ In recent years, several Member States have experienced asylum applicants refusing to give their fingerprints.

In order to convince the applicant to be fingerprinted, Member States may inform the applicant of the obligation to provide their fingerprints in every Member State where he or she applies for asylum. Where the applicant still refuses to co-operate with the authorities, Member States may consider the applicant an irregular migrant and detain the person or examine the application in an accelerated procedure under Article 31(8) of the Asylum Procedures Directive. As a last resort, Member States may use physical coercion. ${ }^{711}$ A questionnaire among Member States revealed that a majority of Member States do not use physical coercion on asylum applicants to be fingerprinted. With regard to irregular migrants who avoid being fingerprinted, several Member States either use coercion or detention. ${ }^{772}$

As to the infrastructure of the Dublin system, several Member States have had to set up separate units that are responsible for the practical application of the Dublin Regulation. The rules on the transmission of data, comparisons and transmitting results and the communication between Member States and the Central Unit are regulated in the implementation rules of the Eurodac Regulation. ${ }^{773}$ The Central Unit has to "carry out comparisons in the order of arrival of requests. Each request must be dealt with within 24 hours. ${ }^{774}$ Member States are allowed to store data of fingerprints for eighteen months. ${ }^{775}$ Under the former Eurodac Regulation this used to be up to two years.

A new controversial provision adopted in the Eurodac Regulation allows 'designated authorities' to have access to the database for law enforcement purposes. ${ }^{776}$ Such designated authorities may request access in the Central System in order to compare finger print data. Access is permitted only if there is no 'hit' in the national fingerprint or other Member States' databases or no 'hit' in the Visa Information System database.

770 Article 17 of the recast Eurodac Regulation.

771 European Commission Staff Working Document on Implementation of the Eurodac Regulation as regards the obligation to take fingerprints, Brussels, 27.5.2015, SWD(2015) 150 final, pp. 3-5.

772 European Migration Network, Ad-Hoc Query on Eurodac fingerprinting, 2014.

773 Council Regulation (EC) No 407/2002 of 28 February 2002 laying down certain rules to implement Regulation (EC) No 2725/2000 concerning the establishment of 'Eurodac' for the comparison of fingerprints for the effective application of the Dublin Convention, OJ L 62/1, 5 March 2002.

774 Article 3(2) of the Eurodac Implementing Regulation.

775 Article 16 of the recast Eurodac Regulation.

776 Article 20 of the recast Eurodac Regulation. 
The second condition to access the Eurodac database is where the comparison is relevant for the purpose of 'the prevention, detection or investigation of terrorist offences or of other serious criminal offences' or the comparison is needed 'in a specific case' and 'there are reasonable grounds to consider that the comparison will substantially contribute to the prevention, detection or investigation of any of the criminal offences in question. ${ }^{1777}$ The UNHCR 778 and the Meijers Committee, ${ }^{779}$ as well as other human rights organizations, strongly disapproved the adoption of this provision by the EU co-legislators.

\subsection{Commission proposal Eurodac Regulation}

The Commission proposal to recast the Eurodac Regulation is not only an instrument to support the effective implementation of the Dublin system, but also serves for broader immigration purposes.

The legal basis of this proposal is Article 78(2)(e) TFEU. As regards other aspects of this proposal, such as identifying irregular third-country nationals in connection with irregular residence and the return of those persons, the proposal uses Article 79(2)(c) TFEU as a legal basis. With regard to the use of information for the purposes of law enforcement, the legal basis is Article 87(2)(a). Furthermore, Article 88(2)(a) TFEU is used as a legal basis for the role and access of Europol to Eurodac.

This proposal further expands the scope of the current Eurodac Regulation. There is an obligation for Member States to take biometric identifiers (facial image), in addition to the mandatory fingerprinting, of third-country nationals of at least six years of age $\mathrm{e}^{780}$ who are found irregularly crossing the border or who are staying irregularly on the territory of a Member State. By adding the facial image data, the Commission aims to solve the challenge that some of the Member States are facing with individual who mutilate their fingertips in order to prevent identification.

Unlike the current Eurodac Regulation, this new proposal will also store age, place and date of birth, sex, nationality, and identity documents, including a data comparison and transmission of fingerprints and facial images. This proposal also allows Member States to sanction individuals that refuse to be fingerprinted or to provide a facial image.

Further new elements include a contentious provision that allows in exceptional circumstances Member States to share data with third countries for the

777 Jones, C., 11 years of Eurodac, Statewatch Analysis, January 2014, pp. 3-4.

778 UNHCR, An efficient and protective Eurodac, November 2012, Brussels.

779 Note Meijers Committee on the EURODAC proposal (COM(2012) 254), 10 October 2012.

780 Currently the age for fingerprints is set at 14 years of age. 
purpose of return. Several organizations have expressed their concern in relation to this derogation and pointed out the risk of sensitive data of individuals who have fled from persecution or serious harm being shared with countries of origin or other third countries. ${ }^{781}$ Finally, this proposal allows experts of the newly established European Border and Coast Guard Agency to take and transmit fingerprints..$^{782}$

\subsection{Analysis}

The recast legislative acts of the CEAS discussed in this chapter show various shortcomings and challenges. First of all, it is important to note that the adoption of the Qualification Directive has been a significant accomplishment in the EU. The adoption was an important first step in the further convergence of national asylum practices regarding the qualification for refugee status or who qualifies for beneficiary of subsidiary protection status. However, the implementation of the former 2004 Qualification Directive by Member States has shown various incomplete and or incorrect national implementing measures on a broad range of issues. ${ }^{783}$ The current recast Qualification Directive has undergone important changes and represents better compliance with international refugee and human rights standards. The Directive is also more in line with the jurisprudence of the European courts.

781 ECRE, Comments on the Commission Proposal to recast the Eurodac Regulation COM(2016) 272, July 2016, p. 16; Fundamental Rights Agency, The impact of the proposal for a revised Eurodac Regulation on fundamental rights, Opinion of the European Union Agency for Fundamental Rights, 22 December 2016, p. 7; Meijers Committee, CM1609, Note on the proposed reforms of the Dublin Regulation(COM (2016) 197), the Eurodac recast proposal (COM (2016) 272 final), and the proposal for an EU Asylum Agency (COM(2016)271 final), p. 7.

782 European Commission, Proposal for a Regulation of the European Parliament and of the Council on the establishment of 'Eurodac' for the comparison of fingerprints for the effective application of [Regulation (EU) No 604/2013 establishing the criteria and mechanisms for determining the Member State responsible for examining an application for international protection lodged in one of the Member States by a third-country national or a stateless person], for identifying an illegally staying third-country national or stateless person and on requests for the comparison with Eurodac data by Member States' law enforcement authorities and Europol for law enforcement purposes (recast), Brussels, 4.5.2016, COM(2016) 272 final, 2016/0132 (COD), pp. 11-15.

783 European Commission, Report from the Commission to the European Parliament and the Council on the application of Directive 2004/83/EC of 29 April 2004 on minimum standards for the qualification and status of third country nationals or stateless persons as refugees or as persons who otherwise need international protection and the content of the protection, Brussels, 16.6.2010, COM(2010)314 final, p.15. UNHCR Report, Asylum in the European Union, A study of the implementation of the Qualification Directive, 2007. 
Despite these improvements, the current Directive remains challenging for Member States. This chapter has identified the following shortcomings: the assessment of international protection and the interpretation of Article 15(c) of the recast Qualification Directive differ significantly between Member States. ${ }^{784}$ It has been submitted that in practice Member States differ in their assessment of the various elements to consider a 15(c) situation in a certain country. Furthermore, Member States differ in the implementation of how facts and circumstances are examined, the examination of 'sur place' applications and the application of cessation clauses, including the credibility assessment. ${ }^{785}$ On a positive note, in comparison to the 2004 Qualification Directive, the current Directive has enhanced the position of beneficiaries of subsidiary protection and limited the discretion allowed to Member States. Most rights and benefits granted to refugee status holders and persons holding the subsidiary protection status have been further approximated, except for residence permits and access to social assistance. 786

The recast Reception Conditions Directive includes a set of rules with regard to the accommodation, detention, health care and the reception of vulnerable asylum applicants with special reception needs. In comparison with the former Directive on reception conditions, the recast Reception Conditions Directive has improved standards. In particular, the waiting period to access employment has been reduced from twelve to nine months. Furthermore, the recast Directive enshrines clearer grounds for the detention of asylum applicants, including more guarantees and safeguards with respect to the detention of vulnerable asylum applicants. ${ }^{787}$ In addition, there have been more detailed rules regarding the assessment of the special reception needs of vulnerable asylum applicants. Despite these improvements in standards, harmonizing reception

784 See Wagner, M., Dimitriadi, A., O'Donell, R., Perumadan, J., Schlotzhauer, J. H., Simic, I., \& Yabasun, D. (2016), The implementation of the Common European asylum system. Brussels: European Parliament, pp. 71-74.

785 Proposal for a Regulation of the European Parliament and of the Council on standards for the qualification of third-country nationals or stateless persons as beneficiaries of international protection, for a uniform status for refugees or for persons eligible for subsidiary protection and for the content of the protection granted and amending Council Directive 2003/109/EC of 25 November 2003 concerning the status of third-country nationals who are long-term residents, Brussels, 13.7.2016, $\operatorname{COM}(2016) 466$ final 2016/0223 (COD), pp. 4-9.

786 Bauloz, C. and Ruiz, G., Refugee Status and Subsidiary Protection: Towards a Uniform Content of International Protection? De Bruycker, P., Chetail, V. and Maiani, F. (eds.), Reforming the Common European Asylum System: The New European Refugee Law, Brill Nijhoff, 2016, pp. 252-257.

787 Peers, S., The EU Asylum System: Challenges and Shortcomings, Mediterranean Yearbook 2014, p. 6. 
conditions in the EU remains a major challenge. The Directive still provides wide discretion as to what is considered an adequate standard of living and how it should be organized. Hence, reception conditions greatly differ between Member States. 788 In addition, due to the increased migration flows to the EU in recent years, several Member States have not been able to provide accommodation that guarantees an adequate standard of living and protection of the physical and mental health of asylum applicants during the procedure. ${ }^{789}$ At the same time, some Member States have proposed laws and policies to reduce the material reception conditions in order to make the country less attractive to asylum applicants. ${ }^{790}$ The shortcomings related to the recast Reception Conditions Directive are also related to the poor implementation by Member States. Studies have shown the significant divergences in the implementation of the Directive. 791

Compared to the former 2005 Asylum Procedures Directive, the current recast Asylum Procedures Directive has set important safeguards and reduced the number of possibilities for to Member States for applying accelerated procedures. However, the current legislative act still grants Member States wide discretion. It remains a complex piece of legislation, which may be interpreted differently and is very challenging to implement in practice.

Despite the fact that the recast Dublin III Regulation has made improvements compared to its predecessor Dublin II Regulation, it is widely accepted that the Dublin system does not function in practice. ${ }^{792}$ Generally, there are

788 EASO, Annual report on the situation of asylum in the European Union 2016, 5 July 2017, p. 104.

789 Wagner, M., Dimitriadi, A., O'Donell, R., Perumadan, J., Schlotzhauer, J. H., Simic, I., \& Yabasun, D. (2016), The implementation of the Common European asylum system. Brussels: European Parliament, pp. 84-85.

790 Wagner, M., Dimitriadi, A., O'Donell, R., Perumadan, J., Schlotzhauer, J. H., Simic, I., \& Yabasun, D. (2016), The implementation of the Common European asylum system. Brussels: European Parliament, p. 42.

791 Wagner, M., Dimitriadi, A., O'Donell, R., Perumadan, J., Schlotzhauer, J. H., Simic, I., \& Yabasun, D. (2016), The implementation of the Common European asylum system. Brussels: European Parliament; ECRE Asylum Information Database, Wrong counts and closing doors, the reception of refugees and asylum seekers in Europe, 2016; European Migration Network (EMN), Synthesis Report, The Organisation of Reception Facilities for Asylum Seekers in different Member States, 2014.

792 Wagner, M., Dimitriadi, A., O'Donell, R., Perumadan, J., Schlotzhauer, J. H., Simic, I., \& Yabasun, D., (2016), The implementation of the Common European asylum system. Brussels: European Parliament; Maiani, F., (2016), The Reform of the Dublin III Regulation, European Parliament, Brussels; and Guild, E., Costello, C., Garlick, M., Moreno-Lax, V., Mouzourakis, M., with the participation of Carrera, S., (2014) New approaches, alternative avenues and means of access to asylum procedures for persons seeking international protection, European Parliament, Brussels. 
various reasons why the system is considered to be a failure. The first and most used argument is the criterion that requires the first Member State that an asylum applicant irregularly enters, is responsible for examining the application. This standard creates an uneven burden on Member States with weaker asylum systems and that are located at the external borders of the Union, most notably Greece and Italy. Second, Dublin procedures may lead to a disruption of family unity. Although the family criteria are high on the list of the Dublin hierarchy, research has revealed that these procedures are not implemented consistently or correctly. ${ }^{793}$ There is a widespread problem across Member States when it comes to the consistent and correct implementation of Dublin rules. Third, the aim of the Dublin Regulation is to swiftly determine the responsible Member State, however, practice has shown that Member States fail to respect the time limits stipulated by the Regulation. In the case of 'take back' requests, applicants may have to wait up to ten months or eleven months in cases of 'take charge' requests. 794 Apart from these flaws, the effectiveness of the Dublin system is also very much dependent on adequate reception conditions, efficient asylum procedures and the integration prospects in a certain Member State. For example, applicants who have submitted their first asylum application in Italy often migrate further to other Member States where they submit a second application because of the poor reception conditions and integration possibilities in Italy. 795 It has been submitted that in M.S.S. and in N.S. it was concluded that there are flaws in the reception conditions in Greece. Following these judgments, Member States have suspended transfers of asylum applicants under the Dublin system to Greece. More recently, it also has been submitted that the CJEU has held that asylum applicants and beneficiaries of international protection should not be transferred to the Member State, which is responsible for examining the asylum application, where the living conditions would expose the applicant to a substantial risk of suffering inhuman or degrading treatment. However, the CJEU interpreted that to fall within the scope of Article 4 of the Charter, a particularly high level of severity must be attained. Such a high level of severity is met where the applicant, given his vulnerability, would find himself in situation of extreme material poverty. In other words, the applicant

793 Fratzke, S., Not Adding Up: The fading promise of Europe's Dublin System, Migration Policy Institute, March 2015, p. 17.

794 European Commission, Proposal for a Regulation of the European Parliament and of the Council establishing the criteria and mechanisms for determining the Member State responsible for examining an application for international protection lodged in one of the Member States by a third-country national or a stateless person (recast), Brussels, 4.5.2016, COM(2016) 270 final, 2016/0133 (COD), p. 9.

795 Fratzke, S., Not Adding Up: The fading promise of Europe's Dublin System, Migration Policy Institute, March 2015, p. 15. 
would not have access to the most basic needs (food, bath and adequate accommodation). It is important to note that the situation is the result of the indifference of the national authorities. ${ }^{796}$

The Eurodac system has since its inception provided Member States with fingerprints of asylum applicants in order to implement the Dublin Regulation. The Eurodac Regulation has also served the purpose of providing Member States with the fingerprints of persons who are apprehended in relation to an irregular crossing of an external border or to check the fingerprints of thirdcountry nationals found illegally residing in a Member State. Gradually, the scope of the Eurodac Regulation has been expanded to allow law enforcement in Member States and Europol to compare fingerprints in relation to criminal investigations with those stored in the Eurodac database. Two issues remain problematic with regard to the implementation of the Eurodac Regulation. Member States are confronted with asylum applicants who aim to obstruct the mandatory fingerprinting by means of mutilating their fingertips in order to avoid identification. ${ }^{797}$ At the same time, there are border Member States who due to the high migratory flows and the already poor asylum systems do not register these asylum applicants in order to prevent responsibility for examining the asylum applications. ${ }^{798}$

Finally, the Commission reform proposals provide a number of positive developments. Nevertheless, in my view, several aspects that are submitted by the Commission could seriously undermine the rights of asylum applicants and beneficiaries of international protection. A striking example is the proposal Qualification Regulation that introduces measures resulting in a further divergence between refugee status holders and beneficiaries of subsidiary protection. If the proposal is adopted, it will reduce the discretion given to Member States, which may provide for more convergence in the asylum decisions, nevertheless it contributes to a weaker protection regime, a further divergence between the two protection statuses and also has implications for the integration of beneficiaries of international protection. ${ }^{799}$ Another notable issue concerns the Commission proposal with regard to the reform of the Dublin Regulation. The crucial question is whether the Commission proposal will genuinely correct

796 Case C-163/17, Abubacarr Jawo v Bundesrepublik Deutschland, 19 March 2019, Court of Justice of the European Union, ECLI:EU:C:2019:218, para. 90.

797 Garlick, M., The Dublin System, Solidarity and Individual Rights, De Bruycker, P., Chetail, V. and Maiani, F. (eds.), Reforming the Common European Asylum System: The New European Refugee Law, Brill Nijhoff, 2016, p. 178.

798 Battjes, H., Brouwer, E., Slingenberg, L. and Spijkerboer, T., The Crisis of European Refugee Law: Lessons from Lake Success, Preadvies Christen Juristen Vereniging, 2016, p. 9.

799 See Yabasun, D., Hervorming Europees asielbeleid: Commissievoorstel Kwalificatieverordening, Journaal Vreemdelingenrecht, no. 3, 2016. 
these chronic deficits of the Dublin system to establish a fair distribution of beneficiaries of international protection in Europe. The foregoing paragraphs have shown that the current Dublin system does not work. The Commission proposal maintains the disputed 'irregularly entry' criterion, which most likely will continue to put the frontline Member States under heavy pressure. The proposal is still based on the flawed presumption that all Member States equally implement protection standards. Hence, in my view, the Dublin system remains unchanged and will continue to be unfair and inefficient.

\subsection{Concluding remarks}

This chapter has examined the CEAS legislative acts and discussed its most relevant provisions. Compared to the first-phase CEAS legislation, the legal standards enshrined in the recast CEAS legislative acts show an improvement. Nevertheless, the evidence reviewed above suggests that the CEAS still suffers from a number of key shortcomings that resulted in notable differences between the Member States in the implementation of reception conditions, recognition rates and procedures on asylum. It has been submitted that the reasons underlying for these outstanding differences are, inter alia, due to the wide discretion allowed for Member States to interpret and implement the CEAS standards, but also because of the various derogation clauses and concepts that are too broad or too vague, which also lead to arbitrary outcomes. These issues are problematic from the perspective of establishing common standards for a fair and efficient asylum procedure. This chapter has also shown that Member States have different approaches as to the interpretation and application of standards and concepts laid down in the CEAS. It has been further submitted that the Commission has proposed a regulation to overhaul the recast CEAS (except for the reception standards). This chapter has argued that the CEAS reform proposals show an ambiguous approach by the Commission in its objective to establish a 'truly common procedure for international protection which is efficient, fair and balanced'. The choice for a regulation could to a limited extent achieve a more uniform application of asylum standards. However, as suggested above, there seems to be an incoherent conceptual understanding between Member States of the standards and concepts in the CEAS. Moreover, it has been submitted that the Commission proposals, if adopted, would seriously jeopardize the rights of asylum applicants and not reduce the divergent practices in Member States. In view of the previous considerations, and also given the lack of solidarity of responsibility sharing for refugees between Member States in the context of the 'refugee crisis', a future system on asylum that is coherent in the interpretation and application of protection standards could, in my view, 
work when Member States fully transfer their national competences on asylum to the EU level.

The next chapter examines how the EU has conceptualized the notion of vulnerability in the context of asylum. I will also assess the legal standards stemming from the recast CEAS legislative acts with regard to vulnerable asylum applicants, including the relevant legal standards with regard to victims of torture and unaccompanied minors. 


\section{6- Vulnerable asylum applicants in the Common European Asylum System}

\subsection{Introduction}

In the previous chapters, I have discussed the notion of vulnerability under international human rights law. I have examined the obligations that stem from international human rights law with regard to victims of torture and unaccompanied minors.

This chapter is divided in two parts. In the first part, I discuss the notion of vulnerability in the context of the CEAS. I examine the legal standards that stem from the recast CEAS legislative acts with regard to vulnerable asylum applicants. I have explained in the introduction chapter that Article 21 of the recast Reception Conditions Directive provides the general principle with regard to vulnerable persons. Hence, it is essential to examine the recast Reception Conditions Directive and to determine what special guarantees are owed to vulnerable asylum applicants in terms of reception. The notion of vulnerability in the context of asylum gives rise to a number of questions: who is presumed to be vulnerable and what makes them vulnerable in the context of asylum, and how to identify vulnerable asylum applicants? In addition, what are the legal implications of being identified as vulnerable in the context of the CEAS?

The second part of this chapter examines the legal standards that stem from the CEAS with regard to victims of torture and unaccompanied minors. The last section of this chapter will compare these legal standards with the obligations that stem from international human rights law. As I have submitted in chapter 1, it follows from Article 78(1) TFEU that the CEAS should be in accordance with the Refugee Convention and other international human rights law instruments. As a result, the legal instruments of the CEAS should be interpreted in conformity with the Refugee Convention and other international human rights treaties. 800 Moreover, the Preambles of the legal instruments of the CEAS stipulate 'the full and inclusive application of the Geneva Convention Relating to the Status of Refugees of 28 July 1951, as amended by the New York Protocol of 31 January 1967' and 'Member States are bound by obligations under instruments of international law to which they are party'. Battjes has submitted that the Refugee Convention and other relevant treaties form a direct standard of review. ${ }^{801}$ Additionally, where a legal standard enshrined in

800 Case C-199/12 to C-201/12, X, Y, and Z v Minister voor Immigratie en Asiel, 7 November 2013, Court of Justice of the European Union, ECLI:EU:C:2013:720, para. 40.

801 Battjes, H., European Asylum Law and International Law, Martinus Nijhoff Publishers, 2006, pp. 98-105. 
the CEAS legal instruments conflicts with obligations stemming from international law, conciliatory interpretation may provide a solution. Article 30(2) VCLT stipulates: 'When a treaty specifies that it is subject to, or that it is not to be considered as incompatible with, an earlier or later treaty, the provisions of that other treaty prevail." This means that when there is a conflict between the obligations stemming from international law and the legal standards as laid down in the CEAS, international law obligations prevail. In comparing the legal standards with obligations stemming from international human rights law, I will apply the following method: I will examine whether the legal standards impede Member States to comply with their obligations under international human rights law. Where necessary I will suggest interpretations in conformity with international human rights law. 802

Before moving on to the analysis of the recast Reception Conditions Directive, in the next section, I will first examine the legal standards laid down in the 2003 Reception Conditions Directive with regard to vulnerable asylum applicants and determine the differences from the current recast Reception Conditions Directive.

\subsection{The Reception Conditions Directive 2003/9/EC and vulnerability}

Article 17 of the 2003 Reception Conditions Directive required Member States 'to take into account the specific situation of vulnerable persons' in their national legislation when they implement the provisions related to the material reception conditions and health care of Chapter II (Articles 13, 14, and 15) of the Directive, and 'only apply to persons found to have special needs after an individual evaluation of their situation'. Thus, the first step by Member States was to identify whether the asylum applicant is a 'vulnerable person' and the second step is to verify whether the vulnerable asylum applicant has special needs. In order to benefit from the special guarantees in the Directive, identification of vulnerabilities is key. However, the weakness of the 2003 Reception Conditions Directive was that it lacked an explicit legal obligation to establish a procedure to identify the special needs of applicants, which resulted in a poor implementation at the national level. The implementation gaps with regard to vulnerable applicants were raised in the Green Paper on the future of the CEAS. It was addressed to take adequate action 'to situations of vulnerability'. The Commission Green Paper on the future of the CEAS concluded: 803

802 Battjes, H., European Asylum Law and International Law, Martinus Nijhoff Publishers, 2006, p. 168. Slingenberg, L., The reception of asylum seekers under international law - Between sovereignty and Equality, Hart Publishing, 2014, p. 384.

803 Green Paper on the future Common European Asylum System, COM (2007)301 final', 6.6.2007, para. 2.4.1, p. 7. 
'All first stage instruments underline that it is imperative to take account of the special needs of vulnerable people. However, it appears that serious inadequacies exist with regard to the definitions and procedures applied by Member States for the identification of more vulnerable asylum seekers and that Member States lack the necessary resources, capacities and expertise to provide an appropriate response to such needs. It appears therefore necessary to prescribe in more depth and detail the ways in which the special needs of the most vulnerable asylum seekers should be identified and addressed in all stages of the asylum process. This kind of comprehensive approach would focus in particular on issues such as regulating more precisely what constitutes adequate medical and psychological assistance and counselling for traumatised persons, victims of torture and trafficking and a proper identification and response to the needs of minors, especially unaccompanied minors'.

Following the Green Paper of the Commission, the matter of vulnerable persons with special needs was once more discussed in the implementation report.

The Commission raised serious concerns in its implementation report of the 2003 Reception Conditions Directive with regard to the shortcomings related to vulnerable asylum applicants in the national systems of Member States. ${ }^{804}$ Shortcomings were identified in the definition of vulnerable groups and addressing the needs of vulnerable asylum applicants has been one of the main shortcomings. In particular, the lack of adequate rehabilitation facilities was a major shortcoming. Serious problems were detected with regard to (unaccompanied) minors with special needs. Moreover, the detention of vulnerable asylum applicants with special needs appeared to be problematic. 805

Furthermore, the implementation of the 2003 Reception Conditions Directive revealed for instance that several Member States have not integrated an identification procedure in their national law with regard to vulnerable applicants with special needs. ${ }^{806}$ Earlier studies have also pointed this out. ${ }^{807}$ The view of the Commission was, however, slightly confusing when it concerned

804 European Commission, Report from the Commission to the Council and to the European Parliament on the application of Directive 2003/9/EC of 27 January 2003 laying down minimum standards for the reception of asylum seekers, Brussels, 26.11.2007, $\operatorname{COM}(2007) 745$ final.

805 European Commission, Report from the Commission to the Council and to the European Parliament on the application of Directive 2003/9/EC of 27 January 2003, laying down minimum standards for the reception of asylum seekers, Brussels 26 November 2007, $\operatorname{COM}(2007) 745$ final, paras. 3.5.1. - 3.5.2.

806 UK, DE, AT, BE, LU, EL, IT, SK, SI.

807 De Bruycker, P. and De Bauche, L., Odysseus Academic Network, Study on the conformity checking of the transposition by Member States of 10 EC Directives in the sector of asylum and immigration done for DG JLS of the European Commission, Directive 2003/09 on Reception Conditions, Synthesis Report, 2007. 
the interpretation of the Directive. On the one hand, the Commission stated that Member States are under the obligation to identify applicants with special reception needs. On the other hand, the Commission stipulated that it is not 'literally an obligation'. 808

\subsubsection{Addressing the needs of vulnerable asylum applicants}

A key issue was the lack of expertise at the national level to identify the special needs of the most vulnerable asylum applicants. 809 The response of the UNHCR and some of the NGOs on this specific issue was quite clear. Vulnerable persons should in principle be exempted from border procedures and not put through accelerated asylum procedures. In addition, better mechanisms to identify vulnerable persons should be in place and in addition vulnerable persons should not be detained. 810

The first Commission recast proposal in 2008 underlined the shortcomings with regard to persons with special needs as the most serious concern in the field of reception of asylum applicants and pointed out the cases of vulnerable asylum seekers in detention, for instance the detention of minors and unaccompanied minors. 811

As well in the Council there was more attention to vulnerable persons. The Council acknowledged in the multi-annual Stockholm Programme (20092014) that vulnerable persons are 'in need of greater protection'. Especially,

808 European Commission, Report from the Commission to the Council and to the European Parliament on the application of Directive 2003/9/EC of 27 January 2003, laying down minimum standards for the reception of asylum seekers, Brussels 26 November 2007, $\operatorname{COM}(2007) 745$ final, para. 3.5.1.

809 Green Paper on the future of the Common European Asylum System, presented by the European Commission, Brussels, 6.6.2007 COM(2007) 301 final, p. 7.

810 See UNHCR, Response to the European Commission's Green Paper on the Future Common European Asylum System, September 2007, p. 16; Amnesty International EU Office, Response to the European Commission's Green Paper on the future of the Common European Asylum System - COM (2007) 301 final, p. 21; European Women's Lobby, Contribution from the European Women's Lobby to the European Commission's Green Paper on the future Common Asylum System COM(2007) 301 final, pp. 6-8; Caritas Europa, CCME Churches' Commission for Migrants in Europe, COMECE - Commission of the Bishops' Conferences of the European Community, ICMC - International Catholic Migration Commission, JRS-Europe - Jesuit Refugee Service Europe QCEA - Quaker Council for European Affairs, Comments on the European Commission's Green Paper on the future Common European Asylum System COM (2007) 301 final, August 2007, pp. 10-11; and Comments by the International Rehabilitation Council for Torture Victims (IRCT), the Green Paper on the future Common European Asylum System, July 2007, pp. 4-6.

811 European Commission, Proposal for a Directive of the European Parliament and of the Council laying down minimum standards for the reception of asylum seekers (recast), Brussels, 3.12. 2008, COM(2008) 815 final, 2008/0244 (COD), p. 6. 
unaccompanied minors represented a particularly vulnerable group. ${ }^{812}$ During the Belgian Presidency in 2010, a Ministerial Conference on asylum with a special focus on vulnerable asylum applicants was organized. The outcome of this meeting stipulated, inter alia, that the 2008 legislative proposal to recast the Reception Conditions Directive required Member States to establish a mechanism in order to identify vulnerable asylum applicants with special needs. The question that was raised was how to assess the vulnerability and special needs of an asylum applicant. The Ministerial Conference pointed out that the $2003 \mathrm{Re}-$ ception Conditions Directive focused more on vulnerable asylum applicants while the recast legislative proposal on the Reception Conditions Directive takes into account the special needs. ${ }^{813}$ The novel approach on vulnerable persons with special needs established a new conceptual issue, namely which vulnerable persons and what kind of special reception needs should be covered by the recast Reception Conditions Directive. 814

In 2011, the Commission modified once again its recast legislative proposal on the Reception Conditions Directive. The Commission proposal mentioned this time that the lack of proper identification mechanisms of applicants with special reception needs not only affects 'access to appropriate treatment', but also the 'quality of the decision-making process.' By introducing the modified proposal, the Commission aimed to guarantee that national authorities establish prompt identification procedures with regard to the special reception needs of vulnerable persons. Moreover, more focus has been put on the special needs of particularly vulnerable persons by introducing a clearer relationship between vulnerable persons and persons with special needs. 815

The UNHCR responded positively to the 2011 Commission proposal to include several other applicants in the list of vulnerable persons. If the provisions on the identification of vulnerable persons with special reception needs are adequately implemented by Member States, may solve the shortcomings that have been identified in the implementation of the Reception Conditions Directive. According to the UNHCR, 'early identification of vulnerability and special

812 2009 Stockholm Programme, paras. 2.3.3. and 6.1.7.

813 Article 17 of the 2003 Reception Conditions Directive is entitled 'Provisions for persons with special needs' and the new Article 21 of the recast Reception Conditions Directive is entitled 'Provisions for vulnerable persons'.

814 Debauche-Discart, L., Asylum seekers with special needs, Ministerial Conference $<<$ Quality and Efficiency in the Asylum Process >>, 13-14 September 2010, pp. 3-4.

815 Amended proposal for a Directive of the European Parliament and of the Council laying down standards for the reception of asylum seekers (recast), Brussels, 1 June 2011, $\operatorname{COM}(2011) 320$ final, 2008/0244 (COD), p. 7. 
needs, at the earliest practicable stage, could be critical to the quality of the asylum determination.' 816

The discussion on the 2003 Reception Conditions Directive and vulnerable persons shows that notion of vulnerability is linked to special needs. Hence, only applicants with special needs are considered vulnerable. Another important issue to note is that the 2003 Reception Conditions Directive lacked an explicit obligation for Member States to establish a procedure for identifying vulnerable applicants, which resulted in implementation deficiencies. In addition, serious problems were identified at the national level concerning the detention of vulnerable applicants with special needs.

\subsection{Vulnerable asylum applicants in the Common European Asylum System: What are the relevant instruments and legal standards?}

In the following sections, I examine the legal standards that stem from the recast CEAS legislative acts with regard to vulnerable asylum applicants.

\subsection{Reception Conditions Directive 2013/33/EU (recast): Vulner- able asylum applicants with special reception needs}

The relevant provisions with respect to vulnerable persons in the EU asylum context have been enshrined in the recast Reception Conditions Directive. Article 2(k) defines an applicant with special reception needs as 'a vulnerable person who is in need of special guarantees in order to benefit from the rights and comply with the obligations provided for in this Directive.' The Directive explicitly mentions in Recital 14 that applicants with special reception needs should be 'a primary concern' for Member States in order to guarantee that reception conditions are adapted to meet their special needs. Article 21 of the recast Reception Conditions Directive obliges Member States 'to take into account the specific situation of vulnerable persons'. The provision does not provide a definition of vulnerability. It only presents a non-exhaustive list of persons who are considered vulnerable.

Table 6.1. Persons considered vulnerable enshrined in Article 21 of the recast Reception Conditions Directive (non-exhaustive)

\begin{tabular}{|l|}
\hline$>$ Minors \\
\hline$>$ Unaccompanied minors \\
\hline$>$ Disabled people \\
\hline
\end{tabular}

816 UNHCR, Comments on the European Commission's amended recast proposal for a Directive of the European Parliament and the Council laying down for the reception of asylum-seekers, Brussels, 2012, p. 16. 


\begin{tabular}{|l|}
\hline$>$ Elderly people \\
\hline$>$ Pregnant women \\
\hline$>$ Single parents with minor children \\
\hline$>$ Victims of human trafficking \\
\hline$>$ Persons with a mental disorder \\
\hline$>$ Persons who have been subjected to torture or other serious forms of psy- \\
chological, physical or sexual violence \\
\hline$>$ Victims of female genital mutilation \\
\hline
\end{tabular}

Compared to Article 17 of the 2003 Reception Conditions Directive, three new categories of vulnerable persons have been added to the non-exhaustive list, namely victims of human trafficking, persons with serious illnesses and persons with mental disorders. Article 21 further stipulates victims of female genital mutilation as an example of a person who has been subjected to physical or sexual violence.

Another change from the former Directive to note is that Article 21 of the recast Directive extends the obligation for the Member States to 'take into account the specific situation of vulnerable persons' when they implement the Directive, rather than only referring to the provisions of Chapter II relating to material reception conditions and healthcare. Peek and Tsourdi claim that Article 21 requires Member States to set a standard on vulnerable applicants in their national formal legislation and that it should not be dealt with by implementing authorities or through circulars. 817

The Return Directive ${ }^{818}$ also presents a list of vulnerable persons. It follows that, unlike the recast Reception Conditions Directive, the list of vulnerable persons presented in Article 3(9) of the Return Directive is exhaustive. Member States should, however, not limit themselves to the list of vulnerable persons explicitly enshrined in Article 3(9) when they deal with vulnerable persons with special needs in the context of return procedures. ${ }^{819}$ The Return Directive further requires the special needs of vulnerable persons to be taken into account pending the return 820 and to pay particular attention to the situation of vulnerable persons in detention, including providing emergency health care and essential treatment of illness. ${ }^{821}$

817 Peek, M. and Tsourdi, L., Asylum Reception Conditions Directive 2013/33/EU in Kay Hailbronner and Daniel Thym (eds.), EU Immigration and Asylum Law, Commentary, $2^{\text {nd }}$ edition (C.H. BECK/Hart/Nomos, 2016), p. 1460.

818 Directive 2008/115/EC of the European Parliament and of the Council of 16 December 2008 on common standards and procedures in Member States for returning illegally staying third-country nationals, OJ L 348/98.

819 European Commission Return Handbook, 2017, p. 13.

820 Article 14(1)(d) of the Return Directive.

821 Article 16(3) of the Return Directive. 


\subsubsection{Establishing a link between vulnerability and special reception needs}

Article 21 of the recast Reception Conditions Directive has to be read in conjunction with Article 22. Article 22 of the recast Reception Conditions Directive establishes several legal obligations for Member States. The first obligation is that Member States have to assess the special reception needs of vulnerable asylum applicants. This assessment should not necessarily be an administrative procedure. It follows from the Council discussions during the negotiations of the recast Reception Conditions Directive that a few Member States were worried about the proposed identification mechanism in Article 22(1) of the modified 2011 Commission proposal. The Commission proposed as following:

'Member States shall establish mechanisms with a view to identifying whether the applicant is a vulnerable person and, if so, has special reception needs, also indicating the nature of such needs. Those mechanisms shall be initiated within a reasonable time after an application for international protection is made. Member States shall ensure that these special reception needs are also addressed, in accordance with the provisions of the Directive, if they become apparent at a later stage in the asylum procedure.'

The text establishes a clear obligation to adopt mechanisms to identify whether the applicant is a vulnerable person and secondly whether the applicant has special reception needs. Member States considered the implementation of such a procedure as costly and an additional administrative burden. In order to meet the wishes of Member States, the Council Presidency proposed therefore that Member States should 'assess' vulnerable applicants as to whether they have special reception needs and not examine whether all asylum applicants are vulnerable. ${ }^{822}$ The final adopted text of Article 22 does not explicitly stipulate that Member States have to identify whether an applicant is a vulnerable person. Peek and Tsourdi argue that an implicit obligation exists. 823

\subsubsection{Assessment procedure of vulnerable asylum applicants in need of special reception guarantees}

It follows from the current text of Article 22(1) of the recast Reception Conditions Directive that Member States should assess whether the applicant has special reception needs. Such an assessment is needed to effectively implement

822 Council of the European Union, Inter-institutional File: 2008/0244 (COD), Amended proposal for a Directive of the European Parliament and of the Council laying down standards for the reception of asylum seekers - Preparation for the first informal trilogue [First reading], 6942/12 ASILE 34 CODEC 491, Brussels 9 March 2012, p. 4.

823 Peek, M. and Tsourdi, L., Asylum Reception Conditions Directive 2013/33/EU in Kay Hailbronner and Daniel Thym (eds.), EU Immigration and Asylum Law, Commentary, $2^{\text {nd }}$ edition (C.H. BECK/Hart/Nomos, 2016), p. 1462. 
Article 21, which requires Member States to take into account the specific situation of vulnerable asylum applicants.

Second, it follows further from Article 22(1) that Member States have to 'indicate the nature of such needs' within a 'reasonable period of time' when the asylum application has been submitted, even if such special reception needs become evident in a later phase of the asylum procedure. It is not required for Member States to establish this assessment as an administrative procedure. ${ }^{824}$ Third, Member States must guarantee to provide support to applicants with special reception needs throughout the asylum procedure and to monitor their situation. The Directive does not mention what is 'a reasonable period of time' to start the assessment procedure nor does it provide a definition of what is meant by 'special needs'.

More significantly, Article 22(3) stipulates that 'only' applicants who have been identified as vulnerable may be considered to have special reception needs and to receive such assistance. Accordingly, the assessment procedure of an asylum applicant with special reception needs as regulated in Article 22(1) of the recast Reception Conditions Procedure is an imperative three-tier assessment: (1) the first important step is that Member States have to assess the "special reception needs' of vulnerable asylum applicants; (2) the second step is to 'indicate the nature of such needs'. This assessment must be performed within a reasonable period of time after an asylum application and may be integrated into existing national procedures; (3) and the third step is that Member States must ensure that the support provided to vulnerable applicants with special needs considers their special reception needs throughout the asylum procedure and to monitor their situation. 825

Recital 14 explicitly confirms that the reception of applicants with special needs should be a 'primary concern' of the Member States and that reception conditions should be adapted to their needs. Hence, as soon as the special needs are identified after an assessment, Member States are required to provide the necessary support to vulnerable asylum applicants that meet their special reception needs. As indicated above, former Article 17 of the 2003 Reception Conditions Directive did not explicitly impose an assessment procedure, which for this reason has led to weak minimum implementation measures by several Member States.

Finally, the recast Directive requires Member States to report to the Commission on how and when the authorities in general identify persons with special reception needs during the asylum procedure and what the result is. The Commission is in particular interested in the following vulnerable groups: un-

824 Article 22(2) of the recast Reception Conditions Directive.

825 Article 22(1) last paragraph. 
accompanied minors, victims of torture, rape or other serious forms of psychological, physical or sexual violence and victims of human trafficking. 826

It can be submitted that the recast Directive requires an assessment procedure of whether an applicant has special reception needs and only vulnerable applicants may be considered to have special reception needs and to benefit from the specific support that is granted by the Directive. ${ }^{827}$ Similar requirement can be found on the assessment whether an applicant is in need of special procedural guarantees. ${ }^{828}$ The recast Directive provides Member States with discretion of how they assess whether a vulnerable applicant has special reception needs. The implementation of such an assessment is crucial as it forms the key element in recognizing potential vulnerabilities and specific special needs. In some cases, vulnerabilities will be more easily detected than others. One of the main challenges of the implementation of the recast Reception Conditions Directive is therefore to put an efficient mechanism in place to identify vulnerable applicants with special needs. ${ }^{829}$ An inefficient identification tool or the lack of an identification mechanism may deprive a vulnerable asylum applicant with special needs from benefiting the special guarantees enshrined in the CEAS. Therefore, Member States should be pro-active in recognizing vulnerable asylum applicants and in identifying their special needs, and to monitor their situation throughout the asylum procedure.

\subsubsection{Methods of identifying vulnerable asylum applicants with special needs}

What is an efficient method to identify vulnerable applicants with special needs? Both the UNHCR 830 and EASO ${ }^{831}$ have created tools to identify vulnerable asylum applicants with special needs. EASO for example has developed standards and indicators in order to measure, inter alia, whether national reception systems adequately take into account the special needs of asylum applicants. The PROTECT Questionnaire is another method to detect whether an

826 Annex 1, para. 1, Directive 2013/33/EU of the European Parliament and of the Council of 26 June 2013 laying down standards for the reception of applicants for international protection (recast), OJ L 180/96.

827 See also the discussion in Jakuleviciene, L., Vulnerable Persons as a New Sub-Group of Asylum Seekers? De Bruycker, P., Chetail, V. and Maiani, F. (eds.), Reforming the Common European Asylum System: The New European Refugee Law, Brill Nijhoff, 2016, p. 364.

828 Article 24 of the recast Asylum Procedures Directive.

829 ECRE, Information Note on Directive 2013/33/EU of the European Parliament and of the Council of 26 June 2013 laying down standards for the reception of applicants for international protection (recast), 2015, p. 34 .

830 UNHCR and the IDC, Vulnerability Screening Tool, Identifying and addressing vulnerability: a tool for asylum and migration systems, 2016.

831 EASO, Guidance on reception conditions: operational standards and indicators, 2016. See also EASO tool for identification of persons with special needs: https://ipsn.easo. europa.eu/easo-tool-identification-persons-special-needs 
asylum applicant has signs of mental illnesses. It is especially designed for nonhealth professionals. ${ }^{832}$

Table 6.2. EASO tool to identify the special needs of asylum applicants

\begin{tabular}{|l|l|}
\hline Standards & Indicators \\
\hline $\begin{array}{l}\text { Ensure a } \\
\text { mechanism is } \\
\text { in place to } \\
\text { identify and } \\
\text { assess special } \\
\text { reception } \\
\text { needs }\end{array}$ & $\begin{array}{l}\text { A standardised mechanism to identify and assess special recep- } \\
\text { tion needs of any applicant is in place } \\
\text { The mechanism clearly prescribes who is responsible for the } \\
\text { identification and assessment of special reception needs } \\
\text { The mechanism clearly prescribes how identification and as- } \\
\text { sessment are recorded and communicated to the applicant and to } \\
\text { relevant actors }\end{array}$ \\
\hline $\begin{array}{l}\text { Ensure the } \\
\text { mechanism } \\
\text { for identifica- } \\
\text { tion and as- } \\
\text { sessment of } \\
\text { special recep- } \\
\text { tion needs is } \\
\text { effectively ap- } \\
\text { plied }\end{array}$ & $\begin{array}{l}\text { Sufficient resources are allocated to identify, assess and monitor } \\
\text { special needs } \\
\text { The initial identification and assessment of special needs is } \\
\text { conducted as soon as possible } \\
\text { Special needs that become apparent at a later stage are ade- } \\
\text { quately identified and assessed } \\
\text { Where relevant, specialised actors are involved in the assessment } \\
\text { of special needs. Communication channels and co-operation be- } \\
\text { tween the reception authority and the determining authority are } \\
\text { established and used } \\
\text { The identification and assessment of special reception needs } \\
\text { takes place without prejudice to the examination of the appli- } \\
\text { cants' need for international protection }\end{array}$ \\
\hline $\begin{array}{l}\text { Adequate and prompt action is taken to respond to the identified } \\
\text { and assessed special needs } \\
\text { If special needs have been identified, there is a mechanism in } \\
\text { place to ensure their regular monitoring }\end{array}$ \\
$\begin{array}{l}\text { cial reception that } \\
\text { needs are ad- } \\
\text { dressed in a } \\
\text { timely manner }\end{array}$ & $\begin{array}{l}\text { and } \\
\text { idied spe }\end{array}$ \\
\hline
\end{tabular}

The most pertinent conclusion that can be drawn from the EASO guidelines is that the roles of the different competent authorities should be clear when it concerns the identification and assessment of special needs. More importantly,

832 http://protect-able.eu. See also Mewes, R., Friele, B. and Bloemen, E., Validation of the Protect Questionnaire: A tool to detect mental health problems in asylum seekers by nonhealth professionals, Torture Journal: Journal on Rehabilitation of Torture Victims and Prevention of Torture, Volume 28, Issue No. 2, 2018. 
in order to ensure that the vulnerable applicants with special needs receive the required support in the form of special guarantees, effective communication between the authorities is essential. It follows further from the EASO guidelines that identification and assessment of any special needs is carried out at the earliest possible moment during the asylum procedure and that this assessment is continuous. Moreover, EASO points out that the competent authorities should make a distinction between the identification and assessment of special needs and the examination of the application for international protection. It can be further observed that 'good practice' entails an integrated identification and assessment mechanism of special needs in the national asylum procedure and to take account of the special needs of other categories of vulnerable applicants than the non-exhaustive list of vulnerable persons enumerated in Article 21 of the recast Reception Conditions Directive. The most prominent example is LGBT applicants. 833

The UNHCR considers that refugees, asylum applicants, victims of human trafficking, stateless persons, irregular migrants and other persons without a legal status may find themselves in a vulnerable situation and may manifest various aspects of vulnerability. The UNHCR advises to apply a vulnerability assessment that is centred on the individual and an approach that is holistic. The tool highlights several situations of vulnerability or 'vulnerability domains'. The tool further points out how to implement the vulnerability tool. One of the most significant aspects of the effectiveness of identifying situations of vulnerability is to have trained personnel with certain competencies in order to deal with situations of vulnerability. Also, the availability and access to services to address the vulnerability of applicants in the country of arrival is important. 834

ECRE advocates that fairness and timing are essential in the transposition of the special needs assessment procedure. Whether such an identification mechanism should take place in an administrative procedure or not, the right to good administration as enshrined under Article 41 of the Charter, which specifies that the right to be heard should be respected. Secondly, timely identification is highly important in carrying out an assessment procedure. 835

\subsubsection{Identifying vulnerable applicants from a medical perspective}

The identification of vulnerable asylum applicants has also drawn the attention of researchers with a medico-legal background. A comprehensive methodology

833 EASO, Guidance on reception conditions: operational standards and indicators, 2016, pp. 4041.

834 UNHCR and the IDC, Vulnerability Screening Tool, Identifying and addressing vulnerability: a tool for asylum and migration systems, 2016, pp. 3-6.

835 ECRE, Information Note on Directive 2013/33/EU of the European Parliament and of the Council of 26 June 2013 laying down standards for the reception of applicants for international protection (recast), 2015, pp. 34-35. 
consisting of twelve steps has been developed to determine personal injury and damage to the applicant. ${ }^{836}$ The medical examination starts with the consent of the applicant (step 1) and continues with the gathering and examination of circumstantial data, which includes reports made by the authorities that provided aid to the applicant in the country of origin or during the migration and clinical data, which includes medical reports that may provide information about the health status of the applicant both prior to and subsequent to the migration (step 2). The following step is the preparation for the examination (step 3), which should be carried out in a location that shows consideration of the privacy and take into account the age, gender identity, sexual orientation and cultural origin in each phase of the procedure. Moreover, a linguistic and a cultural mediator should be involved during the examination. Each phase of the procedure should be electronically stored in a database. Subsequently, a systematic clinical examination should follow (step 4). The examination should follow the guidelines of the Istanbul Protocol and apply the above indicated UNHCR guidelines ${ }^{837}$ where it concerns specific categories of vulnerable applicants such as LGBTs. Following the collection of all collected data (step 5), further detailed examinations may be necessary to acquire an adequate diagnosis (step 6). The next phase is a comprehensive evaluation of all the injury, disease or impairment (steps 7-9). The final phase is to anticipate on the most probable cause and result of each injury, disease or impairment and to report other vulnerability considerations (steps 10-11). The examination finalizes with a medical report indicating critically all injuries, diseases and impairments of the applicant (step 12).

\subsubsection{The legal implications of being identified as a vulnerable asylum ap- plicant in need of special reception guarantees}

The consequences of identifying that a vulnerable asylum applicant has special reception needs and requires special reception guarantees means that he or she may benefit from the 'specific support' enshrined in the Directive. What does this 'specific support' entail? Three forms of specific support can be distinguished: the first form of specific support includes guarantees to detained vulnerable asylum applicants and applicants with special reception needs; the second form of specific support is related to the standard of living and modalities for material reception conditions; and the third one concerns health care. 838

836 Visentin, S., Pelleti, G., Bajanowski, T. and Davide Ferrara, S., Methodology for the identification of vulnerable asylum seekers, International Journal of Legal Medicine, 26 July 2017.

837 UNHCR and the IDC, Vulnerability Screening Tool, Identifying and addressing vulnerability: a tool for asylum and migration systems, 2016.

838 Stoyanova, V., Victims of Trafficking, A Legal Analysis of the Guarantees for 'Vulnerable 
6.4.3.1. Detention of vulnerable asylum applicants and of applicants with special reception needs

One of the most sensitive issues in the domain of asylum is the detention of asylum applicants. Former Article 7(3) of the 2003 Reception Conditions Directive lacked any clear measures or guarantees for detained asylum applicants, which resulted in the widespread use of detention in Member States. The Commission ha2d expressed its great concern. ${ }^{839}$ Hence, the Commission tried to repair this legislative gap with the 2008 Commission proposal. With regard to the detention of vulnerable applicants with special needs the following text was proposed:

'persons with special needs shall not be detained unless an individual examination of their situation by a qualified professional certifies that their health, including their mental health, and well-being, will not significantly deteriorate as a result of the detention'. 840

The 2008 Commission proposal was, however, amended. The 2011 amended Commission proposal, inserted the following text:

'in all cases, vulnerable persons shall not be detained unless it is established that their health, including their mental health, and well-being, will not significantly deteriorate as a result of the detention'. ${ }^{841}$

It is noticeable that the reference to qualified professionals was deleted. However, this amendment was still not enough for Member States. A closer look at the adopted version of the recast Reception Conditions Directive reflects a considerable weakening as it does not stipulate as a general rule to prohibit the detention of vulnerable applicants. ${ }^{842}$ Current Article 11 of the recast Reception Conditions Directive reads:

Persons' under the Second Phase of the EU Asylum Legislation, Seeking Asylum in the European Union, Selected Protection Issues Raised by the Second Phase of the Common European Asylum System (Bauloz, C., Ineli-Ciger, M., Singer, S. and Stoyanova, V. eds.), Brill Nijhoff, 2015, p. 87.

839 European Commission, Report from the Commission to the Council and to the European Parliament on the application of Directive 2003/9/EC of 27 January 2003 laying down minimum standards for the reception of asylum seekers, 2007, para. 3.4.1.

840 European Commission, Proposal for a Directive of the European Parliament and of the Council laying down standards for the reception of asylum seeker (Recast), Brussels, 3.12.2008, COM(2008) 815 final, 2008/0244 (COD), p. 22.

841 European Commission, Amended Proposal for a Directive of the European Parliament and of the Council laying down standards for the reception of asylum seeker (Recast), Brussels, 1.6.2011, COM(2011) 320 final, 2008/0244(COD), p. 25.

842 Tsourdi, L., The Impact of the Negotiations on the Recast Reception Conditions Directive, The Recast Reception Conditions Directive: Central Themes, Problem Issues, and Im- 
'The health, including mental health, of applicants in detention who are vulnerable persons shall be of primary concern to national authorities. Where vulnerable persons are detained, Member States shall ensure regular monitoring and adequate support taking into account their particular situation, including their health.'

It follows from the present text of Article 11 that the detention of vulnerable asylum applicants is allowed. ${ }^{843}$ The recast Directive only stipulates that Member States have 'a primary concern' of the health, including mental health of vulnerable persons in detention and the procedural obligation to monitor vulnerable applicants and to provide 'adequate support' to the particular situation of vulnerable applicants who are detained. ${ }^{844}$ The recast Directive allows Member States wide discretion in interpreting 'adequate support'.

\subsubsection{Material reception conditions}

The second aspect that is relevant to highlight is Article 17 of the recast Reception Conditions Directive, which requires Member States to guarantee an adequate standard of living for persons applying for international protection. In particular, it requires that Member States should ensure a standard of living that meets the specific situation of vulnerable applicants in compliance with Article 21 of the recast Reception Conditions Directive. This includes vulnerable applicants in detention. ${ }^{845}$ It follows from Saciri that material reception conditions in the form of financial allowances must be sufficient to the situation of persons with specific needs. ${ }^{846}$

In addition, Member States have the obligation to take gender and agespecific concerns and the situation of vulnerable persons into account within the premises and accommodation centres at the border or in transit zones. 847 This obligation does not apply to 'private houses, flats, hotels or other premises adapted for housing applicants.' Peek and Tsourdi submit that where such types of housing cannot meet the specific reception needs of applicants, Member States should not accommodate them in such premises. ${ }^{848}$ Furthermore, Mem-

plementation in Selected Member States, (Minderhoud, P, \& Zwaan, K. eds.) 2016, pp. 3334.

843 See in addition Recitals 15-20.

844 Article 11(1) of the recast Reception Conditions Directive.

845 Article 17(2) of the recast Reception Conditions Directive.

846 Case C-79/13, Federaal agentschap voor de opvang van asielzoekers $v$ Selver Saciri and others, 27 February 2014, Court of Justice of the European Union, ECLI:EU:C:2014:103, para. 41.

847 Article 18(3) of the recast Reception Conditions Directive.

848 Peek, M. and Tsourdi, L., Asylum Reception Conditions Directive 2013/33/EU in Kay Hailbronner and Daniel Thym (eds.), EU Immigration and Asylum Law, Commentary, $2^{\text {nd }}$ edition (C.H. BECK/Hart/Nomos, 2016), p. 1448. 
ber States are obliged, as far as possible to accommodate dependent adult applicants with special reception needs with close adult relatives who are already present in the Member States and who are responsible for them. 849

However, the Directive allows for derogations regarding the modalities of material reception conditions. For instance, when an assessment of the specific needs of the vulnerable applicant is required. 850

\subsubsection{Health care}

The general standard requires minimum coverage of health care to asylum applicants. Member States have to provide the necessary health care, which includes 'emergency care and essential treatment of illnesses and of serious mental disorders'. ${ }^{851}$ Applicants with special reception needs on the other hand should receive the 'necessary medical or other assistance' including 'appropriate mental health care where needed'. 852

\subsection{Commission proposal and applicants in need of special reception guarantees}

In their proposal to reform the recast Reception Conditions Directive, 853 the Commission has proposed to replace the term 'vulnerable asylum applicants' with 'applicants with special reception needs'. The definition of applicants with special reception needs is described as persons who are in need of special guarantees. ${ }^{854}$ This is the same definition as enshrined in Article 2(k) of the current recast Reception Conditions Directive. The Commission clarifies that it is not important anymore whether the applicant is vulnerable or not. 855

The proposal also makes amendments with regard to the identification of special reception needs. Member States must 'systematically' and 'as early possible' - instead of 'within a reasonable time' - assess whether the applicant is in need of special reception needs. The assessment may be integrated into existing procedures or into the assessment of applicants with special procedural guarantees mentioned in Article 19 of the Commission proposal Asylum Procedures Regulation. Similar to the current identification of vulnerable applicants with

849 Article 18(5) of the recast Reception Conditions Directive.

850 Article 18(9)(a) of the recast Reception Conditions Directive.

851 Article 19 of the recast Reception Conditions Directive.

852 Article 19(2) of the recast Reception Conditions Directive.

853 Proposal for a Directive of the European Parliament and of the Council laying down standards for the reception of applicants for international protection (recast), Brussels, 13.7.2016, COM(2016) 465 final, 2016/0222 (COD).

854 Article 2(13) of the Commission proposal.

855 Proposal for a Directive of the European Parliament and of the Council laying down standards for the reception of applicants for international protection (recast), Brussels, 13.7.2016, COM(2016) 465 final, 2016/0222 (COD), p. 12. 
special reception needs, Member States are obliged to indicate the nature of such needs and to address the special reception needs when certain signs of special reception needs become visible later in the asylum procedure. The specific support enshrined in the Directive can only be beneficial to identified applicants with special reception needs.

In order to make the assessment mechanism of special reception needs more effective, final important amendments are proposed. Firstly, competent authorities and personnel should be trained in order to identify signs that an applicant is in need of special reception guarantees. Secondly, any special reception needs should be documented and added to the applicant's file, including the nature of the needs and advice regarding the kind of specific support needed. Thirdly, authorities should refer applicants to medical or psychological professionals for additional examination in case there are signs of torture, rape or other types of violence the applicant may have suffered and could have an impact on the reception needs of the applicant. Fourthly, the outcome of the examination should be included in the determination of which form of specific support should be given to the applicant. ${ }^{856}$

Furthermore, the Commission proposal specifically addresses the right to appropriate medical and psychological care for victims of gender-based harm, ${ }^{857}$ and to take into account gender-based harm at different phases of the asylum procedure. ${ }^{858}$ In addition, Member States should apply a gender-sensitive approach where they interpret the CEAS instruments. ${ }^{859}$ As regards the detention of applicants with special reception needs, there are no amendments proposed.

856 Articles 20 and 21 of the Commission proposal.

857 Article 24 of the Proposal for a Directive of the European Parliament and of the Council laying down standards for the reception of applicants for international protection (recast), Brussels, 13.7.2016, COM(2016) 465 final, 2016/0222 (COD).

858 Recital 32 of the Proposal for a Directive of the European Parliament and of the Council laying down standards for the reception of applicants for international protection (recast), Brussels, 13.7.2016, COM(2016) 465 final, 2016/0222 (COD).

859 European Commission, Proposal for a Directive of the European Parliament and of the Council laying down standards for the reception of applicants for international protection (recast), Brussels, 13.7.2016, COM(2016) 465 final, 2016/0222 (COD), pp. 9-10. European Commission, Proposal for a Regulation of the European Parliament and of the Council establishing a common procedure for international protection in the Union and repealing Directive 2013/32/EU, Brussels, 13.7.2016, COM(2016) 467 final, 2016/0224 (COD), p. 10. European Commission, Proposal for a Regulation of the European Parliament and of the Council on standards for the qualification of third-country nationals or stateless persons as beneficiaries of international protection, for a uniform status for refugees or for persons eligible for subsidiary protection and for the content of the protection granted and amending Council Directive 2003/109/EC of 25 November 2003 concerning the status of third-country nationals who are long-term residents, Brussels, 13.7.2016, COM(2016) 466 final 2016/0223 (COD), p. 12. 
Hence, applicants with special reception needs may still be detained. 860

\subsection{Asylum Procedures Directive 2013/32/EU (recast): Applicants in need of special procedural guarantees}

An applicant may not only be in need of special reception guarantees, but also require special procedural guarantees. The assessment whether an applicant requires special procedural guarantees is enshrined in Article 24(1) of the recast Asylum Procedures Directive. This assessment is a new obligation adopted during the recast negotiations. The 2005 Asylum Procedures Directive only made a reference to special procedural guarantees in Recital 14, which stipulated that 'specific procedural guarantees for unaccompanied minors should be laid down on account of their vulnerability'. In addition, an important requirement for Member States involves taking into account the 'vulnerability' of the applicant during the personal interview. ${ }^{861}$ The current obligation is formulated more strongly than the former 2005 Asylum Procedures Directive, which stipulated that the person who conducts the interview 'is sufficiently competent to take account of the personal or general circumstances surrounding the application, including the applicant's cultural origin or vulnerability'. ${ }^{862}$

Issues concerning additional safeguards for vulnerable asylum applicants in need of special procedural guarantees and applicants in need of special reception guarantees were at the centre of the debate during the recast negotiation process. Those in favour of additional safeguards, the Commission, European Parliament and the UNHCR, underlined the need for those safeguards. The Council represented by the Member States opposed the introduction of additional safeguards. They stressed the potential abuse of the system and the higher costs of the process. ${ }^{863}$ Member States strongly resisted the introduction of a mandatory identification procedure whether an applicant is in need of special procedural guarantees. ${ }^{864}$ The modified 2011 Commission proposal on Article 24 of the recast Asylum Procedures Directive obliged Member States to ensure the identification of applicants in need of special procedural guarantees in 'due time' and to apply the mechanism provided in Article 22 of the recast Reception Conditions Directive. Furthermore, Member States should take 'ap-

860 Article 11 of the Commission proposal.

861 Article 15(3)(a) of the recast Asylum Procedures Directive.

862 Article 13(3)(a) of the 2005 Asylum Procedures Directive.

863 Peers, S., Moreno-Lax, V., Garlick, M. And Guild, E., EU Immigration and Asylum Law (Text and Commentary): Second Revised Edition, Volume 3: EU Asylum Law, 2015, p. 242.

864 Vested-Hansen, J., Asylum Procedures Directive 2013/32/ EU in Kay Hailbronner and Daniel Thym (eds.), EU Immigration and Asylum Law, Commentary, $2^{\text {nd }}$ edition (C.H. BECK/Hart/Nomos, 2016), p. 1335. See also Council doc. 8959/12 of 24 April 2012, pp. 78-79. 
propriate measures' to guarantee sufficient time and relevant support for applicants in need of special procedural guarantees in order for them to provide the evidence. 865

\subsubsection{Assessment procedure of applicants in need of special procedural guarantees}

The text of the current central provision with regard to applicants in need of special procedural guarantees provides that Member States must assess within a 'reasonable period of time' following the application for international protection whether the applicant is in need of special procedural guarantees. ${ }^{866}$ An application for international protection means a request ${ }^{867}$ and does not require that the applicant has lodged an application for international protection. 868

It follows from Article 2(d) that 'an applicant in need of special procedural guarantees' is an asylum applicant 'whose ability to benefit from the rights and comply with the obligations provided for in this Directive is limited due to individual circumstances'. Recital 29 provides some clarification on 'individual circumstances' and indicates a non-exhaustive list of elements to consider an applicant in need of special procedural guarantees.

Table 6.3. Elements to consider an applicant in need of special procedural guarantees (non-exhaustive)

\begin{tabular}{|l|l|}
\hline$>$ Age \\
\hline$>$ Gender \\
\hline$>$ Sexual orientation \\
\hline$>$ Gender identity \\
\hline$>$ Disability \\
\hline$>$ Serious illness \\
\hline$>$ Mental disorders \\
\hline$>$ Persons subjected to torture, rape or other serious forms of psychological, \\
& physical or sexual violence \\
\hline
\end{tabular}

The assessment of special procedural guarantees is thus based on the individual circumstances of the applicant. There is no clear indication of what is meant by 'reasonable period of time'. The only clarification is again provided in Recital 29, which stipulates that Member States should 'endeavour' to identify those

865 European Commission, Amended proposal for a Directive of the European Parliament and of the Council on common procedures for granting and withdrawing international protection status (Recast), Brussels, 1.6.2011, COM(2011) 319 final 2009/0165 (COD).

866 Article 24(1) of the recast Asylum Procedures Directive.

867 See Article 2(b) of the recast Asylum Procedures Directive.

868 See Article 6(3) of the recast Asylum Procedures Directive. 
applicants in need of procedural guarantees before the first decision is taken. The next issue is who should undertake such an assessment. This is also not entirely clear. The Directive indicates that Member States have to guarantee that the person who conducts the interview during the asylum procedure is competent to take into account the 'vulnerability' of the asylum applicant. ${ }^{869}$

Finally, Member States have to make sure that special procedural guarantees are also available when this need shows up in a later stage of the procedure. 870 This is particularly important for victims of torture or violence as they may not report their past experiences from the start of the asylum procedure. ${ }^{871}$

Overall, the Directive provides much leeway to Member States as regards the assessment to identify applicants in need of special procedural guarantees. Finally, the assessment may be integrated into existing national procedures or into the assessment enshrined in Article 22 of the recast Reception Conditions Directive. ${ }^{872}$

\subsubsection{The legal implications of being identified as an applicant in need of special procedural guarantees}

Three legal implications can be identified once the applicant is identified as an applicant in need of special procedural guarantees, which are explained hereafter.

\subsubsection{Adequate support}

First, the applicant should receive 'adequate support in order to allow them to benefit from the rights and comply with the obligations of this Directive throughout the duration of the asylum procedure'. 873 Article 22 of the recast Reception Conditions Directive speaks of 'specific support' referring to vulnerable asylum applicants in need of special reception guarantees. Here, it is less certain what is meant by 'adequate support'. Recital 29 clarifies that applicants in need of special procedural guarantees should receive at least 'sufficient time' to put forward the elements to substantiate their application. ${ }^{874}$ Hence, sufficient time is an important special procedural guarantee.

\subsubsection{Exemption from accelerated or border procedures}

The second legal implication is that where Member States cannot provide 'ade-

869 Article 15(3)(a) of the recast Asylum Procedures Directive. See Case C-148/13 to C150/13, A,B,C v Staatssecretaris van Veiligheid en Justitie, Court of Justice of the European Union, 2 December 2014, ECLI:EU:C:2014:2046, para. 70.

870 Article 24(4) of the recast Asylum Procedures Directive.

871 ECRE Information Note Directive 2013/32/EU of the European Parliament and of the Council of 26 June 2013 on common procedures for granting and withdrawing international protection (recast), 2014, p. 29.

872 Article 24(2) of the recast Asylum Procedures Directive.

873 Article 24(3) of the recast Asylum Procedures Directive.

874 Recital 29 of the recast Asylum Procedures Directive. 
quate support' in an accelerated procedure 875 or in a border procedure 876 to applicants in need of special procedural guarantees, Member States should not apply these procedures to such applicants. ${ }^{877}$ In particular, where the applicants are in need of special procedural guarantees as a result of torture, rape or other serious forms of psychological, physical or sexual violence. This follows also from Recital 30, which states that "where adequate support cannot be provided to an applicant in need of special procedural guarantees in the framework of accelerated or border procedures, such an applicant should be exempted from those procedures.'

\subsubsection{Additional guarantees}

The third legal implication is that where Member States do not grant an appeal with automatic suspensive effect to applicants in need of special procedural guarantees whose application for international protection cannot be processed in accelerated procedures or border procedures, they should at least be provided with the necessary interpretation, legal assistance and at least one week to prepare the request in border procedures, including an examination of the decision by a court or tribunal in fact and law. .78

\subsubsection{Prioritise the examination of an asylum application}

Where the applicant has been identified as a vulnerable applicant with special reception needs or an applicant in need of special procedural guarantees, Member States may 'prioritise' the examination of an asylum application, in particular when it involves unaccompanied minors. ${ }^{879}$ In this regard, vulnerable applicants mentioned in Article 31(7(b) refers to Article 22 of the recast Reception Conditions Directive. ECRE pointed out that an examination of an asylum application should be prioritised where the applicant is vulnerable as determined under Article 22 of the recast Reception Conditions Directive, but Member States should also include other categories of vulnerable applicants in order to ensure that their specific vulnerability is not worsened by the length of the procedure. Nonetheless, prioritisation of asylum applications should be assessed on a case-by-case basis, which should be an integral part of the assessment of special needs within the meaning of Article 22 of the recast Reception Conditions Directive and Article 24 of the recast Asylum Procedures Directive. 880

875 Article 31(8) of the recast Asylum Procedures Directive.

876 Article 43 of the recast Asylum Procedures Directive.

877 Peers, S., Moreno-Lax, V., Garlick, M. And Guild, E., EU Immigration and Asylum Law (Text and Commentary): Second Revised Edition, Volume 3: EU Asylum Law, 2015, pp. 242243.

878 Article 46(7) of the recast Asylum Procedures Directive.

879 Article 31(7)(b) of the recast Asylum Procedures Directive.

880 ECRE Information Note Directive 2013/32/EU of the European Parliament and of the 


\subsection{Commission proposal and applicants in need of special proce- dural guarantees}

The Commission proposal 881 introduces improved legal standards concerning the protection of applicants in need of procedural guarantees. The Commission proposes the following amendments: first, Member States must assess 'systematically' and 'as soon as an application is made' and before a decision is taken identify whether an applicant is in need of special procedural guarantees; and second, once the application is submitted, authorities responsible for the registration of applications should specify whether an applicant shows signs of vulnerability, and once the asylum application is formally lodged, the determining authority should continue the process of identifying applicants who require special procedural guarantees.

The Commission proposal points out that the statements of an applicant or his particular conduct as well as physical signs may indicate vulnerabilities. An applicant should be referred to medical or psychological professionals by the determining authority in case there is evidence available that an applicant has been a victim of torture, rape or other serious forms of violence that may impact upon the ability of the applicant to participate effectively in the asylum procedure. Similar to the medical examination of an applicant in need of special reception guarantees, data about indications of vulnerability of the applicant should be added to the applicant's file. Additionally, in determining the kind of specific procedural support provided to an applicant, determining authorities need to take into consideration the outcome of the medical examination. A very important obligation proposed by the Commission is adequately trained personnel in order to identify the first signs of vulnerability of applicants that possibly need special procedural guarantees.

Similar to the present Article 24 of the recast Asylum Procedures Directive, applicants identified as in need of special procedural guarantees may benefit from adequate support and sufficient time in order to effectively participate in the asylum procedure. Crucially, in the circumstances where applicants in need of special procedural guarantees are not able to receive such adequate support within the context of an accelerated or a border procedure, then Member States may not apply those special procedures. This is especially relevant where the applicant is in need of special procedural guarantees following from torture, rape or other serious forms of violence, including a new category gender-based

Council of 26 June 2013 on common procedures for granting and withdrawing international protection (recast), 2014, p. 36.

881 Proposal for a Regulation of the European Parliament and of the Council establishing a common procedure for international protection in the Union and repealing Directive 2013/32/EU, Brussels, 13.7.2016, COM(2016) 467 final, 2016/0224 (COD). 
violence. Accordingly, provided that adequate support can be given to applicants in need of special procedural guarantees, then Member States are not prevented from applying such procedures. ${ }^{882}$ Several commentators have widely criticised these arrangements. The principle of providing applicants in need of special procedural guarantees with adequate support and sufficient time to effectively present all relevant elements necessary to substantiate their asylum application is at odds with accelerated procedures and border procedures that are characterized by short time limits and the widespread use of detention. ${ }^{883}$ The Parliamentary Assembly of the Council of Europe has also advocated excluding victims of torture and unaccompanied minors from accelerated procedures because of 'their vulnerability and the complexity of their cases. 884

Finally, the Commission can through implementing acts submit further guidance and detailed rules for the assessment and the identification with regard to applicants in need of special procedural guarantees. ${ }^{885}$

\subsection{Qualification Directive 2011/95/EU (recast)}

\subsubsection{The assessment of asylum applications}

A crucial component of identifying whether a person is eligible for international protection is the assessment of facts and circumstances of the applicant. It follows in particular from Article 4(3)(c) of the recast Qualification Directive that where national authorities assess the facts and circumstances of the applicant, they must take into account factors such as background, gender and age.

A more general requirement for Member States is enshrined in Article 20(3), which specifies that Member States have to take into account the specific situation of beneficiaries of international protection who are identified as vulnerable persons ${ }^{886}$ with special needs ${ }^{887}$ when implementing the provisions of Chapter

882 Articles 19 and 20 of the Commission proposal.

883 ECRE, Information Note Directive 2013/32/EU of the European Parliament and of the Council of 26 June 2013 on common procedures for granting and withdrawing international protection (recast), 2014, pp. 29-30. IRCT, Position paper on the Proposal for an Asylum Procedures Regulation, July 2016, p. 2. UNHCR, Comments on the European Commission proposal for a Regulation of the European Parliament and of the Council establishing the criteria and mechanisms for determining the member state responsible for examining an application for international protection lodged in one of the Member States by a third-country national or a stateless person (recast) - COM (2016) 270, December 2016, p. 14.

884 Council of Europe, Parliamentary Assembly, Accelerated asylum procedures in Council of Europe Member States, Resolution 1471 (2005), para. 8.12.

885 Article 19(4) of the Commission proposal.

886 The non-exhaustive list of vulnerable persons enumerated in Article 20(3) of the recast Qualification Directive corresponds to the list of vulnerable persons in Article 21 of the recast Reception Conditions Directive. 
VII on the content of international protection.

\subsubsection{Adequate healthcare for vulnerable beneficiaries of international protection}

The general standard is that beneficiaries of international protection have access to healthcare as any other national. ${ }^{888}$ Vulnerable beneficiaries of international protection who have special needs such as 'pregnant women, disabled people, persons who have undergone torture, rape or other serious forms of psychological, physical or sexual violence or minors who have been victims of any form of abuse, neglect, exploitation, torture, cruel, inhuman and degrading treatment or who have suffered from armed conflict' shall have access to 'adequate' healthcare on the same criteria as other nationals. ${ }^{889}$ The recast Directive is, however, silent on the meaning of 'adequate'. 890 The CJEU held in M'Bodj that Member States are not required to grant social welfare or health care benefits to a vulnerable disabled person who may reside on the territory on the basis of a national protection status. ${ }^{891}$

\subsection{Commission proposal and vulnerable beneficiaries of interna- tional protection}

The Commission proposal 892 on the Qualification Regulation does not introduce amendments regarding vulnerable applicants other than stipulating that Member States are obliged to take into account the specific situation of persons with special needs. 893

887 Article 20(4) of the recast Qualification Directive.

888 Article 30(1) of the recast Qualification Directive.

889 Article 30(2) of the recast Qualification Directive.

890 Battjes, H., Asylum Qualification Directive 2011/95/EU, EU in Kay Hailbronner and Daniel Thym (eds.), EU Immigration and Asylum Law, Commentary, $2^{\text {nd }}$ edition (C.H. BECK/Hart/Nomos, 2016), pp. 1276-1277.

891 Case C-542/13, M'Bodj v Etat belge, Court of Justice of the European Union, 18 December 2014, ECLI:EU:C:2014:2452.

892 European Commission, Proposal for a Regulation of the European Parliament and of the Council on standards for the qualification of third-country nationals or stateless persons as beneficiaries of international protection, for a uniform status for refugees or for persons eligible for subsidiary protection and for the content of the protection granted and amending Council Directive 2003/109/EC of 25 November 2003 concerning the status of third-country nationals who are long-term residents, Brussels, 13.7.2016, COM(2016) 466 final 2016/0223 (COD).

893 Article 22(4) of the Commission proposal. 


\subsection{Dublin III Regulation 604/2013 (recast)}

\subsubsection{Transferring vulnerable asylum applicants}

The vulnerability of an asylum applicant has become an important consideration in the application of the responsibility criteria and whether a Dublin transfer is justified. ${ }^{894}$ Member State are required to 'normally keep or bring together' applicants who are 'on account of pregnancy, a new-born child, serious illness, severe disability or old age' dependent on a child, sibling or parent legally resident in one of the Member States. 895 The requirement that they 'shall normally keep or bring together' must be interpreted as 'a Member State may derogate from that obligation to keep the persons concerned together only if such a derogation is justified because an exceptional situation has arisen' ${ }^{896}$ In addition, the vulnerability of an asylum applicant is one of the aspects for Member States that may trigger the application of the 'sovereignty clause' ${ }^{897}$ or the 'humanitarian clause' under the Dublin Regulation. ${ }^{898}$ Both discretionary clauses are, however, interpreted in a restrictive manner or rarely implemented by Member States. 899

With regard to the legality of Dublin transfers, it was mentioned in chapter 5 that the CJEU in N.S. held that Member States may not transfer an asylum applicant from one Member State to another Member State where they cannot be unaware that systemic deficiencies in the asylum procedure and in the reception conditions will result in the asylum applicant facing a real risk of being subjected to inhuman or degrading treatment within the meaning of Article 4 of the Charter. More recently, in C.K., the CJEU decided that a Dublin transfer could result in a violation of Article 4 of the Charter where the transfer of an asylum applicant 'with a particularly serious mental or physical illness would result in a real and proven risk of a significant and permanent deterioration in the state of health'. 900

Furthermore, following the Tarakhel case, transferring States have to obtain individual guarantees concerning adequate reception conditions from the State

894 ECRE, The concept of vulnerability in European asylum procedures, 2017, p. 50.

895 Article 16(1) of the recast Dublin III Regulation. See further Article 11 of Implementing Regulation (EC) No 1560/2003.

896 Case C-245/11, Kv Bundesasylamt, 6 November 2012, Court of Justice of the European Union, ECLI: EU:C:2012:685, para. 46.

897 Article 17(1) of the recast Dublin III Regulation.

898 Article 17(2) of the recast Dublin III Regulation.

899 UNHCR, Study on the implementation of the Dublin III Regulation, Left in Limbo, 2017, pp. 115-132.

900 Case C-578/16, C.K. and Others v Republika Slovenija, 16 February 2017, Court of Justice of the European Union, ECLI:EU:C:2017:27. 
responsible prior to the transfer of vulnerable groups of asylum applicants, in this case a family with minor children. ${ }^{901}$ The ECtHR takes a firm stance in $\mathrm{Ta}$ rakhel. The case marks clearly a shift in the obligation from 'prior notification'902 to 'prior individual guarantees.' The case involved a couple and their five children who were to be returned from Switzerland to Italy on the basis of Dublin rules. The applicants complained that the reception facilities in Italy were affected by 'systemic deficiencies' that are related to the 'slowness of the identification procedure, the capacity of the reception arrangements and the living conditions in the available facilities' ${ }^{903}$ The applicants relied on Article 3 of the ECHR and claimed that without individual guarantees concerning their care, they would be subjected to inhuman and degrading treatment linked to the existence of "systemic deficiencies" in the reception arrangements for asylum seekers in Italy. 904

The Dutch, Swedish, Norwegian and the UK supported the Swiss authorities, which argued that the UNHCR had not appealed to stop the transfers of certain vulnerable groups to Italy. According to the Swedish officials 'Dublin returns to Italy were the subject of a systematic exchange of information between the authorities of the two countries, which was particularly thorough in the case of vulnerable persons and especially unaccompanied children.' 905 The receiving state Italy argued from its side that certain groups of asylum applicants were considered vulnerable by the Italian authorities. In the present case a family with children was assured of, inter alia, accommodation, food, health care and legal assistance. ${ }^{906}$ In its examination of the merits, the ECtHR reiterated that 'to fall within the scope of Article 3 the ill-treatment must attain a minimum level of severity. The assessment of this minimum is relative; it depends on all the circumstances of the case, such as the duration of the treatment and its physical or mental effects and, in some instances, the sex, age and state of health of the victim. ${ }^{907}$

The ECtHR held that 'as a "particularly underprivileged and vulnerable"

901 Tarakhel v Switzerland, Application no. 29217/12, European Court of Human Rights, 4 November 2014.

902 Samsam Mohammed Hussein and Others $v$ the Netherlands and Italy, Application no. 27725/10, European Court of Human Rights, 2 April 2013, para. 77.

903 Tarakhel $v$ Switzerland, Application no. 29217/12, European Court of Human Rights, 4 November 2014, paras. 57-68.

904 Tarakhel v Switzerland, Application no. 29217/12, European Court of Human Rights, 4 November 2014, para. 53.

905 Tarakhel v Switzerland, Application no. 29217/12, European Court of Human Rights, 4 November 2014, paras. 79-80.

906 Tarakhel $v$ Switzerland, Application no. 29217/12, European Court of Human Rights, 4 November 2014, para. 86.

907 Tarakhel $v$ Switzerland, Application no. 29217/12, European Court of Human Rights, 4 November 2014, para. 118. 
population group, asylum seekers require "special protection" and emphasized that the requirement of 'special protection' of asylum applicants is imperative when it involves children because they have specific needs and because of their vulnerabilities, regardless of whether they are accompanied by their parents or unaccompanied.908 Furthermore, the ECtHR pointed out that the child's 'extreme vulnerability' is the decisive factor and takes precedence over considerations relating to the status of illegal immigrants' 909 and that 'children have specific needs that are related in particular to their age and lack of independence, but also to their asylum-seeker status.' It is further interesting to note the partly dissenting opinion of the judges Casadevall, Berro-Lefévre and Jäderblom, asking whether 'such assurances should be required for all asylum seekers liable to be sent back to Italy - who, according to the M.S.S. judgment, are members of a particularly underprivileged and vulnerable population group in need of special protection - or only for families with children?' It can be argued that there is no indication in the judgment to assume that the protection of Article 3 ECHR is restricted to only one category of vulnerable asylum applicants, namely families with children. ${ }^{910}$

The recast Dublin III Regulation includes important obligations for the transferring Member State to provide relevant information to the responsible Member State on any special needs of the transferred applicant. In particular 'any immediate measures which the Member State responsible is required to take in order to ensure that the special needs of the person to be transferred are adequately addressed, including any immediate health care that may be required'. 911 The Commission Implementing Act provides further specific details on the application of the Dublin Regulation. For instance, applicants need to provide information about any special needs they may have concerning their psychical health to the authorities in order to receive the necessary medical care or treatment. In particular applicants that are 'disabled, pregnant, have serious illness or have been subjected to torture rape or other serious forms of psychological, physical and sexual violence' should inform the authorities.912 I would

908 Tarakhel $v$ Switzerland, Application no. 29217/12, European Court of Human Rights, 4 November 2014, para. 118-119.

909 Tarakhel $v$ Switzerland, Application no. 29217/12, European Court of Human Rights, 4 November 2014, para. 99 citing Mubilanzila Mayeka and Kaniki Mitunga v Belgium, Application no. 13178/03, European Court of Human Rights, 12 January 2007, para. 55.

910 See a more detailed case note on Tarakhel $v$ Switzerland, Costello, C., and Mouzourakis, M., Tarakhel: Is 'how bad is bad enough' good enough? Asiel \& Migrantenrecht, no. 10, 2014, pp. 408-411.

911 Article 31(2)(a) of the recast Dublin III Regulation.

912 Commission Implementing Regulation (EU) No 118/2014 of 30 January 2014 amending Regulation (EC) No 1560/2003 laying down detailed rules for the application of Council Regulation (EC) No 343/2003 establishing the criteria and mechanisms for de- 
argue to what extent applicants are well informed or sufficiently aware that they themselves should inform the authorities about their medical details and their specific needs.

Finally, an important obligation for transferring Member States is to exchange specific health data of vulnerable applicants with special needs with the responsible Member State before a Dublin transfer is undertaken, in particular when it concerns disabled persons, elderly people, pregnant women, minors and persons who have been subject to torture, rape or other serious forms of psychological, physical and sexual violence. The responsible Member State should guarantee that such special needs of the applicant are adequately addressed. ${ }^{913}$

\subsection{Commission proposal and vulnerable asylum applicants in the Dublin procedure}

The Commission proposal for a Dublin IV Regulation has not introduced specific changes regarding the provisions to exchange relevant information on any special needs or the medical status of a vulnerable applicant in the framework of the Dublin system. Neither does the proposal contain new provisions specifically safeguarding the rights of vulnerable asylum applicants with special needs. The International Rehabilitation Council for Torture Victims (IRCT) has submitted that the new Dublin IV Regulation should include a vulnerability assessment or at least make a reference to the assessment procedure in the Reception Conditions Directive. Such assessment should be carried out before the responsible Member State is established. Moreover, the outcome of the vulnerability assessment can be taken into account by the responsible Member State to ensure that the special needs of the person to be transferred are adequately addressed. ${ }^{914}$

The Commission proposal does, however, include several important substantial amendments with regard to a specific category of particularly vulnerable applicants, namely unaccompanied minors. These amendments in relation to unaccompanied minors will be addressed in the following chapter.

\subsection{Eurodac Regulation 603/2013 (recast)}

\subsubsection{Fingerprinting vulnerable asylum applicants}

When it concerns vulnerable persons, the recast Eurodac Regulation has no

termining the Member State responsible for examining an asylum application lodged in one of the Member States by a third-country national, L 39/1, 8.2.2014.

913 Article 32(1) of the recast Dublin III Regulation.

914 IRCT, Position Paper on the European Commission's Proposal for the Reform of the Dublin System, May 2016. 
specific provisions except for minors. The principle of the best interests of the child must govern when Member States implement this Regulation. ${ }^{915}$ Importantly, the Commission clarified that in case Member States resort to coercion for taking fingerprints, they must take into account the circumstances and vulnerabilities the person in question. Member States have the discretion to decide not to coercively fingerprint certain vulnerable persons such as minors or pregnant women. When the authorities decide to continue with taking the fingerprint coercively of vulnerable persons, they must in any event guarantee a procedure that is suitable to their vulnerabilities. ${ }^{916}$

\subsection{Commission proposal and vulnerable applicants}

The Commission proposal to recast the Eurodac Regulation obliges Member States to take fingerprints and a facial image of applicants. Where applicants are not complying with the mandatory fingerprinting and taking a facial image, Member States may impose sanctions. However, where it is not possible to take the fingerprints or facial image of vulnerable applicants as a result of a problem with the fingertips or face, Member States may not apply coercion to comply with their obligation. Where the vulnerable applicant merely refuses to comply, Member States may try to re-take the fingerprints or facial image. ${ }^{917}$

\subsection{Analysis}

The previous sections show that there are several issues with the vulnerability approach in the CEAS. First of all, it is important to note that the CEAS does not define the notion of vulnerability. The vulnerability approach in the CEAS is limited to labelling groups presumed to be vulnerable. The recast Reception Conditions Directive does also not explain why the groups listed in Article 21 are presumed to be vulnerable. A further remarkable element is that three new

915 Recital 35, Regulation (EU) No 603/2013 of the European Parliament and of the Council of 26 June 2013 on the establishment of 'Eurodac' for the comparison of fingerprints for the effective application of Regulation (EU) No 604/2013 establishing the criteria and mechanisms for determining the Member State responsible for examining an application for international protection lodged in one of the Member States by a third-country national or a stateless person and on requests for the comparison with Eurodac data by Member States' law enforcement authorities and Europol for law enforcement purposes, and amending Regulation (EU) No 1077/2011 establishing a European Agency for the operational management of large-scale IT systems in the area of freedom, security and justice (recast) OJ L 180/1.

916 Commission Staff Working Document on Implementation of the Eurodac Regulation as regards the obligation to take fingerprints, Brussels, 27.5.2015, SWD(2015) 150 final, para. 7.

917 Article 2(4) of the Commission proposal. 
categories of vulnerable persons have been added to the non-exhaustive list in Article 21, however, without any explanation as to why these additional groups should be presumed vulnerable. It is also important to note that the Directive links the notion of vulnerability with special reception needs. This means that applicants with special reception needs are deemed to be vulnerable persons in the context of the CEAS. However, in order to assess whether an asylum applicant has special reception needs, Member States need to identify persons presumed to be vulnerable. It has been submitted that the CEAS specifies certain groups presumed to be vulnerable in the asylum process, it does, however, not provide guidance with regard to the question of which other groups than the ones listed in Article 21 of the Reception Conditions Directive could be presumed vulnerable. In addition, the use of different notions in the text of the Directives, such as vulnerable persons, applicants with special reception needs and applicants in need of special procedural guarantees, create further confusion. As I have submitted in chapter 1, the EU should adopt a more nuanced approach to vulnerability in the asylum process. This means an approach that includes sources of vulnerability that are not only linked to certain groups, but also takes into account context-specific sources of vulnerability. In this way, the CEAS ensures that various sources of vulnerability are recognized and that someone who does not fall into one of the predetermined groups but who is actually vulnerable is not overlooked.

With regard to applicants in need of special procedural guarantees, it has been submitted that Member States have to examine whether an applicant is in need of special procedural guarantees. How Member States should carry out this assessment is not regulated in the Directive. However, once they are identified as applicants in need of special procedural guarantees, they must receive 'adequate support'. The meaning of adequate support is not defined. The Directive only indicates that applicants in need of special procedural guarantees should receive at least 'sufficient time' to put forward the elements to substantiate their application. Another important obligation for Member States is to discontinue with accelerated procedures or border procedures when adequate support cannot be provided to applicants in need of special procedural guarantees. Moreover, applicants in need of special procedural guarantees should receive additional safeguards where their appeal does not have automatic suspensive effect. In addition, Member States have to make sure that special procedural guarantees are also available when this need shows up in a later stage of the procedure, which is a positive practice as certain applicants have more hidden vulnerabilities or have difficulties to talk about their vulnerabilities right from the start of the asylum procedure.

The foregoing sections also show that the identification of vulnerability in the asylum process is crucial. It has been submitted that the recast Reception 
Conditions Directive and the recast Asylum Procedures Directive allows Member States wide discretion as to how the identification of vulnerability should take place. Both Directives merely provide guidelines and stipulate minimum requirements. In my view, this is problematic because this may lead to considerably different outcomes among Member States as to who is identified as vulnerable.

This chapter has also showed that the Dublin Regulation III has important obligations with regard to the transferring of vulnerable applicants. It has been submitted that transferring Member State should provide relevant information to the responsible Member State on any special needs of the transferred applicant. Applicants need to provide information about any special needs they may have concerning their psychical health to the authorities in order to receive the necessary medical care or treatment. In my view, it is highly questionable to what extent applicants are well informed or sufficiently aware that they themselves should inform the authorities about their medical details and their specific needs.

The previous sections have examined the proposed legislative amendments brought forward by the Commission in relation to vulnerable applicants. I have argued that the proposed changes by the Commission, if adopted, would improve the legal standards with regard to vulnerable asylum applicants. It is noticeable that the Commission has proposed to replace the term 'vulnerable asylum applicants' with 'applicants with special reception needs'. In my view, it seems that the Commission aims to prevent the risk of stigmatization of certain applicants labelled as vulnerable. It has been further submitted that the new obligation for Member States to 'systematically' and 'as early possible' assess whether the vulnerable applicant has special reception needs or is in need of special procedural guarantees, is an improvement compared to the current legal standards. Moreover, there are clear instructions to train the authorities and new guidelines for the division of tasks for the personnel of authorities when dealing with the identification of special needs, including the decision about which type of special support to provide to an applicant. In my view, there are two problematic issues. First, the proposals as a general principle do not rule out applicants in need of special procedural guarantees from accelerated procedures or border procedures. For the reasons given above, these arrangements have been widely criticized. Second, Member States are still allowed to detain vulnerable applicants.

In the following sections of this chapter, I examine the legal standards with regard to victims of torture (section 6.15) and unaccompanied minors (section 6.17) in the CEAS. 


\subsection{Legal standards with regard to victims of torture in the Common European Asylum System}

\subsubsection{Access to appropriate medical and psychological care}

Article 25(1) of the recast Reception Conditions Directive requires Member States to guarantee that asylum applicants who have been subject to torture, rape or other serious forms of violence, have access to the necessary treatment of damages caused by these acts. They should in particular have access to 'appropriate medical and psychological care'. ${ }^{918}$ In addition, victims of torture should continue receiving the medical and psychological treatment also where they are granted international protection status. ${ }^{919}$ Furthermore, competent staff dealing with asylum applicants who are victims of torture, rape or other forms of serious violence should be trained adequately and comply with the principle of confidentiality provided for in national law. 920

The CJEU has held that torture victims may fall under the subsidiary protection regime where 'there is a real risk of them being intentionally deprived, in their country of origin, of appropriate care for the physical and mental aftereffects of that torture'. Two examples are given by the CJEU: first, where the authorities, despite their obligations under Article 14 of the CAT, are not prepared to provide for the rehabilitation; and second, where the authorities have adopted a discriminatory policy which makes it more difficult for certain ethnic groups or individuals to have access to appropriate care. ${ }^{921}$

\subsubsection{Medical examination}

It was submitted in chapter 3 that medical reports play an important role in supporting the claim of a person of being subjected to torture in the past. A medical report in which there is causality between the injuries and the events in the country of origin can support the credibility of statements submitted by the asylum applicant. The recast Asylum Procedures Directive obliges Member States to arrange for a medical examination of the applicant, conducted by qualified medical professionals, where the determining authority deems it relevant. ${ }^{922}$ The question that arises is in which circumstances the medical examina-

\footnotetext{
918 Article 25(1) of the recast Reception Conditions Directive.

919 Article 30 of the recast Qualification Directive.

920 Article 25(2) of the recast Reception Conditions Directive.

921 Case C-353/16, MP v Secretary of State for the Home Department, 24 April 2018, Court of Justice of the European Union, ECLI:EU:C:2018:276, para. 57.

922 Article 18(1) of the recast Asylum Procedures Directive. See also a report on 'Medical examination in the asylum procedure - Article 18 Directive 2013/32/EU - Manual for health professionals and legal workers', The Netherlands Institute for Human Rights and Medical As-
} 
tion is or should be considered 'relevant' by the national authorities. Article 4(4) of the recast Qualification Directive provides that 'the fact that an applicant has already been subject to persecution or serious harm, or to direct threats of such persecution or such harm, is a serious indication of the applicant's well-founded fear of persecution or real risk of suffering serious harm'. Hence, medical examination should be considered relevant where there are serious indications, whether it is physically or psychologically, of past persecution or serious harm. ${ }^{923}$

Applicants may arrange their medical examination to prove indications of past persecution or serious harm, however, only at their own cost. 924 As asylum applicants do not always have the resources, arranging a medical examination at their own cost may be difficult in practice. Furthermore, Member States are required to take into account the result of the medical examination initiated by the authorities and the applicant together with other relevant elements in the assessment of the asylum application. ${ }^{925}$

\subsubsection{Trained personnel}

Member States have to ensure that the competent authority that carries out the assessment of the asylum application has the skills to identify any problems the applicant might have and any unfavourable impact on the applicant's potential to be interviewed. For example, competent personnel should be aware of signs and symptoms that indicate the applicant has been subject to torture or serious harm. ${ }^{926}$ Similarly, where Member States appoint another authority to conduct interviews on the substance of an asylum application, this authority should also be trained to identify traces of torture on the applicant. ${ }^{927}$

\subsubsection{Exemption from accelerated procedures and border procedures}

An important obligation for Member States is to exempt applicants in need of special procedural guarantees from accelerated procedures and border procedures where adequate support cannot be provided. The recast Asylum Procedures Directive in particular stipulates that victims of torture or other forms of violence who are identified as applicants in need of special procedural guarantees should be exempted from accelerated procedures and border procedures

sessment (IMMO), The Hungarian Cordelia Foundation for the Rehabilitation of Torture Victims and the French organization Parcours d'Exil, 2017.

923 ACVZ, Sporen uit het verleden, July 2014, p. 58.

924 Article 18(2) of the recast Asylum Procedures Directive.

925 Article 18(3) of the recast Asylum Procedures Directive.

926 Article 4(3) of the recast Asylum Procedures Directive.

927 Article 14(1) of the recast Asylum Procedures Directive. 
where adequate support cannot be provided. ${ }^{928}$ In this regard, there are two major challenges. According to IRCT, victims of torture have no access to medical reports to corroborate their testimony on alleged torture in accelerated and border procedures. In addition, accelerated and border procedures are characterized by short time frames. ${ }^{929}$ Second, such short procedures tend to be in conflict with the notion of adequate support. For victims of torture to effectively participate in the asylum procedure they need sufficient time to rehabilitate in order to be able to present their claim. ${ }^{930}$ Another aspect that raises concern is the concept of the use of safe countries that puts the burden of proof on the applicant to refute the presumption of safety. This is particularly problematic for victims of torture as Member States may apply accelerated procedures to an applicant arriving from a safe country of origin. ${ }^{931}$ Consequently, it is important to note that victims of torture need sufficient time to effectively present all relevant elements necessary to substantiate their asylum application. However, this is in stark contrast with the concept of an accelerated or border procedure, which is associated with short time limits and the widespread practice of detention.

\subsubsection{Exchange of health data in Dublin transfers}

Another important obligation for Member States is to exchange health data before a transfer is carried out on the basis of the Dublin Regulation. ${ }^{932}$ For instance, an exchange of data on the physical or mental health of the asylum applicant such as persons who have been subject to torture, rape or other serious forms of psychological, physical and sexual violence. Such a rule is not only highly relevant to applicants who are victims of torture or violence but also relevant to several other categories of vulnerable asylum applicants such as disabled persons, elderly people, pregnant women, minors. In this regard, it is also important to note that the CJEU has held in C.K. that the transfer of an asylum applicant with 'a particularly serious mental or physical illness would result in a real and proven risk of a significant and permanent deterioration in the state of health of the person concerned, and that transfer would constitute inhuman and degrading treatment', within the meaning of Article 4 of the Charter. ${ }^{933}$

\footnotetext{
928 Article 24(3) of the recast Asylum Procedures Directive.

929 EMN Ad-Hoc Query on EE AHQ on accelerated asylum procedures and asylum procedures at the border, 13 February 2017.

930 IRCT, Position paper on the Proposal for an Asylum Procedures Regulation, September 2016, p. 2.

931 IRCT, Position paper on the Proposal for an Asylum Procedures Regulation, September 2016, p. 3.

932 Article 32(1) of the recast Dublin III Regulation.

933 Case C-578/16, C.K. and Others v Republika Slovenija, 16 February 2017, Court of Justice of the European Union, ECLI:EU:C:2017:27.
} 


\subsection{Commission proposals and the implications for victims of torture}

The Commission reform proposals make modest changes to the legal standards addressing the protection of victims of torture. As regards the changes to the Reception Conditions Directive, applicants who have been subjected to gender-based violence are added to the list of persons who should have access to appropriate medical and psychological treatment. ${ }^{934}$ More importantly, the Commission proposal on the Reception Conditions Directive requires Member States to systematically, and as soon as possible, to identify whether an applicant has special reception needs. The sooner an applicant is identified as a victim of torture, the faster rehabilitation treatment can be started.

Similarly, the proposal on the Asylum Procedures Regulation requires Member States to systematically assess whether an applicant is in need of special procedural guarantees. Where there are indications that the applicant is a victim of torture and that this may affect his ability to effectively participate in the asylum procedure, the determining authorities of the Member State should provide the applicant with a doctor or a psychologist to further assess the physical and mental state of health. ${ }^{935}$ While these changes can raise the EU legal standards for torture victims, the Commission does not amend the contentious rule that provides the discretion to Member States of applying special procedures to victims of torture.

\subsection{Legal standards with regard to unaccompanied minors in the Common European Asylum System}

\subsubsection{The best interests of the child}

The starting point is that the best interests of the child must be a 'primary consideration' for Member States when they implement EU asylum law. 936 The best interests of the child principle is also enshrined in Article 24(2) of the Charter. Member States should aim to ensure full compliance with the best interests of the child principle in accordance with the Charter, the CRC and the

934 Article 24 of the Proposal for a Directive of the European Parliament and of the Council laying down standards for the reception of applicants for international protection (recast), Brussels, 13.7.2016, COM(2016) 465 final, 2016/0222 (COD).

935 Article 20(3) of the Proposal for a Regulation of the European Parliament and of the Council establishing a common procedure for international protection in the Union and repealing Directive 2013/32/EU, Brussels, 13.7.2016, COM(2016) 467 final, 2016/0224 (COD).

936 See for instance Article 23(1) of the recast Reception Conditions Directive and Article 25(6) of the recast Asylum Procedures Directive. 
ECHR. 937 The former rules of the CEAS contained different restrictions on the scope of the best interests principle, whereas the new recast provisions provide various specific references to the best interest principle and reflect a modest improvement compared to the former adopted EU asylum legislation. 938 In examining the best interests of the child, Member States should take into consideration the family reunification options, the well-being of the minor and social development, safety aspects and the minor's preferences. .39

\subsubsection{Reception conditions for children and unaccompanied minors}

The recast provisions of the CEAS provide for more elaborative child-specific measures. To illustrate, Member States must guarantee 'a standard of living adequate for the minor's physical, mental, spiritual, moral and social development'. Member States are also obliged to ensure that minors have access to leisure activities and to rehabilitation services for those minors that have been, inter alia, subjected to inhuman treatment or who are in need of mental health care. 940

Furthermore, minors should be accommodated with their parents or unmarried minor siblings if it is in the best interests of the minor. ${ }^{941}$ Minors should have access to education under 'similar' conditions as other nationals and more significantly access to education must not be postponed for more than three months. ${ }^{942}$ Where access to education is not possible because of the specific situation of the minor, other educational opportunities should be offered. ${ }^{943}$ Peek and Tsourdi submit that the notion 'specific situation of a person' in the context of education for children enshrined in Article 14(3) of the recast Reception Conditions Directive, may refer to vulnerability and special reception needs as a result of physical or mental impairment or because of a traumatic event children have experienced. 944

As regards unaccompanied minors, the recast Qualification Directive defines them as:

937 Recital 9 of the recast Reception Conditions Directive. See also Papademetriou, T., European Union: Status of Unaccompanied Children Arriving at the EU Borders, The Law Library of Congress, September 2014, p. 4.

938 See for a detailed analysis Smyth, C., European Asylum Law and the Rights of the Child, Routledge, 2014.

939 Article 23(2) of the recast Reception Conditions Directive.

940 Article 23(4) and (4) of the recast Reception Conditions Directive.

941 Article 23(5) of the recast Reception Conditions Directive.

942 Article 14(1) and (3) of the recast Reception Conditions Directive.

943 Article 14(3) of the recast Reception Conditions Directive.

944 Peek, M. and Tsourdi, L., Asylum Reception Conditions Directive 2013/33/EU in Kay Hailbronner and Daniel Thym (eds.), EU Immigration and Asylum Law, Commentary, $2^{\text {nd }}$ edition (C.H. BECK/Hart/Nomos, 2016), p. 1435. 
On reception-related conditions, the Commission introduced new legal standards for Member States to appoint a new guardian to represent and assist the unaccompanied minor. Member States must assign a new guardian no later than five working days from the moment an unaccompanied minor submits an application. Moreover, Member States must make sure that the guardian has no history of child-related crimes or offences. In addition, Member States must ensure that guardians can effectively perform their tasks, and ensure that they are not disproportionately burdened with too many unaccompanied minors. Member States also have the duty to monitor the quality of work performances of the guardians. ${ }^{979}$ Unlike the current recast CEAS instruments, the Commission now provides the definition of a guardian in Article 2(19) of the proposal Qualification Regulation, which stipulates:

'a person or an organisation appointed by the competent bodies in order to assist and represent an unaccompanied minor in procedures provided for in this Regulation with a view to ensuring the best interests of the child and exercising legal capacity for the minor where necessary'

An important additional requirement laid down in the proposal on the Reception Conditions Directive is that persons working with unaccompanied minors should receive regularly training regarding the rights and needs of unaccompanied minors. ${ }^{980}$ It follows from Recitals 30 and 32 that the special reception needs of applicants should be taken into account when it concerns material reception conditions. Reception conditions should be adapted to the specific situation of minors and unaccompanied minors. In particular the rights of children such as healthcare and the right to education have to be respected. It has been submitted before that applicants with special reception needs may be detained. The minor changes inserted by the Commission include that the right to education should be guaranteed by Member States in the circumstances that a minor is detained. Where unaccompanied minors are detained, Member States should adapt the conditions of detention to unaccompanied minors, including taking account of their rights. 981

With regard to procedural-specific changes, the Commission stresses that a high level of protection of vulnerable asylum applicants should be maintained,

979 Article 23 of the Proposal for a Directive of the European Parliament and of the Council laying down standards for the reception of applicants for international protection (recast), Brussels, 13.7.2016, COM(2016) 465 final, 2016/0222 (COD).

980 Article 22(6) of the Proposal for a Directive of the European Parliament and of the Council laying down standards for the reception of applicants for international protection (recast), Brussels, 13.7.2016, COM(2016) 465 final, 2016/0222 (COD).

981 Article 11(2), (3) of the Proposal for a Directive of the European Parliament and of the Council laying down standards for the reception of applicants for international protection (recast), Brussels, 13.7.2016, COM(2016) 465 final, 2016/0222 (COD). 
only be detained in 'exceptional' circumstances. It remains unclear what defines 'exceptional' circumstances. Member States have the obligation to release the detained unaccompanied minor as soon as possible. In any event, unaccompanied minors may never be detained in prison accommodation. 952

In addition, Member States must 'as far as possible, provide unaccompanied minors who are detained 'with accommodation in institutions provided with personnel and facilities which take into account the needs of persons of their age.' Hence, the recast Reception Conditions Directive does not explicitly prohibit the detention of unaccompanied minors, except that they are accommodated separately from adult detainees.

\subsubsection{Procedural guarantees}

\subsubsection{Legal representative}

The recast Asylum Procedures Directive enshrines in Article 25 important and extensive procedural guarantees to unaccompanied minors. A requirement for Member States is to appoint a representative as soon as possible to represent and assist the unaccompanied minor. The representative should have the opportunity to inform the unaccompanied minor about the meaning and possible consequences of the personal interview. ${ }^{953}$ The exception to this right is that Member States may refrain from appointing a representative where the unaccompanied minor will in all likelihood reach the age of 18 before a decision at first instance is taken. 954

Member States should also ensure that the personnel of the determining authority who conduct the interviews have a good understanding of the special needs of minors. 955 In addition, Member States must, free of charge, provide legal and procedural information to the unaccompanied minor and his representative. 956

\subsubsection{Age assessment}

To determine the age, national authorities may perform a medical examination on unaccompanied minors. Such a medical examination may only be performed if there are doubts concerning the applicant's age, 'following general statements or other relevant indications'. Member States must, however, ensure that unaccompanied minors are well informed in a language that they understand prior to the medical examination. Where Member States are still questioning the age of the applicant, they should give the applicant the benefit of the

\footnotetext{
952 Article 11(3) of the recast Reception Conditions Directive.

953 Article 25(1)(a),(b) of the recast Asylum Procedures Directive.

954 Article 25(2) of the recast Asylum Procedures Directive.

955 Article 25(3) of the recast Asylum Procedures Directive.

956 Article 25(4) of the recast Asylum Procedures Directive.
} 
doubt and consider the applicant a minor. 957 The medical examination must be carried out by qualified medical professionals with full respect for the dignity of the child and be 'the least invasive examination.'

Consequently, Member States are allowed to select their own method to assess the age of the applicant. For example, a paediatrician can examine the applicant on the basis of the applicant's medical history. A radiological examination may be involved, including other types of assessment. The other method used is to perform X-rays of the applicant's body of for instance wisdom teeth, the clavicle or wrist bones. Based on the findings of the X-ray, a radiologist provides a report on the age of the applicant. 958

\subsubsection{Accelerated and border procedures}

More problematic is Article 25(6) of the recast Asylum Procedures Directive, which allows in various situations for the possibility of applying accelerated procedures and border procedures (special procedures) to unaccompanied minors. Although the Commission initially proposed to exempt this specific vulnerable group from being subject to such procedures, the Council was opposed to this general exemption. ${ }^{959}$ Currently, there are three broad grounds upon which an unaccompanied minor may be put in an accelerated procedure. First, if the unaccompanied minor arrives from a 'safe country of origin'. Second, the unaccompanied minor has submitted an inadmissible subsequent application for international protection. Third, the unaccompanied minor is a serious danger to the society of the Member State or has been subject to a forced removal. 960

In addition to the aforementioned grounds in Article 25(6)(a) of the recast Asylum Procedures Directive, there are three additional grounds that allow Member States to process unaccompanied minors in border procedures. First, the unaccompanied minor could be sent to a 'safe third country'. Second, the unaccompanied minor has presented false documents. Third, the unaccompanied minor destroyed all relevant identity documents (mala fides). ${ }^{961}$ Hence, it follows from the recast Asylum Procedures Directive that Member States are allowed on several grounds to apply or continue with accelerated procedures or border procedures even if the applicant is an unaccompanied minor. Unless the unaccompanied minor has been identified as an applicant in need of special

957 Article 25(5) of the recast Asylum Procedures Directive.

958 Noll, G., Junk Science? Four Arguments against the Radiological Age Assessment of Unaccompanied Minors Seeking Asylum, International Journal of Refugee Law, Vol. 28, No. 2, 2016, p. 235.

959 Peers, S., Moreno-Lax, V., Garlick, M. and Guild, E., EU Immigration and Asylum Law (Text and Commentary): Second Revised Edition, Volume 3: EU Asylum Law, 2015, p. 246.

960 Article 25(6)(a) of the recast Asylum Procedures Directive.

961 Article 26(6)(b) of the recast Asylum Procedures Directive. 
procedural guarantees and where adequate support cannot be provided within accelerated or border procedures. As rightly claimed by ECRE, accelerated procedures and border procedures are not suited to take into consideration the particular vulnerability of unaccompanied minors and address their special procedural guarantees in practice. The best interests of the child cannot be fully guaranteed in such procedures. Due to their vulnerability, in particular, unaccompanied minors should be prioritized. ${ }^{962}$

\subsubsection{Unaccompanied minors as beneficiaries of international protection}

The recast Qualification Directive requires Member States to undertake several obligations with regard to unaccompanied minors granted international protection. ${ }^{963}$ First, Member States should determine as soon as possible a legal guardian that will represent the unaccompanied minor. Second, national authorities should monitor whether the guardian appropriately applies the needs of the minor. Third, unaccompanied minors should be placed in a suitable foster family or accommodation, including maintaining contact with siblings. Fourth, the tracing of family members should start as soon as international protection has been granted. However, where the tracing has already started, Member States should continue with tracing family members where appropriate. Fifth, those persons involved with unaccompanied minors should be trained to identify the needs of minors.

A general obligation to Member States is guaranteeing that all minors granted international protection status have access to education in the same conditions as other nationals. ${ }^{964}$ However, in the case of minor asylum applicants in respect of whom a final decision has not yet been taken, they should have access to schooling and education in 'similar' conditions as other nationals. ${ }^{965}$

\subsubsection{Dublin transfers}

The recast Dublin III Regulation explicitly recognizes the vulnerability of unaccompanied minors and the need for special procedural guarantees. 966 The objectives of the recast Dublin III Regulation are, inter alia, to keep the family together and take into account the needs of unaccompanied minors, including

962 ECRE, Information Note on Directive 2013/32/EU of the European Parliament and of the Council of 26 June 2013 on common procedures for granting and withdrawing international protection (recast), 2014, p. 32.

963 Article 31 of the recast Qualification Directive.

964 Article 27 of the recast Qualification Directive.

965 Article 14 of the recast Reception Conditions Directive.

966 Recital 13 of the recast Dublin III Regulation. 
other persons in need of special protection. ${ }^{967}$ The ECtHR has recognized that the extreme vulnerability of children is more important than the status of an asylum applicant. 968 The ECtHR has also determined that the CRC 'encourages States to take the appropriate measures to ensure that a child who is seeking to obtain refugee status enjoys protection and humanitarian assistance, whether the child is alone or accompanied by his or her parents. ${ }^{9} 99$

Important legal safeguards with regard to minors are enshrined in Article 6 of the recast Dublin III Regulation. ${ }^{970}$ The best interests of the child should be a primary consideration for Member States in all Dublin procedures carried out. In examining the child's best interests, the sending and receiving Member State shall take into account family reunification possibilities, the well-being and social development of the minor, safety and security aspects, including potential risks of human trafficking and the views of the minor.

With regard to unaccompanied minors, the recast Dublin III Regulation sets important legal standards for determining the responsible Member State. ${ }^{971}$ The primary rule is that Member States should be responsible for the unaccompanied minor where a family member or sibling is legally present, given that this is in the best interests of the unaccompanied minor. Secondly, as regards married minors whose spouse is not legally present in a Member State, the Member State in which the father, mother or other adult responsible for the minor or sibling is legally present should be responsible. Furthermore, where the unaccompanied minor has a relative in another Member State and it is determined that the relative is capable taking care of the minor, then that Member State should be responsible. Again, on the condition that this is in the best interests of the child. 972 Where family members, siblings or relatives as indicated in the previous paragraphs reside in more than one Member State, the best interests of the unaccompanied minor determine the Member State responsible. ${ }^{973}$ To that end, Member States should, as soon as possible, identify the family members, siblings or relatives of the unaccompanied minor legally present on the territory of

967 Tarakhel $v$ Switzerland, Application no. 29217/12, European Court of Human Rights, 4 November 2014, para. 35.

968 Mubilanzila Mayeka and Kaniki Mitunga v Belgium, Application no. 13178/03, European Court of Human Rights, 12 January 2007, para 55 and Popov v France, Application no. 39472/07, European Court of Human Rights, 19 January 2012, para. 91.

969 Popovv France, Application no. 39472/07, European Court of Human Rights, 19 January 2012, para. 91.

${ }^{970}$ See Case C-661/17, M.A., S.A., and A.Z., 23 January 2019, Court of Justice of the European Union, ECLI:EU:C:2019:53.

971 Article 8 of the recast Dublin III Regulation.

972 Article 8(2) of the recast Dublin III Regulation.

973 Article 8(3) of the recast Dublin III Regulation. 
Member States, provided that it is in the best interests of the child. ${ }^{974}$

In case there are no family members, siblings or relatives available, the Member State where the unaccompanied minor has lodged his application for international protection will be responsible. However, shortly after the adoption of the recast Dublin III Regulation, the CJEU confirmed in M.A. that 'where an unaccompanied minor with no member of his family legally present in the territory of a Member State has lodged asylum applications in more than one Member State, the Member State in which that minor is present after having lodged an asylum application there is to be designated the 'Member State responsible'.975 The CJEU emphasized that 'unaccompanied minors form a category of particularly vulnerable persons and therefore 'it is important not to prolong more than is strictly necessary the procedure for determining the Member State responsible, which means that, as a rule, unaccompanied minors should not be transferred to another Member State'. ${ }^{976}$ The M.A. ruling imposed a significant change in the Dublin practice of several Member States. Subsequently, in the light of the M.A. case, the Commission submitted a legislative proposal to amend Article 8(4) of the recast Dublin III Regulation. ${ }^{977}$

\subsubsection{Removal of unaccompanied minors}

Under the Return Directive, before removing an unaccompanied minor from the EU territory Member States are required to ensure that the unaccompanied minor will be returned to 'a member of his or her family, a nominated guardian or adequate reception facilities in the State of return'. ${ }^{978}$

\subsection{Commission proposals and the implications for unaccompanied minors}

The new proposals of the Commission include several important changes specifically addressed to unaccompanied minors.

974 Article 6(4) of the recast Dublin III Regulation.

975 Case C-648/11, The Queen, on the application of MA, BT, DA v Secretary of State for the Home Department, 6 June 2013, Court of Justice of the European Union, ECLI:EU:C:2013:367.

976 Case C-648/11, The Queen, on the application of MA, BT, DA v Secretary of State for the Home Department, 6 June 2013, Court of Justice of the European Union, ECLI:EU:C:2013:367, para. 55.

977 European Commission, Proposal for a Regulation of the European Parliament and of the Council amending Regulation (EU) No 604/2013 as regards determining the Member State responsible for examining the application for international protection of unaccompanied minors with no family member, sibling or relative legally present in a Member State, Brussels, 26.6.2014, COM(2014) 382 final, 2014/0202 (COD).

978 Article 10(2) of the Return Directive. 
On reception-related conditions, the Commission introduced new legal standards for Member States to appoint a new guardian to represent and assist the unaccompanied minor. Member States must assign a new guardian no later than five working days from the moment an unaccompanied minor submits an application. Moreover, Member States must make sure that the guardian has no history of child-related crimes or offences. In addition, Member States must ensure that guardians can effectively perform their tasks, and ensure that they are not disproportionately burdened with too many unaccompanied minors. Member States also have the duty to monitor the quality of work performances of the guardians. ${ }^{979}$ Unlike the current recast CEAS instruments, the Commission now provides the definition of a guardian in Article 2(19) of the proposal Qualification Regulation, which stipulates:

'a person or an organisation appointed by the competent bodies in order to assist and represent an unaccompanied minor in procedures provided for in this Regulation with a view to ensuring the best interests of the child and exercising legal capacity for the minor where necessary'

An important additional requirement laid down in the proposal on the Reception Conditions Directive is that persons working with unaccompanied minors should receive regularly training regarding the rights and needs of unaccompanied minors. ${ }^{980}$ It follows from Recitals 30 and 32 that the special reception needs of applicants should be taken into account when it concerns material reception conditions. Reception conditions should be adapted to the specific situation of minors and unaccompanied minors. In particular the rights of children such as healthcare and the right to education have to be respected. It has been submitted before that applicants with special reception needs may be detained. The minor changes inserted by the Commission include that the right to education should be guaranteed by Member States in the circumstances that a minor is detained. Where unaccompanied minors are detained, Member States should adapt the conditions of detention to unaccompanied minors, including taking account of their rights. 981

With regard to procedural-specific changes, the Commission stresses that a high level of protection of vulnerable asylum applicants should be maintained,

979 Article 23 of the Proposal for a Directive of the European Parliament and of the Council laying down standards for the reception of applicants for international protection (recast), Brussels, 13.7.2016, COM(2016) 465 final, 2016/0222 (COD).

980 Article 22(6) of the Proposal for a Directive of the European Parliament and of the Council laying down standards for the reception of applicants for international protection (recast), Brussels, 13.7.2016, COM(2016) 465 final, 2016/0222 (COD).

981 Article 11(2), (3) of the Proposal for a Directive of the European Parliament and of the Council laying down standards for the reception of applicants for international protection (recast), Brussels, 13.7.2016, COM(2016) 465 final, 2016/0222 (COD). 
especially when it concerns unaccompanied minors. ${ }^{982}$ However, a fundamental issue not addressed by the new Commission's proposal is to amend the rule that allows in various situations for the possibility of applying accelerated procedures and border procedures to unaccompanied minors.

It seems that strengthening the role of the guardian is a high priority for the Commission. The proposal on the Asylum Procedures Regulation equally obliges Member States to assign a guardian not later than five working days from the moment an unaccompanied minor submits an application. ${ }^{983}$ Where the unaccompanied minor is granted international protection, Member States should within five working days make sure that unaccompanied minors are represented by a legal guardian or organisation. ${ }^{984}$ The definition of a guardian is, however, formulated in a different way from the provision provided in the proposal on the Qualification Regulation, which reads: 985

'a person or an organisation appointed to assist and represent an unaccompanied minor with a view to safeguarding the best interests of the child and his or her general well-being in procedures provided for in this Regulation and exercising legal capacity for the minor where necessary.'

A new obligation placed upon the guardian is to inform the unaccompanied minor about the meaning and possible implications of the asylum interview. Additionally, the guardian should be present and be able to intervene during the interview. ${ }^{986}$ Recital 29 also clarifies the role and duties of the guardian.

982 Proposal for a Regulation of the European Parliament and of the Council establishing a common procedure for international protection in the Union and repealing Directive 2013/32/EU, Brussels, 13.7.2016, COM(2016) 467 final, 2016/0224 (COD), p. 14.

983 Article 22(1) of the Proposal for a Regulation of the European Parliament and of the Council establishing a common procedure for international protection in the Union and repealing Directive 2013/32/EU, Brussels, 13.7.2016, COM(2016) 467 final, 2016/0224 (COD).

984 Article 36(1) of the Proposal for a Regulation of the European Parliament and of the Council on standards for the qualification of third-country nationals or stateless persons as beneficiaries of international protection, for a uniform status for refugees or for persons eligible for subsidiary protection and for the content of the protection granted and amending Council Directive 2003/109/EC of 25 November 2003 concerning the status of third-country nationals who are long-term residents, Brussels, 13.7.2016, $\operatorname{COM}(2016) 466$ final 2016/0223 (COD).

985 Article 4(f) of the Proposal for a Regulation of the European Parliament and of the Council establishing a common procedure for international protection in the Union and repealing Directive 2013/32/EU, Brussels, 13.7.2016, COM(2016) 467 final, 2016/0224 (COD).

986 Article 22(6) and Article 32(1) of the Proposal for a Regulation of the European Parliament and of the Council establishing a common procedure for international protection in the Union and repealing Directive 2013/32/EU, Brussels, 13.7.2016, COM(2016) 467 final, 2016/0224 (COD). 
Guardians may also on behalf of an unaccompanied minor lodge an application in his or her own name.987 The ten working-day period for the lodging of an application starts for unaccompanied minors from the moment the guardian is assigned and meets with the unaccompanied minor.988

As to determining the age of the applicant, a psychological assessment may form part of the medical examination. ${ }^{989}$ Moreover, a new paragraph adds that where age assessments are performed by a Member State conducted in compliance with the provision on medical examinations of unaccompanied minors, they shall be recognized by other Member States. 990

Member States are obliged in particular to inform unaccompanied minors about the possibility of access to the asylum procedure where they are detained or where they are present at the external border or crossing points. ${ }^{991}$ The proposal maintains the rule that examinations of applications may be prioritized where the applicant is in need of special reception guarantees or in need of special procedural guarantees. In particular, cases of unaccompanied minors should be prioritized. 992

The new proposal explicitly allows Member States applying an accelerated procedure or border procedure to unaccompanied minors where the applicant

987 Article 31(6) of the Proposal for a Regulation of the European Parliament and of the Council establishing a common procedure for international protection in the Union and repealing Directive 2013/32/EU, Brussels, 13.7.2016, COM(2016) 467 final, 2016/0224 (COD).

988 Article 32(2) of the Proposal for a Regulation of the European Parliament and of the Council establishing a common procedure for international protection in the Union and repealing Directive 2013/32/EU, Brussels, 13.7.2016, COM(2016) 467 final, 2016/0224 (COD).

989 Article 24(1) of the Proposal for a Regulation of the European Parliament and of the Council establishing a common procedure for international protection in the Union and repealing Directive 2013/32/EU, Brussels, 13.7.2016, COM(2016) 467 final, 2016/0224 (COD).

990 Article 24(6) of the Proposal for a Regulation of the European Parliament and of the Council establishing a common procedure for international protection in the Union and repealing Directive 2013/32/EU, Brussels, 13.7.2016, COM(2016) 467 final, 2016/0224 (COD).

991 Article 30(1)(a) of the Proposal for a Regulation of the European Parliament and of the Council establishing a common procedure for international protection in the Union and repealing Directive 2013/32/EU, Brussels, 13.7.2016, COM(2016) 467 final, 2016/0224 (COD).

992 Article 33(5)(b) of the Proposal for a Regulation of the European Parliament and of the Council establishing a common procedure for international protection in the Union and repealing Directive 2013/32/EU, Brussels, 13.7.2016, COM(2016) 467 final, 2016/0224 (COD). 
arrives from a safe country of origin or where security reasons are involved. 993 However, accelerated procedures and border procedures may only be applied to unaccompanied minors within the conditions provided. ${ }^{994}$ A border procedure may also be applied to unaccompanied minors where the applicant arrives from a safe third country or where the applicant has provided incorrect information or documents or not revealed relevant information regarding their identify or nationality. ${ }^{995}$ Finally, the concepts of first country of asylum and safe third country may be applied to unaccompanied minors only where Member States obtain guarantees that the third country is taking care of the applicant and in the third country the applicant can enjoy protection in accordance with international refugee law or receive sufficient protection in that third country. 996

In its proposal to reform the recast Dublin III Regulation, the Commission promotes that the rights of unaccompanied minors have been strengthened because the best interests assessment is applied before transferring to another Member State. ${ }^{997}$ Nevertheless, there are elements in the proposal that are problematic, which would considerably weaken the protection of unaccompanied minors. First, unaccompanied minors would only receive a representative to represent them on the procedures of the Dublin Regulation where they are obliged to be present. 998 This rule would not be in accordance with the CRC. 999

993 Articles 40(5) and 41(5),(a),(b) of the Proposal for a Regulation of the European Parliament and of the Council establishing a common procedure for international protection in the Union and repealing Directive 2013/32/EU, Brussels, 13.7.2016, COM(2016) 467 final, 2016/0224 (COD).

994 Recitals 39 and 40 of the Proposal for a Regulation of the European Parliament and of the Council establishing a common procedure for international protection in the Union and repealing Directive 2013/32/EU, Brussels, 13.7.2016, COM(2016) 467 final, 2016/0224 (COD).

995 Article 41(5),(c),(d) of the Proposal for a Regulation of the European Parliament and of the Council establishing a common procedure for international protection in the Union and repealing Directive 2013/32/EU, Brussels, 13.7.2016, COM(2016) 467 final, 2016/0224 (COD).

996 Articles 44(4) and 45(5) of the Proposal for a Regulation of the European Parliament and of the Council establishing a common procedure for international protection in the Union and repealing Directive 2013/32/EU, Brussels, 13.7.2016, COM(2016) 467 final, 2016/0224 (COD).

997 European Commission, Proposal for a Regulation of the European Parliament and of the Council establishing the criteria and mechanisms for determining the Member State responsible for examining an application for international protection lodged in one of the Member States by a third-country national or a stateless person (recast), Brussels, 4.5.2016, COM(2016) 270 final, 2016/0133 (COD), pp. 14-17. See also Recital 20 of the Dublin Regulation proposal.

998 See in particular Maiani, F., (2016) The Reform of the Dublin III Regulation, European Parliament, p. 41. 
Second, the Commission introduces that, in the absence of family members of unaccompanied minors, the first Member State where the unaccompanied minor has lodged his application is responsible for examining the application, provided this is in the best interests of the minor applicant. ${ }^{1000}$ This specific aspect of the proposal goes against the CJEU judgment in M.A. To reiterate the CJEU 'since unaccompanied minors form a category of particularly vulnerable persons, it is important not to prolong more than is strictly necessary the procedure for determining the Member State responsible, which means that, as a rule, unaccompanied minors should not be transferred to another Member State' 1001 and that 'in the interests of unaccompanied minors, it is important (...) not to prolong unnecessarily the procedure for determining the Member State responsible, and to ensure that unaccompanied minors have prompt access to the procedures for determining refugee status'. ${ }^{1002}$ As submitted by Maiani, 'access to status determination will be swifter if the application is examined where it is lodged and the child is present, rather than after a Dublin procedure.'1003

Finally, under the new proposal for Eurodac, the age to take fingerprints of applicants has been set at six years. With this proposal, the Commission aims to strengthen the protection of unaccompanied minors. The proposal is not entirely clear whether unaccompanied minors may be sanctioned in circumstances where they refuse to give their fingerprints or a facial image. They may be referred to national protection authorities where there are reasons to believe that the child is at risk. ${ }^{1004}$ The Commission does not, as a general principle rule

999 UN Committee on the Rights of the Child (CRC), CRC General Comment No. 6 (2005): Treatment of Unaccompanied and Separated Children Outside their Country of Origin, 1 September 2005, CRC/GC/2005/6, para. 33.

${ }^{1000}$ Article 10(5) of the Proposal for a Regulation of the European Parliament and of the Council establishing the criteria and mechanisms for determining the Member State responsible for examining an application for international protection lodged in one of the Member States by a third-country national or a stateless person (recast), Brussels, 4.5.2016, COM(2016) 270 final, 2016/0133 (COD).

${ }^{1001}$ Case C-648/11, The Queen, on the application of MA, BT, DA v Secretary of State for the Home Department, 6 June 2013, Court of Justice of the European Union, ECLI:EU:C:2013:367, para. 55.

${ }^{1002}$ Case C-648/11, The Queen, on the application of MA, BT, DA v Secretary of State for the Home Department, 6 June 2013, Court of Justice of the European Union, ECLI:EU:C:2013:367, para. 61.

${ }^{1003}$ Maiani, F., (2016) The Reform of the Dublin III Regulation, European Parliament, p. 41. Meijers Committee, Note on the proposed reforms of the Dublin Regulation (COM (2016) 197), the Eurodac recast proposal (COM (2016) 272 final), and the proposal for an EU Asylum Agency (COM(2016)271 final), CM 1609, para. 2.4.

${ }^{1004}$ Article 2(4) of the Proposal for a Regulation of the European Parliament and of the Council on the establishment of 'Eurodac' for the comparison of fingerprints for the effective application of [Regulation (EU) No 604/2013 establishing the criteria and mech- 
out the use of force or coercion to take fingerprints of unaccompanied minors. The Fundamental Rights Agency submits that vulnerable persons such as unaccompanied minors and victims of torture should not be coerced into giving fingerprints, as it is not justified. 1005 Whilst the view of the Commission is that taking fingerprints strengthens the protection of unaccompanied minors as it may assist to establish the identity and trace any family members. 1006

\subsection{Analysis}

In the preceding sections, I have examined the relevant legal standards laid down in the CEAS with regard to victims of torture and unaccompanied minors. This section of the chapter will compare these legal standards with the obligations stemming from international human rights law.

\subsubsection{Victims of torture}

To begin with victims of torture, Article 25(1) of the recast Reception Conditions Directive requires Member States to guarantee asylum applicants who have been subjected to torture and other forms of violence, the necessary treatment of damages caused by such acts. They should in particular have access to medical and psychological care. In chapter 3 it has been submitted that international law standards provide torture victims a holistic rehabilitation, which includes medical and psychological care as well as legal and social support. Rehabilitation should be appropriate and promptly accessible. It is submitted here that Article 14 of the CAT suggests a treatment that is more comprehensive than the standard laid down in the recast Reception Conditions Directive.

Article 18(1) of the recast Asylum Procedures Directive obliges Member

anisms for determining the Member State responsible for examining an application for international protection lodged in one of the Member States by a third-country national or a stateless person], for identifying an illegally staying third-country national or stateless person and on requests for the comparison with Eurodac data by Member States' law enforcement authorities and Europol for law enforcement purposes (recast), Brussels, 4.5.2016, COM(2016) 272 final, 2016/0132 (COD).

${ }^{1005}$ See FRA, Fundamental rights implications of the obligation to provide fingerprints for Eurodac, 2015, p. 9.

${ }^{1006}$ Recital 25 the Proposal for a Regulation of the European Parliament and of the Council on the establishment of 'Eurodac' for the comparison of fingerprints for the effective application of [Regulation (EU) No 604/2013 establishing the criteria and mechanisms for determining the Member State responsible for examining an application for international protection lodged in one of the Member States by a third-country national or a stateless person], for identifying an illegally staying third-country national or stateless person and on requests for the comparison with Eurodac data by Member States' law enforcement authorities and Europol for law enforcement purposes (recast), Brussels, 4.5.2016, $\operatorname{COM}(2016) 272$ final, 2016/0132 (COD). 
States to arrange for a medical examination of the applicant, conducted by qualified medical professionals, where the determining authority deems it relevant. It has been submitted that medical reports play an important role in supporting the claim of a person of being subjected to torture in the past. Medical examination should be considered 'relevant' where there are serious indications, whether it is physically or psychologically, of past persecution or serious harm. ${ }^{1007}$ International law allows both parties to introduce all pertinent information in establishing whether the applicant has been tortured. Pertinent information could include medical, psychological or other independent evidence to support the claim that the applicant has been tortured or subject to illtreatment in the past. In my view, Article 18(1) of the recast Asylum Procedures Directive appears to be in accordance with obligations under international law. It is important to note that this study has submitted that where there are strong indications for believing that the injuries and scars on the applicant may have been caused by torture or ill-treatment, Member States should act upon these indications by obtaining an expert opinion to assess the probable cause of the injuries. Moreover, neglecting further investigation of allegations of torture while it appeared from medical evidence that the injuries were caused by torture can be in violation of Article 3 of the ECHR. In addition, Article 18(2) of the recast Asylum Procedures Directive provides applicants to arrange their medical examination to prove indications of past persecution or serious harm, however, only at their own cost. The Committee against Torture has, however, submitted that one of the measures that should be taken by State parties against possible violations of the principle of non-refoulement is to refer the applicant alleging to have been subjected to torture in the past to an independent medical examination free of charge, in accordance with the Istanbul Protocol. Hence, in my view, this standard falls short of the requirements resulting from Article 3 of the CAT. However, Article 5 of the recast Asylum Procedures Directive allows Member States to adopt or retain more favourable standards.

This chapter has submitted that the Asylum Procedures Directive requires Member States to exempt victims of torture from accelerated and border procedures where adequate support cannot be provided.1008 The wording 'adequate support' indicates a large margin of discretion for the Member States. How does this relate to international law obligations? It is important to note that both the Refugee Convention and other international human rights instruments do not set standards with regard to the establishment of asylum procedures. Nevertheless, to be in accordance with international law, State parties should implement procedures for the granting of refugee status in an effective

1007 ACVZ, Sporen uit het verleden, July 2014, p. 58.

${ }^{1008}$ Article 24(3) of the recast Asylum Procedures Directive. 
way (principle of effectiveness). This would mean that State parties should not establish an asylum procedure that would make it impossible to submit an asylum claim, which could render them at risk on refoulement. ${ }^{1009}$ Hence, it may be argued that the principle of effectiveness is breached where the adequate support does not guarantee that vulnerable persons, such as victims of torture, are able to submit their asylum claim in accelerated and border procedures. In my view, given the vulnerability of victims of torture and the short time limits in accelerated procedures, they should, as a general principle, be exempted from such a procedure. The Commission proposal to reform the CEAS does not amend this contentious possibility for Member States to process victims of torture in accelerated and border procedures.

As regard the Dublin III Regulation, it has been submitted that Member States should exchange health data of vulnerable applicants, such as torture victims, before a transfer is carried out. International law does not provide clear instructions for the interpretation of this standard. This study has, however, submitted that transferring an asylum applicant under the Dublin Regulation would violate Articles 3 and 14 of the CAT where State parties have not ascertained before transferring whether appropriate rehabilitative services are effectively available in the receiving State and accessible to the applicant to guarantee the right to rehabilitation as a torture victim.

\subsubsection{Unaccompanied minors}

A noticeable element is that the definition of unaccompanied minors enshrined in the recast Qualification Directive is different from the definitions provided under international law. Such inconsistencies may have implications for a common understanding of who falls under this category.

It has been submitted that the recast legislative acts of the CEAS bestows upon unaccompanied minors a number of important rights and guarantees in terms of reception and procedural guarantees. In terms of reception, according to Article 24(1) of the recast Reception Conditions Directive, Member States must as soon as possible assign a representative with the necessary expertise to the unaccompanied minor. The Committee of the Rights of the Child indicates that State parties should appoint a guardian, an adult or a legal representative as soon as possible. It is important to note that the Committee makes a clear distinction between a guardian and a legal representative and held that children in asylum procedures should be appointed a guardian and a legal representative. The wording in Article 24(1) of the recast Reception Conditions Directive only refers to representative. The UNHCR Handbook in accordance with the CRC

${ }^{1009}$ Battjes, H., European Asylum Law and International Law, Martinus Nijhoff Publishers, 2006, pp. 292-293. 
requires that that State parties appoint a legal representative in order to assist the unaccompanied minor throughout the asylum procedure. Case law of the ECtHR shows that when State parties fail to appoint a guardian that this could amount to a violation of Article 3 of the ECHR.

On accommodation, the Directive provides the standard that unaccompanied minors who are permitted to stay on the territory of the Member State should be placed with either adult relatives or with a foster family or otherwise in accommodation centres appropriate for minors. International law establishes that when State parties select the type of care and accommodation for children and unaccompanied minors in the context of asylum, the particular vulnerabilities of such a child should be taken into account. Furthermore, the recast Reception Conditions Directive includes the standard that national authorities should as soon as possible start tracing of family members of the unaccompanied minor, taken into account that it is in the best interests of the child. The Committee of the Rights of the Child also has held that during the tracing activities, national authorities should not make reference to the asylum or refugee status of the child. Overall, these standards are consistent with the requirements under international law. Overall, these standards are consistent with the requirements under international law.

On detention, it has been submitted that the recast Reception Conditions Directive allows Member States to detain unaccompanied minors, however, only in 'exceptional' circumstances. In addition, Member States have the obligation to release detained unaccompanied minors as soon as possible. In any event, unaccompanied minors may never be detained in prison accommodation. It also has been submitted that Member States should 'as far as possible', provide unaccompanied minors who are detained 'with accommodation in institutions provided with personnel and facilities which take into account the needs of persons of their age.' It follows from international law that minors may not automatically be detained. When minors are detained, State parties are required to apply certain procedural guarantees. The standards on detention laid down in the recast Reception Conditions Directive suggest to be in line with international law. However, where Member States detain children, accompanied or not, the standards on detention enshrined in the recast Reception Conditions Directive should be interpreted in accordance with the case law of the ECtHR on the detention of children. That is, children are vulnerable and they specific needs that are related to their age, their dependency on others and because of their status as asylum applicants. Hence, when children are detained, the conditions of detention should be adapted to the child's age.

In terms of procedural arrangements, it has been submitted that Member States on the basis of Article 25 of the recast Asylum Procedures Directive have to appoint a representative as soon as possible to represent and assist the unac- 
companied minor. The representative should have the opportunity to inform the unaccompanied minor about the meaning and possible consequences of the personal interview. ${ }^{1010}$ The exception to this right is that Member States may refrain from appointing a representative where the unaccompanied minor will in all likelihood reach the age of 18 before a decision at first instance is taken. ${ }^{1011}$ A closer look at the obligations stemming from the CRC reveals that there is no such exception laid down. ${ }^{1012}$ The Directive, however, leave the Member States large margin of discretion. Furthermore, the legal standards in Article 25 of the Directive provide also that Member States should ensure that the personnel of the determining authority who conduct the interviews have a good understanding of the special needs of minors and that unaccompanied minors and his representative receive, free of charge, legal and procedural information. It is submitted here that these standards are in line with the obligations resulting from international law.

To determine the age of unaccompanied minors, Member States are allowed to perform a medical examination conducted by medical professionals. The medical examination must be performed with full respect for the dignity of the child and be 'the least invasive examination.' International law has, however, contains stronger standards on the determination of the child's age. The Committee on the Rights of the Child has held that such assessments should not only take into account the physical presence of the child but also the psychological maturity. In addition, the age assessment should be performed in a 'scientific, safe, child and gender-sensitive and fair manner.'1013 It is important to note that the Commission in its proposal to reform the CEAS has proposed that a psychological assessment may form part of the medical examination.

Article 25(6) of the recast Asylum Procedures Directive allows Member States three broad grounds upon which an unaccompanied minor may be put in accelerated procedures and three additional grounds to process unaccompanied minors in border procedures. International law does not set conditions for the establishment of asylum procedures. Important is that the effectiveness of protection from refoulement is guaranteed and asylum procedures allow for a meaningful examination and rigorous scrutiny of asylum claims. ${ }^{1014}$ The most

${ }^{1010}$ Article 25(1)(a),(b) of the recast Asylum Procedures Directive.

${ }^{1011}$ Article 25(2) of the recast Asylum Procedures Directive.

${ }^{1012}$ Peers, S., Moreno-Lax, V., Garlick, M. and Guild, E., EU Immigration and Asylum Law (Text and Commentary): Second Revised Edition, Volume 3: EU Asylum Law, 2015, p. 245.

${ }^{1013}$ UN Committee on the Rights of the Child (CRC), CRC General Comment No. 6 (2005): Treatment of Unaccompanied and Separated Children Outside their Country of Origin, 1 September 2005, CRC/GC/2005/6, para. 31.

${ }^{1014}$ Battjes, H., European Asylum Law and International Law, Martinus Nijhoff Publishers, 2006, p. 304. 
basic principle that should apply in these special procedures is the best interests of the child.

On access to education, Article 14(1) of the recast Reception Conditions Directive requires Member States to grant minor asylum applicants in respect of whom a final decision has not yet been taken, access to schooling and education in 'similar' conditions as other nationals. The Refugee Convention, however, requires refugees and asylum applicants the same treatment with regard to schooling and education. ${ }^{1015}$ The standard laid down in the Directive falls below the obligation set in the Refugee Convention. Yet, the Directive allows Member States to adopt or retain more favourable provisions.

This chapter has been submitted that the recast Dublin III Regulation establishes important legal standards for determining the responsible Member State of unaccompanied minors. The standards in the Dublin Regulation show that the presence of family members constitutes the highest criteria for determining the responsible Member State to examine the asylum claim. In addition, in determining the Member State responsible, the principle of the best interests of the child should be taken into account. International law provides some guidance for the interpretation of this standard laid down in the Dublin Regulation. Chapter 3 has submitted that in determining the best interests of the child, substantive, interpretative and procedural elements need to be taken in into account. In addition, in assessing and determining the child's best interests, it is also important to take into account the child's situation of vulnerability. Furthermore, Article 22(1) of the CRC requires taking appropriate measures to ensure that a child who is seeking to obtain refugee status enjoys protection and humanitarian assistance, whether the child is alone or accompanied by his or her parents. It was submitted that in determining the appropriate measures, it is important to take account the particular vulnerabilities. In determining the measures to taken with regard to unaccompanied minors, the Committee on the Rights of the Child has submitted that the child's views and wishes should be taken into account. Further, as has been noted above, case law of the ECtHR has attached importance to the obligation under the CRC to take appropriate measures to ensure asylum seeking children enjoy protection, whether the child is alone or accompanied.

\subsection{Concluding remarks}

In this chapter, I have examined the notion of vulnerability in the CEAS and argued that there are a number of issues. I have submitted that the EU should adopt a more nuanced approach to vulnerability in the asylum process. This

1015 Article 22(1) of the Refugee Convention. 
would mean an approach that includes sources of vulnerability that are not only linked to certain groups, but also takes into account context-specific sources of vulnerability. It also has been submitted that the Directives allow Member States wide discretion as to how the identification of vulnerability should take place and whether an applicant is in need of special procedural guarantees. In my view, this is problematic because it may lead to considerably different outcomes among Member States.

Furthermore, I have examined the legal standards stemming from the recast legislative acts of the CEAS with regard to victims of torture and unaccompanied minors, and compared them to the obligations resulting from international human rights law. My analysis shows that a number of standards are consistent with international human rights law. I have also argued that a number of standards that are laid down in the legal instruments of the CEAS fall short of the requirements adopted under international human rights law. Finally, with regard to several standards, I have suggested interpretations in order to ensure conformity with international law. 


\section{7 - Vulnerable asylum applicants in EU Member States}

\subsection{Introduction}

Before moving on to an in-depth assessment of the implementation of the recast CEAS standards with regard to vulnerable asylum applicants in the Dutch legal framework, the present chapter provides from a bird's eye view the current practice with regard to vulnerable asylum applicants in various Member States.

Based on secondary sources, this chapter assesses a number of issues. First, it examines how many vulnerable asylum applicants arrive in the EU. This is essential in order to know the scale of the issue. Second, it examines how the notion of vulnerability is defined by Member States and which groups are deemed vulnerable in the national asylum process. Third, it assesses whether Member States have implemented a procedure to identify vulnerable asylum applicants. Fourth, it examines whether asylum applicants who are identified as vulnerable with special needs, are provided with special guarantees. Fifth, it examines the key challenges for vulnerable asylum applicants in the course of the Dublin procedure. Finally, sixth, it evaluates how and to what extent victims of torture and unaccompanied minors are adequately identified in the national asylum procedure.

\subsection{The scale of vulnerability in the context of asylum}

\subsubsection{Data on vulnerable asylum applicants}

How many of the asylum applicants that arrive in the EU are victims of torture or unaccompanied minors or belong to one of the other categories of vulnerable asylum applicants? Unfortunately, systematic data on vulnerable persons in the asylum process in order to assess the scale is lacking. The majority of Member States do not keep records of vulnerable asylum applicants. For example, there is hardly any information on disabled asylum applicants or on applicants with mental health problems that arrive in the EU.1016 Member States only collect data of vulnerable asylum applicants such as minors and unaccompanied minors. Only a few Member States register asylum applicants according to different categories of vulnerable groups such as disabled persons, pregnant women or victims of psychological, physical and sexual violence.1017 At least

${ }^{1016}$ FRA Monthly data collection on the current migration situation in the EU, Thematic focus: Disability, August 2016, p. 13.

${ }^{1017}$ BG, CY, EL, HR. See ECRE, The concept of vulnerability in European asylum procedures, 2017, pp. 19-20. 
nine Member States do not break down the number of asylum applicants into different vulnerable groups. 1018

\subsubsection{Victims of torture}

According to the UNHCR, between $20 \%$ and $30 \%$ of asylum applicants are victims of torture. During the period 2000 and 2010 there were around 580.000 potential torture victims among the asylum applicants. ${ }^{1019}$ However, accurate official data on torture victims is hard to obtain. The lack of data has to do with the fact that torture victims find it difficult to report to the authorities and at the same time the options for torture victims to report to the authorities are not sufficient. Several reasons can be given why the registration and reporting is insufficient with regard to this particular vulnerable group. One possible reason is the fact that victims of torture are not registered and also victims of torture themselves do not report past traumatic experiences upon arrival because they are often not provided with immediate psychological care or the identification mechanism to disclose signs of torture is not adequate. 1020

\subsubsection{Unaccompanied minors}

The Commission had already emphasized in 'The Action Plan on Unaccompanied Minors (2010-2014)' that 'the situation cannot be properly assessed, nor appropriate solutions found, without a clear evaluation based on comprehensive, reliable and comparable data.' ${ }^{1021}$ Although Member States are required to annually collect data on unaccompanied minors who apply for international protection, ${ }^{1022}$ data on minors and unaccompanied minors remain fragmented. ${ }^{1023}$ The collected data has not always been consistently disaggregated by age and sex. In addition, there is insufficient data on minors accompanied or unaccompanied that disappeared from the radar or absconded from reception

${ }_{1018}$ AT, BE, DE, ES, IE, MT, NL, PL, SE. See ECRE, The concept of vulnerability in European asylum procedures, 2017, pp. 18-20.

1019 ICRT background paper, Torture victims in Europe, October 2011, p. 1.

${ }^{1020}$ FRA, Current migration situation in the EU: Torture, trauma and its possible impact on drug use, February 2017, p. 3.

${ }^{1021}$ European Commission, Communication from the Commission to the European Parliament and the Council, Action Plan on Unaccompanied Minors (2010-2014), SEC(2010)534, Brussels, 6.5.2010, COM(2010)213 final, p. 3.

1022 Article 4(3)(a) of Regulation 862/2007 of the European Parliament and of the Council of 11 July 2007 on Community statistics on migration and international protection and repealing Council Regulation (EEC) No 311/76 on the compilation of statistics on foreign workers OJ L 199/23, 31.7.2007.

${ }^{1023}$ House of Lords, European Union Committee, 2nd Report of Session 2016-17, Children in crisis: unaccompanied migrant children in the EU, 2016, pp. 60-61. 
facilities. ${ }^{1024}$

Recent years have shown a rise of unaccompanied minors seeking protection in the EU. During the years 2008-2013 between approximately 11000 and 13000 unaccompanied minors were registered per year. ${ }^{1025}$ In 2015, 95205 unaccompanied minors applied for asylum in the EU.1026 In 2016, the numbers slightly decreased to 63280, however, this is still high above the average registered during the period of 2008-2013.1027

Table 7.1. The total number of unaccompanied minors seeking asylum in the EU between 2008-20171028

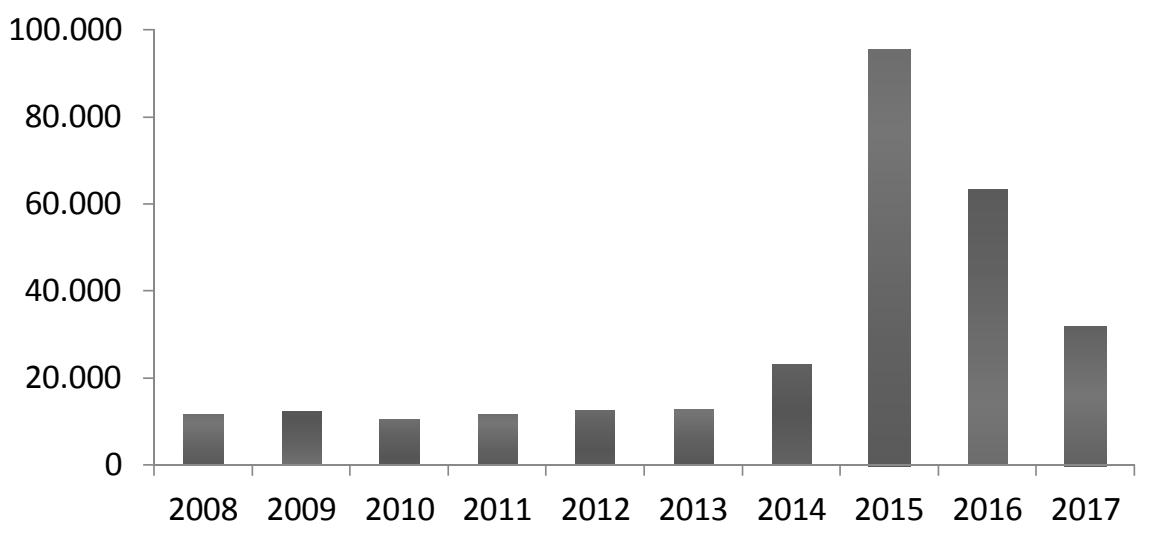

In 2016, the majority of the 63280 registered asylum seeking unaccompanied minors were from Afghanistan, Syria and Iraq. ${ }^{1029}$ Almost 36000 of the unac-

${ }^{1024}$ Communication from the European Commission to the European Parliament and the Council, The protection of children in migration, $\{\operatorname{SWD}(2017) 129$ final $\}$, Brussels, 12.4.2017, $\operatorname{COM(2017)~} 211$ final, p. 15.

${ }^{1025}$ Eurostat Newsrelease, 63300 unaccompanied minors among asylum seekers registered in the EU in 2016, 80/2017, 11 May 2017. See also European Migration Network, Ad Hoc Query on Unaccompanied Minors - updated facts and statistics, 24 April 2012.

${ }^{1026}$ Eurostat press release, Asylum applicants considered to be unaccompanied minors, Almost 90000 unaccompanied minors among asylum seekers registered in the EU in 2015, 2 May 2016.

${ }^{1027}$ Eurostat Newsrelease, 63300 unaccompanied minors among asylum seekers registered in the EU in 2016, 80/2017, 11 May 2017.

${ }^{1028}$ Eurostat, asylum applicants considered to be unaccompanied minors by citizenship, age and sex Annual data, last update 16-05-2018:

http://appsso.eurostat.ec.europa.eu/nui/show.do?dataset=migr_asyunaa\&lang=en. For more details on the number of unaccompanied minors in each Member State between 2008-2017, please see Annex III.

${ }^{1029}$ Eurostat Newsrelease, 63300 unaccompanied minors among asylum seekers registered in the EU in 2016, 80/2017, 11 May 2017. 
companied minors applied for asylum in Germany, followed by Italy with 6000 applications and Austria with 3900 unaccompanied minors seeking asylum.

In 2017, the number of unaccompanied minors who applied for asylum in the EU dropped to 31000, which is almost half of the level of 2016.1030 More than 10000 unaccompanied minors applied for asylum in Italy. Germany and Greece follow with 9100 and 2500 respectively. Afghanistan remains as in 2016 the main country of origin of asylum applicants considered to be unaccompanied minor. ${ }^{1031}$ Remarkably, the number of unaccompanied minors coming from Syria and Iraq dropped drastically compared to 2016.1032 Whether the EU - Turkey deal had an impact on the numbers coming from these countries is not evident; however, it cannot be excluded.

Table 7.2. Main third-countries of origin of asylum applicants considered to be unaccompanied minors, 20171033

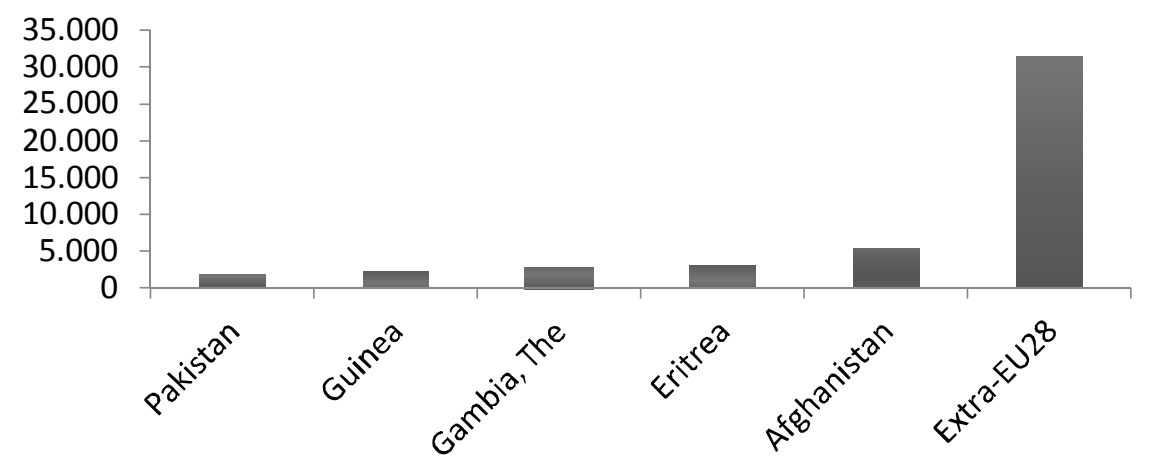

\subsection{Legal challenges, shortcomings and promising approaches with regard to vulnerable asylum applicants in EU Member States}

\subsubsection{Definition of vulnerable asylum applicants at the national level}

As discussed in chapter 6, the recast Reception Conditions Directive does not provide for a definition of vulnerability or vulnerable persons. It only obliges

\footnotetext{
${ }^{1030}$ Eurostat Newsrelease, Over 31000 unaccompanied minors among asylum seekers registered in the EU in 2017, 84/2018, 16 May 2018.

${ }^{1031}$ Eurostat Newsrelease, Over 31000 unaccompanied minors among asylum seekers registered in the EU in 2017, 84/2018, 16 May 2018.

${ }^{1032}$ In 2017, 1.765 unaccompanied minors from Syria and 1.240 unaccompanied minors from Iraq applied for asylum in the EU, whereas in 2016, 11.990 unaccompanied minors form Syria and 4.155 unaccompanied minors from Iraq applied for asylum in the EU.

${ }^{1033}$ Asylum applicants considered to be unaccompanied minors by citizenship, age and sex Annual data, last update 16-05-2018:

http://appsso.eurostat.ec.europa.eu/nui/submitViewTableAction.do
} 
Member States 'to take into account the specific situation of vulnerable persons'. Hence, the discretion granted to Member States to define vulnerability has resulted in a divergence in the categories of asylum applicants labelled as vulnerable.

In a study conducted by European Migration Network (EMN) in 2014,1034 which conducted research in twenty-four Member States, it has been submitted that at least twenty-one Member States consider unaccompanied minors as vulnerable.1035 In six Member States children with specific welfare needs are viewed as vulnerable persons. ${ }^{1036}$ Ten Member States reported victims of trafficking as being considered vulnerable and eleven Member States regard persons with medical or psychological needs including victims and traumatised persons as vulnerable. 1037 In three Member States persons with higher security needs are vulnerable. ${ }^{1038}$

In a study co-ordinated by the European Council on Refugees and Exiles (ECRE) in 20171039 among eighteen Member states, it has been reported that at least fifteen Member States consider unaccompanied minors as vulnerable. ${ }^{1040}$ Fourteen Member States regard minors, ${ }^{1041}$ elderly, ${ }^{1042}$ single parents with minor children ${ }^{1043}$ and persons subjected to forms of psychological, physical or sexual violence as vulnerable. ${ }^{1044}$ Thirteen Member States view disabled persons, ${ }^{1045}$ pregnant women, ${ }^{1046}$ and persons subjected to torture ${ }^{1047}$ as vulnerable. In seven Member States persons with serious illness 1048 or mental disorders 1049 are labelled as vulnerable. One Member State also considers persons with PTSD and survivors, including relatives of victims of shipwrecks as vulnerable. ${ }^{1050}$ Other categories that are deemed vulnerable by Member States:

${ }^{1034}$ EMN study, The Organisation of Reception Facilities for Asylum Seekers in different Member States, 2014, p. 14.

${ }^{1035}$ AT, BE, CY, CZ, EE, DE, FI, FR, HU, IE, IT, LT, LU, NL, PL, PT, SK, ES, SE, UK.

${ }^{1036}$ CY, CZ, FI, IT, PL, SE.

${ }^{1037} \mathrm{BE}, \mathrm{CY}, \mathrm{CZ}, \mathrm{DE}, \mathrm{EE}, \mathrm{FI}, \mathrm{IT}, \mathrm{LV}, \mathrm{LU}, \mathrm{ES}, \mathrm{SE}$.

${ }^{1038}$ CZ, EE, LU.

${ }^{1039}$ ECRE, The concept of vulnerability in European asylum procedures, 2017, pp. 16-17.

${ }^{1040}$ BE, BG, CY, ES, FR, EL, HR, HU, IE, IT, MT, NL, PL, PT, RO.

${ }^{1041}$ BE, BG, CY, ES, FR, EL, HR, HU, IE, IT, MT, PL, PT, RO.

${ }^{1042}$ BE, BG, EL, CY, ES, FR, HR, HU, IE, IT, MT, PL, PT, RO.

${ }^{1043}$ BE, BG, EL, CY, ES, FR, HR, HU, IE, IT, MT, PL, PT, RO.

${ }^{1044} \mathrm{BE}, \mathrm{BG}, \mathrm{CY}, \mathrm{ES}, \mathrm{FR}, \mathrm{EL}, \mathrm{HR}, \mathrm{HU}, \mathrm{IE}, \mathrm{IT}, \mathrm{MT}$, PL, PT, RO.

${ }^{1045}$ BE, BG, CY, ES, FR, EL, HR, HU, IT, MT, PL, PT, RO.

${ }^{1046}$ BE, BG, CY, ES, FR, HR, HU, IE, IT, MT, PL, PT, RO.

${ }^{1047}$ BE, CY, ES, FR, EL, HR, HU, IE, IT, MT, PL, PT, RO.

${ }^{1048} \mathrm{BE}, \mathrm{CY}, \mathrm{EL}, \mathrm{IT}, \mathrm{MT}, \mathrm{PL}, \mathrm{PT}$.

$1^{1049} \mathrm{BE}, \mathrm{CY}, \mathrm{HR}, \mathrm{IT}, \mathrm{MT}, \mathrm{PL}, \mathrm{PT}$.

${ }^{1050} \mathrm{EL}$. 
victims of human trafficking by ten Member States, ${ }^{1051}$ persons with lack of legal capacity are deemed vulnerable in one Member State ${ }^{1052}$ and female genital mutilation in six Member States. ${ }^{1053}$ In Austria, vulnerability is determined at the regional level and not at the national level.1054 A more recent report by EMN demonstrates the divergent approaches among Member States to the application of the concept of vulnerability in the context of asylum and how the procedure for the identification of vulnerable asylum applicants is carried out at the national level. 1055

Whether an asylum applicant is considered as vulnerable is not only dependent on the individual circumstances, but also on the context. The following section provides an insight into the Belgian practice regarding the concept of vulnerability in the asylum context.

\subsubsection{The notion of vulnerability in the asylum process: the practice in Bel- gium}

A study among personnel working in the Belgium asylum system revealed that the concept of vulnerability is interpreted broadly. It showed that their interpretation of vulnerability depends to a large extent on their own experience in the field. In addition to the list of vulnerable persons stipulated at the European and national level, the personnel in the field also identified other factors which could render an applicant vulnerable: 1056

'not being proficient in a contact language, being part of a large family, being part of a "closed community", having cultural and religious practices which differ significantly from those of the host country, being isolated, having limited autonomy, having a low level of education, being illiterate, having a problematic family situation, having a different sexual orientation or gender identity, having an addiction to alcohol or drugs, and being a young adult.'

The study submits that vulnerability not only depends on personal characteristics, but it may also be caused by external factors during the asylum procedure or the reception phase. It is a multi-dimensional phenomenon. Applicants may not be identified as vulnerable in the registration phase because they may not

${ }^{1051} \mathrm{BE}, \mathrm{CY}, \mathrm{ES}, \mathrm{FR}, \mathrm{EL}, \mathrm{IT}, \mathrm{MT}, \mathrm{PL}, \mathrm{PT}, \mathrm{RO}$.

${ }^{1052} \mathrm{HR}$.

${ }^{1053} \mathrm{BE}, \mathrm{CY}, \mathrm{HR}, \mathrm{IT}, \mathrm{MT}, \mathrm{FR}$.

${ }^{1054}$ Bendel, P. and Bekyol, Y., The reception of female refugees and asylum seekers in the EU, Case study Belgium and Germany, European Parliament, Brussels (2016), p. 14.

${ }^{1055}$ EMN Ad-Hoc Query on BE AHQ: Part I - Reception of Vulnerable Applicants for International Protection with Special Reception Needs, 2018. See Annex I for an overview of asylum applicants considered vulnerable persons in Member States and references to national legislation.

${ }^{1056}$ Fedasil, Study into vulnerable persons with specific reception needs, 2016, pp. 16-17. 
fall within the enumerated categories of vulnerable persons. However, they may become vulnerable during the reception. Furthermore, additional factors are important to take into account in considering whether an applicant is considered as vulnerable. For example, an applicant is not automatically vulnerable because she is a pregnant woman, but because she is a single pregnant woman. ${ }^{1057}$

Another observation made by the study is the multi-dimensionality of the reception needs of vulnerable asylum applicants. Because vulnerable applicants are divergent in their vulnerability and needs, there is also a need for 'multidisciplinary, intensive and individual guidance'. A multi-disciplinary approach would involve external specialized experts. In order to provide a comprehensive guidance, one needs time and competent staff, including interpreters. At the same time, there is need for small reception facilities that are close to the specialised medical and psychological services. ${ }^{1058}$

Table 7.3. Specific needs of vulnerable asylum applicants according to Fedasil ${ }^{1059}$

\begin{tabular}{|l|l|}
\hline $\begin{array}{l}\text { Categories of vul- } \\
\text { nerable asylum ap- } \\
\text { plicants }\end{array}$ & Specific needs \\
\hline Children & $>$ Require direct support \\
\hline $\begin{array}{l}\text { Unaccompanied mi- } \\
\text { nors }\end{array}$ & $\begin{array}{l}>\text { Require individual guidance } \\
>\text { Need for a safe, stable and caring environment, } \\
\text { which enables them to create a social network }\end{array}$ \\
\hline $\begin{array}{l}\text { Victims of human } \\
\text { trafficking }\end{array}$ & $\begin{array}{l}>\text { Require a cultural and gender sensitive approach } \\
>\text { Create a safe and confidential environment to } \\
\text { prevent human traffickers contacting the victim } \\
\text { again }\end{array}$ \\
\hline $\begin{array}{l}\text { Persons with mental } \\
\text { disorders }\end{array}$ & $\begin{array}{l}>\text { Specific psychological support and psycho- } \\
\text { education is needed }\end{array}$ \\
\hline $\begin{array}{l}\text { Persons who have } \\
\text { been tortured, raped } \\
\text { or exposed to other } \\
\text { serious forms of psy- } \\
\text { chological, physical or } \\
\text { sexual violence }\end{array}$ & $\begin{array}{l}>\text { Access to specific medical and psychological care } \\
>\text { Require a cultural and gender sensitive approach }\end{array}$ \\
\hline
\end{tabular}

${ }^{1057}$ Fedasil, Study into vulnerable persons with specific reception needs, 2016, pp. 18-19. ${ }^{1058}$ Fedasil, Study into vulnerable persons with specific reception needs, 2016, pp. 20-21. ${ }^{1059}$ Fedasil, Study into vulnerable persons with specific reception needs, 2016, pp. 21-22. 


\begin{tabular}{|c|c|}
\hline $\begin{array}{l}\text { Persons subjected to } \\
\text { female genital mutila- } \\
\text { tion }\end{array}$ & $>$ Require a safe and confidential environment \\
\hline Pregnant women & $\begin{array}{l}\text { Maternity care in their own language or a lan- } \\
\text { guage in which they are proficient }\end{array}$ \\
\hline Elderly persons & $\begin{array}{l}\text { Reception facilities which are adapted to their } \\
\text { limited mobility }\end{array}$ \\
\hline Disabled persons & $\begin{array}{l}\text { An adapted living environment, such as adapted } \\
\text { toilets, no bunk beds } \\
\text { Accessible facilities, such as shorter distances to } \\
\text { the restaurant of the reception centre } \\
>\text { Specific equipment, such as wheelchairs, crutches } \\
\text { or hearing devices }\end{array}$ \\
\hline $\begin{array}{l}\text { Single mothers with } \\
\text { children }\end{array}$ & $>$ Need for childcare \\
\hline $\begin{array}{l}\text { Large families with } \\
\text { children }\end{array}$ & $>$ Support in the education of the children \\
\hline $\begin{array}{l}\text { Persons who cannot } \\
\text { express themselves in } \\
\text { a contact language }\end{array}$ & $>$ Require more visual communication \\
\hline
\end{tabular}

\subsubsection{Assessment of vulnerable asylum applicants with special reception needs}

Already in 2007, the Commission reported in its implementation report, which aimed to give an overview of the transposition and application of the 2003 Reception Conditions Directive by Member States, that at least nine Member States 1060 did not have a mechanism in place to identify the special reception needs of vulnerable asylum applicants. ${ }^{1061}$

In 2009, an EMN ad-hoc query identified that most Member States still did not have an identification mechanism in place to identify vulnerable asylum applicants with special reception needs. ${ }^{1062}$ According to another report con-

1060 UK, DE, AT, BE, LU, EL, IT, SK, SI.

${ }^{1061}$ European Commission, Report from the Commission to the Council and to the European Parliament on the application of Directive 2003/9/EC of 27 January 2003 laying down minimum standards for the reception of asylum seekers, Brussels, 26.11.2007, $\operatorname{COM}(2007) 745$ final, para. 3.5.1.

${ }^{1062}$ EMN Ad-Hoc Query on the needs of vulnerable migrants, 27 October 2009. 
ducted by the EMN - which refers to the situation in Member States in 2013 and most probably did not include the legal standards introduced by the recast asylum instruments - reported that there are fourteen Member States that have implemented an assessment procedure in their domestic law or apply it in practice. ${ }^{1063}$ Member States differ, however, in their methods, timing and the role of national authorities involved. While some Member States assess the vulnerability and special reception needs during the medical screening, ${ }^{1064}$ other Member States assess during the interview. 1065 It has been reported that at least two Member States ${ }^{1066}$ regularly assess the vulnerability of an applicant and at least three Member States ${ }^{1067}$ have not implemented in law or apply in practice an assessment procedure. ${ }^{1068}$

A more recent report by EASO notes that twelve Member States ${ }^{1069}$ have implemented measures to identify at an early stage vulnerable applicants with special reception needs. ${ }^{1070}$ For example, in Belgium and Cyprus, standardization of special registration forms to promptly detect vulnerabilities by competent national authorities has been carried out. ${ }^{1071}$

The Commissioner for Human Rights of the Council of Europe has addressed the situation of vulnerable asylum applicants during his visits to several Member States. According to the Commissioner, in Germany, the asylum system is not 'equipped to identify and provide special support to certain categories of vulnerable persons.' This concerns in particular victims of torture.1072 In Bulgaria, shortcomings have been detected as to the early identification of vulnerable asylum applicants with special reception needs. ${ }^{1073}$ In Slovenia, further improvements were necessary to deal with asylum applicants who are particularly vulnerable and in need of specific support, in particular to cease the deten-

${ }^{1063}$ BE, CY, CZ, DE, EL, FI, HU, IT, LU, PL, SI, SK, SE, UK.

$1064 \mathrm{IE}, \mathrm{LV}$.

${ }^{1065}$ CZ, EE, FI, LU, NL, FR.

${ }^{1066} \mathrm{SE}, \mathrm{BE}$.

${ }^{1067}$ AT, FR, IT.

${ }^{1068}$ EMN study, The Organisation of Reception Facilities for Asylum Seekers in different Member States, 2014, pp. 11-12.

${ }^{1069}$ AT, CY, DE, EE, IT, BE, EL, FR, LT, UK, RO, PL.

${ }^{1070}$ EASO, Annual Report on the Situation of Asylum in the European Union 2016, July 2017, pp. 132-133.

${ }^{1071}$ EASO, Annual Report on the Situation of Asylum in the European Union 2016, July 2017, p. 107.

${ }^{1072}$ Council of Europe, Report by Nils Muiznieks, Commissioner for Human Rights of the Council of Europe, Following his visit to Germany on 24th April and from 4 to 8 May 2015, Strasbourg 1 October 2015, para. 109.

${ }^{1073}$ Council of Europe, Report by Nils Muiznieks, Commissioner for Human Rights of the Council of Europe, Following his visit to Bulgaria from 9 to 11 February 2015, Strasbourg, 22 June 2015, paras. 101 and 135. 
tion of unaccompanied minors. ${ }^{1074}$

Reports show also that there is not only a lack of formal procedures for identifying applicants with disabilities in reception or during detention, but also varied practices between Member States as to how impairments are identified. ${ }^{1075}$ Due to the lack of formal identification procedures, the identification is usually carried out during the interview or during the medical examination. Most of the identification process takes place in an informal or ad-hoc manner, which can lead to the situation of many unidentified applicants in practice. The differences in identification procedures means also the involvement of different actors and on many occasions identification of applicants with disabilities depends on the information provided by the applicants themselves. Another concern is that impairments that are less 'visible' are not immediately identified. ${ }^{1076}$

Country reports issued by ECRE assessing the special reception needs of applicants in the national asylum procedure in eighteen Member States ${ }^{1077}$ show that at least ten Member States have introduced some form of procedure to identify vulnerable asylum applicants with special reception needs. ${ }^{1078}$

However, a closer reading reveals that these procedures are not effective, not applied in a systematic manner and Member States still differ as to the authorities or institutions that are involved in the vulnerability assessment. For instance, in France, despite the introduction of a specific procedure for the identification of vulnerable asylum applicants with special needs, the procedure, however, only addresses the identification of vulnerable asylum applicants with visible specific needs such as families with children, pregnant women and the elderly. At the same time, the introduction of a 'single desk' procedure has improved the coordination between the local authorities that register the asylum applications and the French Office of Immigration and Integration (OFI), which assesses the special needs of vulnerable asylum applicants during the first interview. ${ }^{1079}$ There is a lack of monitoring of special reception needs that may appear during the asylum procedure. Reception centres can inform the competent authorities whether a vulnerable asylum applicant with special needs should be transferred to more adapted accommodation. The key challenge is

\footnotetext{
${ }^{1074}$ Council of Europe, Report by Nils Muiznieks, Commissioner for Human Rights of the Council of Europe, Following his visit to Slovenia from 20 to 23 March 2017, Strasbourg, 11 July 2017, p. 1.

1075 AT, BG, DE, EL, HU, IT, SE.

${ }^{1076}$ FRA, Monthly data collection on the current migration situation in the EU, Thematic focus: Disability, August 2016, pp. 8-12.

1077 See Asylum Information Database, ECRE country reports (2016 update).

${ }^{1078}$ BE, EL, FR, HU, UK, SE, AT, MT, SE, NL.

${ }^{1079}$ EASO, Annual Report on the Situation of Asylum in the European Union 2016, July 2017, p. 107.
} 
how to respond to these special needs. 1080

In Belgium a procedure to identify vulnerable asylum applicants with special reception needs has been put in place. However, the key challenge in Belgium lies in the lack of time to focus on the potential vulnerabilities of applicants, shortage of staff, language and communication problems with applicants at the reception centres and not enough knowledge, experience and training of vulnerabilities. ${ }^{1081}$ Although, the identification starts during the registration phase, the focus is on medical vulnerabilities. ${ }^{1082}$ During the registration phase, the competent authority can register factors that point to the vulnerability of the asylum applicant. The authorities can indicate that the applicant is an unaccompanied minor, elderly (65+), pregnant, a single woman, LGBTI, victim of human trafficking, a person that has been subjected to psychological, physical or sexual violence, whether the applicant has children or any medical or psychological issues. The applicant will undergo a medical examination when there is an indication that the applicant has a medical problem. Where due to medical reasons the applicant needs specialized accommodation, Fedasil will explore the options to accommodate the applicant in a suitable reception centre. However, it is at the reception centres that other vulnerabilities are identified. No later than thirty days after allocation to a reception centre, a legal assessment of special reception needs of vulnerable applicants should take place in order to examine whether the accommodation is adequate to the personal situation. In particular vulnerabilities that are less visible should be taken into account. Where the outcome of the assessment shows that the accommodation is not suitable for such applicants, appropriate measures have to be taken, such as to relocate the applicant to another reception centre. ${ }^{1083}$ Furthermore, in addition to the earlier mentioned issues with the identification of vulnerabilities of asylum applicants and their special reception needs, identification instruments within the reception centres are not always implemented in a coherent and effective way. In particular the high migratory pressure in 2015 lead to divergent practices on the identification procedure between the reception centres in Belgium. ${ }^{1084}$

In Hungary, although the legislation provides that vulnerable applicants with special reception needs will receive the necessary treatment, there is no mechanism to identify vulnerable asylum applicants. Whether an applicant is identified as vulnerable requiring special reception needs at the beginning or during the asylum procedure depends to a large extent on the ability of the asy-

\footnotetext{
${ }^{1080}$ Asylum Information Database, France country report, February 2017, p. 89.

${ }^{1081}$ Fedasil, Study into vulnerable persons with specific reception needs, 2016, p. 26.

${ }^{1082}$ Fedasil, Study into vulnerable persons with specific reception needs, 2016, p. 29.

${ }^{1083}$ Asylum Information Database, Belgium country report, February 2017, p. 81.

${ }^{1084}$ Fedasil, Study into vulnerable persons with specific reception needs, 2016, p. 29.
} 
lum officer. ${ }^{1085}$

The UK has not implemented a procedure to identify vulnerable asylum applicants with special reception needs. However, if the asylum applicant has for instance a medical report indicating the vulnerability, the competent authority should take the vulnerability into account when allocating the applicant to an accommodation centre. Basic health screening is provided in the accommodation centres, which are managed by private companies. A health provider at the accommodation centre may identify vulnerabilities and special needs of applicants or it may be identified because applicants themselves inform a volunteer or community advice organization about their specific impairment. ${ }^{1086}$

In Austria the legislation states that the special reception needs of asylum applicants must be taken into account. However, the legislation does not implement a mechanism to identify vulnerable asylum applicants with special reception needs. Applicants receive only a general health screening. In practice, an asylum applicant or a social worker has to request adequate reception facilities. ${ }^{1087}$

In Malta, applicants that arrive irregularly are brought to an Initial Reception Centre (IRC) to undergo a screening. Applicants who enter the country regularly have no access to a vulnerability assessment in order to detect specific reception needs. In addition, it remains questionable whether all applicants at the initial reception centre are assessed or only applicants with visible vulnerabilities. ${ }^{1088}$

In Greece, shortcomings have been pointed out as to the identification of vulnerable asylum applicants. Applicants receive health screenings, which are not equipped to examine certain vulnerabilities with applicants. Less visible vulnerabilities may not be identified. ${ }^{1089}$ At the same time, the high numbers of arrivals have made the identification of vulnerable asylum applicants in practice not possible. 1090

In Germany, the reception of asylum applicants is the task of the federal States. Therefore, a common systematic assessment procedure for vulnerable asylum applicants with special reception needs does not exist. A few federal States, such as Berlin, have introduced some form of a mechanism at the re-

1085 Asylum Information Database, Country report Hungary, February 2017, p. 65.

${ }^{1086}$ Asylum Information Database, Country report UK, February 2017, pp. 73-74.

${ }^{1087}$ Asylum Information Database, Country report Austria, February 2017, p. 77.

1088 Asylum Information Database, Country report Malta, February 2017, pp. 48-49.

${ }^{1089}$ MSF, Greece in 2016: Vulnerable People Get Left Behind, p. 14.

${ }^{1090}$ Wagner, M., Dimitriadi, A., O'Donell, R., Perumadan, J., Schlotzhauer, J. H., Simic, I., \&

Yabasun, D. (2016), The implementation of the Common European asylum system. Brussels:

European Parliament, p. 87. 
gional level. ${ }^{1091}$

It has been submitted that in Sweden, the authorities have not implemented the legal standards enshrined in Articles 21 and 22 of the recast Reception Conditions Directive concerning vulnerable persons with special reception needs. The reception needs of vulnerable asylum applicants are taken into account on the basis of certain standards that are developed by the Swedish Migration Agency. The standards entail an initial assessment of the special reception needs and an assessment during the asylum procedure. ${ }^{1092}$

\subsubsection{Assessment of applicants with special procedural guarantees}

Similarly, several Member States have some form of a procedure to assess whether an applicant is in need of special procedural guarantees, however, the procedures do not seem to be always effective or only apply to certain categories of vulnerable applicants such as unaccompanied minors. ${ }^{1093}$ For instance, in Cyprus, although the legislation foresees an identification mechanism to assess whether an applicant has special reception needs and or is in need of special procedural guarantees, there is a lack of legislative or procedural guidelines, the identification is not systematically carried out and the tools to assess are not defined or standardised. ${ }^{1094}$

In Germany, a systematic identification of special procedural guarantees for vulnerable applicants is not in place, save for unaccompanied minor applicants. All applicants go through a medical screening, which focuses on detecting infectious diseases rather than elements of vulnerabilities. Where it appears during the interview that the applicant is vulnerable such as suffering from PTSD, the asylum officer is required to consult a special commissioner, which may take over the case. 1095

In Sweden, contrary to the view of the Swedish Migration Agency, the Swedish Red Cross and the UNHCR, the Swedish government has been of the opinion that the current national law sufficiently takes into account the obliga-

${ }^{1091}$ EASO, Annual Report on the Situation of Asylum in the European Union 2016, July 2017, p. 107. See also Asylum Information Database, Country Report Germany, March 2017, pp. 68-69.

1092 Asylum Information Database, Country report Sweden, March 2017, p. 52.

${ }^{1093}$ MT, FR, AT, EL, BE, SE, PL, CY, DE, NL, HR.

${ }^{1094}$ Asylum Information Database, Country report Cyprus, March 2017, pp. 34-35.

1095 Asylum Information Database, Country report Germany, March 2017, pp. 40-42. See also Baron, J. and Hager, N., Eine Frage von Glück und Zufall - Zu den Verfahrensgarantien für psychisch Kranke oder Traumatisierte im Asylverfahren, Beratung und Rechtsschutz - Beitrage zu den Anforderungen an die rechtliche Beratung und Vertretung von Schutzsuchenden, Beilage zum Asylmagazin, Informationsverbund Asylum \& Migration, 78/2017,pp. 17-26. 
tion of Article 24 of the recast Asylum Procedures Directive on the identification on applicants in need of special procedural guarantees and therefore no amendment is needed. ${ }^{1096}$ Asylum applicants in Sweden are given the opportunity to undergo a medical examination, which includes a consultation on the applicant's past and current physical and mental health or whether the applicant has been subjected to torture or other forms of violence. ${ }^{1097}$

\subsubsection{Special reception guarantees}

Once vulnerable asylum applicants are identified as persons having special reception needs, Member States should provide specific support which guarantees a standard of living that meets the specific needs of vulnerable applicants and the necessary medical assistance, including appropriate mental health care where needed. In addition, Member States have the legal obligation to take into account gender and age-specific concerns and the situation of vulnerable persons as regards applicants in premises designed for the housing of applicants during the examination of applications for international protection made at the border or in transit zones and accommodation centres. Where vulnerable asylum applicants are detained, Member States should regularly monitor and guarantee adequate support taking into account their particular situation, including their health.

According to a report of EASO, thirteen Member States ${ }^{1098}$ provide for some form of specific support for vulnerable asylum applicants with special reception needs, such as establishing accommodation that is adapted to applicants with special care needs, training of staff working in reception centres or the introduction of measures to ensure safety. 1099

It appears from the EMN reports that in the majority of Member States vulnerable asylum applicants with special reception needs are accommodated in reception facilities adapted to their specific needs, including the medical assistance and mental health care. ${ }^{1100}$ However, there are varied practices as to the form, level and availability between Member States.

${ }^{1096}$ Asylum Information Database ECRE, Country report Sweden, March 2017, p. 35.

${ }^{1097}$ FRA, Monthly data collection on the current migration situation in the EU, Thematic focus: Disability, August 2016, p. 10.

${ }^{1098}$ CY, AT, BE, EE, FI, IT, LV, PL, SK, NL, SE, ES.

${ }^{1099}$ EASO, Annual Report on the Situation of Asylum in the European Union 2016, July 2017, p. 107.

${ }^{1100}$ EMN study, The Organisation of Reception Facilities for Asylum Seekers in different Member States, 2014, p. 4. See for a more recent overview EMN Ad-Hoc Query on PART II - Reception and Care of Vulnerable Applicants for International Protection with Special Reception Needs, 2018. 
A number of challenges appear at the national level. In Belgium, persons working with vulnerable applicants in reception centres have insufficient skills and tools to provide support to persons with mental disorders or persons subjected to torture or other forms of violence. An important concern is the lack of knowledge and access to specialised external services. Whether internally or through external specialised services, reception centres are often unable to provide adequate care to applicants with psychological needs. ${ }^{1101}$

In Germany, the law does not provide for vulnerable asylum applicants with special reception needs to be accommodated in separate reception facilities. Another issue is the limited number of centres to provide specialised treatment for traumatized asylum applicants and victims of torture. Hence, access to rehabilitation is not always ensured. ${ }^{1102}$

In Hungary, no specialised reception facilities exist for vulnerable asylum applicants with special reception needs save for unaccompanied minors. Other categories of vulnerable asylum applicants such as single women, victims of torture, LGBTI applicants and all accommodated in the same reception centres without focus on their specific needs. ${ }^{1103}$ Also in Estonia, Cyprus and Luxembourg there are no reception facilities for vulnerable asylum applicants with special reception needs, except for unaccompanied minors. ${ }^{1104}$

In Bulgaria, despite the obligation enshrined in the law to take into account the vulnerability of asylum applicants in relation to their accommodation, in practice, this obligation is hardly implemented. ${ }^{1105}$ In Greece, support for vulnerable asylum applicants with special reception needs is limited. There are either no procedures to take into consideration gender and age-specific concerns or there is a lack of sufficient specialised reception facilities for such applicants. 1106

In Spain, the reception facilities do not meet the specific needs of vulnerable asylum applicants with special reception needs. They are referred to external specialised services. ${ }^{1107}$ Sweden established special accommodation for vulnerable persons. For example, special facilities are provided to persons with disabilities and LGBTI persons can be accommodated based on individual grounds in special reception centres. Separate accommodation for traumatized

\footnotetext{
${ }^{1101}$ Fedasil, Study into vulnerable persons with specific reception needs, 2016, pp. 32-36.

1102 Asylum Information Database, Country report Germany, March 2017, pp. 68-69.

${ }^{1103}$ Asylum Information Database, Country report Hungary, February 2017, p. 66.

${ }^{1104}$ EMN Ad-Hoc Query on PART II - Reception and Care of Vulnerable Applicants for International Protection with Special Reception Needs, 2018.

${ }^{1105}$ Asylum Information Database, Country report Bulgaria, February 2017, p. 50.

${ }^{1106}$ Asylum Information Database, Country report Cyprus, March 2017, p. 67. Asylum Information Database, Country report Greece, March 2017, p. 113.

${ }^{1107}$ Asylum Information Database, Country report Spain, February 2017, p. 48.
} 
asylum applicants does not exist. ${ }^{1108}$ Furthermore, there is a lack of specialised accommodation for persons with disabilities. ${ }^{1109}$

As regards the detention of vulnerable asylum applicants and of applicants with special reception needs, in at least fourteen Member States they are not excluded from detention. ${ }^{1110}$ It remains unclear whether Member States ensure regular monitoring and adequate support where vulnerable asylum applicants are detained.

\subsubsection{Special procedural guarantees}

Divergent practices are also identified between Member States concerning the legal obligation for Member States to provide adequate support for applicants in need of special procedural guarantees and to exempt them from accelerated and border procedures, where adequate support cannot be provided.

At least fourteen Member States provide some form of special procedural guarantees. ${ }^{1111}$ For example, in Poland, the identified applicant who is in need of special procedural guarantees will receive special care during the proceedings. However, vulnerable applicants are not exempted from accelerated procedures. ${ }^{1112}$ In Malta, applicants identified as applicants in need of special procedural guarantees are provided with a special caseworker assigned to undertake the interview. Practice reveals however that caseworkers do not always take into account that such applicants are not able to provide detailed information. An accelerated procedure is not applied to applicants who require special procedural guarantees such as torture victims or persons who have been subjected to other serious forms of violence. ${ }^{1113}$ In Hungary, specially trained case officers interview victims of torture. But because there is no formal procedure or mechanism to identify vulnerable asylum applicants with special needs, victims of torture or other vulnerable applicants with special needs may end up being interviewed by a case officer that is not trained to handle such sensitive cases. Furthermore, a border procedure cannot be applied to vulnerable asylum applicants, however it appears in practice that only applicants with physically visible special needs are exempted. ${ }^{1114}$

In Sweden, unaccompanied minors or other vulnerable groups in need of special procedural guarantees are not automatically exempted from accelerated

\footnotetext{
${ }_{1108}$ Asylum Information Database, Country report Sweden, March 2017, p. 53.

${ }^{1109}$ EMN Ad-Hoc Query on PART II - Reception and Care of Vulnerable Applicants for International Protection with Special Reception Needs, 2018.

${ }^{1110}$ BE, IT, DE, AT, NL, SE, UK, PL, HU, HR, ES, EL, CY.

${ }^{1111} \mathrm{Pl}, \mathrm{MT}, \mathrm{HR}, \mathrm{FR}, \mathrm{IT}, \mathrm{UK}, \mathrm{HU}, \mathrm{CY}, \mathrm{SE}, \mathrm{BE}, \mathrm{NL}, \mathrm{EL}, \mathrm{AT}, \mathrm{PT}$.

${ }^{1112}$ Asylum Information Database, Country report Poland, February 2017, pp. 36-37.

1113 Asylum Information Database, Country report Malta, February 2017, p. 32.

${ }^{1114}$ Asylum Information Database, Country report Hungary, February 2017, p. 45.
} 
procedures. ${ }^{1115}$ In Austria, it is not likely that a border procedure is applied to vulnerable asylum applicants in need of special procedural guarantees, such as torture victims. But due to security reasons an accelerated procedure may be applied. ${ }^{1116}$ In Portugal, applicants that are identified as requiring special procedural guarantees may benefit from certain arrangements such as the postponement of the asylum interview or they may be granted extended time to present evidence. However, due to the absence of a specific identification mechanism, such special procedural guarantees are not efficiently implemented. ${ }^{1117}$

Notwithstanding these measures that have been adopted by several Member States, the issue of whether an applicant in need of special procedural guarantees receives adequate support and is exempted from special procedures, where adequate support cannot be provided, is mainly dependent on an identification procedure that should be implemented by Member States, which not only identifies physically visible indicators of vulnerability and addresses the special needs of the applicant but also focuses on less visible indicators.

\subsubsection{Vulnerable asylum applicants in the Dublin procedure}

For the purposes of the Dublin transfer and in order to facilitate the process of determining the Member States responsible, the determining Member State has to carry out a personal interview with the applicant.1118 One of the key challenges that appear is the identification and interviewing of vulnerable asylum applicants with special needs. Most of the Member States have templates and a checklist for the personal interview with references to the health status and vulnerabilities. However, in practice questions are regularly not focused on the vulnerability of the applicant. In at least two Member States questions during the personal interview on any vulnerabilities and special needs of the applicant are not permitted.1119 Applicants with mental health issues or trauma are often disregarded because they cannot present clear evidence during the personal interview. In the majority of the Member States applicants had to point out themselves whether they had specific vulnerabilities and special needs, otherwise national authorities would not examine it. ${ }^{1120}$

Furthermore, vulnerable applicants with medical and mental health issues or trauma appear to be a reason that some Member States apply the sovereignty

\footnotetext{
1115 Asylum Information Database, Country report Sweden, March 2017, p. 35.

${ }^{1116}$ Asylum Information Database, Country report Austria, February 2017, p. 52.

${ }^{1117}$ Asylum Information Database, Country report Portugal, November 2017, p. 46.

1118 Article 5 of the recast Dublin III Regulation.

${ }^{1119} \mathrm{FR}, \mathrm{MT}$.

${ }^{1120}$ UNHCR, Study on the implementation of the Dublin III Regulation, Left in Limbo, 2017, pp. $40-41$.
} 
clause. ${ }^{1121}$ It remains in general unclear how Member States in practice examine whether or not to apply the sovereignty clause in individual cases. ${ }^{1122}$ In addition, the vulnerability of an applicant or where the applicant has special needs is a reason for Member States to apply more often the humanitarian clause. ${ }^{1123}$

As to the modalities of the Dublin transfer, there are at least six Member States who exchange information to the responsible Member State when it concerns a particularly vulnerable applicant or an applicant with health problems. ${ }^{1124}$ The UNHCR reports ${ }^{1125}$ that it remains uncertain to determine how many of these six Member States make use of the standard form ${ }^{1126}$ to exchange vital information on the health of the applicant. Whereas, the Commission reports ${ }^{1127}$ that at least sixteen Member States use this standard form.

Furthermore, some Member States accelerate the transfer if the applicant is particularly vulnerable or an unaccompanied minor. ${ }^{1128}$ In Germany, the vulnerability of the applicant may be a reason to delay the transfer. A few Member States provide escorted transfers for applicants that are particularly vulnerable, unaccompanied minors or vulnerable applicants with minor children. ${ }^{1129}$ In Greece, a key challenge to implement the Dublin transfer in an effective manner is the vulnerability of the applicant or when the applicant has health issues, which renders the applicant incapable of travelling. ${ }^{1130}$

Lastly, it was submitted that since Tarakhel sending countries have to request individual guarantees prior to the Dublin transfer to ascertain that the vulnerable applicant will be treated in accordance with the EU asylum Directives and the ECHR standards. In C.K., the CJEU ruled that the transfer would violate the Article 4 of the Charter where the transfer of an asylum applicant with a particularly serious mental or physical illness would result in a real and

${ }^{1121}$ DK, DE, EL, MT.

${ }^{1122}$ UNHCR, Study on the implementation of the Dublin III Regulation, Left in Limbo, 2017, p. 128.

${ }^{1123}$ UNHCR, Study on the implementation of the Dublin III Regulation, Left in Limbo, 2017, p. 130.

${ }^{1124}$ DK, FR, DE, EL, IT, PL. See also UNHCR, Study on the implementation of the Dublin III Regulation, Left in Limbo, 2017, p. 145.

${ }^{1125}$ UNHCR, Study on the implementation of the Dublin III Regulation, Left in Limbo, 2017, p. 145.

${ }^{1126}$ Annex IX of the Implementing Regulation (EU) No. 118/2014 Standard form for the exchange of health data prior to a Dublin transfer pursuant to Article 32(1) of Regulation (EU) No 604/2013 (Common Health Certificate).

${ }^{1127}$ European Commission, Evaluation of the Implementation of the Dublin III Regulation, Final report, 18 March 2016, p. 64.

${ }^{1128}$ For instance EL.

${ }^{1129}$ DK, EL, DE, IT, MT, UK.

${ }^{1130}$ UNHCR, Study on the implementation of the Dublin III Regulation, Left in Limbo, 2017, p. 147. 
proven risk of a significant and permanent deterioration in the state of health. Notwithstanding the judgments by European courts to take into account the vulnerability of asylum applicants in the context of the Dublin transfer, Member States appear to apply different practices with regard to obtaining prior individualized guarantees for vulnerable asylum applicants.

Although there is no general approach among Member States to require individual assurances for vulnerable applicants, Germany and Belgium for instance aim to ensure that applicants who require medical treatment will continue to receive the specific support in the Member State of destination. Austria assesses on an individual basis whether they request guarantees. In Sweden individual guarantees are not requested before transferring asylum applicants. However, the Swedish policy is that vulnerable asylum applicants are not transferred to Hungary or to Bulgaria. ${ }^{1131}$

\subsection{Legal challenges, shortcomings and promising approaches with regard to victims of torture and unaccompanied minors in EU Member States}

\subsubsection{Victims of torture}

It was submitted in chapter 3 that victims of torture not only have the right to rehabilitation services, including legal and social support but also access to such services as soon as possible after the asylum procedure starts. Therefore, it is crucial to promptly identify asylum applicants as victims of torture in order to provide them with adequate rehabilitation services during the asylum procedure. Other research shows, however, that at least eight Member States do not have an effective mechanism in place to identify victims of torture. 1132

To illustrate a few examples: in Austria, the police carries out the initial interview and usually they do not ask questions about possible torture of the applicant nor do they have experience in identifying torture victims. An asylum officer of the Federal Agency conducts the second substantive interview for Immigration and Asylum. During this interview, the asylum officer may raise questions about past torture. Where the asylum applicant has stated that he has been subjected to torture, it is not always guaranteed that the applicant will be referred to specialised services to receive specific support in terms of accommodation or healthcare. ${ }^{1133}$

${ }^{1131}$ ECRE, The concept of vulnerability in European asylum procedures, 2017, pp. 50-52.

1132 AT, FI, FR, DE, HU, IT, NL, SE. See IRCT, Failing Through the Cracks, asylum procedures and reception conditions for torture victims in the European Union, 2016.

${ }_{1133}$ IRCT, Failing Through the Cracks, asylum procedures and reception conditions for torture victims in the European Union, 2016, p. 12. 
In Finland, key shortcomings are the absence of systematic identification procedure to identify torture victims and specialised support throughout the asylum procedure. During the beginning of the asylum procedure, applicants are medically screened, which means in practice to recognize diseases and not to identify torture victims or other categories of vulnerable applicants. ${ }^{1134}$ In Germany, there is no systematic identification mechanism to identify victims of torture. Applicants are medically screened on diseases and not to detect signs of torture. 1135

In a more recent report, the findings confirm the absence of specific mechanisms, procedures and adequate tools to quickly identify victims of torture in various Member States. It has been reported that authorities only address visible vulnerabilities.1136 Consequently, such inadequate mechanisms or procedures have an impact on torture victims and effectively prevents them from benefitting from special reception guarantees and special procedural guarantees. The lack of specific procedures to identify whether an applicant is a victim of torture remains highly problematic. ${ }^{1137}$ A major challenge is how to ensure early identification of torture victims in times of high arrivals of asylum applicants to the EU, which tools and procedures are adequate for the early identification of vulnerabilities and special needs.

In addition, despite strong recommendations from IRCT members to systematically exclude torture victims from accelerated and border procedures, it appears that in the majority of Member States torture victims are as a general principle not excluded from such special procedures. ${ }^{1138}$

In several Member States, victims of torture do not receive the full support they need, and the mental health problems of torture victims are overlooked or there is no access to the necessary healthcare and rehabilitation. ${ }^{1139}$ In at least six Member States there are no existing specialised reception centres for vic-

${ }^{1134}$ IRCT, Failing Through the Cracks, asylum procedures and reception conditions for torture victims in the European Union, 2016, pp. 15-16.

1135 IRCT, Failing Through the Cracks, asylum procedures and reception conditions for torture victims in the European Union, 2016, p. 22.

${ }^{1136}$ FR, DE, EL, IT, MT, PT. See CIR Rifugiati, Time for needs: Listening, Healing, Protecting. $\square$ A joint action for an Appropriate Assessment of Special Needs of Victims of Torture and Violence, 2017, pp. 28-29.

${ }^{1137}$ AT, BG, DE, EL, HU, IT, SE. FRA, Monthly data collection on the current migration situation in the EU, Thematic focus: Disability, August 2016, p. 22.

${ }^{1138}$ IRCT, Failing Through the Cracks, asylum procedures and reception conditions for torture victims in the European Union, 2016, p. 41.

1139 IRCT, Failing Through the Cracks, asylum procedures and reception conditions for torture victims in the European Union, 2016, p. 39-42. See in addition, Matevžič, G, Hungarian Helsinki Committee, The Response of Eastern Member States to the Special Needs of Torture Survivors and Traumatized Asylum Seekers, 2017. 
tims of torture and other serious forms of violence. ${ }^{1140}$ In France, the lack of an early identification procedure to identify victims of torture is a key challenge. Once an applicant has been identified as a torture victim, the quality of the treatment mainly depends on the region in France and the capacity of the centres to provide specialised services. ${ }^{1141}$

In Germany, the number of specialised care centres for torture victims is limited and access to healthcare is restricted. ${ }^{1142}$ According to the Commissioner for Human Rights of the Council of Europe, Germany has no systematic practice of rehabilitating torture victims. Due to increased numbers of asylum applicants arriving to the country, it appeared that victims of torture did not have access to treatment. There were also issues with regard to the shortage of staff and the infrastructure. In practice this means a limited number of twentyfive centres operated by NGOs manage the rehabilitation work and there are not enough interpreters to assist the torture victims. 1143

In Italy, victims of torture are not systematically identified and specialised centres for vulnerable asylum applicants are limited. At large-scale reception centres vulnerable asylum applicants may have more difficulties to access special reception needs compared to small-scale reception centres where vulnerable asylum applicants have access to specific support. ${ }^{1144}$

In Sweden, the lack of early identification mechanisms and access to specialised accommodation facilities for torture victims remains problematic. Key issues are the coordination between the various specialised services and to assurance that victims of torture receive specialised medical and psychological care. 1145

As regards the arrangement of a medical examination in the light of Article 18 of the recast Asylum Procedures Directive, it has been submitted that at least in twelve Member States national authorities provide for this opportunity in their national asylum procedure where the national authorities deem it rele-

${ }^{1140}$ CIR Rifugiati, Time for needs: Listening, Healing, Protecting. $\square$ A joint action for an Appropriate Assessment of Special Needs of Victims of Torture and Violence, 2017, pp. 31-32.

${ }^{1141}$ IRCT, Failing Through the Cracks, asylum procedures and reception conditions for torture victims in the European Union, 2016, pp. 18-20.

${ }_{1142}$ IRCT, Failing Through the Cracks, asylum procedures and reception conditions for torture victims in the European Union, 2016, pp. 22-23. See also IRCT, Torture and the right to rehabilitation, National report Germany, 2016.

${ }^{1143}$ Council of Europe, Report by Nils Muiznieks, Commissioner for Human Rights of the Council of Europe, Following his visit to Germany on 24th April and from 4 to 8 May 2015, Strasbourg 1 October 2015, para. 109.

${ }^{1144}$ IRCT, Failing Through the Cracks, asylum procedures and reception conditions for torture victims in the European Union, 2016, p. 30.

${ }^{1145}$ IRCT, Failing Through the Cracks, asylum procedures and reception conditions for torture victims in the European Union, 2016, p. 36. 
vant. ${ }^{1146}$ It remains, however, not entirely evident from the investigated Member States in which circumstances national authorities deem it relevant to initiate a medical examination, whether such medical examinations are based on the Istanbul Protocol, whether there is the possibility for the applicant to submit at their own costs a request with a third independent party to start a medical examination and whether the results of the medical examination arranged by the applicant are taken into account by the national authorities in the assessment of the asylum application.

\subsubsection{Unaccompanied minors}

Several key challenges have been identified in Member States with regard to children, including unaccompanied minors in the context of asylum. In various Member States special guarantees apply to unaccompanied minors. ${ }^{1147}$ In addition to the comments that have been made above regarding the fragmented data on (unaccompanied) children, the Commission has encouraged Member States to prioritise children in border procedures and to address the problem that children should receive adequate support during the identification and registration procedure. In general, Member States should implement improved assessment procedures in order to identify vulnerabilities and special needs. The Commission also pointed out that tracing of family members and family reunification procedures are not implemented adequately or suffer from delays. ${ }^{1148}$

As there is no common practice on age assessment of unaccompanied minors, varied practices between Member States have been reported in 2013 regarding the used methods and procedures. ${ }^{1149}$ Recent key issues issued by NGOs and UNHCR with regard to the age assessment procedure were for instance the strong conviction by national authorities on medical examination or the absence of an effective legal remedy against the outcome of an age assessment. ${ }^{1150}$ In a number of times, guardians were only arranged after the age as-

${ }^{1146}$ DE, SE, IE, FR, AT, HU, ES, HR, BG, EL, CY, PT. See country reports Asylum Information Database.

${ }^{1147}$ See Global Legal Research Directorate, Provisions on Child Asylum Seekers in Selected Jurisdictions, The Law Library of Congress, May 2018.

${ }^{1148}$ European Commission, Communication from the Commission to the European Parliament and the Council, The protection of children in migration, $\{\operatorname{SWD}(2017) 129$ final $\}$, Brussels, 12.4.2017, COM(2017 211 final, p. 6.

${ }^{1149}$ EASO, Age assessment practice in Europe, December 2013, pp. 23-51.

${ }^{1150}$ EASO, Annual Report on the Situation of Asylum in the European Union 2016, July 2017, p. 134. See also Wenke, D., Council of Europe, Age assessment: Council of European member states' policies, procedures and practices respectful of children's rights in the context of migration, September 2017. 
sessment had been conducted and in a few occasions minors had to pay themselves to challenge the contentious age assessment.1151

It has been further submitted that reception facilities are not always adapted to the specific needs of children. The personnel working in reception centres lack training or they are not qualified to work with children. In a few occasions, children have been placed in closed facilities because of the limited availability of appropriate accommodation. Another concern is that children do not always have access to education or health care. As regards unaccompanied minors in particular, practice revealed that despite the success of family-based care or foster care for unaccompanied minors, it is not used on a regular basis. 1152

Serious shortcomings have also been established to the number of qualified guardians that are available and how promptly they are arranged. ${ }^{1153}$ In Bulgaria for instance, unaccompanied minor applicants are not appointed a legal guardian. Consequently, due to the lack of guardians and other serious shortcomings with regard to legal representation and upholding the best interests of the child in the asylum procedure, many unaccompanied minors have absconded. ${ }^{1154}$

Compared to other categories of vulnerable asylum applicants, unaccompanied minors are treated more carefully during the personal interview in the course of the Dublin procedure. ${ }^{1155}$ However, Member States apply different practices in the assessment of the best interests of the child in the context of the Dublin procedure. The elements that need to be taken into account in assessing the best interests of the child are not always correctly implemented by Member States or it is on many occasions unclear how the practice is. ${ }^{1156}$ In at least three Member States family reunification is an important element in the assessment of the best interests of the child. ${ }^{1157}$

${ }^{1151}$ European Commission, Communication from the Commission to the European Parliament and the Council, The protection of children in migration, $\{\operatorname{SWD}(2017) 129$ final $\}$, Brussels, 12.4.2017, COM(2017 211 final, pp. 9-10.

${ }^{1152}$ European Commission, Communication from the Commission to the European Parliament and the Council, The protection of children in migration, $\{\operatorname{SWD}(2017) 129$ final $\}$, Brussels, 12.4.2017, COM(2017 211 final, p. 6.

${ }^{1153}$ European Commission, Communication from the Commission to the European Parliament and the Council, The protection of children in migration, $\{\operatorname{SWD}(2017) 129$ final $\}$, Brussels, 12.4.2017, COM(2017 211 final, p. 10.

${ }^{1154}$ Asylum Information Database, Country report Bulgaria, February 2017, pp. 35-36.

${ }_{1155}$ UNHCR, Study on the implementation of the Dublin III Regulation, Left in Limbo, 2017, pp. 40-42.

${ }^{1156}$ UNHCR, Study on the implementation of the Dublin III Regulation, Left in Limbo, 2017, pp. 59-61.

${ }^{1157}$ DE, IT, PL. 
As regards detention, unaccompanied minors are in at least eleven Member States in principle precluded from detention. ${ }^{158}$ In practice it still occurs that unaccompanied minors are detained because there are doubts about the age. ${ }^{1159}$

\subsection{Analysis}

This chapter has examined the question of who is presumed to be vulnerable in the national asylum process and what is the trend in various Member States in identifying vulnerable asylum applicants. I also examined the scale of the problem, namely how many applicants presumed to be vulnerable arrive in the EU. It was submitted that there is no data available on vulnerable asylum applicants. EU law obliges Member States to supply figures on the number of asylum applicants and to disaggregate by age and gender. However, there is no obligation to collect data on the situation of other categories of vulnerable asylum applicants. Without data it remains difficult to assess the scale of the issue.

Although not comprehensively, Member States do keep records of the number of unaccompanied minors that seek protection. One reason that can explain the lack of comprehensive data on unaccompanied minors is the divergent practice between Member States in the methods and procedures on age assessment. This chapter has shown that the number of unaccompanied minors arriving in the EU has been a constant factor during the period 2008-2013 and substantially increased in 2015 during the peak of the refugee crisis.

The findings in this chapter also show that the practice of Member States with regard to vulnerable asylum applicants is inefficient and insufficient in terms of providing the necessary special guarantees. Based on existing secondary reports, the findings have revealed that Member States differ in their approach to vulnerability in the asylum process. The discretion left to Member States has resulted in a divergence in the categories of asylum applicants labelled as vulnerable. The findings have also established that Member States differ in their methods, timing and the national authorities that are involved in the assessment procedure. The procedures or mechanisms that are implemented to identify vulnerable asylum applicants are not applied in a systematic manner. In the majority of the Member States a systematically assessment of whether the applicant is vulnerable and whether the applicant has special needs is lacking. Some improvements can be discerned from the Commission proposals that

${ }^{1158} \mathrm{BE}, \mathrm{PL}, \mathrm{NL}, \mathrm{IE}, \mathrm{FR}, \mathrm{ES}, \mathrm{AT}, \mathrm{HU}, \mathrm{IT}, \mathrm{MT}, \mathrm{CY}$.

${ }^{1159}$ See for instance report of Hungarian Helsinki Committee, The Situation of Unaccompanied Asylum Seeking Children in Hungary, December 2016 or the UN Special Rapporteur on the human rights of migrants concludes his follow up country visit to Greece, May 2016 and Human Rights Watch, "Why are you keeping me here?” Unaccompanied children detained in Greece, September 2016. 
propose a systematic assessment of special reception needs, which should be carried out as early possible and conduct a systematic assessment for the need of special procedural guarantees as soon as an application is made.

Another noticeable finding shows that where applicants are identified as vulnerable applicants that require special reception needs, Member States provide for some form of specific support. However, the form, the level and availability between Member States differ. Similarly, key issues related to applicants in need of special procedural guarantees have been scrutinized. Divergent practices appear as to when Member States make an assessment for the need of special procedural guarantees and it remains unclear what 'adequate support' means in the different Member States, including which types of special procedures can be applied to applicants identified as applicants in need of special procedural guarantees.

I examined also the key issues concerning vulnerable asylum applicants in the Dublin procedure. In the majority of the Member States, applicants had to point out themselves whether they had specific vulnerabilities and special needs, otherwise national authorities would not proactively examine. In addition, Member States have different practices when it comes to obtain prior individualized guarantees for vulnerable asylum applicants.

I have also assessed the key challenges for victims of torture and unaccompanied minors in several Member States. With regard to victims of torture, there is the lack of specific mechanisms, procedures, and adequate tools to promptly identify victims of torture in various Member States. Consequently, the lack of adequate mechanisms or procedures has implications for torture victims throughout the asylum procedure. They may not benefit from receiving special guarantees. Where victims of torture somehow are identified, it appears that in several Member States access to the necessary healthcare and rehabilitation service is insufficient.

As regards unaccompanied minors, the preceding shows that there are serious challenges in Member States in terms of providing adequate reception facilities that are adapted to the specific needs of children and also the different practices used to assess the age and the limited availability of guardians. In addition, it is important to note that Member States have varied or unclear practices as regards the assessment of the best interests of the child in the context of the Dublin procedure.

\subsection{Concluding remarks}

This chapter has examined to what extent Member States have implemented at the national level the standards that stem from the recast CEAS legislative acts with regard to vulnerable asylum applicants, and in particular with regard to 
victims of torture and unaccompanied minors. An important conclusion is that data on vulnerable asylum applicants in the asylum process at the EU and national level is lacking. The majority of Member States do not keep records of vulnerable asylum applicants, such as the number of disabled asylum applicants or applicants with mental health problems that arrive in the EU. The only vulnerable group in the asylum process that is registered by Member States concerns unaccompanied minors.

As far as can be established from secondary sources, it can be concluded that the approach to vulnerability in the asylum context and the implementation of standards that are laid down in the CEAS with regard to vulnerable asylum applicants widely differ between Member States. It has been submitted that Member States have different approaches in identifying vulnerable persons in the asylum process, and that there are significant disparities in the form, the level and availability of specific support to such applicants.

The following chapter focuses on the Netherlands. It will provide a more detailed and robust analysis of the implementing measures, case law and practice with regard to vulnerable asylum applicants, and in particular with regard to victims of torture and unaccompanied minors in the Dutch asylum process. 


\section{8 -Vulnerable asylum applicants in the Netherlands}

\subsection{Introduction}

Chapter 6 has analysed the EU's legal framework with regard to vulnerable asylum applicants and more specifically with regard to victims of torture and unaccompanied minors. I submitted that an effective implementation of the EU asylum legislation that is in accordance with the Refugee Convention and other relevant treaties is to a large extent dependent on a correct and timely implementation in the domestic legal order and essential for the functioning of the CEAS and ultimately leads to an adequate protection of vulnerable asylum applicants. Based on secondary sources, chapter 7 has provided an overview of the approaches of vulnerability in the context of asylum, including the challenges, gaps and promising practices in various Member States. This chapter provides a detailed analysis of the national implementing measures, case law and practice surrounding vulnerable asylum applicants in the Dutch asylum law and policy.

As submitted in chapter 1, the purpose of assessing a single Member State in detail is, firstly, to gain a better understanding of how the EU's notion of vulnerability is applied at the national level and, secondly, to examine to what extent the Netherlands complies with the legal standards that stem from the recast legislative acts of the CEAS with regard to vulnerable asylum applicants, and also with regard to victims of torture and unaccompanied minors.

This chapter is divided in two parts. The first part carries out research on the interpretation and application of the notion of vulnerability and special needs in the Dutch asylum system. Attention is paid to the questions of who is presumed to be vulnerable in the context of asylum. Further whether a mechanism or procedure is implemented at the national level in order to systematically identify vulnerable applicants and whether such applicants have access to the special guarantees as provided in the CEAS.

The second part of this chapter examines in detail the national implementing measures and practice with regard to victims of torture and unaccompanied minors in the domestic asylum procedure. The purpose is to identify the key challenges and critically analyse whether the EU legal standards with regard to these two particularly vulnerable groups are sufficiently ensured at the national level. Before proceeding to examine the implementation of the EU's notion of vulnerability in the Dutch asylum context, it is important to explain the Dutch asylum system. 


\subsection{The Dutch legal framework}

\subsubsection{Statistical overview}

Like many other Member States, the Netherlands experienced in recent years a higher influx of asylum applicants. In 2015, during the so-called refugee crisis the number of asylum applicants entering the Netherlands reached a peak of 43095.1160 However, it remains lower than the number of asylum applications that were registered during the 1990s. In 1994 due to the war in former Yugoslavia and the restrictive asylum policy of Germany the number of applicants applying for asylum in the Netherlands rose to 52575.1161

Figure 8.1. The number of first time asylum applications in the Netherlands between 1990-20171162

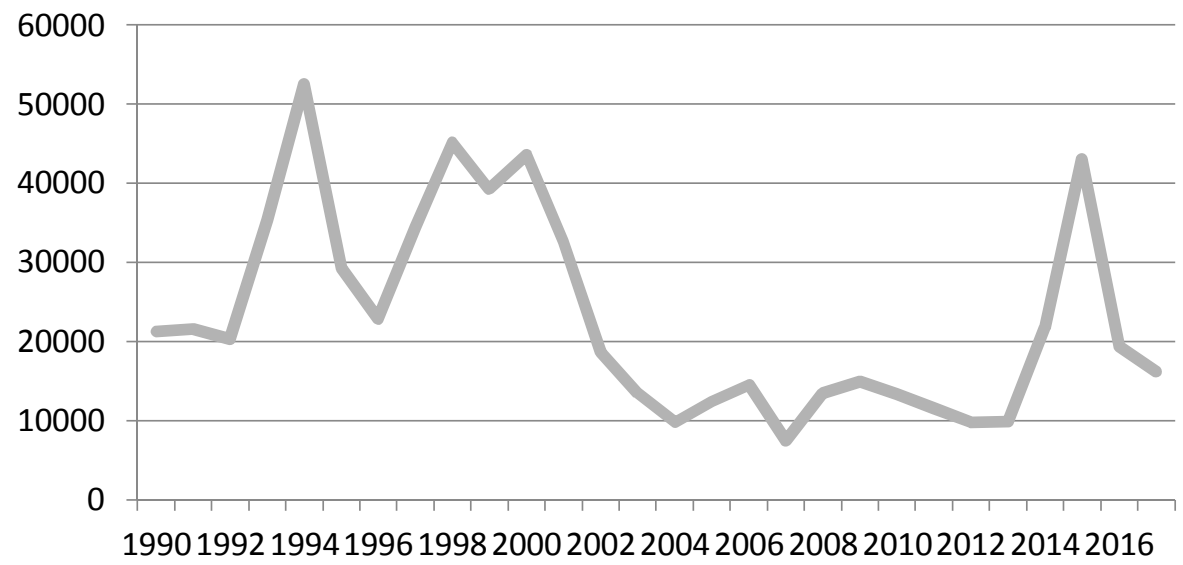

Following a decrease of asylum applications between 1995 and 1997, the number of persons applying for asylum slightly rose again in 1998 to 45215 respectively 43560 in 2000 . The majority of asylum applicants entering the Netherlands are mainly from Syria, Eritrea, Afghanistan, Iraq and Iran. From the total

${ }^{1160}$ Centraal Bureau voor de Statistiek (CBS), Asielverzoeken en nareizigers; nationaliteit, geslacht en leeftijd. Available at Statline:

http://statline.cbs.nl/StatWeb/publication/?VW=T\&DM=SLNL\&PA=83102NED\&LA $=$ NL (Consulted on 15 January 2018).

${ }^{1161}$ Van Bennekom, W., Van den Bosch, M., Groenendijk, K. and Vermeulen, B., Comparative study of member states on immigration law, with special reference to deportation and administrative detention, Center for Migration Law, University of Nijmegen, January 2000, p. 1.

${ }^{1162}$ Centraal Bureau voor de Statistiek (CBS), Asielverzoeken; nationaliteit, vanaf 1975, eerste asielverzoeken. Available at Statline https://opendata.cbs.nl/statline/\#/CBS/nl/dataset/80059ned/table?ts=1518169081786 (Consulted on 2 February 2018). 
number of 16145 first time asylum applications in 2017, 2970 applicants were from Syria and 1590 applicants from Eritrea.

Figure 8.2. Number and country of origin of first time asylum applicants in the Netherlands in 2017 (total number 16145) 1163

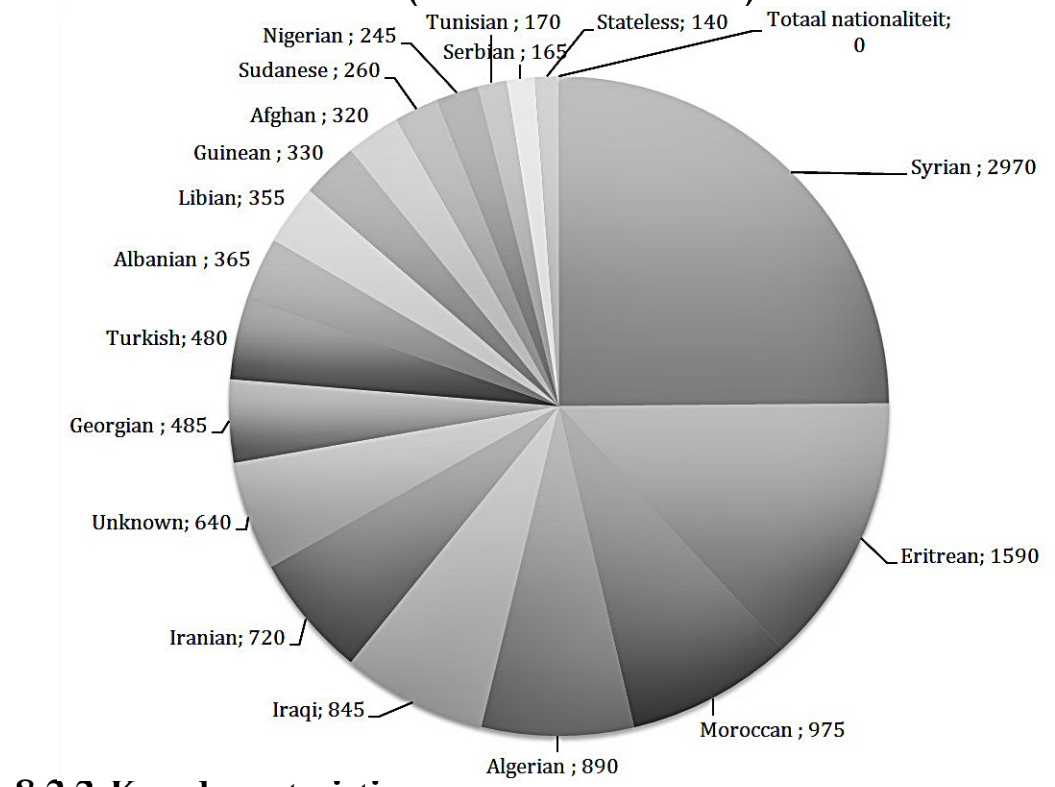

\subsubsection{Key characteristics}

The current Dutch asylum law and policy is based on the Aliens Act 2000 (Vreemdelingenwet 2000). ${ }^{1164}$ Prior to the adoption of the Aliens Act 2000, the Aliens Act of 1965 governed for a long time the legal framework of the Dutch immigration policy. With the introduction of the General Administrative Law Act (Algemene wet bestuursrecht) in 1994 it was necessary to reform the Aliens Act. ${ }^{1165}$ The reform of the Aliens Act in 1994 aimed at reducing the number of procedures and to provide swift clarity regarding the admission. However, the 1994 reform of the Aliens Act did not meet its objectives and therefore a few

\footnotetext{
${ }^{1163}$ Centraal Bureau voor de Statistiek (CBS), Asielverzoeken en nareizigers; nationaliteit, geslacht en leeftijd. Availabe at Statline

https://opendata.cbs.nl/statline/\#/CBS/nl/dataset/83102NED/table?ts=151818523656 4 (Consulted on 10 February 2018).

${ }^{1164}$ Wet van 23 november 2000 tot algehele herziening van de Vreemdelingenwet (Vreemdelingenwet 2000).

${ }^{1165}$ Evaluatie Vreemdelingenwet 2000, Terugkeerbeleid en Operationeel Vreemdelingentoezicht, Commissie Evaluatie Vreemdelingenwet 2000, Wetenschappelijk Onderzoek- en Documentatiecentrum, Kiwa Management Consultants, Bureau Boekhoorn Sociaalwetenschappelijk Onderzoek, 2004, pp. 25-27. See also Spijkerboer, T., Het hoger beroep in vreemdelingenzaken, Sdu Uitgevers BV, 's-Gravenhage, 2002, p. 1.
} 
years later another reform was presented. ${ }^{1166}$

The Aliens Act 2000 had two central objectives: first, to shorten the asylum procedures; and secondly, to have a better quality of decision-making in the first instance. ${ }^{1167}$ In addition, the Aliens Act of 1994 provided for different protection statuses with differences in rights and benefits, which resulted in lengthy court proceedings in order to be granted a 'stronger' status. To prevent the incentive for protection status holders to apply for a 'stronger' status, the Aliens Act 2000 introduced a 'one-status-system' or 'uniform asylum status'.1168 This means that all persons granted an asylum status are entitled to the same package of rights and benefits. 1169

\subsubsection{Multi-layered framework}

The Dutch legal framework on aliens has a four-layer structure. The Aliens Act 2000 (Vreemdelingenwet 2000) ${ }^{1170}$ is an Act of Parliament, which provides the formal legal framework and, inter alia, rules on the admission, residence permits and return of aliens. The Aliens Decree 2000 (Vreemdelingenbesluit 2000) ${ }^{1171}$ is a general administrative order (Algemene maatregel van bestuur), which contains detailed substantive norms on the different aspects of asylum and legal migration. The Aliens Regulation 2000 (Voorschrift Vreemdelingen 2000) ${ }^{1172}$ is a ministerial regulation, which includes, inter alia, rules concerning organizational matters, the amount of fees and the forms to be used by the authorities. The Aliens Act 2000, the Aliens Decree 2000 and the Aliens Regulation 2000 are generally binding regulations (Algemeen verbindende voorschriften), which are addressed to citizens and need a legal basis. The last layer concerns the Aliens Circular 2000

${ }_{1166}$ Van Eijl, C., Tussenland, Illegaal in Nederland, 1945-2000, Hilversum: Verloren, 2012, pp. 128-129.

${ }^{1167}$ Wetenschappelijk Onderzoek- en Documentatiecentrum, Commissie Evaluatie Vreemdelingenwet 2000, De asielprocedure - Deel 1, 2006, p. 21. See also Memorie van Toelichting, Algehele herziening van de Vreemdelingenwet (Vreemdelingenwet 2000), TK 1998/99, 26732, Nr. 3.

${ }^{1168}$ See also Kok, S.G., Eenvormige status op meerdere gronden, Asiel \& Migrantenrecht, No. 4, 2014, pp. 196-197.

${ }^{1169}$ Wetenschappelijk Onderzoek- en Documentatiecentrum, Commissie Evaluatie Vreemdelingenwet 2000, De asielprocedure-Deel 1, 2006, pp. 207-208. See also Memorie van Toelichting, Algehele herziening van de Vreemdelingenwet (Vreemdelingenwet 2000), TK 1998/99, 26732, Nr. 3.

${ }^{1170}$ Wet van 23 november 2000 tot algehele herziening van de Vreemdelingenwet (Vreemdelingenwet 2000).

${ }^{1171}$ Besluit van 23 november 2000 tot uitvoering van de Vreemdelingenwet 2000 (Vreemdelingenbesluit 2000).

1172 Voorschrift Vreemdelingen 2000. Available at http://wetten.overheid.nl/BWBR0012002/2018-01-01. 
(Vreemdelingencirculaire 2000) ${ }^{1173}$ containing policy rules. ${ }^{1174}$ Policy rules are not considered to be generally binding regulations ${ }^{1175}$ and unlike generally binding regulations, they primarily bind the administrative body. Another difference with generally binding regulations is that a judge is not ex officio required to apply policy rules adopted by an administrative body.1176

In addition to the legislation and policy rules on aliens, publicly available procedural instructions of the Immigration- and Naturalisation Service (Immigratie- en Naturalisatie Dienst, IND) may provide clarity on how the IND, inter alia, deals with the notion of vulnerability in asylum procedures.

Table 8.3. Multi-layered structure of the Dutch asylum legislation

\begin{tabular}{|l|l|l|l|}
\hline Layer & Title & $\begin{array}{l}\text { Type of regula- } \\
\text { tion }\end{array}$ & Binding? \\
\hline 1. & $\begin{array}{l}\text { Aliens Act 2000 (Vreemde- } \\
\text { lingenwet 2000) }\end{array}$ & $\begin{array}{l}\text { Act of Parlia- } \\
\text { ment }\end{array}$ & $\begin{array}{l}\text { Yes (general binding } \\
\text { regulations) }\end{array}$ \\
\hline 2. & $\begin{array}{l}\text { Aliens Decree 2000 (Vreem- } \\
\text { delingenbesluit 2000) }\end{array}$ & $\begin{array}{l}\text { General admini- } \\
\text { strative order }\end{array}$ & $\begin{array}{l}\text { Yes (general binding } \\
\text { regulations) }\end{array}$ \\
\hline 3. & $\begin{array}{l}\text { Aliens Regulation 2000 } \\
\text { (Vreemdelingenvoorschrift } \\
\text { 2000) }\end{array}$ & $\begin{array}{l}\text { Ministerial re- } \\
\text { gulation }\end{array}$ & $\begin{array}{l}\text { Yes (general binding } \\
\text { regulations) }\end{array}$ \\
\hline 4. & $\begin{array}{l}\text { Aliens Circular 2000 (Vreem- } \\
\text { delingencirculaire 2000) }\end{array}$ & Policy rules & No \\
\hline
\end{tabular}

As regards the implementation of Directives into the domestic legal order, the CJEU has held:1177

'The transposition of a directive into domestic law does not necessarily require that its provisions be incorporated formally and verbatim in express, specific legislation; a general legal context may, depending on the content of the directive, be adequate for the purpose, provided that it does indeed guarantee the full application of the directive in a sufficiently clear and precise manner so

\footnotetext{
${ }^{1173}$ Vreemdelingencirculaire $2000(\mathrm{C})$. Available at http://wetten.overheid.nl/BWBR0012288/2018-01-01 Vreemdelingencirculaire 2000 (B). Available at http://wetten.overheid.nl/BWBR0012289/2018-01-01

${ }^{1174}$ Kampstra, E.M., Hoofdzaken vreemdelingenrecht, Wolters Kluwer, 2017, p. 6.

1175 Article 1:3(4) General Administrative Law Act.

${ }^{1176}$ Böcker, A., Terlouw, A.B., Broek, J.J, van der., Grütters, C.A., Nijmeijer, A.G.A., Oers, R. van., De gelaagdheid van de vreemdelingenwetgeving in historisch en vergelijkend perspectief, Kluwer, 2013, p. 23.

${ }^{1177}$ Case C-361/88, Judgment of the Court of 30 May 1991. - Commission of the European Communities v Federal Republic of Germany. - Directive - Nature of the measure transposing it into domestic law - Air pollution, ECLI:EU:C:1991:224.
} 
that, where the directive is intended to create rights for individuals, the persons concerned can ascertain the full extent of their rights and, where appropriate, rely on them before the national courts.'

In general, it is considered that policy rules are not adequate as national implementing measures. ${ }^{1178}$ Studies have shown that in the Netherlands, the Directives on asylum and migration are often not implemented in the Aliens Act, but in the hierarchical lower legislative instruments such as the Aliens Decree, whereas in Germany and France these Directives are implemented in Acts of Parliament. ${ }^{1179}$ The main arguments against the implementation of Directives in delegated legislation and policy rules are twofold. First, as rules in delegated legislation can be adopted without the scrutiny of the Parliament, the democratic control is therefore limited. A second implication is that unlike Acts of Parliament, which are subject to an extensive legislative procedure and public debate, rules in delegated legislation can be amended in a swift and flexible manner, which may lead to a lesser quality of legislation and result in legal uncertainty for aliens. ${ }^{1180}$

\subsection{The Dutch asylum procedure}

\subsubsection{Introduction}

Persons entering the Netherlands by land ${ }^{1181}$ who wish to apply for international protection have to report to the IND at the Central Reception Centre (Centrale Ontvangstlocatie) in Ter Apel. At the Central Reception Centre, which takes three days, the registration of asylum applications is carried out, fingerprints are taken and applicants are interviewed about their identity and migration route. ${ }^{1182}$ Subsequently, an asylum applicant can formally lodge an application for international protection by signing and submitting an application form. ${ }^{1183}$ Following this procedure, the applicant is transferred to a Process Reception Centre (Proces Opvanglocatie) where he or she can rest and prepare for

\footnotetext{
${ }^{1178}$ Böcker, A., Terlouw, A.B., Broek, J.J, van der., Grütters, C.A., Nijmeijer, A.G.A., Oers, R. van., De gelaagdheid van de vreemdelingenwetgeving in historisch en vergelijkend perspectief, Kluwer, 2013, p. 30.

${ }^{1179}$ Böcker, A., Terlouw, A.B., Broek, J.J, van der., Grütters, C.A., Nijmeijer, A.G.A., Oers, R. van., De gelaagdheid van de vreemdelingenwetgeving in historisch en vergelijkend perspectief, Kluwer, 2013, pp. 204-205.

${ }^{1180}$ Böcker, A., Terlouw, A.B., Broek, J.J, van der., Grütters, C.A., Nijmeijer, A.G.A., Oers, R. van., De gelaagdheid van de vreemdelingenwetgeving in historisch en vergelijkend perspectief, Kluwer, 2013, pp, 36-42.

${ }^{1181}$ See 8.3.3. on the procedure for persons arriving by boat or plane.

${ }_{1182}$ Asylum Information Database, Country Report the Netherlands, 2016, p. 14.

${ }^{1183}$ Kampstra, E.M., Hoofdzaken vreemdelingenrecht, Wolters Kluwer, 2017, p. 65.
} 
the asylum procedure. After the rest- and preparation period, which takes a minimum of six days, the general asylum procedure starts (Algemene asielprocedure). ${ }^{1184}$ During the rest and preparation period, asylum applicants are offered a medical check. The medical check is carried out on behalf of the IND by an independent organization, referred as Forensisch Medische Maatschappij Utrecht (FFMU). The objective of this medical check is to assess whether an asylum applicant is capable (physically or mentally) of giving an interview. ${ }^{1185}$

As soon as the rest and preparation period has finished the general asylum procedure starts, which in general consists of eight days. ${ }^{1186}$ Day 1 starts with an interview of the applicant. During this interview the IND asks questions about inter alia the identity of the applicant, nationality and ethnicity, the day of arrival to the Netherlands and whether the applicant stayed in a third country. ${ }^{1187}$ Day 2 allows the applicant to prepare himself with his lawyer for the second interview and to comment on the report of the first interview. Day 3 is the second interview that focuses on the motives of the applicant in applying for international protection (Nader gehoor). Day 4 allows the applicant to comment on the report of the second interview and to make adjustments. Subsequently, the IND may decide to continue the examination of the asylum application in the general asylum procedure or continue in the extended procedure (Verlengde asielprocedure). Where the IND has decided to reject the asylum application, they will issue a written letter containing the intention to reject the application for international protection (Voornemen). ${ }^{1188}$ Following the letter of intention to reject the application on Day 5, the applicant and his lawyer are given the opportunity to respond to the decision of the IND on Day 6 (Zienswijze). ${ }^{1189}$ At the latest, the IND has to send the formal decision on Day 8.1190

If the IND needs more time to investigate the application, the asylum applicant can be referred to the extended procedure. ${ }^{1191}$ In that case the asylum applicant is relocated from the Process Reception Centre to Asylum Reception Centre (Asielzoekerscentrum). The applicant's lawyer has four weeks to submit their view on the intention of the IND to reject the application. ${ }^{1192}$ In line with the recast Asylum Procedures Directive, the examination procedure must be con-

\footnotetext{
${ }^{1184}$ Article 3.109 Aliens Decree.

${ }^{1185}$ Asylum Information Database, Country Report the Netherlands, 2016, pp. 14-15.

${ }^{1186}$ Article 3.110 Aliens Decree.

${ }^{1187}$ Article 3.44 Aliens Regulation.

1188 Article 3.114 (1) Aliens Decree.

1189 Article 3.114 (2) Aliens Decree.

1190 Article 3.114 (6) Aliens Decree.

1191 Article 3.115 Aliens Decree.

1192 Asylum Information Database, Country Report the Netherlands, 2016, p. 20.
} 
cluded within six months of the lodging of the application. ${ }^{1193}$ The examination procedure can, in certain conditions, be extended to nine months ${ }^{1194}$ and in exceptional circumstances extended with another maximum of three months. ${ }^{1195}$

\subsubsection{Appeal}

Applicants have the possibility of appealing at the court of first instance against the decision of the IND to reject the application for international protection. The time period to appeal is normally four weeks. When it concerns decisions to reject the application in the general asylum procedure, applications that are not considered on the basis of the Dublin Regulation, inadmissible applications, unfounded applications or in the event of implicit withdrawal or abandonment of the application, the time period to appeal is one week. ${ }^{1196}$ The general rule is that appeal procedures have automatic suspensive effect, which means that the effect of the decision on the application is suspended until the appeal period has expired or a decision on the appeal has been issued. ${ }^{1197}$ This means that the applicant may remain on the territory of the Netherlands pending the appeal.

However, the automatic suspensive effect is not applicable in the following situations: 1198

- Where the application is not taken into consideration on the basis of the Dublin Regulation;

- Where the application is considered inadmissible;

- Where the application is considered manifestly unfounded;

- Where the application is not taken into consideration in the event of implicit withdrawal or abandonment of the application;

- Where the rejected application concerns a subsequent application with reference to a decision that on the basis of the Dublin Regulation another Member State is responsible for examining the application; and

- It concerns a decision to temporarily suspend the conclusion of applications for international protection or the decision to suspend the termination of reception conditions to rejected asylum applicants.

The appeal includes a full and ex nunc examination of both facts and points of law, and where applicable, an examination of the international protection needs in accordance with the recast Qualification Directive 2011/95/EU.1199 The asylum applicant has the possibility of appealing to the Administrative Jurisdiction

\footnotetext{
${ }^{1193}$ Article 42(1) Aliens Act.

${ }^{1194}$ Article 42(4) Aliens Act.

1195 Article 42(5) Aliens Act.

1196 Article 69(2) Aliens Act.

1197 Article 82(1) Aliens Act.

1198 Article 82(2) Aliens Act.

${ }^{1199}$ Articles 83 and 83a Aliens Act.
} 
Division of the Council of State (Afdeling bestuursrechtspraak van de Raad van State) against the decision of the court of first instance.1200 The appeal procedure at the Administrative Jurisdiction Division of the Council of State has no automatic suspensive effect. A provisional measure can be requested in order to ensure that the applicant may remain on the territory during the appeal procedure at the Administrative Jurisdiction Division of the Council of State. ${ }^{1201}$ The time periods to lodge an appeal at the Administrative Jurisdiction Division of the Council of State are similar to the time periods to appeal at the court of first instance, which is four weeks, unless it falls under the exceptions of Article 69(2) Aliens Act. In such cases the time period to appeal is one week.1202

\subsubsection{Border procedure}

Where an asylum applicant arrives to the Netherlands by boat or by plane from a country outside the Schengen area and makes an application for international protection, the border procedure will apply. The border procedure should be concluded within four weeks. ${ }^{1203}$ Applicants in the border procedure are provided with a rest- and preparation period of six days, which may be shortened if the applicant gives his or her consent. ${ }^{1204}$

The consequence of the application of the border procedure means that an applicant's application for international protection at the border is first examined on three grounds: (1) whether another Member State is responsible to examine the application on the basis of the Dublin Regulation; (2) whether the application on the basis of Article 33 of the recast Asylum Procedures Directive can be considered as inadmissible; and (3) whether the application on the basis of Article 32(2) of the recast Asylum Procedures Directive can be considered as manifestly unfounded. 1205

Another characteristic of the border procedure is that during this examination procedure at the border, detention is applied.1206 Applicants in the border procedure may be detained for the purpose of a Dublin transfer, taking into account Article 28 of the Dublin Regulation. ${ }^{207}$ This concerns the situation

\footnotetext{
${ }^{1200}$ Article 83c Aliens Act in conjunction with Articles 8:104 and 8:105 of the General Administrative Law Act.

1201 Afdeling bestuursrechtspraak van de Raad van State, 201609659/3/V2, 29 March 2017, ECLI:NL:RVS:2017:869, paras. 4.2.- 4.3.

${ }^{1202}$ Kampstra, E.M., Hoofdzaken vreemdelingenrecht, Wolters Kluwer, 2017, p. 111.

${ }^{1203}$ Article 3(7) Aliens Act.

${ }^{1204}$ Article 109b(2) Aliens Decree.

${ }^{1205}$ Article 3(3) Aliens Act. See further Article 3.109b Aliens Decree and C1/2.5 Aliens Circular.

${ }^{1206}$ Article 6(3) Aliens Act. See also IND work-instruction 2018/3 (Grensprocedure), p. 3.

${ }^{1207}$ Article 6a(1) Aliens Act.
} 
where there is a significant risk of absconding. If there is no ground to further apply the border procedure, the detention should be lifted and the application for international protection may be continued in the general asylum procedure or in the extended asylum procedure. ${ }^{1208}$

Border detention is not applied to persons if it appears that due to individual circumstances the detention is disproportionately burdensome. ${ }^{1209}$ According to the IND work-instruction 2018/3 certain categories of vulnerable asylum applicants are also exempted from being processed in the border procedure such as unaccompanied minors, ${ }^{1210}$ (in principle) families with minor children and applicants who are identified to be in need of special procedural guarantees as a result of torture, rape or other serious forms of psychological, physical or sexual violence, and who cannot be provided with adequate support in the border procedure or border detention.

\subsection{Grounds for protection}

Protection in the Netherlands can only be granted on two grounds:

- (1) To persons who qualify for refugee status ${ }^{1211}$ in the sense of the Refugee Convention and to whom the persecution reasons are applicable; or

- (2) On the basis of subsidiary protection. ${ }^{1212}$

Subsidiary protection is defined in Article 2(f) of the recast Qualification Directive, which should be read in conjunction with Article 15 of the recast Qualification Directive. Article 15 defines what 'serious harm' constitutes, that is (a) 'death penalty or 'execution'; or (b) 'torture' or 'inhuman or degrading treatment or punishment of an applicant in the country of origin'; or (c) 'serious and individual threat to a civilian's life or person by reason of indiscriminate violence in situations of international or internal armed conflict'. ${ }^{1213}$ The question of whether there is a situation that falls under Article 29(1)(b) Aliens Act (persons who may qualify under subsidiary protection), is assessed by the IND on the following standards: 1214

- Is there in the country of origin, or in a particular area of the country, an exceptional situation in which persons just by their presence in the

\footnotetext{
${ }^{1208}$ Article 3.109b(3) Aliens Decree. See also IND-work instruction 2018/3

(Grensprocedure).

${ }^{1209}$ Article 5.1a(3) Aliens Decree.

${ }^{1210}$ Article 3.109b(7) Aliens Decree.

1211 Article 29(1)(a) Aliens Act. See also C2/3.2. Aliens Circular.

1212 Article 29(1)(b) Aliens Act.

${ }^{1213}$ The concept of subsidiary protection is discussed in chapter 5 .

${ }^{1214}$ C2/3.3. Aliens Circular.
} 
country of origin face a real risk of serious harm;

- Is the applicant member of a group that is systematically exposed to a real risk of serious harm, if there is no exceptional situation;

- Whether the applicant is eligible under the policy on 'vulnerable minority group' (kwetsbare minderheidsgroep) to receive protection, if there is no exceptional situation and systematic exposure;

- If none of the previous standards has occurred, has the applicant based on his or her personal circumstances and individual asylum story made it plausible that he or she runs a real risk of serious harm.

As indicated above, the Dutch asylum policy takes into account whether an applicant is considered to be part of a 'vulnerable minority group'. Where an applicant is considered to be a member of a 'vulnerable minority group', a lower threshold is applied in relation to the assessment of whether the return would amount to a treatment contrary to Article 3 ECHR. ${ }^{215}$

Furthermore, an applicant whose application for international protection has been rejected may still be entitled to a residence permit on the basis of humanitarian grounds. Humanitarian grounds include for instance where the expulsion of a person would breach Article 8 of the ECHR or where the person is a victim of human trafficking. ${ }^{1216}$ Figure 8.4. Total number of protection status granted (of which refugee
status, subsidiary protection and humanitarian protection)

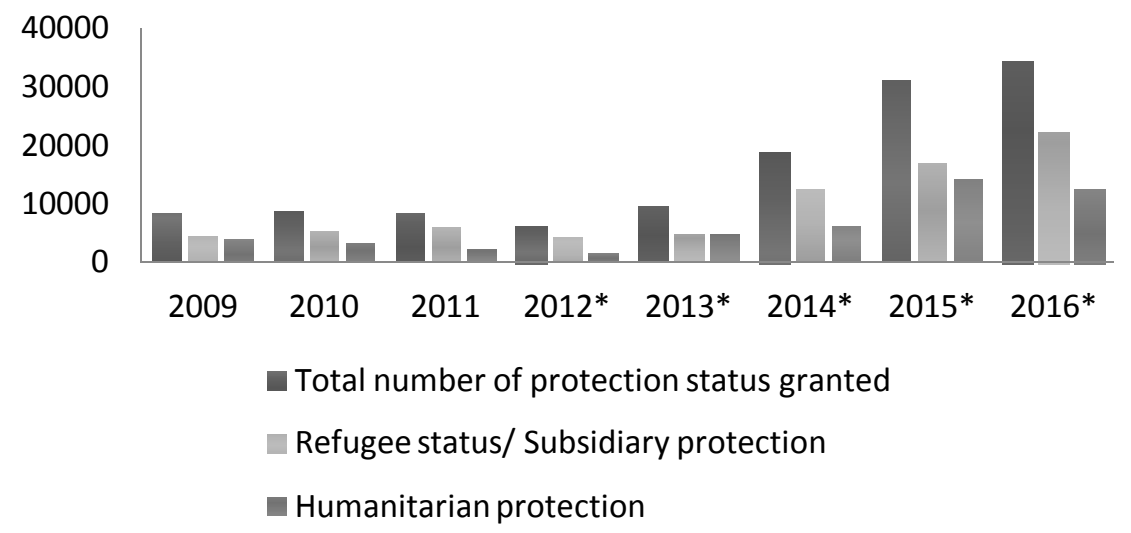

\footnotetext{
${ }^{1215}$ See C2/3.3. Aliens Circular. See also IND-work instruction 2013/14, Kwetsbare minderheidsgroep.

${ }^{1216}$ Article 3.6a Aliens Decree.

${ }^{1217}$ Centraal Bureau voor de Statistiek (CBS), Verblijfsvergunningen voor bepaalde tijd; verblijfsgrond en nationaliteit. Available at Statline https:/opendata.cbs.nl/statline/\#/CBS/nl/dataset/82027NED/table?ts=1527760481010 (Consulted on 10 February 2018).
} 
In 2017, 25815 persons received a protection status in the Netherlands of which 10565 refugee status and subsidiary protection were granted and 15250 persons were granted humanitarian protection. ${ }^{1218}$

Both holders of refugee status and subsidiary protection status are granted a temporary residence permit of five years and entitled to the same rights and benefits. ${ }^{1219}$ However, the Dutch asylum policy does differentiate between the two statuses when it concerns the grounds for refusal or revocation of the temporary residence permit. A refugee status holder may lose his temporary residence permit if he is convicted for a 'particularly serious crime', whereas the threshold is lower for a subsidiary protection holder to lose his temporary residence permit as the law stipulates convicted for a 'serious crime'. ${ }^{1220}$ After five consecutive years of legal residence in the Netherlands and provided that the permit holder fulfils certain conditions such as passing a civic integration exam, a residence permit for an indefinite period can be issued.1221 A residence permit for an indefinite period can be revoked, inter alia, because the permit holder has committed a crime or poses a threat to the national security. ${ }^{1222}$

\subsection{Family reunification}

The Dutch asylum policy makes a clear distinction between family reunification for persons holding a residence permit on asylum grounds (nareis) ${ }^{1223}$ and aliens holding a residence permit for other purposes (reguliere gronden). ${ }^{1224}$ The admission of family members of refugee status holders or beneficiaries of subsidiary protection is regulated in Article 29(2) Aliens Act. Holders of refugee status or subsidiary protection status may benefit from facilitated conditions (for example no income threshold) provided that they submit an application for family reunification within three months after having been recognized as having refugee status or subsidiary protection status and submit the necessary documents. The scope of family members includes the spouse and minor chil-

\footnotetext{
${ }^{1218}$ Centraal Bureau voor de Statistiek (CBS), Verblijfsvergunningen voor bepaalde tijd; verblijfsgrond en nationaliteit. Available at Statline https://opendata.cbs.nl/statline/\#/CBS/nl/dataset/82027NED/table?ts=152776048101 0 (Consulted 25 March 2019).

${ }^{1219}$ Article 28(2) Aliens Act in conjunction with Article 3.105 Aliens Decree.

${ }^{1220}$ See Article 3.105d Aliens Decree and Article 3.105e Aliens Decree.

${ }^{1221}$ Article 34 Aliens Act.

1222 Article 34 Aliens Act.

${ }^{1223}$ See also Case C-635/17, E. v Staatssecretaris van Veiligheid en Justitie, 19 March 2019, Court of Justice of the European Union, ECLI:EU:C:2019:192.

${ }^{1224}$ Cleton, L, Seiffert, L, and Wörmann, H., EMN, Gezinshereniging van derdelanders in Nederland, mei 2017, p. 19.
} 
dren. ${ }^{1225}$ In addition to the members of the nuclear family, partners and adult dependent children may also be included. ${ }^{1226}$ Family members may be granted a derived asylum residence permit (afgeleide asielvergunning) or submit an independent asylum application. ${ }^{1227}$

Where persons holding a refugee status or a subsidiary protection status have failed to apply for family reunification within the three months period after having been granted international protection or fail to provide the necessary documents, an application for family reunification can be submitted. Provided that they fulfil the stricter conditions for family reunification ${ }^{1228}$ that apply to aliens holding a residence permit for other purposes or they can apply for the right to family life enshrined in Article 8 ECHR. ${ }^{1229}$

Unaccompanied minors who are granted an asylum status have also the right to family reunification with their parents provided that they have not reached the age of majority at the date of submitting the application for family reunification. ${ }^{1230}$ In this regard, the CJEU decided in $A$ and $S$ concerning an application for family reunification of an unaccompanied minor that an asylum applicant who arrives below the age of 18 at the moment of entry to a Member State and who reaches the age of majority during the asylum procedure and after that is granted refugee status should be considered a minor. ${ }^{1231}$

\subsection{The reception system}

As discussed in chapter 4, the recast Reception Conditions Directive provides standards for the reception of asylum applicants in Member States, including the conditions of detention. ${ }^{1232}$ The 2005 Regulation benefits to asylum seekers and other categories of aliens (Regeling verstrekkingen asielzoekers en andere categeorieen vreemdelingen 2005) is the main legislative instrument that governs the reception conditions in the Netherlands. The Central Agency for the Reception of Asylum Seekers (Centraal Orgaan Opvang Asielzoekers, COA) is respon-

\footnotetext{
${ }^{1225}$ Article 3.6a Aliens Decree.

${ }^{1226}$ Article 29(2)(b) Aliens Decree.

${ }^{1227}$ Cleton, L, Seiffert, L, and Wörmann, H., EMN, Gezinshereniging van derdelanders in Nederland, mei 2017, p. 42.

${ }^{1228}$ Inter alia income threshold and family member has to pass a basic civic integration exam abroad.

${ }^{1229}$ Cleton, L, Seiffert, L, and Wörmann, H., EMN, Gezinshereniging van derdelanders in Nederland, mei 2017, p. 19.

${ }^{1230}$ Article 29(2)(c) Aliens Act. Cleton, L, Seiffert, L, and Wörmann, H., EMN, Gezinshereniging van derdelanders in Nederland, mei 2017, p. 29.

${ }^{1231}$ Case C-550/16, A and S v Staatssecretaris van Veiligheid en Justitie, Court of Justice of the European Union, ECLI:EU: C:2018:248.

${ }^{1232}$ Article 1 of the recast Reception Conditions Directive.
} 
sible for the reception, allocation and guidance of asylum applicants, ${ }^{1233}$ including of vulnerable asylum applicants with special reception needs. ${ }^{1234}$

Reception facilities are provided to asylum applicants in the general asylum procedure. In addition, asylum applicants have access to basic health care.1235 Asylum applicants have access to reception until four weeks following the decision of the IND that the application is rejected. They have the right to appeal at the court against the negative decision of the IND within four weeks. Subsequently, after an appeal at the court, reception conditions may be prolonged until four weeks after the decision of the court. Pending a higher appeal at the Administrative Jurisdiction Division of the Council of State, asylum applicants do not have the right to benefit from reception facilities, unless a provisional measure has been issued. ${ }^{1236}$

As regards the detention of asylum applicants, the Aliens Act has implemented the grounds stipulated in Article 8(2) of the recast Reception Conditions Directive. Detention of lawfully staying applicants is permitted on the following grounds: 1237

- To determine the identity or nationality;

- To obtain the information necessary for the assessment of the application for international protection, in particular when there is a risk of the applicant absconding;

- Where the applicant is subject to a return procedure in the course of the Return Directive 2008/115/EC;

- The applicant has already had the opportunity to access the asylum procedure;

- There are reasonable grounds to believe that the applicant is making the application for international protection only in order to delay or frustrate the enforcement of the return decision;

- The applicant poses a threat to the national security or public order;

- The applicant is subject to a Dublin transfer in accordance with Article 28 of the recast Dublin III Regulation; ${ }^{1238}$ and

- Where applications are lodged in a border procedure, detention is applied in order to decide on the applicant's access to the territory. 1239

\footnotetext{
${ }^{1233}$ Article 3 Act of the Central Agency for the Reception of Asylum Seekers.

${ }^{1234}$ Article 18a(1) 2005 Regulation benefits to asylum seekers and other categories of aliens.

1235 Article 9(1)(e) 2005 Regulation benefits to asylum seekers and other categories of aliens.

${ }^{1236}$ Asylum Information Database, Country Report the Netherlands, 2016, pp. 50-51.

${ }^{1237}$ Article 59b Aliens Act.

1238 Article 59a Aliens Act.

${ }^{1239}$ Article 3 in conjunction with Article 6(3) Aliens Act.
} 
An applicant may be detained between four and six weeks and this can be extended by another three months. ${ }^{1240}$ Unless it concerns a situation where the applicant poses a threat to the national security or public order, in such cases the detention may be extended to six months ${ }^{1241}$ and again prolonged with another nine months provided that the case involves complicated factual and legal circumstances and there is a serious risk to public order or national security. ${ }^{1242}$

\subsection{The Dublin procedure}

The Dublin procedure is implemented in Article 30 Aliens Act and further detailed in Article 3.109c Aliens Decree. In addition to the checking of the fingerprints of the applicant in the Eurodac database, a personal interview is conducted during the general asylum procedure with the applicant in order to determine which Member State is responsible to examine the application for international protection. Where it is determined that another Member State is responsible for the examination of the application for international protection, the applicant will be informed about the decision of the IND that the application is not examined. ${ }^{1243}$ The procedural guarantees provided during the general asylum procedure such as a rest and preparation period and a medical examination conducted on the applicant are not applied during the Dublin procedure. ${ }^{1244}$

Where the application is not taken into consideration on the basis of the Dublin Regulation, the applicant has to leave the Netherlands within four weeks. During this period the applicant is still lawfully staying on the territory. If the applicant has not voluntarily left the territory after these four weeks, the Dutch authorities may enforce the applicant's transfer to the responsible Member State. ${ }^{1245}$ Detaining an applicant in the course of the Dublin procedure is allowed if there is a significant risk of absconding. ${ }^{1246}$ A significant risk of absconding is considered where for example the applicant is not co-operating with the authorities regarding the transfer to the responsible Member State and in order to secure the transfer procedure within in a short period..$^{1247}$

An applicant has the possibility to appeal within one week against the decision of the Dutch authorities not to assess the application on the basis of the

\footnotetext{
${ }^{1240}$ Article 59b(2), (3) Aliens Act.

${ }^{1241}$ Article59b(4) Aliens Act.

${ }^{1242}$ Article 59b(5)(1)(b) Aliens Act.

${ }^{1243}$ See Article 30 Aliens Act; Article 3.109c Aliens Decree; and C1/2.6. Aliens Circular.

${ }^{1244}$ Article $3.109 \mathrm{c}(1)$ Aliens Decree.

1245 Article 44a(1) Aliens Act.

${ }^{1246}$ Article 59a Aliens Act in conjunction with Article 5.1a(5) Aliens Decree.

${ }^{1247}$ Article 5.1b Aliens Decree.
} 
Dublin Regulation. ${ }^{1248}$ As indicated earlier, the appeal against a decision by the authorities for not assessing the application on the basis of the Dublin Regulation has no automatic suspensive effect. 1249

\subsection{Legislative and policy responses during the refugee crisis}

The increased number of arrivals of asylum applications to the EU in recent years has also created challenges for the Dutch asylum system. The objective of the Dutch government with regard to the increased migration flows has been threefold: first, to reduce the influx of refugees by strengthening regional protection programmes; two, refugees who arrived in the Netherlands should be offered a 'fair but modest' reception; and three, those refugees who received a residence permit in the Netherlands are expected to actively integrate and participate in Dutch society.

To implement these objectives, the following policy measures related to reception facilities and procedures have been adopted. ${ }^{1250}$ One of the major policy developments has been the adoption of an agreement between the national government with provinces and municipalities, including stakeholders to deal with the challenges in the field of reception (Bestuursakkoord Verhoogde Asielinstroom).

Basically, the agreement introduces three broad measures. The first aspect of this agreement emphasizes the extension of reception capabilities for asylum applicants such as the establishment of additional emergency reception locations in different regions of the country and the objective to accommodate unaccompanied minor asylum applicants in small-scale reception facilities. Secondly, the agreement stresses the importance of an efficient flow of beneficiaries of international protection from the reception centres to regular housing. Therefore, the national government and municipalities, including housing corporations aim to complete an additional 14.000 houses for beneficiaries of international protection holders. Furthermore, municipalities have the possibility to accommodate beneficiaries of international protection in temporary housing until permanent housing is available (Gemeentelijk versnellingsarrangement). The third element of this agreement focuses on the civic guidance of beneficiaries of international protection by municipalities and to require beneficiaries of international protection to sign a participation statement as part of their civic integration exam. ${ }^{1251}$ The agreement (except for unaccompanied minors ${ }^{1252}$ ) does not mention any

\footnotetext{
1248 Article 69(2)(b) Aliens Act.

1249 Article 82(2)(a) Aliens Act.

${ }^{1250}$ Kamerbrief over Bestuursakkoord Verhoogde Asielinstroom, 27 November 2015.

${ }^{1251}$ Bestuursakkoord Verhoogde Asielinstroom, 27 November 2015.

${ }^{1252}$ See for further details in 8.5. Unaccompanied minors.
} 
specific measures that have to be taken with regard to the special reception needs of vulnerable asylum applicants.

The next major amendment is the introduction of a so-called 'five-tracks procedure' (Vijf sporen beleid) on 1 March 2016.1253 In an early stage of the asylum procedure the IND determines in which track the asylum applicant should be processed. 1254

Table 8.5. 'Five track policy'

\begin{tabular}{|l|l|}
\hline Track 1 & $\begin{array}{l}\text { Application is processed in the Dublin procedure (Article 3.109c } \\
\text { Aliens Decree) }\end{array}$ \\
\hline Track 2 & $\begin{array}{l}\text { Asylum applicants from 'safe countries of origin' or asylum } \\
\text { applicants who receive international protection in another } \\
\text { EU Member State (Article 3.109ca Aliens Decree) }\end{array}$ \\
\hline Track 3 & $\begin{array}{l}\text { Applications from applicants with a high probability to be granted } \\
\text { international protection such as Syrians or Eritreans (Article } \\
\mathbf{3 . 1 2 3 a} \text { Aliens Decree) }\end{array}$ \\
\hline Track 4 & $\begin{array}{l}\text { Asylum applications that are processed in the general asylum } \\
\text { procedure of 8 days (Article 3.1 10 Aliens Decree) }\end{array}$ \\
\hline Track 5 & $\begin{array}{l}\text { Applications from applicants that require more research on the } \\
\text { documents regarding the identity/nationality (Article 3.123c } \\
\text { Aliens Decree) }\end{array}$ \\
\hline
\end{tabular}

Applicants who are processed in track 1 or track 2 are not provided with a rest and preparation period or medical screening. ${ }^{1255}$ In relation to the Dublin procedure it was mentioned in chapter 6 that the recast Dublin III Regulation includes specific rules that require the transferring Member State to provide relevant information to the responsible Member State about any special needs of applicants that are to be transferred. In particular 'any immediate measures which the Member State responsible is required to take in order to ensure that the special needs of the person to be transferred are adequately addressed, including any immediate health care that may be required'. ${ }^{1256}$ An additional significant obligation for transferring Member States is to exchange specific health data of vulnerable applicants with special needs with the responsible Member State before a Dublin transfer is undertaken, in particular when it concerns disabled persons, elderly people, pregnant women, minors and persons who have been subject to torture, rape or other serious forms of psychological,

\footnotetext{
${ }^{1253}$ Besluit van de Staatssecretaris van Veiligheid en Justitie van 26 februari 2016, nummer

WBV 2016/4, houdende wijziging van de Vreemdelingencirculaire 2000, Nr. 10912.

${ }^{1254}$ TK 2015/2016, 19637, Nr. 2086.

${ }^{1255}$ Article 3.109c and Article 3.109ca Aliens Decree.

1256 Article 31(2)(a) of the recast Dublin III Regulation.
} 
physical and sexual violence. ${ }^{1257}$ To meet these obligations requires an assessment of the individual circumstances of the applicant.

\subsection{The notion of vulnerability in the Dutch asylum law and policy}

\subsubsection{Implementation of the 2003 Reception Conditions Directive}

Vulnerability is not a new notion in the Dutch asylum law and policy. Even before the adoption of the Aliens Act 2000 and before the adoption of the 2003 Reception Conditions Directive, the 1997 Regulation benefits to asylum applicants and other categories of aliens (1997 Regulation) included measures regarding vulnerable asylum applicants. Article 5(4) of the 1997 Regulation provided that in addition to the benefits in a reception centre, vulnerable asylum applicants should be provided with specific counselling. According to the explanatory memorandum to the 1997 Regulation, the responsibility of the reception of in particular unaccompanied minors and persons who suffer from severe mental health issues, such as traumatized asylum applicants should be carried out by specialized organizations. ${ }^{1258}$

Following the adoption of the 2003 Reception Conditions Directive, the provisions on the reception of asylum applicants have been mainly transposed into the revised 2005 Regulation benefits to asylum applicants and other categories of aliens (2005 Regulation), which is the follow-up of the 1997 Regulation. Articles 17(1), 18(2) and 20 of the 2003 Reception Conditions Directive, which are the relevant provisions for the reception of vulnerable asylum applicants, are implemented in very general terms in Article 9(4) of the 2005 Regulation. A serious concern was whether the national implementing measure that was formulated in very general terms would be effective enough in practice and whether the implementation has been carried out in an adequate manner. ${ }^{1259}$ Moreover, the revised 2005 Regulation did not result in substantial changes as regards measures related to the reception of vulnerable asylum applicants. Article 9(4) of the 2005 Regulation merely repeats Article 5(4) of the 1997 Regulation and stipulated that vulnerable persons are entitled to the general reception benefits and as well as specific counselling.

It has been submitted in chapter 6 that the 2003 Reception Conditions Directive did not explicitly oblige Member States to implement an assessment

\footnotetext{
${ }^{1257}$ Article 32(1) of the recast Dublin III Regulation.

${ }^{1258}$ See Regeling verstrekkingen asielzoekers en andere categoriën vreemdelingen 1997 (Rva 1997), Staatscourant 1997, nr. 246, p. 12.

${ }^{1259}$ Franssen, K., Larsson, F., Slingenberg, L., De Opvangrichtlijn, Nieuwsbrief asiel- en vluchtelingenrecht (NAV), No. 6, December 2007, p. 411. See also Larsson, F., De EU-richtlijn over de opvang van asielzoekers, Opvangvoorzieningen in Nederland en Frankrijk en de rechtsbescherming tegen het onthouden van opvang, 2011, p. 133.
} 
procedure to identify vulnerable applicants, ${ }^{1260}$ which resulted in poor implementation measures and serious flaws with regard to the obligation to address the special reception needs of vulnerable persons in the domestic asylum systems of the Member States. It can be argued that the Netherlands was one of the Member States that failed to address the special reception needs of vulnerable persons. Article 9(4) of the 2005 Regulation did not mention how vulnerable applicants with special reception needs should be identified. In a study published by EMN in 2013, it has been submitted that the Netherlands offers specialized facilities to vulnerable groups such as unaccompanied minors and victims of torture. However, no assessments were carried out in the Netherlands that could refer these vulnerable groups of asylum applicants to specialized reception facilities. ${ }^{1261}$

\subsubsection{Evaluation of the revised Dutch asylum procedure and the implica- tions for vulnerable asylum applicants}

In 2010 the Dutch government introduced a revision of the Dutch asylum system. The main objective of the revision was to make sure that asylum procedures are processed in a fast and adequate manner.1262 Four years later, an evaluation study on the revised Dutch asylum procedure raised serious concerns from various non-governmental organizations with regard to the protection of vulnerable asylum applicants. ${ }^{1263}$

The concerns issued by NGOs such as Amnesty International focused on whether the special needs of vulnerable asylum applicants would be adequately addressed during the general asylum procedure and recommended that the reception facilities during the rest and preparation period should be adapted to the special needs of vulnerable asylum applicants. Another NGO questioned whether persons carrying out the medical examination were sufficiently able to identify traumatized applicants. ${ }^{1264}$

Lawyers pointed out that due to inconclusive decisions by the authorities of whether an asylum applicant needs medical treatment, vulnerable asylum applicants end up staying longer in the Process Reception Centre than necessary, which often is not suited to offer specialized medical assistance and may be harmful for vulnerable asylum applicants. Where the authorities decide to

\footnotetext{
${ }^{1260}$ Article 17 of the 2003 Reception Conditions Directive.

${ }^{1261}$ EMN Focused Study 2013, The organisation of reception facilities for asylum seekers in different Member States, The Netherlands, pp. 3-11.

1262 TK 2009/2010, 19637, Nr. 1351.

${ }^{1263}$ Böcker, A.G.M., Grütters, C.A.F.M., Laemers, M.T.A.B., Strik, M.H.A, Terlouw, A.B., Zwaan, K.M., Evaluatie van de herziene asielprocedure, WODC, 2014.

${ }^{1264}$ Böcker, A.G.M., Grütters, C.A.F.M., Laemers, M.T.A.B., Strik, M.H.A, Terlouw, A.B., Zwaan, K.M., Evaluatie van de herziene asielprocedure, WODC, 2014, pp. 33-34.
} 
postpone the start of the general asylum procedure for a vulnerable asylum applicant, a first meeting between a lawyer and a vulnerable asylum applicant will not yet take place, although it is crucial for establishing a trust relation between a lawyer and the vulnerable applicant. 1265 Another comment submitted by lawyers refers to the inadequate identification of vulnerabilities by MediFirst, the organization that carried out the medical examinations. Lawyers established a discrepancy between their own assessment of whether their client was capable enough to be interviewed by the IND and the advice that was always given by MediFirst that the client is suited for an interview. ${ }^{1266}$ Several lawyers believed also that the interviews took too long, which can be very stressful for vulnerable asylum applicants. Furthermore, lawyers pointed out that the IND was very keen to emphasize the contradictions in the asylum story of vulnerable asylum applicants. According to the lawyers, the IND does not sufficiently take the vulnerability of these applicants into account and that there may be good explanations for the contradictions in their asylum story. ${ }^{1267}$

Finally, the majority of respondents submitted that the treatment of vulnerable asylum applicants had not improved with the introduction of the revision of the asylum procedure. ${ }^{1268}$ Remarkably, in a letter on the findings of the evaluation study the Dutch government did not mention once the concerns that were raised by the different organizations with regard to vulnerable asylum applicants in the general asylum procedure. 1269

\subsection{Implementation of the recast Reception Conditions Directive 2013/33/EU and the recast Asylum Procedures Directive 2013/32/EU}

Both the recast Reception Conditions Directive and the recast Asylum Procedures Directive were adopted in 2013 and the implementation period expired on 20 July 2015. The legislative proposal to amend the Aliens Act, including the explanatory memorandum was issued in the Netherlands on 24 November 2014. ${ }^{1270}$ Following the legislative procedure in the Parliament, the Nether-

\footnotetext{
${ }^{1265}$ Böcker, A.G.M., Grütters, C.A.F.M., Laemers, M.T.A.B., Strik, M.H.A, Terlouw, A.B., Zwaan, K.M., Evaluatie van de herziene asielprocedure, WODC, 2014, pp. 85-86.

${ }^{1266}$ Böcker, A.G.M., Grütters, C.A.F.M., Laemers, M.T.A.B., Strik, M.H.A, Terlouw, A.B., Zwaan, K.M., Evaluatie van de herziene asielprocedure, WODC, 2014, p. 90.

${ }^{1267}$ Böcker, A.G.M., Grütters, C.A.F.M., Laemers, M.T.A.B., Strik, M.H.A, Terlouw, A.B., Zwaan, K.M., Evaluatie van de herziene asielprocedure, WODC, 2014, p. 130.

${ }^{1268}$ Böcker, A.G.M., Grütters, C.A.F.M., Laemers, M.T.A.B., Strik, M.H.A, Terlouw, A.B., Zwaan, K.M., Evaluatie van de herziene asielprocedure, WODC, 2014, p. 201.

${ }^{1269}$ Brief Staatssecretaris van Veiligheid en Justitie, Evaluatie Programma Implementatie Vernieuwde Asielprocedure (PIVA), 10 December 2014.

1270 TK, 2014/2015, 34088, Nr. 2 and Nr. 3.
} 
lands implemented both Directives on 8 July 2015.1271

As regards the implementation of the recast Asylum Procedures Directive, amendments have been introduced in the Aliens Act. The recast Reception Conditions Directive has been implemented by adopting amendments in the 2005 Regulation benefits to asylum seekers and other categories of aliens (2005 Regulation). In comparison Germany and France implemented the recast Reception Conditions Directive in a Parliamentary Act. Germany carried out the implementation in the Asylbewerberleistungsgesetz and France in the Code de l'action sociale et des familles. As discussed above, the Netherlands has a strong preference to implement the Directives on asylum and migration in hierarchical lower legislative instruments. Groenendijk and Slingenberg submit that the level of implementation concerning the rights of persons has not only implications on their changeability, but also on the degree of formulation, the extent to which public authorities feel compelled to comply with those rules and possibly also the interpretation by judges. ${ }^{1272}$

As regards the implementation of Articles 21 and 22 of the recast Reception Conditions Directive, which states that Member States have to take into account the specific situation of vulnerable asylum applicants and to assess whether the vulnerable applicant has special reception needs, the explanatory memorandum to the legislative proposal stipulated that these obligations need not be implemented in the national legislation. It is important to note that the Dutch government did not give clear reasons why it is not required to implement it in an Act of Parliament. The explanatory memorandum merely stipulates that the personnel of COA will be trained to be alert to signs of vulnerability and that the 2005 Regulation will be amended. Members of the Socialist Party questioned the Dutch government as to why the Dutch government is of the opinion that implementation of Articles 21 and 22 of the recast Reception Conditions Directive is not required and how the 2005 Regulation will take into account the specific situation of vulnerable asylum applicants. ${ }^{1273}$

Following the response of the Dutch government to questions submitted by Members of the House of Representatives on the legislative proposal, an Amendment was submitted by the Green Left proposing to implement the ob-

${ }^{1271}$ Wet van 8 juli 2015 tot wijziging van de Vreemdelingenwet 2000 ter implementatie van Richtlijn 2013/32/EU van het Europees Parlement en de Raad van 26 juni 2013 betreffende gemeenschappelijke procedures voor de toekenning en intrekking van de internationale bescherming (PbEU 2013, L 180) en Richtlijn 2013/33/EU van het Europees Parlement en de Raad van 26 juni 2013 tot vaststelling van normen voor de opvang van verzoekers om internationale bescherming (PbEU 2013, L 180).

${ }^{1272}$ Groenendijk, K. and Slingenberg, L., Onthouden dagvergoeding aan asielzoekers in noodopvang is onwettig, Asiel \& Migrantenrecht, Nr. 3, 2016, p. 114.

${ }^{1273}$ TK, 2014/2015, 34088, Nr. 5, p. 21. 
ligations enshrined in Articles 21 and 22 of the recast Reception Conditions Directive. ${ }^{1274}$ The proposed Amendment aims to implement the relevant obligations in an Act of Parliament. ${ }^{1275}$ In addition, the Amendment stressed that the best interests of the child should be paramount in the context of reception and that the authorities should take the special reception needs of minor asylum applicants into account. In a revised Amendment that was submitted later, the implementation of the obligation enshrined in Article 22 of the recast Reception Conditions Directive was deleted, which is remarkable because it is a crucial element of the general principles concerning the identification of potentially vulnerable asylum applicants with special reception needs. ${ }^{1276}$ According to the Secretary of State mandatory assessments of the special reception needs of vulnerable asylum applicants would impose a huge administrative burden, which would not improve the level of protection that is already provided in fact. The Netherlands prefers a more pragmatic approach in this regard. ${ }^{1277}$

Also as regards the implementation of Article 11(1) of the recast Reception Conditions Directive concerning the detention of vulnerable asylum applicants and vulnerable asylum applicants with special reception needs, the explanatory memorandum does not intend to implement this measure in national legislation. Again, the Dutch government has not provided a sufficient explanation.

Regarding several important provisions of the Directives that are relevant to vulnerable asylum applicants, including the specific guarantees for victims of torture and unaccompanied minors, the explanatory memorandum specifies that they will be implemented in the Aliens Decree. According to the Dutch Bar Association such guarantees should be implemented in an Act of Parliament rather than in the Aliens Decree. ${ }^{1278}$ An important aspect for applicants who are considered victims of torture is the medical examination as stipulated in Article 18 of the recast Asylum Procedures Directive. Medical evidence in asylum procedures will have a more significant role in the decision-making procedure than before. As explained in chapter 6 medical examinations can support the applicant's statements about past persecution. According to the explanatory memorandum, implementation of Article 18 of the recast Asylum Procedures Directive in an Act of Parliament is not necessary. Implementing it in the Aliens Decree will suffice. An Amendment submitted by the Socialist Party to imple-

${ }^{1274}$ TK, 2014/2015, 34088, Nr. 11.

${ }^{1275}$ The Amendment proposed to implement Articles 21 and 22 of the recast Reception Conditions in Article 3a Wet Centraal Orgaan opvang asielzoekers (Act of the Central Agency of Reception).

${ }^{1276}$ TK, 2014/2015, 34088, Nr. 20.

1277 TK, 2014/2015, 34088, Nr. 21, pp. 27-28.

${ }^{1278}$ Nederlandse Orde van Advocaten, Advies NOVA inzake het voorstel van wet inzake implementatie Procedurerichtlijn en Opvangrichtlijn, 28 December 2013, p. 6. 
ment the provision on medical examination in an Act of Parliament did not pass the voting in the Parliament. ${ }^{1279}$ Also the more advanced guarantees for victims of torture and unaccompanied minors will be implemented in the Aliens Decree.

\subsection{The notion of vulnerability in the Dutch asylum process}

Chapter 7 has submitted that the majority of Member States have implemented a non-exhaustive list of persons that they consider vulnerable in the context of asylum. However, the discretion granted to Member States to define vulnerability has resulted in discrepancies in the categories of asylum applicants labelled as vulnerable. From the Member States examined, only Austria, Germany, Sweden and the UK have not implemented such a list.

The Dutch Secretary of State for migration issues has indicated in a parliamentary debate on the implementation of the recast Reception Conditions Directive and Asylum Procedures Directive, that asylum applicants are not by definition considered as vulnerable persons. A list of vulnerable persons has not been implemented in the Aliens legislation. A first medical screening could indicate whether an applicant is a vulnerable person. ${ }^{1280}$ In one case, the court held that a disabled applicant whose leg had been amputated should be considered a vulnerable person within the meaning of Article 21 of the recast Reception Conditions Directive. ${ }^{1281}$

Although Article 21 of the recast Reception Conditions Directive provides discretion to Member States in defining vulnerable persons in the context of asylum, it sets a minimum standard for Member States to implement in an Act of Parliament. ${ }^{1282}$ In this regard, the Netherlands can be added to the group of Member States that fails to set this standard in their national formal legislation.

\subsubsection{Identification of vulnerable applicants with special reception needs}

With regard to the national implementing measures on vulnerable asylum applicants with special reception needs, it has been submitted that the Dutch government intended to implement these in the 2005 Regulation. It was also established that the COA is the main reception agency in the Netherlands responsible for, inter alia, taking care of the material reception conditions and

\footnotetext{
${ }^{1279}$ TK, 2014/2015, 34088, Nr. 18.

${ }^{1280}$ EK, 2014/2015, Nr. 38, item 8.

${ }^{1281}$ RB Den Haag, AWB 17/5708, 11 April 2017, ECLI:NL:RBDHA:2017:4033.

${ }^{1282}$ Peek, M. and Tsourdi, L., Asylum Reception Conditions Directive 2013/33/EU in Kay Hailbronner and Daniel Thym (eds.), EU Immigration and Asylum Law, Commentary, $2^{\text {nd }}$ edition (C.H. BECK/Hart/Nomos, 2016), p. 1460.
} 
the allocation of asylum applicants in the reception centres. ${ }^{1283}$ According to the explanatory memorandum attached to the national implementing measures, Article 21 and Article 22 of the recast Reception Conditions Directive are implemented in Article 18a of the 2005 Regulation. According to Article 18a of the 2005 Regulation, the assessment of whether the applicant is vulnerable and whether the applicant has special reception needs should be carried out by the COA. This assessment should start after a reasonable period following the asylum application. Special reception needs should also be addressed when they become evident at a later stage in the asylum procedure. The asylum applicant should also have the opportunity to bring forward any special reception needs he or she may have. Adequate support could mean for example that the vulnerable asylum applicant receives a modified living space due to his/her physical disability. ${ }^{1284}$

A closer look at Article 18a(1) of the 2005 Regulation stipulates that the $\mathrm{COA}$ is responsible to take into account the special situation of vulnerable persons during their stay in the reception centre as laid down in Article 21 of the recast Reception Conditions Directive. Paragraph 2 of Article 18a of the 2005 Regulation provides that the COA assesses whether the asylum applicant has special reception needs. This reflects the legal standard in Article 22(1) of the recast Reception Conditions Directive. Paragraph 3 of Article 18a of the 2005 Regulation further specifies that in the case where the applicant has been considered a vulnerable asylum applicant with special reception needs, he or she may benefit from material reception conditions and receive specific support and guidance. This corresponds to the standard laid down in Article 22(3) of the recast Reception Conditions Directive. In my view, the national implementing measures are in general terms in line with the standards laid down in the Directive. However, to ensure the standards prescribed under the Directive, it can be argued that the national implementing measures should stipulate that the assessment by COA is initiated within a reasonable period of time after the application is made (not lodged), including a guarantee that such special reception needs are also addressed when they become evident in a later phase of the asylum procedure. In addition, the support provided to applicants with special reception needs should be guaranteed throughout the duration of the asylum procedure and their situation be properly monitored.

In my view, it remains unclear how the COA assesses whether an individual applicant is vulnerable and whether he or she has special reception needs. It is also not evident who within the COA is responsible for the identification of

${ }^{1283}$ Article 3(1) Act of the Central Agency for the Reception of Asylum Seekers.

${ }^{1284}$ Staatscourant Regeling van de Staatssecretaris van Veiligheid en Justitie van 9 juli 2015, nummer 654765, houdende wijziging van de Regeling verstrekkingen asielzoekers en andere categorieën vreemdelingen 2005, Nr. 20243, 17 Juli 2015. 
vulnerability and of special reception needs. Furthermore, it can be questioned to what extent the current assessment by COA is carried out in a systematic manner and whether there is an efficient system in place to monitor applicants identified as vulnerable asylum applicants with special reception needs throughout the procedure. Although the explanatory memorandum stipulates that the vulnerability and special needs assessment should be initiated after a reasonable period following the asylum application, it would be more adequate to have specified at least the timing of the first assessment. It is true that minors, pregnant women or physically disabled persons may from their appearance be presumed to be vulnerable applicants with special reception needs. But an applicant may have certain hidden vulnerabilities that require a more thorough assessment. In my view, in terms of legal certainty and transparency it can be argued that such an important legal standard for the protection of vulnerable asylum applicants in the asylum process, as laid down in Articles 21 and 22 of the recast Reception Conditions Directive should be implemented in an Act of Parliament. The Netherlands Institute for Human Rights has also contested the policy on the identification of vulnerable asylum applicants with special reception needs. It has been pointed out that the COA has not implemented a policy in which vulnerable asylum applicants are assessed in a systematic manner and whether they have special reception needs. The Human Rights Institute strongly recommends adopting a specific policy focused on vulnerable groups and their special reception needs. 1285

As has been noted in chapter 6, applicants identified as vulnerable applicants with special reception needs may benefit from special guarantees, which requires Member States to take certain measures in the area of detention, material reception conditions and health care. The next section will examine the implementation in these areas.

\subsubsection{Detention of vulnerable applicants and of applicants with special reception needs}

One of the implications of being identified as a vulnerable asylum applicant with special reception needs is that Member States in accordance with Article 11(1) of the recast Reception Conditions Directive, are required to have primary concern of the health, including mental health of detained vulnerable applicants with special reception needs and the procedural obligation to monitor them and to provide adequate support to the particular situation of vulnerable applicants. It is important to note that since 2015 a legislative proposal dealing

${ }^{1285}$ College voor de Rechten van de Mens, Mensenrechten in de noodopvang Heumensoord, 10 Februari 2016, pp. 4-10. 
with the detention of aliens is pending in the House of Representatives. ${ }^{1286}$ The proposal aims to replace the current regime that applies to the detention of aliens (Penitentiaire beginselenwet). The legislative proposal contains specific guarantees for vulnerable groups in detention, including enhanced guarantees for unaccompanied minors, pregnant women and families with minor children. Moreover, the legislative proposal makes a reference to Article 21 of the recast Reception Conditions Directive. It can be concluded that the important legal standards laid down in Article 11(1) of the recast Reception Conditions Directive on vulnerable persons in detention have unfortunately not been implemented yet by the Netherlands. Further, the Commissioner for Human Rights of the Council of Europe had already expressed in 2014 his concerns that the Netherlands fails to adequately address the issue of vulnerable persons in detention and to better ensure the rights of vulnerable persons. ${ }^{1287}$

\subsubsection{Material reception conditions for vulnerable applicants with special reception needs}

As stipulated in Article 17(2) of the recast Reception Conditions Directive, a second important guarantee concerns the obligation for Member States to ensure a standard of living that meets the specific situation of vulnerable asylum applicants in accordance with Article 21 of the recast Reception Conditions Directive. This obligation also covers vulnerable applicants who are in detention. ${ }^{1288}$ In addition, as stipulated in Article 18(3) of the recast Reception Conditions Directive, Member States have the duty to take into account gender and age-specific concerns and the situation of vulnerable persons as regards applicants in premises designed for the housing of applicants during the examination of applications for international protection made at the border or in transit zones and accommodation centres. 1289

The obligation for the Netherlands to ensure a standard of living that meets the specific situation of vulnerable asylum applicants has neither been implemented in the Aliens Act nor in the Aliens Decree. Moreover, in the Netherlands, except for unaccompanied minors, specialized accommodation centres are not available for vulnerable groups of asylum applicants.

\footnotetext{
${ }^{1286}$ TK, 2015/2016, 34309, Nr. 2.

${ }^{1287}$ Council of Europe, Report by Nils Muiznieks, Commissioner for Human Rights of the Council of Europe, Following his visit to the Netherlands from 20 to 22 May 2014, CommDH(2014)18, Strasbourg, 14 October 2014, para. 95. See also Amnesty International, Dokters van de Wereld, Stichting LOS-Meldpunt Vreemdelingendetentie, Opsluiten of beschermen, Kwetsbare mensen in vreemdelingendetentie, April 2016.

1288 Article 17(2) of the recast Reception Conditions Directive.

${ }^{1289}$ Article 18(3) of the recast Reception Conditions Directive.
} 


\subsubsection{Health care for vulnerable applicants with special reception needs}

Asylum applicants in reception centres have access to basic health care.1290 Applicants with special reception needs should receive the 'necessary medical or other assistance' including 'appropriate mental health care where needed' as enshrined in Article 19(2) of the recast Reception Conditions Directive. Although the legislator did not implement Article 19(2) of the recast Reception Conditions Directive in the Aliens Act or in the Aliens Decree in which the mental health care is regulated for vulnerable persons with special reception needs, the Regulation Medical Care for Asylum Applicants (Regeling Medische Zorg voor Asielzoekers) does cover mental health care for asylum applicants in general.1291

\subsubsection{Identification of applicants in need of special procedural guarantees}

It was submitted in chapter 6 that an applicant may not only require special reception guarantees, but may also require special procedural guarantees. Article 24(1) of the recast Asylum Procedures Directive requires Member States to assess within a 'reasonable period of time' following the application for international protection whether the applicant is in need of special procedural guarantees. Hence, the 'reasonable period of time' starts after the applicant has made a request for international protection and it is thus not required that the applicant has formally lodged an application for international protection. The Directive does, however, not give a clear indication of what is meant with 'reasonable period of time'. The only clarification is again provided in Recital 29, which stipulates that Member States should 'endeavour' to identify those applicants in need of procedural guarantees before the first decision is taken.

Furthermore, it follows from Article 2(d) that 'an applicant in need of special procedural guarantees' is an asylum applicant 'whose ability to benefit from the rights and comply with the obligations provided for in this Directive is limited due to individual circumstances'. The assessment of special procedural guarantees is thus based on the individual circumstances of the applicant. There is also no standard as to who should undertake such an assessment. The recast Asylum Procedures Directive only indicates that Member States have to guarantee that the person who conducts the interview during the asylum procedure is competent to take into account the 'vulnerability' of the asylum applicant.1292

${ }^{1290}$ Article 9(1)(e) of the 2005 Regulation benefits to asylum seekers and other categories of aliens.

${ }^{1291}$ See for further information Regeling Medische Zorg Asielzoekers, available at https://www.rmasielzoekers.nl and Pharos, available at http://www.pharos.nl/nl/kenniscentrum/asielzoekers-en-vluchtelingen/asielzoekers-envluchtelingen/gezondheidszorg-voor-vluchtelingen

${ }^{1292}$ Article 15(3)(a) of the recast Asylum Procedures Directive. See Case C-148/13 to C150/13, A,B,C v Staatssecretaris van Veiligheid en Justitie, Court of Justice of the European 
Hence, the recast Asylum Procedures Directive grants Member States great discretion as regards the assessment to identify applicants in need of special procedural guarantees.

The Dutch government has chosen to implement Article 24 of the recast Asylum Procedures Directive in the Aliens Decree. Similar to the provision on vulnerable applicants who require special reception guarantees, it can be argued that in terms of legal certainty and transparency an important provision as Article 24 of the recast Asylum Procedures Directive should be implemented in an Act of Parliament.

Article 24(1) of the recast Asylum Procedures Directive is, however, implemented in Article 3.108b(1) of the Aliens Decree, which stipulates that prior to or during the procedure of the examination of the application for asylum there will be an assessment of the applicant's need for special procedural guarantees. This corresponds largely with the requirement in Article 24(1) of the recast Asylum Procedures Directive, albeit in a different formulation.

As regards the assessment of special procedural guarantees, according to the explanatory memorandum to the implementing law, the assessment is not restricted to a specific moment in the asylum procedure, but rather a continuous process. ${ }^{1293}$ Article 15(3)(a) of the recast Asylum Procedures Directive obliges Member States to make sure that the person who conducts the interview during the asylum procedure is competent to take into account the vulnerability of the asylum applicant. According to the IND work-instruction 2015/8, the IND is responsible for the assessment of special procedural guarantees. All IND personnel dealing with asylum interviews have to take the module 'Interviewing Vulnerable Persons', ${ }^{1294}$ and the identification of vulnerable applicants in need of special procedural guarantees is a continuous process, which should start from the moment the applicant applies for international protection. ${ }^{1295}$ This seems to be in conformity with Article 24(4) of the recast Asylum Procedures Directive, which stipulates that the need for special procedural guarantees is also addressed if it becomes evident in a later stage of the asylum procedure. However, an important measure that ensures that the need for special procedural guarantees is addressed continuously and thus also where they become

Union, 2 December 2014, ECLI:EU:C:2014:2046, para. 70.

${ }^{1293}$ Besluit van 10 juli 2015, houdende wijziging van het Vreemdelingenbesluit 2000 en het Besluit vergoedingen rechtsbijstand 2000 in verband met de implementatie van Richtlijn 2013/32/EU van het Europees Parlement en de Raad van 26 juni 2013 betreffende gemeenschappelijke procedures voor de toekenning en intrekking van de internationale bescherming (PbEU 2013, L 180) en Richtlijn 2013/33/EU van het Europees Parlement en de Raad van 26 juni 2013 tot vaststelling van normen voor de opvang van verzoekers om internationale bescherming (PbEU 2013, L 180), 2015, Stb, 294, p. 24.

${ }^{1294}$ TK, 2017/2018, Nr. 186.

${ }^{1295}$ IND work-instruction nr. 2015/8 (Bijzondere procedurele waarborgen), p. 4. 
evident in a later stage of the asylum procedure, is not implemented in the Aliens Act or in the Aliens Decree. This remains, from a legal point of view, a shortcoming.

\subsubsection{Vulnerability indicators for the assessment of whether the applicant is in need of special procedural guarantees}

As submitted above, the recast Asylum Procedures Directive grants Member States great discretion with regard to the assessment to identify applicants in need of special procedural guarantees. The assessment by the IND of whether an applicant is in need of special procedural guarantees is determined, inter alia, on the basis of observations carried out by the IND personnel during the interview or the behaviour or statements of the applicants themselves may indicate that the applicant needs special procedural guarantees.

The IND work-instruction 2015/8 provides also a list of vulnerability indicators (non-exhaustive) for the assessment of whether the applicant is in need of special procedural guarantees. Where one or more of these indicators is evident in the individual circumstances of the applicant, the IND personnel should be extra careful and assess whether the applicant requires special procedural guarantees and which support is to be offered.

The work-instruction does, however, not imply that every asylum applicant with one or more of these indicators is by definition vulnerable. It remains an individual assessment. ${ }^{1296}$ The indicators represent different aspects of vulnerability and they can be divided into physical, psychological, statements, intellectual and 'others'. ${ }^{1297}$ Flegar and Veys submit that these indicators adopted in the IND work-instruction 2015/8 mostly focus on the physical aspects of vulnerability in the assessment of special procedural guarantees and pay limited attention to situational and structural aspects of vulnerability. ${ }^{1298}$ In my view, the work-instruction contains a generalized list of indicators representing sources of vulnerability that are inherent to the human condition and some situational sources of vulnerability. It can be argued that indicators can address different dimensions of vulnerability and therefore represent a more nuanced approach than just labelling groups presumed to be vulnerable. However, the workinstruction does not clarify what criteria are used to select the indicators of vulnerability and its relevance in the asylum process.

${ }^{1296}$ IND work-instruction nr. 2015/8 (Bijzondere procedurele waarborgen), p. 4.

${ }^{1297}$ IND work-instruction nr. 2015/8 (Bijzondere procedurele waarborgen), p. 8.

${ }^{1298}$ Flegar, V. and Veys, M., De Europese verplichting voor procedurele waarborgen in de Nederlandse asielprocedure en de implementatie vanuit kwetsbaarheidsperspectief, Journaal Vreemdelingenrecht, Nr. 2/11, 2017, para. 5.1. 
Table 8.6. Indicators of vulnerability for the assessment of applicants in need of special procedural guarantees ${ }^{1299}$

\begin{tabular}{|c|c|}
\hline Physical & $\begin{array}{l}\text { - Pregnant } \\
\text { - Disabled } \\
\text { - Deaf/impaired hearing } \\
\text { - Blind/impaired vision } \\
\text { - Stutter } \\
\text { - Severe medical condition (among which diabetes, kidney di- } \\
\text { - alysis patients) } \\
\text { - Applicants on medication } \\
\text { - Physically exhausted (for example due to the travel) } \\
\text { - Use of wheelchair/difficulties to walk }\end{array}$ \\
\hline Psychological & $\begin{array}{l}\text { - Confused } \\
\text { - Tired } \\
\text { - Tense } \\
\text { - Nervous } \\
\text { - Anxious } \\
\text { - Aggressive } \\
\text { - Taciturn } \\
\text { - Suicidal } \\
\text { - Traumatized } \\
\text { - Depressed }\end{array}$ \\
\hline Statements & $\begin{array}{l}\text { - Victim of psychological, physical or sexual violence } \\
\text { - Victim of torture } \\
\text { - Victim of human trafficking } \\
\text { - Intense journey }\end{array}$ \\
\hline Intellectual & $\begin{array}{l}\text { - Illiterate } \\
\text { - Unskilled } \\
\text { - Low-skilled } \\
\text { - Intellectually impaired } \\
\text { - Not self-reliant }\end{array}$ \\
\hline Others & $\begin{array}{l}\text { - Age (high/low) } \\
\text { - Single woman } \\
\text { - LGBT } \\
\text { - Belong to a vulnerable minority group } \\
\text { - Loss of a person that was close to you }\end{array}$ \\
\hline
\end{tabular}

Furthermore, it has been submitted in the work instruction that in the determination of whether an applicant needs special procedural guarantees, other aspects that were discussed during the mandatory training of the IND personnel on 'Interviewing Vulnerable Persons' can also be considered. In addition, indi-

${ }^{1299}$ IND work-instruction nr. 2015/8 (Bijzondere procedurele waarborgen), p. 8. 
cations from partners in the asylum procedure such as lawyers, COA, the Aliens police and the Dutch Refugee Council should also be taken into account.

According to the IND, another important aspect in the assessment of whether the applicant is need of special procedural guarantees concerns the medical check. ${ }^{1300}$ Applicants during the rest and preparation period undergo a medical check, which is carried out by FMMU. According to the Dutch Refugee Council, however, FMMU does not identify whether an applicant is vulnerable. It merely provides advice to the IND regarding the question whether the asylum applicant is capable (physically or mentally) of being interviewed and which special needs the applicant has in order to be interviewed by the IND. ${ }^{1301}$ It could be argued that medical checks are not suitable to identify vulnerable asylum applicants with special needs. Moreover, even if it is determined during the medical check that the applicant is vulnerable and requires special procedural guarantees, the IND has the discretion to decide whether to take into account the conclusions of the medical advice and to decide to take any specific actions or to start the general asylum procedure (without any specific actions). ${ }^{1302}$ Another study has submitted that the FMMU advice that is presented before the start of the asylum procedure on relevant medical aspects, often, has limited indications as to what support is adequate for the applicant in need of special procedural guarantees. ${ }^{1303}$

Furthermore, it has also been submitted that no rest and preparation period or a medical check takes place in the Dublin procedure (track 1) or in the event of an application from 'safe countries of origin' or where applicants already receive international protection in another EU Member State (track 2). Although the recast Asylum Procedures Directive does not require Member States to arrange a medical check for identifying whether the applicant is vulnerable and is in need of special procedural guarantees, the Directive does also not exclude them from such special procedures. Hence, in my view, applicants in track 1 and track 2 should be in principle also assessed as to whether they require special procedural guarantees within the meaning of Article 24 of the recast Asylum Procedures Directive and to benefit from special guarantees. ${ }^{1304}$ Notwith-

${ }^{1300}$ IND work-instruction nr. 2015/8 (Bijzondere procedurele waarborgen), p. 5. See C1/2.2. Aliens Circular.

${ }^{1301}$ Asylum Information Database, Country Report the Netherlands, 2017, p. 38.

${ }^{1302}$ See C1/2.2. Aliens Circular.

${ }^{1303}$ Kok, S., and Rodrigues, P., Bij gebrek aan bewijs, de beoordeling van de geloofwaardigheid van het asielrelaas onder Werkinstructie 2014/10, Universiteit Leiden - VluchtelingenWerk Nederland, November 2016, p. 56.

${ }^{1304}$ See also Flegar, V. and Veys, M., De Europese verplichting voor procedurele waarborgen in de Nederlandse asielprocedure en de implementatie vanuit kwetsbaarheidsperspectief, Journaal Vreemdelingenrecht, Nr. 2/11, 2017, para. 4.2. 
standing that an asylum applicant is from a country of origin that is considered to be safe, an individual examination should take place and in line with the recast Asylum Procedures Directive Member States should at least 'endeavour' to identify whether the applicant may be in need of special procedural guarantees before a first instance decision is taken. ${ }^{1305}$

Chapter 6 showed that the relevant Directives require Member States to implement two identification mechanisms in the asylum procedure. One to identify the special reception needs of vulnerable asylum applicants, and two, to identify the special procedural needs. These identification mechanisms may be integrated into one procedure. The Dutch government has chosen not to implement a formal assessment procedure or to integrate the assessment procedure as allowed under Article 24(2) of the recast Asylum Procedures Directive into the assessment procedure in Article 22 of the recast Reception Conditions Directive. Nevertheless, an applicant requiring special reception guarantees would not necessarily require special procedural guarantees. Furthermore, because the assessment of whether the applicant is in need of special procedural guarantees is not a formal procedure, the outcome is thus also not a decision against which the applicant can appeal. In addition, the IND is required to inform COA about any signs of vulnerability that may become evident during the procedure. ${ }^{1306}$

I agree with Flegar and Veys when they recommend to carry out assessments of vulnerability at fixed periods in the asylum procedure and to provide the opportunity for the applicant to argue as early in the procedure why he or she should receive or should have received special procedural guarantees. Currently, this opportunity is only allowed when the applicant receives a rejection of the application for international protection. It is important to note that an assessment procedure should be carried out as soon as possible in order to prevent the applicant from suffering further harm. ${ }^{1307}$ The argument of a standardised mechanism to identify special procedural guarantees can also be argued for the identification of special reception guarantees, which is to be carried out by the COA. According to the Dutch Court, the IND personnel are required throughout the procedure to observe and to be alert to signals as to whether an asylum applicant is in need of adequate support. ${ }^{1308}$ In my view, it remains questionable whether the IND personnel is adequately equipped to identify whether an applicant is vulnerable and whether the applicant requires special

\footnotetext{
${ }^{1305}$ Recital 29 of the recast Asylum Procedures Directive.

${ }^{1306}$ IND work-instruction nr. 2015/8 (Bijzondere procedurele waarborgen), pp. 6-7.

${ }^{1307}$ Flegar, V. and Veys, M., De Europese verplichting voor procedurele waarborgen in de

Nederlandse asielprocedure en de implementatie vanuit kwetsbaarheidsperspectief, Journaal Vreemdelingenrecht, Nr. 2/11, 2017, para. 5.2.

1308 RB Den Haag, AWB 15/20414, 15 December 2015, ECLI:NL:RBDHA:2015:15942.
} 
procedural guarantees, including what kind of adequate support should be offered in order to allow the applicant to benefit from the rights and comply with the obligations of the Directive. A training module on how to interview vulnerable persons does not seem to be adequate to identify such applicants.

The Advisory Committee on Migration Affairs (Adviescommissie voor Vreemdelingenzaken) has also submitted that despite the guidelines laid down in the IND work-instruction $2015 / 8$ on special procedural guarantees, the implementation in practice does not always meet the standards. In particular, the IND should take the vulnerability of certain asylum applicants such as minors or traumatized asylum applicants more into account.1309

\subsubsection{Adequate support for applicants in need of special procedural guar- antees}

As regulated in Article 24(3) of the recast Asylum Procedures Directive, the legal implication of being identified as an applicant in need of special procedural guarantees is thus that the applicant must receive adequate support in order to allow the applicant to benefit from the rights and comply with the obligations of the Directive throughout the duration of the asylum procedure. This obligation is implemented in paragraph 2 of Article 3.108b Aliens Decree, which provides that where the alien is in need of special procedural guarantees adequate support will be provided throughout the procedure. It has been concluded in chapter 6 that it is up to the discretion of Member States to give substance to the notion of adequate support. Recital 29 of the recast Asylum Procedures Directive clarified that applicants in need of special procedural guarantees should receive at least sufficient time to put forward the elements to substantiate their application. The IND work-instruction 2015/8 stipulates that the type of adequate support that should be provided depends on the individual circumstances and therefore it is not laid down in a regulation. Thus, the meaning of 'adequate support' is not defined in the work-instruction. 1310 This raises also the important question of how to determine whether the provided support is adequate. It has been submitted that Recital 29 of the Directive specifies that 'those applicants should be provided with adequate support, including sufficient time, in order to create the conditions necessary for their effective access to procedures and for presenting the elements needed to substantiate their application for international protection.' It can be argued that support may not be adequate when it is impossible or extremely difficult for the applicant in need of special procedural guarantees to effectively access the asylum procedure and to

${ }^{1309}$ ACVZ, De geloofwaardigheid gewogen, Een advies over het onderzoeken, integraal beoordelen en toetsen van verklaringen in de asielprocedure, May 2016, p. 56.

${ }^{1310}$ IND work-instruction nr. 2015/8 (Bijzondere procedurele waarborgen), p. 6 . 
submit the elements that are needed to substantiate the asylum application. Reneman points out that considering that $70 \%$ of the asylum cases in the Netherlands are processed in the general asylum procedure of eight days, there is a great chance that cases of vulnerable asylum applicants in need of special procedural guarantees are also dealt within the general asylum procedure. She seriously questions whether adequate support can be provided to such applicants in such a short procedure. ${ }^{1311}$ I agree with Reneman that it is contentious whether adequate support can be provided to vulnerable asylum applicants in need of special procedural guarantees in the general asylum procedure of eight days, which is a short time limit. However, the issue is, in my view, more related to the medical check that applicants undergo during the rest and preparation period, which is inadequate to determine whether the applicant a vulnerable person in need of special procedural guarantees. In addition, even if it is determined during the medical check that the applicant is vulnerable and requires special procedural guarantees, the IND still has the discretion to decide whether they postpone the general asylum procedure or consider that the second interview should takes place in the extended asylum procedure. ${ }^{1312}$ Hence, in my view, once asylum applicants are identified as vulnerable applicants in need of special procedural guarantees, they should automatically be transferred to the extended asylum procedure.

\subsubsection{Exemption from accelerated and border procedures}

The next legal implication derived from Article 24(3) of the recast Asylum Procedures Directive is that where Member States cannot provide adequate support to applicants in need of special procedural guarantees in special asylum procedures such as the accelerated procedure and the border procedure, Member States are required not to apply or to cease to apply such special procedures. In particular, where the applicants are in need of special procedural guarantees as a result of torture, rape or other serious forms of psychological, physical or sexual violence. This follows also from Recital 30, which states that 'where adequate support cannot be provided to an applicant in need of special procedural guarantees in the framework of accelerated or border procedures, such an applicant should be exempted from those procedures.' This legal standard provided by the Directive is an important legal safeguard for applicants in need of special procedural guarantees because of the short time limits in accelerated

${ }^{1311}$ Reneman, M., Implementatie van de herziene Asielprocedurerichtlijn: een nieuwe beslissystematiek en meer waarborgen voor asielzoekers, Nederlands tijdschrift voor Europees recht, Nr. 8, September 2015, pp. 252-254.

${ }^{1312}$ IND work-instruction nr. 2015/8 (Bijzondere procedurele waarborgen), p. 2. 
procedures to substantiate their asylum application and the use of detention in border procedures.

According to the explanatory memorandum to the implementing law of the Netherlands, identified applicants in need of special procedural guarantees as a result of torture, rape or other serious forms of psychological, physical or sexual violence are not exempted per se from the border procedure. It should be examined in individual cases whether adequate support can be provided. Where it is not possible to provide adequate support (anymore), the application should not be processed or cease to be processed in the border procedure. The IND work-instruction 2018/3 specifies that applicants who are identified as being in need of special procedural guarantees as a result of torture, rape or other serious forms of psychological, physical or sexual violence, and who cannot be provided with adequate support in the border procedure or in the border detention should also be exempted from being processed in the border procedure. It has been submitted above that what constitutes adequate support' remains obscure. In addition, to benefit from adequate support, the applicant needs to be effectively identified as an applicant in need of special procedural guarantees. The work-instruction 2015/8 seems to suggest that IND personnel on the basis of indicators and observations during the interview assess whether the applicant is in need of special procedural guarantees and which support should be offered. The work-instruction, however, does not provide guidance as to what is the decisive factor(s) for the consideration that the applicant is need of special procedural guarantees.

Furthermore, it is important to note that the work-instruction makes a reference to Article 3.108b of the Aliens Decree, which establishes the obligation to assess whether the applicant is in need of special procedural guarantees and to ensure adequate support during the asylum process. However, Article $3.108 \mathrm{~b}$ of the Aliens Decree or the Aliens Act enshrine the procedural guarantee for vulnerable asylum applicants to exclude them from being processed in the border procedure where no adequate support can be provided. This is, in my view, a serious shortcoming and does not reflect the requirements of the Directive. In my view, the obligation to exempt applicants in need of special procedural guarantees from the border procedure where no adequate support can be provided should preferably be implemented in the Aliens Act. ${ }^{1313}$ In addition, the Directive does not only refer to border procedures but also to accelerated procedures that should not be applied to such applicants where no adequate support can be provided.

${ }^{1313}$ See also ACVZ, Sporen uit het verleden, advies over de rol van medisch onderzoek bij de beoordeling van asielaanvragen, July 2014, p. 22 in which they refer to the implementation of Article 18 of the recast Asylum Procedures Directive (medical examination) and Aanwijzing 2.21. (h) Aanwijzingen voor de regelgeving. 
Furthermore, the last subparagraph of Article 24(3) of the recast Asylum Procedures Directive specifically requires Member States to ensure additional guarantees to applicants in need of special procedural guarantees to whom accelerated and border procedures may not be applied and where his or her appeal at the border has no automatic suspensive effect. Such applicants should at least receive the following additional guarantees: necessary interpretation, legal assistance and at least one week to prepare the request, including an examination of the decision by a court or tribunal concerning fact and law. Two comments can be submitted in this regard. First, the applicant needs to be effectively identified as an applicant in need of special procedural guarantees in the border procedure casu quo border detention before he or she can make use of the additional guarantees. Second, it is not entirely evident from the national implementing measures whether these additional guarantees apply to applicants falling under Article 24(3) of the recast Asylum Procedures Directive. Arguably, it can be submitted that there are serious shortcomings in the implementation of the standards enshrined in Article 24(3) of the recast Asylum Procedures Directive (second subparagraph).

Lastly, as provided in Article 31(7)(b) of the recast Asylum Procedures Directive, where an applicant has been identified as an applicant in need of special reception guarantees or in need of special procedural guarantees, Member States may prioritise the examination of the application. The Netherlands has not implemented such measures.

\subsubsection{Vulnerable asylum applicants as beneficiaries of international pro- tection}

It was submitted in chapter 6 that the recast Qualification Directive does not provide for detailed measures regarding vulnerable asylum applicants with special needs compared to the recast Asylum Procedures Directive and the recast Reception Conditions Directive. Member States are required to take into account the applicant's background, gender and age in identifying whether a person is eligible for international protection. Article 31(4) of the Aliens Act corresponds to the relevant Article 4(3)(c) of the recast Qualification Directive.

Furthermore, Article 20(3) of the recast Qualification Directive requires Member States to take into account the specific situation of vulnerable beneficiaries of international protection concerning the rights and benefits stipulated in Chapter VII of the Directive. For example, where Member States adopt integration policies and measures they should take into account the specific situation of vulnerable persons with special needs or as stipulated explicitly in Article 30(2) of the recast Qualification Directive, Member States should ensure, under the same eligibility conditions as nationals of the Member State concerned, adequate healthcare, and also allow for mental care for vulnerable bene- 
ficiaries of international protection who have special needs. In the Netherlands beneficiaries of international protection have in general the same rights and duties as Dutch nationals, in terms of access to healthcare, the labour market or housing. Except for unaccompanied minors, ${ }^{1314}$ no specific legislation or policy is targeted to vulnerable groups of beneficiaries of international protection with special needs such as pregnant women, elderly people, disabled people or persons who have been subjected to torture, rape or other serious forms of psychological, physical or sexual violence.

\subsubsection{Vulnerable asylum applicants in the context of Dublin transfers}

It has been submitted that the Dublin Regulation requires Member States to 'normally keep or bring together' applicants who are 'on account of pregnancy, a new-born child, serious illness, severe disability or old age' dependent on a child, sibling or parent legally resident in one of the Member States. ${ }^{1315}$ The IND determines on the basis of medical documents whether the applicant is in need of care and is dependent on the assistance of his child, sibling or parent who lawfully resides in the Netherlands. Based on the submitted information the IND assesses whether the child, sibling or parent residing in the Netherlands can take care of the applicant who is residing in another Member State. Provided that they have declared in writing that they wish to do so. ${ }^{1316}$ The Administrative Jurisdiction Division of the Council of State has held that the existence of dependency is assessed on objective documents such as medical attests and what sort of assistance the applicant could provide.1317

In addition, vulnerability of an asylum applicant is one of the indicators for Member States that may trigger the application of the 'sovereignty clause'1318 or the 'humanitarian clause'1319 (also known as the discretionary clauses). It appeared from the UNHCR study on the implementation of the recast Dublin III Regulation that the majority of Member States interpreted the discretionary clauses in a restrictive manner or hardly applied such clauses. ${ }^{1320}$ This applies

\footnotetext{
${ }^{1314}$ TK 2013/2014, 27062, Nr. 95. Further details discussed in 8.5 'Unaccompanied minors'. 1315 Article 16(1) of the recast Dublin III Regulation.

${ }^{1316}$ C2/5 Aliens Circular.

${ }^{1317}$ Afdeling van de bestuursrechtspraak Raad van State, 201403670/1/V3, 5 February 2015, ECLI:NL:RVS:2015:370; Afdeling bestuursrechtspraak van de Raad van State, 201405639/1/V3, 29 May 2015, ECLI:NL:RVS:2015:1787; Afdeling bestuursrechtspraak van de Raad van State, 201502436/1/V3, 1 December 2015, ECLI:NL:RVS:2015:3794.

1318 Article 17(1) of the recast Dublin III Regulation.

${ }_{1319}$ Article 17(2) of the recast Dublin III Regulation.

${ }^{1320}$ UNHCR, Study on the implementation of the Dublin III Regulation, Left in Limbo, 2017, pp. 115-132.
} 
also for the Netherlands. It is laid down in C2/5 of the Aliens Circular that the IND is reticent in the application of the discretionary clauses enshrined in Article 17(1) and (2) of the recast Dublin III Regulation.

It was also pointed out in chapter 6 of this study that vulnerability and special needs of asylum applicants have become important elements to take into account in Dublin transfers. In accordance with Article 31(2)(a) and 32(1) of the recast Dublin III Regulation, transferring Member States are required to exchange relevant information on any special needs including specific health data of vulnerable applicants with the responsible Member State before a Dublin transfer is undertaken, in particular when it concerns disabled persons, elderly people, pregnant women, minors and persons who have been subject to torture, rape or other serious forms of psychological, physical and sexual violence.

Since Tarakhel transferring States have to obtain individual guarantees concerning adequate reception conditions from the responsible State prior to the transfer of vulnerable groups. The Administrative Jurisdiction Division of the Council of State held in several cases that the Dutch authorities could rely on the guarantees provided in a 'circular letter' of 8 June 2015 from the Italian authorities in which they provide information about the availability of adequate reception conditions for families with minor children and to comply with the Tarakhel requirements. ${ }^{1321}$ In a subsequent 'circular letter' on 15 February 2016, the Italian authorities have indicated that from the 161 adequate places for vulnerable asylum applicants only 85 are left. Despite the announced limited availability, the Administrative Jurisdiction Division of the Council of State pointed out that individual guarantees are not required as the Italian authorities indicated it would increase the reception capacity if there is a need for this. ${ }^{1322}$

Furthermore, the Administrative Jurisdiction Division of the Council of State has acknowledged that other categories besides families with minor children could be considered vulnerable persons in the context of the Tarakhel case. The applicant's gender, age and medical condition are aspects to be taken into account in the assessment of whether an applicant is vulnerable. ${ }^{1323}$ The Administrative Jurisdiction Division of the Council of State has consistently held

${ }^{1321}$ Afdeling van de bestuursrechtspraak Raad van State, 201506164/1/V3, 7 October 2015, ECLI:NL:RVS:2015:3209; Afdeling bestuursrechtspraak van de Raad van State, 201504313/1/V3, 27 January 2016, ECLI:NL:RVS:2016:266; Afdeling bestuursrechtspraak van de Raad van State, 201505068/1/V3, 14 March 2016, ECLI:NL:RVS:2016:809.

1322 Afdeling bestuursrechtspraak van de Raad van State, 201605509/1/V3, 9 December 2016, ECLI:NL:RVS:2016:3291. See Battjes, H., Kroniek Dublinverordening, Asiel \& Migrantenrecht, Nr. 2, 2018, p. 76. See also Asylum Information Database, Country Report the Netherlands, 2018, p. 29.

${ }^{1323}$ Afdeling bestuursrechtspraak van de Raad van State, 201504479/1/V3, 3 December 2015, ECLI:NL:RVS:2015:3806. 
that obtaining individual guarantees before a Dublin transfer is carried out is not required where the authorities in accordance with Article 32 of the recast Dublin III Regulation communicate to the Member State responsible the special needs of the applicant to be transferred.1324 It was discussed earlier, however, that the procedural guarantees provided during the general asylum procedure such as a rest and preparation period and a medical examination conducted on the applicant are not applied during the Dublin procedure (track 1). It can be argued that without an adequate medical examination difficulties may arise for the transferring Member State, in this case the Netherlands, to ensure that vital information concerning the state of physical or mental health of vulnerable applicants to be transferred is communicated to the Member State responsible as required by Article 32(1) of the recast Dublin III Regulation. ${ }^{1325}$ According to the Dutch Refugee Council, vulnerable applicants and ill persons are not exempted from being transferred from one Member State to another Member State. The IND examines from the outset whether the applicant should be considered a vulnerable applicant with special needs.1326 It can be contested that such an examination carried out by the IND to consider whether an applicant is a vulnerable person with any special needs for the purposes of communicating this data to the Member State responsible as required by Article 32(1) of the recast Dublin III Regulation seems inadequate. Moreover, Article 32(3) of the recast Dublin III Regulation explicitly requires that the assessment of health data should only be carried out by a health professional.

It follows further from C.K. that where the transfer of an asylum applicant 'with a particularly serious mental or physical illness would result in a real and proven risk of a significant and permanent deterioration in the state of health, that transfer would constitute inhuman and degrading treatment' under Article 4 of the Charter. ${ }^{1327}$ According to Article 64 of the Aliens Act, expulsion does not take place as long as it is not safe to travel in view of the health condition of the applicant or that of one of his family members. In the context of the Dublin Regulation, the Aliens Circular stipulates that a Dublin transfer may be suspended provided that the applicant demonstrates the following evidence: a

${ }^{1324}$ Afdeling bestuursrechtspraak van de Raad van State, 201410601/1/V3, 17 April 2015, ECLI:NL:RVS:2015:1304; Afdeling bestuursrechtspraak van de Raad van State, 201505068/1/V3, 14 March 2016, ECLI:NL:RVS:2016:809; Afdeling bestuursrechtspraak van de Raad van State, 201602689/1/V3, 3 August 2016, ECLI:NL:RVS:2016:2214. See also Battjes, H., Kroniek Dublinverordening, Asiel \& Migrantenrecht, Nr. 2, 2018, pp. 75-76.

${ }^{1325}$ See also Case C-578/16, C.K. and Others v Republika Slovenija, 16 February 2017, Court of Justice of the European Union, ECLI:EU:C:2017:27, para. 82.

${ }^{1326}$ Asylum Information Database, Country Report the Netherlands, 2018, p. 29.

${ }^{1327}$ Case C-578/16, C.K. and Others v Republika Slovenija, 16 February 2017, Court of Justice of the European Union, ECLI:EU:C:2017:27. 
statement that the applicant is under currently under treatment with a practitioner; and evidence concerning the medical situation of the applicant; and medical documents demonstrating that the applicant is unable to be physically transferred to a Member State under the Dublin Regulation. Battjes submits that the latter requirement cannot be traced back to C.K. More significantly, Battjes also argues that the interpretation of the IND of Article 3 ECHR medical removal cases in A3/74.2. of the Aliens Circular is not in compliance with the C.K. case. ${ }^{1328}$ The Administrative Jurisdiction Division of the Council of State held, in light of the C.K. case, that where the applicant provides evidence of a high risk of being suicidal, a medical assessment should be carried out before a decision to transfer is taken. According to the Administrative Jurisdiction Division of the Council of State, the mere consideration by the authorities on whether the applicant is 'fit to fly' and the exchange of information on the medical condition to the Member State responsible in accordance with Article 32 of the recast Dublin III Regulation before the actual transfer is carried out do not suffice. Otherwise the right to an effective remedy for the applicant to challenge the transfer decision under Article 27 of the recast Dublin III Regulation is violated. 1329

\subsection{Victims of torture}

\subsubsection{Reception guarantees for torture victims}

It has been submitted that an important guarantee for torture victims is rehabilitation. On the basis of Article 25(1) of the recast Reception Conditions Directive, Member States should guarantee to asylum applicants who have been subject to torture, rape or other serious forms of violence, the necessary treatment of damages caused by torture, rape or other serious acts of violence and 'access to appropriate medical and psychological care'. This legal standard has been implemented in Article 18c (3) of the 2005 Regulation. However, as it has been argued in chapter 6 that the obligation under international law suggests a much broader obligation than the standard laid down in the Directive. Under international law the obligation of State parties is to provide torture victims a holistic rehabilitation, which includes medical and psychological care as well as legal and social support. In addition, rehabilitation should be appropriate and promptly accessible. More importantly, before victims of torture can make use of the rehabilitation services, they need to be effectively identified as vulnerable

${ }^{1328}$ Battjes, H., Kroniek Dublinverordening, Asiel \& Migrantenrecht, Nr. 2, 2018, p. 78.

${ }^{1329}$ Afdeling bestuursrechtspraak van de Raad van State, 201605946/1/V3, 3 November 2017, ECLI:NL:RVS:2017:2986; Afdeling bestuursrechtspraak van de Raad van State, 201703192/1/V3, 3 November 2017, ECLI:NL:RVS:2017:2980. See also Battjes, H., Kroniek Dublinverordening, Asiel \& Migrantenrecht, Nr. 2, 2018, pp. 77-78. 
applicants who have been subject to torture, rape or other serious forms of violence. As I have argued above, a serious weakness of the Dutch asylum process is that there are no adequate procedures or mechanisms implemented to systematically identify vulnerable applicants such as torture victims. Further, the Committee against Torture has observed that there is no data on the number of identified torture victims among asylum applicants 1330 and a lack of specific care policy for applicants who have experienced torture, rape or other forms of serious violence. 1331

\subsubsection{Trained personnel}

Article 25(2) of the recast Reception Conditions Directive requires Member States to ensure that competent staff dealing with asylum applicants who are victims of torture, rape etc. must be trained adequately and comply with the principle of confidentiality provided for in national law. It is not evident whether and how this obligation has been implemented in law or in fact.

\subsubsection{Medical examination}

An important legal standard for the protection of vulnerable applicants such as victims of torture is enshrined in Article 18 of the recast Asylum Procedures Directive, which requires Member States to arrange a medical examination in order to assess the applicant's claim of suffering from medical or psychological problems or injuries that relate to the past persecution or serious harm.

A medical (evidence) report in which it is evident that there is causality between the injuries and the events in the country of origin can underpin the credibility of statements submitted by the asylum applicant. Until the implementation of Article 18 of the recast Asylum Procedures Directive, medical reports did not play a significant role in the Dutch asylum procedure. ${ }^{1332}$ According to the former Aliens Circular, in principle medical aspects did not play a role in the assessment of an application for international protection, since medically there are (often) no certain statements to be made concerning the cause of medical com-

${ }^{1330}$ Convention Against Torture and other Cruel, Inhuman or Degrading Treatment or Punishment, Seventh Periodic Report, Response of the Kingdom of the Netherlands to the list of issues (CAT/C/NLD/QPR/7) transmitted to the State Party under the optional reporting procedure (A/62/44, paras. 23 and 24), The Kingdom of the Netherlands, 3 July 2017, pp. 20-21.

${ }^{1331}$ Convention Against Torture and other Cruel, Inhuman or Degrading Treatment or Punishment, Seventh Periodic Report, Response of the Kingdom of the Netherlands to the list of issues (CAT/C/NLD/QPR/7) transmitted to the State Party under the optional reporting procedure (A/62/44, paras. 23 and 24), The Kingdom of the Netherlands, 3 July 2017, p. 20.

1332 ACVZ, Sporen uit het verleden, July 2014, p. 15. 
plaints and or scars in relation to the fear of persecution. ${ }^{1333}$ Following R.C. $v$ Sweden and the adoption of Article 18 of the recast Asylum Procedures Directive, medical reports have become more significant in the assessment of credibility in Dutch asylum procedures, ${ }^{1334}$ which has also been confirmed by the Administrative Jurisdiction Division of the Council of State. ${ }^{1335}$

Contrary to the advice of the Advisory Committee on Migration Affairs, 1336 Article 18 of the recast Asylum Procedures Directive has not been implemented in the Aliens Act but in Article 3.109e of the Aliens Decree. ${ }^{1337}$ The Dutch government has maintained its view that the implementation in an Act of Parliament is not necessary because such assessments are part of the credibility assessment of the asylum claim, which are not regulated under the Aliens Act 2000.1338 As has been submitted in chapter 6, Member States are required to arrange for a medical examination of the applicant, conducted by qualified medical professionals, where the determining authority deems it 'relevant'. In determining whether a (forensic) medical examination is relevant, the following circumstances are taken into account by the IND:1339

- The applicant's statements concerning the presence of significant physical and or psychological traces;

- Medical documents submitted by the applicant stating significant physical and or psychological traces;

- Evidence that support the claim that upon return there is a threat of persecution or serious harm;

- The statements of the applicant concerning the cause of the physical and or psychological traces in relation to what public sources report about the country of origin;

- Whether the outcome of a medical examination is decisive for the decision on the application for international protection.

In the Dutch asylum context, a medical report is considered an element of the

${ }^{1333}$ C14/3.5.2. Aliens Circular(former reference). See Staatscourant, Besluit van de Minister voor Immigratie, Integratie en Asiel van 22 maart 2012, nummer WBV 2012/3, houdende wijziging van de Vreemdelingencirculaire 2000, Nr. 6296, 30 March 2012.

${ }^{1334}$ See Reneman, M., de Lange, J., and Smeekes, J., Interpretatie en waardering van medische rapporten door de IND, Medische waarheidsvinding en geloofwaardigheidsbeoordeling in asielzaken, Asiel \& Migrantenrecht, Nr. 10, 2016, p. 460.

${ }^{1335}$ Afdeling bestuursrechtspraak van de Raad van State, 201208171/1/V1, 19 February 2014, ECLI:NL:RVS:2014:600.

1336 ACVZ, Sporen uit het verleden, July 2014, pp. 21-22.

${ }^{1337}$ See also Smulders, S., Medisch steunbewijs en de implementatie van de herziene Procedurerichtlijn, Journaal Vreemdelingenrecht, Nr. 3/26, 2015.

1338 TK, 2014/2015, 34088, Nr. 3 and EK, 2014/2015, 34088, C. See also TK, 2014/2015, 19637, Nr. 1903.

${ }^{1339} \mathrm{C} 1 / 4.4 .4$. Aliens Circular. 
general credibility assessment. The central question is to what extent is there causality between the physical and or psychological signs and symptoms on the one hand and on the other hand the way in which they happened in the country of origin.

Where the IND believes that a medical examination can make a relevant contribution to the credibility assessment, the Dutch Forensic Institute (Nederlands Forensisch Instituut) and or the Dutch Institute of Forensic Psychiatric and Psychology (Nederlands Instituut voor Forensische Psychiatrie en Psychologie) may carry out the medical examination. ${ }^{1340}$ There are, however, not many cases where asylum applicants have been medically examined by these organizations. ${ }^{1341}$ Between 2016 and 2018 only 20 cases have been deemed relevant to start a medical examination. ${ }^{1342}$ The IND work-instruction 2016/4 further clarifies that, in principle, the IND will start a medical examination after the second interview in which they ask the applicant about the motives for applying for international protection. A medical examination is not deemed to be relevant in the view of the IND where: 1343

- The asylum application is already granted; or

- The asylum application is not processed: or

- The asylum application is not taken into consideration: or

- The asylum application is considered unfounded:

- The asylum application, irrespective of the credibility of the statements, cannot lead the adoption of an Article 3 ECHR risk: or

- The statements of the applicant are not considered to be credible and where a forensic medical examination will not lead to a different view on the credibility of the application. For example, where the alleged torture in detention is considered not credible due to contradictory and or very vague and brief statements.

Asylum applicants can also arrange their own medical examination to examine their physical and or psychological signs and symptoms that may indicate past persecution or serious harm in the country of origin. This is in accordance with Article 18(2) of recast Asylum Procedures Directive. Applicants can submit a

${ }^{1340}$ IND work-instruction 2016/4, Forensisch medisch onderzoek naar steunbewijs (FMO), 1 July 2016, pp. 1-2. See also Asylum Information Database, Country Report the Netherlands, 2018, p. 42.

${ }^{1341}$ Reneman, M., de Lange, J., and Smeekes, J., Interpretatie en waardering van medische rapporten door de IND, Medische waarheidsvinding en geloofwaardigheidsbeoordeling in asielzaken, Asiel \& Migrantenrecht, Nr. 10, 2016, p. 460.

${ }^{1342}$ Ministerie van Justitie en Veiligheid, Reactie op nadere vragen n.a.v. reactie van het IMMO inzake evaluatie praktijk bekostiging medisch onderzoek, 5 February 2018.

${ }^{1343}$ IND work-instruction 2016/4, Forensisch medisch onderzoek naar steunbewijs (FMO), 1 July 2016, p. 3. 
request to an independent NGO referred to as the Institute for Human Rights and Medical Assessment (Instituut voor Mensenrechten en Medisch Onderzoek) to carry out this medical examination. Their work method is based on the Istanbul Protocol. 1344

It follows from a report issued by the IND between 1 July 2015 and 1 July 2016, that in 123 cases in which a medical report has been submitted by the Institute for Human Rights and Medical Assessment, 56 cases resulted in a positive outcome of the asylum application. ${ }^{1345}$ Whether a medical report issued by the Institute for Human Rights and Medical Assessment will result in a positive decision of the asylum applications mainly depends on the credibility assessment, which takes place before the medical report is submitted. In all of the cases where a medical report of the Institute for Human Rights and Medical Assessment has been submitted, the IND had already issued an intention to reject the asylum application.

In general, the IND is very critical concerning the interpretation made by the Institute for Human Rights and Medical Assessment in establishing the causality between the physical injuries or mental trauma and the applicant's statements of torture or serious harm in the country of origin. For example, the IND is reticent when the Institute for Human Rights and Medical Assessment draws conclusions concerning the causality between psychological trauma of an applicant and events that occurred in the country of origin. 1346

Article 3.109e(4) of the Aliens Decree provides that the results of the medical examination initiated by the IND and the applicant will be taken into account together with other elements in the assessment of the asylum application. This corresponds with the requirement in Article 18(3) of the recast Asylum Procedures Directive. However, due to limited capabilities at the Institute for Human Rights and Medical Assessment and the extensive time needed to collect evidence, it may take months to prepare and submit the medical report. Often, medical reports issued by the Institute for Human Rights and Medical Assessment are submitted after the concluding of the initial asylum application during the general asylum procedure of eight days. ${ }^{1347}$ Regardless of whether the applicant has on their own initiative started a medical examination through the Institute for Human Rights and Medical Assessment, the IND will, in prin-

\footnotetext{
${ }^{1344}$ See https://www.stichtingimmo.nl/rapporteurs-2/het-onderzoek/

${ }^{1345}$ IND, Onderzoek naar de rol van IMMO rapportages in asielzaken, 3 November 2016, p. 7.

${ }^{1346}$ Reneman, M., de Lange, J., and Smeekes, J., Interpretatie en waardering van medische rapporten door de IND, Medische waarheidsvinding en geloofwaardigheidsbeoordeling in asielzaken, Asiel \& Migrantenrecht, Nr. 10, 2016, pp. 463-470. See also Asylum Information Database, Country Report the Netherlands, 2018, p. 42.

${ }^{1347}$ Böcker, A.G.M., Grütters, C.A.F.M., Laemers, M.T.A.B., Strik, M.H.A, Terlouw, A.B., Zwaan, K.M., Evaluatie van de herziene asielprocedure, WODC, 2014, p. 95.
} 
ciple, not refer the asylum application to the extended asylum procedure, which may take up to six months. ${ }^{1348}$ The majority of medical reports issued by the Institute for Human Rights and Medical Assessment are thus not taken into account in the credibility assessment in the initial asylum application by the IND, but may become relevant in a subsequent application for international protection or during an appeal procedure. 1349

The IND report has revealed that in only 12 cases a medical report that was issued by the Institute for Human Rights and Medical Assessment has been submitted during the initial asylum procedure. ${ }^{1350}$ When the Institute for Human Rights and Medical Assessment has submitted a medical report during a subsequent application, the IND is not required to assess the asylum application again. An asylum application can be declared as inadmissible where no new elements or findings relating to the application have arisen or been presented by the applicant. ${ }^{1351}$ In order to consider a medical report issued by the Institute for Human Rights and Medical Assessment as a new element or finding in a subsequent application, the applicant has to provide a valid statement as to why the medical report could not be submitted earlier. ${ }^{1352}$ Moreover, the Dutch authorities will not reimburse the costs of the medical examination initiated by the applicant during a subsequent application. ${ }^{1353}$

\subsubsection{Indications of torture}

The recast Asylum Procedures Directive also requires that Member States ensure that the personnel, both of the determining authority and of another authority where one is temporarily involved in conducting the interviews, are properly trained to be aware of indications that the applicant may have been subject to torture.

According to the explanatory memorandum, implementation in the national legislation of relevant Article 4(3) of the recast Asylum Procedures Directive is not required and that Article 3.112 and Article 3.113 of the Aliens Decree already

\footnotetext{
${ }^{1348}$ IND work-instruction 2016/4, Forensisch medisch onderzoek naar steunbewijs (FMO), 1 July 2016, p. 3.

${ }^{1349}$ Smeekes, J., and Fourer, M., Medical Reports in Subsequent Asylum Applications - Does Dutch law comply with EU law?, Expert advice by the Migration Law Clinic, June 2015, p. 10.

${ }^{1350}$ IND, Onderzoek naar de rol van IMMO rapportages in asielzaken, 3 November 2016, p. 7.

${ }^{1351}$ Article 30a(1)(a) Aliens Act. See Reneman, M., de Lange, J., and Smeekes, J., Interpretatie en waardering van medische rapporten door de IND, Medische waarheidsvinding en geloofwaardigheidsbeoordeling in asielzaken, Asiel \& Migrantenrecht, Nr. 10, 2016, p. 464. 1352 Afdeling bestuursrechtspraak van de Raad van State, 201400245/1/V1, 29 August 2014, ECLI:NL:RVS:2014:3306.

${ }^{1353}$ EK, 2016/2017, 34088, Nr. G, p. 2.
} 
cover the relevant Article 14(1) of the recast Asylum Procedures Directive. However, this specific obligation enshrined in the relevant Article 14(1) of the recast Asylum Procedures Directive does not appear from Article 3.112 or from Article 3.113 of the Aliens Decree. According to the Dutch authorities, persons interviewing asylum applicants and decision-makers are provided with a course in dealing with trauma or receive a course in interviewing vulnerable persons introduced by EASO, including training on identifying victims of torture. ${ }^{1354}$

Finally, the implementation of the obligation to exempt applicants in need of special procedural guarantees, in particular victims of torture or other forms of violence, from accelerated procedures and border procedures where adequate support cannot be provided, has already been discussed above.

\subsection{Unaccompanied minors}

\subsubsection{The number of unaccompanied minors seeking asylum in the Neth- erlands}

Compared to 2015 and 2016, the number of registered unaccompanied minors in the Netherlands dropped to 1180 in 2017, which is considerably less than 2015, but still higher than during the years 2008-2014.

${ }^{1354}$ Convention Against Torture and other Cruel, Inhuman or Degrading Treatment or Punishment, Seventh Periodic Report, Response of the Kingdom of the Netherlands to the list of issues (CAT/C/NLD/QPR/7) transmitted to the State Party under the optional reporting procedure (A/62/44, paras. 23 and 24), The Kingdom of the Netherlands, 3 July 2017 , p. 22. 
Figure 8.7. The number of unaccompanied minors seeking asylum in the Netherlands between 2008 - 20171355

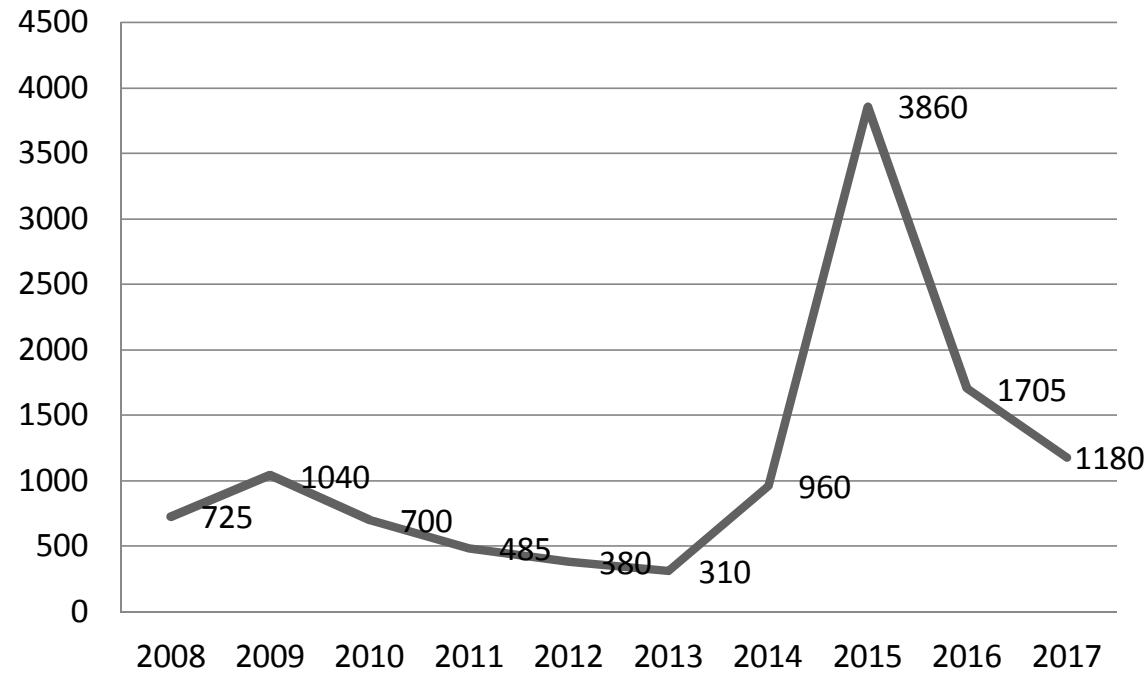

\subsubsection{The best interests of the child principle in the Dutch asylum proce- dure}

The recast CEAS instruments include specific guarantees addressed to minors and in particular unaccompanied minors. ${ }^{1356}$ In accordance with Article 3 of the CRC, the best interests of the child should be a 'primary consideration' in all actions concerning children. The important principle has also been adopted in the recast Reception Conditions Directive. Article 23(1) of the recast Reception Conditions Directive requires that the best interests of the child should be a primary consideration when implementing this Directive and that Member States should guarantee 'a standard of living adequate for the minor's physical, mental, spiritual, moral and social development'. In addition, Article 23(2) of the recast Reception Conditions Directive stipulates that in examining the best interests of the child, Member States should take into consideration the family reunification options, the well-being of the minor and social development, safety aspects and the minor's preferences. The requirements enshrined in Article 23(1) and (2) of the recast Reception Conditions Directive have not been implemented in the Dutch Aliens legislation or in the Aliens Circular. ${ }^{1357}$

\footnotetext{
${ }^{1355}$ Centraal Bureau voor de Statistiek (CBS), Minder alleenreizende minderjarige vreemdeling: nationaliteit, geslacht en leeftijd, 23 April 2018. Available at https://opendata.cbs.nl/statline/\#/CBS/nl/dataset/82045NED/table?ts=1526911932307 1356 See Article 25 of the recast Asylum Procedures Directive. ${ }^{1357}$ See also Slingenberg, L., Kroniek opvang, Asiel \& Migrantenrecht, Nr. 2, 2016, p. 87.
} 
Moreover, the main obligation that the best interests of the child should be a primary consideration in all actions concerning children has not been implemented in the Dutch Aliens Act. ${ }^{1358}$ Although the Administrative Jurisdiction Division of the Council of State has held that Article 3 of the CRC has direct effect, but without further elaboration in the Dutch legislation, the judge can only examine whether the IND has taken into account the best interests of the child in the considerations of the decision. According to the Dutch authorities, the best interests of the child were considered to be taken into account in the asylum procedure when, inter alia, reception or access to education or medical care was guaranteed. 1359 The best interests of the child principle in the Dutch Aliens legislation has thus only a procedural character.

According to Herweijer, the consequence that the Dutch Aliens Act does not give full effect to Article 3 of the CRC and that the Administrative Jurisdiction Division of the Council of State only assesses whether the IND has taken into account the best interests of the child in the considerations of the decision, leads to an inadequate implementation of the international obligation that in all actions concerning children the best interests of the child must be a primary consideration. ${ }^{1360}$ Following the Administrative Jurisdiction Division of the Council of State judgment and due to critical comments by academics, including practitioners, ${ }^{1361}$ Members of Parliament have submitted a legislative proposal to codify the principle of the best interests of the child in the Dutch Aliens legislation. ${ }^{1362}$

Furthermore, in accordance with Article 23(3), (4), and (5) of the recast Reception Conditions Directive, the Netherlands is also obliged to ensure that minors have access to leisure activities and for those minors that have been subjected to torture or inhuman treatment to receive rehabilitation services, includ-

${ }^{1358}$ Herweijer, M., In de kinderschoenen - Naar een volwassen benadering van het belang van het kind in het vreemdelingenrecht, Asiel \& Migrantenrecht, Nr. 8, 2017, p. 342.

${ }^{1359}$ Afdeling bestuursrechtspraak van de Raad van State, 201211554/1/V4, 16 April 2013, ECLI:NL:RVS:2013:3382.

${ }^{1360}$ Herweijer, M. In de kinderschoenen - Naar een volwassen benadering van het belang van het kind in het vreemdelingenrecht, Asiel \& Migrantenrecht, 2017, Nr. 8, p. 342.

${ }^{1361}$ See inter alia Bruin, R., and Kok, S., Het kind in de asielprocedure. Lessen uit internationale rapporten, Asiel \& Migrantenrecht, Nr. 4, 2015, pp. 172-177; Beltman, D., and Zijlstra, E., De doorwerking van het belang van het kind, ex artikel 3 VRK in het migratierecht: Vanuit een bottom-up benadering op weg naar een top-down benadering, Journaal Vreemdelingenrecht, 12/4, pp. 286-306; Reneman, M., Het Kinderrechtenverdrag krijgt tanden: over hoe het VN Verdrag inzake de Rechten van het Kind via het EU-recht en het EVRM binnendringt in het Nederlandse vreemdelingenrecht, Asiel \& Migrantenrecht, Nr. 8, 2011, pp. 349-362.

1362 TK, 2015/2016, 34541, Nr. 3. Legislative proposal still pending in Parliament during the writing of this study. 
ing access to mental health care. In addition, where it is in the best interests of the minor, they should be accommodated by their parents or unmarried minor siblings. These important requirements correspond with the national implementing measures as enshrined in Article 18b(a) and Article 18c(a) and (b) of the 2005 Regulation.

\subsubsection{Defining an unaccompanied minor}

Unaccompanied minors are considered to be a vulnerable group within the Dutch Aliens legislation and therefore they require additional protection. ${ }^{1363}$ Article 1 of the Aliens Act provides that a minor is considered to be a person that has not yet reached the age of 18 . As to the definition of an unaccompanied minor, Article 29(2)(c) Aliens Act refers to Article 2(f) of the Family Reunification Directive 2003/86, which reads:

'Third country nationals or stateless persons below the age of 18 , who arrive on the territory of the Member States unaccompanied by an adult responsible by law or custom, and for as long as they are not effectively taken into the care of such a person, or minors who are left unaccompanied after they entered the territory of the Member States'.

At the same time, Article 1(e) of the 2005 Regulation also provides a definition of an unaccompanied minor, which is narrower than the definition of Article 2(f) of the Family Reunification 2003/86. According to 1(e) of the 2005 Regulation, an unaccompanied minor is:

'An asylum applicant who has not yet reached the age of 18 years old and who stays in the Netherlands without supervision or care of a parent or legal guardian'.

\subsubsection{Age assessment in the Netherlands}

But before unaccompanied minors can benefit from the procedural guarantees enshrined in the recast CEAS, they need to be identified as a minor. Applicants arriving to the Netherlands and where, following statements or other relevant indications, there are doubts concerning the age of the applicant, a medical assessment, provided that applicant gives his or her consent, may be conducted by the Dutch authorities to determine the age of the applicant.

Where the medical age assessment does not take away the doubts, the applicant should be considered to be a minor. ${ }^{1364}$ This corresponds with the requirements stipulated in Article 25(5) (first paragraph) of the recast Asylum Procedures Directive. However, a medical assessment determining the age of 
an alleged unaccompanied minor applicant will only be conducted in the following situations: 1365

- The applicant cannot verify with evidence the he or she is below the age of 18 ;

- The applicant cannot make plausible that he or she is below the age of 18 ;

- The outcome of the age assessment is relevant for the procedure of determining the responsible Member State in the course of the Dublin Regulation, for the procedure to assess whether the applicant is eligible for international protection or for the purposes of legal migration, or reception facilities of the COA; and

- Where on the basis of a preliminary assessment (leeftijdsschouw) conducted by the IND and the Royal Military Police or Aliens Police, cannot be determined that the applicant is evidently above or below the age of 18 .

A preliminary assessment includes three persons from the IND and the Royal Military Police or Aliens Police who assess the appearance and statements submitted by the applicant. The IND and Royal Military Police separately assess the applicant and draw conclusions as to whether the applicant is evidently above or below the age of 18 . A unanimous decision has to be reached in order to be able to conclude that the applicant is evidently above or below the age of 18. In addition to appearance and statements, factors that are taken into account during a preliminary assessment are 'the behavior' of the applicant and 'other relevant circumstances'. Consequently, a medical age assessment will only be initiated where the preliminary assessment cannot determine that the applicant is a minor or above the age of 18 . The medical age assessment is conducted during or after the rest and preparation period and consists of X-rays of the hand, wrist and clavicles. ${ }^{1366}$ Based on the medical results of the X-rays, medical professionals determine whether the applicant is a minor. ${ }^{1367}$

An important requirement for Member States is to ensure the least invasive medical examination possible. However, since the introduction of age assessment using X-rays in 1996, several organizations and medical specialists national and international have been very critical of X-rays as a method to determine the age. 1368

\footnotetext{
${ }^{1365} \mathrm{C} 1 / 2.2$. Aliens Circular.

${ }^{1366}$ Keunen, A.M., Roscam Abbing, H.D.C., Schumacher, J.H., Age assessment of unaccompanied minor asylum seekers in the Netherlands, The Dutch Association of Age Assessment Researchers (DA-AAR), May 2013, pp. 9-10.

${ }^{1367} \mathrm{C} 1 / 2.2$. Aliens Circular.

${ }^{1368}$ See inter alia Van Ree, C.J., and Schulpen, T.W.J., Ethische tekortkomingen van het
} 


\subsubsection{Reception guarantees for unaccompanied minors}

All unaccompanied minors have to submit their asylum application at the Central Reception Centre in Ter Apel. Applications of unaccompanied minors in the border procedure are not processed. ${ }^{1369}$ They will be referred to the general asylum procedure or the extended asylum procedure. Subsequently, those who are between 15 and 17 years old are referred to a special Process Reception Centre in preparation for the general asylum procedure. Unaccompanied minors are granted in practice a three weeks rest- and preparation period. ${ }^{1370}$ During the rest- and preparation period they receive also a medical screening.

The Netherlands is required in accordance with Article 24(1) of the recast Reception Conditions Directive and Article 25(1) of the recast Asylum Procedures Directive to appoint a guardian who assists the unaccompanied minor during the asylum procedure. In the Netherlands, Nidos is by law responsible to arrange guardians for each unaccompanied minor arriving to the Netherlands. 1371

Article 24(2) of the recast Reception Conditions Directive obliges Member States to place unaccompanied minors who are permitted to stay on their territory, with either adult relatives or with a foster family or otherwise in accommodation centres appropriate for minors. In 2016 a new reception model for unaccompanied minors has been introduced in the Netherlands. ${ }^{1372}$ The new reception model includes small-scale reception facilities that replace the former large-scale campuses. Unaccompanied minors up to the age of 14 (before the age of 12) will be placed in foster families co-ordinated by Nidos. ${ }^{1373}$ Unac-

leeftijdsonderzoek ter beoordelingen van minderjarigheid van alleenstaande asielzoekers, Nederlands Tijdschrift Geneeskunde, 3 February 145(5), 2001; Hammarberg, T, Methods for assessing the age of migrant children must be improved, The Commissioner for Human Rights, Council of Europe, Strasbourg, 9.8.2011; Keunen, A.M., Roscam Abbing, H.D.C., Schumacher, J.H., Age assessment of unaccompanied minor asylum seekers in the Netherlands, The Dutch Association of Age Assessment Researchers (DA-AAR), May 2013, pp. 11-14; Sauer, P., Nicholson, A., Neubauer, D., Age determination in asylum seekers: physicians should not be implicated, European Journal of Pediatrics, On behalf of the Advocacy and Ethics Group of the European Academy of Paediatrics, March 2016, Vol. 175, Issue 3, pp. 299-303; and see also Noll, G., Junk Science? Four Arguments against the Radiological Age Assessment of Unaccompanied Minors Seeking Asylum, International Journal of Refugee Law, Vol. 28, No. 2, 2016.

${ }^{1369}$ Article 3.109b(7) Aliens Decree.

${ }^{1370}$ TK 2012/2013, 27062, Nr. 75.

${ }^{1371}$ Article 2(1) Besluit aanvaarding rechtspersoon Burgerlijk Wetboek Boek 1. See also Article 3.109d(1) Aliens Decree.

${ }^{1372}$ TK 2013/2014, 27062, Nr. 95.

${ }^{1373}$ See de Ruijter, L., Melin, E., Ishola, P., Dolby, P., Murk, J., and van de Pol, P., Reception and living in families, Overview of family-based reception for unaccompanied minors in the EU 
companied minors from 15 years old and unaccompanied minors below the age of 15 who cannot be placed in foster families, are accommodated in small-scale units (maximum of 16-20 persons) with 24-hours supervision by the COA. Unaccompanied minors who are 17,5 years old or older will be placed in smallscale accommodation located in a reception centre.

In addition, unaccompanied minors should stay as much as possible in the same region or area whenever they have to move from one reception centre to another, in order for them to maintain their social network and to guarantee continuity at the same school. The second objective of the new reception model is to start as soon as possible with the integration process for unaccompanied minors who have received asylum. Those who stay in reception centres coordinated by the COA and who receive asylum, are accommodated by Nidos in foster families in order for them to start with their integration process. ${ }^{1374} \mathrm{Re}-$ search carried out by the Inspectorate Youth Care of the Dutch Ministry of Health, Welfare and Sport in 2015 identified several shortcomings concerning unaccompanied minors in the 'protected reception centres' (beschermde opvang), which aim to accommodate unaccompanied minors who are victims of human trafficking. The research concluded, inter alia, that professionals do not provide adequate support to unaccompanied minors. Another concern was the incautious application of confinement to unaccompanied minors in reception centres and that unaccompanied minors disappeared from the reception centres with unknown destination. ${ }^{1375}$ In subsequent research conducted in 2016, it revealed that these issues remain problematic. 1376

Paragraph 3 of Article 24 of the recast Reception Conditions Directive requires national authorities to trace family members of the unaccompanied minor as soon as possible. This would mean, in my view, that tracing of family members should start during the reception phase. However, in the Netherlands the tracing process of family members of unaccompanied minors is initiated once the asylum application has been rejected and the unaccompanied minor has to return. ${ }^{1377}$

Additionally, paragraph 4 of Article 24 of the recast Reception Conditions Directive obliges Member States to ensure that professionals working with unaccompanied minors are trained adequately in order to support their needs.

Member States, NIDOS, SALAR, CHTB, February 2015. See also NIDOS: https://www.nidos.nl/en/

${ }^{1374}$ TK 2013/2014, 27062, Nr. 95, p. 2.

${ }^{1375}$ Inspectie Jeugdzorg, Ministerie van Volksgezondheid, Welzijn en Sport, Kwaliteit opvang alleenstaande minderjarige vreemdelingen, September 2016.

${ }^{1376}$ Inspectie Jeugdzorg, De kwaliteit van de beschermde opvang voor alleenstaande minderjarige vreemdelingen - Hertoets, June 2017.

${ }^{1377}$ TK 2013/2014, 27062, Nr. 91, p. 13. 
The aforementioned research carried out by the Inspectorate Youth Care of the Dutch Ministry of Health, Welfare and Sport established that the supervision provided by professionals working with unaccompanied minors in reception centres lacked quality. 1378 In 2017, the COA registered 675 unaccompanied minors that were residing in the reception centres. 1379

\subsubsection{Detention of unaccompanied minors in the Netherlands}

As regards detention, chapter 6 had concluded that the detention of unaccompanied minors is not prohibited. Article 11(3) of the recast Reception Conditions Directive establishes that unaccompanied minors may only be detained in 'exceptional' circumstances' and they should be released as soon as possible. Unaccompanied minors should never be detained in prison accommodation. It was already argued above that the national implementing measures concerning the detention of vulnerable persons are not in compliance within the meaning of Article 11(1) of the recast Reception Conditions Directive. This applies also to the implementation of Article 11(3) of the recast Reception Conditions Directive on the detention conditions for unaccompanied minors. The Aliens Act and the Aliens Decree, including the current regime that applies to the detention of aliens (Penitentiaire beginselenwet) have no specific legal provisions implementing the legal standards concerning the detention conditions of unaccompanied minors as enshrined in Article 11(3) of the recast Reception Conditions Directive.

As also submitted above, a legislative proposal containing specific guarantees for vulnerable persons in detention, including enhanced guarantees for unaccompanied minors is pending since 2015 . Currently, the only reference stipulating guarantees concerning the detention of unaccompanied minors is provided in policy rules. A5/2.4. Aliens Circular stipulates that detention of unaccompanied minors is only applied in exceptional circumstances and as short as possible. Detention of unaccompanied minors is only allowed in the following situations:

- The unaccompanied minor is suspected or convicted of a crime;

- The return of an unaccompanied minor can be realized within maximum fourteen days; or

\footnotetext{
${ }^{1378}$ Inspectie Jeugdzorg, De kwaliteit van de beschermde opvang voor alleenstaande minderjarige vreemdelingen-Hertoets, June 2017, pp. 11-12.

${ }^{1379}$ COA, Personen in de opvang uitgesplitst naar leeftijd en land van herkomst: https://www.coa.nl/nl/over-coa/bezetting/personen-in-de-opvang-uitgesplitst-naar-leeftijden-land-van-herkomst
} 
- The unaccompanied minor has disappeared before from the reception centre with an unknown destination or has not complied with his duty to report or confinement.

As regards border procedures, asylum applications of unaccompanied minors in border procedures are excluded from being processed. ${ }^{1380}$ A5/3.2. Aliens Circular specifies that detention may not applied to unaccompanied minors in the border procedure, unless there are doubts about the age of the unaccompanied minor and the IND has not yet determined the age.

Since 2014, families with minor children who are about to be returned or who have applied for asylum in the border procedure or unaccompanied minors who are about to be returned can be detained in a closed reception centre (Gesloten Gezinsvoorziening) in Zeist. Families with minor children can be detained for a maximum period of two weeks.

For unaccompanied minors, however, there is no maximum limit of detention. ${ }^{1381}$ It may be argued that in practice the closed reception centre complies with the guarantees as enshrined in Article 11(3) of the recast Reception Conditions Directive, such as 'unaccompanied minors shall never be detained in prison accommodation' and 'where unaccompanied minors are detained, Member States shall ensure that they are accommodated separately from adults'. At the same time, however, it may be argued that such important guarantees should be implemented in the Dutch Aliens legislation or in policy rules such as the Aliens Circular. From a legal perspective, that such important guarantees are not codified remains a serious shortcoming. A recent report from the Ministry of Justice and Security shows that the number of unaccompanied minors in detention increased from 30 in 2016 to 50 in 2017.1382

\subsubsection{Procedural guarantees for unaccompanied minors}

Article 25(6)(a) of the recast Asylum Procedures Directive provides several grounds upon which Member States may apply accelerated and border procedures to unaccompanied minors. Accelerated procedures may only be applied to unaccompanied minors where the unaccompanied minor arrives from a 'safe country of origin'; or where the unaccompanied minor has submitted a subsequent application for international protection; and where the unaccompanied minor is a serious danger to the society of the Member State or has been subject to a forced removal. As established above, it is explicitly laid down in the Aliens

${ }^{1380}$ Article 3.109b(7) Aliens Decree.

${ }^{1381}$ See A5/2.4 and A5/3.2 Aliens Circular.

${ }^{1382}$ Ministerie van Justitie en Veiligheid, Rapportage Vreemdelingenketen, Periode januaridecember 2017, p. 41. 
Decree that in principle, the border procedure is not applied to unaccompanied minors.

As regards accelerated procedures, applicants in track 2 (asylum applicants coming from 'safe countries of origin' and asylum applicants who have already received international protection in another EU Member State) ${ }^{1383}$ are as in the general asylum procedure processed in eight days, but they are not provided with a rest and preparation period and certain guarantees that are normally applied in the general asylum procedure are also excluded. Therefore, it can be argued that track 2 is an accelerated procedure. ${ }^{1384}$ According to the Dutch authorities, track 2 is considered a 'simplified asylum procedure'. 1385 The recast Asylum Procedures Directive does, however, not allow asylum applicants, including unaccompanied minors who already have received international protection in another EU Member State to be processed in an accelerated procedure. 1386

As has been discussed above, Member States have to assess, within a 'reasonable period of time' following the application for international protection, whether the applicant is in need of special procedural guarantees and those identified as applicants in need of special procedural guarantees should receive adequate support. In comparison with other categories of vulnerable applicants, unaccompanied minors are by definition considered applicants who require special procedural guarantees. ${ }^{1387}$ Hence, in accordance with Article 24 of the recast Asylum Procedures Directive, unaccompanied minors should receive adequate support and be exempted from accelerated and border procedures where no adequate support can be provided. Most of the asylum applications of unaccompanied minors are processed in the eight days asylum procedure,

\footnotetext{
${ }^{1383}$ Article 3.109ca Aliens Decree.

${ }^{1384}$ See Reneman, M., Versnelling, verlenging en vereenvoudiging van asielprocedure vanwege hoge instroom - Spanning met het Europees recht, Asiel \& Migrantenrecht, Nr. 6/7, 2016, p. 267.

${ }^{1385}$ See IND, The simplified asylum procedure, April 2017: https://ind.nl/Documents/DVAP_Engels.pdf

${ }^{1386}$ Reneman, M., Versnelling, verlenging en vereenvoudiging van asielprocedure vanwege hoge instroom - Spanning met het Europees recht, Asiel \& Migrantenrecht, Nr. 6/7, 2016, p. 267.

${ }^{1387}$ Besluit van 10 juli 2015, houdende wijziging van het Vreemdelingenbesluit 2000 en het Besluit vergoedingen rechtsbijstand 2000 in verband met de implementatie van Richtlijn 2013/32/EU van het Europees Parlement en de Raad van 26 juni 2013 betreffende gemeenschappelijke procedures voor de toekenning en intrekking van de internationale bescherming (PbEU 2013, L 180) en Richtlijn 2013/33/EU van het Europees Parlement en de Raad van 26 juni 2013 tot vaststelling van normen voor de opvang van verzoekers om internationale bescherming (PbEU 2013, L 180), 2015, Stb, 294, p. 25.
} 
which is fast and intensive. ${ }^{1388}$ As it has been submitted, it remains highly contentious whether adequate support can be provided to vulnerable asylum applicants in need of special procedural guarantees, such as unaccompanied minors, in a relatively short procedure such as the general asylum procedure of eight days.

The question is also whether the general asylum procedure of eight days should be considered an accelerated procedure. ${ }^{1389}$ The recast Asylum Procedures Directive does not provide a definition of an accelerated procedure. In addition, the explanatory memorandum to the implementing law indicates that the general asylum procedure is the standard asylum procedure and not an accelerated procedure within the meaning of the recast Asylum Procedures Directive. 1390 However, as Reneman submits, such reasoning remains highly questionable. ${ }^{1391}$ The Committee on the Rights of the Child has also held that the general asylum procedure of eight days which endeavours to examine asylum applications in a speedy way, places constraints on procedural guarantees. 1392 The general asylum procedure of eight days implemented in the Netherlands is significantly shorter than the six months time frame allowed by the Directive and even the shortest regular procedure in the EU.1393 Hence, in my view, it can be argued that a formal time limit of eight days for deciding on asylum applications is significantly short time frame.

Member States are allowed in accordance with Article 31(7)(b) of the recast Asylum Procedures Directive, to prioritise the examination of asylum applications of vulnerable applicants in need of special reception guarantees or special procedural guarantees, in particular unaccompanied minors. According to Goeman and Walst, there is no policy in the Netherlands prioritizing the examination of asylum applications of unaccompanied minors. ${ }^{1394}$

${ }^{1388}$ Bruin, R., and Kok, S., Het kind in de asielprocedure. Lessen uit internationale rapporten, Asiel \& Migrantenrecht, 2015, Nr. 4, p. 177.

${ }^{1389}$ See Reneman, M., Implementatie van de herziene Asielprocedurerichtlijn: een nieuwe beslissystematiek en meer waarborgen voor asielzoekers, Nederlands tijdschrift voor Europees recht, Nr. 8, September 2015 and Reneman, M., Herziene Procedurerichtlijn: is de Algemene Asielprocedure een versnelde procedure?, Verblijfblog, 21 august 2015.

${ }^{1390}$ TK 2014/2015, 34088, Nr. 3, p. 31.

${ }^{1391}$ Reneman, M., Versnelling, verlenging en vereenvoudiging van asielprocedure vanwege hoge instroom - Spanning met het Europees recht, Asiel \& Migrantenrecht, Nr. 6/7, 2016, pp. 265-266.

${ }^{1392}$ Committee on the Rights of the Child, Concluding observations on the fourth periodic report of the Netherlands, CRC/C/NLD/CO/4, 16 July 2015, p. 12.

${ }^{1393}$ See ECRE, The length of asylum procedures in Europe, October 2016.

${ }^{1394}$ Goeman, M., and Walst, J., Stand van zaken drie jaar herijking AMV-beleid - Beschadigen of beschermen? Asiel \& Migrantentenrecht, Nr. 8, 2016, p. 370. 
Further procedural guarantees for unaccompanied minors include that Member States should, free of charge, provide legal and procedural information to the unaccompanied minor and his representative. 1395 In addition to the appointment of a guardian, all unaccompanied minors arriving to the Netherlands are assigned a lawyer. Next to the guardian and the lawyer, the Dutch Refugee Council may provide unaccompanied minors legal and procedural information in the asylum procedure. ${ }^{1396}$

Furthermore, Member States should also ensure that the personnel of the determining authority who conduct the interviews have a good understanding of the special needs of minors, including that interviews are conducted in a child-appropriate manner. ${ }^{1397}$ This guarantee is not enshrined in the Aliens legislation. In practice, unaccompanied minors are interviewed by specially trained IND personnel in a child-friendly room located in Den Bosch. ${ }^{1398}$ Article 3.45a Aliens Regulation explicitly requires that the interview of minors should be conducted in a child-friendly manner. However, what this precisely means is not further elaborated. Unaccompanied minors younger than 12 years old may benefit from special rules. During the first interview of an unaccompanied minor younger than 12 years old, the IND is limited in the questions that they may ask. The IND may, inter alia, ask questions on the identity, nationality and family composition in the country of origin. ${ }^{1399}$ Following this first interview, an unaccompanied minor younger than 12 years old will be referred to the extended asylum procedure. ${ }^{1400}$

\subsubsection{Assessing the asylum applications of unaccompanied minors}

As regards the examination of asylum applications, the recast Qualification Directive requires that the Dutch authorities should take into account the individual circumstances, including aspects of background, gender and age. ${ }^{1401} \mathrm{~A}$ similar requirement has been implemented in Article 31(4)(c) of the Aliens Act. The Aliens Circular further stipulates that the Dutch authorities should take para-

${ }^{1395}$ Article 25(3),(4) of the recast Asylum Procedures Directive.

${ }^{1396} \mathrm{EMN}$ focussed Study 2014, Policies, practices and data on unaccompanied minors in 2014, Contribution Netherlands, p. 35. Available at https://ec.europa.eu/home-affairs /sites/homeaffairs/files/what-we-do/networks/european_migration__ network/ reports/docs/emn-studies/20a_netherlands_uam_study_final_english.pdf See also UNHC

$\mathrm{R}$, The heart of the matter - Assessing Credibility when Children apply for Asylum in the European Union, 2014, p. 47.

${ }^{1397}$ Article 15(3)(b) of the recast Asylum Procedures Directive.

${ }^{1398}$ EMN focussed Study 2014, Policies, practices and data on unaccompanied minors in 2014,

Contribution Netherlands, p. 13.

${ }^{1399} \mathrm{C} 1 / 2.11$ Aliens Circular.

${ }^{1400}$ See Article 3.113(7)(b) Aliens Decree in conjunction with C1/2.4 Aliens Circular.

1401 Article 4(3)(c) of the recast Qualification Directive. 
graphs $213-219$ of the UNHCR Handbook into account when assessing the asylum applications of unaccompanied minors. Without further concrete explanation, C1/3.2 Aliens Circular merely refers to the general guidelines of the UNHCR Handbook concerning the qualification for refugee status of unaccompanied minors.

As has been submitted in chapter 3, a minor asylum applicant may present inconsistent statements during the interview. Hence, it is essential that the degree of his mental development and maturity should be taken into account when assessing the refugee status. ${ }^{1402}$ However, there have been reports that inconsistencies submitted by minors during interviews in an asylum procedure may be used against them without taking into account the minor's degree of mental development. ${ }^{1403}$

\subsubsection{Secondary rights to unaccompanied minors who are beneficiaries of international protection}

The recast Qualification Directive provides to unaccompanied minors who are beneficiaries of international protection several secondary rights concerning the assignment of guardians, family unity with siblings and the guarantee that unaccompanied minors are placed in either foster families or adequate accommodation for minors.

Additionally, Member States should start tracing family members of the unaccompanied minor following the granting of international protection. As regards tracing the family, it was already submitted above that the Aliens Act or the Aliens Decree or the policy rules in the Aliens Circular do not include provisions on the tracing of family members of unaccompanied minors in the asylum procedure. It appears that family tracing of unaccompanied minors is not a priority for the Dutch authorities, except where it concerns the return of unaccompanied minors to the country of origin. In this regard, the Red Cross could assist the unaccompanied minor to trace his or her family members. ${ }^{1404}$

Furthermore, Nidos remains the organization that is legally responsible for the care of all unaccompanied minors until they have reached the age of 18 years old. Unaccompanied minors with an asylum status until 14 years old are placed with foster families. Unaccompanied minors from 15 years old with an

1402. Para. 214 of Handbook on Procedures and Criteria for Determining Refugee Status under the 1951 Convention and the 1967 Protocol relating to the Status of Refugees, HCR/IP/4/Eng/REV.1 Reedited, Geneva, January 1992, UNHCR 1979.

${ }^{1403}$ Committee on the Rights of the Child, Concluding observations on the fourth periodic report of the Netherlands, CRC/C/NLD/CO/4, 16 July 2015, p. 12.

${ }^{1404}$ See Article 3(4)(c) Besluit Rode Kruis 1988. 
asylum status will be placed in small-scale living accommodation. ${ }^{1405}$ Those unaccompanied minors who obtained an asylum status may also apply for family reunification. The CJEU has decided in $A$ and $S$ that an applicant who has applied for an asylum application as a minor but who in the meanwhile reached the age of majority and subsequently is granted international protection, should be regarded as a minor. ${ }^{1406}$ Once the unaccompanied minor has been reunited with his or her parents, they will be accommodated in a regular housing or remain in the reception centre. The unaccompanied minor stays under the guardianship of Nidos until the court has decided to refer the guardianship to the parents. ${ }^{1407}$

\subsubsection{Unaccompanied minors in the Dublin procedure}

Finally, concerning the protection of unaccompanied minors in the Dublin procedure, it was submitted in chapter 6 that the recast Dublin III Regulation explicitly recognizes the vulnerability of unaccompanied minors and the need for special procedural guarantees. It is also important to note that the CJEU has held in M.A. that 'where an unaccompanied minor with no member of his family legally present in the territory of a Member State has lodged asylum applications in more than one Member State, the Member State in which that minor is present after having lodged an asylum application there is to be designated the 'Member State responsible'. ${ }^{1408}$ Important guarantees for minors and unaccompanied minors are enshrined in Articles 6 and 8 of the recast Dublin III Regulation. As regards the Dutch practice with regard to unaccompanied minors, the following observations are in order. In order to determine the responsibility to examine the application of unaccompanied minors in the Dublin procedure, the IND will ask during the first interview whether the unaccompanied minor has family members, siblings or relatives legally present on the territory of Member States. The tracing and identification of family members of the unaccompanied minor only starts where: 1409

\footnotetext{
1405 Vereniging van Nederlandse Gemeenten/OTAV and Platform Opnieuw Thuis, Factsheet Alleenstaande Minderjarige Vreemdelingen (AMV'ers), Juli 2016, p. 2.

${ }^{1406}$ Case C-550-16, A and S v Staatssecretaris van Veiligheid en Justitie, Court of Justice of the European Union, ECLI:EU: C:2018:248.

${ }^{1407}$ Vereniging van Nederlandse Gemeenten/OTAV and Platform Opnieuw Thuis, Factsheet Alleenstaande Minderjarige Vreemdelingen (AMV'ers), Juli 2016, p. 10.

${ }^{1408}$ Case C-648/11, The Queen, on the application of MA, BT, DA v Secretary of State for the Home Department, 6 June 2013, Court of Justice of the European Union, ECLI:EU:C:2013:367.

${ }^{1409} \mathrm{C} 2 / 5$ Aliens Circular.
} 
- The IND has determined that the applicant is a minor and that the applicant is not registered in another Member State as a person of 18 years of age or older;

- The applicant has provided documents to support his statements about family members or relatives; and

- The applicant has provided concrete information to the IND concerning his or her family members or relatives in another Member State. Concrete information includes name- and surname, date- and place of birth, former and current nationality and the current whereabouts in the Member State.

According to the policy rules, in all procedures concerning the tracing and identification of family members or relatives of unaccompanied minors in Dublin procedures will only take place when it is in the best interests of the child. In assessing the best interests of the child, the IND takes into account the factors of Article 6(3) of the recast Dublin III Regulation. Where the IND determines that the family reunification of the family members or relatives with the unaccompanied minor is not in the best interests of the child, the Dutch authorities will take the responsibility to examine the application for international protection. Where the unaccompanied minor has a relative in the Netherlands and it is determined by the Dutch authorities that the relative is capable taking care of the minor and it is in the best interests of the child, in that case the Netherlands will take responsibility to examine the asylum application. Where there are no family members, siblings or relatives legally present, the Administrative Jurisdiction Division of the Council of State has decided in accordance with the M.A. decision that the Dutch authorities should have taken the responsibility to examine the asylum application of an unaccompanied minor without family members and not send the applicant back to Italy. ${ }^{1410}$ To date, the Dutch authorities continue to carry out this policy. ${ }^{1411}$ The Administrative Jurisdiction Division of the Council of State has, however, determined that where another Member State has registered the unaccompanied minor as a person of 18 years or older and despite the fact that it is not evident who or how the age assessment has been carried out by the other Member State's authorities, the Dutch authorities are not required to offer an age assessment to the applicant, which they normally would do if the applicant cannot provide documents to proof his age. Based on mutual trust, the Dutch authorities should be able to rely on the age

${ }^{1410}$ Afdeling bestuursrechtspraak van de Raad van State, 201205236/1/V4, 20 September 2013, ECLI:NL:RVS:2013:1220.

${ }^{1411}$ Asylum Information Database, Country Report the Netherlands, 2018, p. 26. 
assessment conducted by the other Member State's authorities and it is for the applicant to proof otherwise. ${ }^{1412}$

\subsection{Analysis}

The previous sections show that there are a number of outstanding legal issues and challenges with regard to vulnerable asylum applicants in the asylum process. First of all, it has been submitted that the legislative proposal to implement the recast Reception Conditions Directive and the recast Asylum Procedures Directive were timely implemented on 8 July 2015.1413 To implement both Directives, the Dutch authorities introduced changes in the hierarchically lower legislative instruments such as the Aliens Decree or the 2005 Regulation or by introducing new policy rules in the Aliens Circular. It has been submitted that the Dutch legal framework on asylum has a layered structure and that the trend has been to implement the asylum Directives in the hierarchically lower legislative acts or in policy rules. I argued that in terms of legal certainty and transparency, important special guarantees for vulnerable asylum applicants should preferably be implemented in the national law.

This chapter has examined the notion of vulnerability. I identified that vulnerability is not a new phenomenon in the Dutch asylum law and policy. Even before the adoption of the recast CEAS instruments, several organizations, including lawyers in the Netherlands have been very critical concerning the identification and treatment of vulnerable asylum applicants in the general asylum procedure.

The preceding sections show that the vulnerability approach in the Dutch asylum process differs from the approach to vulnerability in the CEAS. While the CEAS labels groups presumed to be vulnerable, the Netherlands uses indicators to determine whether the applicant is presumed to be vulnerable and whether the applicant requires special procedural guarantees. It has been submitted that the indicators are very much focused on sources of vulnerability that are inherent to the human condition and less on context-specific sources of vulnerability. The findings also suggest that the indicators are used to identify vulnerable asylum applicants in need of special procedural guarantees but not

1412 Afdeling bestuursrechtspraak van de Raad van State, 201604107/1/V3, 21 June 2017, ECLI:NL:RVS:2017:1596. See Battjes, H., Kroniek Dublinverordening, Asiel \& Migrantenrecht, Nr. 2, 2018, p. 78.

${ }^{1413}$ Wet van 8 juli 2015 tot wijziging van de Vreemdelingenwet 2000 ter implementatie van Richtlijn 2013/32/EU van het Europees Parlement en de Raad van 26 juni 2013 betreffende gemeenschappelijke procedures voor de toekenning en intrekking van de internationale bescherming (PbEU 2013, L 180) en Richtlijn 2013/33/EU van het Europees Parlement en de Raad van 26 juni 2013 tot vaststelling van normen voor de opvang van verzoekers om internationale bescherming (PbEU 2013, L 180). 
to identify vulnerable asylum applicants who are in need of special reception arrangements. It is important to note that the IND and COA use different methods to identify whether the asylum applicant is vulnerable and whether the applicant has special needs.

With regard to vulnerable asylum applicants in need of special reception arrangements, I submitted that the current national implementing measures are in line with the standards enshrined in Articles 21 and 22 of the recast Reception Conditions Directive. However, I also argued that there is no procedure or mechanism in place that systematically and efficiently identifies vulnerable asylum applicants with special reception needs and also monitors them. As a result, vulnerable asylum applicants with special needs can be overlooked.

As regards applicants in need of special procedural arrangements, it has been argued that there are serious shortcomings in the implementation of the legal standards laid down in Article 24 of the recast Asylum Procedures Directive, which requires inter alia Member States to stop or to cease to apply accelerated procedures and border procedures where adequate support cannot be provided to vulnerable asylum applicants in need of special procedural guarantees. ${ }^{1414}$

On detention, I submitted that the Netherlands has not implemented important mandatory guarantees with regard to detained vulnerable asylum applicants. In addition, it has been submitted that the requirement of the Netherlands to ensure a standard of living that meets the specific needs of vulnerable asylum applicants has not been implemented in the Aliens legislation. Moreover, except for unaccompanied minors, specialized accommodation centres are not available for certain groups of vulnerable asylum applicants.

The previous sections also show that several important legal standards enshrined in the legislative acts of the CEAS with regard to vulnerable asylum applicants have not been implemented at all in in the domestic asylum legislation and that the practice of the Dutch authorities to identify whether an applicant is a vulnerable person with special needs for the purposes of informing the Member State responsible in the Dublin procedure is inadequate.

This chapter has also examined the implementation of legal standards laid down in the Directives with regard to torture victims and unaccompanied minors in the Dutch asylum legislation and policy. It has been submitted that in comparison to unaccompanied minors, data concerning victims of torture is lacking. A serious shortcoming in the Dutch asylum procedure is as argued above, the lack of adequate procedures or mechanisms to systematically identify vulnerable persons, such as torture victims, which may lead to impede tor-

${ }^{1414}$ See also Rosa Coene, E., Het concept van bijzondere procedurele behoeften in het kader van de Nederlandse grensprocedure, Journaal Vreemdelingenrecht, No. 2, 2019. 
ture victims from accessing rehabilitation services as required by international and European law. Also, the lack of specialized facilities for torture victims, including a specific care policy for applicants who have experienced torture, rape or other forms of serious violence is problematic.

Lastly, as regards unaccompanied minors, it has been found that the Dutch Aliens Act does not give full effect to the principle of the best interests of the child. The foregoing sections also show the lack of specific provisions implementing the guarantees with regard to the detention conditions of unaccompanied minors as enshrined in Article 11(3) of the recast Reception Conditions Directive. In addition, it also has been submitted that there are contentious practices concerning the assessment of age and family tracing of unaccompanied minors.

\subsection{Concluding remarks}

This chapter has carried out a case study. I critically examined the national implementing measures and practice surrounding vulnerable asylum applicants in the Dutch asylum procedure. The purpose of this chapter was to examine the Dutch approach to vulnerability in the asylum process and to what extent the Netherlands complies with the legal standards enshrined in the recast legislative acts of the CEAS with regard to vulnerable asylum applicants.

In this chapter, I have argued that there are a number of outstanding shortcomings and challenges in the Dutch asylum system. An important finding in this chapter is that the vulnerability approach in the Dutch asylum process differs from the approach to vulnerability in the CEAS. With regard to vulnerable asylum applicants with special reception needs, I have submitted that there is no procedure or mechanism in place that systematically and efficiently identifies and monitors them. Further, as regards applicants in need of special procedural guarantees, there are serious shortcomings at the national level in the implementation of the legal standards laid down in Article 24 of the recast Asylum Procedures Directive. In addition, this chapter has shown that the Netherlands has not implemented important mandatory guarantees with regard to detained vulnerable asylum applicants. In particular the lack of specific provisions implementing the guarantees with regard to the detention conditions of unaccompanied minors is problematic. Another important finding identified in this chapter is the lack of adequate procedures to identify torture victims and the lack of specialized facilities. The previous considerations lead to the conclusion that vulnerable asylum applicants in the Netherlands are impeded from fully participating in the asylum process. 
THE COMMON EUROPEAN ASYLUM SYSTEM 


\section{9- Conclusions}

\subsection{The purpose of the study}

This study has examined the rights of vulnerable asylum applicants in the Common European Asylum System. I have assessed the legal standards that are laid down in the recast legislative acts of the CEAS with regard to vulnerable asylum applicants, and in particularly with regard to victims of torture and unaccompanied minors.

This study had two main objectives. The first objective was to analyse the CEAS and to examine whether the Tampere policy objective of establishing common standards for a fair and efficient asylum procedure has been realized with regard to vulnerable asylum applicants. The second objective of this study was to examine whether the legal standards that stem from the recast CEAS legislative acts with regard to vulnerable asylum applicants are in accordance with international human rights law, and whether these standards have been adequately implemented at the national level.

In this final chapter, I will bring together the most important findings of this study. In section 9.2. I answer the first main research question, which is to what extent are the legal standards that stem from the recast CEAS legislative acts with regard to vulnerable asylum applicants, in particular with regard to victims of torture and unaccompanied minors, in accordance with international human rights law. Subsequently, in section 9.3. I will address the second main research question of this study, namely whether the recast CEAS provide common standards for a fair and efficient asylum procedure with regard to vulnerable asylum applicants. In section 9.4. I will answer the third main research question of this study, that is to what extent are the legal standards that are laid down in the recast CEAS legislative acts with regard to vulnerable asylum applicants, in particular with regard to victims of torture and unaccompanied minors, adequately implemented at the national level. Finally, section 9.5. will formulate recommendations for the future.

\subsection{Examination of the CEAS standards with regard to vulnerable asylum applicants in relation to international human rights law}

Chapter 2 assessed the notion of vulnerability under international human rights law. Several sub-questions were presented: what is the approach to vulnerability under international human rights law; why certain groups are presumed to be vulnerable; and what are the legal implications of being considered vulnerable under international human rights law. 
It has been submitted that the Refugee Convention does not contain a definition of vulnerability or indicates which refugees are presumed to be vulnerable. I identified that the ExCom Conclusions with regard to children and women adopt a nuanced approach to vulnerability because they explain why children and women are presumed to be particularly vulnerable in the refugee context. In addition, the ExCom Conclusions on children and women included both inherent sources of vulnerability as well as recognized situational sources of vulnerability in the refugee context.

I also reviewed the notion of vulnerability under the General Comments and General Recommendations of the UN human rights treaty monitoring bodies. I submitted that the understanding of vulnerability in the General Comments and General Recommendations is either too narrow or too broad. Vulnerable groups are listed without specifying that the list is non-exhaustive. At times a broad understanding of vulnerability is applied. As a result, nearly everyone has been deemed vulnerable. It is not always evident why certain groups are presumed to be vulnerable. Overall, it can be concluded that a clear definition of the notion of vulnerability or certain criteria of why someone is vulnerable is lacking under international human rights law. I argued that a nuanced approach to vulnerability should explain why certain groups are presumed to be vulnerable and also include context-specific sources of vulnerability.

Furthermore, I examined the legal implications to be considered vulnerable in the view of the UN monitoring bodies. It has been submitted that vulnerability considerations have resulted in recommendations to State parties to take appropriate measures for the removal of legislation or practices that affect the enjoyment of their human rights. I also examined the vulnerability reasoning in the case law of the ECtHR. I argued that the ECtHR applies a rigid approach to vulnerability. Further, the notion of vulnerability in the case law of the ECtHR has re-inforced the positive obligations of State parties. Another important implication is that in cases involving recognized vulnerable groups, the threshold to reach a violation of Article 3 of the ECHR is low.

In chapter 3, I examined which obligations stem from international human rights law with regard to victims of torture and unaccompanied minors. I discussed the relevant provisions of the CAT and subsequently the CRC. In addition, I assessed the case law of the ECtHR with regard to these two vulnerable groups. With regard to torture victims, I identified three aspects that are relevant to torture victims in the asylum process. I presented that medical reports play an important role in the assessment of the applicant's claim of being subjected to torture and that State parties should be more lenient when it concerns the credibility assessment of asylum applicants claiming to be victims of torture. Case law of the ECtHR has made it also clear that victims of torture are 
vulnerable. The ECtHR attaches considerable weight to medical reports explaining the physical or mental trauma and past torture allegations of the applicant. I argued that effective documentation of torture allegations is highly important in the asylum process as it may support the credibility of the asylum claim of the applicant. I also submitted that the measure to detain torture victims should be regularly reviewed. In addition, State parties should refrain from adopting measures that would allow the detention of asylum applicants in deplorable conditions. Furthermore, I explained that asylum applicants who are torture victims should have prompt and effective access to rehabilitative services, which includes medical and psychological care as well as legal and social support.

With regard to unaccompanied minors, I argued that the General Comments of the CRC show a nuanced understanding of vulnerability because they include both inherent and situational sources of vulnerability. Furthermore, I identified a number of obligations under the CRC for State parties with regard to children and especially on unaccompanied minors in the field of asylum. I submitted that State parties should take appropriate measures to ensure adequate protection to asylum seeking children and refugee children. The case law of the ECtHR has shown in a number of cases involving the detention of children that Article 3 of the ECHR was violated because the conditions of detention were not adapted to the child's age. The ECtHR has submitted that children have specific needs that are related to their age and dependency to others, but also because of their status as asylum applicants. Given their vulnerability, they require special protection. An important conclusion is that the vulnerability of children has been unequivocally accepted under international human rights law. In addition, I concluded that unaccompanied minors in the view of the ECtHR are considered to be the most vulnerable group.

In the second part of chapter 6, I examined which legal standards stem from the CEAS recast legislative acts with regard to victims of torture and unaccompanied minors, and compared them to the obligations adopted under international human rights law. It has been submitted that Article 78 TFEU requires the CEAS to be in accordance with the Refugee Convention and other international human rights law instruments. My analysis showed that a number of CEAS standards with regard to victims of torture and unaccompanied minors fall short of the requirements adopted under international human rights law. To ensure conformity with international law, I suggested interpretations with regard to the standards laid down in the legal instruments of the CEAS.

To conclude, it can be argued that several of the standards enshrined in the CEAS with regard to victims of torture and unaccompanied minors are not in accordance with the obligations adopted under international human rights law. However, it also has been submitted that the Directives allow Member States to 
introduce or maintain more favourable standards to be in accordance with international law.

\subsection{Assessment of common standards for a fair and efficient asylum procedure with regard to vulnerable asylum applicants}

As far as the second main research question concerned, I first addressed what the EU has done so far in the field of asylum. Chapter 1 submitted that one of the main Tampere policy objectives was to establish a system that includes common standards for a fair and efficient asylum procedure. In chapter 4 , I first analysed extensively why and how the CEAS has been established. I examined the intergovernmental co-operation on asylum between 1985-1992 to the adoption of the CEAS in 1999 at the Tampere European Council meeting and critically discussed the policy responses at the EU level in the context of the 'refugee crisis'. My analysis showed that the development of EU asylum policy is characterized by the constant tension between the legitimate interest of states to control the access to the territory and the international obligation to protect the fundamental rights of refugees. I also argued that the approach of the EU shows a clear tendency to prevent the access of asylum applicants to the territory of the EU, which undermines the fundamental right to seek asylum.

In chapter 5, I examined the following sub-question: what are the key shortcomings and challenges of the recast CEAS legislative acts. It has been submitted that the legal instruments of the CEAS allow Member States wide discretion to interpret and implement the CEAS standards. In addition, the legal instruments contain various derogation clauses and concepts that are too broad or too vague, which is problematic from the perspective of establishing common standards for a fair and efficient asylum procedure. My analysis also suggested that Member States have different approaches with regard to the interpretation and application of standards and concepts laid down in the CEAS. For example, with regard to the interpretation of Article 15(c) of the recast Qualification Directive. My assessment of the Commission proposals to overhaul the CEAS shows that several proposed amendments, if adopted, will lower the protection standards for asylum applicants. Lastly, in overcoming the structural problems with the CEAS and given the approach of the Member States during the 'refugee crisis', I argued that Member States should fully transfer their national competences on asylum to the EU level.

In chapter 6, I assessed the EU's approach to vulnerability. The formulated sub-question was: how the EU has conceptualized the notion of vulnerability in the context of asylum. I submitted that the CEAS does not define the notion of vulnerability. The vulnerability approach of the CEAS is to simply label groups presumed to be vulnerable. I argued that the EU should adopt a more nuanced 
approach to vulnerability in the asylum process. This would mean an approach that includes sources of vulnerability that are not only linked to certain groups, but also takes into account context-specific sources of vulnerability. The CEAS should ensure that various sources of vulnerability are recognized and that someone who does not fall into one of the predetermined groups but who is actually vulnerable is not overlooked. In addition, the use of different notions in the text of the Directives, such as vulnerable persons, applicants with special reception needs and applicants in need of special procedural guarantees creates further conceptual confusion. It can be argued that the lack of a clear definition of the notion of vulnerability or the lack of certain criteria of why someone is presumed to be vulnerable under international human rights law has bearing on the EU's approach to vulnerability in the CEAS.

I also examined which legal standards stem from the CEAS recast legislative acts with regard to vulnerable asylum applicants. An important theme in this study has been the identification of vulnerable asylum applicants in the asylum process. It has been argued that the Directives do not provide for a method that systematically and efficiently identifies vulnerable asylum applicants with special needs. Consequently, the procedure to identify vulnerability is at the discretion of national authorities. I submitted that this is problematic because this may lead to considerably different outcomes among Member States with regard to the identification of vulnerable persons in the asylum process. The analysis of the Commission proposal to recast the Reception Conditions Directive shows that Member States are required to 'systematically' and 'as early possible' carry out the identification procedure, which is an improvement compared to the current Directive standards.

Once asylum applicants are identified as vulnerable asylum applicants with special reception needs, they may benefit from the 'specific support' enshrined in the Directive. I identified three forms of 'specific support' that are related to the detention conditions of vulnerable asylum applicants, to material reception conditions and health care. In addition, asylum applicants may benefit from special procedural guarantees enshrined in the Asylum Procedures Directive. For example, where Member States cannot provide 'adequate support' in an accelerated procedure or in a border procedure to applicants in need of special procedural guarantees, Member States should not apply these procedures to such applicants. In particular, where the applicants are in need of special procedural guarantees as a result of torture, rape or other serious forms of psychological, physical or sexual violence. The wording 'adequate support' is not defined and allows Member States a large margin of discretion. I submitted that certain asylum applicants, such as victims of torture and unaccompanied minors, should, as a general rule, be exempted from such special procedures because of their vulnerability. 
In view of the previous considerations and the incoherent conceptual approach to vulnerability adopted in the CEAS, it can be concluded that the CEAS does not establish common standards for a fair and efficient procedure with regard to vulnerable asylum applicants.

\subsection{Evaluation of the implementation of CEAS standards with re- gard to vulnerable asylum applicants at the national level}

Chapter 7 examined the sub-question to what extent have Member States implemented the legal standards that stem from the recast legislative acts of the CEAS at the national level with regard to vulnerable asylum applicants, and also with regard to victims of torture and unaccompanied minors. An important research finding is that data, except for unaccompanied minors, on vulnerable asylum applicants in the asylum process at the EU and national level is lacking. The general trend among Member States shows that the practice surrounding vulnerable asylum applicants is inefficient and insufficient in terms of providing the necessary special guarantees. It also has been submitted that Member States differ in terms of who they presume to be vulnerable. In addition, there are also disparities in the Member States' methods, timing and the national authorities that are involved in the identification procedure of vulnerable persons in the asylum process. In the majority of the Member States a systematically assessment of identifying whether the applicant is a vulnerable applicant with special needs is lacking.

Furthermore, I examined the key challenges with regard to victims of torture and unaccompanied minors at the national level. It is striking to note that specific mechanisms, procedures and adequate tools to promptly identify victims of torture in various Member States is lacking. With regard to unaccompanied minors, a noticeable concern is that there are serious challenges in Member States in terms of providing adequate reception facilities that are adapted to the specific needs of children. Overall, the conclusion should be that there is no common approach to vulnerability in the asylum process at the national level.

In chapter 8, I focused on one country in-depth: the Netherlands in this case. The sub-question submitted was how has the Netherlands implemented the EU's approach to vulnerability in the national asylum process. I argued that the vulnerability approach in the Dutch asylum process differs from the approach to vulnerability in the CEAS. The findings show that in line with the CEAS, the majority of the Member States simply labels groups as presumed to be vulnerable. As far as I know, the Netherlands is the only country that uses indicators to determine whether the applicant is presumed to be vulnerable and whether the applicant requires special procedural guarantees. The indicators are, however, very much focused on sources of vulnerability that are inherent to the hu- 
man condition and less on context-specific sources of vulnerability. The findings suggest that the vulnerability indicators are used to identify vulnerable asylum applicants in need of special procedural guarantees. These indicators are not used to identify vulnerable asylum applicants who are in need of special reception arrangements.

It was also found that the implementation of the Directives on asylum is mainly carried out in the hierarchically lower legislative acts or in policy rules. I argued that in terms of legal certainty and transparency, important special guarantees for vulnerable asylum applicants should preferably be implemented in the national law.

The last sub-question raised by this study was: to what extent does the Netherlands comply with the legal standards that stem from the recast legislative acts of the CEAS with regard to vulnerable asylum applicants, and also with regard to victims of torture and unaccompanied minors. This study has shown that the current national implementing measures with regard to vulnerable asylum applicants in need of special reception arrangements, in general terms, meet the standards enshrined in Articles 21 and 22 of the recast Reception Conditions Directive. Nevertheless, it has been submitted that there is no procedure or mechanism in place that systematically and efficiently identifies applicants in need special reception arrangements. I argued that this shortcoming in the Dutch asylum process may fail to recognize vulnerable asylum applicants that warrant special reception arrangements.

I also submitted that the important standards laid down in Article 11(1) of the recast Reception Conditions Directive on vulnerable persons in detention have unfortunately not yet been implemented by the Netherlands. In addition, serious shortcomings have been identified in this study with regard to the implementation of the CEAS standard that requires Member States to stop or to cease to apply accelerated procedures and border procedures where adequate support cannot be provided.

Lastly, this study has shown that there is a lack of specialized facilities for torture victims, including a specific care policy for applicants who have experienced torture, rape or other forms of serious violence. As regard unaccompanied minors, this study has submitted that there is a lack of specific provisions implementing the guarantees with regard to the detention conditions of unaccompanied minors as enshrined in Article 11(3) of the recast Reception Conditions Directive. It also has been argued that the age assessment and the practice surrounding family tracing of unaccompanied minors are contentious. This study has identified several outstanding number of implementation gaps at the national level.

To sum up, it can be convincingly concluded that the Netherlands is not complying with all its obligations arising from the CEAS standards with regard 
to vulnerable asylum applicants. It can be argued that vulnerable asylum applicants in the Netherlands are impeded from fully participating in the asylum process.

\subsection{Recommendations}

In line with the previous conclusions, this study suggests the following recommendations:

\section{The CEAS should adopt a more nuanced approach to vulnerability in} the asylum process. This study has submitted that the CEAS approach of labelling groups as vulnerable in the asylum process may stigmatize and stereotype groups. However, rejecting the labelling approach, may risk leaving certain groups unprotected. Hence, I argued that the CEAS should develop a more nuanced approach to vulnerability. This would mean, an approach that not only includes sources of vulnerability that are linked to certain groups, it also takes into account context-specific sources of vulnerability. It is also important to explain why certain groups are presumed to be vulnerable in the asylum process and to apply a coherent conceptual approach to vulnerability.

\section{The identification of vulnerable asylum applicants should be carried} out in a standardized manner. A recurring theme in this study has been the identification of vulnerable persons in the asylum process. It has been submitted that the CEAS leaves much discretion to Member States in the procedure of identifying vulnerability. It also has been submitted that an adequate identification system is crucial in the asylum process. Otherwise potential vulnerable asylum applicants may not be identified and thus not benefit from special reception and or special procedural arrangements. Moreover, vulnerability of applicants may reveal at different stages of the asylum process. In order to ensure more coherence and protection for vulnerable asylum applicants in the asylum process, this study argues to standardize the identification procedure.

3. Victims of torture and unaccompanied minors should not, as a general rule, be processed in accelerated procedures and border procedures. The general standard laid down in Article 24(3) of the recast Asylum Procedures Directive requires Member States to exempt applicants in need of special procedural guarantees from being processed in accelerated procedures and border procedures where they cannot provide 'adequate support'. The wording 'adequate support' indicates a large margin of discretion for the Member States. Consequently, what constitutes 'adequate support' is obscure and arbitrary. Moreover, to benefit from adequate support, the applicant needs to be effectively identified as an applicant in need of special procedural guarantees. Given their vulnerability and special needs, it is submitted that victims of tor- 
ture and unaccompanied minors should, as a general rule, be exempted from such special procedures.

4. Member States should collect more data on vulnerable asylum applicants. This study has identified that data on vulnerable asylum applicants arriving in the EU territory is not available. Currently, Member States only collect data of vulnerable asylum applicants such as minors and unaccompanied minors. It has been submitted that EU law obliges Member States to provide figures on the number of asylum applicants and to disaggregate by age and gender. There is, however, no obligation for Member States to collect data on the situation of other categories of vulnerable asylum applicants. To know the scale of the problem and to evaluate the impact of existing legislative and policy measures, reliable figures on the number of vulnerable asylum applicants in the Member States is needed.

5. Vulnerable asylum applicants in the Netherlands should not, as a general rule, be detained. Where vulnerable asylum applicants, and in particular unaccompanied minors, are detained, the Netherlands should pay particular attention to their special needs and legislative measures should be in place to ensure their access to special guarantees. This study has identified that the Dutch authorities have not implemented important standards enshrined in the recast Reception Conditions Directive with regard to the detention of vulnerable asylum applicants. The Dutch Parliament should adopt the pending legislative proposal on the detention of aliens, which includes guarantees for vulnerable persons, including specific guarantees for unaccompanied minors, pregnant women and families with children.

6. The CEAS standards that ensure special guarantees for vulnerable asylum applicants should be implemented in the Dutch Aliens Act rather than in the hierarchically lower legislative instruments. In terms of transparency, democratic control by the Parliament and legal certainty, this study has argued that special reception guarantees and special procedural guarantees addressed to vulnerable asylum applicants should be implemented in the Aliens Act. It is evident from the research findings that the Netherlands has a strong preference to implement the Directives on asylum in hierarchically lower legislative instruments. Germany and France, on the other hand, have implemented the recast Reception Conditions Directive in an Act of Parliament.

7. The European Commission should carry out an in-depth assessment of the implementation of the CEAS standards with regard to vulnerable asylum applicants at the national level. The last time the Commission issued an implementation report on the Reception Conditions Directive was in 
2007. Regular monitoring is essential for the effective implementation of EU measures for the protection of vulnerable asylum applicants. Based on secondary sources, this study showed that the implementation of CEAS standards with regard to vulnerable asylum applicants widely differ between Member States. I also carried out a detailed analysis of the national implementing measures, case law and practice of the Netherlands. This study suggested that a detailed assessment as conducted in chapter 8 on the Netherlands could serve as a template for the Commission to examine the law and practice surrounding vulnerable asylum applicants in all Member States.

8. Member States should fully transfer their national competences on asylum to the EU level in order to establish a coherent and effective European asylum policy. This study has shown that the EU asylum policy suffers from structural weaknesses, such as the incoherent interpretation and application of CEAS standards by Member States, the dysfunctional Dublin system and the lack of solidarity to share the responsibility between Member States. Therefore, this study suggested that a future European asylum policy could function when there is more European integration in the field of asylum, not less. 


\section{Samenvatting}

Dit boek onderzoekt het gemeenschappelijk Europees asiel stelsel (GEAS) en beoordeelt of de conclusie van de Europese Raad te Tampere, het vaststellen van gemeenschappelijke normen voor een eerlijke en efficiënte asielprocedure, is gerealiseerd met betrekking tot kwetsbare asielzoekers. Dit boek onderzoekt ook of de wettelijke normen die voortvloeien uit de herschikte wetgevingsinstrumenten van het GEAS met betrekking tot kwetsbare asielzoekers in overeenstemming zijn met de internationale mensenrechtenstandaarden, en of deze wettelijke Europese normen adequaat zijn geïmplementeerd op nationaal niveau. Dit boek focust met name op slachtoffers van foltering en niet-begeleide minderjarigen asielzoekers. Het geselecteerde land om de implementatie van relevante wettelijke Europese normen met betrekking tot kwetsbare asielzoekers te beoordelen, is Nederland. Een belangrijke vraag die in dit boek aan de orde wordt gesteld, hoe kwetsbaarheid in de context van asiel moet worden begrepen.

In hoofdstuk 2 wordt het begrip kwetsbaarheid in de context van internationale mensenrechtenverdragen onderzocht en waarom bepaalde groepen geacht worden kwetsbaar te zijn. Het concept kwetsbaarheid wordt in relatie tot het Vluchtelingenverdrag onderzocht en met betrekking tot andere relevante internationale mensenrechtenverdragen: het Internationaal Verdrag inzake burgerrechten en politieke rechten (ICCPR); het Internationaal Verdrag inzake economische, sociale en culturele rechten (ICESCR); het Verdrag inzake de uitbanning van alle vormen van discriminatie van vrouwen (CEDAW); en het Verdrag inzake de rechten van personen met een handicap (CRPD). In het tweede deel van hoofdstuk 2 wordt het EVRM en het begrip kwetsbaarheid in de jurisprudentie van het EHRM besproken, in het bijzonder met betrekking tot asielzoekers. Dit hoofdstuk laat zien dat het Vluchtelingenverdrag geen definitie van kwetsbaarheid bevat of aangeeft welke vluchtelingen geacht worden kwetsbaar te zijn. Met betrekking tot de internationale mensenrechtenverdragen laat dit hoofdstuk zien dat kwetsbaarheid een belangrijk begrip is in de internationale mensenrechtenverdragen. Zowel de ExCom-conclusies als de VNComités hebben verschillende mensenrechtensituaties geïnterpreteerd van groepen die als kwetsbaar worden beschouwd en beide hebben bepaalde groepen als bijzonder kwetsbaar erkend. Verder laat dit hoofdstuk zien dat in verschillende 'General Comments' en 'General Recommendations' van de VN-Comités bepaalde groepen als bijzonder kwetsbaar, gemarginaliseerd of benadeeld worden beschouwd om te benadrukken dat zij een groter risico lopen op schade. Staten die partij zijn bij deze verdragen worden aanbevolen passende maatregelen te nemen om hun bescherming ten aanzien van deze kwetsbare groepen te verbeteren. Deze aanpak kan mogelijk leiden tot een betere rechtsbescherming van kwetsbare groepen. De kwetsbaarheidsbenadering zoals gebruikt door de VN-Comités is echter te beperkt of te breed. Soms wordt een breed begrip van kwetsbaarheid toegepast, waardoor bijna 
iedereen als kwetsbaar wordt beschouwd. Daarnaast zijn er verwijzingen naar 'de meest kwetsbare groepen' zonder te specificeren welke groepen als de meest kwetsbare groepen moeten worden aangemerkt.

Met betrekking tot het begrip kwetsbaarheid in de jurisprudentie van het EHRM wees dit hoofdstuk erop dat het EHRM een rigide benadering hanteert. Verder heeft het begrip kwetsbaarheid in de jurisprudentie van het EHRM belangrijke implicaties voor de positieve verplichtingen van lidstaten. Dit houdt onder andere in dat lidstaten rekening moeten houden met de specifieke behoeften van individuen die tot een kwetsbare groep behoren. Daarnaast heeft kwetsbaarheid belangrijke implicaties voor de beoordeling of een gedraging de minimale drempel van ernst heeft bereikt die vereist is om te komen tot een onmenselijke of vernederende behandeling in de zin van artikel 3 van het EVRM.

In hoofdstuk 3 wordt onderzocht welke verplichtingen voortvloeien uit internationale mensenrechtenverdragen met betrekking tot slachtoffers van foltering en niet-begeleide minderjarigen. Het doel is om de geïdentificeerde verplichtingen te vergelijken met de relevante wettelijke normen die zijn neergelegd in de herschikte wetgevingsinstrumenten van het GEAS met betrekking tot slachtoffers van foltering en niet-begeleide minderjarigen. Dit hoofdstuk onderzoekt de relevante bepalingen van het Verdrag tegen foltering (CAT) en vervolgens het Verdrag inzake de rechten van het kind (CRC). Naast het onderzoek van deze internationale verdragen zal de aandacht worden gevestigd op de jurisprudentie van het EHRM. De focus op slachtoffers van martelingen en niet-begeleide minderjarigen in dit boek is gebaseerd op een aantal redenen. Beide categorieën worden over het algemeen beschouwd als de meest kwetsbare groepen in de context van asiel. Gezien hun kwetsbaarheid biedt het GEAS wettelijke normen die zijn gericht op hun speciale bescherming. Bovendien hebben beide geselecteerde categorieën naar alle waarschijnlijkheid speciale garanties nodig wat betreft opvang en procedurele regelingen. Dit hoofdstuk heeft een aantal verplichtingen geïdentificeerd die voortvloeien uit internationale mensenrechtenverdragen die relevant zijn met betrekking tot slachtoffers van foltering en niet-begeleide minderjarigen in de asielprocedure.

In hoofdstuk 4 wordt geëvalueerd wat de EU tot nu toe heeft gedaan op het gebied van asiel. Verder wordt onderzocht waarom en hoe het GEAS tot stand is gekomen, en hoe de EU de situatie van kwetsbare personen heeft aangepakt. Dit hoofdstuk laat zien dat sinds 1999 de EU werkt aan een Europees asielsysteem met gemeenschappelijke normen voor de opvang, procedures om te bepalen of een persoon in aanmerking komt voor internationale bescherming en welk land verantwoordelijkheid is voor de behandeling van asielaanvragen. Het GEAS is echter verre van coherent, uniform en efficiënt. Bovendien bespreekt dit hoofdstuk de belangrijkste wetgevings- en beleidsreacties op EU- en nationaal niveau in reactie op de 'vluchtelingencrisis'. 
Hoofdstuk 5 onderzoekt de juridische instrumenten van het GEAS en identificeert de belangrijkste tekortkomingen. Ondanks deze verbeteringen blijft de huidige richtlijn een uitdaging voor de lidstaten. De bevindingen laten zien dat het GEAS nog steeds te kampen heeft met een aantal belangrijke tekortkomingen die hebben geleid tot aanzienlijke verschillen tussen de lidstaten bij de toepassing van opvangvoorzieningen, inwilligingspercentages en asielprocedures. De redenen die hieraan ten grondslag liggen, zijn onder andere te wijten aan de ruime beoordelingsvrijheid die de lidstaten hebben om de GEAS-normen te interpreteren en uit te voeren, maar ook vanwege de verschillende uitzonderingen en concepten die veel ruimte laten voor interpretatie, wat ook tot arbitraire resultaten leidt. Deze kwesties zijn problematisch vanuit het oogpunt van het vaststellen van gemeenschappelijke normen voor een eerlijke en efficiënte asielprocedure. Dit hoofdstuk laat ook zien dat de lidstaten verschillende benaderingen hebben met betrekking tot de interpretatie en toepassing van normen en concepten die zijn vastgelegd in het GEAS. Verder zijn in dit hoofdstuk de 2016 voorstellen van de Commissie ter hervorming van het GEAS onderzocht. Behalve een aantal positieve ontwikkelingen zijn er ook verschillende aspecten die de rechten van asielzoekers en vluchtelingen, ernstig kunnen ondermijnen.

Hoofdstuk 6 gaat dieper in op het begrip kwetsbaarheid in de context van het GEAS. De juridische normen die voortvloeien uit de herschikte GEASwetgevingsinstrumenten met betrekking tot kwetsbare asielzoekers worden onderzocht. Het begrip kwetsbaarheid in de context van asiel roept een aantal vragen op: wie wordt verondersteld kwetsbaar te zijn en wat maakt iemand kwetsbaar in de context van asiel, en hoe kunnen kwetsbare asielzoekers worden geïdentificeerd? Wat zijn bovendien de juridische implicaties om als kwetsbaar te worden aangemerkt in het kader van het GEAS? Het tweede deel van dit hoofdstuk gaat in op de wettelijke normen die voortkomen uit het GEAS met betrekking tot slachtoffers van foltering en niet-begeleide minderjarigen, en het laatste deel van dit hoofdstuk vergelijkt deze wettelijke normen met de verplichtingen die voortvloeien uit de internationale mensenrechtenverdragen. Dit hoofdstuk laat zien dat er verschillende problemen zijn met de kwetsbaarheidsbenadering in het GEAS. In dit hoofdstuk wordt gepleit voor een meer genuanceerde benadering van het begrip kwetsbaarheid in het GEAS. Ook is aangevoerd dat de richtlijnen de lidstaten een ruime beoordelingsmarge bieden met betrekking tot de vraag hoe de kwetsbaarheid moet worden vastgesteld bij een asielzoeker en of een asielzoeker bijzondere procedurele garanties nodig heeft. Dit is problematisch omdat dit tot aanzienlijk verschillende uitkomsten tussen de lidstaten kan leiden. Verder wordt in dit hoofdstuk de voorgestelde wetsvoorstellen behandeld die de Commissie naar voren heeft gebracht met betrekking tot kwetsbare asielzoekers. Tot slot laat de analyse zien dat een aantal normen die voortkomen uit het GEAS met betrekking tot slachtoffers van foltering en niet-begeleide minderjarigen in overeenstemming zijn met de 
internationale mensenrechtenstandaarden. Aangetoond wordt dat een aantal normen die zijn vastgelegd in de juridische instrumenten van het GEAS niet voldoen aan de eisen die worden gesteld door de internationale mensenrechtenverdragen.

Hoofdstuk 7 geeft een overzicht van de huidige praktijk met betrekking tot kwetsbare asielzoekers in verschillende lidstaten. Dit hoofdstuk gaat in op de vraag wie als kwetsbaar wordt beschouwd in de nationale asielprocedure en wat de tendens is in verschillende lidstaten om kwetsbare asielzoekers te identificeren. Een belangrijke conclusie is dat gegevens over kwetsbare asielzoekers in de asielprocedure op EU- en nationaal niveau ontbreken. De meeste lidstaten houden geen gegevens bij over kwetsbare asielzoekers, zoals het aantal gehandicapte asielzoekers of asielzoekers met geestelijke gezondheidsproblemen die in de EU aankomen. De enige kwetsbare groep in de asielprocedure die door de lidstaten is geregistreerd betreft niet-begeleide minderjarigen. Verder kan worden geconcludeerd dat de aanpak van de kwetsbaarheid in de context van asiel en de implementatie van normen die zijn vastgelegd in het GEAS met betrekking tot kwetsbare asielzoekers sterk verschillen tussen de lidstaten. Bovendien hebben de lidstaten verschillende benaderingen bij het identificeren van kwetsbare personen in de asielprocedure en zijn er aanzienlijke verschillen in de vorm, het niveau en de beschikbaarheid van specifieke ondersteuning voor dergelijke asielzoekers.

Het laatste deel van dit boek bevat een case study van Nederland. In hoofdstuk 8 wordt de interpretatie en toepassing van het begrip kwetsbaarheid in het Nederlandse asielsysteem onderzocht. Er wordt aandacht besteed aan de vraag wie wordt verondersteld kwetsbaar te zijn in het kader van asiel en of een procedure op nationaal niveau wordt geïmplementeerd om kwetsbare asielzoekers systematisch te identificeren en of dergelijke asielzoekers toegang hebben tot de speciale garanties zoals verstrekt in het GEAS. Het tweede deel van dit hoofdstuk gaat in detail in op de nationale uitvoeringsmaatregelen en de praktijk met betrekking tot slachtoffers van foltering en niet-begeleide minderjarigen in de Nederlandse asielprocedure. Dit hoofdstuk laat zien dat er een aantal juridische kwesties en uitdagingen zijn met betrekking tot kwetsbare asielzoekers in de Nederlandse asielprocedure. Daarnaast laat dit hoofdstuk zien dat Nederland belangrijke garanties met betrekking tot gedetineerde kwetsbare asielzoekers niet heeft geïmplementeerd. Dit boek concludeert dan ook dat Nederland niet voldoet aan al zijn verplichtingen die voortvloeien uit de GEAS-normen met betrekking tot kwetsbare asielzoekers en dat kwetsbare asielzoekers in Nederland worden belemmerd om volledig deel te nemen aan de asielprocedure. 


\section{Summary}

This book examines the Common European Asylum System (CEAS) and assesses whether the European Council Tampere policy objective of establishing common standards for a fair and efficient asylum procedure has been realized with regard to vulnerable asylum applicants. It also examines whether the legal standards that stem from the recast CEAS legislative acts with regard to vulnerable asylum applicants are in accordance with international human rights law, and whether these legal standards have been adequately implemented at the national level. In this regard, this book focusses on victims of torture and unaccompanied minors. The country selected to assess the implementation of relevant legal standards with regard to vulnerable asylum applicants is the Netherlands. An important question that is raised herein is how vulnerability should be understood in the context of asylum.

Chapter 2 examines the notion of vulnerability employed in international human rights law and determines why certain groups are presumed to be vulnerable. After discussing the Refugee Convention, the chapter examines the notion of vulnerability in the context of the following treaties: the International Covenant on Civil and Political Rights (ICCPR); the International Covenant on Economic, Social and Cultural Rights (ICESCR); the Convention on the Elimination of All Forms of Discrimination against Women (CEDAW); and the Convention on the Rights of Persons with Disabilities (CRPD). The second part of chapter 2 discusses the ECHR and the notion of vulnerability in the case law of the ECtHR, in particular with regard to asylum applicants. This chapter shows that the Refugee Convention does not contain a definition of vulnerability nor indicates which refugees are presumed to be vulnerable. With regard to the international human rights treaties, the chapter demonstrates that vulnerability is an important notion in international human rights law. Both the ExCom Conclusions and the reviewed UN treaty monitoring bodies have interpreted various issues related to the human rights situation of groups that are considered vulnerable and both have recognized certain groups as particularly vulnerable. Furthermore, this chapter shows that the reviewed General Comments and General Recommendations of the UN human rights treaty monitoring bodies label certain groups as particularly vulnerable, marginalized, or disadvantaged to highlight that they are at greater risk of harm, and State parties are recommended to take appropriate measures to improve their protection. This approach may lead vulnerable groups increasingly enjoying of the substantive rights at issue. However, the vulnerability approach as used by the treaty monitoring bodies in the General Comments and General Recommendations is both too narrow and yet too broad. At times, a broad understanding of vulnerability is applied, meaning that nearly all groups are deemed vulnerable. In 
addition, there are references to 'the most vulnerable groups' but without specifying which groups qualify as the most vulnerable.

With regard to the notion of vulnerability in the case law of the ECtHR, this chapter points out that that ECtHR applies a rigid approach to vulnerability. Furthermore, the notion of vulnerability in ECtHR case law has important implications for the positive obligations of State parties. State parties are required to take into account the particular needs of applicants who belong to a vulnerable group. In addition, vulnerability has important implications when assessing whether the severity of a conduct has reached the minimum level of severity required to amount to inhuman or degrading treatment within the meaning of Article 3 of the ECHR.

Chapter 3 examines which obligations stem from international human rights law with regard to victims of torture and unaccompanied minors. The objective is to compare the identified obligations with the relevant legal standards enshrined in the recast legislative acts of the CEAS in respect to victims of torture and unaccompanied minors. This chapter examines the relevant provisions of the Convention against Torture (CAT) and subsequently the Convention on the Rights of the Child (CRC). As well as examining these international treaties, attention is focused on the ECtHR case law. The focus on victims of torture and unaccompanied minors here is based on a number of reasons. Both categories of applicants are generally considered the most vulnerable in the context of asylum. Considering their vulnerability, the CEAS explicitly provides enhanced legal standards that are aimed at their special protection. In addition, both categories are most likely to require special guarantees in terms of reception and procedural arrangements. This chapter has identified a number of obligations that stem from international human rights law that are of relevance with regard to victims of torture and unaccompanied minors in the asylum process.

Chapter 4 assesses what the EU has done so far in the field of asylum. The chapter examines why and how the CEAS has been established. In addition, it examines how the EU has addressed the situation of vulnerable persons in the CEAS. This chapter shows that since 1999 it has been the EU's aim to establish a CEAS, which includes common standards on the reception, procedures for determining whether a person qualifies for international protection, and the allocation of responsibility among Member States for the examination of asylum claims. However, the CEAS is currently far from being coherent, uniform, and efficient. Furthermore, this chapter discusses the main legislative and policy responses at the EU and national level in response to the 'refugee crisis.'

Chapter 5 examines the legal instruments of the CEAS and identifies key shortcomings and challenges. The evidence suggests that the CEAS still suffers from a number of key shortcomings that have resulted in notable differences between the Member States in terms of the implementation of reception conditions, 
recognition rates, and procedures on asylum. It has been submitted that the reasons underlying these outstanding/continued differences are, inter alia, due to the wide discretion allowed for Member States to interpret and implement the CEAS standards, but also because of the various derogation clauses and concepts that are too broad or too vague, which also lead to arbitrary outcomes. These issues are problematic from the perspective of establishing common standards for a fair and efficient asylum procedure. This chapter also shows that Member States have different approaches in interpreting and applying standards and concepts laid down in the CEAS. Furthermore, this chapter examines the 2016 Commission proposals to reform the CEAS and identifies a number of positive developments. Nevertheless, several aspects that have been submitted by the Commission could seriously undermine the rights of asylum applicants and beneficiaries of international protection.

Chapter 6 examines the notion of vulnerability in the context of the CEAS. The first part of this chapter examines the legal standards that stem from the recast CEAS legislative acts with regard to vulnerable asylum applicants. The notion of vulnerability in the context of asylum gives rise to a number of questions: who is presumed to be vulnerable and what makes them vulnerable in the context of asylum, and how are vulnerable asylum applicants identified? In addition, what are the legal implications of being identified as vulnerable in the context of the CEAS? The second part of this chapter examines the legal standards that stem from the CEAS with regard to victims of torture and unaccompanied minors, with the last section comparing these legal standards with the obligations that stem from international human rights law. This chapter shows that there are several issues with the vulnerability approach in the CEAS. It has been argued that the EU should adopt a more nuanced approach to vulnerability in the asylum process. It has also been submitted that the Directives allow Member States wide discretion as to how the identification of vulnerability should take place and whether an applicant is in need of special procedural guarantees. This is problematic because it may lead to considerably different outcomes between Member States. Furthermore, this chapter also examines the proposed legislative amendments brought forward by the Commission in relation to vulnerable applicants. Its proposed changes, if adopted, would improve the legal standards with regard to vulnerable asylum applicants. Finally, my analysis shows that a number of standards that stem from the CEAS with regard to victims of torture and unaccompanied minors are consistent with international human rights law. The analysis also shows that a number of standards that are laid down in the legal instruments of the CEAS fall short of the requirements adopted under international human rights law.

Chapter 7 provides an overview of the current practice with regard to vulnerable asylum applicants in various Member States. This chapter examines who is presumed to be vulnerable in the national asylum process and what trends can be 
seen in various Member States in identifying vulnerable asylum applicants. An important conclusion is that there is a lack of data on vulnerable asylum applicants in the asylum process at both the EU and the Member State level. The majority of Member States do not keep records of vulnerable asylum applicants, such as the number of disabled asylum applicants or applicants with mental health problems. The only vulnerable group in the asylum process that Member States register concerns unaccompanied minors. Furthermore, the approach to vulnerability in the asylum context and the implementation of the standards laid down in the CEAS with regard to vulnerable asylum applicants differ widely between Member States. In addition, Member States have different approaches in identifying vulnerable persons in the asylum process and there are significant disparities in the form, level and availability of specific support to such applicants.

The final part of this book entails a case study of the Netherlands. Chapter 8 examines the interpretation and application of the notion of vulnerability and special needs in the Dutch asylum system. Attention is paid to the questions of who is presumed to be vulnerable in the context of asylum and whether a mechanism or procedure is implemented at the national level in order to systematically identify vulnerable applicants, and whether such applicants have access to the special guarantees as provided in the CEAS. The second part of this chapter examines the national implementing measures and practice with regard to victims of torture and unaccompanied minors in the domestic asylum procedure. This chapter shows that there are a number of outstanding legal issues and challenges with regard to vulnerable asylum applicants in the Dutch asylum process. In addition, it shows that the Netherlands has not implemented important mandatory guarantees with regard to detained vulnerable asylum applicants. This book concludes that that the Netherlands is not complying with all its obligations arising from the CEAS standards with regard to vulnerable asylum applicants and that vulnerable asylum applicants in the Netherlands are impeded from fully participating in the asylum process. 


\section{Valorisation addendum}

\section{Relevance}

For more than twenty years, the EU has been working towards establishing a Common European Asylum System (CEAS), which includes common standards for a fair and efficient asylum procedure. Since its inception in 1999, the CEAS has undergone two legislative phases. The first phase concluded in 2005 , which consisted of minimum standards on asylum. The second phase of the CEAS was concluded in 2013 and recast the existing minimum standards (recast CEAS).

This book focuses on the recast CEAS and the rights of vulnerable asylum applicants in the asylum procedure. I analyze whether the legal standards that stem from the recast CEAS legislative acts with regard to vulnerable asylum applicants, in particular with regard to victims of torture and unaccompanied minors, are in accordance with international human rights law, and whether these legal standards have been adequately implemented at the national level. I provide a robust analysis of the national implementing measures, case law and practice of the Netherlands with regard to vulnerable asylum applicants in the asylum procedure. The case study that I have conducted here has relevance to policy-makers at both the EU and national level, including legal practitioners in the field of asylum. Therefore, this book not only contributes to the academic debate with regard to the concept of vulnerability in the asylum context but also provides a better understanding of the various legal and policy instruments on asylum to improve the rights of vulnerable asylum applicants.

\section{Target groups}

The intended audience of the research and findings are academics working in the field of European asylum law, because the book includes a detailed analysis of the EU rules with regard to the reception conditions and special procedural arrangements of vulnerable asylum applicants, and how those standards relate to international law. This book should also be of interest to both national and EU policy-makers, and judges, as well as legal practitioners working in international organisations, NGOs and lawyers representing asylum applicants, because it provides a rich source of information and an assessment of the implementation of legal standards that stem from the CEAS at the national level. Finally, the book is also addressed to asylum applicants in general who wish to gain more knowledge about the European asylum system and their rights during the asylum procedure. 


\section{Innovation}

This research is innovative because it analyzes the development of EU asylum policy, the recast CEAS legislative acts and the rights of vulnerable asylum applicants in a comprehensive and systematic manner. I carried out an indepth country study of Dutch asylum law and policy with regard to vulnerable asylum applicants, with a particular focus on victims of torture and unaccompanied minors. The case study could serve as a template to examine the law and practice surrounding vulnerable asylum applicants in other Member States.

\section{Outreach and dissemination of research findings}

The findings of this research have already been disseminated at various events during which scholars, policy-makers and practitioners met to exchange their views on the topic of European asylum policy. I presented parts of my research at the Migration Policy Conference, which was organized by the Dutch Ministry of Justice in the Hague (2013) and during the Migration Policy Research Seminar at the School of Governance in Maastricht (2014), and also during an expert workshop organized by the International Centre for Migration and Policy Development (ICMPD) in Brussels on the implementation of the Common European Asylum System (2016). Furthermore, I also disseminated my research findings at the annual Student Forum Maastricht conference and during a public lecture on the 'refugee crisis' held at Maastricht University (2015). In addition, parts of my findings with regard to the legislative acts of the CEAS have also been used in a study for the LIBE Committee of the European Parliament and published as articles in Journaal Vreemdelingenrecht.

\section{Implementing the research results}

In order to further disseminate the research outcomes, I will distribute my book to policy-makers at the EU and national level, as well as to legal practitioners working in the field of asylum. Finally, I intend to write several articles based on my research results and to seek funding to continue my research on the future of the CEAS. 


\section{Bibliography and Annexes}

\section{International documents}

The 1889 Montevideo Treaty on International Penal Law

The 1967 Declaration on Territorial Asylum

The 1969 American Convention on Human Rights

The 1969 OAU Convention Governing the Specific Aspects of Refugee Problems in Africa

The 1981 African Charter of Human and Peoples' Rights

The 1984 Cartagena Declaration

The Declaration on the Protection of All Persons from Enforced Disappearance

UN General Assembly, Universal Declaration of Human Rights, 10 December 1948, 217 A (III)

UN General Assembly, Convention Relating to the Status of Refugees, 28 July 1951, United Nations, Treaty Series, vol. 189, p. 137

UN General Assembly, Convention Against Torture and Other Cruel, Inhuman or Degrading Treatment or Punishment, 10 December 1984, United Nations, Treaty Series, vol. 1465, p. 85

UN General Assembly, Convention on the Elimination of All Forms of Discrimination Against Women, 18 December 1979, United Nations, Treaty Series, vol. 1249 , p. 13

UN General Assembly, Convention on the Rights of Persons with Disabilities: resolution / adopted by the General Assembly, 24 January 2007, A/RES/61/ 106

UN General Assembly, Convention on the Rights of the Child, 20 November 1989, United Nations, Treaty Series, vol. 1577, p. 3

UN General Assembly, Declaration on the Elimination of Violence against Women, 20 December 1993, A/RES/48/104

UN General Assembly, International Covenant on Civil and Political Rights, 16 December 1966, United Nations, Treaty Series, vol. 999, p. 171

UN General Assembly, International Covenant on Economic, Social and Cultural Rights, 16 December 1966, United Nations, Treaty Series, vol. 993, p. 3

UN General Assembly, Optional Protocol to the Convention on the Rights of the Child on the Sale of Children, Child Prostitution and Child Pornography, 16 March 2001, A/RES/54/263

UN General Assembly, Protocol Relating to the Status of Refugees, 31 January 1967, United Nations, Treaty Series, vol. 606, p. 267

UN General Assembly, Second Optional Protocol to the International Covenant on Civil and Political Rights, Aiming at the Abolition of the Death Penalty, 15 December1989, A/RES/44/128

UN General Assembly, New York Declaration for Refugees and Migrants: resolution / adopted by the General Assembly, 3 October 2016, A/RES/71/1

UN General Assembly, Global Compact on Refugees, 2018, A/73/12 (Part II)

UN General Assembly, Global Compact for Migration, 2018 


\section{United Nations Treaty Monitoring Bodies - General Comments and Gen- eral Recommendations}

Committee against Torture, General Comment No. 2: Implementation of Article 2 by States Parties, 24 January 2008, CAT/C/GC/2

Committee against Torture, General Comment No. 3 of the Committee against Torture Implementation of article 14 by States parties, 19 November 2012

Committee against Torture, General Comment No. 4 (2017) on the implementation of article 3 of the Convention in the context of article 22, 9 February 2018

Committee on the Elimination of Discrimination against Women, General Recommendation, No. 18 on disabled women, 1991

Committee on the Elimination of Discrimination against Women, General Recommendation No. 19: Violence against Women Adopted at the Eleventh Session of the Committee on the Elimination of Discrimination against Women, in 1992 (Contained in Document A/47/38)

Committee on the Elimination of Discrimination against Women, General Recommendation No. 24: Article 12 of the Convention (Women and Health), 1999, A/54/38/Rev.1, chap. I

Committee on the Elimination of Discrimination against Women, General Recommendation No. 27 on older women and protection of their human rights, 16 December 2010, CEDAW/C/GC/27

Committee on the Elimination of Discrimination against Women, General Recommendation No. 28 on the core obligations of States parties under article 2 of the Convention on the Elimination of All Forms of Discrimination against Women, 16 December 2010, CEDAW/C/GC/28

Committee on the Elimination of Discrimination against Women, General Recommendation No. 30 on women in conflict prevention, conflict and postconflict situations, CEDAW/C/GC/30, 18 October 2013

Committee on the Elimination of Discrimination against Women, General Recommendation No. 36, (2017) on the right of girls and women to education 27 November 2017, CEDAW/C/GC/36

Committee on the Rights of Persons with Disabilities, General Comment No. 2 (2014), Article 9 Accessibility, Committee on the Rights of Persons with Disabilities Eleventh session 31 March-11 April 2014, CRPD/C/GC/2, 22 May 2014

Human Rights Committee, CCPR General Comment No. 20: Article 7 (Prohibition of Torture, or Other Cruel, Inhuman or Degrading Treatment or Punishment), 10 March 1992

Human Rights Committee, CCPR General Comment No. 17: Article 24 (Rights of the Child), 7 April 1989

Human Rights Committee, CCPR General Comment No. 20: Article 7 (Prohibition of Torture, or Other Cruel, Inhuman or Degrading Treatment or Punishment), 10 March 1992 
Human Rights Committee, CCPR General Comment No. 21: Article 10 (Humane Treatment of Persons Deprived of Their Liberty), 10 April 1992

Human Rights Committee, CCPR General Comment No. 28: Article 3 (The Equality of Rights Between Men and Women), 29 March 2000, CCPR/C/21/ Rev.1/Add.10

Human Rights Committee, CCPR General Comment No. 31 [80], The nature of the general legal obligation imposed on States Parties to the Covenant, 26 May 2004, CCPR/C/21/Rev.1/Add.13

Committee on Economic, Social and Cultural Rights, General Comment No. 6: The Economic, Social and Cultural Rights of Older Persons, 8 December 1995, E/1996/22

Committee on Economic, Social and Cultural Rights, General Comment No. 7: The right to adequate housing (Art.11.1): forced evictions, 20 May 1997, E/1998/22

Committee on Economic, Social and Cultural Rights, General Comment No. 9: The domestic application of the Covenant, 3 December 1998, E/C.12/1998/24

Committee on Economic, Social and Cultural Rights, General Comment No. 11: Plans of Action for Primary Education (Art. 14 of the Covenant), 10 May 1999, E/1992/23

Committee on Economic, Social and Cultural Rights, General Comment No. 13: The Right to Education (Art. 13 of the Covenant), 8 December 1999, E/C.12/1999/10

Committee on Economic, Social and Cultural Rights, General Comment No. 5 : Persons with Disabilities, 9 December 1994, E/1995/22

Committee on Economic, Social and Cultural Rights, General Comment No. 14: The Right to the Highest Attainable Standard of Health (Art. 12 of the Covenant), 11 August 2000, E/C.12/2000/4

Committee on Economic, Social and Cultural Rights, General Comment No. 15: The Right to Water (Arts. 11 and 12 of the Covenant), 20 January 2003, E/C.12/2002/11

Committee on Economic, Social and Cultural Rights, General Comment No. 16: The Equal Right of Men and Women to the Enjoyment of All Economic, Social and Cultural Rights (Art. 3 of the Covenant), 11 August 2005, E/C.12/2005/4

Committee on Economic, Social and Cultural Rights, General Comment No. 19: The right to social security (Art. 9 of the Covenant), 4 February 2008, E/ C.12/GC/19

Committee on Economic, Social and Cultural Rights, General comment No. 20: Non-discrimination in economic, social and cultural rights (art. 2, para. 2, of the International Covenant on Economic, Social and Cultural Rights), 2 July 2009, E/C.12/GC/20

Committee on Economic, Social and Cultural Rights, General comment no. 21, Right of everyone to take part in cultural life (art. 15, para. 1a of the Covenant on Economic, Social and Cultural Rights), 21 December 2009, E/C.12/GC/21 
Committee on the Rights of the Child, General Comment No. 17 (2013) on the right of the child to rest, leisure, play, recreational activities, cultural life and the arts (art.31), 17 April 2013

Committee on the Rights of the Child, General Comment No. 6 (2005): Treatment of Unaccompanied and Separated Children Outside their Country of Origin, 1 September 2005, CRC/GC/2005/6

Committee on the Rights of the Child, General Comment No 14. (2013): on the right of the child to have his or her best interests taken as a primary consideration (art. 3, para. 1), 29 May 2013, CRC /C/GC/14

Committee on the Rights of the Child, General Comment No. 5, 'General measures of implementation of the Convention on the Rights of the Child', U.N. Doc CRC/C/GC/2003/5 (2003)

Committee on the Rights of the Child, General comment No. 15 (2013) on the right of the child to the enjoyment of the highest attainable standard of health (art. 24), 17 April 2013, CRC/C/GC/15

\section{Concluding observations}

Committee on the Rights of the Child, Concluding observations on the fourth periodic report of the Netherlands, CRC/C/NLD/CO/4, 16 July 2015

Convention Against Torture and other Cruel, Inhuman or Degrading Treatment or Punishment, Seventh Periodic Report, Response of the Kingdom of the Netherlands to the list of issues (CAT/C/NLD/QPR/7) transmitted to the State Party under the optional reporting procedure (A/62/44, paras. 23 and 24), The Kingdom of the Netherlands, 3 July 2017

\section{UN Committee on Economic, Social and Cultural Rights - Individual Communications}

Marcia Cecilia Trujillo Calero v Ecuador, Communication No. 10/2015, 26 March 2018

Mohamed Ben Djazia and Naouel Bellili v Spain, Communication No. 5/2015, 20 June 2017

\section{UN Committee on the Elimination of Discrimination Against Women - Individual Communications}

Guadalupe Herrera Rivera v Canada, CEDAW/C/50/D/26/2010, Communication No. 26/2010, 18 October 2011

M.P.M. v Canada, CEDAW/C/51/D/25/2010 (CEDAW), Communication No. 25/2010, 24 February 2012

N.S.F. $v$ United Kingdom of Great Britain and Northern Ireland, CEDAW/C/38/D/10/2005, UN Committee on the Elimination of Discrimination Against Women (CEDAW), Communication No. 10/2005, 12 June 2007 
Zhen Zhen Zheng $v$ The Netherlands, CEDAW/C/42/D/15/2007, UN Committee on the Elimination of Discrimination Against Women (CEDAW), Communication No. 15/2007, 17 February 2009

\section{UN Committee Against Torture - Individual Communications}

CAT 103/1998, Case S.M.R. and M.M.R.v Sweden

CAT 203/2002, Case A.R. v The Netherlands

CAT 256/2004, Case M.Z.v Sweden

CAT 322/2007, Case Njamba v Sweden

CAT 379/2009, Case Bakatu-Biav Sweden

CAT 101/1997, Case Halil Hayden v Sweden

CAT, 319/2007, Case Nirmal Singh v Canada

CAT, 396/2009, Case Combey Brice Magloire Gbadjavi v Switzerland

CAT, 416/2010, Case Ke Chun Rong v Australia

CAT, 43/1996, Case Kaveh Yaragh Tala v Sweden

CAT, 142/2000, Case Z.T.v Australia

CAT, 742/2016, Case A.N.v Switzerland

CAT, 758/2016, Case Adam Harun v Switzerland

\section{UNHCR documents}

UNHCR, ExCom Conclusion, General Conclusion on International Protection, No. 77 (XLVI) - 1995, 20 October 1995

UNHCR, ExCom Conclusion, Refugee Protection and Sexual Violence, No. 73 (XLIV) - 1993, 8 October 1993

UNHCR, ExCom Conclusion, Refugee Women and International Protection, No. 39 (XXXVI) - 1985, 18 October 1985

UNHCR, ExCom Conclusion, Refugee Women and International Protection, No. 64 (XLI) - 1990, 5 October 1990

UNHCR, ExCom Conclusion, Refugee Women, No. 60 (XL) - 1989, 13 October 1989

UNHCR, ExCom Conclusion, Women and Girls at Risk, No. 105 (LVII) - 2006, 6 October 2006

UNHCR, ExCom Conclusion, Children at Risk, No. 107 (LVIII) - 2007, 5 October 2007, No. 107 (LVIII) - 2007

UNHCR, ExCom Conclusion, Refugees with disabilities and other persons with disabilities protected and assisted by UNHCR, Conclusion No 110 (LXI), 12 October 2010

UNHCR and the IDC, Vulnerability Screening Tool, Identifying and addressing vulnerability: a tool for asylum and migration systems, 2016

UNHCR Comments on the European Commission proposal for a Regulation of the European Parliament and of the Council establishing the criteria and mechanisms for determining the member state responsible for examining an 
application for international protection lodged in one of the Member States by a third-country national or a stateless person (recast) - COM (2016) 270, December 2016

UNHCR Comments on the European Commission's amended recast proposal for a Directive of the European Parliament and the Council laying down for the reception of asylum-seekers, Brussels, 2012

UNHCR Handbook and Guidelines on Procedures and Criteria for Determining Refugee Status under the 1951 Convention and the 1967 Protocol Relating to the Status of Refugees, December 2011, HCR/1P/4/ENG/REV. 3

UNHCR, Policy on Refugee Women, 20 August 1990

UNHCR, Asylum in the European Union, A study of the implementation of the Qualification Directive, 2007

UNHCR, Age, Gender and Diversity Policy, 8 June 2011

UNHCR, An efficient and protective Eurodac, November 2012

UNHCR, Building on the Lessons Learned to Make the Relocation Schemes Work More Effectively, Recommendations, January 2016

UNHCR, Global Consultations on International Protection, Refugee Women, EC/GC/02/8, 25 April 2002

UNHCR, Global Trends, Forced Displacement, 2015

UNHCR, Guidelines on Determining the Best Interests of the Child, May 2008

UNHCR, Guidelines on Gender-Related Persecution within the context of Article 1A(2) of the 1951 Convention and/or its 1967 Protocol relating to the Status of Refugees, 2002

UNHCR, Guidelines on International Protection No. 1: Gender-Related Persecution Within the Context of Article 1A(2) of the 1951 Convention and/or its 1967 Protocol Relating to the Status of Refugees, 7 May 2002, HCR/GIP/02/01

UNHCR, Guidelines on International Protection No. 4: "Internal Flight or Relocation Alternative" Within the Context of Article 1A(2) of the 1951 Convention and/or 1967 Protocol Relating to the Status of Refugees, 23 July 2003, HCR/GIP/03/04

UNHCR, Guidelines on International Protection: The application of Article 1A(2) of the 1951 Convention and/or 1967 Protocol relating to the Status of Refugees to victims of trafficking and persons at risk of being trafficked, HCR/GIP/06/07, 7 April 2006

UNHCR, Guidelines on Policies and Procedures in dealing with Unaccompanied Children Seeking Asylum, 1997

UNHCR, Guidelines on the Protection of Refugee Women, UN Doc. ES/SCP/67, 1 July 1991

UNHCR, Improving Asylum Procedures: Comparative Analysis and Recommendations for Law and Practice - Key Findings and Recommendations, March 2010

UNHCR, Legal considerations on the return of asylum-seekers and refugees from Greece to Turkey as part of the EU-Turkey Cooperation in Tackling the Migration Crisis under the safe third country and first country of asylum concept, 23 March 2016 
UNHCR, Note on UNHCR's Interpretation of Article 1D of the 1951 Convention relating to the Status of Refugees and Article 12(1)(a) of the EU Qualification Directive in the context of Palestinian refugees seeking international protection, May 2013

UNHCR, Position on Conventions Recently Concluded in Europe (Dublin and Schengen Conventions), 16 August 1991

UNHCR, Procedural Standards for Refugee Status Determination under UNHCR's Mandate, 20 November 2003

UNHCR, Response to the European Commission's Green Paper on the Future Common European Asylum System, September 2007

UNHCR, Revised Note on the Applicability of Article 1D of the 1951 Convention relating to the Status of Refugees to Palestinian Refugees, October 2009

UNHCR, Sexual and Gender-Based Violence against Refugees, Returnees and Internally Displaced Persons, Guidelines for Prevention and Response, May 2003

UNHCR, Study on the implementation of the Dublin III Regulation, Left in Limbo, 2017

UNHCR, The heart of the matter - Assessing Credibility when Children apply for Asylum in the European Union, 2014

UNHCR, Thematic Compilation of Executive Committee Conclusions, August 2009, 4th edition

UNHCR, Welcome EU moves towards a common asylum system, Briefing notes, 14 June 2013

UNHCR, Policy on Older Refugees, 19 April 2000, EC/50/SC/CRP.13

UNHCR, Revised Guidelines on Applicable Criteria and Standards relating to the Detention of Asylum-Seekers, February 1999

UNHCR, Guidelines on the Applicable Criteria and Standards relating to the Detention of Asylum-Seekers and Alternatives to Detention, 2012

\section{OHCHR documents}

Office of the High Commissioner for Human Rights, Observations on the Standard Minimum Rules for the Treatment of Prisoners prepared by Committee on the Rights of Persons with Disabilities, 20 November 2013

Office of the United Nationals High Commissioner for Human Rights in cooperation with the United Nations Support Mission in Libya, Abuse Behind Bars: Arbitrary and unlawful detention in Libya, April 2018

Office of the United Nationals High Commissioner for Human Rights Recommended Principles and Guidelines on Human Rights and Human Trafficking, 2002

\section{Council of Europe documents}

Council of Europe, Committee of Ministers Recommendation 2003(5) on measures of detention of asylum seekers

Council of Europe, Committee of Ministers (2009), Guidelines on human rights protection in the context of accelerated asylum procedures 
Council of Europe, European Committee of Social Rights, Defence for Children International (DCI) $v$ the Netherlands, Complaint No. 47/2008, Decision on the merits, 20 October 2009

Council of Europe, European Convention for the Protection of Human Rights and Fundamental Freedoms, as amended by Protocols Nos. 11 and 14, 4 November 1950, ETS 5

Council of Europe, Parliamentary Assembly, Accelerated asylum procedures in Council of Europe Member States, Resolution 1471 (2005)

Council of Europe, Parliamentary Assembly, PACE Resolution 1810 (2011), Unaccompanied children in Europe: issues of arrival, stay and return

Council of Europe, Parliamentary Assembly, PACE Resolution 2136 (2016), Harmonising the protection of unaccompanied minors in Europe

Council of Europe, Report by Nils Muiznieks, Commissioner for Human Rights of the Council of Europe, Following his visit to the Netherlands from 20 to 22 May 2014, CommDH(2014)18, Strasbourg, 14 October 2014

Council of Europe, Report by Nils Muiznieks, Commissioner for Human Rights of the Council of Europe, Following his visit to Germany on 24th April and from 4 to 8 May 2015, Strasbourg 1 October 2015

Council of Europe, Report by Nils Muiznieks, Commissioner for Human Rights of the Council of Europe, Following his visit to Bulgaria from 9 to 11 February 2015, Strasbourg, 22 June 2015

Council of Europe, Report by Nils Muiznieks, Commissioner for Human Rights of the Council of Europe, Following his visit to Slovenia from 20 to 23 March 2017, Strasbourg, 11 July 2017

The 2005 Council of Europe Convention on Action against Trafficking in Human Beings

\section{Case law of the European Court of Human Rights}

Abdullahi Elmi and Aweys Abubakarv Malta, Applications nos. 25794/13 and

28151/13, European Court of Human Rights, 22 November 2016

Aksoy v Turkey, Application no. 21987/93, European Court of Human Rights, 18

December 1996

Alajos Kiss v Hungary, Application no. 38832/06, European Court of Human

Rights, 20 May 2010

Aydin v Turkey, Application no. 23178/94, European Court of Human Rights, 25

September 1997

B. $v$ The Republic of Moldova, Application no. 61382/09, European Court of Human Rights, 16 July 2013

Bader and Kanbor $v$ Sweden, Application no. 13284/04, European Court of Human

Rights, 8 November 2005

Bati and Others v Turkey, Application nos. 33097/96 and 57834/00, European

Court of Human Rights, 3 June 2004 
Breukhoven v The Czech Republic, Application no. 44438/06, European Court of Human Rights, 21 July 2011

Chahalv the United Kingdom, Application no. 22414/93, European Court of Human Rights, 15 November 1996

Chapman v the United Kingdom, Application no. 27238/95, European Court of Human Rights, 18 January 2001

D.H. and others $v$ The Czech Republic, Application no. 57325/00, European Court of Human Rights, 13 November 2007

Dudgeon v the United Kingdom, Application no.7525/76, European Court of Human Rights, 22 October 1981

Dybekuv Albania, Application no. 41153/06, European Court of Human Rights, 18 December 2007

Farbtuhs v Latvia, Application no. 4672/02, European Court of Human Rights, 6 June 2005

Gisayev v Russia, Application no. 14811/04, European Court of Human Rights, 20 June 2011

H.A.v Greece, Application no. 19951/16, European Court of Human Rights, 28

February 2019

H.L.R.v France, Application no. 24573/94, European Court of Human Rights, 29 April 1997

Hajduová v Slovakia, Application no. 2660/03, European Court of Human Rights, 30 November 2010

Heinischv Germany, Application no. 28274/08, European Court of Human Rights, 21 July 2011

Hilal v the United Kingdom, Application no. 45276/99, European Court of Human Rights, 6 March 2001

Hirsi Jamaa and Others v Italy, Application no. 27765/09, European Court of Human Rights, 23 February 2012

I v Sweden, Application No. 61204/09, European Court of Human Rights, 5 September 2013

Kanagaratnam and Others v. Belgium, Application no. 15297/09, European Court of Human Rights, 13 December 2011

Keenan v the United Kingdom, Application no. 27229/95, European Court of Human Rights, 3 April 2001

Khan v France, Application no. 12267/16, European Court of Human Rights, 28 February 2019

Khlaifia and Others v Italy, Application no. 16483/12, European Court of Human Rights, Grand Chamber, 15 December 2016

Kiyutinv Russia, Application no. 2700/10, European Court of Human Rights, 10 March 2011

M.S. $v$ the United Kingdom, Application no. 24527/08, European Court of Human Rights, 3 August 2012 
M.S.S.v Belgium and Greece, Application no. 30696/09, European Court of Human Rights, 21 January 2011

Mamatkulov and Askarovv Turkey, Application no. 46827/99 and 46951/99, European Court of Human Rights, 4 February 2005

Mohammed Lemine Ould Barar v Sweden, Application no. 42367/98, European Court of Human Rights, 19 January 1999

Mubilanzila Mayeka and Kaniki Mitunga v Belgium, Application no. 13178/03, European Court of Human Rights, 12 October 2006

Mudric v The Republic of Moldova, Application no. 74839/10, European Court of Human Rights, 16 July 2013

Muskhadzhiyeva and Othersv Belgium, Application no. 41442/07, European Court of Human Rights, 19 January 2010

N. v Finland, Application no. 38885/02, European Court of Human Rights, 26 July 2005

N.A. $v$ the United Kingdom, Application no. 25904/07, European Court of Human Rights, 17 July 2008

Nechiporuk and Yonkalo v Ukraine, Application no. 42310/04, European Court of Human Rights, 21 April 2011

Neulinger and Shuruk v Switzerland, Application no. 41615/07, European Court of Human Rights, 6 July 2010

Nunezv Norway, Application no. 5597/09, European Court of Human Rights, 28 June 2011

O.M.v Hungary, Application no. 9912/15, European Court of Human Rights, 5 July 2016

Opuzv Turkey, Application no. 33401/02, European Court of Human Rights, 9 June 2009

Paposhviliv Belgium, Application no. 41738/10, European Court of Human Rights, 13 December 2016

Popovv France, Application no. 39472/07 and 39474/07, European Court of Human Rights, 19 January 2012

Price v the United Kingdom, Application no. 333/94/96, European Court of Human Rights, 10 July 2001

R.C. $v$ Sweden, Application no. 41827/07, European Court of Human Rights, 9 March 2010

R.J. v France, Application No. 10466/11, European Court of Human Rights, 19 September 2013

Rahimi v Greece, Application no. 8687/08, European Court of Human Rights, 5 April 2011

Rantsev v Cyrprus and Russia, Application no. 25965/04, European Court of Human Rights, 7 January 2010

Salah Sheekh v The Netherlands, Application no. 1948/04, European Court of Human Rights, 11 January 2007 
Samsam Mohammed Hussein and Others $v$ the Netherlands and Italy, Application no. 27725/10, European Court of Human Rights, 2 April 2013

Shamayev and Others v Georgia and Russia, Application no. 3637802 European Court of Human Rights, 12 October 2005

Siliadin v France, Application no. 73316/01, European Court of Human Rights, 26 July 2005

Slawomir Musial v Poland, Application no. 28300/06, European Court of Human Rights, 5 June 2009

Storck v Germany, Application no. 61603/00, European Court of Human Rights, 16 September 2009

Sufi and Elmi v The United Kingdom, Applications nos. 8319/07 and 11449/07, European Court of Human Rights, 28 June 2011

Tarakhel $v$ Switzerland, Application no. 29217/12, European Court of Human Rights, 4 November 2014

V.M. and Others $v$ Belgium, Application no. 60125/11, European Court of Human Rights, 7 July 2015

Vilvarajah and Others $v$ the United Kingdom, Application no. 13163/87, 13164/87, $13165 / 87,13447 / 87,13448 / 87$, European Court of Human Rights, 30 October 1991

Z.H.v Hungary, Application no. 28973/11, European Court of Human Rights, 8 February 2013

\section{European Union documents}

Charter of Fundamental Rights of the European Union, (2010/C 83/02) and Explanations relating to the Charter of Fundamental Rights, (2007/C 303/02)

Commission Implementing Regulation (EU) (EU) No 118/2014 of 30 January 2014 amending Regulation (EC) No 1560/2003 laying down detailed rules for the application of Council Regulation (EC) No 343/2003 establishing the criteria and mechanisms for determining the Member State responsible for examining an asylum application lodged in one of the Member States by a third-country national

Commission Regulation (EC) No 1560/2003 of 2 September 2003 laying down detailed rules for the application of Council Regulation (EC) No 343/2003 establishing the criteria and mechanisms for determining the Member State responsible for examining an asylum application lodged in one of the Member States by a third-country national, OJ L 222/3

Convention Implementing the Schengen Agreement of 14 June 1985 between the Governments of the States of the Benelux Economic Union, the Federal Republic of Germany and the French Republic, on the Gradual Abolition of Checks at their Common Borders ("Schengen Implementation Agreement"), 19 June 1990 
Council Directive 2001/55/EC of 20 July 2001 on minimum standards for giving temporary protection in the event of a mass influx of displaced persons and on measures promoting a balance on efforts between Member States in receiving such persons and bearing the consequences thereof, OJ 2001 L 212/12

Council Directive 2003/109/EC of 25 November 2003 concerning third-country nationals who are long-term residents, OJ L 16/44

Council Directive 2003/9/EC of 27 January 2003 laying down minimum standards for the reception of asylum seekers, OJ $2003 \mathrm{~L} 31 / 18$

Council Directive 2004/83/EC of 29 April 2004 on minimum standards for the qualification and status of third country nationals and stateless persons as refugees or as persons who otherwise need international protection and the content of the protection granted, OJ 2004, L 304/12

Council Directive 2005/85/EC of 1 December 2005 on minimum standards on procedures in Member States for granting and withdrawing refugee status, OJ 2005, L 326/18

Council Regulation (EC) 343/2003 of 18 February 2003 establishing the criteria and mechanisms for determining the Member State responsible for examining an asylum application lodged in one of the Member States by a third-country national, OJ L50/1

Council Regulation (EC) No 407/2002 of 28 February 2002 laying down certain rules to implement Regulation (EC) No 2725/2000 concerning the establishment of 'Eurodac' for the comparison of fingerprints for the effective application of the Dublin Convention, OJ L 62/1

Council Regulation 343/2003/EC of 18 February 2003 establishing the criteria and mechanisms for determining the Member State responsible for examining an application for asylum lodged in one of the Member States by a third-country national, OJ 2003 L 50/1

Council Regulation No 2725/2000 of 11 December 2000 concerning the establishment of 'Eurodac' for the comparison of fingerprints for the effective application of the Dublin Convention, OJ L 316/1

Decision No 573/2007/EC of the European Parliament and of the Council of 23 May 2007 establishing the European Refugee Fund for the period 2008 to 2013 as part of the General programme Solidarity and Management of Migration Flows and repealing Council Decision 2004/904/EC

Directive 2001/95/EC of the European Parliament and of the Council of 3 December 2001 on general product safety

Directive 2005/29/EC of the European Parliament and of the Council of 11 May 2005 concerning unfair business-to-consumer commercial practices in the internal market and amending Council Directive 84/450/EEC, Directives 97/7/EC, 98/27/EC and 2002/65/EC of the European Parliament and of the Council and Regulation (EC) No 2006/2004 of the European Parliament and of the Council 
Directive 2008/115/EC of the European Parliament and of the Council of 16 December 2008 on common standards and procedures in Member States for returning illegally staying third-country nationals, OJ L 348/98

Directive 2010/64/EU of the European Parliament and of the Council of 20 October 2010 on the right to interpretation and translation in criminal proceedings, OJ L 280/12

Directive 2011/83/EU the European Parliament and of the Council of 25 October 2011 on consumer rights, amending Council Directive 93/13/EEC and Directive 1999/44/EC of the European Parliament and of the Council and repealing Council Directive 85/577/EEC and Directive 97/7/EC of the European Parliament and of the Council

Directive 2011/95/EU of the European Parliament and of the Council of 13 December 2011 on standards for the qualification of third-country nationals or stateless persons as beneficiaries of international protection, for a uniform status for refugees or for persons eligible for subsidiary protection, and for the content of the protection granted (recast) OJ L 337/9

Directive 2012/13/EU of the European Parliament and of the Council of 22 May 2012 on the right to information in criminal proceedings, OJ L 142/1

Directive 2012/29/EU of the European Parliament and of the Council of 25 October 2012 establishing minimum standards on the rights, support and protection of victims of crime, and replacing Council Framework Decision 2001/220/JHA, OJ L 315/57

Directive 2013/32/EU of the European Parliament and of the Council of 26 June 2013 on common procedures for granting and withdrawing international protection (recast) OJ L 180/60

Directive 2013/48/EU of the European Parliament and of the Council of 22 October 2013 on the right of access to a lawyer in criminal proceedings and in European arrest warrant proceedings, and on the right to have a third party informed upon deprivation of liberty and to communicate with third persons and with consular authorities while deprived of liberty, OJ L294/1

European Union, Treaty of Nice, Amending the Treaty on European Union, the Treaties Establishing the European Communities and Certain Related Acts, 11 December 2000, Official Journal C 80 of 10 March 2001; 2001/C 80/01

Regulation (EU) No 439/2010 of the European Parliament and of the Council of 19 May 2010 establishing a European Asylum Support Office, 2010, OJ L132/11

Regulation (EU) No 516/2014 of the European Parliament and of the Council of 16 April 2014 establishing the Asylum, Migration and Integration Fund, amending Council Decisions 2008/381/EC and repealing Decisions No $573 / 3007 / E C$ and No 575/2007/EC of the European Parliament and of the Council and Council Decision 2007//435/EC

Regulation (EU) No 603/2013 of the European Parliament and of the Council of 26 June 2013 on the establishment of 'Eurodac' for the comparison of finger- 
prints for the effective application of Regulation (EU) No 604/2013 establishing the criteria and mechanisms for determining the Member State responsible for examining an application for international protection lodged in one of the Member States by a third-country national or a stateless person and on requests for the comparison with Eurodac data by Member States' law enforcement authorities and Europol for law enforcement purposes, and amending Regulation (EU) No 1077/2011 establishing a European Agency for the operational management of large-scale IT systems in the area of freedom, security and justice (recast) OJL 180/1

Regulation (EU) No 604/2013 of the European Parliament and of the Council of 26 June 2013, establishing the criteria and mechanisms for determining the Member State responsible for examining an application for international protection lodged in one of the Member States by a third-country national or a stateless person (recast)

Regulation 862/2007 of the European Parliament and of the Council of 11 July 2007 on Community statistics on migration and international protection and repealing Council Regulation (EEC) No 311/76 on the compilation of statistics on foreign workers OJ L 199/23

Single European Act, adopted 28 February 1986, entered into force 1 July 1987, Official Journal L 169, 29 June 1987

The Treaty of Amsterdam (Amending the Treaty on European Union, The Treaties establishing the European Communities and certain related acts, adopted 2 October 1997, Amsterdam, entered into force 1 May 1999) Official Journal C 340

The Treaty on European Union, adopted on 7 February 1992, entered into force 1 November 1993, Official Journal C 191

Treaty of Lisbon amending the Treaty on European Union and the Treaty establishing the European Community, OJ C 306/1, 17 December 2007

\section{European Council and Council of the European Union documents}

Action Plan of the Council and the Commission on How Best to Implement the Provisions of the Treaty of Amsterdam on an Area of Freedom, Security and Justice, Text adopted by the Justice and Home Affairs Council of 3 December 1998, OJ C 19/01, 23 January 1999

Conclusion on countries in which there is generally no serious risk of persecution, SN 4821/92 WGI 1281 of 1/12/92

Conclusion on people displaced by the conflict in the former Yugoslavia (London, 30 November - 1 December 1993)

Council and Commission Action Plan implementing the Hague Programme on strengthening freedom, security and justice in the European Union, OJ C198/01, 12 August 2005

Council Conclusions on unaccompanied minors, 1018th Council meeting, Justice and Home Affairs, Luxembourg, 3-4 June 2010 
Council Decision (EU) 2015/1523 of 14 September 2015 establishing provisional measures in the area of international protection for the benefit of Italy and of Greece

Council Decision (EU) 2015/1601 of 22 September 2015 establishing provisional measures in the area of international protection for the benefit of Italy and Greece

Council Decision of 2 December 2004 establishing the European Refugee Fund for the period 2005 to 2010, L 381/52, 28 December 2004

Council Decision of 21 February 2006 on the conclusion of the Agreement between the European Community and the Kingdom of Denmark extending to Denmark the provisions of

Council Regulation (EC) No 343/2003 establishing the criteria and mechanisms for determining the Member State responsible for examining an asylum application lodged in one of the Member States by a third-country national and Council Regulation (EC) No 2725/2000 concerning the establishment of 'Eurodac' for the comparison of fingerprints for the effective application of the Dublin Convention, OJ L 66/37

Council of the European Union, European Pact on Immigration and Asylum, Brussels, 24 September 2008, 13440/08, ASIM 72

Council of the European Union, Inter-institutional File: 2008/0244 (COD), Amended proposal for a Directive of the European Parliament and of the Council laying down standards for the reception of asylum seekers - Preparation for the first informal trilogue [First reading], 6942/12 ASILE 34 CODEC 491, Brussels 9 March 2012

Council Regulation (EC) 2007/2004 of 26 October 2004 establishing a European Agency for the Management of Operational Cooperation at the External Borders of the Member States of the European Union, OJ L 349

Council Resolution 95/C 262/01 of 25 September 1995 on burden-sharing with regard to the admission and residence of displaced persons on a temporary basis

Council Resolution of 20 June 1995 on minimum guarantees for asylum procedures, OJ C274

European Council Decision of 4 March 1996 on an alert and emergency of displaced persons on a temporary basis, OJ L63/10

European Council, Seville, 21 and 22 June 2002

European Council, Presidency Conclusions, Thessaloniki, 19 and 20 June 2003

European Council, Presidency Conclusions, Brussels 15 and 16 December 2005

European Council, Presidency Conclusions, Laeken 14-15 December 2001

European Council, Presidency Conclusions, Tampere 15-16 October 1999

European Council: EU-Turkey statement, 18 March 2016

Extraordinary Council meeting, Justice, Home Affairs and Civil Protection, Brussels, 20 September 2001 
General Secretariat of the Council, Conclusions European Council meeting (28 June 2018)

Press release Council of the European Union, Luxembourg, 20 June 2013 11160/13 (OR. en) Presse 267

Resolution on a harmonized approach to questions concerning host third countries, SN 4823/92 WGI 1283 of 19/11/92

Resolution on certain common guidelines as regards the admission of particularly vulnerable persons from the former Yugoslavia (Copenhagen, 1 June 1993)

Resolution on manifestly unfounded applications for asylum, Ad Hoc Immigration Group, SN 4822/1/92 WGI 1282 of 2//12/92

Stockholm Programme - An open and secure Europe serving and protecting citizens, OJ C 115/1, 4 May 2010

The Council of the European Union, Stockholm Programme mid-term review, 15921/12, Brussels 13 November 2012

The Hague Programme: Strengthening Freedom, Security and Justice in the European Union, OJ C 53/1, 3 March 2005

The Joint Position 96/196/JHA of 4 March 1996 adopted by the Council on the basis of Article K. 3 of the Treaty of the European Union on the harmonised application of the definition of the term 'refugee' in Article 1 of the Geneva Convention of 28 July 1951 relating to the Status of Refugee, OJ L63/2

Valletta summit on migration, 11-12 November 2015 - action plan and political declaration

\section{European Commission documents}

Amended proposal for a Directive of the European Parliament and of the Council laying down standards for the reception of asylum seekers (recast), Brussels, 1.6.2011, COM(2011) 320 final, 2008/0244 (COD)

Amended proposal for a Directive of the European Parliament and of the Council laying down standards for the reception of asylum seekers (recast), Brussels, 1 June 2011, COM(2011) 320 final, 2008/0244 (COD)

Amended proposal for a Directive of the European Parliament and of the Council on common procedures for granting and withdrawing international protection status (Recast), Brussels 1 June 2011, COM(2011) 319 final, 2009/0165 (COD)

Amended proposal for a Regulation Regulation of the European Parliament and of the Council concerning the establishment of 'Eurodac' for the comparison of fingerprints for the effective application of Regulation (EC) No [.../...] [establishing the criteria and mechanisms for determining the Member State responsible for examining an application for international protection lodged in one of the Member States by a third-country national or a stateless person] (Recast version), Brussels, 10.9.2009, COM(2009) 342 final, 2008/0242 (COD)

Commission Implementing Regulation (EU) No 118/2014 of 30 January 2014 amending Regulation (EC) No 1560/2003 laying down detailed rules for the 
application of Council Regulation (EC) No 343/2003 establishing the criteria and mechanisms for determining the Member State responsible for examining an asylum application lodged in one of the Member States by a third-country national, L 39/1

Commission staff working document on Implementation of the Eurodac Regulation as regards the obligation to take fingerprints, Brussels, 27.5.2015, SWD(2015) 150 final

Commission staff working document on the implementation of the EU Action Plan on Unaccompanied Minors, Brussels, 28.9.2012, SDW(2012) 281 final

Communication from the Commission to the Council and the European Parliament on the Managed Entry in the EU of Persons in Need of International Protection and the Enhancement of the Protection Capacity of the Regions of Origin: 'Improving Access to Durable Solutions', Brussels, 4.6.2004, COM(2204 410 final)

Communication from the Commission to the Council and the European Parliament, Towards a common asylum procedure and uniform status, valid throughout the Union, for persons granted asylum, Brussels, 22.11.2000, COM(2000) 755 final

Communication from the Commission to the Council and the European Parliament, Priority actions for responding to the challenges of migration: First follow-up to Hampton Court, Brussels, 30.11.2005, COM(2005) 621 final

Communication from the Commission to the Council and the European Parliament on Regional Protection Programmes, Brussels, 1.9.2005, COM(2005) 388 final

Communication from the Commission to the European Parliament and the Council, First Annual Report on the Facility for Refugees in Turkey, Brussels, 2.3.2017, $\operatorname{COM}(2017) 130$ final

Communication from the Commission to the European Parliament, the European Council and the Council, Next operational steps in EU-Turkey co-operation in the field of migration, Brussels, 16.3.2016, COM(2016) 166 final

Communication from the Commission to the European Parliament, the Council, the European Economic and Social Committee and the Committee on the Regions, The Global Approach to Migration and Mobility, Brussels, 18.11.2011, $\operatorname{COM}(2011) 743$ final

Communication from the Commission to the European Parliament, the Council, the European Economic and Social Committee and the Committee of Regions, Policy Plan on Asylum, an integrated approach to protection across the EU, Brussels, 17.6.2008 COM (2008) 360 final

Communication from the Commission to the European Parliament, the Council, the European Economic and Social Committee and the Committee of Regions, Policy Plan on Asylum, an integrated approach to protection across the EU, Impact Assessment, Brussels, 17.6.2008 SEC (2008) 2029 
Communication from the European Commission to the European Parliament and the Council, The protection of children in migration, $\{\operatorname{SWD}(2017) 129$ final $\}$, Brussels, 12.4.2017, COM(2017) 211 final

EMN Ad-hoc query on EE AHQ on accelerated asylum procedures and asylum procedures at the border, 2017

EMN Ad-Hoc query on detention of asylum applicants at the border: Requested by NL EMN NCP, 28 November 2014

EMN Ad-Hoc query on Eurodac fingerprinting, 2014

EMN Ad-hoc query on the needs of vulnerable migrants, 2009

EMN Ad-hoc query on using video-recordings as the evidence in the asylum procedures, 2014

EMN Ad-Hoc query on unaccompanied Minors - updated facts and statistics, 24 April 2012

EMN Ad-hoc query on BE AHQ: Part I - Reception of Vulnerable Applicants for International Protection with Special Reception Needs, 2018

EMN Ad-hoc query on PART II - Reception and Care of Vulnerable Applicants for International Protection with Special Reception Needs, 2018

EMN Focused Study, The organisation of reception facilities for asylum seekers in different Member States, The Netherlands, 2013

EMN Focussed Study, Policies, practices and data on unaccompanied minors in 2014, Contribution Netherlands, 2014

EMN study, The Organisation of Reception Facilities for Asylum Seekers in different Member States, 2014

European Commission - Fact Sheet, First measures under the European Agenda on Migration: Questions and Answers, 27 May 2015

European Commission - Press release, Future-proof migration management: European Commission sets out way forward, Brussels, 7 December 2018

European Commission - Announcement, EU and Turkey agree European response to refugee crisis, 19 March 2016

European Commission - Fact Sheet, EU - Turkey Statement: Questions and Answers, Brussels, 19 March 2016

European Commission - Fact Sheet, Refugee Crisis: European Commission takes decisive action - Questions and answers, 9 September 2015

European Commission - Press release, Completing the reform of the Common European Asylum System: towards an efficient, fair and humane asylum policy, Brussels 13 July 2016

European Commission - Press release, European Agenda on Migration: Commission reports on progress in making the new European Border and Coast Guard fully operational, Brussels 25 January 2017

European Commission - Press Release, Relocation and Resettlement: Commission calls on all Member States to deliver and meet obligations, 16 May 2017

European Commission proposal for a Regulation of the European Parliament and of the Council establishing a crisis relocation mechanism and amending Regula- 
tion (EU) No 604/2013 of the European Parliament and of the Council of 26 June 2013 establishing the criteria and mechanisms for determining the Member State responsible for examining an application for international protection lodged in one of the Member States by a third country national or a stateless person, Brussels, 9.9.2015, COM(2015) 450 final, 2015/0208(COD)

European Commission Recommendation of 27 November 2013 on procedural safeguards for vulnerable persons suspected or accused in criminal proceedings, (2013/C 378/02), OJ L C378/8

European Commission Return Handbook, 2017

European Commission staff working document on Implementation of the Eurodac Regulation as regards the obligation to take fingerprints, Brussels, 27.5.2015, SWD(2015) 150 final

European Commission working document, The relationship between safeguarding internal security and complying with international protection obligations and instruments, Brussels, 05.12.2001, COM(2001) 743 final

European Commission, Communication from the Commission to the European Parliament, the European Council and the Council, Commission contribution to the EU Leaders' thematic debate on a way forward on the external and the internal dimension of migration policy, Brussels, 7.12.2017, COM(2017) 820 final

European Commission, Communication from the Commission to the European Parliament, to the Council, The European Economic and Social Committee and the Committee of the Regions, Delivering an area of freedom, security and justice for Europe's citizens, Action Plan Implementing the Stockholm Programme, Brussels, 20 April 2010, COM(2010) 171 final

European Commission, Communication from the Commission to the European Parliament and the Council, Towards a reform of the Common European Asylum System and enhancing legal avenues to Europe, Brussels, 6.4.2016, $\operatorname{COM}(2016) 197$ final

European Commission, Communication from the Commission to the European Parliament, to the European Council and the Council, First Report on the progress made in the implementation of the EU-Turkey Statement, Brussels, 20.4.2016, $\operatorname{COM}(2016) 231$ final

European Commission, Communication from the Commission to the European Parliament and the Council, The protection of children in migration, $\{\operatorname{SWD}(2017) 129$ final $\}$, Brussels, 12.4.2017, COM(2017) 211 final European Commission, Communication from the Commission to the European Parliament, the Council, the European Economic and Social Committee and the Committee of the Regions, A European Agenda on Migration, Brussels, 13.5.2015, $\operatorname{COM}(215) 240$ final

European Commission, Communication from the Commission to the European Parliament and the Council, Action Plan on Unaccompanied Minors (20102014), Brussels, 6.5.2010, COM(2010)213 final 
European Commission, Communication from the Commission to the European Parliament and the Council on the State of Play of Implementation of the Priority Actions under the European Agenda on Migration, 10 February 2016, $\operatorname{COM}(2016) 85$ Final

European Commission, Communication from the Commission to the European Parliament, the Council, the European Economic and Social Committee and the Committee of the Regions, A European Agenda on Migration, Brussels, 13.5.2015, $\mathrm{COM}(215) 240$ final

European Commission, Evaluation of the Implementation of the Dublin III Regulation, Final report, 18 March 2016

European Commission, Fact Sheet, Implementing the EU-Turkey Agreement Questions and Answers, Brussels, 4 April 2016

European Commission, Fact sheet, Towards a Comprehensive Migration Policy: 20 Years of EU Action, Brussels 4 March 2015

European Commission, Implementing the Common European Asylum System: Commission acts on 9 infringement proceedings, Brussels, 10 February 2016

European Commission, Opening Statement by Commissioner Dimitris Avramopoulos during the European Parliament plenary debate on Migration, Strasbourg 25 November 2014

European Commission, Press release, Completing the reform of the Common European Asylum System: towards an efficient, fair and humane asylum policy, Brussels, 13 July 2016

European Commission, Press release, Implementing the Common European Asylum System: Commission escalates 8 infringement proceedings, Brussels, 10 December 2015

European Commission, Press release, Implementing the Common European Asylum System: Commission acts on 9 infringement proceedings, Brussels, 10 February 2016

European Commission, Press release, More responsibility in managing the refugee crisis: European Commission adopts 40 infringement decisions to make European Asylum System work, 23 September 2015

European Commission, Proposal for a Directive of the European Parliament and of the Council laying down minimum standards for the reception of asylum seekers (recast), Brussels, 3.12. 2008, COM(2008) 815 final, 2008/0244 (COD)

European Commission, Proposal for a Regulation of the European Parliament and of the Council establishing the criteria and mechanisms for determining the Member State responsible for examining an application for international protection lodged in one of the Member States by a third-country national or a stateless person (Recast), Brussels, 3.12.2008, COM(2008) 820 final, 2008/0243 (COD) 
European Commission, Proposal for a Regulation of the European Parliament and of the Council concerning the establishment of 'Eurodac' for the comparison of fingerprints for the effective application of Regulation (EC) No [.../...] [establishing the criteria and mechanisms for determining the Member State responsible for examining an application for international protection lodged in one of the Member States by a third-country national or a stateless person] (Recast version), Brussels, 3.12.2008, COM(2008) 825 final, 2008/0242 (COD)

European Commission, Proposal for a Regulation of the European Parliament and of the Council amending Regulation (EU) No 604/2013 as regards determining the Member State responsible for examining the application for international protection of unaccompanied minors with no family member, sibling or relative legally present in a Member State, Brussels, 26.6.2014, COM(2014) 382 final, 2014/0202(COD)

European Commission, Proposal for a Regulation of the European Parliament and of the Council establishing an EU common list of safe countries of origin for the purposes of Directive 2013/32/EU of the European Parliament and of the Council on common procedures for granting and withdrawing international protection, and amending Directive 2013/32/EU, Brussels, 9.9.2015, COM92015) 452 final

European Commission, Proposal for a Regulation of the European Parliament and of the Council establishing a common procedure for international protection in the Union and repealing Directive 2013/32/EU, Brussels, 13.7.2016, $\operatorname{COM}(2016) 467$ final, 2016/0224 (COD)

European Commission, Proposal for a Regulation of the European Parliament and of the Council establishing the criteria and mechanisms for determining the Member State responsible for examining an application for international protection lodged in one of the Member States by a third-country national or a stateless person (recast), Brussels, 4.5.2016, COM(2016) 270 final, 2016/0133 (COD)

European Commission, Proposal for a Regulation of the European Parliament and of the Council on standards for the qualification of third-country nationals or stateless persons as beneficiaries of international protection, for a uniform status for refugees or for persons eligible for subsidiary protection and for the content of the protection granted and amending Council Directive 2003/109/EC of 25 November 2003 concerning the status of third-country nationals who are long-term residents, Brussels, 13.7.2016, COM(2016) 466 final 2016/0223 (COD)

European Commission, Proposal to the Council for a Joint Action based on Article K.3(2)(b) of the Treaty on European Union concerning temporary protection of displaced persons (OJ 1997 C106/13

European Commission, Rencontre à Paris sur la migration: Déclaration conjointe 'Relever le défi de la migration et de l'asile', Déclaration Conjointe relever le défi de la migration et de l'asile, Paris, 28 August 2017 
European Commission, Report from the Commission to the Council and to the European Parliament on the application of Directive 2003/9/EC of 27 January 2003, laying down minimum standards for the reception of asylum seekers, Brussels 26 November 2007, COM(2007) 745 final

European Commission, Report from the Commission to the European Parliament and the Council on the application of Directive 2005/85/EC of 1 December 2005 on minimum standards on procedures in Member States for granting and withdrawing refugee status, Brussels, 8 September 2010, COM(2010) 465 final

European Commission, Report from the Commission to the European Parliament and the Council on the evaluation of the Dublin system, $\{\operatorname{SEC}(2007) 742\}$, Brussels, 6.6.2007, COM(2007) 299 final

European Commission, Report from the Commission to the European Parliament and the Council on the application of Directive 2004/83/EC of 29 April 2004 on minimum standards for the qualification and status of third country nationals or stateless persons as refugees or as persons who otherwise need international protection and the content of the protection, Brussels, 16.6.2010, $\operatorname{COM}(2010) 314$ final

European Commission, Report from the Commission to the European Parliament and the Council on the application of Directive 2005/85/EC of 1 December 2005 on minimum standards on procedures in Member States for granting and withdrawing refugee status, Brussels, 8.9. 2010, COM(2010) 465 final

European Commission, Report from the Commission to the European Parliament and the Council on the application of Directive 2005/85/EC of 1 December 2005 on minimum standards on procedures in Member States for granting and withdrawing refugee status

Eurostat Newsrelease, 63300 unaccompanied minors among asylum seekers registered in the EU in 2016, 80/2017, 11 May 2017

Eurostat Newsrelease, Over 31000 unaccompanied minors among asylum seekers registered in the EU in 2017, 84/2018, 16 May 2018

Eurostat press release, Asylum applicants considered to be unaccompanied minors, Almost 90000 unaccompanied minors among asylum seekers registered in the EU in 2015, 2 May 2016

Eurostat, asylum applicants considered to be unaccompanied minors by citizenship, age and sex Annual data, last update 16-05-2018

Green Paper on the future of the Common European Asylum System, presented by the European Commission, Brussels, 6.6.2007 COM(2007) 301 final

Proposal for a Directive of the European Parliament and of the Council laying down minimum standards for the reception of asylum seekers (recast), Brussels, 3.12.2008, COM(2008) 815 final, 2008/0244 (COD)

Proposal for a Directive of the European Parliament and of the Council on the conditions of entry and residence of third-country nationals for the purposes of highly skilled employment, Strasbourg, 7.6.2016, COM(2016) 378 final, 2016/0176 COD 
Proposal for a Directive of the European Parliament and of the Council laying down minimum standards for the reception of asylum-seekers (Recast), COM(2008) 815 final, 3 December 2008

Proposal for a Directive of the European Parliament and of the Council on minimum standards for the qualification and status of third country nationals or stateless persons as beneficiaries of international protection and the content of the protection granted (Recast), COM(2009) 551 final, 21 October 2009

Proposal for a Directive of the European Parliament and of the Council on minimum standards on procedures in Member States for granting and withdrawing international protection (Recast), COM(2009) 554 final, 21 October 2009

Proposal for a Directive of the European Parliament and of the Council laying down standards for the reception of applicants for international protection (recast), Brussels, 13.7.2016, COM(2016) 465 final, 2016/0222 (COD)

Proposal for a Regulation of the European Parliament and of the Council establishing the criteria and mechanisms for determining the Member State responsible for examining an application for international protection lodged in one of the Member States by a third-country national or a stateless person (Recast), COM(2008) 820 final, 3 December 2008

Proposal for a Regulation of the European Parliament and of the Council establishing the criteria and mechanisms for determining the Member State responsible for examining an application for international protection lodged in one of the Member States by a third-country national or a stateless person (recast), Brussels, 4.5.2016, COM(2016) 270 final, 2016/0133 (COD)

Proposal for a Regulation of the European Parliament and of the Council on standards for the qualification of third-country nationals or stateless persons as beneficiaries of international protection, for a uniform status for refugees or for persons eligible for subsidiary protection and for the content of the protection granted and amending Council Directive 2003/109/EC of 25 November 2003 concerning the status of third-country nationals who are long-term residents, Brussels, 13.7.2016, COM(2016) 466 final 2016/0223 (COD)

Proposal for a Regulation of the European Parliament and of the Council establishing a common procedure for international protection in the Union and repealing Directive 2013/32/EU, Brussels, 13.7.2016, COM(2016) 467 final, 2016/0224 (COD)

Proposal for a Regulation of the European Parliament and of the Council on the establishment of 'Eurodac' for the comparison of fingerprints for the effective application of [Regulation (EU) No 604/2013 establishing the criteria and mechanisms for determining the Member State responsible for examining an application for international protection lodged in one of the Member States by a third-country national or a stateless person], for identifying an illegally staying third-country national or stateless person and on requests for the comparison with Eurodac data by Member States' law enforcement authorities and Europol 
for law enforcement purposes (recast), Brussels, 4.5.2016, COM(2016) 272 final, 2016/0132 (COD)

Proposal for a Regulation of the European Parliament and of the Council on the European Union Agency for Asylum and repealing Regulation (EU) No 439/2010, Brussels, 4.5.2016, COM(2016) 271 final

Proposal for Directive of the European Parliament and of the Council on minimum standards on procedures in Member States for granting and withdrawing international protection (Recast), Brussels, 21.10.2009, COM(2009) 554 final, 2009/0165 (COD)

Proposal of the European Parliament and of the Council establishing a Union Resettlement Framework and amending Regulation (EU) No 516/2014 of the European Parliament and the Council, Brussels, 13.7.2016, COM(2016) 468 final, 2016/0225 (COD)

Regulation of the European Parliament and of the Council of 14 September 2016 on the European Border and Coast Guard and amending Regulation (EU) 2016/399 of the European Parliament and of the Council and repealing Regulation (EC) No 863/2007 of the European Parliament and of the Council, Council Regulation (EC) No 2007/2004 and Council Decision 2005/267/EC, OJ L251/1, 16.9.2016

Report from the Commission to the European Parliament and the Council, Fourth Progress Report on the Partnership Framework with third countries under the European Agenda on Migration, Strasbourg, 13.6.2017, COM (2017) 350 final

Report from the Commission to the European Parliament, the European Council and the Council, Fifth Report on the Progress made in the implementation of the EU-Turkey Statement, Brussels, 2.3.2017, COM(2017) 204 final

\section{European Parliament documents}

Apap, J., Vulnerability of unaccompanied minors and separated child migrants, European Parliament briefing, European Parliamentary Research Service, December 2016

Ballegooij, W. et al., European Parliamentary Research Service, The Cost of NonEurope in Asylum Policy, 2018

Bendel, $\mathrm{P}$. and Bekyol, Y., The reception of female refugees and asylum seekers in the EU, Case study Belgium and Germany, European Parliament, Brussels, 2016

European Parliament, Report on a strategy for strengthening the rights of vulnerable consumers (2011/2272(INI), Committee on the Internal Market and Consumer Protection, Rapporteur: Maria Irigoyen Perez, 8.5.2012

Guild, E., Costello, C., Garlick, M., Moreno-Lax, V., Mouzourakis, M., with the participation of Carrera, S., (2014) New approaches, alternative avenues and means of access to asylum procedures for persons seeking international protection, European Parliament, Brussels

Jensen, U., Humanitarian visas: option or obligation? European Parliament study, Brussels, 2014 
Maiani, F., The Reform of the Dublin III Regulation, European Parliament, 2016

Neville, D. and Rigon, A., European Parliament Briefing, Towards an EU humanitarian visa scheme? 2016

Rijpma, J., The Proposal for a European Border and Coast Guard: evolution or revolution in external border management? European Parliament Study, Brussels, 2016

Wagner, M., Dimitriadi, A., O'Donell, R., Perumadan, J., Schlotzhauer, J. H., Simic, I., \& Yabasun, D. (2016), The implementation of the Common European asylum system. Brussels: European Parliament

\section{European Union Agency documents}

EASO, Guidance on reception conditions: operational standards and indicators, 2016

EASO, Age assessment practice in Europe, December 2013

EASO, Annual Report on the Situation of Asylum in the European Union, 2016, July 2017

EASO, The Implementation of Article 15(c) QD in EU Member States, EASO Practical Guided Series, July 2015

Eurostat newsrelease, EU Member States granted protection to more than 700000 asylum seekers in 2016, 70/2017, 26 April 2017

Eurostat newsrelease, 1.2 million first time asylum seekers registered in 2016, 46/2017, 16 March 2017

Eurostat newsrelease, 63300 unaccompanied minors among asylum seekers registered in the EU in 2016, 80/2017, 11 May 2017

Eurostat newsrelease, EU Member States granted protection to more than 330000 asylum seekers in 2015, 75/2016 - 20 April 2016

Eurostat newsrelease, Record number of over 1.2 million first time asylum seekers registered in 2015, 44/2016 - 4 March 2016

Eurostat newsrelease, The number of asylum applicants in the EU jumped to more than 625000 in 2014, 53/2015 - 20 March 2015

Eurostat newsrelease, Asylum decisions in the EU - EU Member States granted protection to more than half a million asylum seekers in 2017 - Almost onethird of the beneficiaries were Syrians, 67/2018, 19 April 2018

Eurostat, Asylum and first time asylum applicants by citizenship, age and sex Annual aggregated data, last update 30-03-2018

\section{Case Law of the Court of Justice of the European Union}

Case C-245/11, Kv Bundesasylamt, 6 November 2012, Court of Justice of the European Union, ECLI: EU:C:2012:685

Case C-585/16, Serin Alheto $v$ Zamestnik-predsedatel na Darzhavna agentsia za bezhantsite, 25 July 2018, Court of Justice of the European Union, ECLI:EU:C:2018:584

Cases C-71/11 and C-99/11, Bundesrepublik Deutschland $v$ Y and Z, 5 September 2012, Court of Justice of the European Union, ECLI:EU:C:2012:518 
Case C-542/13, Mohamed M'Bodj v État belge, 18 December 2014, Court of Justice of the European Union, ECLI:EU:C:2014:2452

Case C-112/00, Eugen Schmidberger, Internationale Transporte und Planzüge and Austria, 12 June 2003, Court of Justice of the European Union, ECLI:EU:C:2003:333

Case C-133-/06, European Parliament v Council of the European Union, 6 May 2008, Court of Justice of the European Union, ECLI:EU:C:2008:257

Case C-148/13 to C-150/13, A, B, C v Staatssecretaris van Veiligheid en Justitie, Court of Justice of the European Union, 2 December 2014, ECLI:EU:C:2014:2046

Case C-155/15, George Karim v Migrationsverket, 7 June 2016, Court of Justice of the European Union, ECLI:EU:C:2016:410

Case C-175/11, H.I.D., B.A.v Refugee Applications Commissioner, Refugee Appeals Tribunal, Minister for Justice, Equality and Law Reform, Ireland, Attorney General, 31 January 2013, Court of Justice of the European Union, ECLI:EU:C:2013:45

Case C-179/11, Cimade, Groupe d'information et de soutien des immigrés (GISTI) v Ministre de l'Intérieur, de l'Outre-mer, des Collectivités territoriales et de l'Immigration, 27 September 2012, Court of Justice of the European Union, ECLI:EU:C:2012:594

Case C-19/08, Migrationsverket v Edgar Petrosian and Others, 29 January 2009, Court of Justice of the European Union, ECLI:EU:C:2009:41

Case C-199/12 to C-2012/12, X (C-199/12), Y (C200/12) and Zv Minister voor Immigratie en Asiel (C-201/12), 7 November 2013, Court of Justice of the European Union, ECLI:EU:C:2013:720

Case C-285/12, Aboubacar Diakitév Commissaire général aux réfugiés et aux apatrides, 30 January 2014, Court of Justice of the European Union, ECLI:EU:C:2014:39

Case C-31/09, Nawras Bolbol v Bevándorlási és Állampolgársági Hivatal, 17 June 2010, Court of Justice of the European Union, ECLI:EU:C:2010:351

Case C-353/16, MPv Secretary of State for the Home Department, 24 April 2018, Court of Justice of the European Union, ECLI:EU:C:2018:276

Case C-361/88, Judgment of the Court of 30 May 1991. - Commission of the European Communities $v$ Federal Republic of Germany. - Directive - Nature of the measure transposing it into domestic law - Air pollution, ECLI:EU:C:1991:224

Case C-364/11, Mostafa Abed El Karem El Kott, Chadi Amin A Radi, Hazem Kamel Ismail v Bevándorlási és Állampolgársági Hivatal, 19 December 2012, Court of Justice of the European Union, ECLI:EU:C:2012:826

Case C-394/12, Shamso Abdullahiv Bundesasylamt, 10 December 2013, Court of Justice of the European Union, ECLI:EU:C:2013:813

Case C-4/11 Opinion of Advocate General Jääskinen, Bundesrepublik Deutschland v Kaveh Puid, 18 April 2013, ECLI:EU:C:2013:244

Case C-4/11, Bundesrepublik Deutschland v Kaveh Puid, 14 November 2013, Court of Justice of the European Union, ECLI:EU:C:2013:740 
Case C-404/17, Av Migrationsverket, 25 July 2018, Court of Justice of the European Union, ECLI:EU:C:2018:588

Case C-443/14 and C-444/14, Kreis Warendorf v Ibrahim Alo and Amira Osso v Region Hannover, 1 March 2016, Court of Justice of the European Union, ECLI:EU:C:2016:127

Case C-465/07, Meki Elgafaji and Noor Elgafaji v Staatssecretaris van Justitie, 17 February 2009, Court of Justice of the European Union, ECLI:EU:C:2009:94

Case C-528/11, Zuheyr Frayeh Halafv Darzhavna agentsia za bezhantsite pri Ministerskia savet, 30 May 2013, Court of Justice of the European Union, ECLI:EU:C:2013:342

Case C-550/16, A and S v Staatssecretaris van Veiligheid en Justitie, Court of Justice of the European Union, ECLI:EU:C:2018:248

Case C-578/16, C.K. and Others v Republika Slovenija, 16 February 2017, Court of Justice of the European Union, ECLI:EU:C:2017:27

Case C-620/10, Migrationsverket v Nurije Kastrati and Others, 3 May 2012, Court of Justice of the European Union, ECLI:EU:C:2012:265

Case C-63/15, Mehrdad Ghezelbash v Staatssecretaris van Veiligheid en Justitie, 7 June 2016, Court of Justice of the European Union, ECLI:EU:C:2016:410

Case C-638/16 Opinion of Advocate General Mengozzi, PPU, X and Xv Etat belge, Opinion delivered on 7 February 2017, ECLI:EU:C:2017:93

Case C-638/16, PPU, X and Xv Etat belge, 7 March 2017, Court of Justice of the European Union, ECLI:EU:C:2017:173

Case C-648/11, The Queen, on the application of MA, BT, DA $v$ Secretary of State for the Home Department, 6 June 2013, Court of Justice of the European Union, ECLI:EU:C:2013:367

Case C-69/10, Brahim Samba Dioufv Ministre du Travail, de l'Emploi et de l'Immigration, 28 July 2011, Court of Justice of the European Union, ECLI:EU:C:2011:524

Case C-79/13, Federaal agentschap voor de opvang van asielzoekers v Selver Saciri and others, 27 February 2014, Court of Justice of the European Union, ECLI:EU:C:2014:103

Case C-57/09 and C-101/09, Bundesrepublik Deutschland v B (C-57/09), D (C-101/09), 9 November 2010, Court of Justice of the European Union, ECLI:EU:C:2010:661

Case T-192/16, T-193/16 and T-257/16, NF, NG and NMv European Council, 28 February 2017, Court of Justice of the European Union, ECLI:EU:T:2017:128 Cases C-148/13 to C-150/13, A (C-148/13), B (C-149/13), C (C-150/13)v Staatssecretaris van Veiligheid en Justitie, 2 December 2014, Court of Justice of the European Union, ECLI:EU:C:2014:2406

Cases C-175/08, C-176/08, C-178/08 and C-179/08, Aydin Salahadin Abdulla (C175/08), Kamil Hasan (C-176/08), Ahmed Adem, Hamrin Mosa Rashi (C-178/08), Dler Jamal (C-179/08) v Bundesrepublik Deutschland, 2 March 2010, Court of Justice of the European Union, ECLI:EU:C:2010:105 
Cases C-411/10 and C-493/10, N.S. v Secretary of State for the Home Department and M. E. and others v. Refugee Applications Commissioner, Minister for Justice, Equality and Law Reform, 21 December 2011, Court of Justice of the European Union, ECLI:EU:C:2011:865

Cases T-192/16, T-193/16 and T-257/16, NF, NG and NM v European Council, 28 February 2017, Court of Justice of the European Union, ECLI:EU:T:2017:128

Case C-473/16, F, 25 January 2018, Court of Justice of the European Union, ECLI:EU:C:2018:36

Case C-56/17, Bahtiyar Fathi v Predsedatel na Darzhavna agentsia za bezhantsite, 4 October 2018, Court of Justice of the European Union, ECLI:EU:C:2018:803

Case C-369/17, Shajin Ahmed v Bevándorlási és Menekültügyi Hivatal, 13 September 2018, Court of Justice of the European Union, ECLI:EU:C:2018:713

Case C-713/17, Ahmad Shah Ayubi v Bezirkshauptmannschaft Linz-Land, 21 November 2018, Court of Justice of the European Union, ECLI:EU:C:2018:929

Case C-18/16, K. v Staatssecretaris van Veiligheid en Justitie, 14 September 2017, Court of Justice of the European Union, ECLI:EU:C:201 7:680

Case C-601/15 PPU, J.N. v Staatssecretaris voor Veiligheid en Justitie, 15 February 2016, Court of Justice of the European Union, ECLI:EU:C:2016:84

Case C-180/17, X. and Yv Staatssecretaris van Veiligheid en Justitie, 26 September 2018, Court of Justice of the European Union, ECLI:EU:C:2018:775

Case C-175/17, X, 26 September 2018, Court of Justice of the European Union, ECLI:EU:C:2018:776

Case C-239/14, Tall, 17 December 2015, Court of Justice of the European Union, ECLI:EU:C:2015:824

Case C-662/17, E.G.v Republika Slovenija, 18 October 2018, Court of Justice of the European Union, ECLI:EU:C:2018:847

Case C-269/18, Staatssecretaris van Veiligheid en Justitiev C \& J, 5 July 2018, Court of Justice of the European Union, ECLI:EU:C:2018:544

Case C-213/17, Xv Staatssecretaris van Veiligheid en Justitie, 5 July 2018, Court of Justice of the European Union, ECLI:EU:C:2018:538

Cases C-47/17 and C-48/17, X \& Xv Staatssecretaris van Veiligheid en Justitie, 13 November 2018, Court of Justice of the European Union, ECLI:EU:C:2018:900

Case C-646/16, Jafari v Bundesamt für Fremdenwesen und Asyl, 26 July 2017, Court of Justice of the European Union, ECLI:EU:C:2017:586

Case C-647/16, Adil Hassan v Préfet du Pas-de-Calais, 31 May 2018, Court of Justice of the European Union, ECLI:EU:C:2018:368

Case C-490/16, A.S. v Republika Slovenija, 26 July 2017, Court of Justice of the European Union, ECLI:EU:C:2017:585

Case C-201/16, Majid Shiri v Bundesamt für Fremdenwesen und Asyl, 25 October 2017, Court of Justice of the European Union, ECLI:EU:C:2017:805

Case C-670/16, Tsegezab Mengesteab v Bundesrepublik Deutschland, 26 July 2017, Court of Justice of the European Union, ECLI:EU:C:2017:587 
Case C-661/17, M.A., S.A., A.Z., 23 January 2019, Court of Justice of the European Union, ECLI:EU:C:2019:53

Case C-360/16, Aziz Hasan v Bundesrepublik Deutschland, 25 January 2018, Court of Justice of the European Union, ECLI:EU:C:2018

Case C-60/16, Mohammad Khir Amayry v Migrationsverket, 13 September 2017, Court of Justice of the European Union, ECLI:EU:C:201 7:675

Case C-528/15, Chodor, 15 March 2017, Court of Justice of the European Union, ECLI:EU:C:2017:213

Case C-635/17, E.v Staatssecretaris van Veiligheid en Justitie, 19 March 2019, Court of Justice of the European Union, ECLI:EU:C:2019:192

Joined Cases C-297/17, C-318/17, C-319/17 and C-438/17, Ibrahim and others v Bundesrepublik Deutschland, 19 March 2019, Court of Justice of the European Union, ECLI:EU:C:2019:219

Case C-163/17, Abubacarr Jawo v Bundesrepublik Deutschland, 19 March 2019, Court of Justice of the European Union, ECLI:EU:C:2019:218

\section{Domestic documents}

Besluit van de Staatssecretaris van Veiligheid en Justitie van 26 februari 2016, nummer WBV 2016/4, houdende wijziging van de Vreemdelingencirculaire 2000, Nr. 10912

Brief Staatssecretaris van Veiligheid en Justitie, Evaluatie Programma Implementatie Vernieuwde Asielprocedure (PIVA), 10 December 2014

Centraal Bureau voor de Statistiek (CBS), Asielverzoeken en nareizigers; nationaliteit, geslacht en leeftijd

Centraal Bureau voor de Statistiek (CBS), Asielverzoeken; nationaliteit, vanaf 1975, eerste asielverzoeken

Centraal Bureau voor de Statistiek (CBS), Minder alleenreizende minderjarige vreemdeling: nationaliteit, geslacht en leeftijd, 23 April 2018

Centraal Bureau voor de Statistiek (CBS), Verblijfsvergunningen voor bepaalde tijd; verblijfsgrond en nationaliteit

Evaluatie Vreemdelingenwet 2000, Terugkeerbeleid en Operationeel Vreemdelingentoezicht, Commissie Evaluatie Vreemdelingenwet 2000, Wetenschappelijk Onderzoek- en Documentatiecentrum, Kiwa Management Consultants, Bureau Boekhoorn Sociaal-wetenschappelijk Onderzoek, 2004

IND work-instruction 2016/4, Forensisch medisch onderzoek naar steunbewijs (FMO)

IND work-instruction 2018/3 (Grensprocedure)

IND work-instruction 2015/8 (Bijzondere procedurele waarborgen)

IND-work instruction 2013/14, Kwetsbare minderheidsgroep

IND, Onderzoek naar de rol van IMMO rapportages in asielzaken, 3 November 2016

IND, The simplified asylum procedure, April 2017

Inspectie Jeugdzorg, De kwaliteit van de beschermde opvang voor alleenstaande minderjarige vreemdelingen-Hertoets, June 2017 
Inspectie Jeugdzorg, Ministerie van Volksgezondheid, Welzijn en Sport, Kwaliteit opvang alleenstaande minderjarige vreemdelingen, September 2016

Kamerbrief over Bestuursakkoord Verhoogde Asielinstroom, 27 November 2015

Ministerie van Justitie en Veiligheid, Rapportage Vreemdelingenketen, Periode januaridecember 2017

Ministerie van Justitie en Veiligheid, Reactie op nadere vragen n.a.v. reactie van het IMMO inzake evaluatie praktijk bekostiging medisch onderzoek, 5 February 2018

Vereniging van Nederlandse Gemeenten/OTAV and Platform Opnieuw Thuis, Factsheet Alleenstaande Minderjarige Vreemdelingen (AMV'ers), Juli 2016

Wetenschappelijk Onderzoek- en Documentatiecentrum, Commissie Evaluatie Vreemdelingenwet 2000, De asielprocedure - Deel 1, 2006

\section{Dutch Parliamentary documents}

EK, 2014/2015, 34088, C

EK, 2014/2015, Nr. 38, item 8

EK, 2016/2017, 34088, Nr. G

TK 1998/99, 26732, Nr. 3

TK 2009/2010, 19637, Nr. 1351

TK 2012/2013, 27062, Nr. 75

TK 2013/2014, 27062, Nr. 91

TK 2013/2014, 27062, Nr. 95

TK 2015/2016, 19637, Nr. 2086

TK, 2014/2015, 19637, Nr. 1903

TK, 2014/2015, 34088, Nr. 11

TK, 2014/2015, 34088, Nr. 18

TK, 2014/2015, 34088, Nr. 2

TK, 2014/2015, 34088, Nr. 20

TK, 2014/2015, 34088, Nr. 21

TK, 2014/2015, 34088, Nr. 3

TK, 2014/2015, 34088, Nr. 5

TK, 2015/2016, 34541, Nr. 3

TK, 2015/2016, 34309, Nr. 2

TK, 2017/2018, Nr. 186

\section{Dutch legislation}

2005 Regulation benefits to asylum seekers and other categories of aliens (Regeling verstrekkingen asielzoekers en andere categeorieen vreemdelingen 2005)

Act of the Central Agency of Reception (Wet Centraal Orgaan opvang asielzoekers)

Aliens Act 2000 (Vreemdelingenwet 2000)

Aliens Circular (Vreemdelingencirculaire 2000) 
Aliens Decree 2000 (Vreemdelingenbesluit 2000)

Aliens Regulation 2000 (Voorschrift Vreemdelingen 2000)

Besluit van 10 juli 2015, houdende wijziging van het Vreemdelingenbesluit 2000 en het Besluit vergoedingen rechtsbijstand 2000 in verband met de implementatie van Richtlijn 2013/32/EU van het Europees Parlement en de Raad van 26 juni 2013 betreffende gemeenschappelijke procedures voor de toekenning en intrekking van de internationale bescherming (PbEU 2013, L 180) en Richtlijn 2013/33/EU van het Europees Parlement en de Raad van 26 juni 2013 tot vaststelling van normen voor de opvang van verzoekers om internationale bescherming (PbEU 2013, L 180), 2015, Stb, 294

Besluit van 23 november 2000 tot uitvoering van de Vreemdelingenwet 2000 (Vreemdelingenbesluit 2000)

Staatscourant Regeling van de Staatssecretaris van Veiligheid en Justitie van 9 juli 2015 , nummer 654765 , houdende wijziging van de Regeling verstrekkingen asielzoekers en andere categorieën vreemdelingen 2005, Nr. 20243, 17 Juli 2015

Staatscourant, Besluit van de Minister voor Immigratie, Integratie en Asiel van 22 maart 2012, nummer WBV 2012/3, houdende wijziging van de Vreemdelingencirculaire 2000, Nr. 6296, 30 March 2012

Wet van 23 november 2000 tot algehele herziening van de Vreemdelingenwet (Vreemdelingenwet 2000)

Wet van 8 juli 2015 tot wijziging van de Vreemdelingenwet 2000 ter implementatie van Richtlijn 2013/32/EU van het Europees Parlement en de Raad van 26 juni 2013 betreffende gemeenschappelijke procedures voor de toekenning en intrekking van de internationale bescherming (PbEU 2013, L 180) en Richtlijn 2013/33/EU van het Europees Parlement en de Raad van 26 juni 2013 tot vaststelling van normen voor de opvang van verzoekers om internationale bescherming (PbEU 2013, L 180)

\section{Dutch case law}

Afdeling bestuursrechtspraak van de Raad van State, 201205236/1/V4, 20 September 2013, ECLI:NL:RVS:2013:1220

Afdeling bestuursrechtspraak van de Raad van State, 201208171/1/V1, 19 February 2014, ECLI:NL:RVS:2014:600

Afdeling bestuursrechtspraak van de Raad van State, 201211554/1/V4, 16 April 2013, ECLI:NL:RVS:2013:3382

Afdeling bestuursrechtspraak van de Raad van State, 201400245/1/V1, 29 August 2014, ECLI:NL:RVS:2014:3306

Afdeling bestuursrechtspraak van de Raad van State, 201403670/1/V3, 5 February 2015, ECLI:NL:RVS:2015:370

Afdeling bestuursrechtspraak van de Raad van State, 201405639/1/V3, 29 May 2015, ECLI:NL:RVS:2015:1787 
Afdeling bestuursrechtspraak van de Raad van State, 201410601/1/V3, 17 April 2015, ECLI:NL:RVS:2015:1304

Afdeling bestuursrechtspraak van de Raad van State, 201502436/1/V3, 1 December 2015, ECLI:NL:RVS:2015:3794

Afdeling bestuursrechtspraak van de Raad van State, 201504313/1/V3, 27 January 2016, ECLI:NL:RVS:2016:266

Afdeling bestuursrechtspraak van de Raad van State, 201504479/1/V3, 3 December 2015, ECLI:NL:RVS:2015:3806

Afdeling bestuursrechtspraak van de Raad van State, 201505068/1/V3, 14 March 2016, ECLI:NL:RVS:2016:809

Afdeling bestuursrechtspraak van de Raad van State, 201505068/1/V3, 14 March 2016, ECLI:NL:RVS:2016:809

Afdeling bestuursrechtspraak van de Raad van State, 201506164/1/V3, 7 October 2015, ECLI:NL:RVS:2015:3209

Afdeling bestuursrechtspraak van de Raad van State, 201602689/1/V3, 3 August 2016, ECLI:NL:RVS:2016:2214

Afdeling bestuursrechtspraak van de Raad van State, 201604107/1/V3, 21 June 2017, ECLI:NL:RVS:2017:1596

Afdeling bestuursrechtspraak van de Raad van State, 201605509/1/V3, 9 December 2016, ECLI:NL:RVS:2016:3291

Afdeling bestuursrechtspraak van de Raad van State, 201605946/1/V3, 3 November 2017, ECLI:NL:RVS:2017:2986

Afdeling bestuursrechtspraak van de Raad van State, 201609659/3/V2, 29 March 2017, ECLI:NL:RVS:2017:869

Afdeling bestuursrechtspraak van de Raad van State, 201703192/1/V3, 3 November 2017, ECLI:NL:RVS:2017:2980

RB Den Haag, AWB 15/20414, 15 December 2015, ECLI:NL:RBDHA:2015:15942

RB Den Haag, AWB 17/5708, 11 April 2017, ECLI:NL:RBDHA:2017:4033

\section{Books, papers and journal articles}

Abrisketa, J., Churruca, C., De la Cruz, C., Garcia, L., Margues, C., Morondo, D., Nagore, M., Sosa, L. and Timmer, A., Human rights priorities in the European Union's external and internal policies: an assessment of consistency with a special focus on vulnerable groups, FRAME, 2015

ACVZ, De geloofwaardigheid gewogen, Een advies over het onderzoeken, integraal beoordelen en toetsen van verklaringen in de asielprocedure, May 2016

ACVZ, Sporen uit het verleden, July 2014

Al Tamimi, Y., The Protection of Vulnerable Groups and Individuals by the European Court of Human Rights. Journal européen des droits de l'homme / European Journal of Human Rights, 2016(5) 
Amnesty International EU Office, Response to the European Commission's Green Paper on the future of the Common European Asylum System - COM (2007) 301 final

Amnesty International Report, A blueprint for despair - Human rights impact of the EU-Turkey deal, 2017

Amnesty International report, Asylum-seekers and refugees denied effective protection in Turkey, March 2016

Amnesty International, Dokters van de Wereld, Stichting LOS-Meldpunt Vreemdelingendetentie, Opsluiten of beschermen, Kwetsbare mensen in vreemdelingendetentie, April 2016

Angeleri, S., The Impact of the Economic Crisis on the Right to Health of Irregular Migrants, as Reflected in the Jurisprudence of the UN Committee on Economic, Social and Cultural Rights, European Journal of Migration and Law, 19, 2017

Asylum Information Database (AIDA) country reports

Australian Administrative Appeals Tribunal, Migration and Refugee Division, Guidelines on Vulnerable Persons, July 2015

Baron, J. and Hager, N., Eine Frage von Glück und Zufall - Zu den Verfahrensgarantien für psychisch Kranke oder Traumatisierte im Asylverfahren, Beratung und Rechtsschutz - Beitrage zu den Anforderungen an die rechtliche Beratung und Vertretung von Schutzsuchenden, Beilage zum Asylmagazin, Informationsverbund Asylum \& Migration, 7-8/2017

Battjes, European Asylum Law and International Law, Martinus Nijhoff Publishers, 2006

Battjes, H., Asylum Qualification Directive 2011/95/EU, EU in Kay Hailbronner and Daniel Thym (eds.), EU Immigration and Asylum Law, Commentary, 2nd edition (C.H. BECK/Hart/Nomos, 2016)

Battjes, H., Brouwer, E., Slingenberg, L. and Spijkerboer, T., The Crisis of European Refugee Law: Lessons from Lake Success, Preadviezen Christen Juristen Vereniging, 2016

Battjes, H., In Search of a Fair Balance: The Absolute Character of the Prohibition of Refoulement under Article 3 ECHR Reassessed, Leiden Journal of International Law, 22

Battjes, H., Journaal Vreemdelingenrecht, JV 2011/68

Battjes, H., Kroniek Dublinverordening, Asiel \& Migrantenrecht, Nr. 2, 2018

Battjes, H., Legal Effects of the Istanbul Protocol, Care Full - Medico-legal reports and the Istanbul Protocol in asylum procedures, 2006

Bauloz, C. and Ruiz, G., Refugee Status and Subsidiary Protection: Towards a Uniform Content of International Protection? De Bruycker, P., Chetail, V. and Maiani, F. (eds.), Reforming the Common European Asylum System: The New European Refugee Law, Brill Nijhoff, 2016

Beltman, D., and Zijlstra, E., De doorwerking van het belang van het kind, ex artikel 3 VRK in het migratierecht: Vanuit een bottom-up benadering op weg naar een top-down benadering, Journaal Vreemdelingenrecht, 12/4 
Berman, P., From Laeken to Lisbon: The Origins and Negotiation of the Lisbon Treaty, EU Law After Lisbon, Edited by Andrea Biondi, Piet Eeckhout, Stefanie Ripley, Oxford University Press, 2012

Billet, C., EC Readmission Agreements: A Prime Instrument of the External Dimension of the EU's Fight against Irregular Immigration. An Assessment after Ten Years of Practice, European Journal of Migration and Law, Volume 12, Issue 1,2010

Björgvinsson, D., The Protection of the Rights of Persons with Disabilities in the Case Law, The UN Convention on the Rights of Persons with Disabilities, Martinus Nijhoff Publishers, 2009

Bloemen, E., and Kollen, M., Bewijs geleverd - Medisch steunbewijs en medische beperkingen in asiel, Journaal Vreemdelingenrecht, Nr. 3/27, 2015

Bloemen, E., Vloeberghs, E. and Smits, C., Psychological and psychiatric aspects of recounting traumatic events by asylum seekers, Care Full-Medico-legal reports and the Istanbul Protocol in asylum procedures, 2006

Boccardi, I., Europe and Refugees, Towards an EU Asylum Policy, Kluwer Law International, 2002

Böcker, A., Terlouw, A.B., Broek, J.J, van der., Grütters, C.A., Nijmeijer, A.G.A., Oers, R. van., De gelaagdheid van de vreemdelingenwetgeving in historisch en vergelijkend perspectief, Kluwer, 2013

Boeles, P., and Terlouw, A., Minimum Guarantees for Asylum Procedures, International Journal of Refugee Law, Vol. 9, No. 3, 1997

Boeles, P., den Heijer, M., Lodder, G., and Wouters, K., European Migration Law, Intersentia, 2009

Bonjour, S., Explaining Ambition: the Elaboration of the Working Program for the European Asylum Policy, 1996-1999, Migration, Integration and Citizenship, A Challenge for Europe's Future, Volume II, Edited by Hildegard Schneider, Forum Maastricht, 2005

Bossuyt, M., Categorical rights and vulnerable groups: moving away from the universal human being, The George Washington International Law Review, 48:4, 2016

Brandl, U. and Czech, P., General and Specific Vulnerability of Protection-Seekers in the EU: Is there an Adequate Response to their Needs? Protecting Vulnerable Groups, The European Human Rights Framework, Ippolito, F., and Iglesias Sanchez, S. (eds.), 2015

Broderick, A., The Long and Winding Road to Equality and Inclusion for Persons with Disabilities, Intersentia, 2015

Bruin, R., and Kok, S., Het kind in de asielprocedure-Lessen uit internationale rapporten, Asiel \& Migrantenrecht, Nr. 4, 2015

Bunyan, T., Trevi, Europol and the European State in Statewatching the new Europe, Statewatch Publication, 1993

Caritas Europa, CCME - Churches' Commission for Migrants in Europe, COMECE - Commission of the Bishops' Conferences of the European Community, ICMC - International Catholic Migration Commission, JRS-Europe - 
Jesuit Refugee Service Europe QCEA - Quaker Council for European Affairs, Comments on the European Commission's Green Paper on the future Common European Asylum System COM (2007) 301 final, August 2007

Carlier, J., Des droits de l'homme vulnérable à la vulnérabilité des droits de l'homme, la fragilité des équilibres. Revue interdisciplinaire d'études juridiques, 2017, volume 79(2)

Carrera, S., et al., The European Border and Coast Guard, Addressing migration and asylum challenges in the Mediterranean? 2017

Carrera, S. and Guild, E., EU-Turkey plan for handling refugees is fraught with legal and procedural challenges, CEPS, 10 March 2016

Carrera, S., and Guild, E., CEPS Policy Brief, Can the new refugee relocation system work? Perils in the Dublin logic and flawed reception conditions in the EU, October 2015

Carrera, S., and Lannoo, K, We're in this boat together-Time for a Migration Union, CEPS, June 2018

Carrera, S., Blockmans, S., Gros, D., Guild, E., The EU's Response to the Refugee Crisis: Taking Stock and Setting Policy Priorities, CEPS, December 2015

Carrera, S., The Impact of the Treaty of Lisbon over EU Policies on Migration, Asylum and Borders: The Struggles over the Ownership of the Stockholm Programme, The First Decade of EU Migration and Asylum Law, Edited by Elspeth Guild and Paul Minderhoud, Martinus Nijhoff Publishers, 2012

Carrera, S., The Impact of the Treaty of Lisbon over EU Policies on Migration, Asylum and Borders: The Struggles over the Ownership of the Stockholm Programme, The First Decade of EU Migration and Asylum Law (Elspeth Guild and Paul Minderhoud eds.), Martinus Nijhoff Publishers, 2012

Casas, M., The instruments of pre-border control in the EU: A new source of vulnerability of asylum-seekers? The protection of vulnerable individuals in the context of EU policies on border checks, asylum and immigration, 31 May 2016,

Chapman, A., and Carbonetti, B., Human Rights Protections for Vulnerable and Disadvantaged Groups: The Contributions of the UN Committee on Economic, Social and Cultural Rights, Human Rights Quarterly, Vol. 33, No. 3, 2011

Chetail, V., Looking Beyond the Rhetoric of the Refugee Crisis: The Failed Reform of the Common European Asylum System, European Journal of Human Rights, $2016 / 5$

Chetail, V., The Common European Asylum system: Bric-á-Brac or System? De Bruycker, P., Chetail, V. and Maiani, F. (eds.), Reforming the Common European Asylum System: The New European Refugee Law, Brill Nijhoff, 2016

CIR Rifugiati, Time for needs: Listening, Healing, Protecting. A joint action for an Appropriate Assessment of Special Needs of Victims of Torture and Violence, 2017

Clayton, G., Asylum Seekers in Europe: M.S.S. v Belgium and Greece, Human Rights Law Review, 11(4), 2011

Cleton, L, Seiffert, L, and Wörmann, H., EMN, Gezinshereniging van derdelanders in Nederland, Mei 2017 
College voor de Rechten van de Mens, Mensenrechten in de noodopvang Heumensoord, 10 Februari 2016

Collet, E., The Paradox of the EU-Turkey Refugee Deal, Migration Policy Institute, March 2016

Compte, F., A New Agency is Born in the European Union: The European Asylum Support Office, European Journal of Migration and Law, Volume 12, Issue 4, 2010

Conte, C., What about Refugees with Disabilities? The Interplay between EU Asylum Law and the UN Convention on the Rights of Persons with Disabilities, European Journal of Migration and Law, Volume 18, Issue 3, 2016

Coomans, F., Grunfeld, F., and Kamminga, M., Methods of Human Rights Research, Intersentia, 2009

Coomans, F., The Extraterritorial Scope of the International Covenant on Economic, Social and Cultural Rights in the Work of the United Nations Committee on Economic, Social and Cultural Rights, Human Rights Law Review, Volume, 11, Issue 1, 2011

Costello, C. and Hancox, E., The Recast Asylum Procedures Directive 2013/32/EU: Caught between the Stereotypes of the Abusive Asylum Seeker and the Vulnerable Refugee, De Bruycker, P., Chetail, V. and Maiani, F. (eds.), Reforming the Common European Asylum System: The New European Refugee Law, Brill Nijhoff, 2016

Costello, C., and Mouzourakis, M., Tarakhel: Is 'how bad is bad enough' good enough? Asiel \& Migrantenrecht, no. 10, 2014

Cremona, M., The Two (or Three) Treaty Solution: The New Treaty Structure of the EU, EULaw After Lisbon, Edited by Andrea Biondi, Piet Eeckhout, Stefanie Ripley, Oxford University Press, 2012

Crescenzi, A., Unaccompanied Minors in International Law, Unaccompanied Minors in International, European and National Law, (Ralf Rosskopf eds.), Berliner Wissenschafts- Verlag, 2016

Crock, M., Ernst, C., and McCallum, R., Where Disability and Displacement Intersect: Asylum Seekers and Refugees with Disabilities, International Journal of Refugee Law, Vol. 24, No. 4, 2012

Da Lomba, S., The Right to seek Refugee Status in the European Union, Intersentia, 2004

De Bruycker, P. and De Bauche, L., Odysseus Academic Network, Study on the conformity checking of the transposition by Member States of 10 EC Directives in the sector of asylum and immigration done for DG JLS of the European Commission, Directive 2003/09 on Reception Conditions, Synthesis Report, 2007

De Hert, P., and Mantovani, E., Specific Human Rights for Older Persons? European Human Rights Law Review, Issue 4, 2011

De Schutter, O., The Prohibition of Discrimination under European Human Rights Law, European Commission report, May 2011 
Debauche-Discart, L., Asylum seekers with special needs, Ministerial Conference $<<$ Quality and Efficiency in the Asylum Process>>, 13-14 September 2010

Den Heijer, M, Rijpma, J. and, T., Coercion, prohibition, and great expectations: The continuing failure of the Common European Asylum System, Common Market Law Review, Issue 3, 2016

Den Heijer, M. and Spijkerboer, T., Is the EU-Turkey refugee and migration deal a treaty? EU Law Analysis Blog, 7 April 2016

Den Heijer, M., Reflections on Refoulement and Collective Expulsion in the Hirsi Case, International Journal of Refugee Law, Volume 25, No. 2, 2013

Detrick, S., A Commentary on the United Nations Convention on the Rights of the Child, Martinus Nijhoff Publishers, 1999

Dörig, H., Asylum Qualification Directive 2011/95/EU, EU in Kay Hailbronner and Daniel Thym (eds.), EU Immigration and Asylum Law, Commentary, 2nd edition (C.H. BECK/Hart/Nomos, 2016)

ECRE and the Dutch Council for Refugees report, The DCR/ECRE desk research on application of a safe third country and a first country of asylum concepts to Turkey, May 2016

ECRE Asylum Information Database, The Legality of Examining Asylum Claims in Detention from the Perspective of Procedural Rights and their Effectiveness, October 2015

ECRE Asylum Information Database, The length of asylum procedures in Europe, 2016

ECRE Asylum Information Database, Wrong counts and closing doors, the reception of refugees and asylum seekers in Europe, 2016

ECRE, Comments on the Commission Proposal to recast the Eurodac Regulation COM(2016) 272, July 2016

ECRE, Information Note on Directive 2013/33/EU of the European Parliament and of the Council of 26 June 2013 laying down standards for the reception of applicants for international protection (recast), 2015

ECRE, Chartering a way to protection: the EU Charter of Fundamental Rights - an indispensable instrument in the field of asylum, 2017

ECRE, Comments on the Commission Proposal for an Asylum Procedures Regulation $\operatorname{COM}(2016)$ 467, November 2016

ECRE, Information Note Directive 2013/32/EU of the European Parliament and of the Council of 26 June 2013 on common procedures for granting and withdrawing international protection (recast), 2014

ECRE, Information Note on Directive 2013/32/EU of the European Parliament and of the Council of 26 June 2013 on common procedures for granting and withdrawing international protection (recast), December 2014

ECRE, The concept of vulnerability in European asylum procedures, 2017

Edwards, A., Age and gender dimensions in international refugee law, Refugee protection in international law, Edited by Erika Feller, Volker Türk and Frances Nicholson, Global Consultations, 1 January 2003 
Edwards, A., Transitioning Gender: Feminist Engagement With International Refugee Law and Policy 1950-2010, Refugee Survey Quarterly, Vol. 29, No. 2, 2010

Edwards, A., UNHCR Displacement, Statelessness and Questions of Gender Equality under the Convention on the Elimination of All Forms of Discrimination against Women, August 2009, PPLAS/2009/02

Eisele, K., The External Dimension of the EU's Migration Policy, Different Legal Positions of Third- Country Nationals in the EU, A Comparative Perspective, Wolf Legal Publishers, 2013

European Women's Lobby, Contribution from the European Women's Lobby to the European Commission's Green Paper on the future Common Asylum System $\operatorname{COM}(2007) 301$ final

Fedasil, Study into vulnerable persons with specific reception needs, 2016

Fineman, M.A., and Grear, A., (eds.), Vulnerability: reflections on a new ethical foundation for law and politics, 2013

Fineman, M.A., Beyond Identities: The Limits of an Anti-discrimination Approach to Equality, Boston University Law Review, Vol. 92, No. 6, 2012

Fineman, M.A., Equality, Autonomy, and the Vulnerable Subject in Law and Politics in Vulnerability: Reflections on a New Ethical Foundation for Law and Politics, Martha Albertson Fineman and Anna Grear (eds.), Ashgate, 2013

Fineman, M.A., The Vulnerable Subject: Anchoring Equality in the Human Condition, Yale Journal of Law \& Feminism, Vol. 20(1), 2008

Flegar, V. and Veys, M., De Europese verplichting voor procedurele waarborgen in de Nederlandse asielprocedure en de implementatie vanuit kwetsbaarheidsperspectief, Journaal Vreemdelingenrecht, Nr. 2/11, 2017

Flegar, V., Who is deemed vulnerable in the governance of migration? Asiel \& Migrantenrecht, 2018, Nr. 8

Floor, M., UNHCR's role in combating human trafficking in Europe, Forced Migration Review, No. 25, May 2006

FRA, Current migration situation in the EU: Torture, trauma and its possible impact on drug use, February 2017

FRA, Current migration situation in the EU: Torture, trauma and its possible impact on drug use, February 2017

FRA, Fundamental rights implications of the obligation to provide fingerprints for Eurodac, 2015

FRA, Monthly data collection on the current migration situation in the EU, Thematic focus: Disability, August 2016

Franssen, K., Larsson, F., Slingenberg, L., De Opvangrichtlijn, Nieuwsbrief asiel- en vluchtelingenrecht (NAV), No. 6, December 2007

Fratzke, S., Not adding up, The fading promise of Europe's Dublin system, Migration Policy Institute, March 2015 
Freeman, M., Chinkin, C. and Rudolf, B., The UN Convention on the Elimination of All Forms of Discrimination against Women, A Commentary, Oxford University Press, 2012

Freeman, M., Chinkin, C., Rudolf, B., The UN Convention on the Elimination of All Forms of Discrimination against Women, A Commentary, Oxford University Press, 2012

Fundamental Rights Agency, The impact of the proposal for a revised Eurodac Regulation on fundamental rights, Opinion of the European Union Agency for Fundamental Rights, 22 December 2016

Garlick, M., The Dublin System, Solidarity and Individual Rights, De Bruycker, P., Chetail, V. and Maiani, F. (eds.), Reforming the Common European Asylum System: The New European Refugee Law, Brill Nijhoff, 2016

Gil-Bazo, M., The Charter of Fundamental Rights of the European Union and the Right to be Granted Asylum in the Union's Law, Refugee Survey Quarterly, Volume 27, Issue 3, 2008

Gilson, E., Vulnerability, Ignorance, and Oppression, Hypatia, Vol. 26, No.2, 2011

Global Legal Research Directorate, Provisions on Child Asylum Seekers in Selected Jurisdictions, The Law Library of Congress, May 2018

Goeman, M., and Walst, J., Stand van zaken drie jaar herijking AMV-beleid - Beschadigen of beschermen? Asiel \& Migrantentenrecht, Nr. 8, 2016

Gondek, M., The Emerging European Asylum Law: Between Protection and Rejection, Migration, Integration and Citizenship, A Challenge for Europe's Future, Volume II, Edited by Hildegard Schneider, Forum Maastricht, 2005

Goodwin-Gill, G., and McAdam, J., The Refugee in International Law, Oxford University Press, 2007

Goodwin-Gill, G., The International Law of Refugee Protection, E. FiddianQasmiyeh, G. Loescher, K. Long, and N. Sigona (eds), The Oxford Handbook of Refugee and Forced Migration Studies, Oxford, OUP, 2014

Gorlick, B., Common Burdens and Standards: Legal Elements in Assessing Claims to Refugee Status, International Journal of Refugee Law, 2003

Grahl-Madsen, A., The Status of Refugees in International Law, Volume II, Asylum, Entry and Sojourn, A. W. Slijthoff-Leiden, 1972

Groenendijk, K. and Slingenberg, L., Onthouden dagvergoeding aan asielzoekers in noodopvang is onwettig, Asiel \& Migrantenrecht, Nr. 3, 2016

Guild, E., Does the EU Need a European Migration and Protection Agency? International Journal of Refugee Law, vol. 28, Issue 4, 2016

Guild, E., and Garlick, M., Refugee Protection, Counter Terrorism, and Exclusion in the European Union, Refugee Survey Quarterly, Vol. 29, No. 4, 2011

Guild, E., The Europeanisation of Europe's Asylum Policy, International Journal of Refugee Law, 2006, Vol. 18, Issue 3-4

Guiraudon, V., The constitution of a European immigration policy domain: a political sociology approach, Journal of European Public Policy, 10:2 April 2003 
Haddad, E., The External Dimension of EU Refugee Policy: A New Approach to Asylum? Government and Opposition, An International Journal of Comparative Politics, Vol. 43(2)

Hailbronner, K. and Thym, D., Legal Framework for EU Asylum Policy in Kay Hailbronner and Daniel Thym (eds.), EU Immigration and Asylum Law, Commentary, $2^{\text {nd }}$ edition (C.H. BECK/Hart/Nomos, 2016)

Hammarberg, T, Methods for assessing the age of migrant children must be improved, The Commissioner for Human Rights, Council of Europe, Strasbourg, 9.8.2011

Hathaway, J., Refugees and Asylum, 2012

Hathaway, J., The Rights of Refugees under International Law, Cambridge University Press, 2005

Herweijer, M., In de kinderschoenen - Naar een volwassen benadering van het belang van het kind in het vreemdelingenrecht, Asiel \& Migrantenrecht, Nr. 8, 2017

House of Lords, European Union Committee, 2nd Report of Session 2016-17, Children in crisis: unaccompanied migrant children in the EU, 2016

Hruschka, C. and Maiani, F. in Kay Hailbronner and Daniel Thym (eds.), EU Immigration and Asylum Law, Commentary, $2^{\text {nd }}$ edition (C.H. BECK/Hart/Nomos, 2016)

Hungarian Helsinki Committee, The Situation of Unaccompanied Asylum Seeking Children in Hungary, December 2016

Immigration and Refugee Board Canada, Guideline 8 Guideline on Procedures with Respect to Vulnerable Persons Appearing Before the IRB, 2012

International Association of Refugee Law Judges, Guidelines on Procedures With Respect To Vulnerable Persons, October 2008

IRCT, Torture victims in Europe, October 2011

IRCT, Comments on the Green Paper on the future Common European Asylum System, July 2007

IRCT, Position paper on the Proposal for an Asylum Procedures Regulation, July 2016

IRCT, Failing Through the Cracks, asylum procedures and reception conditions for torture victims in the European Union, 2016

IRCT, Position Paper on the European Commission's Proposal for the Reform of the Dublin System, May 2016

IRCT, Position paper on the Proposal for a recast on the Reception Conditions Directive, September 2016

IRCT, Position paper on the Proposal for an Asylum Procedures Regulation, September 2016

IRCT, Position paper on the Proposal for an Asylum Procedures Regulation, September 2016

IRCT, Recognising Victims of Torture in National Asylum Procedures, A comparative overview of early identification of victims and their access to medico-legal reports in asylum-receiving countries, 2013 
IRCT, Recognising Victims of Torture in National Asylum Procedures, A comparative overview of early identification of victims and their access to medico-legal reports in asylum-receiving countries, 2013

Jakuleviciene, L., Vulnerable Persons as a New Sub-Group of Asylum Seekers? De Bruycker, P., Chetail, V. and Maiani, F. (eds.), Reforming the Common European Asylum System: The New European Refugee Law, Brill Nijhoff, 2016

Jansen, S., Pride or Shame? Assessing LGBTI asylum applications in the Netherlands following the XYZ and ABC judgments, 2019

Joly, D., Haven or Hell?: Asylum policies and refugees in Europe, Oxford, Palgrave Macmillan, 1996

Jones, C., 11 years of Eurodac, Statewatch Analysis, January 2014

JRS, Becoming Vulnerable in Detention, June 2011

Kälin, W., Supervising the 1951 Convention Relating to the Status of Refugees: Article 35 and beyond in Refugee Protection in International Law, Erika Feller, Volker Türk and Frances Nicholson (eds.), UNHCR's Global Consultations on International Protection, 2003

Kampstra, E.M., Hoofdzaken vreemdelingenrecht, Wolters Kluwer, 2017

Kaunert, C., and Leonard, S., The EU asylum policy: Towards a common area of protection and solidarity? Freedom, Security and Justice after Lisbon and Stockholm (Sarah Wolf, Flora Goudappel and Jaap de Zwaan eds.), T.M.C. Asser Press, 2011

Kaunert, C., and Leonard, S., The European Union asylum policy after the Treaty of Lisbon and the Stockholm Programme: Towards supranational governance in a common area of protection? Refugee Survey Quarterly, Vol. 31, No. 4

Keunen, A.M., Roscam Abbing, H.D.C., Schumacher, J.H., Age assessment of unaccompanied minor asylum seekers in the Netherlands, The Dutch Association of Age Assessment Researchers (DA-AAR), May 2013

Kok, S., and Rodrigues, P., Bij gebrek aan bewijs, de beoordeling van de geloofwaardigheid van het asielrelaas onder Werkinstructie 2014/10, Universiteit Leiden - VluchtelingenWerk Nederland, November 2016

Kok, S.G., Eenvormige status op meerdere gronden, Asiel \& Migrantenrecht, No. 4, 2014

Kritzman-Amir, T. and Spijkerboer, T., On the Morality and Legality of Border: Border Policies and Asylum Seekers, Harvard Human Rights Journal, Volume. 26, Issue 1, 2013

Ktistakis, Y., Protecting Migrants under the European Convention on Human Rights and The European Social Charter, Council of Europe, A handbook for legal practitioners, 2013

Lamont, R., The EU Charter of Fundamental Rights, A Commentary, Edited by Peers, S., Hervey, T., Kenner, J. and Ward, A., Hart Publishing 2014

Larsson, F., De EU-richtlijn over de opvang van asielzoekers, Opvangvoorzieningen in Nederland en Frankrijk en de rechtsbescherming tegen het onthouden van opvang, 2011 
Lautherpacht, E., and Bethlehem, D., The scope and content of the principle of nonrefoulement: Opinion, Refugee Protection in International Law, Global Consultations, 1 January 2003, Erika Feller, Volker Turk and Frances Nicholson (eds.)

Lavenex, S., The Europeanisation of Refugee Policies, between human rights and internal security, Ashgate Publishing Company, 2001

Lord, J., and Brown, R., The Role of Reasonable Accommodation in Securing Substantive Equality for Persons with Disabilities: The UN Convention on the Rights of Persons with Disabilities, Social Science Research Network (SSRN), 2010

Luna, F, Elucidating the Concept of Vulnerability: Layers not Labels, International Journal of Feminist Approaches to Bioethics, Vol. 2, No.1, 2009

Luna, F., 'Vulnerability', and Interesting Concept for Public Health: The Case of Older Persons, Public Health Ethics, Vol. 7, No. 2, 2014

Luna, F., Identifying and evaluating layers of vulnerability - a way forward, Developing World Bioethics, 2018

Mackenzie, C., Vulnerability, Needs and Moral Obligation in Vulnerability, Autonomy and Applied Ethics (editor Christine Straehle), Routledge, 2017

Mackenzie, C.,Rogers, W. and Dodds, S., Introduction: what is Vulnerability, and Why Does It Matter for Moral Theory? In Vulnerability: New Essays in Ethics and Feminist Philosophy (Mackenzie, C.,Rogers, W. and Dodds, S. eds.), Oxford University Press, 2014

Maiani, F., The Dublin III Regulation, De Bruycker, P., Chetail, V. and Maiani, F. (eds.), Reforming the Common European Asylum System: The New European Refugee Law, Brill Nijhoff, 2016

Martin, S., Gender and the Evolving Refugee Regime, Refugee Survey Quarterly, Vol. 29, No. 2, 2010

Matevžič, G, Hungarian Helsinki Committee, The Response of Eastern Member States to the Special Needs of Torture Survivors and Traumatized Asylum Seekers, 2017

McAdam, J., Complementary Protection in International Refugee Law, Oxford University Press, 2007

McLachlan, C., The Principle of Systemic Integration and Article 31(3)(c) of the Vienna Convention, International \& Comparative Law Quarterly, Vol. 54, Issue 2, 2005

Mechlem, K., Treaty Bodies and the Interpretation of Human Rights, Vanderbilt Journal of Transnational Law, Vol. 42, 2009

Megret, F., The Human Rights of Older Persons: A Growing Challenge, Human Rights Law Review, Vol. 11(1), 2011

Meijers Committee on the EURODAC proposal (COM(2012) 254), 10 October 2012

Meijers Committee, CM1609, Note on the proposed reforms of the Dublin Regulation(COM (2016) 197), the Eurodac recast proposal (COM (2016) 272 final), and the proposal for an EU Asylum Agency (COM(2016)271 final 
Meijers Committee, Comments on the proposals for a Qualification Regulation (COM(2016) 466 final), Procedures Regulation (COM(2016) 467 final), and a revised Reception Conditions Directive (COM(2016) 465 final), CM1614

Mewes, R., Friele, B. And Bloemen, E., Validation of the Protect Questionnaire: A tool to detect mental health problems in asylum seekers by non-health professionals, Torture Journal: Journal on Rehabilitation of Torture Victims and Prevention of Torture, Volume 28, Issue No. 2, 2018

Mol, M, De Directe Werking van de Grondrechten van de Europese Unie, Wolf Legal Publishers, 2014

Moreno-Lax, V., The legality of the 'safe third country' notion reconsidered: an appraisal in light of general international rules on the law of treaties, International Migrants, 2010 Research Session of the Centre for Studies and Research in International Law and International Relations, The Hague Academy of International Law, Goodwin-Gill (ed.), 2014

Mouzourakis, M., Taylor, A., Dorber, J., Sbarai, E., and Pollet, K., Common asylum system at a turning point: Refugees caught in Europe's solidarity crisis, Asylum Information Database, Annual Report 2014/2015

MSF, Greece in 2016: Vulnerable People Get Left Behind

Mueller, J., Schmidt, M., Staeheli, A. and Maier, T., Mental health of failed asylum seekers as compared with pending and temporarily accepted asylum seekers, European Journal of Public Health, Vol. 21, No. 2, 2010

Nederlandse Orde van Advocaten, Advies NOVA inzake het voorstel van wet inzake implementatie Procedurerichtlijn en Opvangrichtlijn, 28 December 2013

Nicholson, F., Challenges to Forging a Common European Asylum System in EU Immigration and Asylum Law, Text and Commentary, Edited by Steve Peers and Nicola Rogers, Martinus Nijhoff Publishers, 2006

Nifosi-Sutton, I., The Protection of Vulnerable Groups under International Human Rights Law, Routledge, 2017

Noll, G., and Vested-Hansen, J., Temporary Protection and Burden-Sharing: Conditionalising Access Suspending Refugee Rights? in Implementing Amsterdam, Immigration and Asylum Rights in EC Law, Edited by Guild, E., and Harlow, C., Hart Publishing, 2001

Noll, G., Junk Science? Four Arguments against the Radiological Age Assessment of Unaccompanied Minors Seeking Asylum, International Journal of Refugee Law, Vol. 28, No. 2, 2016

Noll, G., Negotiating Asylum, the EU Acquis, Extraterritorial Protection and the Common Market of Deflection, Martinus Nijhoff Publishers, 2000

O'Sullivan, M., Acting the Part: Can Non-State Entities Provide Protection Under International Refugee Law? International Journal of Refugee Law, Vol. 24, Issue 1, 2012

Papademetriou, T., European Union: Status of Unaccompanied Children Arriving at the EU Borders, The Law Library of Congress, September 2014 
Peek, M. and Tsourdi, L., Asylum Reception Conditions Directive 2013/33/EU in Kay Hailbronner and Daniel Thym (eds.), EU Immigration and Asylum Law, Commentary, 2nd edition (C.H. BECK/Hart/Nomos, 2016)

Peers, S., Legislative Update: EU Immigration and Asylum Competence and Decision-Making in the Treaty of Lisbon, European Journal of Migration and Law, 10, 2008

Peers, S., Moreno-Lax, V., Garlick, M., en Guild, E. (red.), EU Immigration and Asylum Law (Text and Commentary), Second Revised Edition, EU Asylum Law, Vol. 3,2015

Peers, S., The EU Asylum System: Challenges and Shortcomings, Mediterranean Yearbook 2014

Peers, S., The final EU/Turkey refugee deal: a legal assessment, EU Law Analysis Blog, 18 March 2016

Peers, S., The second phase of the Common European Asylum System: A brave new world - or lipstick on a pig? 8 April 2013

Peroni, L., and Timmer, A., Vulnerable groups: The promise of an emerging concept in European Human Rights Convention law, International Journal of Constitutional Law, 2013

Peter Fritzsche, K., in Menschenrechte besonders verletzlicher Gruppen, Menschenrechte Eine Einführung mit Dokumenten, 2016

Pétin, J, Vulnérabilité et droit Européen de l'asile: quelques précisions necessaires, 18 April 2015 and La vulnérabilité en droit Européen de l'asile, RDLF 2017

Phuong, C., Persecution by Non-state Agents: Comparative Judicial Interpretations of the 1951 Refugee Convention, European Journal of Migration and Law, 4, 2003

Piotrowicz, R., The UNHCR's Guidelines on Human Trafficking, International Journal of Refugee Law, Volume 20, Issue 2, 2008

Provera, M., JRS Europe, Discussion paper, The EU-Turkey deal, 29 April 2016

Provera, M., The Detention of Asylum Seekers in the European Union and Australia, A Comparative Analysis, Oisterwijk, Wolf Legal Publishers, 2013

Reneman, M., de Lange, J., and Smeekes, J., Interpretatie en waardering van medische rapporten door de IND, Medische waarheidsvinding en geloofwaardigheidsbeoordeling in asielzaken, Asiel \& Migrantenrecht, Nr. 10, 2016

Reneman, M., EU Asylum Procedures and the Right to an Effective Remedy, Hart Publishing, 2016

Reneman, M., Herziene Procedurerichtlijn: is de Algemene Asielprocedure een versnelde procedure? Verblijfblog, 21 august 2015

Reneman, M., Het Kinderrechtenverdrag krijgt tanden: over hoe het VN Verdrag inzake de Rechten van het Kind via het EU-recht en het EVRM binnendringt in het Nederlandse vreemdelingenrecht, Asiel \& Migrantenrecht, Nr. 8, 2011

Reneman, M., Identification of asylum seekers with special reception needs and procedural needs in the Dutch asylum procedure, VU Migration Law Serieus, No. 16, 2018 
Reneman, M., Implementatie van de herziene Asielprocedurerichtlijn: een nieuwe beslissystematiek en meer waarborgen voor asielzoekers, Nederlands tijdschrift voor Europees recht, Nr. 8, September 2015

Reneman, M., Implementatie van de herziene Asielprocedurerichtlijn: een nieuwe beslissystematiek en meer waarborgen voor asielzoekers, Nederlands tijdschrift voor Europees recht, Nr. 8, September 2015

Reneman, M., Versnelling, verlenging en vereenvoudiging van asielprocedure vanwege hoge instroom - Spanning met het Europees recht, Asiel \& Migrantenrecht, Nr. 6/7, 2016

Report on 'Medical examination in the asylum procedure -Article 18 Directive 2013/32/EU - Manual for health professionals and legal workers', The Netherlands Institute for Human Rights and Medical Assessment (IMMO), The Hungarian Cordelia Foundation for the Rehabilitation of Torture Victims and the French organization Parcours d'Exil, 2017

Rogers, W., MacKenzie, C. and Dodds, S., Why bioethics needs a concept of vulnerability, International Journal of Feminist Approaches to Bioethics, Vol. 5, No. 2, 2012

Roman, E., Baird, T., and Radcliffe, T., Why Turkey is Not a "Safe Country", Statewatch Analysis, February 2016

Rosa Coene, E., Het concept van bijzondere procedurele behoeften in het kader van de Nederlandse grensprocedure, Journaal Vreemdelingenrecht, No. 2, 2019

Ruijter, L., Melin, E., Ishola, P., Dolby, P., Murk, J., and van de Pol, P., Reception and living in families, Overview of family-based reception for unaccompanied minors in the EU Member States, NIDOS, SALAR, CHTB, February 2015

Sauer, P., Nicholson, A., Neubauer, D., Age determination in asylum seekers: physicians should not be implicated, European Journal of Pediatrics, On behalf of the Advocacy and Ethics Group of the European Academy of Paediatrics, March 2016, Vol. 175, Issue 3

Scheinin, M., The art and science of interpretation in human rights law in Andreassen, B.A., Sano, H. and McInerney-Lankford, S. (eds.), Research methods in human rights: a handbook, Edward Elgar, 2017

Schneider, H., Migration, Integration and Citizenship, A Challenge for Europe's Future, Volume II, Forum Maastricht, 2005

Schroeder, D., and Gefenas, E., Vulnerability: Too Vague and Too Broad? Cambridge Quarterly of Healthcare Ethics, 2009

Seatzu, F., Reshaping EU Old Age Law in the Light of the Normative Standards in International Human Rights Law in Relation to Older Persons, Protecting Vulnerable Groups, The European Human Rights Framework, Ippolito, F., and Iglesias Sanchez, S. (eds.), 2015

Sigvardsdotter, E., Vaez, M, Rydholm Hedman, A. and Saboonchi, F., Prevalence of torture and other war-related traumatic events in forced migrants: A systematic review, Torture Journal, 2016, 26(2) 
Slingenberg, L., The reception of asylum seekers under international law-Between sovereignty and Equality, Hart Publishing, 2014

Slingenberg, L., Kroniek opvang, Asiel \& Migrantenrecht, Nr. 2, 2016

Smeekes, J., and Fourer, M., Medical Reports in Subsequent Asylum Applications Does Dutch law comply with EU law? Expert advice by the Migration Law Clinic, June 2015

Smulders, S., Medisch steunbewijs en de implementatie van de herziene Procedurerichtlijn, Journaal Vreemdelingenrecht, Nr. 3/26, 2015

Smyth, C., European Asylum Law and the Rights of the Child, Routledge, 2014

Smyth, C., Is the Right of the Child to Liberty Safeguarded in the Common European Asylum System? European Journal of Migration and Law, Volume 15, Issue 2, 2013

Smyth, C., The common European asylum system and the rights of the child: an exploration of meaning and compliance, 2013, Doctoral Thesis, Leiden University

Sorel, A., Asylum, Migration and Border controls in the Hague Programme, Freedom, Security and Justice in the European Union, Implementation of the Hague Programme, T.M.C. Asser Press, De Zwaan, J., and Goudappel, F. Editors, 2006

Spijkerboer, T., Fact Check: Did the EU-Turkey Deal Bring Down the Number of Migrants and of Border Deaths? Border Criminologies Blog, 28 September 2016

Staffans, I., Evidence in European Asylum Procedures, Leiden/Boston: Martinus Nijhoff (2012)

Storey, H., EU Refugee Qualification Directive: A Brave New World? International Journal of Refugee Law, 2008

Stoyanova, V., Complementary Protection for Victims of Human Trafficking under the European Convention on Human Rights, Goettingen Journal of International Law, Vol. 3, No. 2, 2011

Stoyanova, V., Victims of Trafficking, A Legal Analysis of the Guarantees for 'Vulnerable Persons' under the Second Phase of the EU Asylum Legislation, Seeking Asylum in the European Union, Selected Protection Issues Raised by the Second Phase of the Common European Asylum System (Bauloz, C., Ineli-Ciger, M., Singer, S. and Stoyanova, V. eds.), Brill Nijhoff, 2015

The Guidance on Vulnerable Persons of the Australian Migration Review Tribunal - Refugee Review Tribunal, June 2012

Tiedemann, P., Subsidiary protection and the function of Article 15(c) of the Qualification Directive, Refugee Survey Quarterly, 2012, Vol. 31, No.1

Tiller, E.H. and Cross, F.B., What is Legal Doctrine? Northwestern University Law Review, 517, 2006

Timmer, A., A Quiet Revolution: Vulnerability in the European Court of Human Rights, Fineman, M.A., Equality, Autonomy, and the Vulnerable Subject in Law and Politics, Fineman, M.A., and Grear, A., (eds.), Vulnerability: reflections on a new ethical foundation for law and politics, 2013 
Truscan, 'Considerations of vulnerability: from principles to action in the case law of the European Court of Human Rights', Retfcerd: Nordic Journal of Law and Justice, no. 3/142, 2013

Tsourdi, E., The Impact of the Negotiations on the recast Reception Conditions Directive in The recast Reception Conditions Directive: Central Themes, Problem Issues, and Implementation in Selected Member States, Minderhoud, P, and Zwaan, K. (eds.), Wolf Legal Publishers, 2016

Tsourdi, L., The Impact of the Negotiations on the Recast Reception Conditions Directive, The Recast Reception Conditions Directive: Central Themes, Problem Issues, and Implementation in Selected Member States, (Minderhoud, P, \& Zwaan, K. eds.) 2016

Turner, B.S., Vulnerability and Human Rights, 2006

Ulusoy, O., and Battjes, H., Situation of Readmitted Migrants and Refugees from Greece to Turkey under the EU- Turkey Statement, VU Migration Law Series No 15, 2017

Van Bennekom, W., Van den Bosch, M., Groenendijk, K. and Vermeulen, B., Comparative study of member states on immigration law, with special reference to deportation and administrative detention, Center for Migration Law, University of Nijmegen, January 2000

Van der Aa, S., Variable Vulnerabilities? Comparing the Rights of Adult Vulnerable Suspects and Vulnerable Victims under EU Law, New Journal of European Criminal Law, Vol. 7, Issue 1, 2016

Van Eijl, C., Tussenland, Illegaal in Nederland, 1945-2000, Hilversum: Verloren, 2012 Van Oort, H., Battjes, H., and Brouwer, E., Evaluation of the Common European Asylum System under Pressure and Recommendations for Further Development, CEASEVAL, 2018

Van Ree, C.J., and Schulpen, T.W.J., Ethische tekortkomingen van het leeftijdsonderzoek ter beoordelingn van minderjarigheid van alleenstaande asielzoekers, Nederlands Tijdschrift Geneeskunde, 3 February 145(5), 2001

Van Selm, J., Immigration and Asylum or Foreign Policy: The EU's Approach to Migrants and Their Countries of Origin, Migration and the Externalities of European Integration, edited by Sandra Lavenex, and Emek Ucarer, Lexington Books, 2003

Velluti, S., Reforming the Common European Asylum System - Legislative Developments and Judicial Activism of the European Courts, Springer, 2014

Velluti, S., The Revised Reception Conditions and adequate and dignified material reception conditions for those seeking international protection, International Journal of Migration and Border Studies, 2 (3)

Venturi, D., The potential of a vulnerability-based approach: some additional reflections following O.M. v Hungary, Strasbourg Observers, 25 October 2016

Vested-Hansen, J., Asylum Procedures Directive 2013/32/ EU in Kay Hailbronner and Daniel Thym (eds.), EU Immigration and Asylum Law, Commentary, $2^{\text {nd }}$ edition (C.H. BECK/Hart/Nomos, 2016 
Vink, M., The Europeanization of Domestic Asylum Policy: National Executive Power and Two-Level Games, ECSA Seventh Biennial International Conference, 2001

Visentin, S., Pelleti, G., Bajanowski, T. and Davide Ferrara, S., Methodology for the identification of vulnerable asylum seekers, International Journal of Legal Medicine, 26 July 2017

Waddington, L., Vulnerable and confused: the protection of "vulnerable" consumers under EU law, European Law Review, 2013, 38(6)

Wenke, D., Council of Europe, Age assessment: Council of European member states' policies, procedures and practices respectful of children's rights in the context of migration, September 2017

Wiesbrock, A., Disability as Form of Vulnerability, Protecting Vulnerable Groups, The European Human Rights Framework, Ippolito, F. and Iglesias Sanchez, S. (eds.), 2015

Wouters, K., International Legal Standards for the Protection from Refoulement, Intersentia, 2009

Yabasun, D., Hervorming Europees asielbeleid: Commissievoorstel Kwalificatieverordening, Journaal Vreemdelingenrecht, No. 3, 2016

Yabasun, D., The revised Asylum Qualification Directive: a first step towards the completion of a common European asylum system by 2012? Journaal Vreemdelingenrecht, No. 1, 2012

Zimmerman, A. and Mahler, C., Article 1A, para. 2, A. Zimmermann (ed.), The 1951 Convention Relating to the Status of the Refugees and its 1967 Protocol: A Commentary, Oxford, OUP, 2011

Zimmerman, A., The 1951 Convention Relating to the Status of Refugees and its 1967 Protocol, A Commentary, Oxford University Press, 2011

Zwaan, K., Medisch steunbewijs in de asielprocedure: de processie van Echternach? Asiel \& Migrantenrecht, Nr. 10, 2013 


\section{About the author}

Dersim Yabasun holds a law degree (LL.M.) in Dutch Law and European Law from Maastricht University. Subsequently, he graduated from the European Inter-University Centre for Human Rights and Democratisation (EIUC) in Venice and attended a semester at the Institut des Hautes Etudes Européennes (IHEE) in Strasbourg.

Dersim has extensive teaching experience in European asylum and migration law. Currently, he is involved in a large-scale EU research project evaluating refugee integration measures. Before working at Maastricht University, Dersim worked in the Hague as a policy advisor at the Dutch Ministry of Foreign Affairs and the Dutch Ministry of the Interior. Furthermore, he has worked with non-profit organisations supporting refugees in the Netherlands. 
2019 is an important milestone for the European asylum policy. Twenty years ago, the European Council decided in Tampere, Finland to establish a Common European Asylum System (CEAS). One of the main Tampere policy objectives was to create a system that includes common standards for a fair and efficient asylum procedure in the European Union (EU). In 2015, when the number of asylum applications in the EU doubled compared to previous years, it appeared that the CEAS was unable to address the migration challenges. The unprecedented number of asylum applicants has caused serious challenges for Member States to meet their obligations in providing adequate reception conditions and to ensure procedural arrangements. This situation has most likely affected a growing number of asylum applicants who are particularly vulnerable. Examples of asylum applicants who are presumed to be particularly vulnerable include victims of torture and unaccompanied minors.

This book examines the CEAS and assesses whether the European Council Tampere policy objective of establishing common standards for a fair and efficient asylum procedure has been realized with regard to vulnerable asylum applicants. It also examines whether the legal standards that stem from the recast legislative acts of the CEAS concerning vulnerable asylum applicants, in particular with regard to victims of torture and unaccompanied minors, are in accordance with international human rights law, and whether these legal standards have been adequately implemented at the national level. The country selected to assess the implementation of relevant legal standards with regard to vulnerable asylum applicants is the Netherlands.

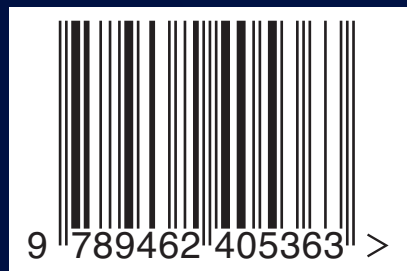

